HANFORD WORKS MONTHLY REPORT

FOR

MARCH 1951

Compiled By

Division Managers

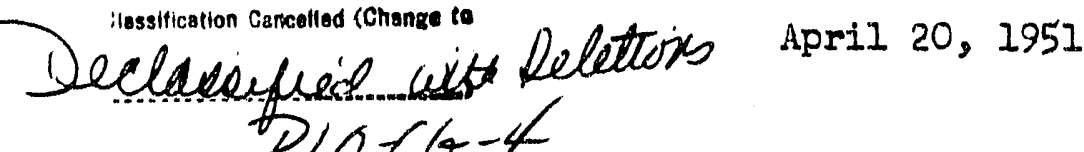
y Authoritu nif 60 . $6(6-4$ (4)A-5nyuten o/10/92

HA:IEORD WORKS RICHI NID, W'SSHINGTON
HW- -2067I-Del.

DE92 011305

PMcack $=19-19.20$ operated

for the itomic Energy $C_{0}$
by the
General Electric Comyany
under
Cnntract $\# W-31-109$-eng- 52

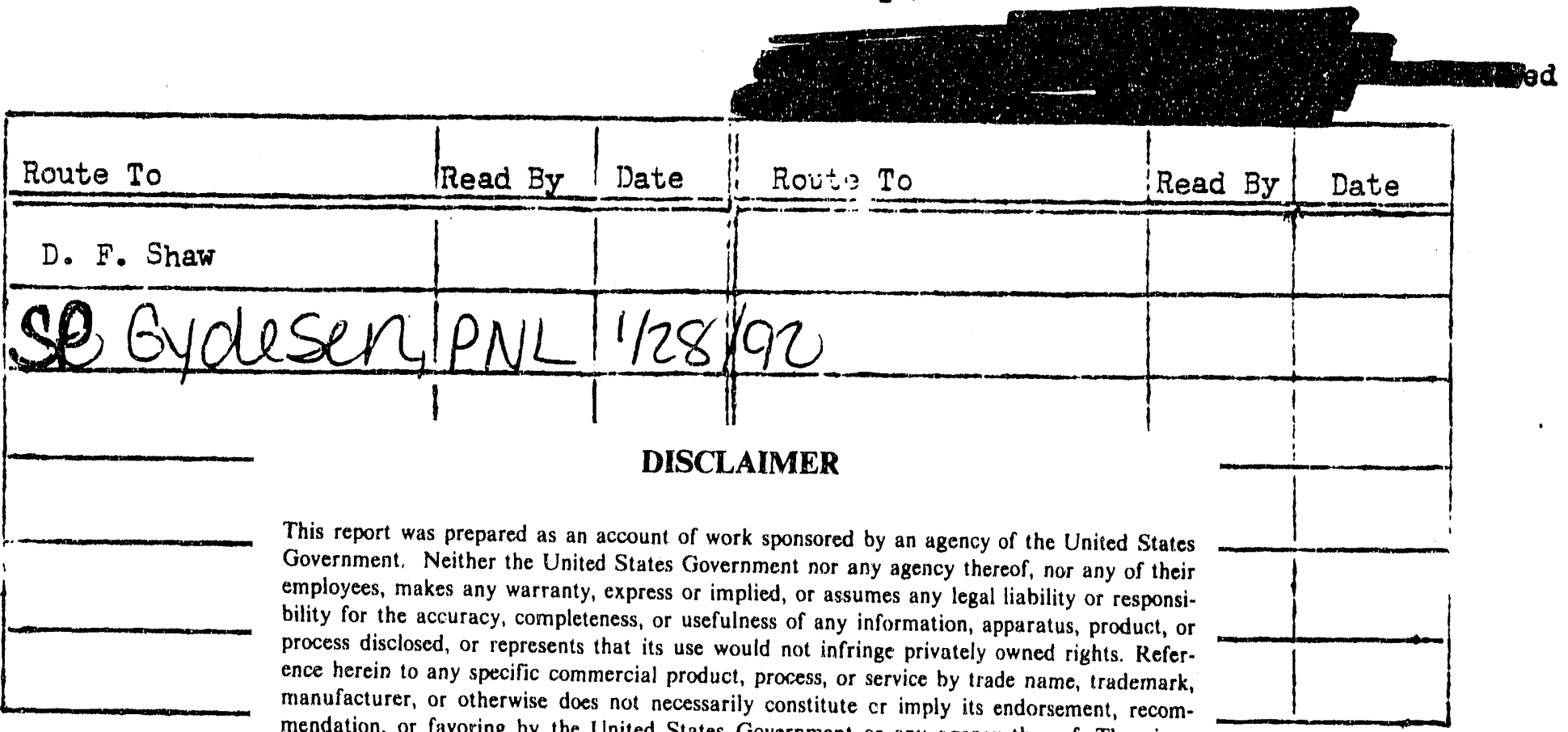

mendation, or favoring by the United States Government or any agency thereof. The views and opinions of authors expressed herein do not necessariiy state or reflect those of the United States Government or any agency thereof.

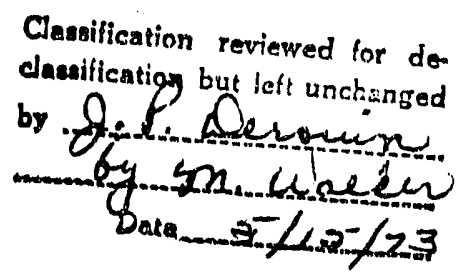




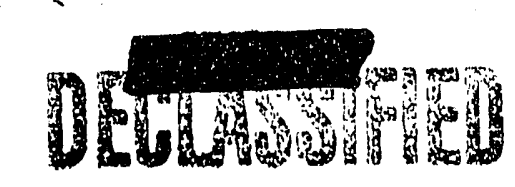

IW 20671-Del

COPY NUMBER

1

2

3

4

5

6

7

$8-12$

13

$14-15$
DISTRIBUTION

Yollow Copy - H. A. Winne

Knolls Atomic Power Laboratory Attention: C. G. Suits

Knolls Atomic Power Laboratory Attention: W. H. Milton, Jr.

G. R. Prout

C. N. Gross

A. B. Greninger

R. E. Davison

Hanford Operations Office Attention: D. F. Shaw, Manager

Hanford Operations Office Attention: R. W. Richardson, Historian

700 File 
General Summary ..................... . . 4

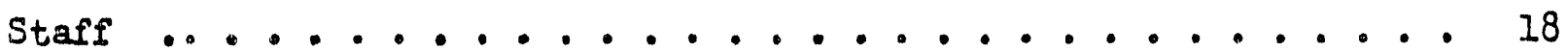

Force Report ... . . . . . . . . . . . . . . 19

Personnel Distribution . . . . . . . . . . . . . . 20

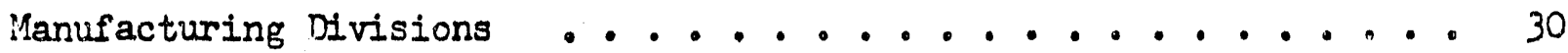

Plant Statistics . . . . . . . . . . . . . . . . 33

Manufacturing Accounting .............. 36

Production Divisions

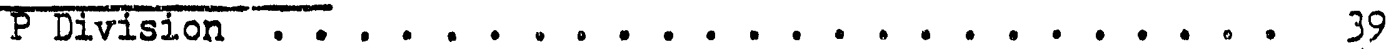

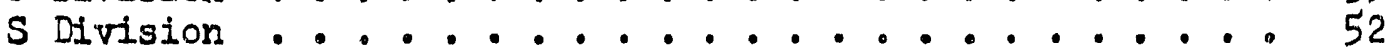

Plant Utilities \& Vlaintenance Divisions

Instrument Division .............. 76

Maintenance Division ............. 80

Electrical Division............... 83

Transportation Division .............. 88

Power Division ................... 93

Technical Divisions . . . . . . . . . . . . . 99

Pile Technology Division . . . . . ........ 103

Separations Technology Division............ 124

Technical Services Division ....................... 140

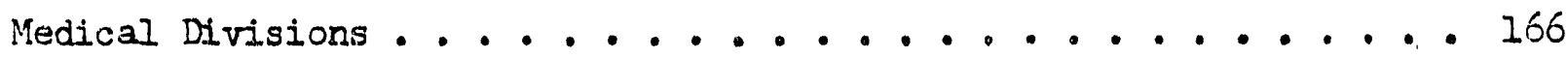

Health Instrument Division . . . . . . . . . . . . 178

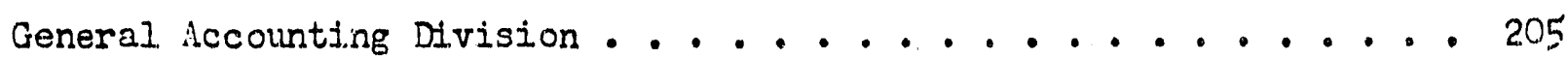

Plant Security and jervices Divisions . . . . . . . . . 230

Purchasing and Stores Divisions . . . . . . . . . . . 266

Employee and Community Relations Division . . . . . . . . 283

Municipal, Real Estate and General services Divisions . . . . . 316

Accounting Division . . . . . . . . ..... 317

Engineering and Contract Division . . . . . . . . 320

Municipal Divisions ................... 328

Public Works Division ............. 329

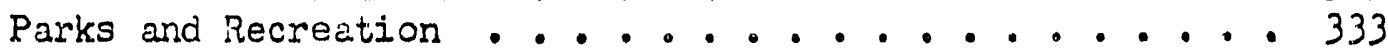

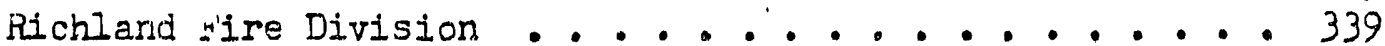

Richland Police Division ........... . . 342

Public jafety livision ............ . . 351

Real Istate Divisions . . . . . . . . . . . . . 353

Housing and Es Estate Maintenance Division . . . . 354

Commercial and Cther Property Division ....... 364

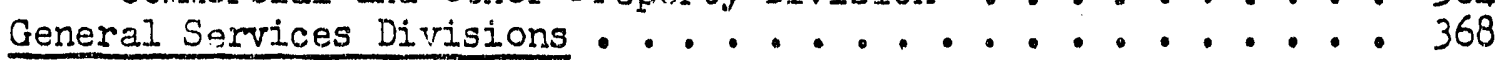

Engineering and Construction Divisions . . . . . . . . 374

Project and Related Personnel . . . . . . . . . . . . 403 
HANFORD WORKS MONTHLY REPORT

General Summary

: MLNUFACTURING DIVISIONS

Production Divisions

A total of 82 tons of metal was discharged during the month at the goal value. The special request program required 220 man hours of P Division time. Ten tubes of special request material were charged into the piles, 9 tubes wero discharged, and 22 casks containing irradiated material were shipped off site. An additional 180 man hours were required for charging, discharging, and shipping of Chemical 68-56.

A new time operated efficiency record of 94.0 percent for five piles was achieved during the month even though there were 34 hours unproductive pile down time due to a planned electrical outage on March 7, and a ruptured P-10 slug or March 22, 1951.

Pile production exceeded that of any previous month by 20 percent. Gains in maximum operating levels for all piles amounted to $170 \mathrm{MN}$ detailed as follows:

$\begin{array}{llllll} & \text { B } & \text { D } & \text { IR } & \text { H } & \text { F } \\ \text { March } & 425 & 395 & 526 & 510 & 4.15 \\ \text { Febinzary } & 415 & 385 & 484 & 500 & 380\end{array}$

The average level overall gain was I32 MN.

A total of 90 tons of acceptable slugs was canned at a yield of 91.6 percent. The machining yield was 80.0 percent. The melt plant produced 16 tons of billets at a record yield of 88.3 percent and a solid metal yield of 93.9 percent. A total of 1200 man hours of overtime work was done by the $P$ Division 300 Area for the du Pont Company.

A total of 1 ill charges was started in the canyon buildings. This production exceeds the previous high by 8 charges and a new single area record of 75 charges started was also established in T Plant. Charges completed in the concentration buildings also represent a new record at 140 regular runs plus 2 acid washes and $5 \mathrm{P}-11$ runs. The previous high was 132 charges completed. The T Plant total of 73 regular charges plus 1 acid wash completed is a new record.

A record total of 149 runs were completed in the isolation building, which included 2 acid washes and 11 special mus. The total material bottled exceeded previous records by approximately 5 percent.

The average cooling time was 60 days with the minimum cooling period for dissolved material being 44 days. The average purity of completed charges was 98.4 percent.

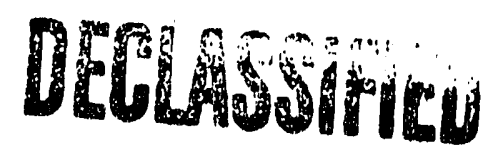


Plant Utilities and Maintenance Dl.visions

The electric power demands for the month were:

$\begin{array}{ll}\text { Irocess }-3-8-51(1: 00-2.00 \text { P.M. }) & 69,550 \mathrm{KW} \\ \text { VIIlage }-3-5-51(5,00-6,00 \text { P.M. }) & 31,100 \mathrm{KW} \\ & 100,650\end{array}$

The process load demand is at a new all time high. The Village peak demand is declining from the Jaruary seasonal high.

There was a planned electrical outage on March 7, 1951 for the completion of the $230 \mathrm{kV}$ temporary by-pass line and other work associated with the 251 substation expansion.

Work on revising the preliminary specifications for our industrial lubricants was completed. These are now ready for distribution to interested oil companies. Before this can be done, however, a procedure must be developed to handle the samples that w1ll be submitted by the oil companies for approval consideration. This procedure must cover the laboratory and field testing of the samples.

At the request of the Atomic Energ Commission, the Transportation Division presented a program on the "Operation of the Transportation Division at Hanford Works", at the March 9 meeting in Richland of the Inter-Agency Motor Equipment Advisory Committee of Oregon and Washinglon. Agencies represented included BPA, General Services Administration, Fish and Wild Life Service, Atomic Energy Commission, Bureau of Reclamation, Corps of Engineers, Bureau of Public Roads, U.S. Forest Service, U. S. Soil Conservation Service, and Bureau of Animal Industry. The program included tours of Richland, North Richland, and vicinity, and prosentation of briefs on Hanford Works Transportation operations, costs, savings programs, et cetera.

\section{TECHNICAL DIVISIONS}

\section{Pile Technology Division}

Problems in connection with the design of the $C$ Pile have requircd the divorsion of effort from some of the longer range programs. Studies undertaken include shielding changes, ball third safety design, coring of graphite channels, improved and increased test facilities, provisions for increascd water flow, and use of enriched uranium.

The programs of investigation of plutonium critical mass, pile lattice design, radiation shielding development, xenon cross section, and test pile measuremonts were continued normally during the month.

Predictcd long term reactivity changes in the $\mathrm{H}-10$ load indicate that losses during the next throe months can be compensated by charging nidturil uranium without the use of additional U-235. Improved xenon poison values from tables prepared by the IBM Computing Group are expected to cnabli more accurate pile reactivity control and balances. 


\section{DECLASNFIED \\ WirTh UEEtilons}

HW 20671

Mcasurements of graphitc samples exposed in the F Pile 1ndicato a burnout rate of 0.6 percont per 1,000 diys in the conter of the pilo at $380^{\circ} \mathrm{C}$. and a build-up of 0.5 percent per 1,000 days in the fringe zone at $105^{\circ} \mathrm{C}$. The genoral program of graphite radiation danage is being axpanded although handicapped by a shortage of laboratory facilitios.

A roviow of the transient watex flow requiranents for the $C$ Pilo was completed and a similar study for the opcrating piles is under way. Installation of flow laboratory equipment for the wator quality study was continued.

Seven in-pile expcrimcnts wore under irradiation during the month, two for plant assistance and fivo for off-site reactor development.

Plant assistance studies of uranium machining and canning directed towards improved slugs wore continued. Examination of a mptured slug in the radiometallurgy laboratory resulted in widespread contanination.

Tritium production was limited to experimental runs. Tosts of the all-metal production lino with intetive gases progrcssed satisfactorily during the month. Construction activitios on projects $P-10-C, P-10-D$, and $P-10-D$, Part II were cortinued.

\section{Scparations Tochnology Division}

A nuw systcm of maturial accountability, which is expected to result in moro nuarly corroct ylelds and material balances, was initiatcd in the soparntions plants during the past month. Production testing of roduced Bismuth Phosphate procoss volumes has been carried to a $30 \%$ volume reduction without significant changes in cither wasto losses or docontamination. Rccent abnormally high hold-ups of product in tho Isolatio. Building nutsches have made it nocessary to institute more froquent leaches and clean-outs. Production testing of direct hydrofluorination of oxilate procipitates in Building $234-5$ has bnen successfully completed and the now procoduro is boing given a trial in the plant. Reccnt difficulties with hi.zh lanthanum content of plutonium castings wore corrccted by changing the addition f Chemical 70-58 back to Casting from Reduction.

In Redox and TBP procoss dovolopment, Technical Manual preparation has continued to 69\% completion of the Redor Manuel and 16\% complction of the TBP Mamal. The first group of 20 "S" Division supurvisors and 28 opurators has completid ts six-wecks operations trairing assignmont in Building 321, and a socond group is now being trained. The prozram of assistance to ORNL Purcx process design has bcen carricd to the point whcre the design of the lurox columns can now be scopedo Enginoering development studies are continuing on Production Plant pumps and matorials of construction. The lump sum construction of the Hot semi-works was started during the month, with oxcavation for the Hot Process Building approxime.tely 60\% complite at month's end.

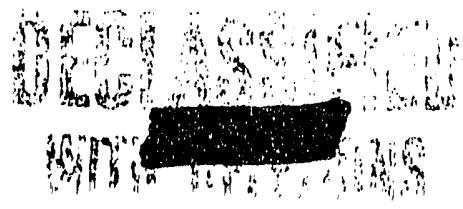




\section{UEE HarewiED}

HW $20671-$ Del

In the research laboratory, studies have been continued on the use of scavengers for the decontamination of Bismuth hosphate first cycle supernatants, concentration of Redox final product solution and its coupling to metal production, and the recovery of plutonium from $234-5 \mathrm{slag}$ and crucible wastes. ifforts are being made to improve the methods of scavenger separation in the Redox process. Additional fundamental investigations have been carried out in the stability of TBP, pulse colum mechanisms, and the effects of head-end treatment on Purex process decontamination. Supporting studies for the P-II Critical Mass Project have also been carried out.

Further study of the proposed skull recovery process has uncovered improved methods of skull dissolution. Continued investigation of the number of peroxide cycles required to obtain tho required plutonium metal purity has succeeded in narrowing impurity problems to only a few elements. Laboratory Reductions with sulphur instead of iodine used as the booster have given vields only slightly below those nornally obtained with iodine. Further investigation of methods of oxalate iestruction for supernatant recovery is being carried out in the laboratory.

The program of investigation of the concentrations of ammonia and oxides of nitrogen in the Dissolver off-gas during the change-over from coating removal to metal dissolution has indicated that the previously suspected formation of ammonium nitrate in the Silver Reactor and Fiberglas filter is extremely unlikely. A spot check of the I 31 removal efficiency of the $4-5 L$ Silver Reactor at $B$ Plant during the month indicated an efficiency of $99.9 \%$.

Technical Services Division

In automatic rezorder has been installed on the' mass spectrometer used for $\mathrm{P}-10$ process sanple analyses, and has been used in the routine analysis of 309 samples during the month. Although not offering greater speed, the unit does give more information and in a recorded form. A review of the completed spectra reveals that about 26 methane is present in out-gas samples but not in other extracted fractions. A 50 foot section of copper tubing has been connected to the mass spectrometer head to allow stuily of direct in-line analyses and has given promising results.

Mass spectrometers for the isotopic analysis of uranium oxide recovered from tho Redox and Metal Recovery Processes are being ordered. The original instmument specifications were altered to allow delivery of these instruments by September 15, 1951 .

A series of six plutonium nitrate solutions has been analyzed for $\mathrm{Pu}^{240}$ with the recently installed spontaneous fission counter. The values obtained are in reasonable agroement with those calculatcd by the Pile Physics Scction, and with exporimental data obtained in the 231 Building laboratory indicating the presenthly cmoloyed isotopic correction factors to bc in error.

A modificd exuraction-spcetrochemical procedure has bccn introduccd into control practice for tho determination of impuritics in plutonium motal. Although the proceduro is still difficult and subjcet to uncortaintics, more accurate results will be outaincd by tho use of optimum conditions of spectrographic exposure end by tho use of riferunce standards that have bcen processed through the entirc analytical procodure.

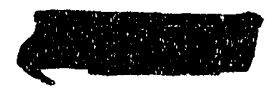




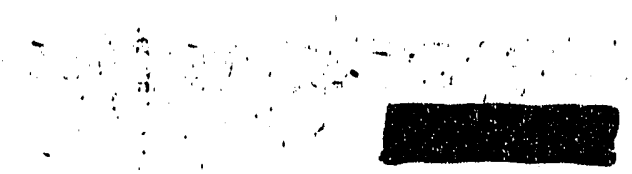

An Investigation of infrared absorption techntques for the determination of carbon monoxide has yielded an accurate procedure that will prove to be of assistance to Pile Technology Division projects for the study of in-pile experiments on graphite reactions and the rate of graphite burn-out. Observations of value to in-Iine monitoring include a method for making airtight seals of cell windows on the absorption cell and the effect of inert gases on the absorption by carbon monaxide.

Final design of the Fadiochemistry Bullding was completed by the Leland S. Rosener Company on schedule, aid most questions regarding it had been resolved by monthend. An A.E.C. directive modification was received, authorizing the constmuction of this bullding and raising to $14,680,000$ the total expenditure authorlzed for this new Works Laboratory facility.

Close fleld Jialson continued on the new Redox Analytical \& Plant Assistance Laboratory, cunstruction of which was $95 \%$ complete by month-end. Several special tongs and a slave-type manipulator were designed for the multicurie cells' in this new laboratory, and these are being fabricated in the Technical Shops. Development of Junior Cave and gloved box accessories for use in this building also was continued.

A.E.C. D1rective No. HW-219 was modified to cover the design and construction of the rescoped Iibrary and Files Building. The design of this facility was subcontracted to the C. T. Main Company (of Boston), which A-E firm also has the Pile Technology Butlding. Good design progress was reported for both of these facilities.

The Dix Steel Company (of Spokane) broke ground on the Phase I construction of the Mechanical Development Building in the Works Laburatory Area, and made good progress on the footings for this prefabricated steel structure. A Part 2 Project Proposal covering the interior construction (Phase II) of this building was approved by the A \& B Committee and forwarded to the A.E.C. Commission consent was obtained by Engineering and Construction for the negotiation of a lump sum design and construction subcontract for this Phase II work with the Dix Steel Company. The required design criteria are being prepared.

At P1le, Engineering Section request, a statistical study was begun of panellit pressure readings for the H-10 loading to see if the rupture of P-10 lithiumaluminum alloy slugs can be predicted and prevented. Another study of the expected exposures of tubes in the H-10 loading in tre production piles was made by the Computing Laboratory. Considerable statistical effort was devoted to the study of isotope correction factors and chemical assay-radioassay ratios in connection with analytical control of the separation process.

The Technical Information Group resolved several Hanford questions in connection with the forthooming A.E.C. revision of the Standard Distribution Lists for research and development reports. Arrangements also were completed for treatment of the files in the Schenectady Office (of the llucleonics Department) as a branch of the Hanford Classified Files, with local accountability for all classified documents transmitted thore.

HEALTH INSTRUT ENT DIVISTONS

There were three informal investigations and one Class I investigation of special hazards incidonts. 
The control programs of all the divisions showed no result significantly different from the expected pattern, except in the increased release and deposition of $I^{13 I}$.

The development division appeared to have proved specifically the production of tritium in the $\mathrm{P}-13$ experiment, beyond the concentrations suggested by the current physical constants. Further investigation of this interesting problem would be outside the responsibilities of the division.

The biology division reported several experiments suggestive of ways in which tritiatod water may be introduced into the body, and how it would be utilized by the body. The fish laboratory work tonded to confirm the previous interprotation that pile effluent was more toxic as a chemical poison than as a radiological one.

\section{PLANT SECURITY AND SERVICES DIVISIONS}

There were no major injuries during the month. The major injury frequency rate was further roduced to 0.25 for the yoar to date.

The Hanford Works of the Coneral Electric Company was doclared the winner of the AEC Safety Improvement Contest for Group I in 1950.

There were no industrial firos during March.

Laundry volumo decreased slightly in tho plant laundry and remained approximatoly the same in the 700 irea Inundry.

Volumc of work deminded of the CIErical Sorvices group continued to increase.

All records have now been transferred from $712-A$ and $712-B$ Hutmonts to the Rccords Sarvice Centor.

Mothods and forms control activities resultod in ostimated savings of 16,734 of which 14,308 will be on a recurring annual basis.

A joint AEC - GE sccurity cducational program was begun this month.

\section{EMPLOYEE AND CONTUNITY REIUITIONS DIVISIONS}

The number of apnlicants intervicwed decreased from 1,934 in February to 1,671 in March. Of these applicants, 712 were individuals who applicd for omploymont with the Goneral Elactric Company for the first time. In addition, 821 ncw applicants submitted applications through tho mail. Opon, nonexempt, nontechnical requisitions increascd from 548 at the beginning of the month to 621 at month cnd. Total plant roll increased from 8,027 to 8,080. Turnover rate incroased from $1.73 \%$ in Febmary to $2.38 \%$ in March. During March, 70 new requests for transfers to othcr type of work wero rcceived by the Employment Office, and 63 transfurs were offcted. During March the imploymont office again remained open on Saturdays, with the rosult of 375 applicants being intervicwed on those days, of which 206 wore new applicints. Of thesc, 79 wcre placed in process and 30 othcrs arc under consideration. During March, advertiscmants wuro placed in 17 Pacific Northwest nuwspapcrs on 15 different dates, and spot radio announccmonts woro given over 14 local radio stations fivo timcs wokly. Field recruitmont was conducted in Portland, Oregon, for draftsmon and dosignors, and for cost and accounting clcriss on March 19, 20 and 21. 
There were 255 applicants interviewed, of which 20 were made offers and $3 \dot{u}$ wre being given active consideration. Lower Columbia Junior College, Longview, Washington, was visited on March 22, 1951, and 5 laboratory assistant candidates were interviewed, Offers were made to 2 and the others are being considered.

During March, four employee deaths occurred and four employees retired. Two hundred and five visits were made to employees confined at Kadlec Hospital, and 67 salary checks were delivered to eriployees either confined at the hospital or at home. The plant Red Cross Drive was completed on March 16, with employees at Hanford Works contributing $114.8 \%$ of the $\$ 13,650$ quota established by the County Chairman. During the month, 54 letters were written to employees relative to the new ruling of the Pension Board concerning the survivorship options. At the end of March, there were 737 employees registered under the Selective Service Act and 653 military reservists on the rolls. Since August 1 , 1950, 117 employees have terminated to enter military service. At month end, participation in the Pension Plan was 95.5\%, the Insurance PIan $95.3 \%$, and the Employee Savings and Stock Bonus Plan 37.5\%.

A total of 23 supervisors attended the 40-Hour Training Program during March. PMS Groups 13, 1.4, 15 and 16 met during March. The 8-hour Nonexempt Training Program was held on March 9, 1951, with eleven "S" Division employees in attendance. During the months of February and March, a total of 228 meetings, or 76 complete series of conferences, on "How Our Business System Operates" was made available at Hanford works. A total of 785 people, or 4l. $3 \%$, participated in the three-session program. A schedule will be prepared for presentation of HOBSO to nonexempt employees in April. During March, orientation was given to 4 re-engaged, 5 transferred, and 216 new employees. Re-engaged and transferred emplovees indicated $100 \%$ participating in thi G-E Insurance PIan, and $89.8 \%$ of new enployees signed to participate. A net of 16 copies of the Supervisor's handbook on Employee Relations were distributed during March. Thirty-two Handbooks were turned in and re-issued. Section 1.7 was revised and distributed to Handbook holders during the month of March. Twenty-four copies of the book, MEN IND VOLIS were sold. "Let's Talk It Over" discussions wore held at the time of Annual Ratings with exempt members of the Training 3 taff.

A total of 90 news releases were written and distributed during March, 63 of which were sent to the "local list", and 27 were sent to the "daily list". During the month of February, 360 column inches were printed of news concerning Honford Works in newspapers throughout the Northwest.

An instruction letter defining the responsibility for the release of information at Hanford Works was distributed.

A magazine article about the Health Instrument Division, with photographs, was sent to the MONOGRAM, and will appear in an sarly issue:

A survey was conducted during the month to determine whethcr or not Richland businessmon and ministers and oducators would like to receive a "Community News Letteri", to be put out by Community Relations. Of the 30 percent returns from the survoy, the majority indicated that they would desiro to receive the news lctter, which will be produced and distributed rogularly in the near future. 


\section{DUUASFIFE}

nhe News Bureau Supervisor, Editor of the Works News, and the Community Relations Supervisor addressed Journalism students at Columbia High School on the subject "Journalism's Part in Employee and Fublic Relations". An invitation was extended for students to visit the Community and Public Relations Division, in the near future, and put out a section of the Works News.

During the month, a meeting was held with presidents of the local Kiwants, Rotary, and litons Clubs to outiline a suggested procedure for presenting HOBSO to RIchland residents.

Civil defense Information was released to residents through local newspapers, radio stations, and the Works News.

Five speeches were delivered during the month by G-E employees. Twenty-one hand prints and 11 glass slides were prepared for two of the speeches.

Arrangements were completed during the month for the Employee and Conmunity Relations Divisions Manager's presentation of HOBSO before three groups in Portland.

Arrargements were made for use of the 4 EC Security darkroom on a temporary basis by one employee of the Photo House until more space is made available. The congestion in the Photo House darkroom was thus relieved sufficiently to allow handling of the increased volume of requests for services being received from Hanford Vorks Jivisions.

Black and white photographs, $16 \mathrm{~mm}$ color motion pictures and $35 \mathrm{~mm}$ color slides were made of the IIIC Bafety Award Ceremony.

One hundred three general photo assignments were completed during the month, involving the production of a total of 7,298 prints.

Services by Special Programs to Union Reiations included a letter to all H. W. patrolmen and Richland policemen concerning the representation election; and the iNorks News column "Union Relations News" which appeared twice.

A 12-page booklet, "Lets Get Acquainted", was produced for distribution to hospital patients by Kadlec Hospital.

A public relations outline to accompany the current construction and inprovement program at Kadlec Hospital was drawn up and put into effect. It includes meal tray cards, inserts for the now patients' booklet, a four-color hospital floor plan for the lobby showing the improvements being made, and a newspaper photo of the "ground breaking ceremonies".

Publicity carried in the Norks News included: Red Cross Drive, metering of electricity in Richland, the need for rooms in homes of employees to house new employees, civil defense activities, employee benefit plans, suggestion system, and the need for certain classifications of employees at Hanford works:

Four women's pages appeared in the Hanford Works News during the month. They featured the YWCA Suppor Club, recipes, Spririg fashion forecast, and spring housecleaning.

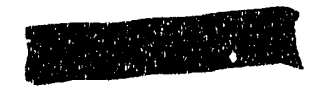


The women's activities feature writer supplied a feature story with pictures for the Norks News on the new North Rlchland teen-age center. This writer also completed a double page feature for an Aprill issue of the Works News on the new Records Service Center in the 700 Area.

In an NLRB conducted election on March 23, 1951, the Richland and North Richland Police and Plant Security Guards voted in favor of representation by the International Guards Union in collective bargaining matters. The NLRB gave notice on March 7. that proposed union shop election had been postponed. A hearing was scheduled in the case of the Village Firemen for April 4. The HAMIC-GE contract was not reopened.

On March 22, the Davis Panel requested further negotiations at the local level on the isolation pay issue. Negotiations with Painters concluded March 14, granting ten cents an hour effective December 9, 1950, and seven cents an hour effective llay 1, 1951. A new premium of fiteen cents an hour was agreed upon for work on Swinging Scaffold or Boatswains Chair. It is reported that the Teamsters will hold representation and union authorization elections in the near future. Puget jound Sheet Metal (Seattle), itkinson-Jones vendor, is faced with the possibility of a strike on April 2. They are to furnish and erect 19 tanks. This ol'fice is prepared to assist in the event an actual work stoppage occurs.

Compiled data of the Northwest survey was completed and sent to Printing. Also completed was the special Pacific Coast Design and Drafting Wage Rate Survey. 1 case was prepared for presentatios to Wage Stabilization Board for Increased rates for Designers and Draftsmen, the classification of Chlorinator Serviceman, and a plan for granting merit increases to Designers. The survey of non-unit clerical jobs in the Medical livision was completed.

\section{PURCHASING IND STORES DIVISIONS}

The number of purchase requisitions received and assigned was 3,900 as compared with 2,848 in the previous month.

The dollar value of orders placed during the month amounted to $\$ 2,794,475.18$ as compared with $\$ 2,397,876.82$ for the previous month.

Alterations to purchase orders as a result of design changes and material substitutions increased $35 \%$ during the month. It was necessary to requisition additional personnel to handle this additional work load.

Claims from vendors totaling $4: 150,000$ as a result of design changes were received. At month end thorough review and analysis of these claims was under way.

The Initial requisitions for Project $\mathrm{C}-43 \mathrm{I}$ were received and at month end orders had been negotiated for all of the misonite requirements, all the reinforcing steel requirements and a portion of the structural steel requirements.

Beciuse of limited funds approved for Project C-43I, the Purchasing Division arranged to submit a daily reporti of commitments to rcspective Technical, ingincering and Construction managers. 
An order originally placed by the University of California for 300 vacuum tanks was taken over by the Seneral Electric Company for the P-10 Program.

Contracts were awarded for our requirements of oxygen and acetylene gas.

Escalation clauses in coal contracts were invoked by the suppliers due to increased wages effective February 1, 1951 . As a result, the Continental Coal Company contract was cancelled and price increases allowed to the BairCollins Company and the Kemmerer Coal Company.

The inspection work load continued heavy on fabricated equipment for the Redox and TBP Frograms.

It was necessary to place additional bulk orders for stainless steel for Projects $\mathrm{C}-36 \mathrm{I}$ and $\mathrm{C}-362$ due to failure of the Kellex Corporation to make complete take-oifs at the time the initial orders were placed.

The work load with respect to priorities and allocations increased substantially. Several of tre more critica? materials ale now under allocation which necessitates keeping detailed records in accordance with NPA Regulations.

The number of purchase requisitions processed through screening was 3,383 , with the rcsult that $2,545^{\circ}$ items were supplied from project inventories thus obviating the necessity of expenditure of new funds by purchasing from outside sources.

There wore 86 items of stainless steel not immediately available on the open market and were supplied to our fabricators from project inventories to expedite delivery of critical vessels.

Maintenance materials and supplies valued at $\$ 262,451.15$ were disbursed from operations inventories.

Materials and equipment valued at $\$ 215,891.79$ was disbursed to construction forces from inventories of Construction Materials Held for Possible Future Use. In addition, materials valued at $\$ 31,177.60$ were disbursed for use in operations and matcrials valued at $\$ 72,770.62$ were declared excess from this same account.

Material and equipment valued at $\$ 80,085.14$ was withdrawn from excess inventories for use on the project. Of this amount, $\$ 75,962.46$ was for construction.

$5,054,512$ board feet of excess lumber was shipped from the project at the direction of the Commission.

A decision was reached by the Commission that they would handle the contracts for construction of the new Central Varehouse facilities and at month end they werc negotiating an architect-ongincering contract covcring functional. study and finc.l design.

Thirty represcntatives of the government, and private business were escorted. through our warchouscs and scrap yards for the purposc of negotiating sales of scrap and transfer of surplus propexty. 
Scrap sale revenue for the month was $\$ 24,564.93$.

The Uni ga Paciflc Railroad changed their time of delivery to the project thereby providing an additional 24 hours of free time for loading and unloading cars.

The Interstate Commerce Comission, on March 14, granted the railroads a freight rate increase of $4 \%$ withtn Eastern Territory, $2 \%$ within Southern and Western Territory, and $2 \%$ interterritorially among the three territories which resulted in a maximum increase on coal of 6 cents per ton.

As a result of rate reductions obtained from carriers, a total savings of freight rate charges for the month anounting to $\$ 16,145.28$ was effected.

\section{MUNICIPAI, REAI ESTATE AND GENERAL SERVICES DIVISIONS}

The Richland Investment Company building commenced operation on March 30 , 1951, with the following businesses as sub-lessees; McKay's Jariety Store, The Wren House, Wiley's Shoe Repair Store and an optometry office operated by Dr. Charles it. McCartney.

Total housing anplications pending - 508 .

\section{MEDICAI DIVISIONS}

An epidemic of influenza which reached a peak during the month has almost endel. It influenced a.ll phases of medical activity. About 15: of the popuiation was involved according to a rough estimate.

The operating room supervisor attended a 5-day institute on operating room techniques at Santa Monica, California, for one week.

Dr. Herman imith, consultant on the Kadlec Hospital construction krogram, was here on March 10 and 11.

Miss C. Kinney, University of Washington School of Nursing, visited the division of Public Health.

Employee physical examinations increased from 2,346 to 2,817. Dispensary treatments increased from 7,894 to 9,161 largely due to a high incidence of influenza among employees.

New equipment for the more scientific testing of hearing and seeing was obtained and will greatly improve these phases of employee physical examinations.

Cancer was the health topic for the month.

Sickness absenteeism (weekly employees) for March increased by $1.49 \%$ to $3.92 \%$ while total absenteeism increased by $1.61 \%$ to $4.65 \%$. This is the highest monthly rate of sickness absenteeism since the beginning of operations here and was due to the epidemic of influenza. 
The average daily census at Kadlec Hospital incroased from 102.3 to 112.0 (97.7 adults, 14.3 infants). The census was 86.4 a year ago. This is the highest infant census over recorded at Kadlec, 90 deliveries being made. The high adult census was partially due to the epidemic of influenza. The adult occupancy rate was $94.9 \%$. The rate for the mixed services (all services except obstetrics) was 100\%. The very high occupancy rates for the past several months indicate a need for more adult beds at Kadlec. A modification of the scope of project $\mathrm{C}-20 \mathrm{C}, \mathrm{A}, \mathrm{B}$ is being requested to allow for adding more bed space at Kallec with whatever funds remain after completion of the project in its present scope. Dr. Herman 8 mith, our hospital consultant, concurs in this recomendation.

The Public Health Division arranged for a regional meeting of the Washington State Public Health Association, with about 64 local and out of town people in attendance. This was the first regional meeting of this type to be held in this state and received commendation from the state organization.

The net cost of operating the lledical Livisions, before assessments to other divisions, was $\$ 82,415$, a decrease of $\$ 9,403$ and $\$ 7,876$ below the budget figure.

The improvement resulted in large part from the (1) lower salary costs due to the shorter month, (2) decrease in transferred charges from other divisions which more than off'set (a) lower assessments to other divisions and (b) a small decrease in revenue. The revenue was high because of a higher average hospital census thar was anticipated.

\section{GENERAL ACCOUNTING DIVISION}

Volume of work handled in the Accounts Pisyble Section during March, 195'1, exceeded that handled during any month since decentralization of the Accounting Hisisions in 1948. In spite of the shortage of personnel, 211 invoices were paid when due and were promptly audited and forwarded to AEC for final approval. As of larch 31, 1951, total vouchers on hand and in process, including those paid and unpaid, numbered 1,513. This represents approximately $58 \%$ of the number currently received in one month. Final audit of approximutely 20,000 purchase order f'olders which contain information as to quantities recelved and amounts paid is being deferred until additional personnel is made available. This audit is necessary before these files can be forwarded to permanent storage.

Revision of budgets for FY 1952 and preparation of budgets for FY 1953 progressed during the month. As budget datc was received from division heads and coordinated by the Sudget Accounting Section, a close working arrangement was maintained with the AEC budget office. As a result, AEC recommendations and questions were considered as the work progressed and preliminary approval was obtained on a considerable amount of completed work.

As a result of the Incorporation of Froject Engineoring with Engineering and Construction Divisions, bases of all assessment studles were thoroughly reviewed and revisions were made where necessury. 
Arrangements were made for the segregation of work and selection of employees who are to be transferred to Technical, ingineering and Construction Divisions. Work substantially comprises compiling, analyzing and reporting Technical operating and research and development costs and related budgets. A total of seven employees ( 3 from Cost, 2 from Budget Accounting and 2 from Acrounts Payable) are to be transferred.

Plant Accounting personnel is in process of reviewing depreciation rates of several classes of plant and equipment. Rates were established at the time of the plant appraisal in June 1949, and in many instances it has become apparent that revisions to rates originally established should be made. Plans were nearing completion relative to the assignment of Plant Accounting pcrsonnel to the aroas where they will be rosponsible for coordinating work in connection with plant accounting. Continuing physical inventorles of certain types of equipment are also to be conducted by these employoes.

Internal Auditors started work on two new sudit programs in March; namely, Standardization of Inventory Sub-Accounts and Physical Inventory and Booking of Spocial Materials. The following audits are currently in progress: Timekeoping Procedures, Hospltal and Bus Rovenue, Receiving and Shipping, State Excise Tax, Physical. Inventory procedures and Study of Tormination Clearance Procedure. Audits were completed and reports issued on Revilew of Proposal to Purchase Marine Insurance Policy and Revenue and Change Funds of School of Nuclear Engineering.

Request for roimbursemont authorization covcring the Emergency Loan Plan for ill or laid-off pension participanis was transmitted to the Commission on February 28, 1951, and Reinbursemen: Authorization No. 142 dated Larch 26, 1951, was issued by the itomic Inergy Comission approving the plan for reimbursoment effective February 1, 1951. Hanford Works Instructions Letter No. 166 was issued in March covering the provisions of the plan, which was placed in effect as of February 1, 1951 on a company-wide basis.

Payroll deductions for Red Cross contributions amountcd to $45,388.85$. Deductions were made in March from salaries of 1,122 weekly paid employces and 603 monthly paid employees. A check covorlng these collections will be issued to American Rcd Cross and forwarded to the chairman of the Nucleonics Dopartmont Rod iross Drive.

The retroactive portion of the $3 \%$ Gencral Salary Increase (minimum $4 \phi$ per hour) applicable to July 2, 1950 rates, effective September 18, 1950 for employees repr scnted by the H.M.M.T.C. and for cmployeses represcnted by Local 201, Building. Trades Service Employees Union, was paid during the month of March. The retroactive paymont covered the poriod September 18, 1950 through Fobruary 11,1951 amounted to $\$ 147,894.74$ and was paid to 3,332 umployeos.

There are $135 \mathrm{cmployecs,} \mathrm{as} \mathrm{of} \mathrm{March} \mathrm{31,} \mathrm{1951,} \mathrm{who} \mathrm{have} \mathrm{left} \mathrm{the} \mathrm{Company} \mathrm{to}$ enter the irmed forces of the inited Statcs. Military Duty allowance equivalent to one month's salary has been paid to 36 weikly paid cmployces and two monthly paid umployoes totaling "il, 481.52 as oi March 31, 2951. 
The high percontage of absenteelsm during March was also reflected in an increase in the number of disability claims processed under the G.E. Insurance Plan. Absences of payroll personnel in March and the high percentage of absenteeism in all divistons, which increased the work load in the Weekly Payroll, made it necessary to reschedule many of the statistical reports and related payroll work in order to complete oalculation and distribution of payrolis according to normal schedules.

Advances from AEC Increased from $\$ 5,000,000$ as of February 28, 1951 to $\$ 6,500,000$ as of March 31,1951 . Advances are accounted for as follows:

$\begin{array}{lrr} & \text { March } & \text { Fetruary } \\ \text { Cash in Bark - Contract Accounts } & \$ 5596364 & \$ 4470490 \\ \text { Cash in Bank - Salary Accounts } & 50000 & 50000 \\ \text { Cash in Transit } & 428636 & 79510 \\ \text { Advances to Subcontract,ors } & 300000 & 300000 \\ \text { Travel Advance Funds } & 125000 & 100000 \\ \quad \text { Total } & \$ 6500000 & \$ 5000000\end{array}$

Hanford works cash disbursements and cash receipts, excluding advances from Atomic Energy Commission for the month of March 1951 as compared with tebruary 1951 may be summaxized as follows:

Disbursements

March February

Material and Freight - GE

Payrolls - GE (Net)

Payments to Subcontractors

Pension Trust Fund - Company Portion

Payroll Tax

Goneral \& Administrative expenses

Stock Bonus Flan - Employers contribution 168451

U. S. Savings Bonds

Others

Total

$\$ 23800 \%$

2530812

4015533

$-0-$

396907

200000

140325

409811

$\$ 10241909$

\$ 124.438

11308

51598

$40 \quad 277$

18265

21 340

9315

24236

1212

10684
313273

$\$ 9928 \quad 636$

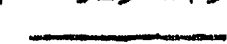

Other

Total

Net Disbursements

Recejpts

Refunds from vendors

Income from special funds

Miscellaneous Accounts Receivable

Scrap Sales

-type contractor
$\$ 2 \quad 35 ; 419$

$197 \% 441$

3611335

1213300

434035

200000

-0 -

143156

364775

$\$ 10292461$ 
General Manager ............... G. R. Prout Manager, Schenectady Office ............ B. R. Prenticu Assistant General llanager .............. F. K. IlcCune Assistant to the General Manager ............... I. Patnode (Technical and Education Matters)

Assistant to the General Manager ............... R. Rue Assistant to the General Manager and Manager of the Plant jecurity and Services Divisions ...... G. G. Lail Department Comptroller ............... F. E. Baker Counsel G. C. Butler

Manager, !lunicipal, Real Estate and General Services Divisions ....................... F. Huck Manager, Engineering and Construction Divisions ...... R. E. Daviscn Manager, Manufacturing Divisions .......... C. i. Gross Manager, Technical Divisions ................. Greninger Manager, Health Instrument Mivisions ......... H. M. Parker Manager, Medical Division ................ D. Norwood, M Manager, Employee and Community Relations Divisions ..... H, E. Callahan Manager, Purchasing and Stores Divisions ......... ... Jeffrey

\section{DECLASSFFED}




$\frac{\text { HETANPT }}{2-28-513-30-51} \frac{\text { NON EXXIMPT }}{2-28-513-30-51} \frac{\text { TOTAL }}{2-28-513-30-51}$

GEMTRAI

IAW

ENGR. \& CONST. DIVISIONS Construction

Const. icetg.

Design

No. Richland Realty

Proj. Engr-MJ

Proj. Engr-MD

MANUFACTURING DIVISIONS

MfE. General

$\mathrm{MPB}$. Acctg.

Industrial Engr.

Plant Utilities \& Maint.

Power

Maintenance

Electrical

Instrument

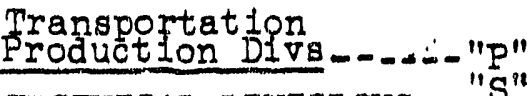

TECENICAL DIVISIONS

Administrative

Plie Tech.

Separations Tech.

Technical Services

MEDICAI

HEAITH INETRUMENT DIVS.

General

Operational

Development

Biology

ACCOUNTING DIVISIONS

EMPI. \& COMM. EEIATIONS

PLANT SEC. \& SERVICES

Patrol \& Sec.

Safety \& Fire

Gen. \& Off. Services

PURCEASING \& STOFES DIVISIONS

Purchasing

Store日

COMMUNITY DIVISIONS

TOTAI
19

20

2

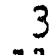

11

235

17

50

52

31

31

.50

51

2

3

2

5

4

15

7

0

88

56

54

54

60

146

4

115

106

132

48

2
10
230
17
40
52

38

62

211

97

36

78

25
63
232
96
31
76

41

73

446

114

86

130

27

73

462

113

71

128

56

4
55
6

20

63

17

13
7

23

92

54

53

55

58

152

4

116

?.05

730

483

341

249

223

548

290

456

26

37

240

45

240

480

326

246

231

556
288

469

2

1.00

42

$? 31$

237

571

397

303

277

608
367

602

6

211

143

288

288

282

6

54
42

34

25

36

6
54
42
32

3
171

$-76$

42

4
174
79

79

43

29

11.8

76

164

188

189

65

71

101

107

54

38

23

562

107

577

106

232

616

145

247

633

148

255

59

69

18

86

94

203

145

235

163

216

444

664

655

208

211

456

6078

6120

8027

8080 


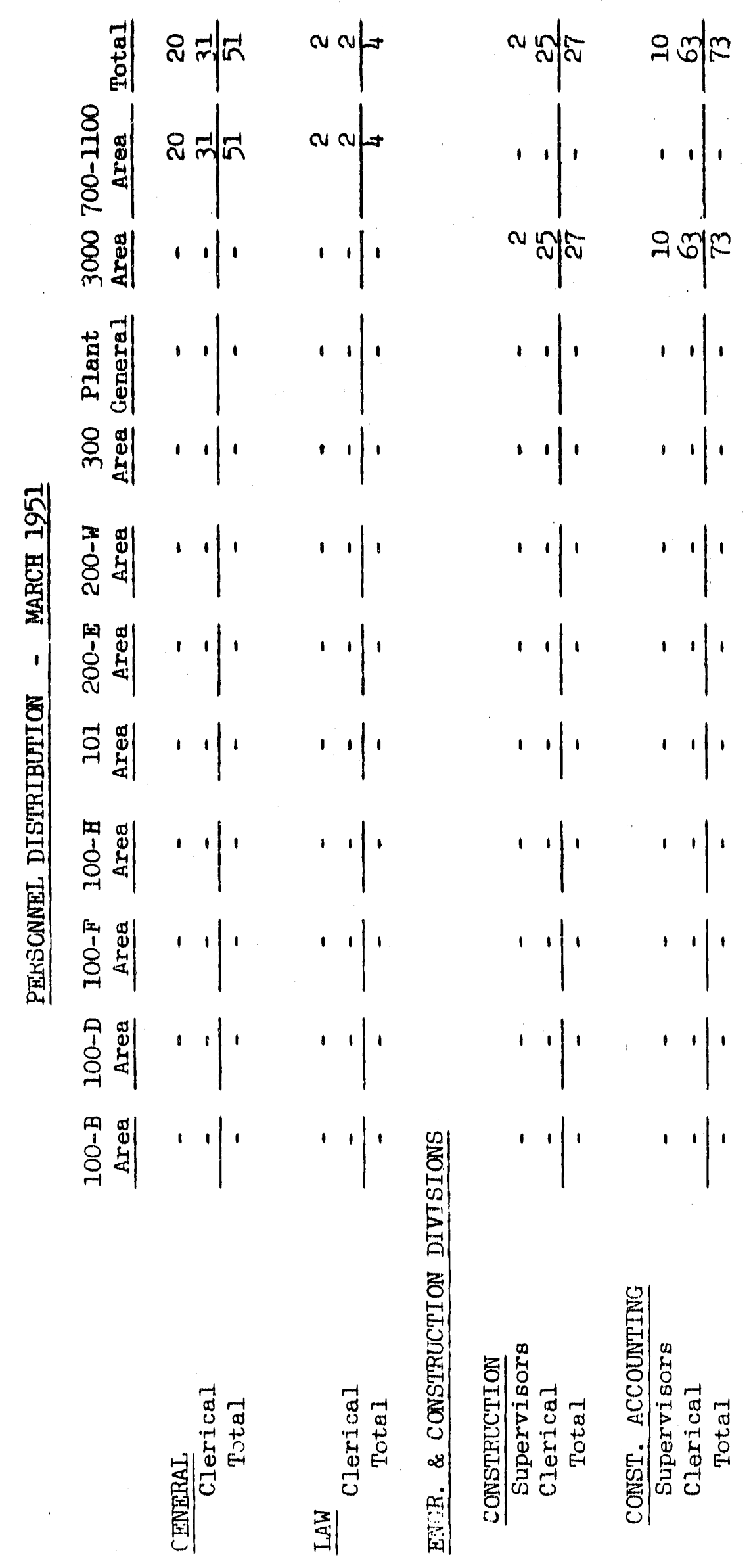




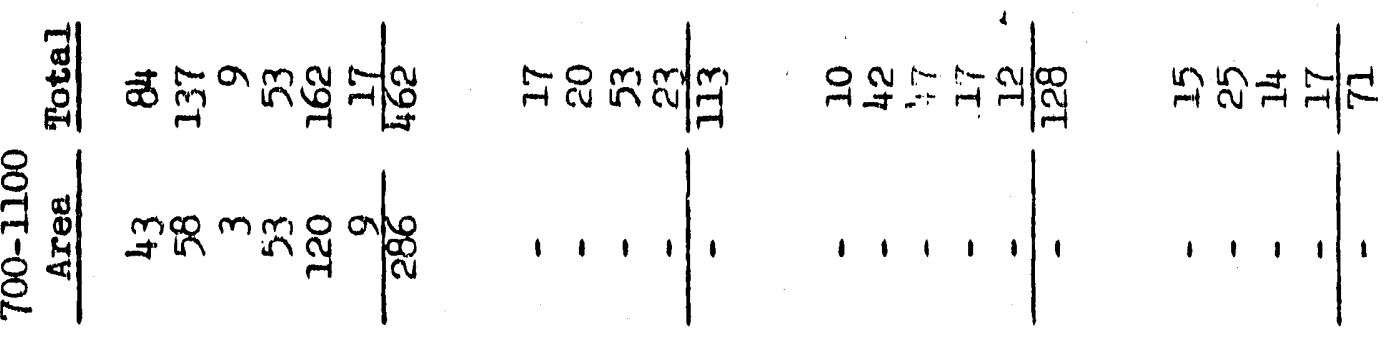

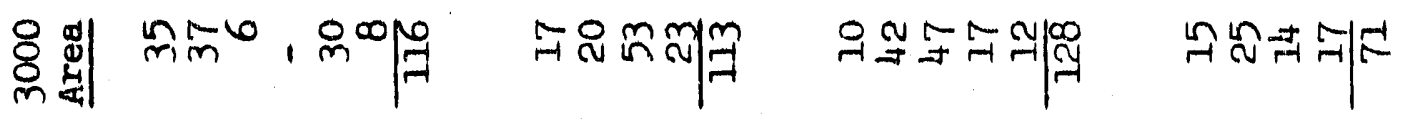

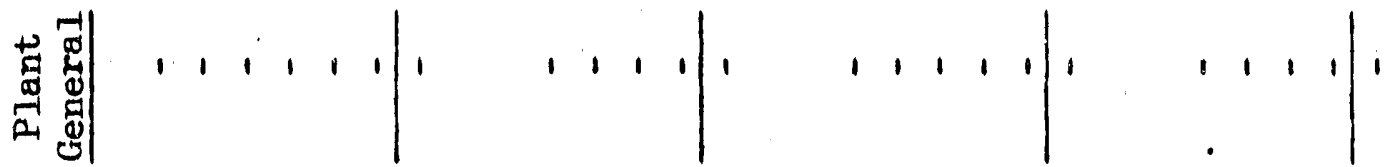

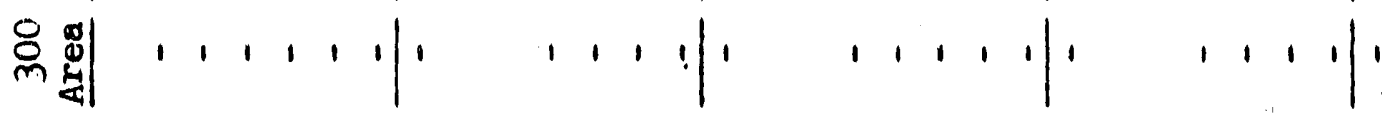

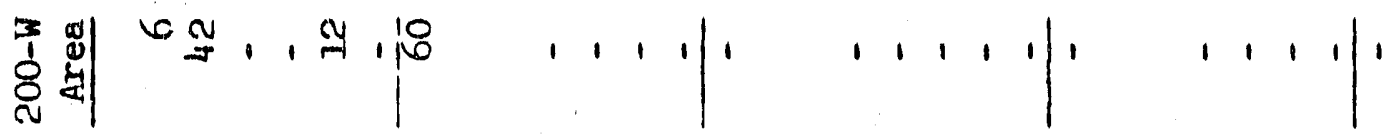

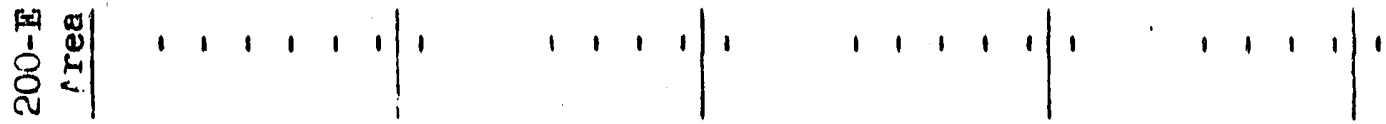

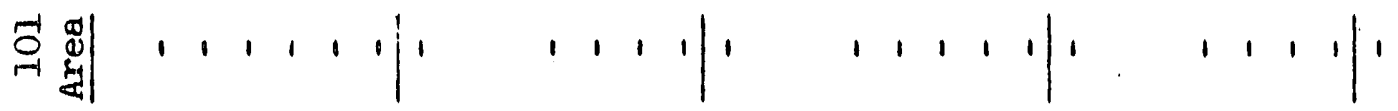

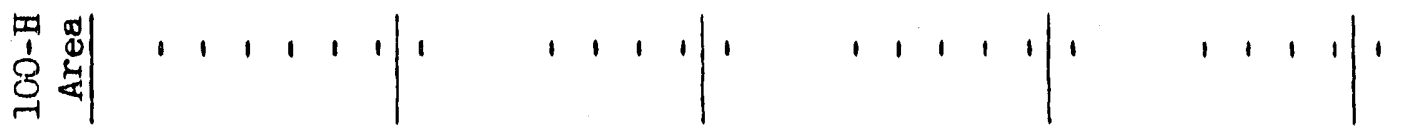

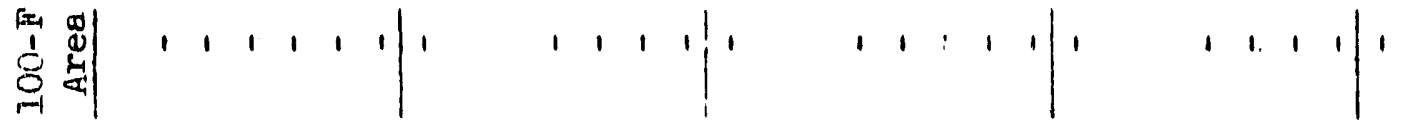

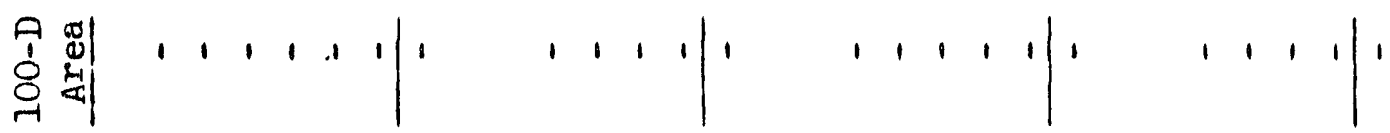

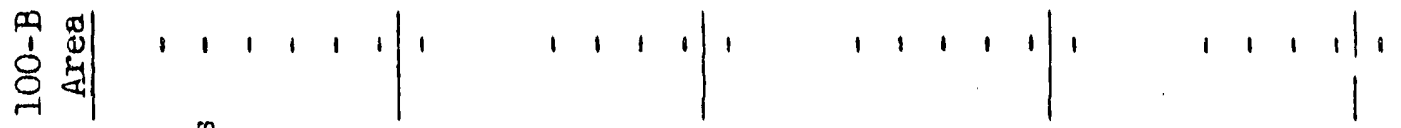

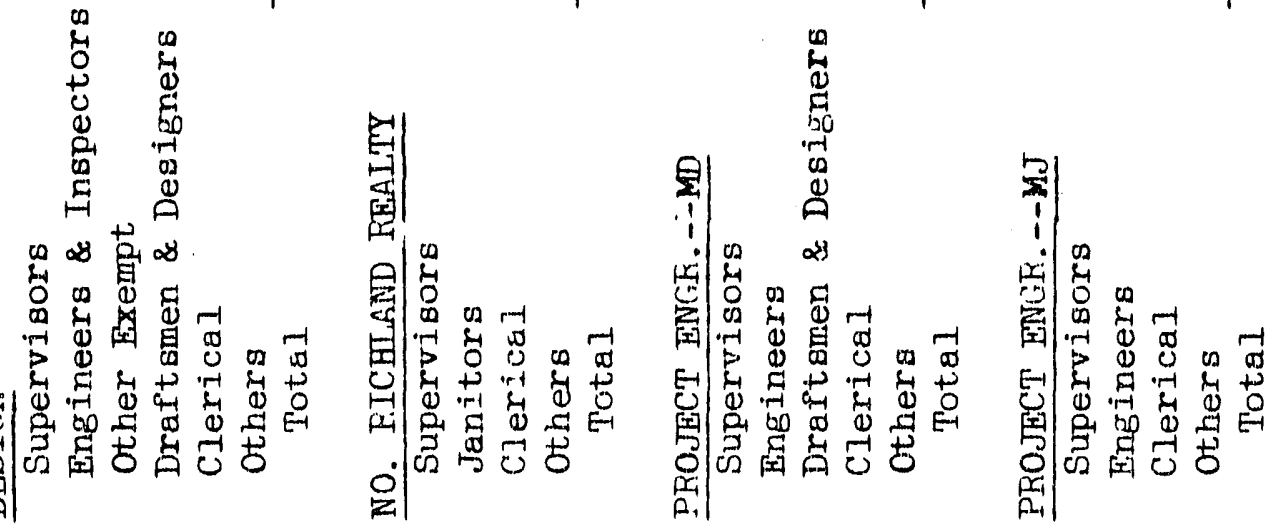



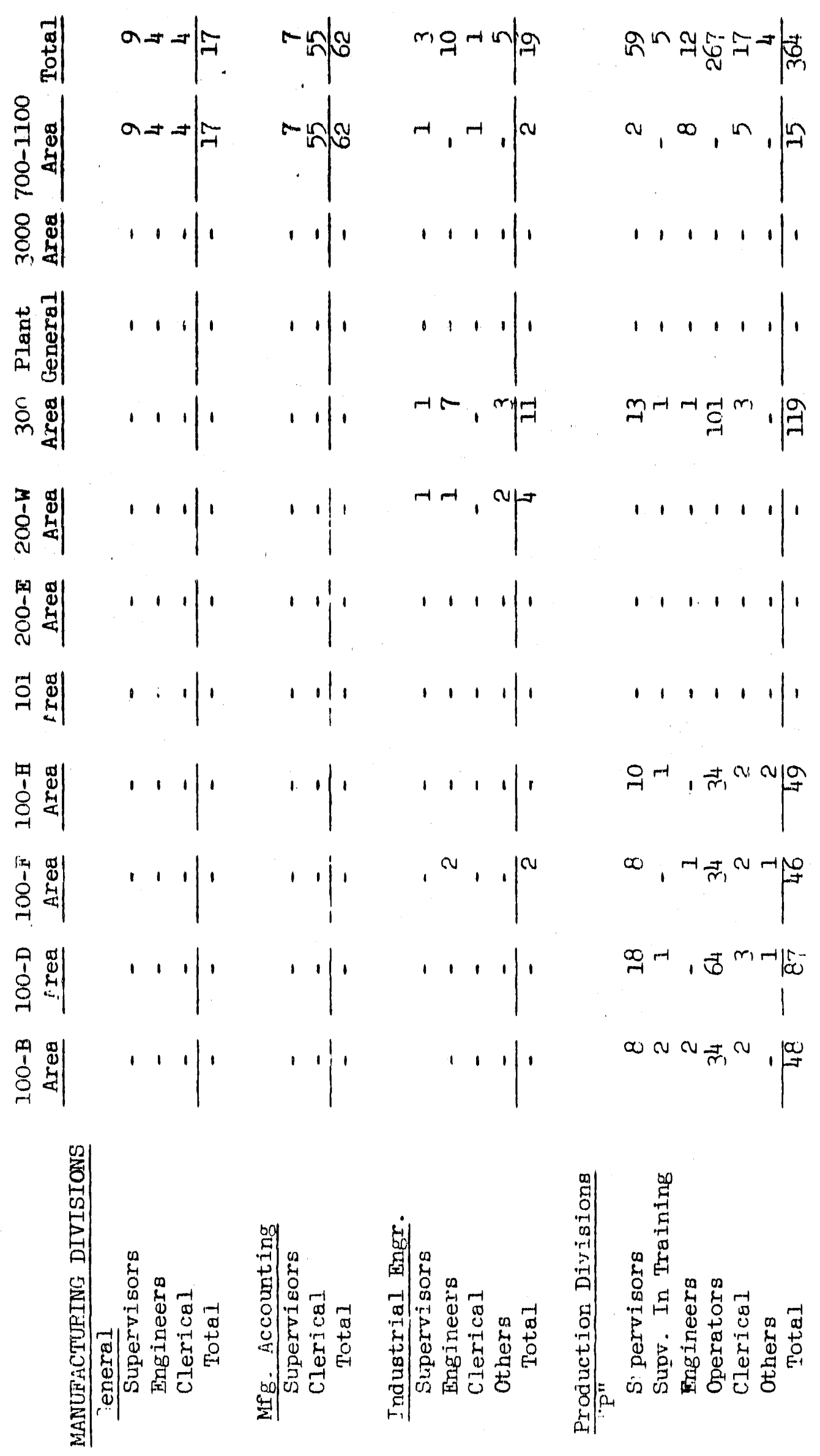

Puge \# 3 


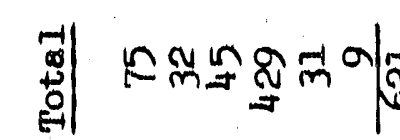

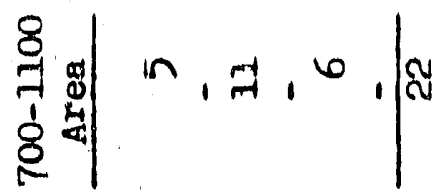

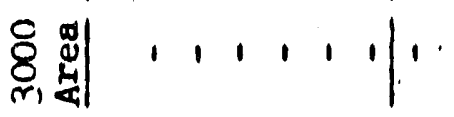

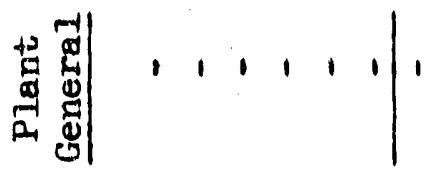

品弯

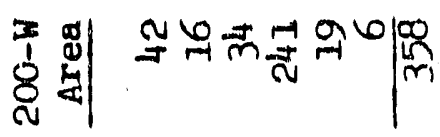

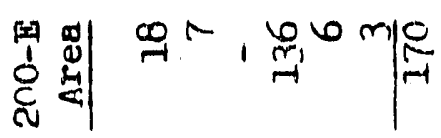

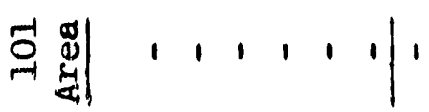

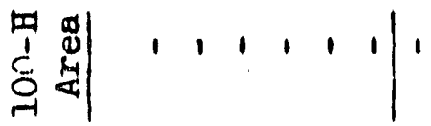

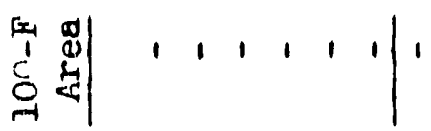

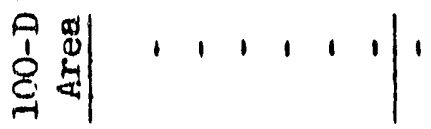

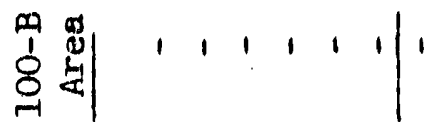

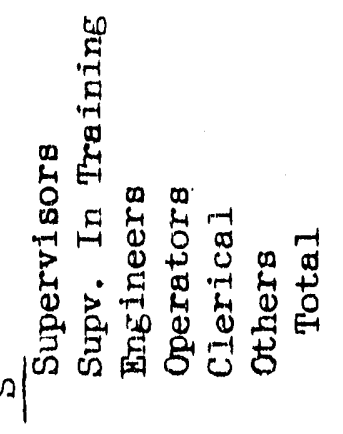

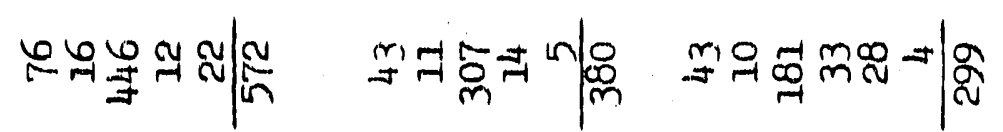

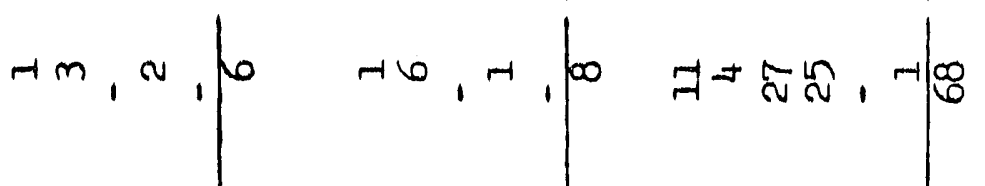

$\cdots 1 \mid 1,1,1$,

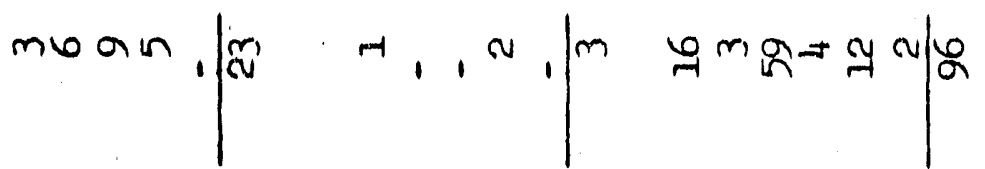

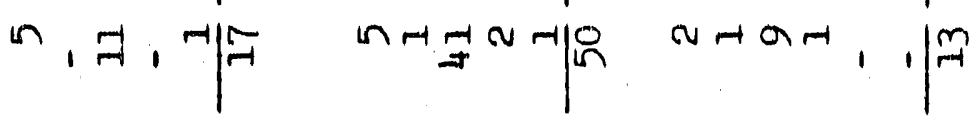

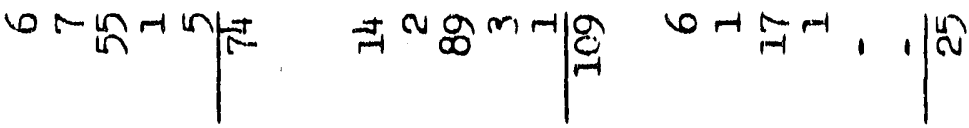

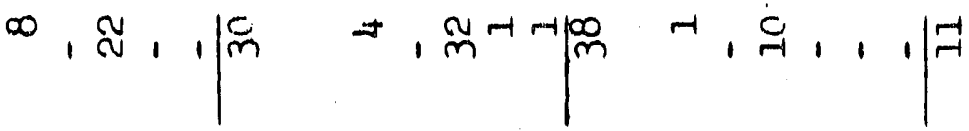

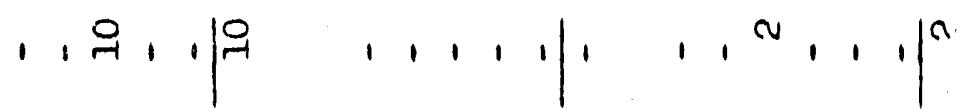

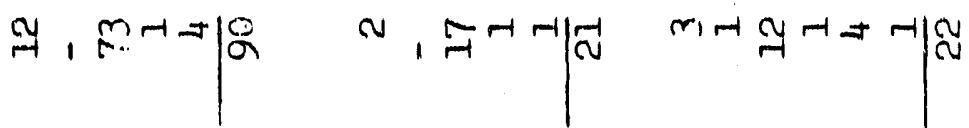

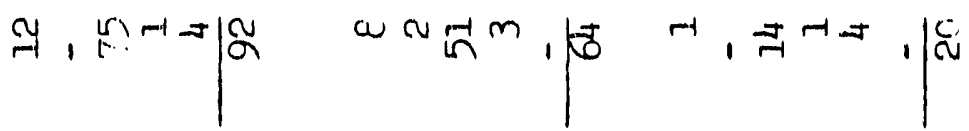

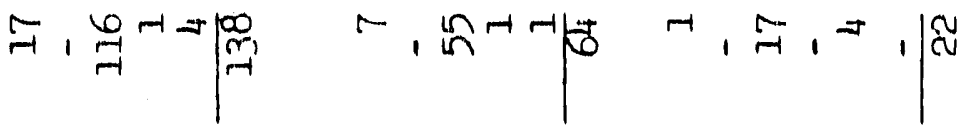

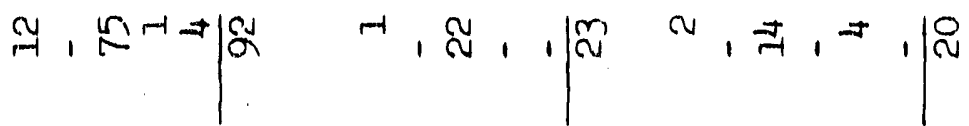

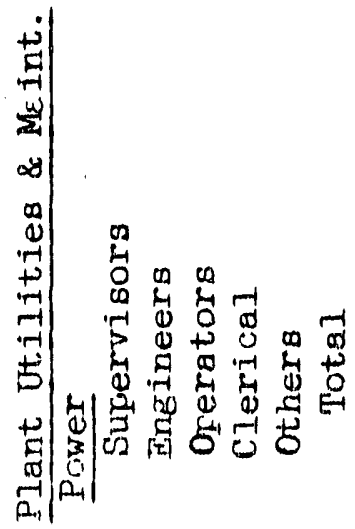




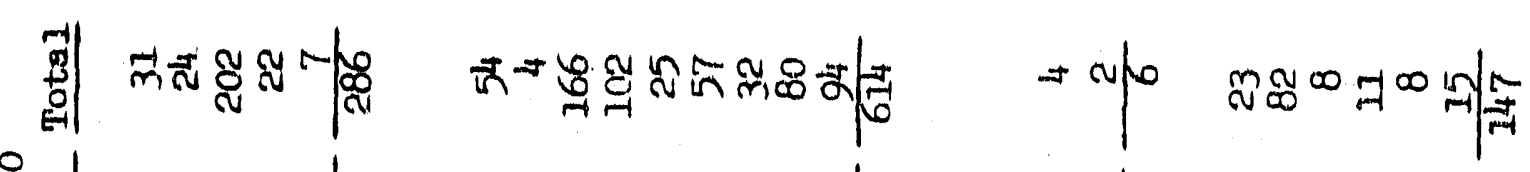

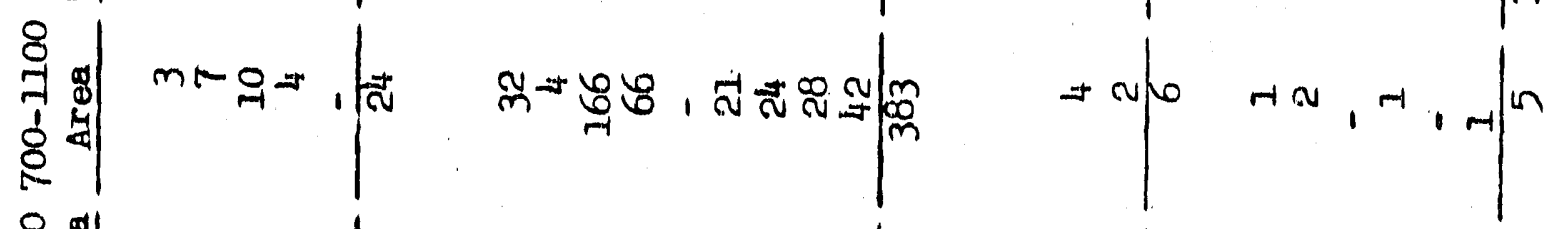

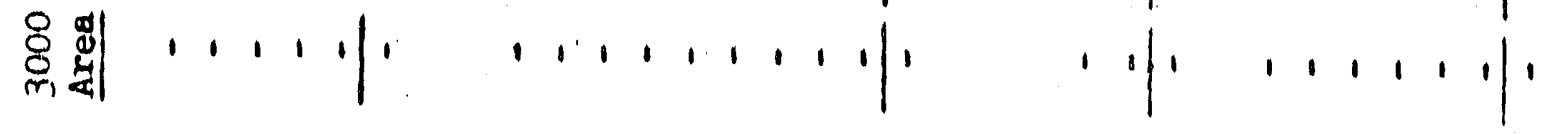

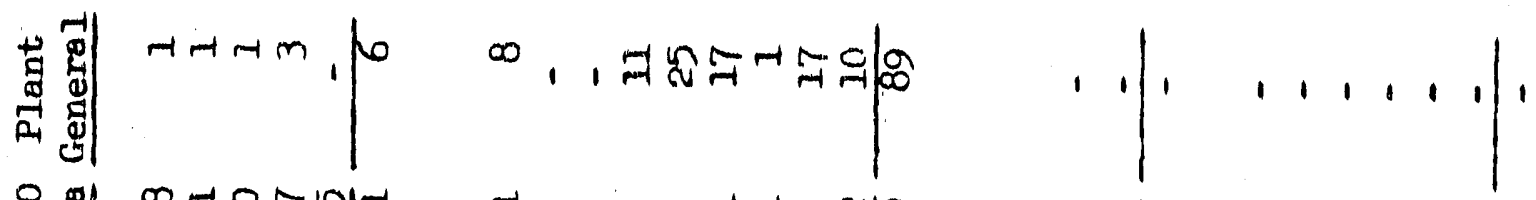

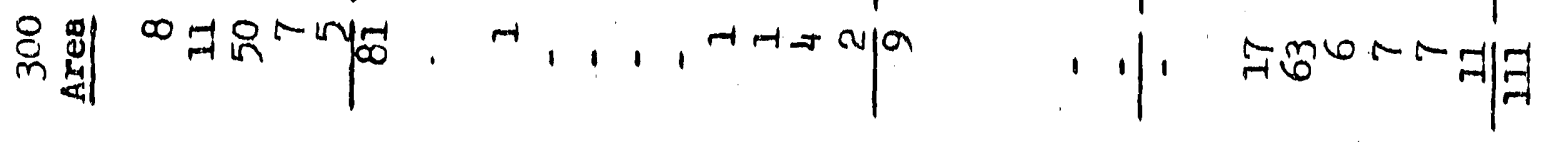

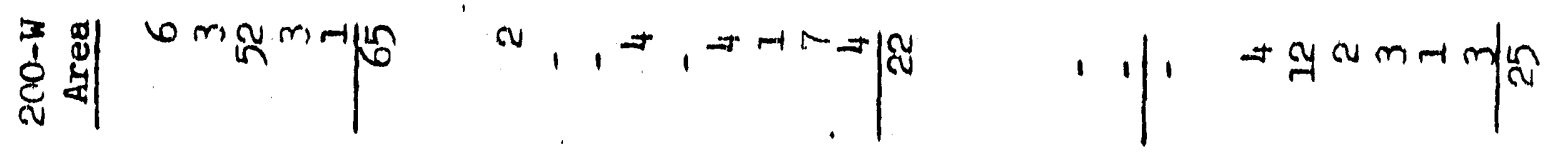

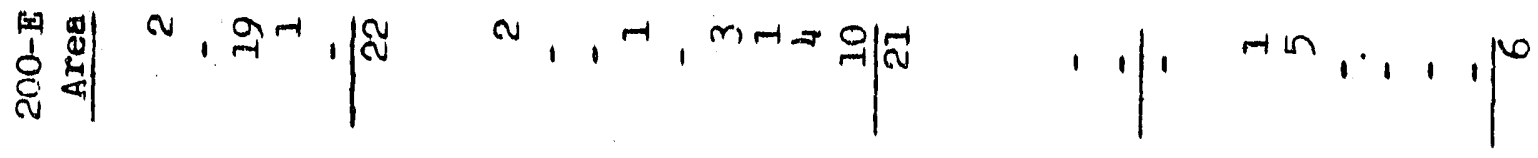

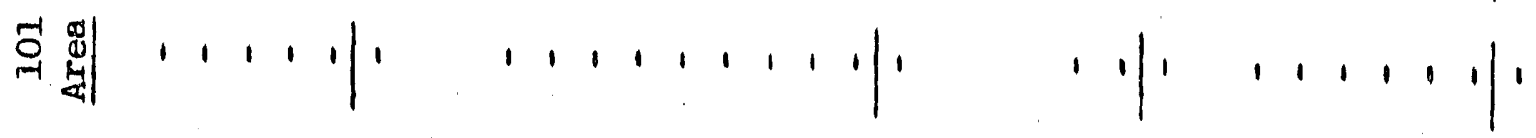

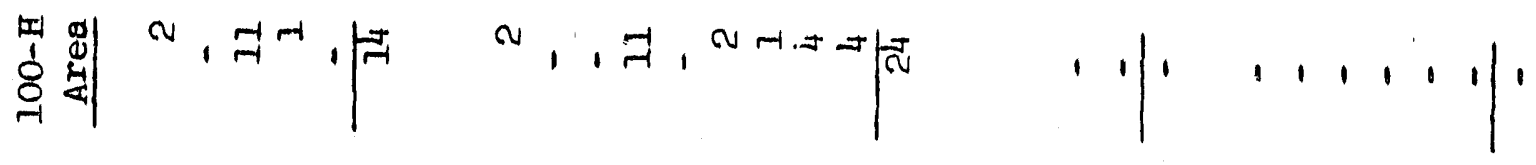

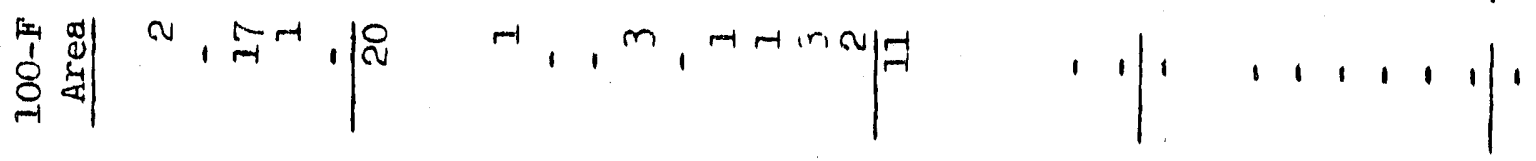

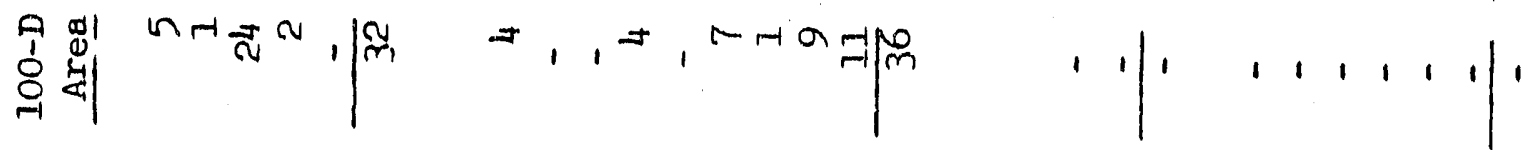

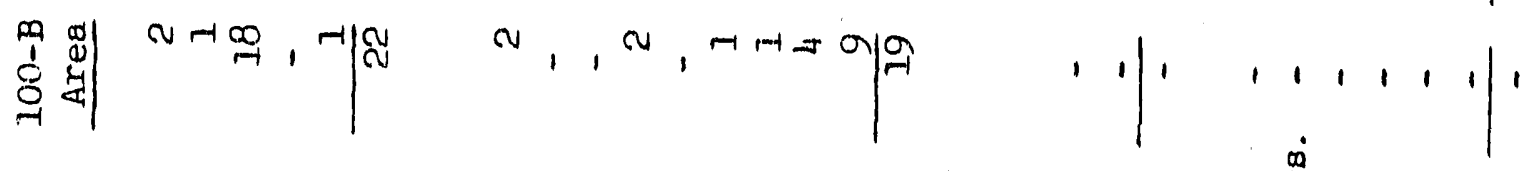

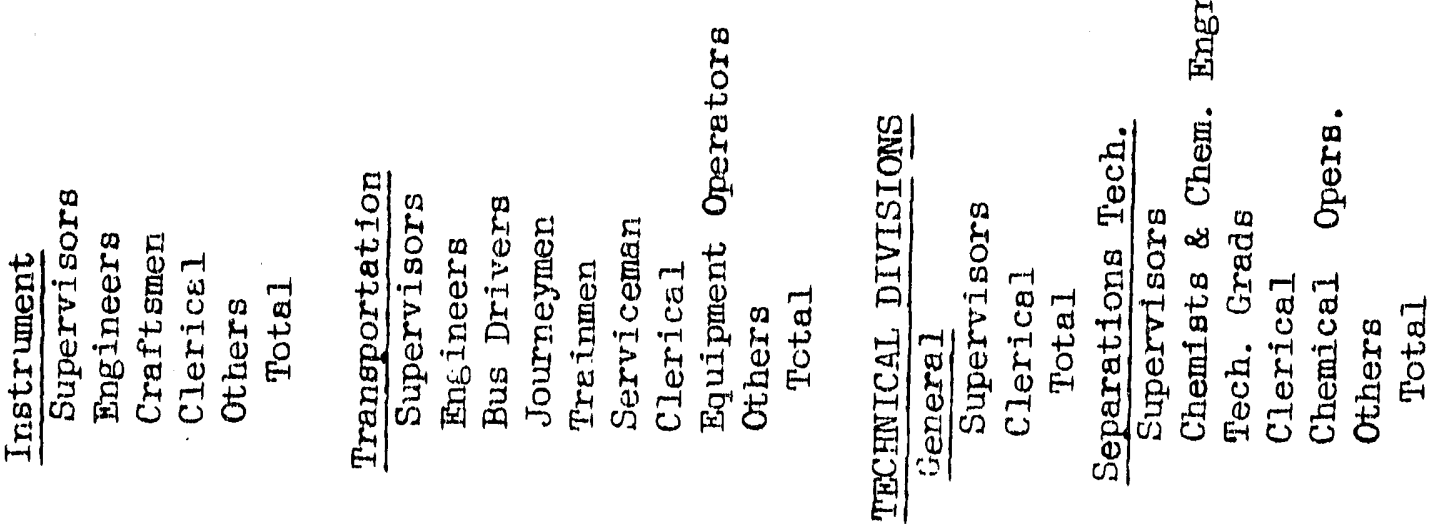

Pago \# 5 


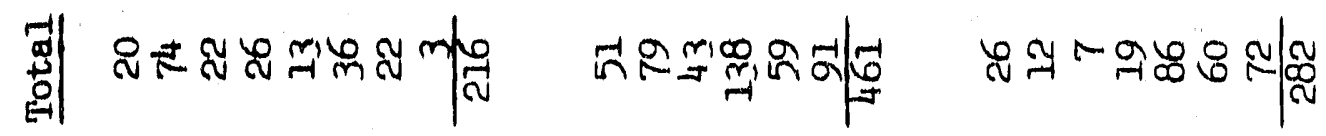

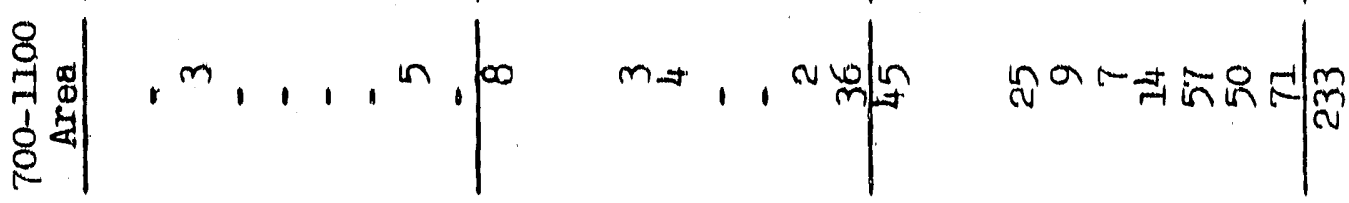

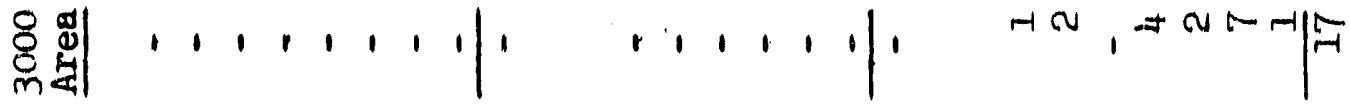

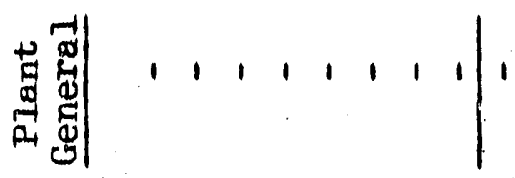
$\ldots, \ldots, \mid,-1,-1, \ldots$

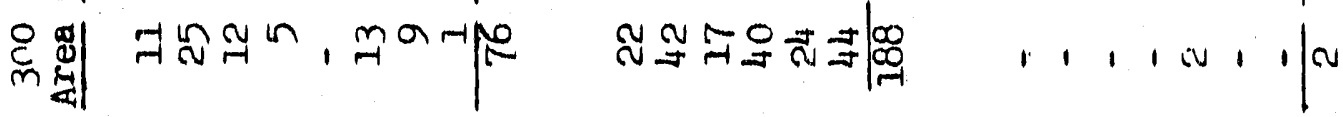

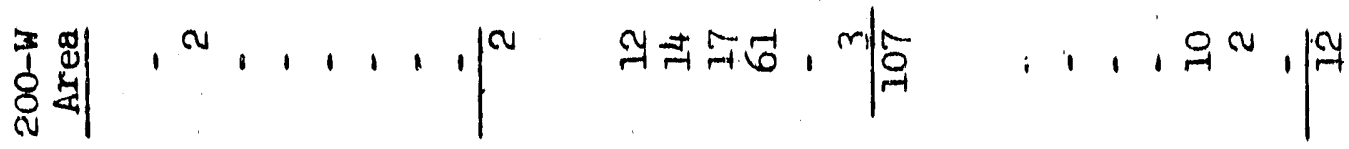

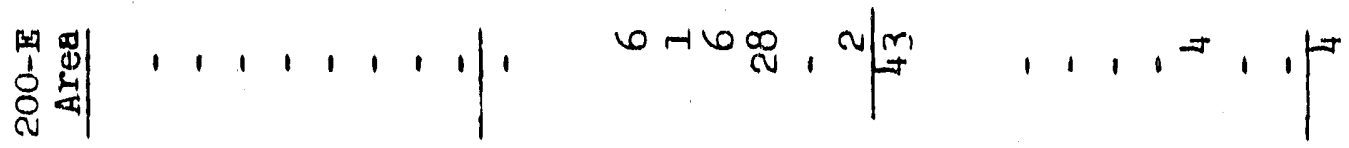

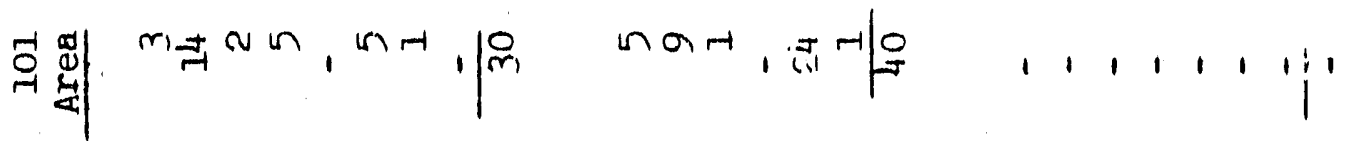

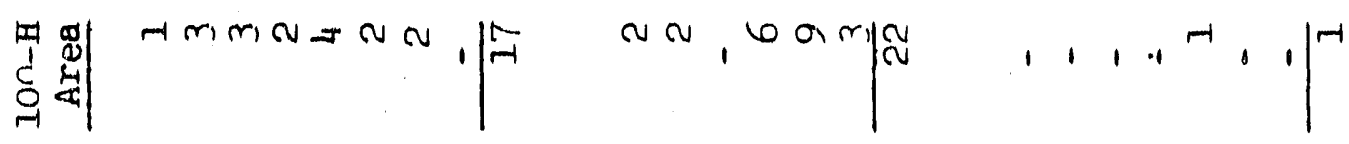

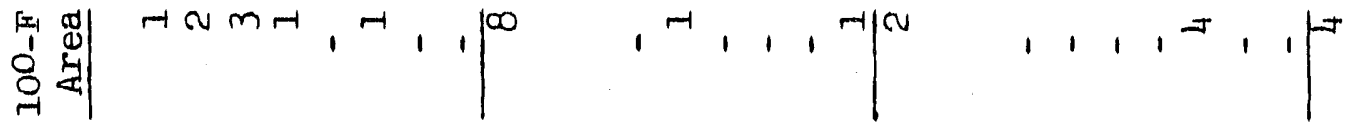

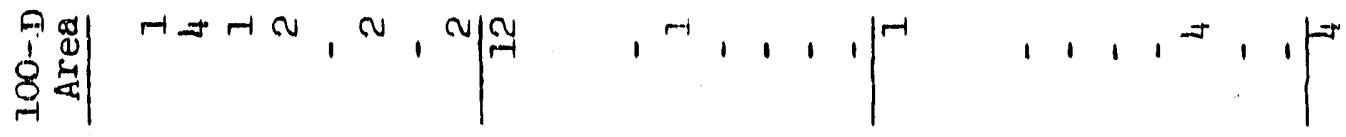

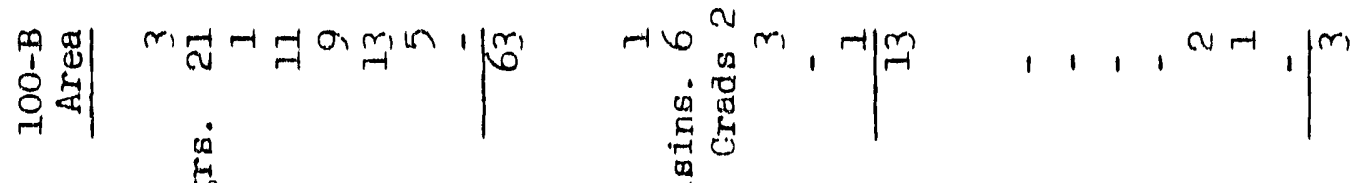

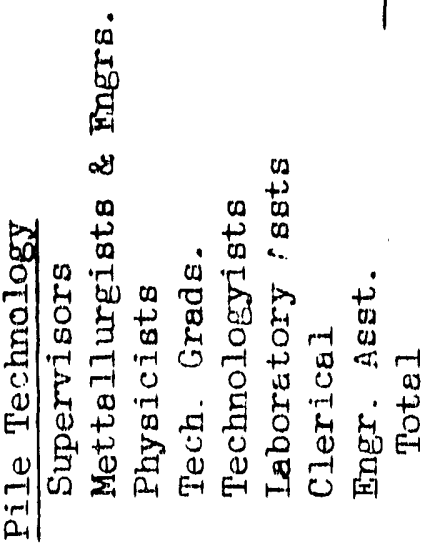

Pare \# 6 


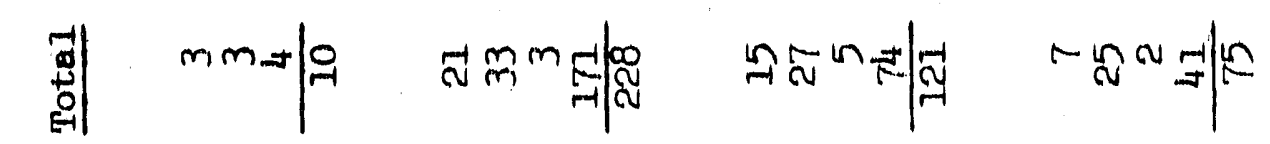

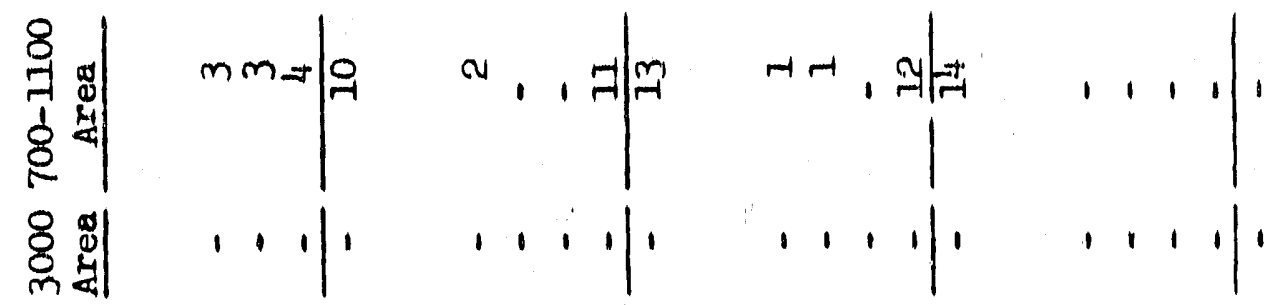

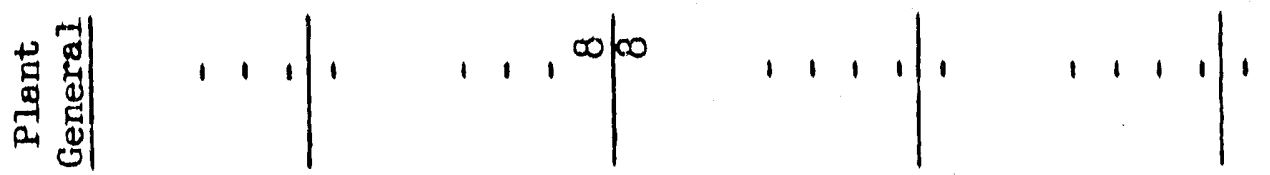

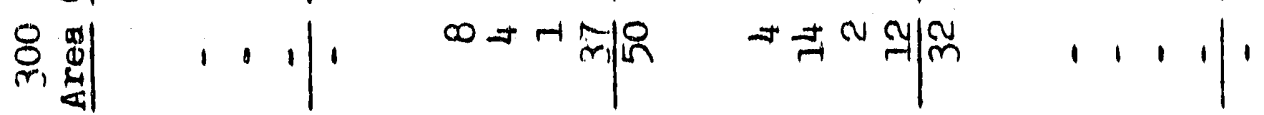

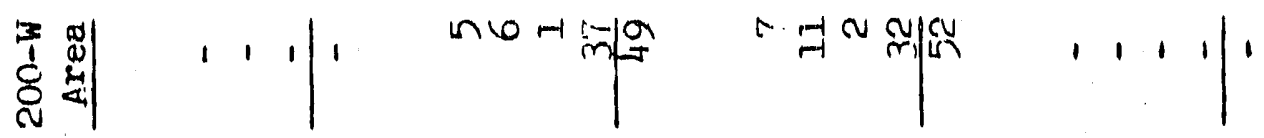

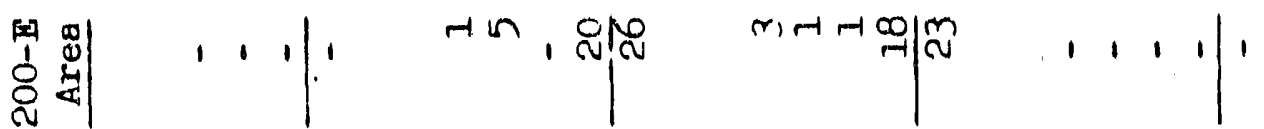

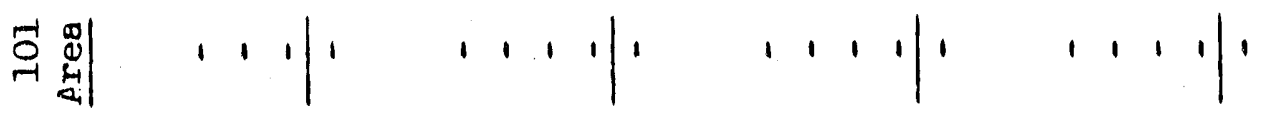

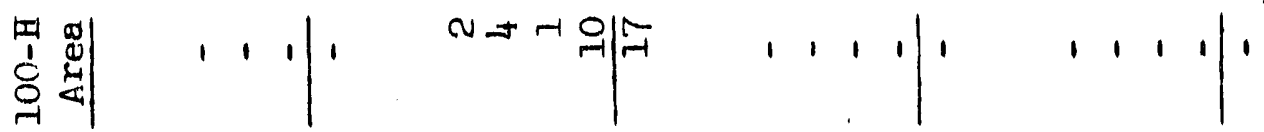

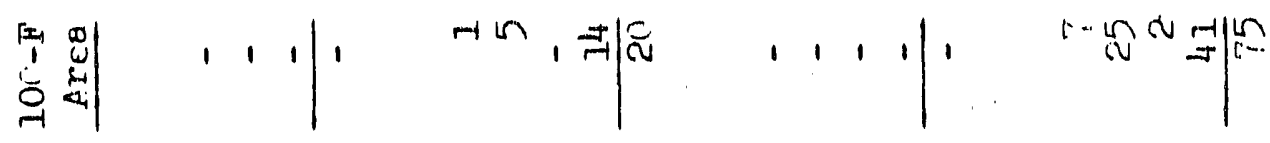

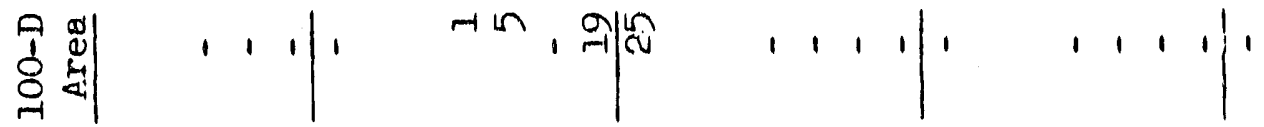

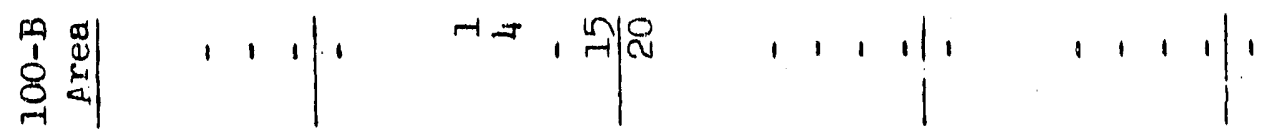

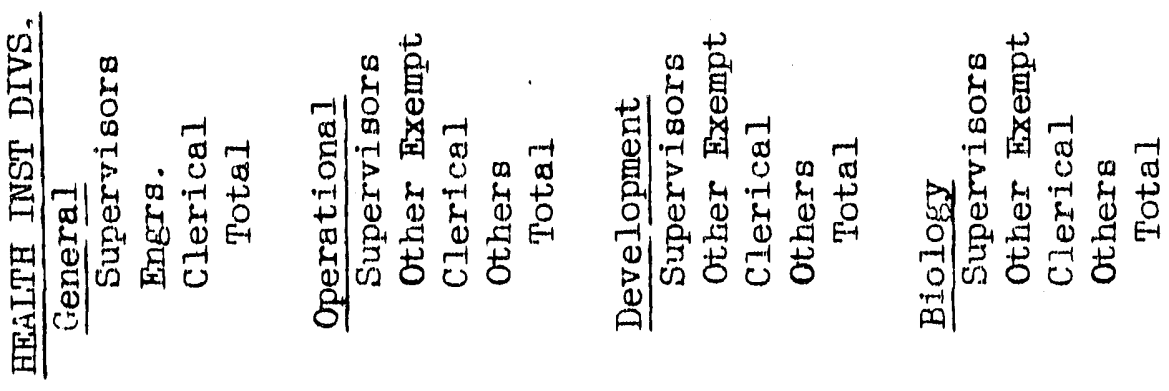




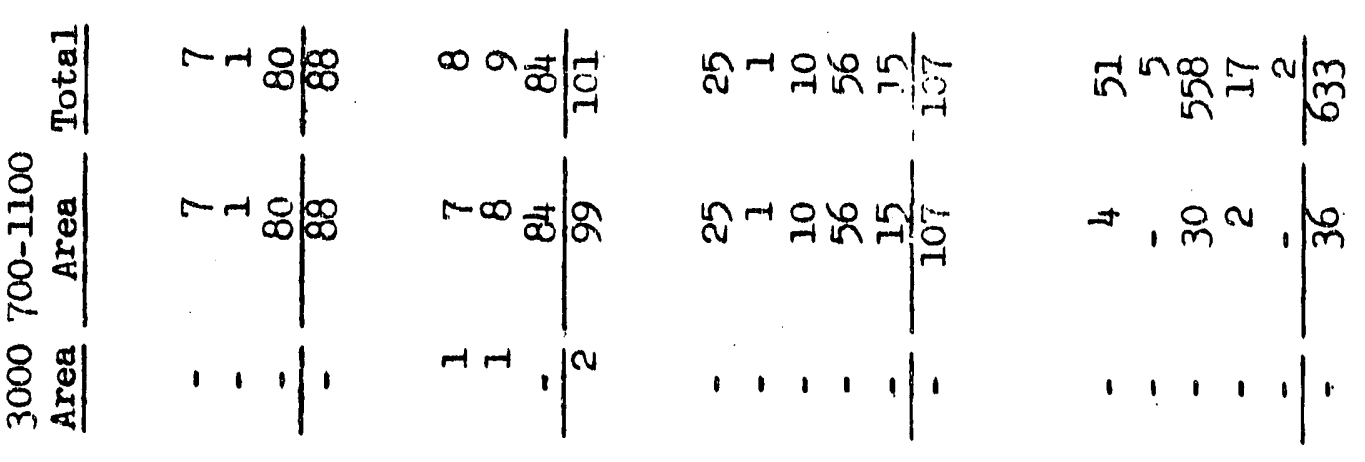

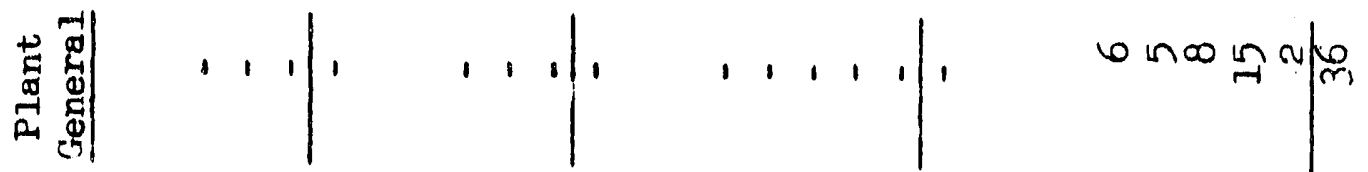

尺,

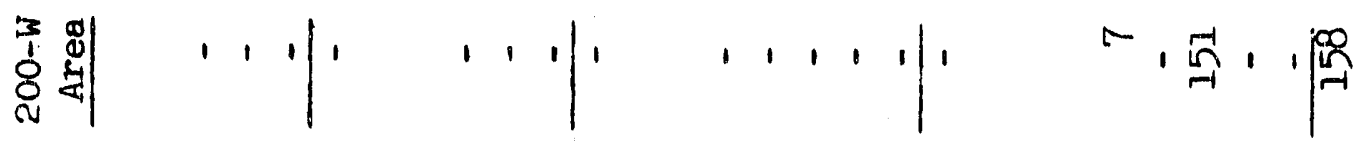

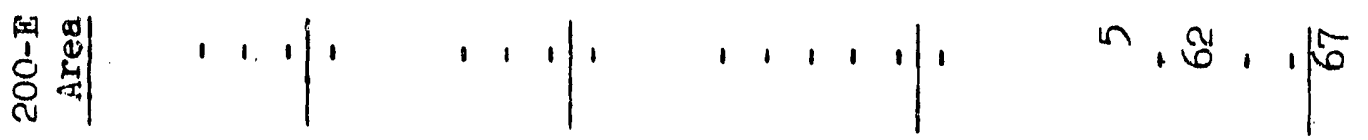

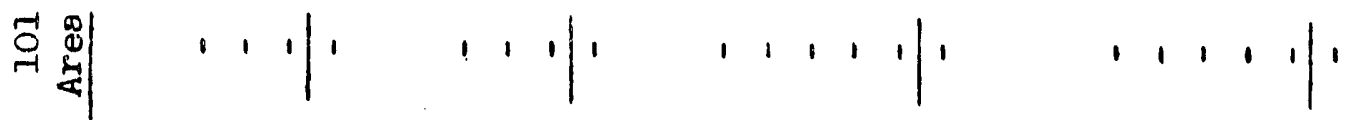

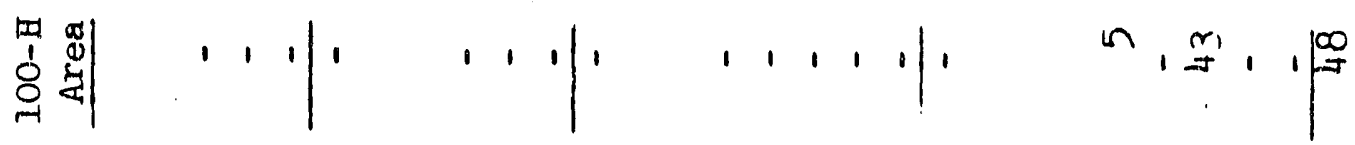

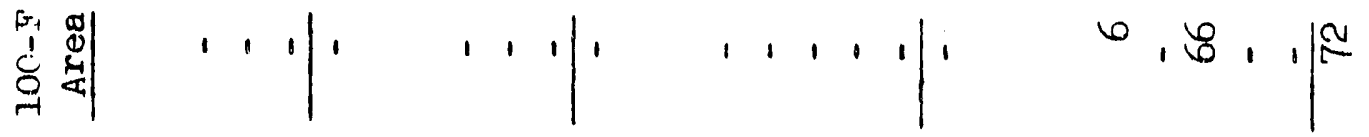

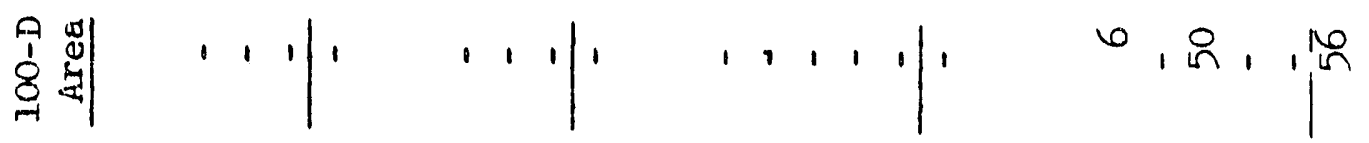

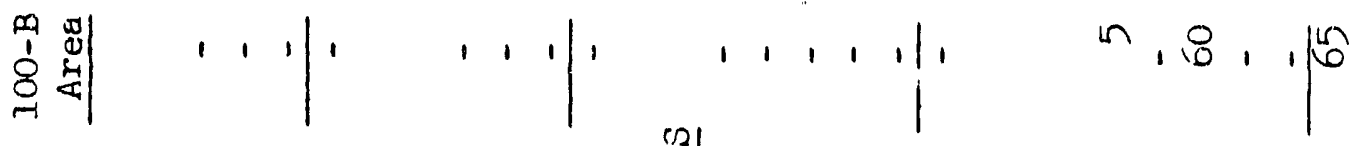

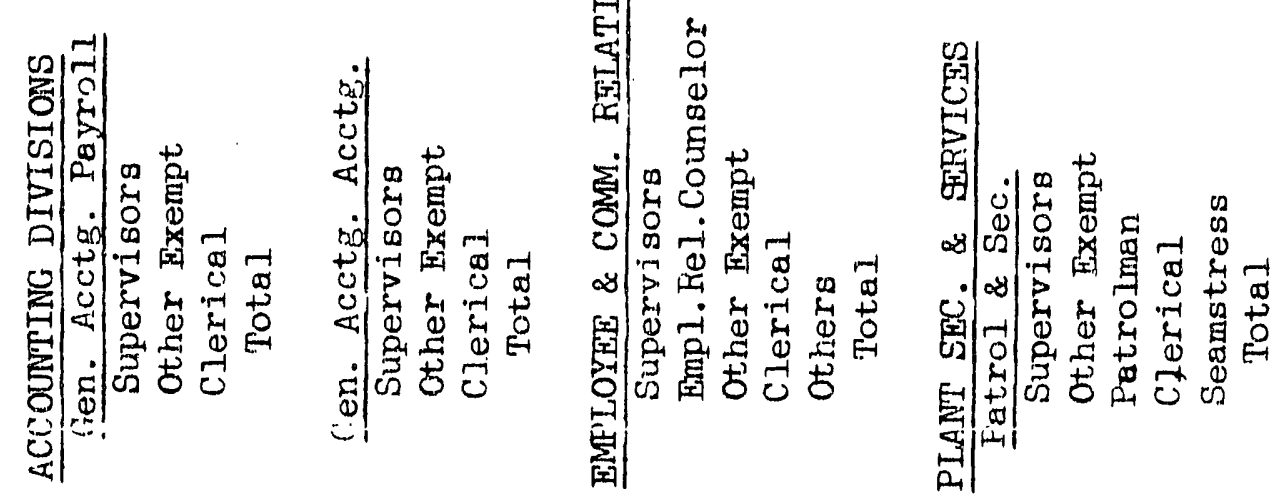




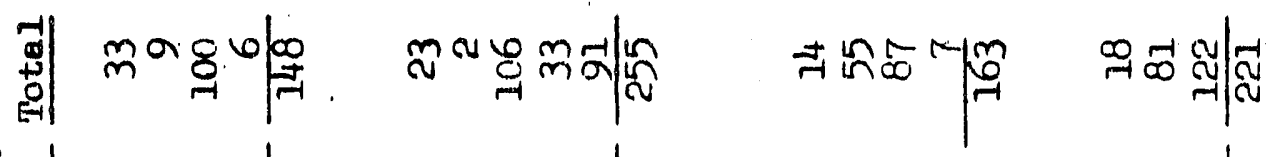

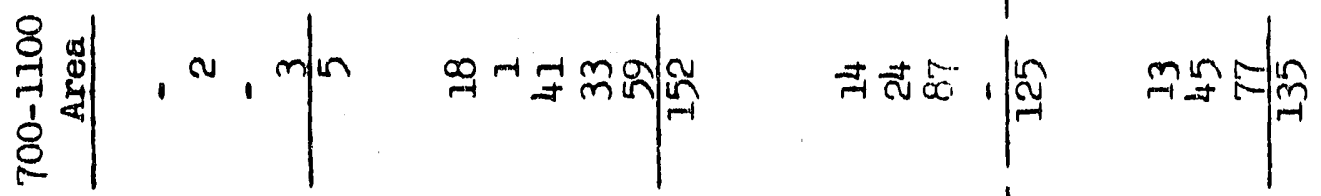

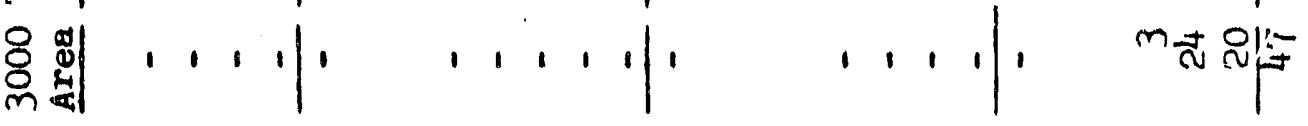

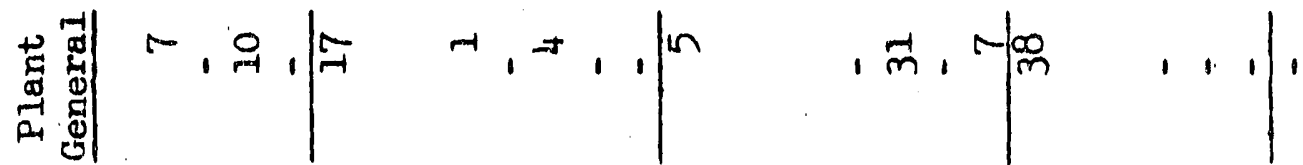

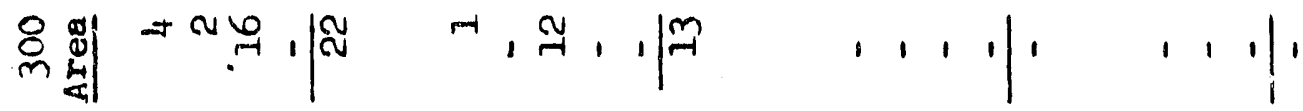

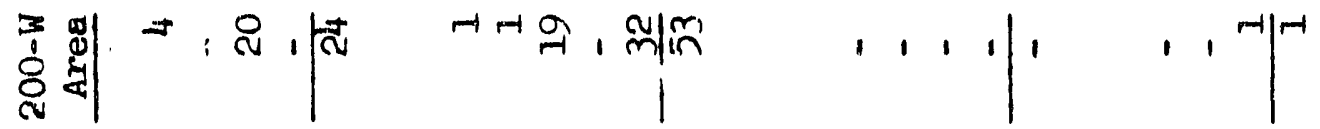

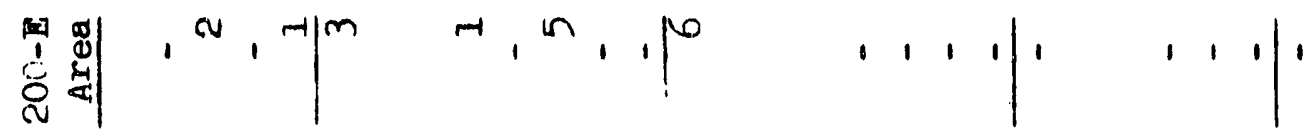

.

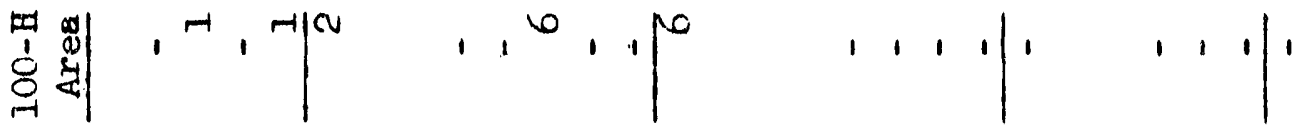

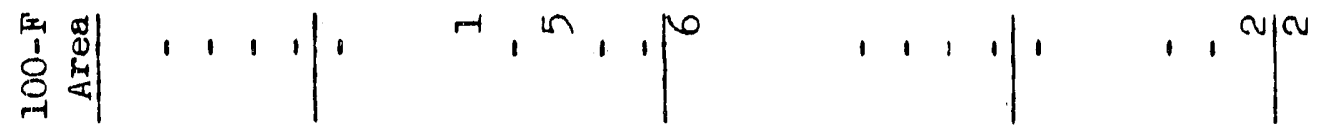

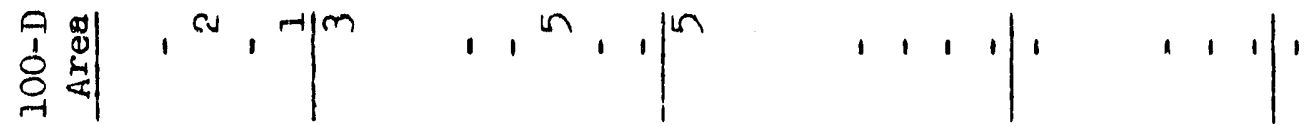

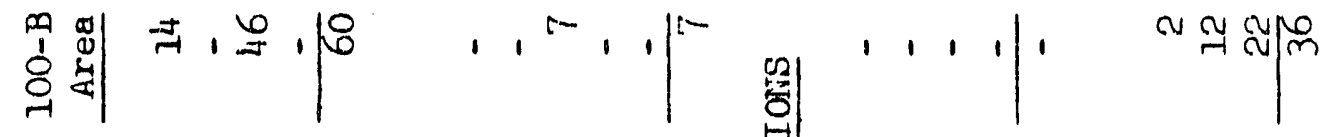

Page \# 9 


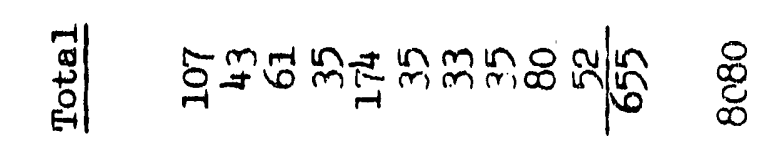

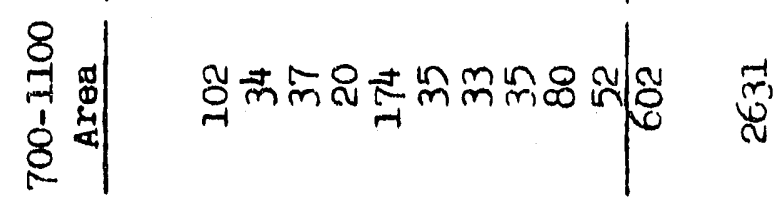

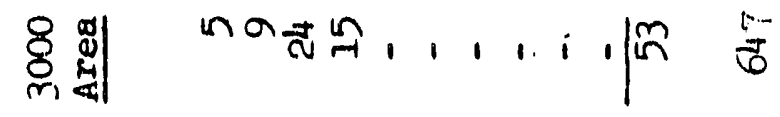

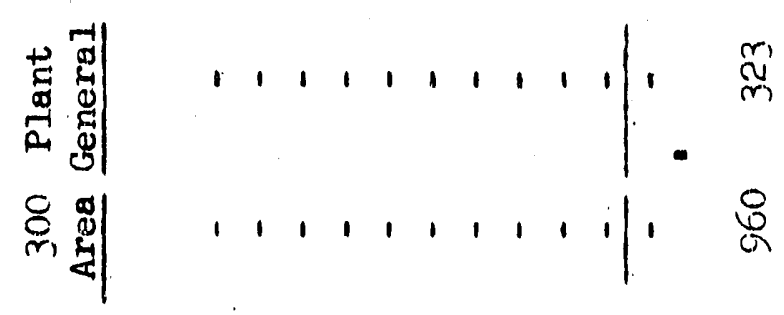

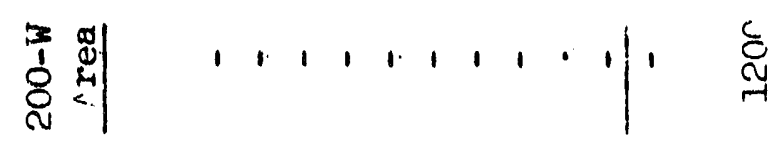

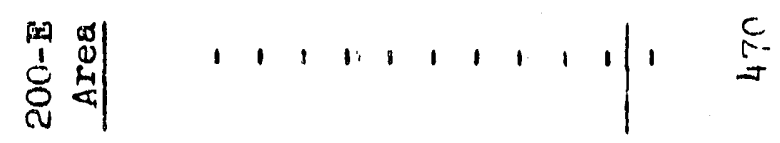

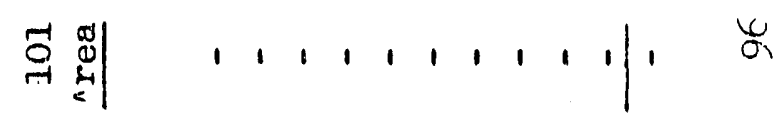

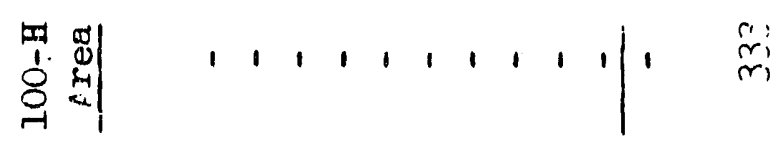

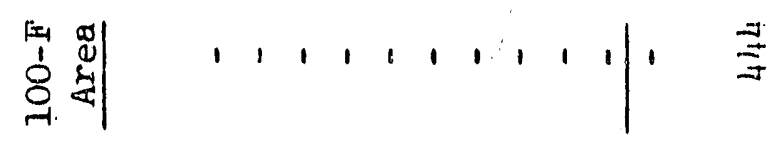

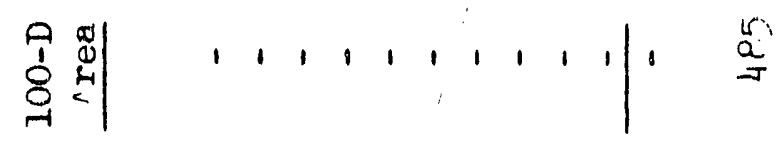

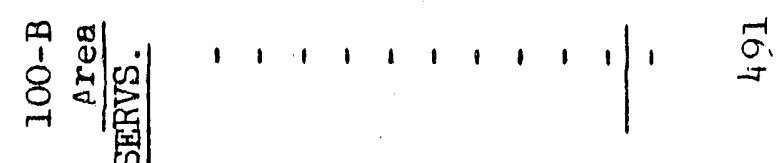

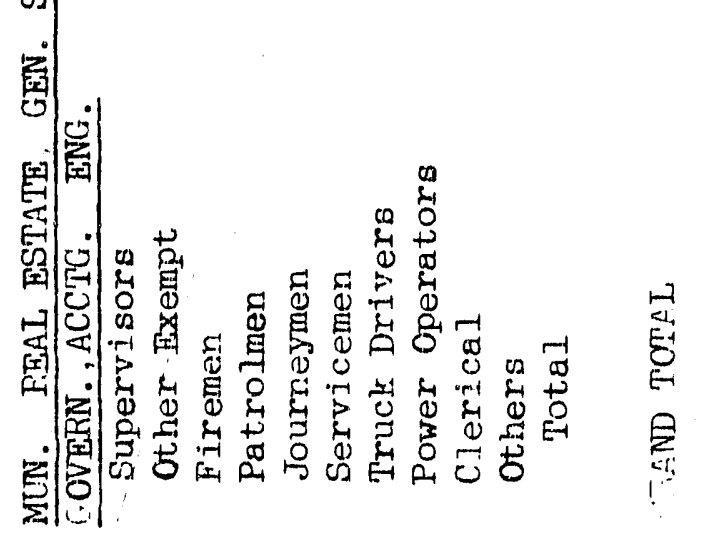

Page \#主它 


\section{DESA ASEFFIED}

\section{MAINUFACTURINO DIVISIONS}

\section{MARCH 1951}

\section{SUMRARY}

\section{Production Divisions}

A total of 82 tons of motal was discharged during the month at the goal value. The spectal reouest program required 220 man hours of $P$ Division timen Ten tubes of special request material were charged into the piles, 9 tubes were discharged, and 22 casks containing irradiated material were shipped off site. An aclitional 180 man hours were required for charging, discharging, and shipping of Chemical 68-56.

A new time operated efficiency record of 94.0 percent for five piles was achieved during the month even though there were 34 hours unproductive pile down time due to a janned electrical outage on March 7, and a ruptured P-10 slug on Marck: 12, 1951.

Pile production exceeded that of any previous month by 20 percent. Gains in maximum operating levels for all piles amountod to $170 \mathrm{MW}$ detalled as follows:

$\begin{array}{llllll} & \text { B } & \text { D } & \text { DR } & \text { H } & \text { F } \\ \text { March } & 425 & 375 & 526 & 510 & 415 \\ \text { February } & 415 & 385 & 484 & 500 & 380\end{array}$

The average level over-all gain was $132 \mathrm{MW}$.

A total of 90 tons of acceptable slugs was canned at a yield of 91.6 percent. The machining yield was 80.0 percent. The melt plant produced 16 tons of billets at a record yield of 88.3 percent and a solid metal yield of 93.9 percent. A total of 1200 man hours of overtime work was done by the $P$ Division 300 Area for the du Pont Company.

A total of 141 charges was started in the canyon buildings. This production exceeds the previous high by 8 charges and a new single area record of 75 charges started was also established in T Plant. Charges completed in the concentration buildings also represent a new record at 140 regular runs plus 2 acid washes and 5 P-1 1 muns. The previous high was 132 charges completed. The $T$ Plant total of 73 regular charges plus 1 acid wash completed is a new record.

A record total of 149 runs were completed in the isolation building, which included 2 acid weshes and 11 special runs. The total material bottled exceeded previous records by approximately 5 percent.

The average cooling time was 60 days with the minimum cooling period for dissolved material being 44 days. The averace purity of completed charges was 98.4 percent. 


\section{Plant Ot1lities and Maintenance Divisions}

The electric power demands for the month were:

$$
\begin{aligned}
& \text { Process }-3-8-51(1: 00-2.00 \text { P.M. }) \\
& \text { Village }-3-5-51(5: 00-6: 00 \text { P.M. })
\end{aligned}
$$$$
69,550 \mathrm{KW}
$$$$
\frac{31,100 \mathrm{KW}}{100,650 \mathrm{KW}}
$$

The process load demand is at a new all time high. The Village peak demand is declining from the January seasonal high.

There was a planned electrical outage on March 7, 1951 for the completion of the $230 \mathrm{KV}$ temporary by-pass Iine and other work associated with the 251 substation expansion.

Work on revising tha preliminary specifications for our industrial Iubricants was completed. Thise are now ready for distribution to interested oil companies. Before this can be done, however, a procedure must be developed to handle the samples that will be sutmitted by the oil companies for approval consideration. This procedure must cover the laboratory and field testing of the samples.

At the request of the Atomic Energy Commisston, the Transportation Division presented a program on the "Operation of the T:ansportation Division at Hanford Works," at the March 9 meeting in R1ch and of the Inter-Agency Motor Equipment Advisory Committee of Oregon and Washington. Agencies represented included BPA, General Services Administration, Fish and Wild Life Service, Atomic Energy Commission, Bureau of Reclamation, Corps of Engineers, Bureau of Public Roads, U. S. Forest Service, U. S. Soll Conservation Service, and Bureau of Animal Industry. The program included tours of Richland, North Richland, and vicinity, and presentations of briefs on Hanford Works Transportation operations, costs, sovings programs, et cetera.

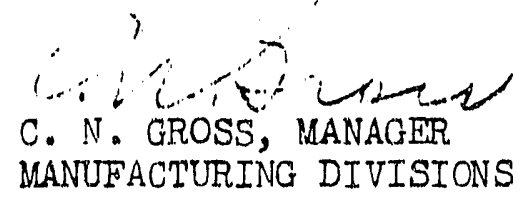




\title{
MANUFACTURING DIVISIONS
}

\section{PATENT REFORT SUMMARY \\ FOR \\ MONTH OF MARCH 1951}

\author{
Richland, Washington \\ April 10, 1951
}

All persons engaged in work that might reasonably be expected to result in inventions or discoveries advise that, to the best of their knowledge and belief, no Inventions or discoveries were made in the course of their work during the period covored by this report except as listed below. Such persons further advise that, for the perlod therein covered by this report, notebook records, if any, kept in the course of their work have been examined for powible inventions or discovaries,

\section{INVENTOR}

F. C. Schermer

Maintenance Division

H. J. Bellarts

Project Engineoring Division

\section{TITLE}

Alteration of Chapman \#660 Valve

Fusible Safety Reloase - Drawing $\mathrm{H}-1-2543$

(This invention was submitted a.s Ruport of Invention S-857.6, HWIR295. Fusible Safety Release, datod $2-1-51$, and is a part of invention reported for November 1950, "Tube Cutter, Emorgency (Centrifugal)."

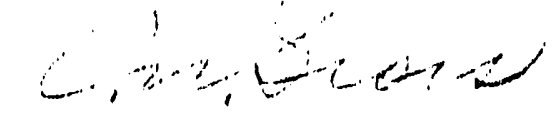

C. N. GROSS, MANAGER 


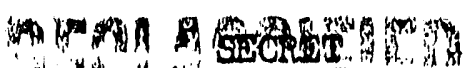

$H W-20671-22 Z$

it ${ }^{*}$.

fyla

\section{DECHRERPID

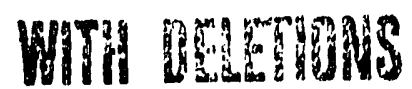

1. 


\section{nEPI \\ Exstoviritit \\ WITH DELETIONS}




\section{MDA

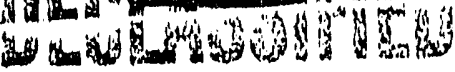

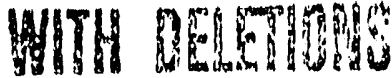




\section{DECLISSSFFED}

MANUFACTURING ACCOUNIING

MARCH 1951

\section{SUMMARY}

Verlous activitles were carried forward during the month looking to. ward expanded responsiblilties, Improvement in cost and budget methods, and better utilization of personnel. Among these were:

Preparation for B1Iling Electric1ty to Resldentlal and Comerclal Users

The Statiot1cs section ordered the followling 1tems to Implement bililng of metered alectrical charges beglnning September 1, 1951:

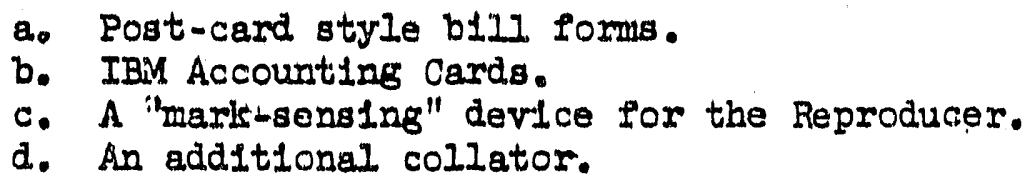

Meter readers will employ IBM cards and speclal penclls to register meter readings. The "mark-sensing" device through the reproducer translates the marks into standard key-punch holes, making the card usable for imprinting by tabulating maciline.

Compllation of Operating Reports on IBM

For the purpose of decreasing routine hand clerfcal labor so that the saved time can be used for better purposes, s study was begun in March of the feasibility of compliling Monthly operating Reports on existing IBM equipment. The Analysis and Statistics groups are conducting the Investigation.

Operation of New Budget Method FY 1952-1953 Budget

Major criticisms of the Operating Budgat Procedure used in the past have been:

A. Required excessive clerical work of Operating Divisions.

B. As compliation was made as a whole under a tight dead-Iine, insufficlent time remained for analysio of final figures and discussions between Servicing and Production Divisions as to the correctneas of charges.

To minlmize clerlcal work by Operating Divisions, within-division information (number of people, clasalfication, money value of material) was requosted and the within-division portion of the Budget bullt up from these facts in Manuf'acturing Accounting. Historical information on charges out from servicing divisions were provided in terms of man. 
Manufaoturing Acoounting

power to operating personnel, enabling them to make estimates in the same terms, decreasing the magnitude oft flgures to be bandled.

By divlding the budget effort lato sectlons, portions of the budget were resubmitted for revlew by div1siong as the work progressed. At the end of March we were able to submit detalls of servicing divisions charges for revlew by all Manufacturing D1v1slons. Adjustmento have been made of prelimtnary flgures of operating and accountiug diviolons through cnoperative effort and it is generally felt that the new method is a distinct forward step.

Constimuction Budget

Durlng the month the Work Order Control Section reorganlized 1ta records preperatory to revlewing the Conetruction Budget, the preparation of which w1ll be a new responslbillty of th1s section.

Distribution of Power Costs

Conalderable work. wa done In the Analys is and Reports Section toward development of a system for charging steam and water consumed to cuatomers on a unit cost bes1s. Th1s 1s consldered to be a distinct Improvement over the present method of direct 11quidation by area.

B1111ng by Service Rather Than Div1sion

In order to "tel1 a story" w1th the backs of the Operat1ng Reports rather than ahowlag only the divialon bliling, analyols of code structure of" servlcing divislons is now under way in the Analysis and Reports Section. Work has been inftiated on a functional code structure for Transportation Automotivo (412) and Electrical DIV1alons simliax to the code atructure astablished for Ralilroad Operation 1n January.

Product Cost Accounting

Meetings attended by DIvialons Maragers were celled by the Assistant General Manager to revlew the mothods used in computing product cost. Altemate methods of computing process inventory value were submitted (welghted average; f'lrat-In first-out; and roliling average process cycle).

It was decided that rolling average production costa computed for a perlod of time that 1s commensurate with the process cycle wolld be used.

Asalstance was furmlshed to the Production Divislons in analyzing detalls to determine the reasons for changes in product undt costa. Plans have been made and some overtime authorlzed to furnish detalls of product cost at an earlier date to enable the Production Divisions to make the Lr analyses soon after the Surmary of Production Costs statement la lasued.

\section{DECLSSHEI}




\section{MEPU SeUIIED}

Mariufaoturing Acoounting

Organlzation and Personnel

Number of Bmployees on Payroll:

$\begin{array}{lr}\text { Beglnning of the Month } & 63 \\ \text { Acqulsitions } & 2 \\ \text { Transfers out } & 2 \\ \text { End of Month } & 63\end{array}$

Much difficulty is belng experlenced in obtalning enough alutable personnel to meet the raplaly increesing work loed. The expanded work load 1o due to accounting for new plants, electricity metering, A. . C. demands for more detalls, particularly on budgets and more cost analysis work. 
Apr11 5, 1951

\section{P DIVISION}

MARCH, 1951

\section{GENERAI}

Sibstantial galns in maximum operating levels were achleved during the month of March, totaling 107 M for all 11les. The problem of slug fallure during pile operation cortinued to be an impediment to naximum production. Although no uranium slugs falled during March, 18.6 hours of unscheduled outage time at If P1le were required for the removel of a ruptured and distorted P-10 target slug. Otherwise, operation of all piles was normal, and a gain of approximately $25 \%$ in total pile production was realized over the previous month.

The average time operated efficlency for 5-plle operation reached a new maximum at $94 \%$. The total number of outage hours for all piles was 219.7. Eighty-eight percent of this non-operating time is chargeable to plutonium production and 12\% is chargeable to other 1rradiation programs.

The followlng gains in maximum operating levels were achleved: B Pile was ralsed from $415 \mathrm{MW}$ to $425 \mathrm{MW}$, D Pile ras raised from $385 \mathrm{MW}$ to $395 \mathrm{MW}$, DR P.le was raised from $4.84 \mathrm{MW}$ to 526 $\mathrm{MW}$, H P1le was raised from $500 \mathrm{MW}$ to $510 \mathrm{MW}$, and $P$ Plle was raised from $380 \mathrm{MW}$ to $415 \mathrm{MW}$. This brings the total maximum operating level of al.1 five plies to 2271 compared to $2164 \mathrm{MW}$ for last month for a gain of 107 MWD.

A record billet yield of $88.3 \%$ was achleved in the 300 Area Melt plant facility.

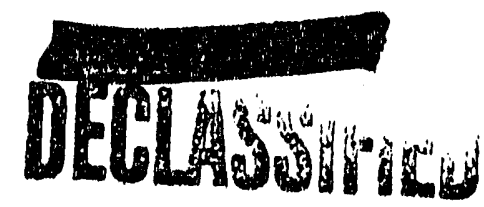




\title{
P. Division
}

\section{ORGANIZAIIION AND PEIRSONMEIS}

\author{
Number of Holoyees on Payroll - March, 1951 \\ Begluning of Month - 367 \\ End of Month 364 \\ Net Decrease 3
}

There were no personnel ohanges in the rotational training progrem during the wonth. However, arrangements were completed for the assignment to the P DIv1sion of seven additional Techalcal Graduates from a group of recently hired personnel. These Technical Graduates are expected to report to the P DIviston during Apri1, 1951, and will provide additional personnel in connection with the operation of anticipated new facilities.

Đ. J. F111p, Area Supervisor, was promoted to Asslatant Chlef Supervisor, effective March 1.

R. G. Sw1ft, Sh1ft Superv1sor, reslgned on March 16 to accept employment elsewhere.

K. V. Stave was promoted from Supexvisor-1n-iraining to Sh1ft Supervisor, effective March 1.

Six new operators were hired Into the 300 Area. Five operators and one General Clerk C terminated voluntarliy from the 300 Area, Two operators from the 300 Area transferred to the Electrical Division.

Mr. W. W. Windshelmer inspected facilities at Argonne National Laboratory in ChIcago, IIlinois on March 12 and attended a meeting of the Reactor Safeguard Committee in Chlcago on March 1.3.

III. AREA ACTIVIIIES

100 Areas - Pile Irradiation

The Murch production represents an 1ncrease of more than $20 \%$ over the highest previous month since the startup of the Hanford piles. Thls increase was due largely to higher pile levels and better operating techniques. Level. increases were primarily the result of improved flattening, graphite annealir:g and reactivity gains at the $D R$ Pile. The technigue of purging during pile operation, recently developed by the $P$ Division, also promises to contribute substantially to future production.

The following table summarizes pile levels, efficlencles, et cetera:

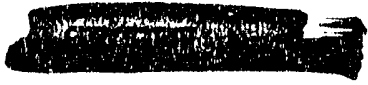


Pile Production Summary

Maximum Ievel Attained (MN)

Average Operating Level (MN)

Time Operated Efficiency (\%)

Unschealuled outage Time (Hours)

*Inlet Water Temperature ( $\left.{ }^{\circ} \mathrm{C}.\right)$

* Outlet Water Temperature (Max.

${ }^{O C}$., 10 tubes $0.240^{\prime \prime}$ zone)

Maximum Grephite Temperature

Metal Discharged (Tons)

Inhours Gained

Inhours in Rods

Inhours Polsoned
Pile B Plie D Pile DR Plie $\mathrm{E}$ Plie $\mathrm{F}$

$\begin{array}{ccccc}425 & 395 & 526 & 510 & 415 \\ 397 & 376 & 496 & 493 & 391 \\ 90.9 & 91.9 & 97.3 & 94.2 & 96.1 \\ 0 & 0.1 & 0.2 & 1.0 & 0 \\ 6.4 & 8.8 & 6.3 & 6.5 & 5.0\end{array}$

64.8

$\begin{array}{ll}64.3 & 72.2\end{array}$

378

26.84

$-2$

76

503
33.83

27

80

515
313

1.76

67

142

319
66.1 392

9.42

$-1.4$

87

70
49.6

383

9.84

35

505

* Month end figures.

Pile downtime during the month of March was mainly attributable to the scheduled discharge of metal, removal of a ruptured P-10-A slug from $\mathrm{H}$ Pile and a scheduled electrical outage. A tabular breakdown of outage time is given below:

\begin{tabular}{|c|c|c|c|c|c|c|}
\hline Cause of Outage Time & Pile B & Pile D & Pile DR & Pile $\mathrm{H}$ & P1le $F$ & Tota \\
\hline $\begin{array}{l}\text { Metal Discharge } \\
\text { Ruptured Slug Removal }\end{array}$ & 39.0 & 30.3 & 2.0 & $\begin{array}{l}23.9 \\
18.6\end{array}$ & 13.0 & $\begin{array}{r}108.2 \\
18.6\end{array}$ \\
\hline $\begin{array}{l}\text { Pile Mairtenance } \\
\text { Special Requests (Except }\end{array}$ & 22.5 & 20.5 & & & 6.5 & 49.5 \\
\hline $\begin{array}{l}\text { P-13) } \\
\text { P-13 } \\
\text { Electrical Outage } \\
\text { Safety Circuit Trips }\end{array}$ & 6.0 & 9.0 & $\begin{array}{r}2.0 \\
15.6 \\
0.2 \\
\end{array}$ & 0.4 & 9.5 & $\begin{array}{r}26.5 \\
0.4 \\
15.6 \\
0.9\end{array}$ \\
\hline Totals (Hours) & 67.5 & 59.9 & 19.8 & 43.5 & 29.0 & 219. \\
\hline
\end{tabular}

As will be noted from the above tabulation, less than half of the total outage time was actually required for regular metal aischarge. Special request handling consumed 12 percent of the outage time, pile maintenance - 22 percent with approximately 8 percent each for remuval of a ruptured slug and the electrical outage.

Operating Experience

Operating experience during the month was normal except for a scheduled one-day electrical outage for all piles and a one-day unscheduled outage at $H$ Pile required to remove a ruptured $P-10$ target slug. Production tests having operational significance are reported below:

105-103-P (Corrosion Rates at Elevated Temperatures, Supplement D) At $F$ Pile, 16 tubes are operating satisfactorily at elevated temperatures under the provisions of this test. Buring the month, four of these tubes were discharged and recharged. 
P Diviaion

105-354-P (Operation of ANL-140 with Fuel. Installed)

Operation of the II P1le was interrupted for 0.4 hour

on March 13 due to an unexplatned impulse from the

Pm13 equipment safety. circuit. No definite cause could be established. A production 1088 of 47 MWD resulted. During the March 7 outage, three test sections were removed from the pile tube and replaced by three new sections. Except as noted above, oreration of the equipment using hydrogenated water has been normal throughout the month. Beactivity changes were negligible as predicted. Total production loss attributable to the P-13 project to date is $245^{\circ}$ MWD.

105-372-P (Measurement of Vertical Graphite Expansion at Near and Far Sides - B, D, and F Plies)

Measurements taken at D Pfle on March 7 tend to corroborate previous data, showing continued annealing of graphite in the central pile regions with some indication of a slight increase in displacement of the colder zone near the front ends of the tubes.

105-407-P (Pile Test of Magnesium Front Dumies) At B Pile on March 7, the front sections of five process tubes were borescoped and a pattern of 14 sol1d magresium dunmies installed in the front ends of the five tubes. From the performance of these and other slugs previously charged into the piles, It is expected to obtain data for use in evaluating the installation of solid magnestum dummies in all tubes as a corrosion preventive measure.

105-402-P (Effect of Water Vapor Concentration on Pile Gas Equilibria)

Tests previously reported as in progress on February 28 were completed on March 1 , and the use of silica gel driers in the ges circulation system was resumed. Followlng the test, rate of molsture removal was normal" and no unusual operational effects were ob. served.

105-417-P (Process Thube Purge During Pile Operation) On March 7, the DR P1le was purged during the normal shutdown period from a level of 472 MW and on March 22, the DR P1le was purged while operating at a level of $350 \mathrm{MW}$. Both purges were successful and no operational difficulties were encountered.

The special request program required approximately 220 manhours of time during the month. Cask handling and decontamination work continued to consume a large portion of the time charged to this work. Ten tubes of special request material were charged into the piles for irradiation. Nine tuber containing special request samples were discharged and 22 casks containing irradiated samples were 


\section{P. Division}

shipped off site. In addition, approximately 180 manhours were reguired for the charging, discharging and shipping of chemical $68-56$.

A total of 81.69 tons of uranium slugs was discharged during the month of which 1.12 tons was at $114 \%$ of goal value, 0.12 tons was at $50 \%$ of goel value and 80.45 tons was at $100 \%$ of goal value.

At $\mathrm{B}$ PIle an unscheduied outage of 18.6 hours duration occurred on March 22 in order to remove a ruptured and distorted P-10 target slug from tube 3483-H. Detalis are reported in document HW-20653, "Removel of Ruptured P-10 Target Slug from Tube 3483-H". In view of the two failures of P-10 target slugs during recent weeks, the tubes contalning P-10 loadings are being carefully monftored in an attempt to spot incipient failures and effect removal before damage occurs. Considerable vigilance is required since the regular water sampling equipment is of no value in detecting P-10 target slug failure.

A planned electrical outage of all piles occurred on March 7 in order to allow for the connection of new 200 Area transformer facilities. Since this outage was scheduled sufficiently far ahead to allow for advance planning of pile discharges, to coincide with the outage, all possible advantage was taken of the downtime. Thus, no actual lost production time was charged to this outage except at the DR Pile where metal was not ready for discharge.

DR P1le geined approximately 67 inhours during the month and additional P-10 chargea were loaded into the plle for improved flattening, allowing further increases in the operating level. Flow recording instruments at the DR Pile were recalibrated resulting in a favorable correction to $D R$ Pile level and production Pigures.

\section{Mechanical Experience}

The general mechanical condition of the pile components and equipment continued good throughout the month. Experience was normal except for the fallure of a screen during a purge at $D$ Pile resulting in crossheader screen plugging, and the continuation of leakage problems at the $H$ Area retention basin. The program of training operators in the proficlent use of the $H$ and DR tool dollies is progressing satisfactorliy.

All horizontal and vertical safety rods are in satisfactory operating condition at month end except the following:

a. Ilorizontal contro 1 rod $A$ at 100-D continues to bind in several positions. Investigation has shown that the rod is rubbing on the top of the thimble. It is planned to remedy the condition by replacing the graphite rod. track with thinner sections, machined down to correct for the bowing of the pile matrix.

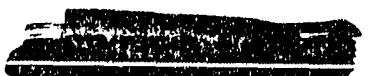




\section{P Division}

b. Vertical safety rod 11-B cannot be ralsed from the pile under power. The rod is now tied out of service and repairs are planned for a subsequent outage.

Difflculties with vertical safety rod 20-DR, reported in February, were eliminated by making adjustments to the slack cable limit switch, Horizontal rod $6-F$ was relleved of the binding tendency, reported in February, by realignvient of the rod gate assembly.

The unclad 2-S aluminum tube in channel $2180 \mathrm{~m}$ was replaced with a 72-S clad tibe on March 21 in accordance with the P DIvision program for replacement of all unclad 2-S tubes.

Tube 3060-B, reported damaged in February, was replaced on March 21 and returned to service.

During a solids purge at the D P1le on March 6, a valve pit screen at the injection pumps falled, allowing coarse super-cel to pass into the process water which resulted in the plugging of numerous crossheader screens on $B$ and $D$ risers. It was necessary to clean the screens before starting the pile.

Routine testing and practice operation of the tool dollies at 100-DR and 100-H Areas continued through the month. At H Area, the installation of mock-up facilities for complete functional testing of the dolly was begun. This equipment will expedite the training of personnel in operation ana testing of the dolly.

A new type ultra-flexible jointed vertical safety rod was installed in \#20 position (without VSR thimble) at $D$ Pile on March 7 . It was test-operated satisfactorily through the special step plug and gas seal and remained in position until March 28. At that time, the gas seal was leak tested. No leaks were found and the new rod was removed and replaced by the original knuckle rod. Poison effectiveness of the new rod whs tested at 31 inhours as compared to 35 inhours for the standard type jointed vertical safety rod.

At H Area, leakage in the 107 retention basin continued. A program of major repairs is awaiting the scoping of a project to provide the necessary funds. Meanwhile, every precaution is being taken to maintain the basin in operable condition unt1l permanent repairs are possible.

Gas Processing

Operation of this equipment was normal during the month. Some acceleration in gas leakage rates was experienced at $B$ and $F$ Piles. As reported under Pile Development, the F Pile gas leaks were greatly reduced by the installation of boots on four leaking Pront bellows. The leaks in the $B$ Pile gas system have not yet been isolated. It is suspected that one or more bellows on the rear face may be leaking.

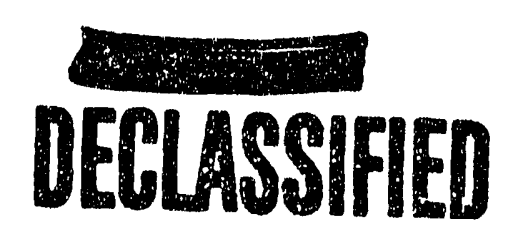


Pile Development.

A new type rubber boot for repair of leaking gunbarrel bellows was developed at $F$ Plle and a technique was worked out which permits installation on front face nozzles during plle operation. Four of these boots were put on leaking front bellows on F Pile reducing consumption from 3400 cubic feet per day to about 1400 cubic feet per day.

An innovation in water sample room monitoring equipment was introduced at DR P1le during the month. Test equipment which allows electrical impulses from adjacent near side headers to "buck" against each other was installed in the near sample room. This arrangement replaced a system in which impulses from a given header on the near side "bucked" impulses from the same header on the far side. This resulted in an erractic recording pattern. The new system has effectively eliminated exit water monitor pattern shifts and irregularities due to reactivity changes within the pile. It is expected that a considerable increase in instrument reliability w1ll result, making detection of ruptured slugs easier and more certain.

\section{Special Hazards}

Since the startup of H Plle, alrborne effluent vapor contamination has been a chronic problem in various areas of the H Pile bullding. Recent studies have indicated that the principle source of contamination is the unsealed hole through which the downcomer vent reaches the roof. This allowrs contaminating vapor from the vent to enter the bullding. Under certain atmospheric conditions, the problem becomes critical. During the outage of March 22, the apace around the vent pipe was tightly sealed with lead wool. Subsequent surveys have shown that contamination immediately beneath the vent has been reduced by a factor of 10,000 and gratifying improvements have been made in airborne contamination throughout the entire pile building.

At $D$ Pile, continued effort is being made to eliminate the source of effluent vapor contamination in the water sample rooms. The Installation of large vents at the upper ends of the sewer risers has improved the situation considerably. However, the $X$ and $Y$ rooms are still generally above tolerance level and are in a restricted status.

A loose manhole cover on the far effluent line from the DR Pile was found to be emitting vapors giving dosage rates as high as 35 $\mathrm{rep} / \mathrm{hr}$. including $2 \mathrm{r} / \mathrm{hr}$. at eight inches from the leak. The situation was handled by switching to the near effluent line. Repairs are planned for the next scheduled outage.

\section{Process Control}

In addition to routine activities, a new monthly production study was developed giving a comprehensive forecast picture of production, 


\section{P Division}

manpower and cost for the 100 Arees and the 300 Area. It is planned to isaue this report monthly, improving and modifying it to meet the needs of the. P Division and other divisions affected by production schedules.

On March 5, Process Control was extended to the 300 Area with the assignment of a Process Control Engineer to that area.

During the month, steps were taken to insure adequate continuity of records required for pile production scheduling in the event of a disaster affecting the Richland Area.

300 AREA METAI FABRICATION

OPERATINTG SUMMARY

All 300 Area operations were normal throughout the month. A new record billet yield of $88.3 \%$ was attained in Melt Plant operation. Intensive investigation was continued in all phases of slug fabrication and testing which might result in improvements of slug guality and eliminate the possibility of slug fallure during pile exposure. Substantial progress was made in canning production and in the elimination of marred gurface rejects through an improved organization of the canning lines.

\begin{tabular}{|c|c|c|c|}
\hline Uranium Fabrication & February & Mirch & $\begin{array}{c}\text { To Date } \\
1951\end{array}$ \\
\hline Billets Produced (Tons) & 27 & 16 & 53 \\
\hline Bare Pieces Machined (Tons) & 85 & 91 & 275 \\
\hline Briquettes Produced (Tons) & 12 & 12 & 37 \\
\hline oxide Burned (Weight out - Tons) & 3 & 2 & 9 \\
\hline Acceptable Pieces Canned (Tons) & 82 & 90 & 267 \\
\hline Melt Plant Billet Yield $(\%)$ & 86.7 & 88.3 & 87.7 \\
\hline Melt Plant Solid Yield (\%) & 93.9 & 93.9 & 93.5 \\
\hline MachIning Yleld $(\%)$ & 81.6 & 80.0 & 81.2 \\
\hline Chip Recovery Yield (\%) & 87.6 & 85.3 & 87.5 \\
\hline Canning Yield $(\%)$ & 91.2 & 91.6 & 91.3 \\
\hline Autoclave Frequency (No./M) & 0.17 & 0.24 & 0.19 \\
\hline
\end{tabular}

\section{OPERATING EXXER IENCE}

Melt Plant

The billet yleld for March was the highest attained at Hanford to date. This record yield was attributed mainly to the absence of broken stopper rods. Two leaky stopper rods and one cracked crucible were the only operating difficulties encountered during the month.

Machining

The lower yield for March resulted from poorer surface quality of the rods machined. All lots processed, except one, were U type material recelved in January and exhibited a high percentage of 
P Division

laps, cracks and seams. Many of these defects falled to clean up during machlning and caused abnomally high tool breakage.

The installation of pneumatic rod feeders on all roller turner lathes was completed in March. During the short perlod these feeders have been in use they have proved to be very satisfactory and have successfully eliminated a serlous strain hazard.

\section{Chip Recovery}

The ch1p recovery process was operated without incldent.

During the month, calcium nitrate was substituted for calcium chloride as a flocculating agent for treating the chip recovery wash solutions. The use of this material has made it possible to produce a precipate which has less bulk, is free of chlorides, dries more rapidly and has less tendency to cake.

\section{Canning}

The canning yield for March was olightly hlgher than that reported for February. From a total of 90 tons classifled, 2.2\% were re. jected for marred surface, $1.3 \%$ for non seat1ng, 1.2\% for A.I-S1 on outside of the can, $1.0 \%$ for bad welds and $2.7 \%$ for miscellaneous causes.

Reorganization of the canning crews so that each crew handles only lts own material has been instrumental in reducing marred surface rejects.

Defective cans accounted for the rejection of $0.7 \%$ of the total slugs canned. Although this percentage is similar to that experlenced in February, cans processed toward the end of the month did not exhlbit the blisters which were noticed previously. DurIng the month, correspondence was received from the Aluminum Company of America in which they indicated the blisters originated from gas bubbles in the aluminum casting from which the cans were fabricated. To further study the cause for defective cans, the Aluminum Company has been asked to segregate cans from each casting.

\section{Inspection}

A total of eleven autoclave fallures occurred during the month. Five of the fallures were the result of minute pin holes extending through the weld into unbonded ureas between the cap and can side wall. Three fallures were caused by very fine cracks in the caps. The cause of the remaining failures could not be defintely established.

None of the slugs tested for penetration during the month were found to be penetrated within $0.010^{\prime \prime}$ of the outer can surface.

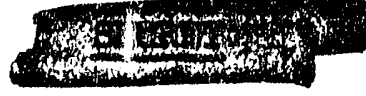




\section{P Division}

305

The following tests were run durlng March:

Description

Regular slugs

B1liet egs

Determine the density correction factor to be used in graphite testing

Measure the purity of graphite bars

Measure the reactivity of uranium slugs with varying thickness of end caps

Determine the variation in reactivity of slugs in the same lot

Determine the surface contamination on urantum egg samples

Test aluminum to be used for the fabrication of cans Measure the absorption cross section of material to be charged into 105 piles
No. of Testa

67

31.

74

22

20

54

18

14

2

Special Fabrlcation Work

One thousand nine hundred seventy-seven poison slugs were canned.

During the month, considerable time was spent fabricating olugs for the dupont Company. This work consisted of processing approximately 700 pieces 6 to 8 inches long and $3 / 4$ to 1 inch in diameter. All of this work was performed on a sclieduled overtime basis and required approximately 1200 manhours.

In addition, 10 manhours were spent in fabricating 80 single dipped canned dumies for corrosion tests.

Material Handiling

Sixty-nine tons of normal canned slugs were shlpped to the 100 Areas. Seven and one-half tons of solld uranium scrap were shipped to Ios Alamos.

A total of $1447 \mathrm{U}_{235}$ aluminum alloy slugs and assoclated scrap materials were shipped to ORNL. In addition, five slugs were transferred to Pile Technology for use as standards in a production test.

Approximately 26 manhours were devoted to making miscellaneous off-plant shipments.

A total of 221 tons of alpha rolled rods was received from simonds Saw and Steel Corupany.

Special Hazards

No unusual conditions developed during the month. 


\section{Development}

The timing equipment installed previously on two welding machlnes to control the rate of preheating and welding has produced very satisfactory reaulto. Similar equipment is currently being installed on the two remeining machines, When the installation is complete, optimum rates of revolution will be established and the speed regulators will be fixed permanently to standardize the process.

To guarantee proper centrifuging and to reduce tin carry-over into the Al-S1 canning baths, a centrifuge was altered so that after starting it would operate on a deflnite time cycle and then be automatically stopped. Use of this device has proved very satis. factory in that tin carry-over has been reduced, and the autoniatic control is influential. In keeplag the canning operation on the required time cycle. Steps are betag taken to convert the three romaining centrifuges.

The use of dry lce in the melt plant cold traps was discontinued during the month. Information oblained at Mallincirodt Chemical Works and ANL indicated this practice was unnecessary. Operation Without the benefit of the cold traps has not affected the furnace vacuum. An annual savings of $\$ 3400$ in material costs will result from this change.

The time isequired to load canned slugs into the vans for routine shlpment to the 100 Areas was reduced by $80 \%$ during the month. This development was made posalble by altering a high-lift so that it can be driven inside the vans to elininate individual handing of the slug boxes. Through this system, a 10 ton shipment can be loaded in less than 45 minutes. Prevlously, it took about 4 hours to perform the job. It is estimated that this change will regult in a savings of $\$ 590$ per year.

At the request of the production group, a study was made by the Process Control Group to determine the benefits to be derived from recanning reclalmed slugs by the lead dip canning process. PreIIminary results indicate that the adoption of the practice would increase the one shift canning capacity of the 300 Area by approximately 75 tons per year. In addition, the cost of processing this materlal would be reduced by approximately $\$ 8,000$ per year. The final report on this study will be published in the near future and the program will be submitted for approval.

\section{ENGINEERING PROGRAM}

Contact Ingineering Section

The Contact Engineering Group continued work on Project $C-431-B$, 100-C plant, on a alx day per week basia. The reactor builinge design criteria, with the exception of the instrumentation section, were reviewed and approved. 


\section{P Divilaton}

The dealgn and ansoclated drawings for Project C-41.L (J glug Handiling) are complate and approved. The revised scope of the project has been submitted to the Atomio Energy Commision.

\section{Engtneering Control Section}

The efforts of the Elagineering Control croup were applied malnily toward preparation of the DIV1,10n's operating and construation budgets. The construction budget was essentlaliy completed but, due to major revistons of the budget assumptions, preparation of the operating budget was only about $50 \%$ complete at month end. Varlous cost studies and reports were completed during the month In addition to the normal. cost control work. Prsparation of project proposals and follow-up of approved projects was continued throughout the month.

Projecta and proposals requirlag conslderable attention Included: C.438 - Ball 3X Faclilties; B-865 - Repalrs to 107 Basins; B-821 Repalr to Effluent Downcomers; C-330 - Improved Ventllation Bldg. 31.3 and 314 ; and M-713 - Deslgn and Development of Flextble VSRs.

\section{Project Status}

Below 1a sumarised the atatus of P Division profecta which are currently actlve:

C-330 (Improved Ventilation - Bullding j13-314 (EnglneerIng and Development Only)

Preliminary results on Hergey bag filters indicate better than 90 percent efflclency with exhaust alr below tolerance limita. Improvements in cruclble burnout design, chip recovery ventliation and rod stralghtener ventilation are in progress.

\section{M-71.3 (Flextble Vertical Rod)}

The full acale rod was tested in position 20 at $D$ Pile on March 7. Performance under power and by scrarming was satisfactory. An extenalon of the directive date will be requested to allow time for additional gravity drop testa slmulating emergency operation.

\section{C-411 (J Slug Storage and Shlpplng Facllities)}

A letter is being prepared requesting the Atomic Energy Commisstom to modify the directive to reflect the reduction in estimated project cost due to curtaliment of the program previously reportied.

\section{C-431-B (New Production Facilitiles)}

Desicn and development work are proceeding a authorlzed in directive $\mathbb{H W}-222$.

C-420 ( $\mathrm{CO}_{2}$ Bulk Handing Facilities) The ${ }^{2}$ low pressure tank concrete supports at 110-D have been installed. Further work 1a awniting 
matertala, proouremedt of whtch is in progress.

M-825 (Mechanlcal Feeds for Bullding 313 Turalng Lathes) The fleld work as been sompleted. The feeds are Inatalied and functiondng sabiafactorily.

M-826 (Crosabeader Presgure Mon1torlng, 105 $\mathrm{H}$ ) Inataliation of the pressure monitoring aystem at II Plie 18 approximately $30 \%$ complete. It lo expectod that the job wili be completed during April.

M-829 (D.DR Safety Clrcult Interlook)

Work is in progreas, but being delayod by lack of essential parto.

$B-1886$

C. -438

$B-544-R$

\section{(Bel1 3X system)}

A letter projeot proposal has been submitted to the Atom10 Inergy Comilasion for englneering and procurement of oritical l, tems.

(Steel Process Sewor - 105-107-B)

The recomendation for replacement is now being considered in the light of the new productilon faclilty contemplated in B Area.

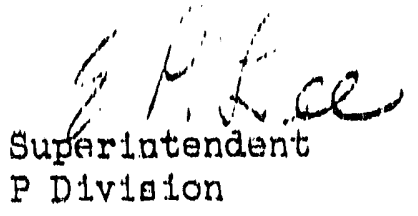


Richland, Washington

April 5, 1951

\section{S OTVISION}

MARCH, 2951

I. RESPONSIBILITY

There were no changes in S Divi.ston responglbillties during March.

IJ. ACHIBVEMENT

A. Operating Experience

1. Product on Stat1stios

a. Oter-a11 Performanoe - Canyon, Conoentration and Isolation Building (3-1-51 thru 3-31-5.1, Inclusive)

\begin{tabular}{|c|c|c|c|c|c|}
\hline $\begin{array}{c}\text { B P } \\
\text { Normal }\end{array}$ & $\begin{array}{l}\text { ant } \\
\text { Acld } \\
\text { Wast }\end{array}$ & $\begin{array}{c}\text { N } \\
\text { Normal }\end{array}$ & $\frac{\frac{\text { lant }}{\text { Ac } 1 d}}{\text { Wash }}$ & $\begin{array}{r}\text { Com } \\
\text { Normal } \\
\end{array}$ & $\begin{array}{r}\text { bined } \\
\text { Acld } \\
\text { Wesh }\end{array}$ \\
\hline 66 & 0 & 75 & 0 & 1.41 & \\
\hline 67 & 5 & 73 & - & 140 & \\
\hline 64 & $\begin{array}{l}1 \\
-\end{array}$ & 72 & $-\begin{array}{l}1 \\
-\end{array}$ & 1.36 & $\begin{array}{l}2 \\
11 \\
98.4\end{array}$ \\
\hline & $\begin{array}{l}5 \\
7.6\end{array}$ & & $\begin{array}{l}66 \\
98.4\end{array}$ & & $\begin{array}{l}60 \\
98.0\end{array}$ \\
\hline & 2.4 & & 01.2 & & 101.7 \\
\hline
\end{tabular}


b. Oanvon and Ooncentration Bulldtng Performance Data for dompleted Charges (3-1-51 thru 3-31-51, Inciustve)

B Plant I Plant Combined

Percentage of starting product in waste:

$\begin{array}{llll}\text { Thts month } & 2.3 \text { (a) } & 2.2 \text { (a) } & 2.3 \\ \text { Last month } & 3.4 \text { (b) } & 3.3 \text { (b) } & 3.4 \\ \text { Oumulative to Date } & 3.8 \text { (c) } & 3.7 \text { (o) } & 3.8\end{array}$

Percentage of starting product recovered:

$\begin{array}{lrrr}\text { This month } & 100.6 & 100.1 & 100.3 \\ \text { Last month } & 96.2 & 95.6 & 95.9 \\ \text { Cumrla tive to Date } & 96.9 & 95.9 & 96.4\end{array}$

Percentage of atarting product accounted for:

$\begin{array}{lrrr}\text { This month } & 102.9 & 102.3 & 102.6 \\ \text { Last month } & 99.6 & 98.9 & 99.3 \\ \text { Cumulative to Date } & 100.7 & 99.6 & 100.2\end{array}$

Gamma decontanination factor (Log.)

$\begin{array}{llll}\text { This month } & 6.95 & 7.06 & 6.97 \\ \text { Last month to Date } & 7.14 & 7.08 & 7.11 \\ \text { Cumulative tio } & 7.28 & 7.35 & 7.31\end{array}$

(a), (b), and (c): Includes waste from processing recycle. The recycle wasteg are estimated as: (a) $0.012 w$, B Plant; $0.013 \%$, T Plant. (b) $0.017 \%, B$ Plont; $0.017 \%$, T Plnnt. (o) $0.011 \%, B$ Plant; $0.066 \%$, T Plant.

c. Isolntion Bullding P rformance Data (3-1-51 thru 3-3.2-51, Inclusive)

\begin{tabular}{|c|c|c|c|c|c|}
\hline & $\begin{array}{l}\text { Prepared for } \\
\text { Shlpment }\end{array}$ & Recycle & Waste & $\begin{array}{l}\text { Retained } \\
\text { Samples }\end{array}$ & $\begin{array}{l}\text { Material } \\
\text { Balance }\end{array}$ \\
\hline $\begin{array}{l}\text { verage for this month } \\
\text { verage for last month } \\
\text { verage to date }\end{array}$ & $\begin{array}{l}93.7 \\
90.8 \\
95.1\end{array}$ & $\begin{array}{l}5.45 \\
6.20 \\
4.90\end{array}$ & $\begin{array}{r}0.04 \\
-0.10 \\
0.04\end{array}$ & $\begin{array}{c}0.04 \\
-0.09 \\
0.011\end{array}$ & $\begin{array}{r}99.2 \\
96.9 \\
100.1\end{array}$ \\
\hline
\end{tabular}

d. Depleted Uranium and Waste Storage Status

200 East Area

Tark Farm $\frac{\text { Galions (203) in Storage }}{B \text { B }} \frac{\text { Batches to Process }}{\text { BX Total }}$

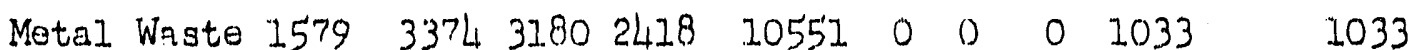

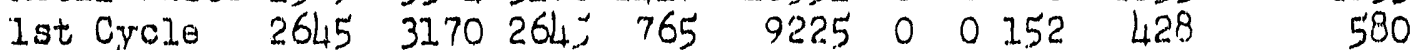

and Cycle $1195 \quad 0 \quad 0 \quad 0 \quad 1195377,072$ gal crubed from

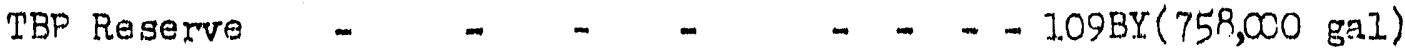

Waste Evap.

Re serve 


\section{Aprid 5, 1951}

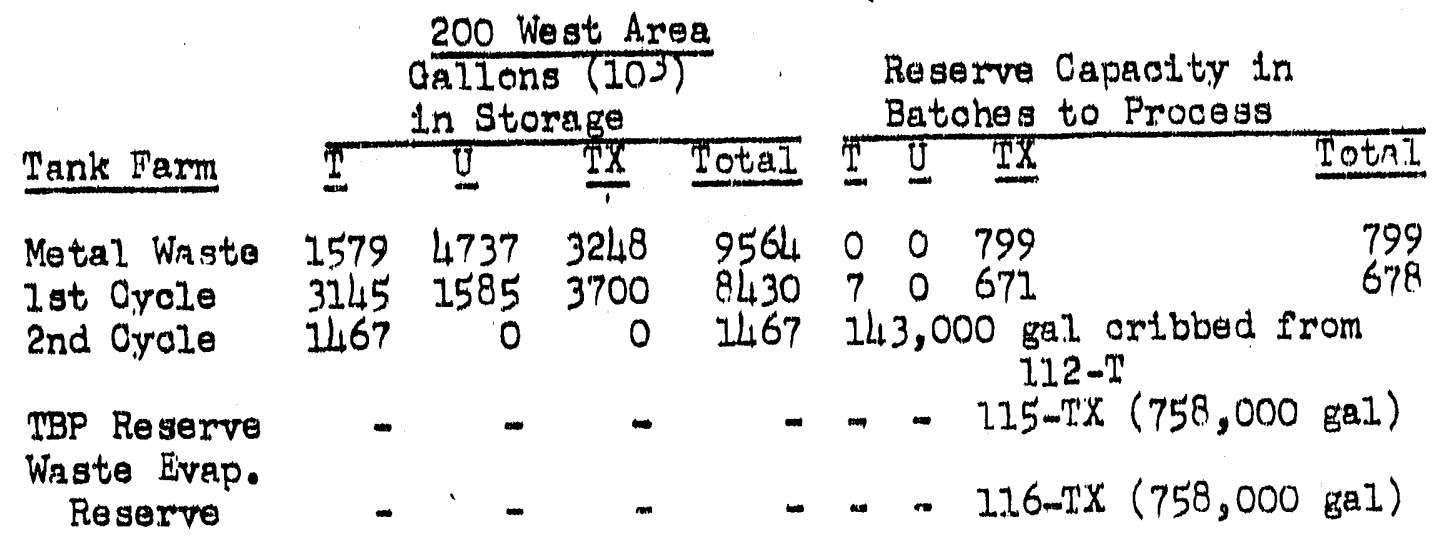

2. Production Aotivities

\section{a. General}

Over-all. time cycles of 10.6 hours and 10.3 hours were malntalned at the Canyon and Conoentration Bullding, respectively, during March. This includes standard charges and acid washes which had been started in extraction Just prior to the beginning of the month. Also included are five charges of $\mathrm{P}-11$ test material which were returned for rew processing through the loncentration Bullding at B Plant. This particular phase required time equivalent to five standard charges, therefore the production of Plutonium was decreased pronortionately. The number of total charges strirted in the Canyon Bulidings and completed through the Concentration Buildings constitute the highest production level yet attained at Hnnford works. At T Plant, the effluent I the from the 202-T settling tank for Concentration Bullding wastes continues to exhiblt partinl plugging. Efforts to relieve this condition during the month were mediocre7.y successful and further work is contemplated. The denleted Uranium loss which occurred at the 2LI-BX Tank. Farm during February has been finally caloulated to amount to anproximale 10.7 tons. Also, a loss of Plutonium associated with this Uranium loss wns astimated to be approximately 10 to 12 units.

b. Extriction

Signiflcant data on extraction waste losses nre tabulated below:

March Fabrunry

Anr lyses before rework

Anplyses after rework

(throw-away)

Average MWD/Ton
1.84

1.80

1.45

405

$$
1.45
$$

410
B Plant

T Plant Marchit Fobruary

2.43

1.91
*Includes twelve charges from $632 \mathrm{MWD} / \mathrm{T}$ motal. 


\section{S Division}

\section{c. Acid Washes - B and T Plants}

An acid wash was completed through one parallel line of the Canyon Buildings and through the Concentration Buildings. The B Plant results are higher than normal due to the pick-up of a Plutonium heel in the product hold-up tank in the extraction section and a defective distributor in the first decontamination cycle precipitator tank. At T Plant, the Concentration Building preflush was higher than normal due to the plck-up of plutonium in the F-Cell precipitator tank. Corrective measures have been instituted by replacing defective equipment and by modifying operating procedures. Data is tabulated below which indicates the percentage of product recovered in terms of a standard charge:

Sect. 12 \& 2nd 221224 Total thru Preflush B,

Run Extraction lst Cycle Cycle Bldg. Bldg. Process ERCF Cells

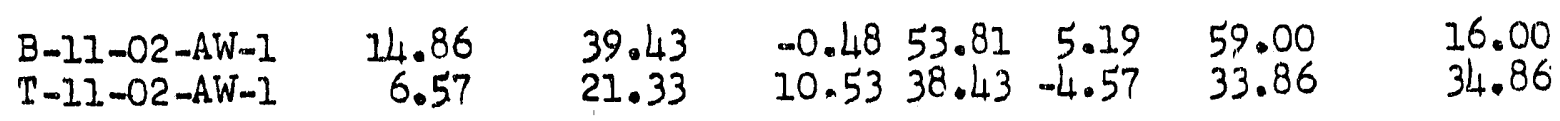

d. Depleted Uranium Loss - B Plant

After confimation that a plug existed in the cascade line between the 102-BX and 103-BX tanks, the current extraction wastes ware diverted to the 104-BX series where it will cascade through into the 104-BY series. Meanwhile the special jet assembly which was installed in the 102-BX tank, during February, was used to transfer supernate to the 103-BX tank, where it cascades into the 10.L-BY series. Eventually this series will be filled, thus utilizing its capacity to the fullest extent bv diverting back at a later date to the 101-BX. series in order to refill the 102-BX tank. It has been determined that the spread of contamination, due to the leak in the 102-8X tank, will not interfere with future construction work on Project C-362 (TBP) since the soil. is contaminated in a zone considerably below the lowest elevation of construction activities. Further exploratcry work will possibly be undertiken following the installation of the new froilities.

\section{e. Neutsch Filter Block Cleanouts - Isolation Building}

Since it apdeared that 60 percent nitric acid leached the filter blocks more efficiently timn 25 percent nitric acid, the first cycle filter blocks in Cells 2,3 and 4 were treated with the higher strength cid. The total combined recovery of Plutonium amounted to 595.64 percent of a standard chnrge. This abnomal hold-up probably ruspresents a long term hold-up. Effective immediately, the frequency of cleanouts will be incrcased from a monthly to a sumi-monthly basis 
using the stronger acid, and the results will be examined carefully.

\section{f. Recovery of Americium}

Twenty-four milligrams of Americium were recovered by making a third peroxide precipitation of aged Isolation Building product from two sample cans. The Americium bearing supernatant as obtained after precipitation of the plutonium was shipped off-site without any attempts belng made to further concentrate the solution.

g. Crtbbing of Second Decontamination Cycle Waste

Approxdmately 377,000 gallons of second decontamination cycle waste supernatant were cribbed from the 112-B tank. Also, about 143,000 gallons were cribbed from the 112-T tank. The cribbing operation was suspended at month end in the $T$ tank farm when work was initiated on constant overflow facilities. (Project $\mathrm{C}-415$ )

\section{Process Control}

a. Dissolvr Off-Gas Filter (Project C-337) and Silver Reactor (Project $(-378)$

The major portion cf materials for the fabrication of the fifth reactor filter assembly have been ordered and the construction of the unit is scheduled to start in April.

One of the new higher capacity steam ejectors has been installed. It is indicated that a satisfactory increase in the vacuum on the dissolvers has betn realized, however, a complete evaluation of its performance will be made before installing the remaining three units.

b. First Decontamination Cycle Waste Evaporator (Project C-369)

The over-all construction phase of the project is proceeding satisfactorily with 85 percent completion at month end.

A small portion of the aged First Decontamination cycle waste formerly stored in the $T$ Tank Farm wels transferred successfully.y to the designated storage tanks in the TX Tank Farm, in preparation for start-up which is tentatively scheduled early in May.

The Project Proposal for the 200-L evaporator has been resubmitted to the Engineering and Construction Division for a re-estimate. 
c. Cell Drain Conductivity Meters (Profect C-397)

The installation of the conductivity meter leak detection device was completed in Cell $7 R$ at $221-T$. This completes the work outlined in the project and formal acceptance has been made.

d. Additional Waste Storage Facilities - 241-BZ (Profect C-417) and 24I-IY. (Project C-418)

Project $C-4.17$ has been cancelled, since approval has been received from the AEC to increase the metal anrichment level to $600 \mathrm{MWD} / \mathrm{Ton}$, which precludes the necessity for the construction of additional process waste storage facilities at this time in the 200-E Area.

Preliminary construction work has been started on Project C. -418 , and will continue as rapidly as conditions permit, in the 200-W Area.

e. Section 5 Waste Disposal (Project C-415)

Construction work was started in the 24l-T Tank Farm during the past month.

f. Special Samples

A five liter sample of unneutralized process waste was obtained from a settling tank at the 234-5 Building and shipped to the Separations Technology Division, Chemical. Research Section, 300 Area.

4. Investigation and Develonment

a. Extraction Preciditation Bismuth Concentration (Production Tost $221-B-10)$

Since the previous month's experience indicated that processing in the extraction precipitation step could be successfully accomplished with a bismuth ion concentration of $2.5 \mathrm{~g} / \mathrm{l}$, further volume reduction aspects wero explored at B Plant. A. series of ten runs were processed at 56\% and $49 \%$ of the original standard, with intervening series of normal volume runs for control. There were no significant differences in the waste losses of the runs at reduced volume $z$ s compared to the standard runs. However, there was a definite increase in the number of turbid product solutions in the first and second decontamination cycles. At month end this condition is being investignted and further evaluation will continue during the coming month. 
b. Elimination of Radio-iodine from Stack Effluent (Production Test $22(-B-9)$

Tests continued curing the month, and it was indicated that the radio-1odine may be driven off effectively by the controlled air sparging of the metal solution. However, further confirmatory tests are scheduled for April.

c. Reprocessing of P-11 Test Material

The equivalent of five standard runs of material, with the phosohate ion present, were returned from P-Il for reprocessing through the Concentration Building at B Plant. EssentialIy these muns were processed as master recycle muns and only routine processing difficulties were experienced.

B. Equipment Experience

\section{Operating Continuity}

There were no equinment fajlures which effected the continuity of operations.

2. Insoection, Maintenance and Replacements

a. Cenyon Equipment Failures - B S T Plants

Equipment failures in the Canyon Buildings are summarized below:

1) In B Plant, the Section 14 precipitator tank distributor failed, due to a broken dip tube, and was replaced. The unit removed was stored for disposal.

2) In B Plant, the dip leg plugged on the Section 14 precipitator tank weight determination assembly. Repeated attempts to dislodge the plug were unsuccessful and the dip leg was replaced. The dip leg removed was stored pending disposal.

3) In B Plant, the Section 14 centrifuge developed a luak in the overflow line to the catch tank. lfter decontaminating tho centrifuge successfully to reasonable working limits, a new overflow line was installed and the unit was restored to service.

4) In T Plant, the Section 7 precipitator to centrifuge A jet assembly failed at the discharge flange of the jut and was replaced. The defective assembly is stored for possible salvage.

5) In $T$ Plant, the Section 14 precipitator tank distributor became inoperative due to plugging, and was ruplaced. The 
defective distributor was stored for possible future renovation.

6) In. T Plant, the jet assembly which is used to transfer unneutralized extraction waste from the catch tank in Section 7 to the neutralizing tank in Section 9, failed. A spare assembly was installed as a replacement and the defectlve assembly was stored for possible removal of the faulty gasket in the steam inlet connector head.

7) In $T$ Plant, a transfer fet a ssembly, which is used to transfer second decontamination cycle br-product waste from the hold-up tank in Section 18 to the collection tank in Section 15 became inoperative due to plugging. Several attempts to unplug the assembly were unsuccessful; however, it is possible that it will be salvaged, eventually, when the oress for time decreases.

8) At $T$ Plant, the Section 16 first decontamination cycle precipitator to centrifuge $A$ jet assembly has been inoperative for several. weeks die to the inability of connecting the steam inlet connector head to the cell wall stub. Investigation revealed pipe creepage has occurred and the flanged wall stub has moved toward the kick plate. This is the first occurrence of thi: type, although the reverse has been observed to a limit $3 d$ extent. The problem will be further investigated.

9) In T Plant, at Section 19, the connector failed, due to plugging, in the assembly which is used to obtain samples of waste solutions from the second cycle decontamination centrifuge catch tank. A spare unit was installed and the plugged connector will be salraged.

10) In T Plant, an agitator assembly was renovated by the replacement of the motor, which had failed in January 1951. This assembly was formerly in service at Section 15 in the second decontamination cycle waste neutralizing tank. The defective motor will bo examined to determine the possibility of salvaging.

b. Concentration Building Mechaniczl Difficulties - B \& T Plants

1) In T Plant, the $B$ C $\in I I$ centrifuge drivehead upper bearing failed. The failure was determined to be caused by lack of lubrication due to the fact that an improper type of oil Dick-un nozzle had been used. Further investigation revealed that the roblacement drivehead was similarly equinded. This condition has been corructed and no further difficulty has been experienced. The ruason that these two driveheads were equipned with this type of oil pick-uo nozzle is not readily explainable since four other simllar 
urits in the same building are equipned with nozzles of proper design. However there is very little difference between this nozzle and the nozzle actually designed for the drivehead and it is assumed that an error occurred during assembly.

2) At the 224-T Building, a centrifuge spray assembly failed when corrosion occurred on a disc which is welded to the bottom end of the vertical section of pipe to which the spray nozzles are attached. It is suspected that Type 347 Stainless Steel was used, instead of Type 309, when the spray assembly was fabricated. The replacement assembly' appears to be satisfactory.

c. Coil Failures, Sodium Hydroxide Storage Tanks

A routine analysis of the steam condensate from Sodium Hydroxide solution storage Tanks SQ 141 and 143 in B PIant indicated that the heating coils were leaking in both tanks. At month end preparations have been made to empty and clean these tanks in order to effect repairs.

d. Inspection of Hydrofluoric ncld Stors ge Systems

At B Plant the hydrofluoric acid system at the Concentration Building was drained to permit isspection and testing of the relief value, mature disc and pipe lines. No abnormalities were encountered. At T Plant, nll of the nrincipal stornge tanks were audignged to determine the thickness of metal in the tank shel.s. There was no appreciable variation from the results obtained in Augu.st 1950, and no abnormalities were apparent.

\section{Improvements}

1. Rdoptions

a. Volume Reduction and Bismuth Concentration

The results thus far obtained in accordance with Production Test 221-B-10 indicate that volumes may be reduced as far as $49 \%$ of the original volume $(9-1-46)$ in extraction with a bi.smuth concentration of $2.5 \mathrm{~g} / \mathrm{l}$. However, the total effect of the volume reduction requires further evaluation in steps up to meththesis, and sdditional work is planned during April. At the present time it appears that the extraction and first decontamination cycle waste volumes will be substrntially reduced, dependent upon which volume reduction bngis is adopted os standerd.

b. Ise of 50 Percent Fydrogen Peroxide - Isolation Building

During the latter part of the month the use of 27.5 porcent hvdrogen poroxide was discontinued in favor of the 50 percent 


\section{S Division}

reagent. It is indicated that the volume of solution recycled to the Concentration Bulldings will be reduced with no sacriflce in Plutonium losses in the waste effluent.

c. Samole Can Adaptor Plugs - Isolation Building

Following extensive investigation, the stainless steel adaptor plugs were replaced by plastic plugs on sample cans shtpped to the 234 Building. This substitution of material effects a cost reduction of about 50 percent and is in keeplng with the program to conserve stalnless steel.

d. Americium-Curium Correction Factor

Following extensive research and investigation as to the Americium-Curium content of Canyon Building process waste effluents, beginning this month a correction factor was applied which reduced the total apparent plutonium content of process wastes approximately 50 percent. It is believed that about 65\% of the Americium-Curium is accounted for in extraction while the balance is removed in the first and second decontamination cycles. Total waste losses through the Concentration Buildings amount to approximately $1.8 \%$

- as comoared to the $3.4 \%$ previously reported.

2. Inventions and D1scoveries

No inventions or discoveries of a patentable nature were reported during the month.

\section{PERSONNEL EXPERIENCE}

A. Organization Changes

R. B. Bixler, M. I. Short and J. F. Newland were promoted from Shift Supervisors to Senior Supervisors, effective March 1.

C. R. Gangnath, G. W. Morrow, G. R. Ruzicka, H. P. Simonds, W. J. Smith, Jr., N. M. Craft, W. J. Luke, A. J. Waligura, W. P. Wood, Luther Welsh, W. A. Haney, R. M. Shervem, and D. E. Peterson were promoted from Supervisors-in-Training to Slift Supervisors, effective March I.

O. D. Erlandson, Keith Gunnar, C. W. Malody, R. A. Yoder, and C. F. Yuenger, Jr., were promoted from Technical. Graduates to Supervisorsin-Training, effective March 1.

A. H. Hinkson was promoted from the weekly roll to Supervisor-inTraining, on March 1.

B. Force Changes 
S Division

1. Number of Employees on Roll

Beginning of Month

End of Month

Net. Increase (decrease)

2. Personnel Changes

\begin{tabular}{ccc} 
Monthiy & Neekly & Total \\
\cline { 2 - 3 } 146 & 459 & 605 \\
$\frac{153}{7}$ & $\frac{476}{629}$ & 24
\end{tabular}

Monthly Weekly Total

Transfers from other Div. Transfers to other Div. Reactivated

New Hires

Resigned

Transfers from Weekly to Monthly 6

Any other description

Total

\begin{tabular}{rrr}
1 & 11 & 12 \\
0 & -2 & -2 \\
0 & 1 & 1 \\
0 & 18 & 18 \\
0 & -5 & -5 \\
6 & -6 & 0 \\
0 & 0 & 0 \\
\hline 7 & 17 & 24
\end{tabular}

C. Saf'etr Experience

There were no major or sub-major injuries incurred by $S$ Diviston personnel during the month of March.

D. Radiation Protection

1. Samiling Incident

Extremely high readings were obtained on the sampling equipment, following the sampling of a first decontemination cycle product solution at I Plant. ifforts to decontaminate the equipment were unsuccessful, and while removing the bayonet tip with a pair of tongs, the bayonet tip shattered, contaminating a small area in the vicinity of the sample port. There was no over-exposure or personnel contamination, and the work area was successfully decontaminated to within permissible limits.

2. Radiation Levels - 24I-TX Tank Farm

Coincidental with the diversion of T Plant extraction wastes from the 101-TX series to the 105-IX series, the radiation level at the four inch electrode measuring riser was $100 \mathrm{mr} / \mathrm{hr}$. The necessary precautions are buing taken to prevent the overexposure of personnel. It is expected that the present high reading will decrease, as the tank fills, due to the shielding effect of the supernate above the sludge. 


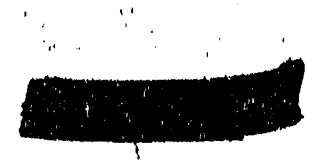

5 Division

V. EXPANSION SECTTON

A. TBP Project $(C-362)$

1. Genera1

\section{a. Project Status}

The project status at month end is as follows:

1) Elghty flve percent of the detall design has been completed as compared to a scheduled 80\% completton. It is expected that substantlally complete design will be reached by April 1, a two month advnnce from the origtnal. design schedule.

2) A total of 734 requisitions or substantialiy $100 \%$ of the required requisitions have been received and approved for all phases of the TBP Project. 95\% of those recelved are covered by purchase orders.

3) Construction is $15.7 \%$ complete based on man hour requirement. This progress is slightly behind schedule due to delay in recoiving matorials. The Engineering and Desi gn Division issued a revised "Composite Construction Schudrale for C-362" on 3-1-51 which shows: November 1, 1951 as completion date of the phases ruquired for 8 ton production compared to an orlginal completion date of October 1, 1951; August 1, 1951 as complation date of the lat waste removel unit comprred to an original completion date of June 1, 1951; and Febmanry 1, 1952 is the completion date of the whole project compared to an original. completion date of May 1, 1952. This revisod schedule reflects the efects of the procurement diffloulties encountered up to the present date in nddition to the construction forces roallocation of mnpower.

4) Present comnttmentis on materials and equipinent costs for the C-362 Profect agree verv closely with the projeot proposal estimate. A revised projuct proposnl will be issued in the enrly pert of Moy, 1951.

\section{b. Acceptince Tist Procedures}

A weighted tabulation of Acceptance Tust Procedure complotions showed $49 \%$ of the procedures for all phases to be completed during tho month.

c. Tests for Motnl Wasto Spill

Due to the splilage of metal. waste in the vicinity of the 102-BX tank, a serios of six test holes was dug at planned locations in the genernl nre? in which the trink pits and pipe 
4

w'"

enonsementa are to be constmoted. The test holes were excavated to a depth of 8 - 10 feet, and no detectable radiation was encountered. It was concluded that the apllled material would not 1nterfere with the oroposed ocinstruct ion.

\section{Essential Materials}

a. The Purchasing Division has been making oontacts with ohemical suppliers this month in an endeavor to $11 \mathrm{rm}$ up ohemical requilements for this project. The contraot for Sulfamic Acld was released. Progress has keen made on 1.4 mestone procurement as well as on TBP and DIluent procurement.

b. The Manufacturing DIvL sLons requested procurement of excessed $46 " \times 54$ " pallets avaliablo at the Pagoo Depot to replace $5^{\prime} \times 5^{\prime}$ palitets ordeglnaliy ordered.

3. Procurement

Durlng the month corrosion fallures which have previously been reported have dropoed off to a negliglble quentitty; therefore, if this present trend continues there will be virtualiy no adverse effect on the vendor fabrioated 1tems other than those which were involved in the filures of January and February.

The delivery schedules of most of the bulk orders for plate and pipe are satfsfactory at this time and are rapidly approaching completion. It appears, however, that the delivery of new plpe which is required by the Kellex requisition alterations will be between September and December, 1951. Flangea, stralners, valves, and fittings ordered on bulk requisition alterations will probably have similar dates. These bulk items are represerited by $27 \mathrm{re-}$ quisition alterations.

The total estimated doling value of purchase orders, contracto and material trunsferred prior to March 23 is $\$ 13,255,000$.

4. Deglgn

a. Phase I, Metal Removal - One Cascade; Phase II, Metal RemovalRemalning Cascades

1) Sanitary Water Supply

Original scoped plans to provide sant tary water to UR Installations by tanktruck and at OR tank farm by the instaliztion of a small. chlorinator and filtor unit on the raw water system have been abendoned. On the basts of recent Health Instrument Divlsion directives and the request of the Manufacturing Divistors, sanitary water 
whil be plped to the are arens. The work 1s ourrentily being oovered under Phase VII and Is bolng expedt ted to Insure the neads of construotion foroes ourrentily workeng In these areas.

\section{2) TI Tank Farm Tte In}

since present plang Indtate that metal wasto is to be otored In the firgt two tanks of the new TY Tark Farm, the Marucacturing DI.vil gilons have requested three addthonal 6" spare connectors to be instalied In the TXat-1.51 magter deversiton box in order that this metel waste oan be reoovered at a later date using existing faclitites. In addition plans are baing drawn up to oonatruot pump and slutse pits on the two tanks in the TI Farm. Plping to these boxes will be tubbed of at a rensonable distance for future cold tio in to wate removal faoll1t1es. Detall drrwlings for the now tank farm plts wil.1 be drawn up to oonform with Kellex driwings so that Interohangablilty of equipment oan be realized.

3) Blend Tank Cooling Co1.1. 2L4-UR

Corrosion tests on the l. pllpe allotted for these coolIng colis show the materl, I to be unaocentablo. To met construction sohodules, it will be necosary to use 3 " seamlass tubing avalinble at Hanford Works: Nocordingly, the requited amount of plpe la being sent to the ventor. Kellox Corporation is modifying the deglgn to make the most efflotent uge of the larger diametor ptpo.

4) Master Diverstion Box PLping - Phaso II

The orlginal Kollex design routed the varlous prosess lines from the wast-West ptpe Lincisoment System direotiy to the $B$ and $C$ area procuss blend vaults. The Manufncturing Divisions were not in acoord with this deslgn since maximum flextbility and utilization of all process Ilnes could only be attained by routing all litnes through the mester diversion boxes in the $B$ \& $C$ arens. This alteration was agregable with the Englneering and Design Division and the changes are currently being made.

\section{b. Phaso IrI - Dusign of Underground Plpelinos}

Physloal design is now complete wh the thexcoption of "fleld changes" and $\Lambda$ cceptance Test Procodurss. Phase III acoeptanoo Test Prooedurog are rbout 90 if complete.

\section{c. Phasu IV - Renctivition and Convorston of 200 -U for TBP}
1) Uso of Sub-Standind Stainless Steel

Due to sub-standard $r$ sults of corrosion test on

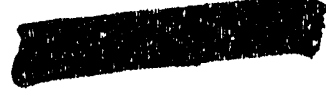




\section{S. Divlsion}

purohased stalnless steel, it was necesaary to constder. means of effeotively using this prooured matertal in order to minimtae delay in the ultimate projoot comple. tion. A polioy was establishod and agreed to by the Manufacturing and Englneering and Conatiruotion Divisiong whioh inciluded the following pointe:

a) Stalniess stoel that passes the corroston atandard of $108 \mathrm{~s}$ than $.0021 . p . \mathrm{m}$. W..7.1 be used for all vessels whiloh cannot be replaced and which are in 80 roloes requiring high corrosion reststance. A 11 st of vessels subjeot to severe corrosion conditions was establishod.

b) Vessels not included in 1tem a) may be fabricated of steel which fat.ls to me日t the $.0021, p . m$. speolfication. However, every effort wlili bo expended towards utlliaing this abmstandard stalniless steel in the fabrioation of the minimum rumber of units and in those units requiring the milder corrosion servilue.

a) When the extent of the use of the sub-standard stainless steel is determined, members of the ManufaoturIng and Engl neerling and Construction Divlsions will review ihe stalnlegs steel ugage and Issue purchase orders for spare vessels as substitutes for those deemed short I.tved.

During the month, nine vessels were authorlzed to be fabricatied from the sub-standard steel, all nine belng in mild corrosion service.

2) Iubricuation Jumpers

A review of the number of canyon aquipment pieces requiring the use of the remote lubricator assembly $r e$ realed that remote lubrication is required on 24 cell pumos located in 10 different cell.s. Ten of those pumps are located in flve identioal concentrator cells, two per cell, and 2 " process connectors are avatlable in the se ceils for conversion to lubrlcation service for these pumps with no design conflict foreseen. Since the use of the remote lubricator will roquire the pililing of cell blooks which in turn may require concentrator equipment shut down and since the design for the lubrication of these numps is not in accord with previous deslgn agrements with Keilex on cell lubrioation the Manufacturing Dtivistons requested that the se ten pumps be serviced by lubrication fumpers. The Degign Division was in accord and ars directing Kellex to make the necessury changes. 


\section{3) D1fferential Pressure Ingtruments}

By lotter to the Design Division, the Manufacturing Divisions roquestod Lnotallation of 221 -U Bullding differential air pressure instruments not previously covered in deglgn. At the guggestion of the Destgn Instrument representative, it has been requested that ring balanoes be used for this servioe instead of the inclined manometerg now in use in $\mathrm{BLPO}_{4}$. Two slioh Instruments will be requested to measure the four differentlal. pressures to be read. The se pressurea are as follows:

\section{Atmosphere to operating gallery \\ 2. Atmosohere to canyon \\ 3. Onarating galiery to canyon \\ 4. Operating gallery to SWP lobby}

d. Phase VI - Increased Power Faollitiles for 200-W Area

The 283-W filter plant addition drawings" were approved with minor comments. Filter plant design 1.s $90 \%$ complete. Approved vendors drawings for the $284 \mathrm{wW}$ water softener have been recolved allowlng the $P$ \& M DIvision to proceed with their portion of thet design. Vendor's approved electrical prints for $284_{4}-W$ are about 2 incinths overdue, howevory thus $P$ \& $M$ eleotrioal work is belng held up pending arrivel of these drawlings.

Design is 100\% complete on the following portions of Fhast $\nabla I$.

1. 277-U Mook-up Bullding

2. 282-W pump houso and reservolr

\section{Construction}

\section{a. Phase I}

Concrete pourting continues for the pump and slutce pits over the "T" tanks; forms are being set and steel l.s being placed for the olt floor of T'K-UR-OOL, the HNO, Acld Storage Tank. The slurry aocumulator tank, 24L-UR-001, is now belng installed in the vault. The exhaust duct from the $244-U R$ Blend Tank Vault to the ventilation flilter and stack is being instalited. The 2LL-UR Vault is 49 o complete. Conorete poiring continues on the 2LI-WR Diversion Tank Vault, and backfiling has boen completed to the 676 foot elevation. The 241.-WR Tank Vault is $28 \%$ complute.

b. Phase TI

Forms are being set and conerete is betng poured for the foundation for the 24L-CR Blend I'ank Vault. Excavation is 


\section{S Division}

In progress for the ptts over the "O" farm tanks. In the "B" farm area, excavation is underway for plta over the $B X$ tanks, for the 24/4-BXR Blend tank Valut, and master, diveraton box. The 244-TXR Blend Tank Valt exoavation continues.

\section{c. Phase III}

1. The East-West transfer IIne 1: $60 \%$ oompJ.ete.

At months end 16,350 feet of the required 19,860 feet of the six Ilne enossement have been poured and 8,400 foet of plpe have been installed, whtoh represents the lnstallation of six pipes in 1,400 feet of enongement. 6,880 feet of the $s 1 x$ line enonsement have been Amercoated todate. In the three IIne enoasement 6,240 feet of encasement herre been poured and 12,000 feet of pipe installed, representing the iristallation of three plpes in 4,000 feet of trench.

2. Work continues on the uncovering of the existing encasements in the vioinity of the 22l, -U Bullding as well as the outting out and relocating of plpe looated in these oncasements:

\section{d. Phase IV}

\section{1-U Stack Facilities}

Concrete pouring and form sotting continues for the walls of the 291-U sand filter. The sand filter is $22 \%$ complete.

\section{7-U Mook-Up Building}

In the 277-U Buliding work continues on the erection of fabricated structural steel for mock-up assemblies, and is about, 33\% complete. Over-all 277-U Building is 62.5\%.

221-U Building

In the 22l-lU Building painting of the cells and pipe trench continues as does the irstallation of utility lines and panel boards. Nork has also begun on the fabrloation of a 6" header which is to be installed in the pipe trench. Approximately 2.5 of the 221-U Building is complete.

\section{e. Phrse VT}

Work conthnues on the fabrication and we]ding of the lo" and 1.l" steam 7.tno. Thu 10" aast 1ron sewer from the 224-U Building has been completed and tested. The test, however, indicated a leak in the sewer lino which was found upon reexcavation to be due to a hole broken in the top by a stone during backfiling. This is being corrected. 
The 282-W purm house portion of Phase VI is $45 \%$ complete.

B. $\mathrm{UO}_{3}$ Projoct

1. General

a. Project Status

The project status at month end is as follows:

1) Detall design is substantially 100\% complete, exclusive of segregation.

2) Requisitions have been issued on all design-procured items. Current information on several fabricated vessels indicates a 3 month delay in deliveries beyond the required dates. These deliveries will be expedited.

-3). Construction is estimated to be $15 \%$ conplete. A revised construction schedule based on the latest procurement outlook shows the $\mathrm{UO}_{3}$ construction to be completed August 1,1951 in comparison to an original scheduled. date of JuIy 1, 1951.

2. Design

a. Segregation of Feeds

The feasibility study on segregation of Redox and TBP feed through the $\mathrm{UO}_{3}$ Conversion Plant was reviewed by the various interested Divisions. Several changes to the original proposal were adopted in order to attain an operable plant. The Atomic inergy Commission was requested to authorize an additional expenditure of $\$ 150,000$ to the $C-361$ Project to provide for the installation of these segregation facilities. Modification \#5 of Directive $\mathrm{HW}-1.58$ authorizing this added expenditure was issued by the Atomic Energy Commission on. $3-23-51$.

Every effort will be made to complete the installation of these faclitities in time to effect segregation of the first TBP production from Redox production but uncertainties of procurement indicate that this may not be possible. Tie in of the segregation facilities will be made as soon as they are completed and can be done without over-all production loss. In the meantime, the existing design is being modified in such a manner that the segregation facilities can be installed with a minimum of change to structures and equipment.

The segregation facilities will include in essence the addition of two $8^{\prime} \times 30^{\prime}$ stainless steel tanks, one for the sturige of the 75 , Win concentrato from the TRP product concentrators, and one for the storage of the 60\% UNH Redox 
solution. This latter tank will have facilities to enable the solution to be concentrated during its storage hold up period prior to its feed to the decomposition pots. The feed and return loop header to the decomposition pots will be altered to take care of intermittent feed of these two sources to the decomposition pots.

\section{b. Fabrication of Decomposition Pots}

A meeting was held with members of the Design and Manufacturing Divisions to adopt a policy towards procurement of cast decomposition pots based on examination of the first cast pot which was dissected. Although several flaws and some sponglness existed near the center of the 5/8" thick wall the Design Division feels confident that the pots are structurally sound for all services expected of them.

The cost of these cast pots is estimated at $\$ 1,300$ each, compared to an estimated cost of $\$ 3,000$ for pots fabricated from plate. The delivery of the cast pots is estimated at flve months compared to a seven month delivery for plate. fabricated pots. Considering the above fiacts it was concluded that cast pots will be purchased provided the quality of the units will be equal to or better than the original one examined. Purchase specifications are being drawn up with this factor included.

\section{Construction}

a. Over-all this project is $15 \%$ complete.

b. 2714 Warehouse

Construction is $73 \%$ complete. Structural. steej. erection is comolete and painted.

c. 24L-U Building

Construction is $7.7 \%$ complete. Concrete removal is essentially complete. Form work for the operating platform in the pot room is complete and $30 \%$ of the pot room slabs have been poured. Additions and changes to electrical wiring are in progress as is shop fabrication and installation of process piping.

d. Outsidu Facilities

Construction is $19.5 \%$ complete. The $210-U$ cribs are essentially complete except for piping. The railroad spur to the warehouse is complete except for ballasting. Tests are in progress on the process stwer. 
C. Redox (Project $C-187-D$ )

1. General

a. Reports continued to be received through the Purohasing Division during the past month of various heats of stainless steel required for Class I vessel fabrication which had failed to meet the corrosion test speciflcations. In almost all cases the use of the off-standard material in the speclfled locations could be reasonably justified from the standpoint of mild process conditions; however, failure of a heat of Trpe $309 \mathrm{sCb}$ stainless steel used in the fabrication of the reinforeing pad on the inside of the tower flange nozzle of the T-160 Pot (Waste Concentrator) is regarded as surious since corrosive conditions to which the part is subfected are fairly severe and, in addition, the part is a major structural element of the vessel. Because the vessel is urgently needed at the constmuction site and because any attempt at replacement of the inferior grade flange would almost certainly result in damage to the vessel, the vessel has been accepted. Steps are being taken to assure that only soecification grade material is fabricated into the $T-160$ "operational spare" pot.

b. In order to expedite the installation of 4 " piping in the hot pipe tunnel, the subcontractor was authorized to install untested 4" stainless steel pipe in certain specified locations concurrent with the performance of corrosion tests on sample coupons. Should the corrosion tests dictnte, this piping will be replaced with accuptable material.

c. Recommendations of the Separations Technology Division Equipment Development Section concerning changes to the nitric acid-hexone blending system have been transmitted to the Design Division and are currently being put in the form of a field change request for incorporation in the silo piping.

d. Because of somewhat delayod 211-S tank fabrication schedules, it has been a greed by the Purchasing Division that initial delivery of $72 \%$ ANN solution originally scheduled for 5-1-51 may now be delayed until 6-1-51. This delay will also aid in relieving unnecessary pressure on the fNN vendor to complete his facilities.

e. Equipment tests performed in the Mock-Up Building during the past month designed to determine absoluti tolerance limits for the proner fit of cell jumner's has resulted in some relaxation of the nozme dimension tolerances on Class I vessels. These tolerances previously specified as $\pm 1 / 16$ " in the horizontal plane and $\pm 1 / 32 "$ in the vertical 01 ine have now been doubled and are set at $+1 / 8$ " in the horizontal plane and $\pm 1 / 16 "$ in the vertical plane. This nction was 
taken in order to expedite delivery of Class I vessels for the 202-S Bullding and is based on the premise that any corrective measures to compensate for of $\mathrm{f}$ tolerance nozzles will be made during vessel mock-up. The authorization does not constitute an official change in specifications and is not intended for transmittal to the vessel vendors.

f. All purchase orders for the dissolver off-gas silver reactors and associated auxillaries have now been placed, and it appears possible to arrive at a decision in mid-april as to whether the silver renctors or the previously designed caustic off-gas scrubbers will be installed initially in the dissolver cells. Electrical switch gear components are the limiting factors in this equipment delivery.

g. Some difficulty has been experiunced during the past month with seal water leakage through several class I agitator shaft seals during the inftial two-hour run in period in the Mock-U. Building. Several seals have beenadjusted by subcontractor oersonnel with good initial results, and efforts are being made to run in all such equipment as rapidly as possible to determine the norm for seal water leakage and to determine what, if any, corrective action must be taken on the sen].s.

\section{Construction}

\section{202-S Building}

Nt month end the 202-5 Bui]ding structure was estimated to be 947 complete. Pouring of concrete in the stio region of the building has orogressed to the silo roof level at the north end of the buildine and in the remeindur of the silo to the operating gallery floor luvel. hooling work for the service portion of the building progressed rapidly. Concrete block partitioning work in the service nreas is approximately 75\# complete.

Cell finishing optrations are nearing completion with the pouring of the finished f'loor in D Cell and the fabrication of stipinless steel floor liners in CeIIS $E$ and $F$.

Installation of piping in the hot pipe tunnel is nearing completion and is expected to be $100 \%$ complete (except for hydrostatic testing) by hpril 9. Work on service headers and chemicol headers in the gilury portions of the building continu.d r.t 7 ripid rate. Piping around the gallery welgh tanks is prok, ressing very slowly, however rapid fins in bipe installation in the rqueous makc-un portion of the building are buing mode. 
Mock-Up operations progressed at a reasonable rate during the Dast month, with alght tanks mocked up as fnr as is practical, and awalting installation in the building cells. Sufficient equipment was on hand during the month to prevent a lag in 1 mock-up operations.

Installation of the stainless steel stack liner was started during the month and reached a helght of $160^{\circ}$ in the stack by month end. Placement of the final layer aggregate in the sand filter has been completed and the filter has buen sealed.

The over-all project, (excluding the $241-S$ Waste Facilities, under the Fred J. Early contract) is estimated to be $68.6 \%$ complete versus a scheduled $79.9 \%$. Actual progress during the month lagged slightly with respect to scheduled progress; the lag resulting in part from the fact that canyon and cells have not been completed sufficiently to allow the installation of process equipment which is passed through the MockIn Building.

\section{241-S Waste Facilities}

Construction work on the 24I-S Thnk Farri and associated facilities progressed at an even pace through the month. Due, however, to the rapid progross scheduled for this month, added lag in actual percentage completion versus schedulod comnletion was exrerionced. (Scheduled, 73\%; Actual, 57.5\%)

The welding and Xoray of nII tank linurs was completed during the post month, and the over-all parcentage of field weld repairs on the liners was quite low (2.10\%).

Membrane water procfing, guniting, and concrete pour is continuing on the tanks in sequence. Some backfilling has been started and dome forms and reinforcing steel for the domes are being placud on Tanks 104 and 107 .

D. Mraining and Procedures

1. Training

1. Training Lectures

The Training Lecture Series is curruntly in its fourth and lnst cycle. Thise lecturs s will end on April 25, 1951.

b. Redox-TBP Trainine 3chool - 321 BldE.

The first six-wetk trainine cycle ends on hpril 2. 
On March 19, the responsibility for operation of the simulated Redox equipment at the 321 BIdg. was turned over to the "S" Division Shift Supervisors and Trainees. This step provided a two week period of more intensifled training in the performance of all phases of the building operation. Similar frecdom of operation of the simulated TBP equipment cannot be realized at present. "Data-runs" are currently being mun on the pulse column battery and the rigid conditions established preclude the possibility of operpting with trainees.

The Second Training Cycle begins on April 2. OperatiorTrainee personnel will include seven (7) Chemical Trainees. Seventeen (17) Supervisor-Trainees are scheduled to attend the Second Cycle.

The Chemical Development Section expect to remove three of their Column Engineers from the shift training organization to other assignments early in April. These Engineers are to be replaced by the "S" Division Supervisor-Instructors presently assigned to the Training School.

\section{Procedures}

a. Redox

Further agreements have been made between the $S$ Division, the Instrument Division, and the Separations Technology Division in regard to the arens of rtsponsibilities, and the methods to be used, in the clibration of Redox process instrumentation. The writing of the detalied procedures and the setting up of the data sheets is in progress.

Further agreement has been reached with the General Chumical Company on resnonsibillties and nrocedures to apply in the unloading, nt the Redox plant, of nitric acid and aluminum nitrnte solution to be delivered via tank truck br this vendor.

b. TBP and $\mathrm{UO}_{3}$

Rough drafts of Forms, Records and Reports for the 221-U, $22 L-U$, and 24.1 Buildings hrve been preparod and submitted for comment.

The procedure for unlozding $\mathrm{H}_{1}$ fo 3 from tank trucks wns roturned with comments from the vendor. ill comments wer. of a minor nature and will be incorpornted in the procedure. Corrections and ruvisions vre being made to the special Hazard procedures as a result of the comnuts made on the original drafts. 
S Division

At months end the rough drafts of Job Hazard Breakdowns for the 221-U, 22L-U and 241 Bulldings were being onmpleted.

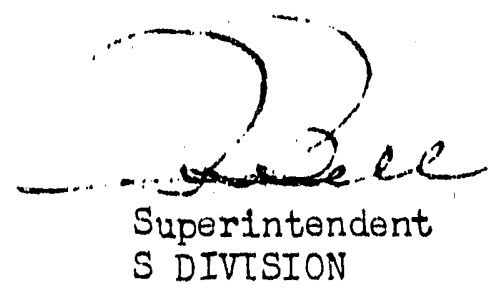

RS Bell:mvk 


\section{DECLIASMIIED}

INSTRUMONT DIVISION

MONTHLY REPPORT

MARCH 1951

\section{GENERAL}

The six day work week cont1nued for those maintenance forces required to meet current work load requirements. This amounted to $64 \%$ of total division forces. The total force was Increaged by flve through new hires and transfers from other divlsions.

Construction of the new Instrument Meintenance and Development Shop, BuildIng $3717-\mathrm{B}$ is nearing completion. It is expected that the building will be occupled in the early part of April, with a few minor items remaining to complete the profect.

\section{ARFAS (Reference: HW-20738)}

100-B Area

One process tube thermocouple failed and was replaced by another from a tube charged with solid aluminum. The protective tubing and wire insulation was found to be deteriorating from exposure to the neutron fleld.

Responsibility for leak detection on the P-10 Metal Line has been assumed by the Maintenance Divisjon, with the Instrument Division continuing this work on the glass Iines.

\section{0-D Ares}

Routine inspection of process water pressure monitor gauges has been resumed, revealing numerous minor defects.

\section{0-DR Area}

A correction of $2 \%$ was made on each of the two riser transmitters of the Bailey Power Calculator system to compensate for the $2 \%$ error discovered in a volumetric flow rate test. 


\section{$100-$ Ares}

An additlonal range was added to the Power Level recorder to allow for the increase in power.

During the recharging operation of the P-11 unit an electronio Ifquid level indicator, having an accuracy of 0.01 Inches, was installed.

\section{0-H Area}

Three thermocouple wells on the process tube temperature monitor developed leaks during the month. One of these had been replaced in December.

The range of the Brown Power Level Recorder was Increased due to the increase in operating power level. Temporery modiflcation was made until a decision is reached on the design change for all areas.

\section{Shutdown Experience}

100-B Area - None due to Instrument fallure.

100-D Area - Scrained at 8:45 A.M., Maxch 30, due to a.larm on pressure monitor that would not reset in aliotted time. A power surge occurred. coincident with the scram, apparently the cause for the alarm relay tripping. Unit was back to full power at 9:15 A.M.

100-DR Area - Scramed at 8:53 P.M. March 3, due to short circult in Instrument power supply during work in electrical equipment room. Unit was back to full power at 9:30 P.M.

100-F Aree - None due to instrument fallure.

100-H Area - Unit was manue1ly shut down at 5:34 A.M., March 9, when pressure monitor alarm could not be reset in allotted time. Faulty switch terminal was found in the pressure gauge. The unit was back to full power at 6:28 A.M.

Unit scrammed at 7:32 A.M. March 13, due to an alarm on P-13 equipment. Investigation indicated no operating irregularities and unit was started up, reaching nominal powir at $8: 18 \mathrm{~A} . \mathrm{M}$.

Unit was manually shut down at 5:10 A.Mn, March 22 due to rapid temperature and pressure increase on tube No. 3483. Investigation revealed a ruptured slug. Unit was started at 11:55 P.M., March 22, and reached full power at $2: 25$ A.M., March 23.

\section{AREAS (Reference: HW-20739)}

\section{I \& B Plant Production Instruments}

Resistance thermometers were installed on gang valve vents in building 221-T to indicate steam leakage, as this had been found to spread contamination within the canyon.

\section{DEEEASSTFED}


Instrument Division

Profoot 0-397 - Cel1 Dratn Conduot1uttr Meters

Instrument work has been completed on the installation of conductivity moters in Individual cell drains in Building 221-T. The unit in 7-R has not funotioned properly, but wa found to be dus to fouling with debris and not a feult of the installation.

\section{Z Plant Production Instruments}

Depletion of oxpgen supply dropped pressure on the gas mixting system of Hood 8, butlding 234-5, allowing H.F. gas to back-diffuse through the glass rotameter tubes. Ten were dameged to varying degrees, one being a total 1085. Inquiry is being made into the cost of replacing ali glass tibes with fluorothene and improving the oxggen pressure alarm so that it cannot be shut of during a condition of this nature.

Installation of a heat trap in the Plranl tube vacuum gauge IInes on Hood 25-B has increased the life of the tubes over $400 \%$.

\section{AREA (Reference: HW-20740)}

MANUFACTURING SECTION

\section{Profect C-424 - Safety C1rcutt Controllers}

Fabrication of four safety clrouit controllers for the 105-D flow-lab corrosion test was started late in the montll.

Profect C-399 - Toepler Pump Control Untitg

The remaining six units of the thirty to be fabricated for this profect have been delivered, completing all assigned work on the project.

Appropriation M-820 - Procurement of Thres South Bend Lrathes

The three 10 Inch South Bend Lathes ordered as replacements have been installed and are now in operation. The old lathes have been prepared for shlpping to the vendor.

\section{Profect $(-289$ - Additional Laundry Facilities}

Two additional Beta-Gamma clothing monitors were completed and delivered, bringing the total shipped to five. The completion of the final unit is awalting receipt of a special power transformer.

\section{DESIGN SECTION}

Drawlings have been completed for the waste tank periscope that allows the periscope to be moved from tank to tank, with the protective sleeves and ilght sources ramaining in their respective tanks. Scanning with the periscope is independent of the movement of the light. 
Instrument Viviston

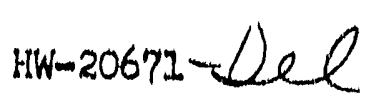

\section{DEVELORMENT SECTION}

\section{Process Sube Tomperature Mapolng Dlsplax}

Assembly of the demonatration equipment for viaual indication of multiple tempersture condltions taken at Intervals of 0.1 second 1 s neariy complete. The equipment is boling assembled on a carriage preparatory to making teats and demonstrations in the 100 Areas. Performance to date has been encouraging.

\section{Beckmar Automatic Range Changer}

Further work on the automat 10 range changer has been postponed pending the out oom of a developmental test to determine the feastblilty of converting a Bochan migromicroameter to a logarithmic instrument indioat Ing from $10^{-6}$ to $10^{-13}$ amperes on one soale. To date it has been possible to go as low as 10-12 and work $1 \mathrm{~s}$ progressing to extend this down to $10^{-13}$.

\section{ENGINBEFING \& CONSTRUCTION GROUP - 760 BLDG. (Heference: HW-20747)}

\section{Profect $0-431-100-C$ Area}

A Ilst of troublesome items that have appeared as a result of 100-DR water plant design has been complied and steps taken to eliminate or correct them for the lon-c Area design.

Design criterla have been prepared on certaln major items for the reactor. A report is in progress outlining to the Kellex Corporation changes in Interconnections and building layout revired by instirumentation.

\section{Profect $C-414$ - P1Ie Technologx Buflding}

It has been decided that the Instrunent Section will complete the panel design for this faolilty. Instrument specifications and wiring diagrams are complete for two of the three panel arrangements.

\section{Profect $C-187$ - Redox Procesg and Fac1lities}

Installation of instrumentation in Building 202ms is following equipment Installation as closely as practical. Fleld changes have been mede to improve operation and maintenance as suggested.

\section{Profect $\mathrm{C}-362$ - Tri-Butyl Phosphate Process and Facilities}

Requisitions have been issued to cover $99 \%$ of the total instrumentation for Phases I, II and IV. It has been established that there Is no obstacle at the present time to prevent completion of engineering on the graphic panels. Procurement of electric switches for the alarm system may delay shipment of the penels.

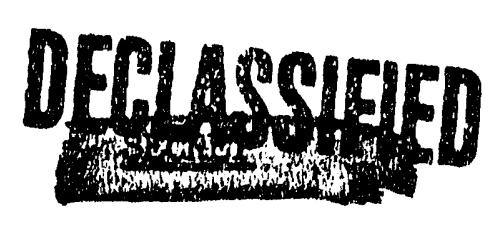




\author{
MAINMEMANOE DIVISION
}

MAROH, 1951

\title{
GENERAL:
}

The diviston's beoklog of work a of Februany 28 was 5126 mandays, which represents 17 days of worle for the present force.

\section{A.REAS:}

All of the 100 Areas were shut down for slxteen hours on Maroh 7 to allow a tie-in to be made between exdsting and new faclilties at the 251 substation.

\section{0-BAres:}

During the planned shutdown on Maroh 21 the gun barrel on process tube \#3060 was repaired. New $72 \mathrm{~s}$ aluminum tubes were installed in process tubes \#3060 and \#2180 in aocord with the program to replace 28 tubes with $72 \mathrm{~S}$,

\section{0-D Ares:}

One of the 50 mesh screang in the valve pit falled due to fatigue during the premahut down purge of the "D" plle. This allowed coarse matexial to elog the 30 mesh soreens on the oross headers off the B and D risers. These screens had to be removed and oleaned causing meintenence work planned for the shutdown that reautred the use of the front elevator to be postponed.

\section{Profect Mer13 - VerticeI Rod Corrective Design}

One rod was fabricated and then installed on the schoduled shutdown on March 7. After the rod was operatad successfully it was removed and in the near future will be given test to destruction. This will be done in 1EI-F Bullding where a thimble will be installed in a vacant puinp well.

\section{$\underline{105-E}$}

A now nethod of repeiring muptured gun barrel bellows while the pile is in operation has boon developed. T'o do this a sheot of nooprene is wrapped around the bellows and clamped at elther end. The horlzontal joint is comented and held tight by a length of spring wire against the gas pressure until the cement has set. Previously these repairs were made during a shutdown and required the use of the elevetor for three hours per repalr. This time will now be avallable for other elevator requitroments.

\section{$\underline{105-\mathrm{H}}$}

A track and roller assembly was installed to facilitate moving the 4000 pound cask at the "YH test hole on the $X-2$. I evel away from the side of the unit.

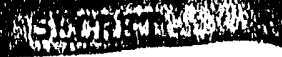


On Maroh 22 there was an omergenoy shutdown of the "fl" plile caused by a ruptiured silug in prosess tube \#3284. The removel. of this slug was acoomplished with no abnomal diffloultios.

\section{AREAS}

200 NeEt

Final design drawings have been preparad for the inatallation of enulpment to be used in repleolng opll conneotor gegkets. They cover the Installation of a movable work platform and two monoralis with holats above the Deap Cell in 221-T. The method to be used was devised in oonjunction with the "g" Divialon after a trial job was done on one conneotor in December. The connector is aukmerged in water in the Deop Coll and then the gagkets are ahanged by the use of long hendled tools. Prior to this job some conneotors had been disoarded bocause high radiation readings had made it impossible to work on them. It is estimated that a many as ten connectors a year may be salvaged In this menner, at a savings of $\$ 1,000$ ench. In addltion, conneators, which aro now beling repalrod at considerable expense dus to short exposure time limits, will be done more economicaliy in the Deep Cell.

An equipment manual is being prepared oovering the Redox Plant. This w1II contain desoriptions and speolfications on all the equipment instalied in the Redox. Bullding and will bo a useful tool in planning and exeouting the maintenanoe program in this now facllity.

Profect C-397 - Conductiv1ty Meterg for Ce11 Drains - 221 - TeB Bulldings

The work is complete and final aoceptrince was made after an inspeotion on March 21.

\section{Eest}

A traller to be used when working on diversion box fobs has been designed and bullt. It contalns a water tank, pump, alootrio generator, and flood. Iights and will eliminate the necessity of bringing a water tmack, flat bed tmuck, and a portablo electrio generator to tho job. It la expocted that a gevings of $\$ 500$ per job will be mede by the use of this trailer.

\section{Meta I Fabrication}

The ofl reservolr for the spare roughing pump was revised to be interchargerble with the ones used on Hoods \#25 and \#26. This saves three hours of down time for each bi-weekly oll change in the roughing pumps.

The monol diaphrngms on the \#1 Pulsfeed pumps on Hoods \#29 and \#30 falled during the month ovidontly due to the use of nitric acid in special operating rung. These were ropleced and tho special muns heve been discontinued.

A list of proposed spare perts to be bought by Construction for Phase III of $234 \mathrm{~m} 5$ hag beon prepared by the GECL. This Iist is being studied to ascertain if the coverage will be adequate and economical. Recommeridetions for any revisions to the list will be mede by May 1. 


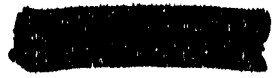

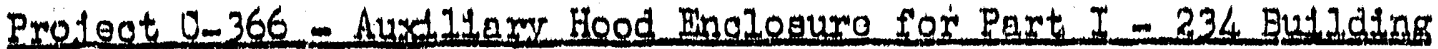

The Ingtallation of the bood assembly wes nearly completed durding the month. The remalning work w1ll be finlshed in April.

Profect M-739 - Auxt11ary Vent1lation for Dry Box Hoods - 234-5 Budid1ng

AlI work is complete and the projeot was 1nspeoted and acoepted on March 21.

\section{Aree}

Fabriortion was completed on en experimental device, designed by Plant Asslstance, to cool. slugs after oanning by water spray instend of by immersion. This slug cooler conslsta of a stand, a contalner to hold two slugs, and brass gpray heads that fit over the cap of the alug. The cap will be held lin place and oooled before the rest of the slug. It 1s expeoted that a better braze between the oap end con w11I result from thla mothod.

Two mild steel lebortory sinks were fabricated and the interior spray coated with Polyetheleno. These w1ll be used to replece stalniess steel sinks In Buildings 3706 and 222-T. The resiatanoe of Polyethelene to corrosive egonts and the ease with which It may be docontaminated should meke it a satIsfectory substitute for stalniess steel laboretory sinks at a lower cost.

\section{Profect M-825 - Mechantog1 Rod Feeders - Butlding 313}

The Installation of the rod feeders on the 10 Glsholt Roller Tumer lathes is complete. Th1s installation, which wis deslgned by the Meintenance Division, consists of an air actuated cylinder and a clamping devlice to grip the rods. Rods welghing as much as 250 pounds that formerly had to be pughed or pulled through the lathe spindle by the operator are now fed by operating a valve lever. Thls has eliminatod s. safetiy hazard and reduced the fatigue previously associated with the jol.

\section{Profect $0-330$ - Increased Vent1lation - Buildings 313 and 314}

A new type of burner for the Melt Plant oruclble burn out station was fabricnter and 1nstalled. This completed the work assigned to the Maintenanoo Division. 


\section{EIECTRICAL DIVISION}

MARCH, 1951

\section{GEIURAL:}

The schedule of work assigmments at month end was 6,192 mandays for the ensuing month, or 24.9 mandays per non-exempt employee. This represents a very slight increase from the previous month end.

The power demands for the month were:

$\begin{array}{llll} & \text { Date } & \begin{array}{l}\text { March } \\ K W \text { Demand }\end{array} & \begin{array}{l}\text { Comparative } \\ \text { Febmary Demand }\end{array} \\ \text { Process Load } & 3-8-51(1: 00-2: 00 \mathrm{pm}) & 69,550 & 69,000 \\ \text { Village Load } & 3-5-51(5: 00-6: 00 \mathrm{pm}) & 31,100 & 31,500\end{array}$

The process load demand is at a new all-time high. The Village peak demand is declining from the January seasonal high. A chart is attached showing the two peak day loads.

Co-ordinating activities with design groups were:

(I) Establishment of final plans to provide constmuction power for Project C-43I from a $66 \mathrm{kV}$ source.

(2) General review of specifications and drawings pertaining to "inside" electrical work, 382 and 384 Euildings in the 300 srea.

Hanford Works Instructions Letters Nos. 167 and 168 were prepared and issued, pertaining to the telephone system and to the electrical distribution system, respectively. The Electrical Division will be responsible for effecting arrangements whereby required services are available when needed. Substantial over-all. savings will be achieved by providing for co-ordinated system expansion, minimum cost for new facilities, improved capital accounting routine, and centralized responsibility for service.

The principal ectivities of the Electrical Standards Subcomittee pertained to development of inside lighting standaris and outside line material specifications.

The Electrical Superintendent and the $\Lambda$ ssistant to the Superintendent attended the 20 th Session of the Bonneville Regional Advisory Council in Portland. Th.. discussion of system planning, long range as well as immediate, to meet defense requirements will be of material assistance in correlating our own requirements to the overall Regional plans.

\section{AREA A.CTIVITIES:}

Process Pump Motor No. 7 in Building 190-B failed during an attempted start-up on March 7. This was the seventeenth winding failure of these $800 \mathrm{HP} 2200$ volt motors and was similar to previous failures as a turn-to-turn breakdown in the coil end turns. The two metors which burned out last month have been rcwound. One was 
returned to servico and the other is being held in 190-B as a standby until motor No. 7 can be rewound.

In the 105-DR Pile Builcting, a "scram" occurred at 9:40 p.m. on Marsh 3, concurrent with the operation of the switch supplying D. C. power to the tool dolly. A careful investigation revealed no electrical trouble and no relation betweeil the tool dolly circuit and the safety circuit.

The 105-H Pile Building was "scrammed" at 7:32 a.m. on March 13, apparently due to the P-13 Project. However, checks of the equipment falled to reveal any conclusive evidence as to the specific cause. The Electrical Division has developed a time delay feature for the P-13 safety circuit, which, when installed, should eliminate most of the unexplained scrams from this source.

The new instrument installation at Meteorological T'ower Building 622 was completed on March 26. This involved the installation of instrument cables in conduit to the 400 foot lievel of the tower.

Auxiliary trolley pick-up shoes were installed on the 221-T Building 75 ton crane to serve as an emergency means of supplying power to the trolley and hoist motors in case of failure of the regular shoes. This was nocessary because of the very short time linit allowed for working in this area during certain operating periods.

New Exide 120 volt storage batteries were installed in the Power House Buildings $284-E$ and $284-W$ to replace the original Gould batteries which were in very poor condition after approximately seven years or service.

A push button station was installed in the tripping circult of the main circuit breaker in Substation BB3-S4 in the 300 Area. The push button is mounted in a locked metal box outside the substation fence, with the key under control of Patrol. This will allow Patrol to trip the breaker to completcly de-energize all the 300 i.rea circuits in the event of an emergency evacuation.

TRANSMISSION AND DISTRIBUTION:

Special arrangements were again made for March 18 tests by the manufacturer of the $220 \mathrm{KV}$ high interrupting capacity oil circuit breakers at Grand Coulee. The isolation of the Hanford loop from the Bonneville Power Administration system together with one generator each at Grand Coulee and Bonneville enabled continuous operation at Hanford without loss of production in the 100 Areas. These tests of Brown-Boveri breakers, we believe, complute the series of tests by various manufacturers.

Project C-295 (Enlarging 251 Substation) - a ntw dead-end structure was constructed in the $230 \mathrm{KV}$ loop just west of the substation anc the temporary by-pass line was tied in. Six inoming 1250 MCM lead covered $13.8 \mathrm{KV}$ cables from the "R" transformer which were no longer being used were removed, and work was started on temporary wiring for the new "Y" bank. All vork is procceding on schedule.

The 100-H Area Army Camp $13.8 \mathrm{KV}$ feeder was energized on March 22. The 100-D and 2OO-ir hisa Army Camp feedors worc cnurgized on March 2?. 
A total of 57 broken and rotted poles were changed out throughout the areas, mostiy in the $2.3 \mathrm{KV}$ and telephone circuits in the vicinity of Hanford, Riverland and the 200 North Lreas.

One-hundred eighty-elght services were spliced out and relocated to new service entrance attachments of the prefab rehabilitation program.

\section{TEIEPHONE SECTION:}

A new 26 pair cable and terminal was installed to serve the Desert Inn, replacing the 11 pair cable formerly used.

Nine additional trunk circuits were established between the North Richland exchange and the "BY" Tandem Office, making a current total of 15 .

Several engineering studies and estimates were made relative to the use of telephono and radto communication equipment in the Civil Defense program. A chart of proposed communication channels and equipment was prepared.

Detailed plans were completed relative to the method of providing telephone service for construction activities on Project $\mathrm{C}-43.1$.

$\Lambda 11$ necessary details and information were prepared for the Project Engineering Division, permitting preparation and submittal for approval of two important Project Proposals:

$$
\begin{aligned}
& \text { B-1889 - Additional Iine Equipment and Conversion to Four Party Service - } \\
& \text { Richlard } \\
& \text { B-1846 - BY Telephone Exchange - Additions and Changes }
\end{aligned}
$$

Telephone drops were relocated on 220 prefab houses in Ridiland as required by the rehabilitation program.

\begin{tabular}{|c|c|c|c|c|}
\hline & $\begin{array}{l}\text { Linos in } \\
\text { Service } \\
\end{array}$ & $\begin{array}{l}\text { Stations in } \\
\text { Service }\end{array}$ & $\begin{array}{l}\text { Extensions } \\
\text { in Service }\end{array}$ & $\begin{array}{l}\text { Vacant } \\
\text { Lines } \\
\end{array}$ \\
\hline $\begin{array}{l}\text { Richland } \\
\text { Project Total }\end{array}$ & $\begin{array}{l}3,792 \\
5,2.59\end{array}$ & $\begin{array}{l}5,988 \\
7,534\end{array}$ & $\begin{array}{l}1,010 \\
1,833\end{array}$ & $\begin{array}{l}208 \\
691 *\end{array}$ \\
\hline
\end{tabular}

The following is a summary of current telephone service rendered by the Project Telephone System:

* The number of vacont lines reported last month did not include the Richland Exchange. 
PQWER STATISTICS - EIECTRICAI DIVISION

FOR MONTH ENDING M 1 RCH 31,1951

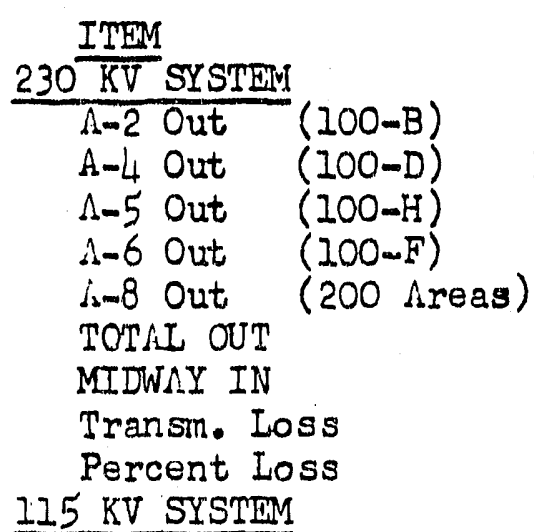

ENERGY - MW HRS. Febo March

MAX. DEMAND - KW

IOAD FACTOR - $\%$

$7.040 \quad 7.740$

Feb.

March

Feb.

March

12,090

6,984

13,570

6,330

8,856

7,050

4,212

36,656

37,262

4,500

41,726

606

42,523

1.6

BI-SL Out (N.Rich.)

BBI-S2 Out

BB3-SL Out (300 l.rea)

TOTII OUT

Benton In

So. Richl and In

TOTAL IN

Transm. Loss

Percent Loss

$66 \mathrm{KV}$ SY STEM

B7-SIO Out (W.BIuffs)
Hanford Out
TOTII OUT
HANFORD IN
Transm. Loss
Percent Loss

PROJECT TOTAL

$230 \mathrm{KV}$ Out

$115 \mathrm{KV}$ out

$66 \mathrm{kV}$ out

TOTII OUT

$230 \mathrm{KV} \mathrm{In}$

$115 \mathrm{KV} \mathrm{In}$

$66 \mathrm{KV}$ In

TOT:I IN

Transm. Loss

Percent Loss

* Coincidental Demand

* Non-Coincidental Demand

309

726

729

36,656

16,912

726

54,294

37,262

17,220

729

55,211

$\begin{array}{rcccc}2,165 & 3,686 & 3,974 & 82.4 & 73.2 \\ 7,354 & 15,570 * * & 15,120 * * & 65.8 & 65.4 \\ 7,564 & 16,200 * * & 16,110 * * & 66.5 & 63.1 \\ 832 & 1,840 & 1,814 & 60.8 & 60.8 \\ 17,915 & 37,296 * * & 37,044 * * & 67.5 & 65.0 \\ 18,410 & 36,000 * & 36,800 * & 41.6 & 67.2 \\ 0 & 36,300 * & 0 & 29.4 & 0 \\ 18,410 & 72,300 * * & 36,800 * * & 35.4 & 67.2 \\ 495 & & & & \\ 2.6 & & & & \end{array}$

\section{$417 \quad 465$}

3.4

330

795

797

2

$$
\begin{gathered}
1,237 \\
600 \\
1,837 \% 4 \\
1,700 *
\end{gathered}
$$

1,237 600

50.2

76.7

$1,837 \ldots 58.8$

1.,700:

63.8

50.5

73.9

58.2

63.0

$917 \quad 1,304$

41,716
17,915
795
60,426
42,523
18,410
797
61,730
1,304
2.1

73.2

63.1

60.8

67.2

.2 2

$\begin{array}{rrrr}71,620 * * & 70,520 * * & 7.6 .2 & 79.5 \\ 37,296 * * & 37,044 * * 4 & 67.5 & 65.0 \\ 1,837 * * & 1,837 * * & 58.8 & 58.2 \\ 110,753 * * & 109,401 * * & 72.9 & 74.2 \\ 62,000 * & 62,000 * & 89.4 & 92.2 \\ 72,300 * * & 36,800 * * & 35.4 & 67.2 \\ 1,700 * * & 1,700 * * & 63.8 & 63.0\end{array}$

\section{2,200}

12,400

85.9

21,000

86.9

20,700

18,000

19,800

11,200

52.5

7,920

7,920

85.6

$71,620 * 4$

$70,520: * *$

79.1

$62,000 *$

$62,000 *$

76.2

1.9

83.9

66.9

84.6

76.4

79.5

92.2

Average Power Factor - $230 \mathrm{KV}$ System---94.3 hvercge Power Factor - $115 \mathrm{KV}$ System-95.4 I.verage Power Factor - $66 \mathrm{KV}$ System--85.6 


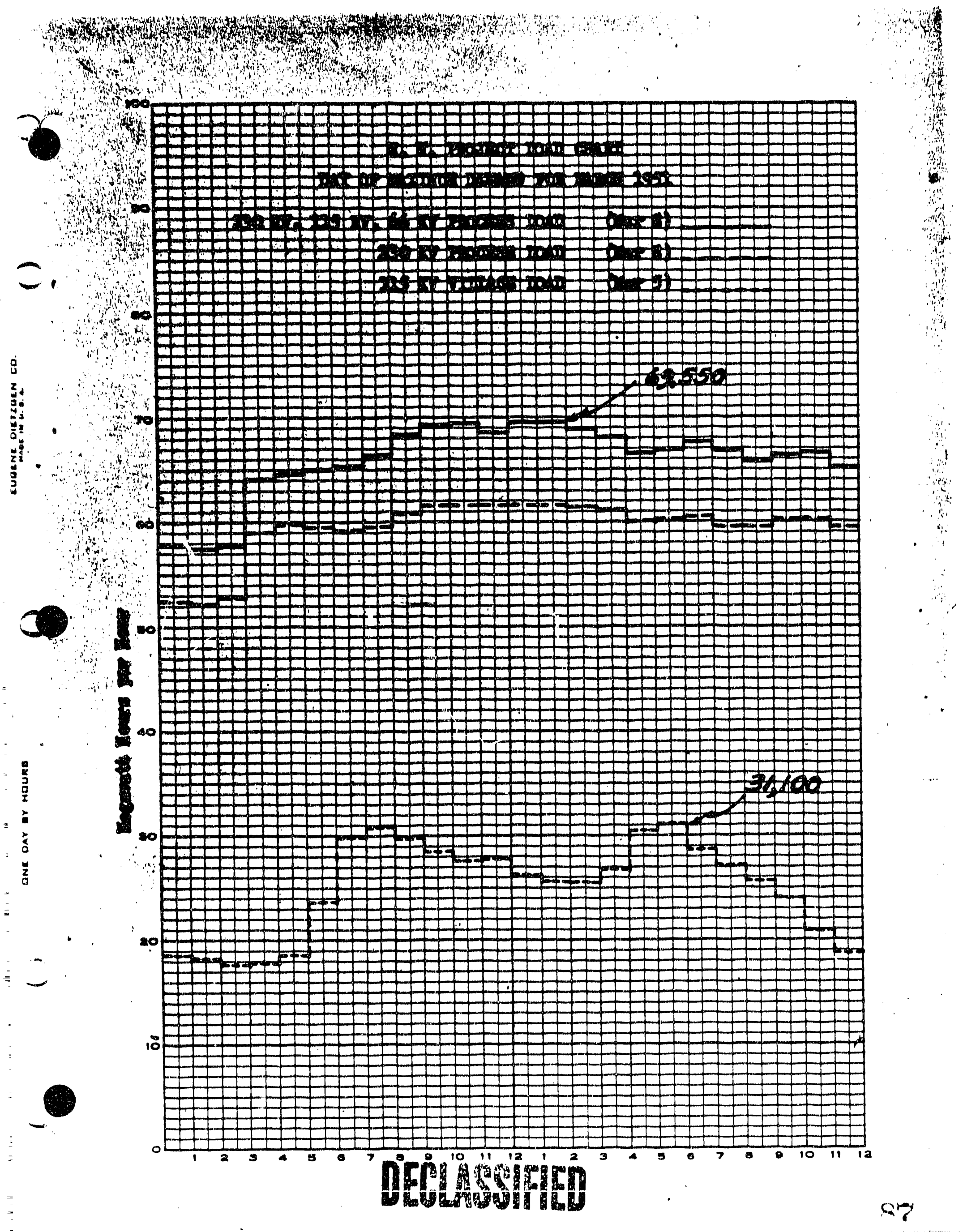


At the request of the Atamic Energr Commission, the Transportation Division presented a program on the "Operation of the Transportation Division at Hanford Works" at the March 9 meeting held in Richland of the Inter-Agency Motor Equipment Advisory' Corms tites of Oregon and Washington. Agencies represented included the 7 snevid le Fower Adninistration, General Services Administration, Fish and Wid Life Service, Atomlc Enetgi Commission, Bureau of Reclamation, Corps of Thisfrears, Bureau of Public Roads, United States Forest Service, United States Soil Conservation Service, and Department of Animal Industry.

Transportation Division personnel forces increased from 605 to 608 anployees during the month by 16 new hires, 9 transfers in, 1 re-activation - personal iliness, 13 transfers out, and 10 terminations.

\section{RAILROAD ACTIVITIES}

Commercial cars handled during March increased $7.9 \%$ over February with the retum of normal coal receipts and an increase in outbound shipment of lumber.

Process movements during March increased 34.4\% over February with all service being completed as scheduled.

Cars: handled in March including process movements totaled 1,984 compared to I, 793 in February and 2,625 in January.

The 200-East Tank Farm. Track was out of service from March 6 through March 20 to permit installation of underground lines making it necessary to serve the 221-B Buildilig by a shoofly.

The following recapitulation idicates the number of comnercial cars handled: Carload Movements - General Electric Company Loads In Empties In Loads Out Empties Out

$\begin{array}{llll}522 & 120 & 120 & 513\end{array}$

Carload Movements - Subcontrgctors and Others Loads In Empties In Loads Out Enpties Out

Atkinson Se Joned Co.

I. E. Baldwin \& Asoociates

F. J. Earlir

Elestric Snith Co.

Hageri \& Woife Co.

Martin Fireproofing

61
12
14
1
1
3

$\vdots$

$\begin{array}{lr}- & 58 \\ - & 11 \\ - & 13 \\ - & 1 \\ - & 1 \\ - & 5\end{array}$


Transportation Division

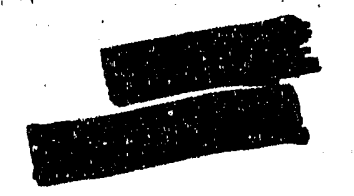

$H W-20671$

\section{Loads In Empties In Loads Out Empties Out}

MePhatl Engineering Co. Morrison-Knudsen Co. S. S. Mulien Co. Ploneer Insulation Co. RIchland Fuel \& Lumber Co. Roof Service Co. West Coast Heating \& Plumbing U. S. Army Corpg of Englineers

$\begin{array}{cccc}3 & - & - & 5 \\ -1 & 4 & 4 & - \\ 2 & - & - & 1 \\ 1 & - & - & 2 \\ 1 & - & - & 1 \\ 1 & - & - & 1 \\ 2 & 1 & 1 & 2 \\ - & 15 & 15 & -\end{array}$

Inspection of 80-ton Diesel electric locomotive 39-3722 revealed that the plates on both ends of the center castings were cracked around the weld and castings were pushing upward into the engine frame. Castings and plates have been removed preparatory to installing new plates and supports over castings to prevent a recurrence of this nature.

Flat car 10-A 3625 was moved from 200-East to Riverland for major repairs to the frame ard undercarriage. This work is being performed under Special Work Permit regulations.

Removed snow plow equilment from flat car $10 \mathrm{~A} 3619$ and installed weed spraying equipment.

Railroad track maintenance and rehabilitation work continued on a near rormal basis throughout the five sections. Removal of ice and snow from switches and flangeways reculred 169 mar-hours. Surfacing was in progress on the 183-B track, Riverland, 200-East lead, 272 shop track, 221-B track, "A" line and throughout Section $V$ requiring 3,305 man-hours. Instalied lil switch ties at Riverland; 151 siwitch ties and 443 cross ties in 200-East Area; and 742 cross ties in Section III requiring 2,080 man-hours. Hauling and distributing ties required 431 man whours. Instalied 3,400 85 \# rail anchors requiring 187 man-hours.

\section{AUTCINTIVE ACTIVITIES}

The Area Bus System trangrorted $3.9 \%$ more passengers in March than in February. The following tabulation indicates the March passenger volume by shifts and the total reverue received:

$$
\begin{array}{lc}
\text { No. } 1 \text { outbound and No. } 3 \text { inbound } & 25,636 \\
\text { No. } 2 \text { outbound and No. I inbound } & 57,641 \\
\text { No. } 3 \text { outbourd and No. } 2 \text { inbound } & 54,689 \\
\text { Total } & 137,966 \\
\text { Revenue } & \$ 6,898.30
\end{array}
$$

The following is a comparative breakdown of average daily bus trips to the Plant Areas:

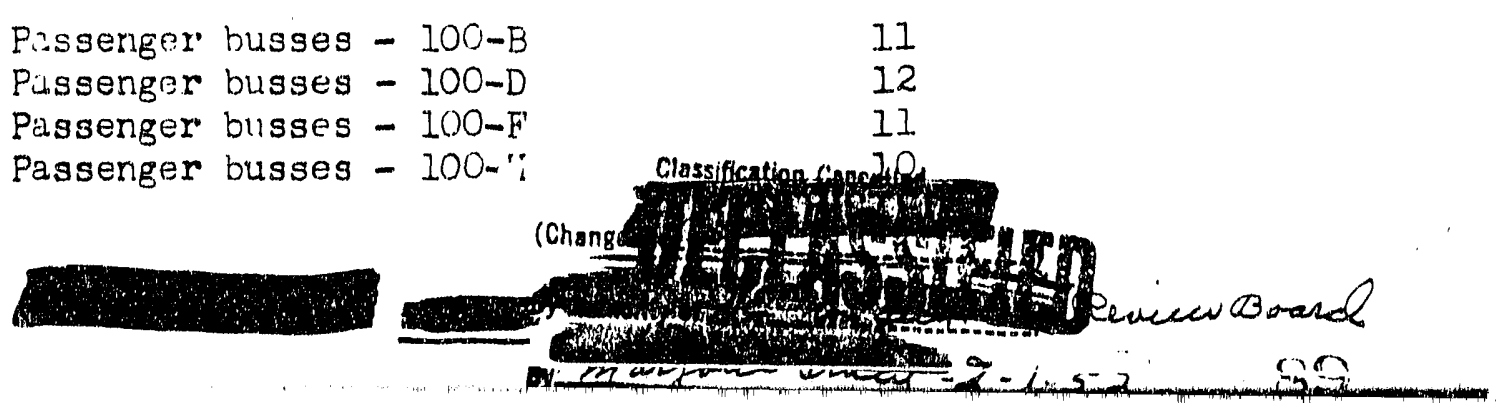


Transportation DIviaion

HW-20671_Led

$\begin{array}{lr}\text { Passenger busses - Harford } & 4 \\ \text { Passenger busses - 200-West } & 20 \\ \text { Passenger busses - 200-East } & 12 \\ \text { Passenger busses - 300 Area } & 7 \\ \text { Passenger busses - Rlverlard } & 3 \\ \text { Passenger busses - Platol Range } & 1 \\ \text { Passenger busses - White Bluffs } & 3 \\ \text { Passenger busses - North Rlchland } & 3 \\ \text { 700-300 Area Shuttle } & 26 \\ \text { Inter-Area Passenger Service } & 3 \\ \text { Inter-Area Express Service } & 1 \\ \text { Inter-Area Mail Service } & 1\end{array}$

Effective March 2, nine $K-7$ Internationsl 37-passenger busses assigned to the Area Bus System were replaced with a like number of white 42-passenger busses.

A special bus tour of RIchland and North Rlchland was made for representatives attending the March 9 meeting held in Richland of the Inter-Agency Motor Equipment Advisory Comittee of Oregon and Washington.

Special bue tours were made on March 19 and 20 for the convenience of prospective tract house buyers at the request of Purchasing and Stores Divisions.

Effective March 26, bus service to White Bluffs was established for a]l shifts at the request of the Safety and Fire Protection Division.

The Richland Local. Bus System transported $5.6 \%$ more passengers in March than in February. Volume of service rendered is indicated in the following statistics:

$$
\begin{array}{lr}
\text { Total passengers, including transfers } & 44,205 \\
\text { Total bus trips } & 3,765 \\
\text { Total bus miles } & 20,708 \\
\text { Total revenue } & 3,066.70
\end{array}
$$

Off-Plant automoblle trips (Comnany business and/or official visitors) totaled 216.

The following tabulation indicates the service rendered by the Drivers' Test UnIt:

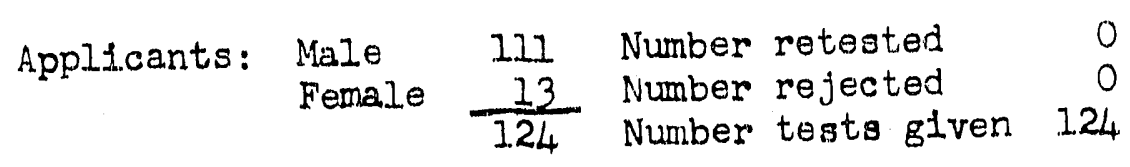

Permits issued: Limited to driving with glasses 19

$$
\text { Unlinited } \frac{105}{124}
$$

Permits reissued: $\quad 48$ Chassification cancolled

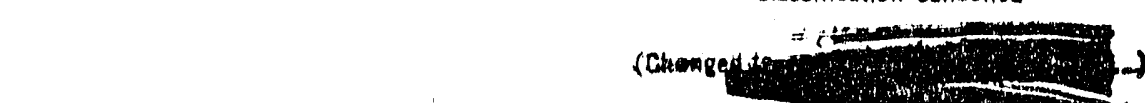

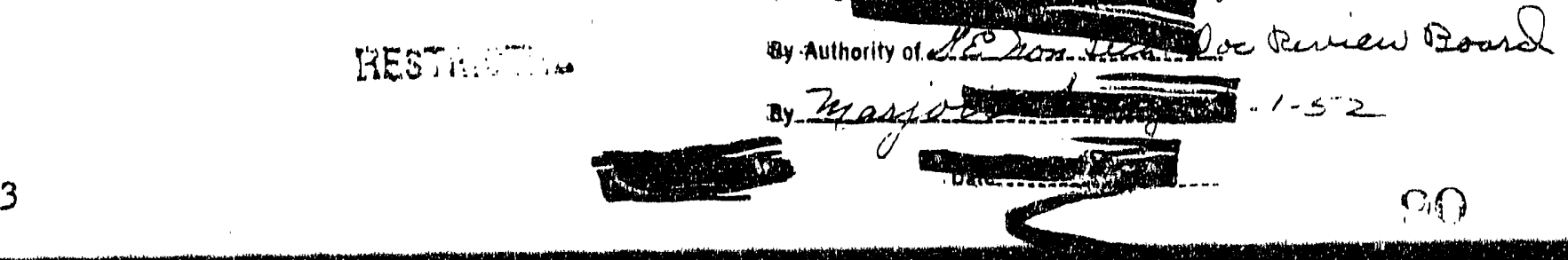


Oute $12+18-5 \%$

The following tabulation Indicates the Plantwlde usage or "artomotive equipment:

\begin{tabular}{|c|c|c|c|}
\hline Code & Type & of Units & Total M1leage \\
\hline \multirow[t]{2}{*}{$\begin{array}{l}\text { IA } \\
1 B \\
I C \\
1 D \\
I E \\
1 G \\
68 \text { Series }\end{array}$} & $\begin{array}{l}\text { Sedans } \\
\text { Busses } \\
\text { PLckup Trucks } \\
\text { Panel, Carryall, Sta. Wagon } \\
\text { Armored Cars } \\
\text { Jeeps } \\
\text { Trucks }\end{array}$ & $\begin{array}{r}320 \\
170 \\
465 \\
111 \\
12 \\
2 \\
312\end{array}$ & $\begin{array}{r}472,127 \\
206,021 \\
233,937 \\
115,928 \\
346 \\
439 \\
78,185\end{array}$ \\
\hline & & 1,395 & $1,106,983$ \\
\hline
\end{tabular}

The following tabulation indicates the volume of fuel distribution by the Equipment Maintenanco Section:

\begin{tabular}{|c|c|c|c|c|c|}
\hline & Gasoline & $\begin{array}{l}\text { Diesel } \\
\text { Fuel }\end{array}$ & $\begin{array}{c}50 \\
\text { Cetane } \\
\end{array}$ & Kerosene & $\begin{array}{c}\text { Whyte } \\
\text { Gas }\end{array}$ \\
\hline $\begin{array}{l}\text { Stook at start of month } \\
\text { Received durlng month } \\
\text { Total. } \\
\text { Delivered to Areas } \\
\text { Stock at end of month }\end{array}$ & $\begin{array}{r}44,650 \\
106,998 \\
151,548 \\
112,011 \\
39,537\end{array}$ & $\begin{array}{l}12,970 \\
26,560 \\
39,530 \\
23,140 \\
16,390\end{array}$ & $\begin{array}{r}5,511 \\
30,263 \\
35,774 \\
29,612 \\
6,162\end{array}$ & $\begin{array}{l}4,878 \\
1,085 \\
5,963 \\
4,522 \\
1,441\end{array}$ & $\begin{array}{r}22 \\
212 \\
234 \\
79 \\
155\end{array}$ \\
\hline
\end{tabular}

The following tabulation indlcates the volume of inapection and maintenance service rendered to Hanford Works automotive and heavy equipment by the Equipment Malntenance Section: 22 motor over-hauls, 94 Class A Inspections and Repairs, 1,330 Class B Inspections and Lubrications, 1,448 other routine maintenance repairs and service ca.11s, 505 tire repairs, and 483 wash jobs.

Received two new Buick sedans and sorviced preparatory to assignment.

Inspected, serviced, and made necessary repairs to 26 white 42 -passenger busses preparatory to off-Plant, assj.gnment by the Atomic Energy Commission. LABOR ACTIVITIES

The following tabulation indicates ir gallons the volume of asphalt road material handled by the Services Section:

$\begin{array}{cccc}\text { MC 1 } & \text { MC 3 } & \text { MC 4 } & \text { MC 5 } \\ 0 & 1,035 & 0 & 0 \\ 0 & 9,467 & 0 & 0 \\ 0 & 6,072 & 0 & 0 \\ 0 & 4,430 & 0 & 0\end{array}$

Stock at start of month Received durine month Dispensed during month Stock at end of month

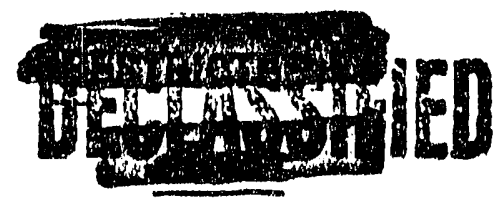


The following tabulation indicates the volume of materlals handled by the Services Section and a breakdown by Plant Areas:

$\begin{array}{lrrrrrrrr}\text { Cars coal unloaded } & 68 & 122 & 55 & 50 & 22 & 13 & 0 & 330 \\ \text { Cars other matertal } & 4 & 5 & 1 & 4 & 6 & 4 & 5 & 29 \\ \text { Cars loaded out } & 0 & 4 & 0 & 0 & 0 & 0 & 0 & 4\end{array}$

Crushed and stockplled 1,080 oubic yards of 5/8" orushed rock and 623 cublc yards of 1/4" crushed rock requiring 550 man-hours. Manufactured 365 tons of $3 / 4^{\prime \prime}$ pre-mix material and 221 . tons of $1 / 4^{\prime \prime}$ pre-mix material requirting 120 man-hours. Maintenance of primary roads requiled 260 man-houra; patro. roads required 255 man-hours.

Handling of mlscellaneous materials for the Stores Division at White Bluffs required 2,210 man-hours.

Handling, unloading and transporting of materials for the Storea Division in the 700, 1100 and 300 Areas requitred 478 man-hours.

Movement of material for the Stores Division in the 3000 Area required 800 man-hours.

Handling of Area deliveries required 1,240 man-hours: Stores deliveries 311 man-hours and office furnticure 954 man-hours.

Handling and loading of 8 carloads of lumber, 2 carloads of steel, 2 carloads of equipment, 7 carloads of material, 93 truckloads of lumber, 42 truckloads of equipment and 16 . truckloads of material required 2,578 man-hours.

Routine Area maintenance and labor services were performed in all

Mariufacturing Aress.

Labor and transportation equipment were furrished for Projects P-172, P-177, $\mathrm{P}-290, \mathrm{P}-291, \mathrm{P}-326, \mathrm{P}-340, \mathrm{P}-341, \mathrm{P}-347, \mathrm{P}-349, \mathrm{P}-366, \mathrm{P}-377, \mathrm{~F}-382, \mathrm{P}-398$, $\mathrm{P}-399, \mathrm{P}-410, \mathrm{P}-415, \mathrm{P}-423, \mathrm{P}-432, \mathrm{M}-713, \mathrm{M}-769, \mathrm{M}-770, \mathrm{M}-810, \mathrm{M}-820, \mathrm{M}-822$, and $\mathrm{M}-824$.

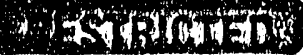



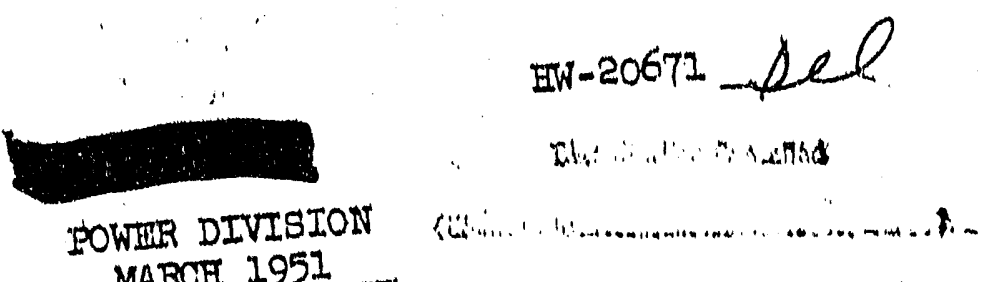

MARCH 1951

GHNBRAI GHNERAI
The semi-amual aurvey of coel stockplies was completed in all
Power areas during the month.

\section{PHIRSONNEI,}

Five weekly roll employees were promoted to shift supervisors on

March 15, in connection with the expansion of Power faolilties ln the 200 West Area.

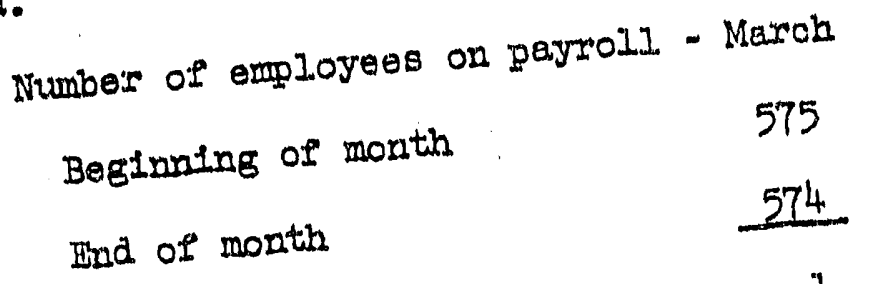

\section{Net Decrease}

Thalcated net decrease 19 the reault of the transfer into the The lnalcated net amployees, whlle one superrisor and four non-exempt exployees terminated.

\section{AREAS}

River water turbldity fluctuated greatly during the month, reaching a max1mum of $220 \mathrm{ppm}$ on March 28. Coagriant feeds were Increased to a maximum of $1.5-20 \mathrm{ppm}$ in order to produce water on. quality。

The remaining two deverators were removed from the 100-D Area, 185 ind 3. Removal of stmuctiral stoel Deaerator Bullaing betwe balance of the month. In the 100-B Area, wes in $\mathrm{F}$ eress durlins removal of deaerators was all work was a.c185 Deaerator Bullalis renetors had been removed. By month's end, four deatererator Removal Project. complished on the $\mathrm{C}-172$ Deaerator In the 100-T Area, 190 Process Pump for a short production test on was ralsed to 50 psi alove nommal "P" Division.

The levels of the elevated process water storage tanks in the 105-Dn Area were lowered on March 7 to check the operation of the Grove automatio valve on the oxport raw water. The finstalization of an electric sump pump wastallation was nocessary The Instalization House on March 14. This listallation 
Power Division

200 AFTHAS

In the Hast Area, construotion forces removed the 3-1noh ateam Ine along the east slde of the 24 I-BX and BI Iank Farms for constiuction actirity in theso areas. This Iine 1o to bo roplaced by construation upon conpletion of the work planned in these areas.

On March 11, the Fire and Sanftery water system supilying the "U" and Redox Construction areas was out of service for $81 x$ hours whllo repalirs were made on a 10-Inch lateral to the "U" Area. Thls IIne had been broken by construction foroos on March 5 whilo excavating for the new 20-1nch rew water Ine to Redox.

In the 200 West Area, the ventilation belancing arew made an alr flow survey in the 224-T Concentration Bullaing, for use of the EnglneerIng and Construotion Divisions, In determining ventilation requirements of the $\mathrm{NO}_{3}$ Building.

A new set of battersios was Installed in tho 284 Power House in Hest Area, on March 19, and the 284 Power House in West Area, on Maroh 22. These batteriog roplaced the orlghnal installation whlch hed served Its useful I1fo as Indloated by the badly corroded plates.

101. SHOPS

A fire in the cosi storage p1lo was found on March 15. The fire was put out by diggling out the burning coel with a bulldozer and repackIng the plie.

\section{WHITE BIUFES ICE PIANT}

The production and storage of 1 ce for the 1951 season wes startied on March 27.

\section{POWHR ENGINTEERING SECTION}

The high flow test through the filter plant at 100-B Area is continuing as planned. The average fllter flow rates were 3,450 epm per filter unlt as comparod with 2,800 to 3,100 3pm per fliter in the other 100 areas. An evaluation of the hicher llow rate cannot be" made uritil severel additional results experfonoe has beon obtained.

The rate of process water pressure arop within the P1le continues to be a problom, espocialiy in 100-H and DR Areas, because of the higher operating levels. Wator flow roduction oaused by the pressure drop incroase is currontly in oxcoss of 100 epm por day in those aroas. There seems to bo littio nopo that present mothods of water troatment can remedy the rapid Incroase in prossuro drop as long as present power lovels aro hold. Rovoarch progrums by other DIvisions are directed toward devoloping othor moans of overcoming this difficulty. 


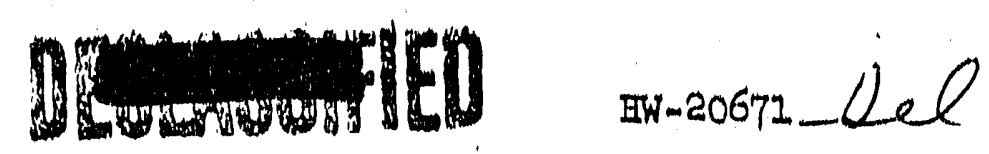

\section{Power D1V1010n}

Project Proposal No. C-433, "Ilxpansion or 300 Area Power House and Pumping Station" has beon approvod by the Approprlation and Budget Comittese and has beon forverded to the Atomio \#nergy Commisalon for approval. Proparation of deslgn opodifloations for this projeat are conqleted.

Industral Englneerting Feport No. 3 "Ut1lization of Fuel 011 in Hanford Works Boller Houses", and Report No. 5, "Ut1llzation of Natural Gas Fuel In Eanford Works Boller Houses" have beon revlewod by the Power D1vislon and forwarded w1 th comments to the Atomio Enexey Comission. 


\section{FOWIIR DIVISION STATISTICS}

\section{W-20671-0EC}

Irom March 1, 1951

Through Mareh 31, 195.1

$A R$ I A S

RIVWR PUMP HOUSE (Bu1la1ng 181)

Riter Elevation (mol It.) $\begin{array}{r}(\max ) \\ (\min \\ (\mathrm{arg})\end{array}$

Fiver Temerature

Water to Reservoly

Water to $183 \mathrm{DR}$

RESHIROIR (Bullding 182)

Flow to Filter Plant

W' Jow to Cond. System

H'low to Cond. System(DR)

Flow to Ixport System

Flow to Export System

avg. ${ }^{\circ} \mathrm{F}$.

Epm arg. rate

gpm avg. rete

Chlorine, Added (\#I Inlet)

gpm avg.rate

gom avg.rate

gpon avg.rate

gem evg. rate

gpm nor.rate

FITTHRED WAITHR（Bu1Ia1ng 183)

Flow to Power House

Flow to Process (190)

Flow to DR

5pm avg.rate

Flow to F1ro \& Sanitary

spm avg. rate

gpm. avg. rate

gpm avg.rate

WATMR TREATMENT (Bullaing 283)

Chlorine - Consumed

pounis

IIme - Consumed

Coag - Consumed

Raw Water pH

Finlshed Water $\mathrm{pH}$

Alkalinityr, M.0. - Raw

Fintished

Resldual Chl. - Finlshed

Iron - Raw

North Clearwell

South Clearwell

Hardness - Finoshed

Turbidity - Raw

Filterod ppm avg.

pounds

ppm ave.

pounds

ppin avg.

$\mathrm{pH}$ Q $\mathrm{VVB}$.

pH avg.

ppm avg.

ppm arro.

ppm arg.

ppin avg.

ppm ave.

ppm avg.

Ipin avg.

ppm aves.

ppm avg. $\begin{array}{ll}390.5 & 382.1 \\ 387.9 & 380.0\end{array}$

$389.3 \quad 381.1$

38.1

40,450

38.3

53,651

31,348

35,377

45,263

$3,123 \quad 3,056$

$1,950 \quad 1,780$

5,270 5,270

$11,620 \quad 19,653$

$34,320 \quad 43,515$

$2,983 \quad 3,953$

855

683

5,270

11,500

5,270

12,500

2.72

31,214

$$
\begin{array}{r}
500 \\
31,414 \\
3,775 \\
183
\end{array}
$$

275
012

269

36,366

31,012
232

39,477

197

4,080

2, 507

1.08

50,050

3.8

148,600

11.3

7.92

7.66

62

61

.14

.39

.019

.016

76

33

1.13

80,850

4.8

192,000

1.1 .4

7.86

7.73

61

58

.10

.78

.019

.020

66

43
10,900
.93

66,600

5.7

$160,200135,558180,260$

$\begin{array}{lll}13.7 & 20.6 & 11.1 .\end{array}$

8.02

7.64

60

58

.16

.86

.017

.013

75

45
7.90

7.70

4,500

1.16

4 .

4,000

.95

2,000

8.00

7.78

64

59

59

.15

.63

.016

.016

76

40
61

.16

.80

.017

82

45 
From March 1, 1951

Through March 31, 1951

POWER HOUSE (Bu1laing 184)

$100-\mathrm{B} \quad 100-\mathrm{D} \frac{\mathrm{A} \text { E A S }}{100-\mathrm{DR}}$ 100-T $100-\mathrm{B}$

$\begin{array}{ll}\text { Marimm Steam Generated } & \text { Ibs./hr: } \\ \text { Tiotal Steam Generated } & \text { M Ibs. } \\ \text { Steam Loed - Avg. Rate } & \text { Ibs./hr. } \\ \text { 225 psI Steam to Flant (est) } & \text { M Ibs. } \\ \text { I5 psI Steam to Plant(est) } & \text { M Ibs. } \\ \text { Coal Consumed } & \text { Tons } \\ \text { Coal In Storage (est) } & \text { Tons }\end{array}$

BUIDDING 190 - TANKS

F'low to 190

Dichromete-Consumed

Chemical Analjsis:

pE

Dichromato gpm avg.rate pounds

pH avg.

ppm avg.

PROCESS PUMT ROOLI (Bulläing 190)

Flow to 105

Water Temoerature

gpm avg.rate gpm nor .rate Avg: "F.
162,000

102,756

138,113

86,354

783

6,652

38,988
296,000

188,600

253,495

159,150

783

12,059

37,982
$154,000161,000$ $102,610 \quad 96,578$ $137,917129,809$ $86,23081,115$ 783

6,831 39,294 783 6,292 37,370
30,864 23,600

$7: 62$
1.8
31,164

22,000

7.64

1.9
36,366

26,600

30,762

22,000

39,227

$$
7.64
$$$$
1.9
$$

7.64

1.8

7.69
30,689

33,000

40.8

30,989

33,400
44.6

35,558

36,200

30,58

31,400
40.6

39,052

40.6

41,300

VAIVE PIT (Euilding 105)

Solids Consumed pounds

$2,800 \quad 4,000$

3,400

1,400

6,100

Chemical analysis

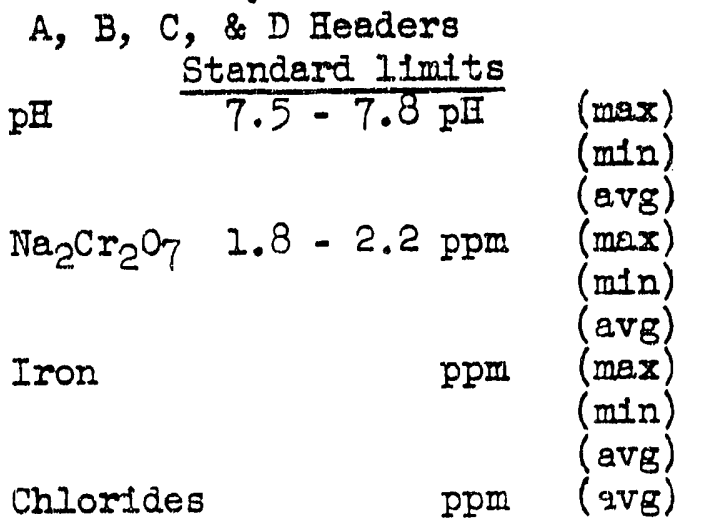

7.65

7.60

7.61

1.9

1.8

1.8

.030

.010

.015

7.65
7.60
7.63
2.0
1.8
1.9
.025
.010
.014
1.5

7.70

7.50

7.63

7.70

7.60

7.65

2.1

2.0

1.8

1.8

1.9

.025

.020

.010

.015

.013

1.4

1.5

7.75

7.55

7.65

2.0

$1: 8$

1.8

.025

.010

.015

1.5 
From March 1, 1951

Through March 31, 1951

200 A R E A S

TWESERVOIR (Builaing 282)

Raw Water Pumped

gpm arg. rate

FIITER PLANT (Builalng 283)

F1ltered Water Purpod

Chlorine Consumed

gpm avg. rate

Alum Consumed

Ib.

1b.

Chlorine Residuel - Senitary Water ppm

POWER HOUSE (Bufla1ng 284)

Maximur Steam Generated

Steam Generated - Total

Steam Gencrated - Ave. Rate

Coal Consumed (est.)

Coal in Storage (est.)

Ibs./hr.

$M I b$.

Ib./hr.

Tons

Tons

Ibs./hr.

$M I b$,

Ib. Mr.

Tons

Tons

43, 000

120,000

26,278

72,396

35,320

1,799

8,950

97,306

4,740

17,314

300 Area

POWHR HOUSE (Buflaing 384)

Maximu Steam Generated

Steam Generated - Total

Steam Generated - Avg. Rate

Coal Consumed - Total (est.)

32,000
18,526
24,900
1,237
1,672

CANIMAIIY AND FIRE SYSTTIM

Santtary Water from 3000 frea

gal.

ge.l.

gal/day

Total Water Der Day

Total Water

Chlorine FiestdunI

gom avg. rate

ppm

$$
\begin{array}{r}
25,823,793 \\
20,291,600 \\
1,487,593 \\
1,033 \\
.40
\end{array}
$$

MISCELIANTEOUS ARERS

WEITE BLUFFS

Ice Manufectured

Ibs.

174,900

101 SHOPS

Coal Consuned 


\section{DECLASSFIED \\ Witin Deleitions}

MECENICAL DIVISIONS

March, 1951

SUMMARY

$4 / 20 / 51$

\section{P1le Technology Division}

Problems in connection with the desion of the $C$ pile have required the diversion of effort from some of the longer range programs. Studies undertaken include shielding changes, ball third safety design, coring of graphite channels, improved and increased test facilities, provisions for increased water flow, and
use of enriched uranium.

The programs of investigation of plutonium cxitical mass, plle lattice design, radiation shielding development, xenon cross section, and test pile measurements were continued normally during the month.

Predicted long term reactivity changes in the H-10 load indicate that losses during the next three months can be compensated by charging natural uranium Without the use of additional U-235. Improved xenon poison values from tables prepared by the IBM Computing Group are expected to enable more accurate pile reactivity control and balances.

Measurements of graphite samples exposed in the F PIle injicate a burnout rate of 0.6 percent per 1,000 days in the center of the pile at $380^{\circ} \mathrm{C}$ and a build-up of 0.5 percent per 1,000 days in the eringe zone at $1050 \mathrm{C}$. The general program of graphite radiation damage is belng expanded although handicapped by a shortage of laboratory facilities.

A review of the transient water flow requirements for the C Pile was completed and a simliur study for the operating piles is under way. Installation of flow laboratory equipment for the water quality study was continued.

Seven in-pile experiments were under irradiation during the month, two for plant assistance and f1ve for off-site reactor development.

Plant assistance stuiles of uranium machining and canning directed towards Improved slugs were continued. Examination of a ruptured slug in the radiometallurgy laboratory resulted in wldespread contamination.

Tritium production was limited to experimental runs. Tests of the all-metal production line witi inactive gases progressed satisfactorily during the month. Construction activi" es on projects $P-10-C, P-10-D$, and $P-10-D$, Part II were continuec. 
Beparations Technology Division

A new system of material accountability, which is expected to result in more nearly correct ylelds and materlal balances, was inltiated in the saparations plants during the past month. Production testing of reduced B1smuth Phosphate process volumes has been carried to a $30 \%$ volume reduction without significant changes in elther waste losses or decontamination. Recent abnormally high hold-ups of product in the Isolation Bullding nutsches have made it necessary to Institute more Irequent leaches and clean-outs. Production testing of direct hydrofluorination of oxalate precipitates in Bullding 234-5 has been successfully completed and the new procedure is being given a trial in the plant. Recent difficulties with high lanthanum content of plutonium castings were corrected by changinis the addition of chemical 70-58 back to Casting from Reduction.

In Redox and TBP process development, Technical Manual preparation has continued to $69 \%$ completion of the Redox Manual and $16 \%$ complotion of the TBP Manual. The flrst group of 20 " $\mathrm{g}$ " Division supervisors and 28 operators has completed its six-weeks operations training assigment in Bullding 321 , and a second group is now being trained. The program of assistance to ORNL Purex process design has been carrled to the polnt where the deston of the Purex columns can now be scoped. Engineering development ptudies are continuing on Production Plant pumps and materials of construction. The lump sum construction of the Hot SemiWorks was started during the month, with excavation for the Hot Process Bullaing approximately $60 \%$ complete at month's end.

In tha research laboratory, studies have been continued on the use of scavenger 3 for tile decontamination of Bismuth Phosphate first cycle supernatants, concelltration of Redox flnal product solution and its coupling to metal production, and the recovery of plutonium from 234-5 slag and crucible wastes. Efforts are being made to impxove the methods of scavenger separntion in the Redox process. Additional fundamental Investigetions have been carried out in the atablifty of IIBP, pulse column mechanisms, and the effects of head-end treatment on Purex process decontamination. Supporting studies for the P-II Critical Mass Project have also been carried out.

Further study of the proposed skull recovery process has uncovered Improved methods of skull dissolution. Continued investigntion of the number of pexoxidr cycles required to obtain the required plutonium metal purity has succeeded in narrowing 1mpurity problems to only a few elements. Laboratory Reductions with sulphur Instead of lodine used as the booster have given yields only slightly below those normally obtained with lodine. Further investigation of methods $c$ : oxalate destructior for supernatant recovery is being carrled out in the laboratory.

The program of investigation of the concentrations of ammonia and oxides of introgen in the Dissolver off'-gas during the change-over from conting removal to metal dissolution hr.s indicated that the previously suspected f'ormation of amonium nitrzie 1 : the Silver Renctor and Fiberglas filter is extremely unlika ${ }^{\prime}$ A spot check oI tLi. $[1.31$ removel efficiency of the $4-5 I$ S I. ver Reactor at $B$ Plant during tire mi. th indicated an efficiuncy of $99.9 \%$. 
Technical Services Division

An automatic recorder has been Installed on the mass spectrometer used for P-10 process sample analyses, and has been used in the routine analysis of 309 samples during the month. Although not offering greater speed, the unlt does Bive more informatiou and in a recorded form. A revlew of the completed spectra reveals that about $2 \%$ methane is present in out -gas samples but not in other extracted fractions. A 50 foot section of copper tubing has been connected to the mass apectrometer head to allow study of direct $1 n-I i n e$ analyses and has biven promising results.

Mass spectrometers for the 1sotopic analysis of uranium oxide recovered from the Redox and Metal Recovery Processes are being ordered. The original instrument speclifcations were altered to allow delivery of these instruments by September 15, 1951.

A series of six plutonium nitrate solutions has been analyzed for Pu ${ }^{240}$ with the recently installed spontaneous fission counter. The values obtained are in reasonable agreement with those calcula'ied by the PIle Physics Section, and with experimental data obtained in the $23 \mathrm{l}$ Bldg. laboratory indicating the presentlyemployed 1sotopic correction factors to be in error.

A modifled extraction-spectrochemical procedure has been introduced into contro." practice for the determination of impurities in plutonium metal. Although the procedure is still difficult and subject to uncertainties, more accurate results will be obtained by the use of optimum conditions of spectrographic exposure and by the use of reference standards that have been processed through the entire analytical procedure.

An investigation of infrared absorption techniques for the determination of carbon monoxide has ylelded an accurate procedure that will prove to be of assistance to P1le Technology Division projects for the study of in-pile experiments on graphite reactions and the rate of graphite burn-out. Observations of value to in-Iine monitoring include a method for making alrt1ght seals of cell windows on the absorption cell. and the effect of inert gasen on the absorption by carbon monoxide.

Final design of the Radiochemistry Bldg. was completed by the Leland S. Rosener Company on schedule, and most questions regarding it had been resolved by monthend. An A.E.C. directive modiflcation was received, authorling the constmuction of this buflding and raising to $\$ 4,680,000$ the total expenditure authorlzed for tbis new Works Laboratory facility.

Close ficld liaison continued on the new Redox Analytical \& Plant issistance Laboratory, construction of which was $95 \%$ complete by month-end. Several apecial tongs and a slave-type manipulator were designed for the multicurie cells in this new laboratory, and these are belng fabricated in the Technical Shops. Devejomment of Junicr Cave and gloved box accessories for use in this bullalng alsc räs intinued.

A.E.C. Directive 10 . BW-219 was modified to cover the design and constructior. of the rescoped Librury and Files BIdg. The design of this facility was subcontracted to the C. T. Main Co. (of Bostun), which $\hat{i}_{-} \mathrm{E}$ firm also has the Pile Technology Bldg. Good design progress was reported for both of these facilities. 
The Dix Steel Company (of Spoksane) broke ground on the Phese I construction of the Mechanical Development BIdg. In the Works Iraboratory Area, and made good progress on the footings for this prefabricated steel structure. A Part 2 Project Proposal coirering the interior construction (Phase II) of this builaing was approved by the $A$ \& Comittee and forwarded to the A.E.C. Comnission consent was obtained by $E$ \& C for the negotiation of a lump sum design and construction subcontract for this Phase II work with the Dix Steel Company. The required design criteria are being prepared.

At P1le Engineering Section request, a statistical study was begun of panellit pressure readings for the H-10 loading to see if the rupture of P-10 lithiumaluminum alloy slugs can be predicted and prevented. snother study of the expected exposures of tubes in the H-10 loading in the production piles was made by the Computing Laboratory. Considerable statistical effort was devoted to the study of isotope correction factors and chemical assay-radioassay ratios in connection with analytical control of the separations process.

The Technical Information Group resolved several Eanford questions in connection with the forthcoming A.B.C. revision of the Standard Distribution Iists for research and development reports. irrangements also were completed for treat.. ment of the files in the schenectady Offlce (of the Nucleonics Dept.) as a branch of the Eanford Classifled. Files, with local accountability for all classifled documents transmitted there.

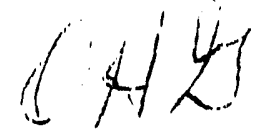




\section{PIIT TECERNOLOGY DIVISION}

MARCI, 2951

VISITORS AND BUSINVSS TIIIPS

\begin{tabular}{|c|c|c|c|}
\hline Visitor & Address & Date & Furpose \\
\hline J. A. Ayres & Knolis Atomic Power Lab. & $\begin{array}{l}3-1-51 \\
3-2-51\end{array}$ & Interview \\
\hline H. Hurwitz & Knolls Atomic Powor Lab. & $\begin{array}{l}3-1-51 \\
3-3-51\end{array}$ & $\begin{array}{l}\text { Discuss the KNPL } \\
\text { assistance to Hanford } \\
\text { procram. }\end{array}$ \\
\hline James Moyrex & Knolis Atomic Power Laj. & $\begin{array}{l}3-1-51 \\
3-5-51\end{array}$ & P-10 Consultation \\
\hline $\begin{array}{l}\text { J. G. Morcan and } \\
\text { H. E. Pobertson }\end{array}$ & $\begin{array}{l}\text { N.E.P.A. Division, } \\
\text { Oak Ridge Nat'1. Lño. }\end{array}$ & $\begin{array}{l}3-?-51 \\
3-10-51\end{array}$ & $\begin{array}{l}\text { Consultation and work } \\
\text { on the aluminum creep } \\
\text { appratus at the D PIle }\end{array}$ \\
\hline
\end{tabular}


P110 Technologs DIVla1on

Visitor

I. A. Welsch

D. I. Watrous

Mr. Plckett

H. W. Bousman

R. D. MeCrosk

F. A. Damewood
Address

Date

Knolis Atomle Power Lab. 3-8-51

$3-9-51$

Goneral Engineering Iab. 3-19-51

$3-23-51$

M1Iwaukee General

Blectric X-Rey Co.

$3-28-51$

$3-29-51$

General Enginoering Iab. 3-22-51

$3-30-51$

E. I. deNemours duPont Co.3-15-5I

$3-30-51$

E. I. deNewours dupont Co.3-16-5I

$3-30-51$
Purpose

Intervlew

P-10 Consultation

Consultation on $x-r a y$ work.

P-10 Consultation

To follow cenning of speciel pleces.

To follow canning of special pieces.

Business Trips of Pile Tochnolocy Division Personnol duning March were as follows:

Neme

W. T. Kattner
Place Visited

Malilnckrodt Chom. Whs.
Tate

$3-1-51$
Nrgonne Nat'l. Iab.

New York AEC

Westinghouse Atomic Iab.

Battolie Memorlal

Institute

Knolls Atoric Powor Lab. 3-9-51

R. S. Dalrymple

National rssocintion of Corrosion Eneinuers

Battelle ifuoring Institute
$3-2-51$

$3-5-51$

$3-6-51$ $3-7-51$

$3-8-51$

$3 \cdot-12-51$

$3-15-51$

$3-15-51$

$3-20-51$
Purpose

To attend a meeting on quality and specifications of metal and to inspect the plant and discuss operating metilods.

Discuss canning operation.

Consultation on metal fabrication.

Irradiation Damage

Meeting

Consultation on Battelle's program for Hanford.

Metaliurgical consultation.

Corrosion conference.

Discussion on anodizing of slugs. 
$\underline{\text { Neme }}$

R. S. Dalrymle

R. G. Wheeler

T. C. Nelson

W. L. Scha11101
Place Visited

Alcos Aluminum Co.

Western Motals Congress

Western Metals Congress

Research Welding and

Inglneoring Compang

Amerlcen Welalng Socioty 3-21-51

I. B. Mantgomory

I. P. Dupp,

E. P. Warekois,

I. A. Mcclaine, \&

W. J. Ozeroff

C. W. Botgford

A. R. Matheson

N. Endow

I. M. Loob frgonno Nutional Lab.

University of Calcoco

Ios Alarsos Nat'1. Lab.

Oregon Etate Collogo

Knolls Atomic Power Iab.

Westinghouse A.tomic Ie!).

$3-1-51$ $3-2-51$

$3-6-51$

$3-7-51$

$3-12-51$

$3-13-51$

$3-12-51$ $3-1.3-51$

$3-30-51$

$3-12-51$

Knolls Atomic Fower Lab. 3-26-51 $3-29-51$ $3-17-51$
Purpose

Discussion of aluminum problems.

Convention

Convention

Technical alscussions on a vacuun tank.

Sessions of the American Welaine Soclety

Consultation regording test plle design.

Attend the Redidtion

Damage Meeting.

Consultation on Eraphite problems.

Reactor Safeguerd Comittee Meeting

P-10 Consultation

Tecinical discussions.

P-10 Consultation

Consultation on a KAPI enginecrins experilnent.

ORGANTZATION AND PERSONNTI

\section{Fobruary March}

Physics Section

Engineering rection

Metallurgy Soction

P-10 Profect

Adninistrative

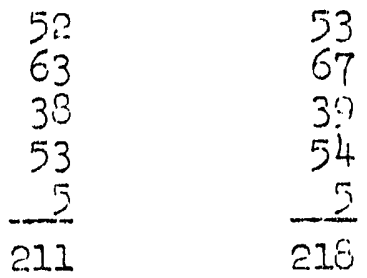


A general clerk and a steno-typlst were hired for the Physics Section. One technical rraduate trensferred in from Project Engineoring and a laboratory assistant transferred to the Electrical DIvlsion. A steno-typist terminated. from the Physics Section.

In the Ingineering Section, three engtneers, two laboratory assistants, and one steno-typist wes hired. An engineor and one steno-typist torminated.

A metallurglst transferred Prom Separations Technology to the Metallurgy Section.

A chemist was hilod for the P-10 Section, and a fleld clerk transferred in from Trensporteition. A leboratory assistiant trensferred from the P-10 section to the Flectrical. Div1:ion.

\section{PEYSICS}

Area Phys:tlcs Work

The celculation of the number of effectivo contral tubes is sensitive to the water flow rates used in calculatine the output of the most productive tubes and there is some uncortalnty in the flow retos of individual tubes. The month-end values are tabulated bolor.

$\begin{array}{rr}B P 110 & 1294 \\ I P 110 & 1327 \\ D R P I 10 & 1186 \\ \text { F P110 } & 1502 \\ H P 110 & 1413\end{array}$

There were no outstanding chanfos during the month. The number of effective central tubes which can be achloved at the $B$ and $D$ Piles is limitod by the relation between locel power and graphite temperature which exists in various portions of these pilos.

A study has been made of the behavior of an operating p1].e which suddenly acquires an increased reactivity. If the safety circuits are tripped by the resulting power increase and function proper'ly, a pile operating at $500 \mathrm{lW}$ given 100 inhours oxcess ronctivity will rise to a poak of $900 \mathrm{MW}$ before tlle powor begins to fall. For an excess roactivity of 800 inhours, which would result from loss of water, the subsoquent peak would be of the order of a million megawatts if the power level increaso is the actuator of the safety circuit. However, if a drop in water pressure actuates the circuit the situation is considerably improvod since sevoral soconds would elapse botwoun a drop in pressure and the ejection of wator from the p1lo by boliling. In this case the power level increase may bo hell to a nominal valuo. An autometic trip, actucted by low wator pressure, is therefore highly desircble lor the now ball type third safoty system. A detailed report on this work is being prupared.

During a start up of If P1le it was possible to calibrato the control rods used in a roactivity coefficient test performed in Januarr. These calibrations were then used to analyse the data obtained during the tost. The results were in arreement with provious tronds. 


\section{Tritium Production}

The results of the study of long term reactivity changes, reported last month, have beon applled to the H-10 loading and a forecast made of the reactivity and power level of $\mathrm{H}$ Pile during the coming months. Thls forecest was based on presontly proposed discharge schedules for H-10 and natural uranlum tubes. The results are that the expocted reactivity losses during the next three months can be compensated by charging the remeining dumy and P-10 tubes with natural uranium. A drop in power of twenty to thirty megawatts may be expected in the seme period due to distortions of the neutron distribution produced by roplacing I-10 tubes with natural uranium and 1 w w11l be necessary to d 1scharge tho tubes in symotrical patterns to avold additionel power cuts.

\section{Critlcal Mass of Plutonium}

The exper!mental work directly related to the present separation process is substantlally complote. Some chemlcal analyses of the solutions used in the Iinal experimonts aro st1II in procoss and interpretation of the results will require some additional time. Since soveral troublesome loaks have developed in the equipmont, it is expellent to suspond oporetions at this time for a complete overhaul and rovamping. The romainder of the oritical mass program will be devoted princlpally to obtalning bacic scientific data on plutonlum critical mass probloms by a serios of exporiments with untampod reactors. Fabrication of equipment lor this work is pioceedirg.

Changed operating procedures in the 235 Bullding wore revlewe 1 and recomendations for maintaining duclear sax'oty were made indocument HW-20572.

\section{Lattice Deslgn}

The effect of fast neutrons from the arificial sources used in measurements in the standard pile hes beon treatod by a method described by Chormick and Kaplan in B.N.L. 77. This has produced bottor agreemont betweon theory and experiment and givon an improved value for tho thermal noutron diffusion longth in tho graphite of which the p1lo is built. Further improvement was obtained by a more caroful treatment of the source positions. Th1s work will be described fully in a roport on the standard pile which is now being propared.

Further measurements wore made in the exponential pile with the present Hanforal lattice to establish the neutron-effective dimonsions of the pile.

Development of a small neutron counter for exponential pilo work had beon unsuccessful due to a chango in counting rate with respect to time when tho counters were placed in a known constant neutron flux. The source of this trouble has now been traced to the insulating glass used. Although the mechanism is not understood, the difficulty has beon eliminated by switching to a different type of glass.

A report, HW-20484, was issuod giving a simplified method of computing rerlector effocts in large therral plies.

\section{DECLASSFFIED


Shlelding

Prelininary design work has been coupleted on tile lron-masonfte slabs whlch wll be used to calibrate the siliald test facility in tile top shleld of the DR PIle. Followlng the callbration study, this facllity will be used to test new types of shielaing material.

Analjsis of the data obtained in the stepped plug shleld facility is continuing.

\section{Spectel Request Program}

A total of thirty-two receptacle slugs were opened durlng the month. In two cases it wes not possible to remove the sample casing from the opened slug and In one other cese the cap sheared prevonting opening of the sIug. The requesting laboratory has asked that these throe slugs be shipped to them for further efforts to remove the samples.

A proposed revision of the speclal request cost code system, to reduce the possiblilty of errors, wes prepared and subritted to the Cost hccounting Section.

Because of the diversion of manpower to the design and construction of $\mathrm{C} \mathrm{PIIe,}$ the Engineering and Construction Divisions havo aslied that the responsibility for the garma-irradiation of non-metalile materials, now beling conducted for the General Engineering Laboratory, bo assumed by the PIIe Technoloey Division. Preliminary conversation with e represontative of the Generel Ingineering Iaboratory has revoaled that this work mlght better be carried out by the preparation of a gama source, such as redioactive tantelum at Hanford and shipment of this source to the General inglneering Iaboratory where the irradiations would be done.

It was discoverod that a special requost sample wes stuck in the B-Hole facility at $\mathrm{H}$ P1le and attempts to romove it were unsuccessful.

The vlew git In the H area storage basin was cleared of cuntamination and it is now possible to worls in this area without radiation zone restrictions.

Monthly statistics on the special request program are tabulated below:

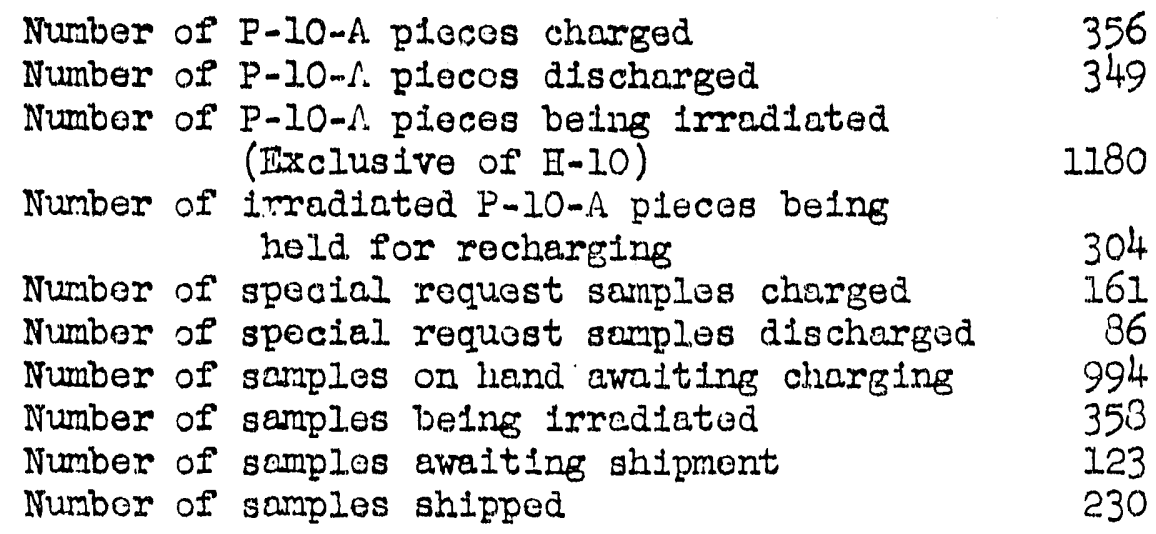


Tost Pile

Assistance wes rendered to the P DIVIsion in obtalning satisfactory performance from the differential galvanometer. Tils instrument was dismantled and cleaned by Instrument D1Fision personnel who required nssistance from the Technice. representative in roinstalling it.

Speclal Work Requests performed during the month were:

SWR-193 for the measurement of the varlation in react17ity of uncanned slugs. Slugs from the same lot demonstrated thet the varlations were within the error of measurement.

Wor's on 5WR-194 Indicated considerable surface contamination on billet egf
samples.

SWR-195 involved mecsureinents of the purity of graphite bers to be used by the Graphite Studies Group.

\section{Xenon Cross Section Measuroment}

The test hole faclilty installod in the $\mathrm{W} P$ ile to furnish a noutron beam for this moasurement was opened for short periods of tirie. The bean intensity was as expected; the general rudiation background licreased only slightly and the temporary bean catcher was found til be satisfactory.

Work on the development of the renon production system is contiming.

Instrument Development

Work is proceeding on the. Inbrication of the mapnetic spectrometer. The chamber has been assembled and is vacum-tight.

Reactivity

During the latest period of aperation under equilibrium conditions the reactivity status of the f'ive production piles was as follows:

\begin{tabular}{|c|c|c|c|c|c|}
\hline & B Pile & D Pile & DR Plie & FP11e & H Pile \\
\hline $\begin{array}{l}\text { In rods } \\
\text { In xenon poison* } \\
\text { In Speciel Requests }\end{array}$ & $\begin{array}{r}76 \\
619\end{array}$ & $\begin{array}{r}80 \\
605\end{array}$ & $\begin{array}{l}142 \\
635\end{array}$ & $\begin{array}{r}96 \\
613\end{array}$ & $\begin{array}{r}87 \\
720\end{array}$ \\
\hline $\begin{array}{l}\text { Matcrials Testing Program } \\
\text { Other } \\
\text { In lead-cadmium colurms }\end{array}$ & $\begin{array}{r}33 \\
10 \\
0\end{array}$ & $\begin{array}{r}38 \\
39 \\
0\end{array}$ & $\begin{array}{l}0 \\
0 \\
0\end{array}$ & $\begin{array}{r}37 \\
34 \\
0\end{array}$ & $\begin{array}{r}15 \\
0 \\
0\end{array}$ \\
\hline $\begin{array}{l}\text { In plant assistance } \\
\text { In dumy columns } \\
\text { In overall coefficient } \\
\text { Total cold, clean reactivity }\end{array}$ & $\begin{array}{r}10 \\
5 \\
-290 \\
904\end{array}$ & $\begin{array}{r}36 \\
12 \\
-346 \\
853\end{array}$ & $\begin{array}{r}0 \\
11 \\
-171 \\
975\end{array}$ & $\begin{array}{r}20 \\
32 \\
-394 \\
320\end{array}$ & $\begin{array}{r}5 \\
20 \\
-158 \\
719\end{array}$ \\
\hline
\end{tabular}


* The senon polson values this misnth bave been calculated using the tables prepared by the IIM Computing Group. These values from IW-20418 are more accurate than the formulas used heretofore. This makes a conslderable difference in the Ilnal reactivity balance for the $B, D$, and $f$ P1Ies. The actual and apparent changes during the month for the plles are as follows:

Sctual

B P1le
D P110
DR P1le
F P110
H P110

B P1I0

DR

H P110
2 th 1088

5 in in

67 th gain

32 in gain

I4 th 1088

\section{Apparent}

30 th gain

58 in gain

67 th gain

9 in gain

It th Ioss

PIIE ENG INEHTR IIVG

Ball Thlrd Sefety Proeram

The Ball 3-X program is progressing on schedule. Technlcal dotalls st1ll under conslderation Include bail flow-rate timing, shlelding requiraments, and ball recovery techniques. Be.ll fabrlcation and speciflcation work is in progress by the Metallurgical Sect1on, the Battolle Inst1tute, the Universal Ball Compeny, and the Cruclble steel Company. This developnent work $1 \mathrm{~s}$ being done to insure delivery of the required tipe balls when needed. Design of the fluted stepped plugs, vacurum system, and other related aquipment is in progress by the Plant Engineering Division.

\section{Ruptured SIug Equipmont}

Mock-up tests have been made of special equipment for the removal of ruptured slugs; these tests indicete that the equiprent, with minor modifications, will greatly facliltatie this removal problem.

Marnesium Front Dummies

A total of nineteen tubes now have magnesium durmies in the inlet section. As provlded in Production Test-105-407-P, these will be discharged after exposures of two to $81 x$ months and ezaminations w1ll be made to detemine if any unexpected adverse effects are occurring.

Heat Transfor Stualies

Calculations are being mede to establish new minimum water flow requirements for the present piles followine a power outage. At the present time, the requirements are based on the very conservative assumption that only one vertical safety rod, with an approxinate strength of 60 in, will operate. In the interests of econom, the water transient for the C F1.le w1.11 be based on the assumption that 400 ih of control will enter the pile immediately after a power outage. Because the control strength of the VST's in the present piles varies from 70 percent to 100 percent of that in the proposed C Pile rods, limits for the present piles will be based on the same amount of control. 


\section{Weter Bolling Considerations}

As part of the study of bolling limitatlons, ax experimentel program is being planned, in conjunction with the Recetor Division, to determino the minimum cross section of the outlet fittings which would move the critical flow condstion

from the outlet of the downstream pigtali back into the process tube. The pressuro drop through plgtalis of different cross sectlons, lengths, and shapes Is also to be determined.

\section{Process Water Studies}

Construction of the 105-D Flow Iaboratory facllity is continuing. Work to date hes consisted of (a) collecting and modifying equipmont which is on hand, includIng $p$ and turbldity tanks, the raw water fliter, and auxillary pumps, (b) purchasing off-site equipment, and (c) preparing the sito and constructing pump foundations. Worls is now starting on fabrication of the heat axchangers and on the actual installation of piping in the flow laboratory. It is anticipated that the flow laboratory will be completed in about six weoks if the necessary materials can be secured on time.

A survey of the possibility of increasine production rabes by increasing header pressure is nearly complete. The study Indicates substential increases can be ob'rined if the plmplne systom $1 \mathrm{~s}$ modified to supply a nominal $3500 \mathrm{gpm} / \mathrm{pump}$ at 500 psig casing pressure. Sevoral problems aro introduced by this proposed pressuro incroese; these includo consideration of a.1lowable working pressure for the inlet risers, and requirod clienges in instrumentation.

Irradiation Effects of Graphite, RDA ; 4 TIP-10

The flrst serles of graphite samples for the determination of burnout has been removed from the F P1le. These sarples, loccted at the center, Intermediate, and fringe zones were exposed to pile atmosphere in a bare process channel for a period of 52 calendar days during pile operation. Thermocouple readings in each of these zones ultimately reached $380^{\circ}, 330^{\circ}$, and $105^{\circ} \mathrm{C}$ and were fairly steady for the lest 22 days of exposure during whlch the pile gas contained 98 percent $\mathrm{CO}_{2}$ and 0.3 percent $\mathrm{H}_{2} \mathrm{O}$. The burnout rate in the central zone averaged 0.6 percent/1000 days for unirradiated grephite, which seems reasonable In comparison with the rates observed in the D P1le experimont using pure carbon dioxide. The burmout rate in the intermediate zone gave values which were consistent, but not considerably greater then posilble experimental orrors. In the fringe zone the samples eained weight. For two samples which had previous cold test hole exposure, the rete of bulld-up was 1.4 percent $/ 1,000$ days and for four virgin samples the build-up areraged 0.5 percent $/ 1,000$ days. A film was visible on each of the fringe zone sarples. Spectrographic analysis of surface scrapings from these samples indlcated that no metalilc irpurities were responsible for the weight increases. These data give the first direct evldence of graphite transport in the plies, and also confirz provious conclusions regarding the accelerating effects of Eraphite radiation damage.

Sensitive interferometric measuroments of trensverse physical expansion annealing spectra have been completed for an oxtensive series of irradiated CSF graphite. Six samples with previous cold exposures between 120 and $680 \mathrm{MD} / \mathrm{CT}$ each show an 
Inttlal Increase in lenfth prior to the expected decrease in length on annealing. This length Increase occurs at annealing temperctures below $400^{\circ} \mathrm{C}$ and appears to be a function of exposure, in that the tempexature at which the maximum length occurs decreases with increesing exposure.

The traverse of thermal conductivity meosuremonts on the C hole graphite stringer from the B PIIe hes beon completed. The results are in good afreement with similar meesurements made on the $\Lambda$ hole koywey from the $D$ P1le and show a sherp eradient of damage extending into the reflector graphite. Mcximum damege occurs directly in IIne with tube-row 96 where the $K_{0} / K$ value is about 27 . The central. region graphite exhibits constent thermal conductivity with a $K_{0} / K$ value of about 14.

X-rey diffraction studies made on the graphite bursout scmples indicate that no crystal growth occurred in the virgin samples durine the oxposure of about $100 \mathrm{MD} / \mathrm{CT}$, however, the proviously irradiated samples showed about a 15 percent pilo annod.

Tomperatures rocorded during the month for the controlled temperature exposure of Braphlto averogod $215^{\circ} \mathrm{C}, 170^{\circ} \mathrm{C}, 144^{\circ} \mathrm{C}$, and $115^{\circ} \mathrm{C}$. Those ropresent a further slight Increase above Inltial levels.

The graphite core borer has beon Indified to romovo samples 0.4 in. In diamoter. The instrument operates satisfactorily aid woris has been scheduled to remove pile samplos.

Work Involving the mechanlcal properties and dowsity of partially oxidized Graphite, development work on tho twin calorimeter, and the in-pile controlled atmosphere experiment under project $\mathrm{C}-410$ is progressine satisfactorily.

\section{Pile Powor Levels}

Power level increases were again made in all pliles durlng the month. The maximum power levels attained durlng this month and the month of February are listed in the following table:

\begin{tabular}{|c|c|c|}
\hline File & February & March \\
\hline B & $41.5 \mathrm{MW}$ & $425 \mathrm{MW}$ \\
\hline$D$ & 385 & 395 \\
\hline$D R$ & 484 & 526 \\
\hline$F$ & 380 & 415 \\
\hline 표 & 500 & 510 \\
\hline & $2164 \mathrm{MW}$ & $2271 \mathrm{MW}$ \\
\hline
\end{tabular}

Tho recent instaliation of acditional. Eraphite temperature monitoring thermocouples made possible the optimun use of pnison colurins and control rods to alstort the power genoration. This allowed an improvod hoct distribution which placed tho meximum heat genaration in those purtions of the pile which lavo the highest thermal conductivity, und doos not nocessarily result in increased. radial flattenine. The $D R$ and $B$ Plles current $I y$ are linitod by the tube boiling considerations while the B, D, and F Piles are linitod by graphite temperaturos. 
IR PIIe Mot1on

Results of a vertlcal traverse of the top central process tube have reveeled. that the DR FIle saplate Frowth is occurring at approxinately the same rate previously obtained on the $\mathrm{B}$ PIle. The meximun vertical expension $1 \mathrm{~s} 0.31$ in. which ls about equal to the expension of the II P1Ie at a silehtly lower total exposure.

\section{Purge of the DR P1le During Oporation}

The DR P1le wes succesafully purged whlle operating at a reduced level of $350 \mathrm{MW}$, and while shutting down from a $480 \mathrm{MW}$ level. No advorse effects were noted. The test results inalcate that purging of plles in which the power level is restricted by f1Im formation is technically feasible and operationally desirable.

\section{J Slug Fxposure Behatfor}

The enrlched $\mathrm{H}-10$ fuel. slugs are slightly unstable during p1le oxposure, but the induced chances at present exposure levels have not beon of a serlous nature. In gonoral, the slues incroase in lonfth and increcse in diameter. The rate of elongation decreases with increasires expisure. Measuromonts on two eight-Inch slugs after about 13.5 percont burnip incicatod length changes of 0.050 and 0.030 inches and diameter cherfos of 0.007 and 0.012 inches.

KAPI Fuel Elémont Tests (Eota Experimont, STR-79, PT-105-180-P)

The Influcnco of Hanford $P 110$ filux on tile bohavior of fuel elenents in contact with sodium is bolng determinod exporimentally. Slug $R-5$, $\tau^{235}$ in a stainless steol-jacketed titanlum pin, had boon Irradiatod for 253 days in tube 0865-F through March 26. The fuol eloment copsule R-I was shippod to KAPI on March 5 .

High Pressure Water ChanneI (P-13, fNIM-140, PT-105-354-P)

The behavior of water, fuel, and structural materials is being cetermined undor conditions simulating those of the STR as nearly as is possiblo in the Hanford Piles. Operation during larch was routine with reclrculating water at $540^{\circ} \mathrm{F}$ and 1500 ps1. Cartriches $\| 2,5$, and 6 , contrining U-Zr fuel platos, canned coramlcs, and exposed stmuctural natarials, wore discharced March 6 and returned to lirgonne National Laboretory. Cartridge ${ }^{\prime} 10$ contalning samples of gear and bearing materials" exposed to the water, was installed. Authorized hydrogen adaitions have not beel made because of a four to five liters por day water Ieak.

Differential Trensformer Calibration (WAPD-M-103, PT'-105-379-P)

A test was in progress to coternino the influonce of pile flux on the calibration of a differential transfomor, and on the electrical resistivity and dimensional siability of zirconium. During tie first 30 days of irradiation slue Ylelding resistance data similar to that obtained from slue $\# 1$. On March 7 , a leak developed in the nozzle and tile experiment had to be abancioned. Another slug may be chareel in $\Lambda$ pril. 


\section{Creep of Z1rcontum (PNeumet1c Looding) (WAPD-M-106, PT-105-430-P)}

A. zirconfum tensile specimon stressed at 14,000 psi and heated to $260 \pm I^{\circ} \mathrm{C}$ Is belng irrediated to determine the creep rate. Installation proceeded as planned. The specimen had been under stress at rated temperature for $124 \mathrm{hrs}$. before Instailation, and wes charged into the process tube without interrupting the terperature or load condltion. Second stage creop had not been ostablished at the time of charging, but enough data have been accumulated to lndicate that the creep rate is decreased by Irradiation.

\section{Creep of Aluminum (PT-105-381-P)}

An experiment was being performed to determine the influence of Hanford flux on tho crecp rate of annealed 2S aluminum. During the shutdown of March 7, one oreep slug designed for water-cooling was charged into tube 1883-D. The slug stuck during charging and some rough handling was necessary to free 1t. A leak developed several hours aftor installation and no data were obtained from the test. Aislug deslgned to maesuro the spring-rate of a stalnless steel bellows, and callbrate the IVDT against fleded stops, was charged into tube 2680-D. Data were obtalned from. this slug for throe days, at which time the core travel had apparently been mesked by thermal expansion. The data have not been succossfully intorpreted.

Thermel Conductivity of U-..20 Alloys (ANIM-172 - PT-105-432-P)

It is proposed that an expurimontal slug be inserted in a process tube to determine the effect of Irradiation on the thermal conductivity of U-Zr a.1loys. A durn alug assembly was recelved and las been testod in the flow laboratory. There was no chattering and the assombly exhlbltod the proper discharge characteristics. Arcorno Mat1onal Iaboratory has been notifled that a regular slue assembly will be accepted for Irradiation.

A slug assembly Includes a housing for a flua meter, hoater, and thermocouple; whlch is mechanlcally jolned to the thermal. conductivity slug.

\section{Slug Temperature Measuroments (PT-105-311-P)}

Uranium slugs with intemal thermocouplea w1ll be irradiated in cooled process tubes to determine the thermel effects of various types of plie operation. One slug was installed in tube 2469-T on March 7 .

Elevated Temperature Irradiation (Proposed ANIM-179 and 180)

Two special requests proposo irradiation of reactor construction materlals at maximum neutron flux and elevated tomperatures in dry process tubes.

A preliminary heat transfer study indicetes that a reduction in heat generation, or the removal of heat by gas cooling, is necessary to avold oxceeding: (1) safe internal pressure in tho ANL-180 autoclaves, and (2) the marirnum temperature lirit for pilo graphite. 
P1le Technology D17lo1on

METATLURGY

Oranium B1ilet Casting and Rod Fabrication

The March shipment of rolled rods, conslsting of throe car loads produced from MCW and Henford billets, exhlbits surface quality similar to those of the February shipment. Fleid results on the latter shipment have Indicated a yleld loss of approximately two percent resulting froin inferfor rod quality. Most of this increase in the number of rejects wes due to crecks and doep flssures in the body of the rod. The P DIVlsion hes agreed to segregate such unsound slugs pending results of tests to establish quelity limits and standards for machined slugs.

The depth of the surfece striations on experimentel sweged and drewn rods wes found to vary from 0.001 in. to 0.008 in.; however, the majorlty of them fell In the 0.003 in. to 0.004 in. renge. These defects should not materially effect the canning properties of the metal.

Ninoteen rods, cold drewn to flinal slug $81 z e$, heve been recelved for study. An attempt will be made to cut these rods into slug longths and can them wlthout mechlning the surfece. These rods w11l be processed on Production Test 313-115-M.

\section{Oranium Canning}

Further data substantlates previous evidonce that the number of caps Improperly seating in the cans, non-seats, occurring with the use of a two day old Al-S1 bath is only about half those occurring with the first day's use. There is also strong evidence that the number of non-seats increases with increasing silicon concentration up to 11.5 percent s111con. A test to re-evaluate the silicon concentration limits of the canning bath is belng prepared.

In a two-week trlal perlod, a bronze bath tong gulde lock-out device, deslgned to insure that oomplete trensformation has been accomplished in every slus, functioned in an entirely satisfactory manner. Construction of similar equipment for all bronze beths is now in progress.

During some of the recent thermel shock tests applied to increase the severity of the autoclave operation, a number of slugs exhibited melted areas on passing through the frost test machine. These irost test rejects were examined and re-frost tested under standard operating conditlons with no reappearance of the melted arees. It is believed that the original apperent defectiveness of these slugs was probably due to their having cooled insufficlently before beling put in the frost test constant temperature air bath.

In another tast, 36 slugs with bad wolds were first autoclaved $40 \mathrm{hrs}$. then subjected to ten thermal shocks from approximntely $180^{\circ} \mathrm{C}$ by submersion in cold water. Followine this shock treatment, one sling showed a melted area on the Prost test where none had appeared before.

Uranium Metallurgy

Using an experimental set up simulating conditions in the double diffraction technlque proposed for raclonctive samples, measurements were made of background radiation from an irradiated uranium semple. While it was found that the Bragb 
angle of the single arystal wes aritloal in that higher angles provided better shlelding between the sample and the counter, it was felt that background was sufficlentig low at useable angles tu permit use of the double diffretction method. However, the sample had an activity of only $5 R$ at the surface, and plans are under way to repeat the experiment at a later date on a more active sample. Work Is also being inltiated to check the IIne intensity vbtainable by double diffration.

\section{Dilatomatry}

Analys is of the degree of siug transformetion versus expension data using transformation ralues calculated on a rolume basis has been completed. The results show that on present metal the slug dilatometxic test is capable of rejecting most slugs which are lass than 75 porcent transformed and acoepting most slugs which are completely transformed. Slugs in the 75 to 99 percent transformed range would be partlally accepted and partialiy rejected. Stat lat lcs indicate that, for an expension limit giving virtually no rejects of completely trensformed pleces, 99.9 percent of the accepted slugs would be greater than 75 percent trensformed. If the expansion limlt were set to reject a few transformed pleces, the lower percent transformation limit of acceptod pleces would be correspondingly raised.

Work on modiflcation of tho automatic recordine dilatometer and adaptation design of the 234-5 dilatonetor is continuinr.

Plans aro boing made to purchase a Motals Comparator for dogreo of transformation studies un bare urenium pieces. KAPI liss already shown that the comparator mothod is fetathle for alpha rollod urailium.

$\underline{\text { Radiometallurgy }}$

Cannine date observed on the slug that falled in tube 3188-DR revealed that it was a standard s1ze rollod plece, canned on $G$ line March 10, 1950, from truck lot 5 and had been autoclave tostad. This plece hes boen placed in a contalner and stored for future examinstion. Contaminntion resulting from tho seperation. wf the cep, canned slug and procese tube continues to limit exporinuntal work In the 111-B Bulldine. Proper factiltles for alr control in the effected aroe of the bullding has been approved and the work by construction forces should start soon.

Tho bowed slug Prom tube 0263-F, that had the cannlag deta obliterated, was chargod on September 30, 1948. This canning date wolld Indicate that thils piece probably was not fully tranefirmoc? into the beta phaso. 
Responsiblilty for the operation of Metallurgy's anelyticel linos was turned over to the Analytical Section on March 19, 1951.

As of this date two aluminum-Ilthium slugs have swollen and ruptured in the II Plle. A detalled report on the fallure in 3177-\# 1s now beins prepared and the examination of the second fallure from tube 3483-H w1Il proceed when the activity of the aluminum has decayod. A study of the failure in tube 3177-H Indlcates that water gained entrance to the AI-II alloy and the resulting solid and gaseous corrosion products caused the swelling and finel mpture of the al.rminum can.

Canned II-AI slugs, which were subjected to an extended 300 Areatoclave test after first havine the outer can plerced, corroded in the region of the glug-can interiace. The corrosion pruduct, a white monohydrate of aluminum, which formed at the interface, caused an outward expansion of the can similar to that observed in the I1-nI slue which falled in the p1le. This tert was performed at the request of the P-10 Prociuction Group.

Considerable time has been spent in a Ilalson capacity between personnel of Purchasing and the P-10 Development Section of Hanford Woriss and of the Los Angeles vendor who 18 new fabricating tritium conteiners.

\section{Corrosion}

Sarples taken from an $\Lambda$ Ilegheny-Iuclum Type 347 stalnless steel plate, Heat 32251 , Lot $2 C$, whlch previously falled corrosion tests, were heat treated in several menners to determine whether such treatments would improve the corrosion resistance to boling 65 percent nitric ac1l. Huey corrosion tests indicated a slenificant improvemont for two heat treatmonts investicated.

Data obtained on other heats and/or lots exposed in the as-welcod condition to process streams, RNF, RAW, RCU, and ROS, Indicate that heat treatment of this materfal does not appear to be warranted. Corrosion rates obtainod were of the order of 0.0002 in./mo. or less.

An investigation of two lots of stainless steel plpe which failed Huey corrosian tests is currentIy underway. This program is simliar to that outlined for the stainless steel plate described above. 
Adaltional corrosion tests have begun on four lots of Type 347 atainless steel tubing whlch are to be applied to the Hot Serl-Works project. These tests will be completed next month.

\section{Speclal Roquesto}

Under the epeclal reques'c proerem, the followlag pleces were processed, tested, and/or inspected:

\section{6 papoose slugs.}

3 receptacle slugs bearing Special Request specimens..

39 test hole pleces.

39 process tube pleces.

Mlscellaneous

The lepth of rolds undor blisters on a number of aluminum cans were measured to determine the extent of the cefects. These blisters appenr when the cans are heated in the cannine operation. The volc's ranced 1.n depth from 0.001 in. to slightly less than 0.006 in. Steel wool was used in an attompt to remove some of the blisters; huwever, reheating caused. nut of the blisters to reappear even though as unch as a 0.002 in. Iaver was relioved from the surface.

During the last two wooks of March, wurk was rosumed on special cannine program for the dupont Company. Principal omplasis las beon placed on canning $3 / 4$ in. $x$ 8 in. urantum sluce. The tendency of this snill diameter materlal. to warp during heatine has prosented groat ubstacles to the completion of tive program.

The surface of these three-quarter Inch lametor rods, fabricated in shaped pesses at hllegheny-Iucliur., iad a mucil poorer surface then Hanford rod fabrlcated at Lockport. There were numerous surfoce wrinkles snd a fow falds, some of them 0.010 in. to $0.015 \mathrm{in.} \mathrm{deep.}$

\section{P-10 PROJECT}

\section{Extraction Operations}

The Glass Iine extraction focliftles were employed curlng the month as follows:

Line 1 - Research and development. Operated by Ertraction Group personnel. To bo operatel by Developiunt Group persimel next month:

Iino 2 - Roprocessing air-contominated product.

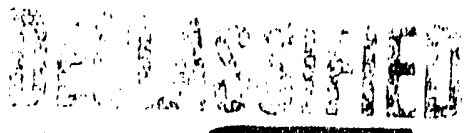


Ins 3 - Construction revis10n. To be operated by Extraction Group personnel next month.

Ins 4 - Research and development: Operated by Ixtraction Group personnol.

IIno 5 - Research and development. Operated by Development Group personnel. To be revised and operated by Process Devolopment Group personnel noxt month.

One glass blower exceeded the worlseng limlt for Internal tritium contamination but did not exceed the meximurn permissible concentration.

Effect1ve Merch 1, 1951, mass apectrometric analyses of product fractions were used to determine purity for accountablilty and record purposes.

A product shipment was made on March 30, 1951.

The scrubbing towex has been by-pessed in the glass Iine furnace ventilation aystem. The ambliat furnace air is now pumped alreotly to the stack.

Metal Iine Developmont

Additional tests of the motal soparation 1 ino and 1ts associated equipment on non-radionctive materlals vero conductod durln; March. A five channel mercury level sensing olroult whs substituted for tho previous single channel, nine clrcult unit. This substitution will pornit moro rapld and eocurate evaluation of process conditions durine a man. Dealin of the conflections for the strippins Ine addendum was frozun to allow fir nocessary fabrlcation vefore tho lino bocomes radioactive. Procuroment datails pertinent to the furnace pots and shlpplne contalners have oryotallized with assurance that a sufficlent number of each w11l be avallable to permit linitod production operation in April. Preliminary testing of mechenical appurtennnces necessary to slue handilng from the 105-B Bullaling, through" decannlne and into a furmace pot attached to tho separation system has indicated the necosalty of moderate redesign to assuro convenelence and normal radiation contml. Consideration hes boen glven to tho possiblilty of on-Iine monltoring of the process by mess or amission spectroscopv:

The results of elght tests are lndicated below:

\begin{tabular}{llll} 
Product Analysis & Ave. o & Max. & M1n. $\%$ \\
\cline { 3 - 4 } Hydrogon & 99.6 & 1.00 .0 & 98.7 \\
Hellum & 0.28 & 0.59 & 0.00 \\
Oxyen & 0.02 & 0.12 & 0.00 \\
N1trogon & 0.12 & 0.63 & 0.02 \\
Other Componor.ts & 0.05 & 0.11 & 0.03 \\
Water & 0.5 & 1.0 & 0.5
\end{tabular}




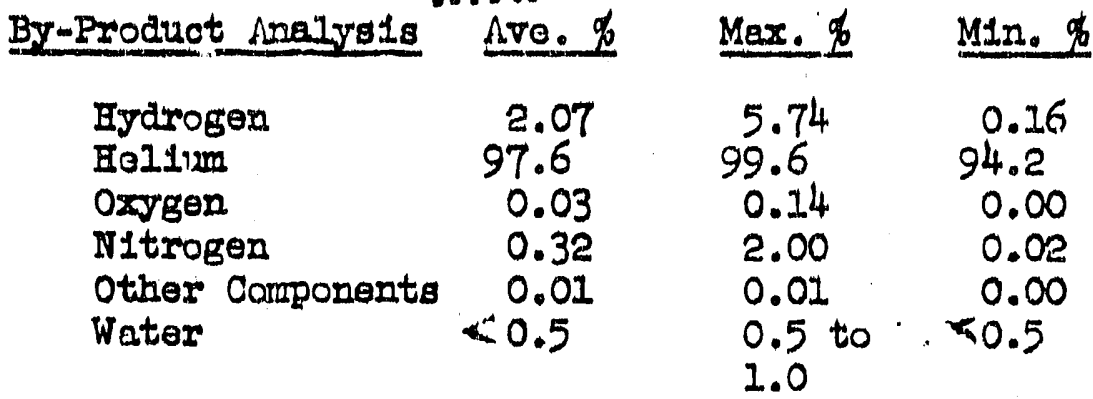

The average alscrepency between $\mathrm{H}_{2}$ charged and $\mathrm{H}_{2}$ In product is 0.130 . The average hydrogen in the by-product by the HIPPD inethod 180.14 porcent.

Inspection of the mexima and minlma leeds to the conclusion that some values are spurious. In genoral, operational explanations have been found for these data. Only two discrepancies are serlous onough to merlt discussion. The hich hydrogen analysis in the by-product is ast considrred to be representative but rather the result of improper mierine prior to sampling. This is borme out by (1) Iow velues $(K 0.5)$ by the HIPPD mothod (2) low values $(<0.5)$ by mass spectrometer when precaution was taken to mix the eas, and (3) high hydrogon mass balances $>100$ porcont whon the hleh aralyses were used. The hlgh values for axygen and nitrogon aro attributed to Improper outgassing of the semple bulbs and thoir connocting pipo.

Profoct Construction nctivity

Conotruction activitios continuel on projects P-10-C, P-10-D, and P-10-D, Part II.

The Scope of Project C-412, P-10-Z, wes presented on March 23, 1951, by memorandum; Subject: Desifn Criteria, T. $\Lambda$. Buwmen and J. C. Chatten.

Development Glass IIne

Metal plinch-off samples were taken of by-product eqses from a hifh exposure slug and were turned over to the P-11 Reactor Group for Ho3 cross-soction testing.

A. muptured $\Lambda I-I 1$ slug from II $\Lambda r e a, 370-39$, was cut Into threo pleces; wo1ghed; and the piecos extracted indivilunily. The two NI-II slugs adjacent to the ruptured slug were decenner, wo filled, and oxtrocted to socure ylold cata for comparison with that obtalrud from the rupturod sluk. No olenificant difference In yield was obtained indicatine that product losses wore incurred onlJ where the metal was acturly consumed in the fornation of corrosion products, said corrosion products belng romoved in plckline solutions prior to extraction.

A slug from a polson trube in D. frea, 79-30, and an $1-10$ plece, 172-12, were cut up similarly to the rupturad slue and extracted to detormine if there were any 


\section{PIlo Technology Divialón

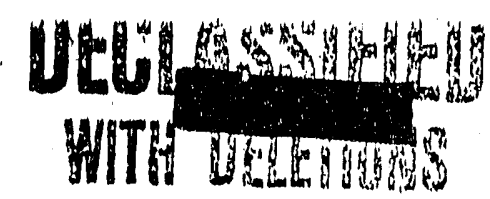

s1gatploant geseious distributional effecte in the slugs. The y1elds did show varlation but these varlations cannot be consldered sleniflcant unt1l conflrming runs are mado.

An extensive testing program of step-wise extractions is proceedirg using single slugs. Of particular 1nterest was the extraction of a canned alub in which no alloying of the 25 aluminum can was attempted. The major portion of the product was extracted without plexcing the can. Surprisingly, the quantity of outgas obtalnod from an unoleaned, canned slug wes very small. Several cublc centlmeters of water was obtalned in the outgas but activity Indicating HTO or $\mathrm{T}_{2} \mathrm{O}$, was Low.

Production Tests

Hydrogen Diffus Ion throuch Stalnless Steel Furnace Thbos: Further tests have been mado to determino hydrocen if fuelan. ratos throuch stalnless stoel furnace tubes. A measured amount of hydrogen was addod to a hoatod funnace tube and withdrawn linto a callurated volumo after a clven time intorval. The hydrogen 
$-$

pressure in the tube we monitored throughout the oycle. In the tests performed the solublilty effoct wes the same ordor of magnitiude as the diffusion effeot. The prosence of AI-II approximately doubjos the over-all 1osses.

An attempt wes made to resolve the hydrogen solublilty offect by allowlng hydrogen to enter a heated furnace tuhe where it remained in contact with the tube while the tube cooled. At the ond of the coollne perlod, the hydrogen wes pumped out and meesured. Be-evolut1on of" tho alssolvod bydrogen was then attcmptod by hoat 1ng the tube to $800^{\circ} \mathrm{O}$. Th1s test wes ropeated with a furraco tube contalating ore loed slur; with a fumace tube containing one lead slust and one Al-Ii slue; and with a furnace tube contalning only a single fl-If slufs. The tube containing lead alono showed a very low loss and a high recovory as compared to the other throe tubes. However, the losaes in the tube contalning load and $\Lambda I-I L$ were greater than those mesured in the tube containing only the Al-II slug.

\section{Narnesium Gottering}

$\Lambda$ stalnless steel furnace tube hes been modifled for use with magnesium in tho water decomposition studiso. Prelimingry mas have been made using this furnace tube and a rebullt vacuum ine $t$, determine the extont of leakage and alffusion rates, mapnosium vaporization, and gonoral operation of the system. operation of the furnace at $500^{\circ} \mathrm{C}$ has sliuwn sume vaporlzation and subsequent condensation of magnesium vapor in the coolur rectons of the furnece tubu, but no dusting of the moenosilum or transfor of dust to the glass vacuum systom have boen encountered. Unlike uranium, magnosium does not prosent the problom of tritium holdup on any particles transforred to the cooler portions of the cystem.

\section{Miscellansous Act171tios}

Motal Ion chambers for product analysos on the metal Ine inve heen callbrated with high purity tritiun an analyzed by the buovancy balance. By-product metal Ion chambers are also beins callbrated in a similar manner.

The revisions of gliss IIne "i 3 , the fourth Iine to be revised, to incorporate metal pots, bellows, by,-puss checks, etc., have boen completed and the lino is undergolng f'inal accoptance tosta.

The calibration of a Kanne charaber 1 s now underway after expenditure of considerable effort to:asanre a ras-tight system, a necessity in this instance as the Kanne chamber and associated pumps are not located withiln a hood.

Production assistance type of whele is urderway in rofiard to tho motal ine. At the present time this includes extended data analyses, shippinc container outcessins, provisions for on-l.ine sampline; and furnace chargine and discharging.

\section{INVHANTIONS}

All Plle Technology Diviaicn pere nnel oncagod in work that micht reasonebly be expeoted to result in invontions or aiscovories advise that, to the best

of their lenowledee and belicm, no invontions or discoveries woro mede in the 
course of thelr work during the perlod cuvered by this report, except as Ilsted below. Such person further edv1se that, for the perfod therein covered by this report, notebook records, if any, kept in the course of their work have been examined for possible Inventions or discovertes.

Inventor

J. V. MaMaster

H. A. Johnson

W. A. Clark
Title

Roller-Crimpling Aluninum Contalners

Mercury - Contact Storage Element

Six Blnary - Diglt Storage Register

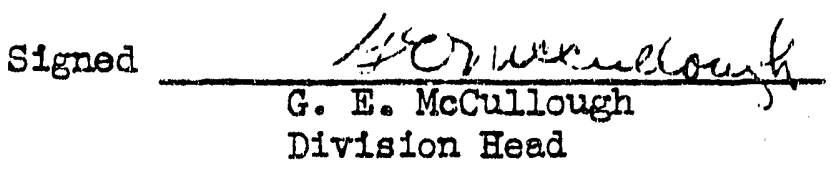

GEMCC : jr 


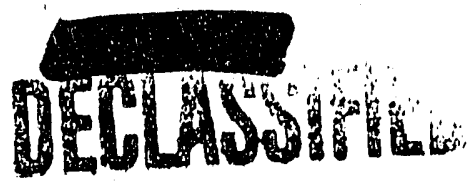

Apr11 10, 1951

SEPARATIONS TECENOLCGY DIVISION

MONTEIY REPQRT

MARCH, 1951

\section{VISITORS AND BUSINESS TRIPS}

H. CrandeIl, of the Califorala Research \& Development Company, visited Hanford on March 9 for consultations regarding separations process design and operation.

G. W. Watt, Consultant from the Unlversity of Texas, visited this site from Merch 12-17 for research and development consultations.

B. $\nabla$. Coplan and R. C. Feber of KAPL Visived here for discussions of separations process 1mprovements, Coplan from March 26 through 29 and Feber from March 26 through 28.

C. Groot and B. Weldenbaum visited the Ios Alamos Sclentific Laboratory for 234-5 consultations, Groot on March 5 and 6 and Weldenbaum from Merch 5 through7.

R. B. Richards and F. W. Woodfield attended the A.I.Ch.E. Meeting at White Sulpher Springs, W.Va., from March 12 throligh 14.

ORGANIZATION AND PERIONNEI

Personnel totals are as follows: February Merch

Administretion Specir. Assignment

Research Section

Developmont Section

Process Section

\begin{tabular}{rr}
2 & 2 \\
2 & 2 \\
36 & 34 \\
73 & 75 \\
31 & 31 \\
\hline 144 & 144
\end{tabular}

Research Sect1on: One Chemist was granted a leeve of cbsence and one Toch. Grad. was tronsferred to the "S" Division.

Development Soction: One Chemlcal Englneer and ono Expeditor wore torminated. One Steno-Typ1st B retumed from $\varepsilon$ lea.ve of absence, one Stono-Typist $C$ was transforrod from the Stores Division, and one Steno-Typist ${ }^{3}$ and o Draftsmon II woro added as new hires.

Process Section: One Motallurgival Englnocr was terminated and ono was transferred to the P1le Techrology Division. One Tech. Grad. wns transforred from the Technical Sorvices Division and a Technologist $C$ was ndded as a now hire. 


\section{AREAS PLANT ASSISTANCE}

\section{Canyon Bulldings}

The starting solution nind accuralated total waste analyses, as determined by redioessays, are now being corrected for the alpho counts of amerlcium and curlum beginning with the first mun of March, 1951. Th1s correction w111 lower reported waste losses by 1.5 to $2 \%$ at the $420 \mathrm{MWD} /$ ton level, wh1le production capacity and reported jleld will be Increased by a similar cmount. The use of a radioassay of the final Isolation Bullalng solution, AT, for plant meterial balance purposes whs initiated with the same run. It is expected that this will result in more nearly correct material balances, since there have been indicotions that the factors for converting radio analyses to product weight are in error. It is ant1clpcted that new plutonlum 1sotope correction factors w1Il be aveilable for use on the first run started in April. The use of these revised 1sotope correction factors should increcse production capecity by epproximately 2 to $3 \%$.

Kuns processed under Production Test 221-B-10 at B Plant here shown no significont shrnge in waste losses or decontamination with process volumes reduced by $30 \%$. The frequency of incompletely dissolved first cycle product solutions was greatly increased, however. Test runs are belng mode with first cycle volumes reduced by $30 \%$ but with sufflclent acld used for the first cycle product solution to result in $20 \%$ reduction of process volumes through the second cycle and the Ccacentration Bullding.

One additional test of air sparging during metal dissolution to remove iodine from metal solution wes made at B Plant under Froduction Test 223-B-9. An lodine removel efflclency of $90 \%$ wes indiccted. An carlier test, under grood control, resulted in an efficlency of $40 \%$. Additional tests are plonned.

\section{Concontretion Bullaings}

Product solutions contelning phosphoric acla wero rotumod to process after use by the P-II Profect. Recovery wos cecomplished without incldent by ro-processing the material sterting with the lonthonum fluoride by-product precipitation.

Recycling of the metcthosis wash offluent following contrifugetion appears to have lowerod the product hold-up in the metathesis cell at B Plant. Further tosting is in progress e.t both $B$ and $T$ Plonts.

\section{Isolation Bullaling}

Product rotumed from the P-II Project containing blsmuth, was processed without incidont.

Lonches of the filtors used to filtor the solutions recelvod from the Concontmtion Bulldings indicetod abnormaliy largo cccumulations of produst; approximetuly $150 \%, 80 \%$, and $115 \%$ of $c$ stindard run were rocovered from cells 2,3 , cnd 4 , rospectively. Locchos modo cpproximntoly two weoks lotor in Cells 2 and 3 and ono week later in Coll 4 rocovered $70 \%$, 50\%, and 30\%, respectively. The nature and couse of the proluct hold-up heve not been detormined. Frequent leoches oro boing mede on a routino besis unt1] tho situr.tion hes boon corroctod. 
Approximately $24 \mathrm{mliligrams}$ of americlum were recovered in the supernatant solutions from specle. americlum recovery runs carrled out by third-cycle peroxide preclpltations of aged product in three sample cans. No difficulties were encountered.

The use of $50 \%$ hydrogen peroxide was inftiated for a test perlod of approximately two months.

\section{Furification and Fabrication Bullding}

Production Test 234-1 (Removal of Iodides and Oxalates from Oxalate Supernates) hos been discontinued tempornrily. A maximum of four supernatant batches can be concentrated in one operation. Th1s maximum is established by the volume of coustic whlch can be bandled in the scrubber system. A separate report is being prepared on this test.

An Aloxite filter which was deslgned and tested by the Plant Assistance Group wos Installed in Hood 5 (Purlfication) during the month. Supermatant solutions were drnw directly from the recctor to the fliter to the supermatant hold tank in Hood 5. Product losses in the supernates averages 0.0346 grams per kllogram In supernates which were filterod, compared to 0.060 gram per k1logram for supermates filtered through the filter paper assemblies.

Conversions in Dry Chemlstry during the month of March avernged $96.4 \%$.

Production Test 234-4 (I1rect Fluorination of Oxclate Frecipltates) wcs completes, dcta accumulated, and the report started during the month of March. The results of the test have been discussed with the members of the "S" Division with recomenartions that the process be adopted as a standard operating procedure for one month, at whlch time a discussion will be held concerning its continuance.

Hood 10 (Reduction) reductions for the month of March avoragod $98.4 \%$. The addition of Chemicel 70-58 nt the Roduction step was discontinued during March. The lenthonum content of buttons incrensed when the 70-58 was filrst added in the Reduction stop. Thls incroaso was within tolernce but the continued recycling of tumings to the operction augmented this incroese in lonthanum content of buttons and, consequontly, costings to the point where some castings in March contalnod as high as $10,000 \mathrm{ppm}$. Ianthonum. The lanthnnum content in severn I buttons made without 70-58 addition in Reduction near the end of March was from 20 to $40 \mathrm{ppm}$. Which $1 \mathrm{~s}$ compcrable to the button purity experlenced prior to tho above-montionod process chonge.

The avernge $c / q$ sumetion for custings produced during the month of February whs 0.52 .

Now dies which hn:to been usod during the month of Merch have produced pleces of the desired dimensions. Somo units were mede during the month of Merch on which no hand-cleaning wes ccrrled out, and the piocos matched satisfactorliy. Most piecos, however, roquirod slight hnnd-work to remove the ridge produced by the knock-out punch. It is believod that this ridge can be controlled to a depth of a fow ten-thousands of cn inch, so that hand-cleaning would not be necessary on the plutonium units and that the ridge con then be romoved from tho coatod units. Fast exporience indicates that any imperfoction such as o ridge on the bese metal is reproducod quite accurately on the conted surfece. 
REDOX AND METAI WASTIE RECOVHFY DEVALOPMENTI

\section{Technical Manuals}

The writlng of the Redox Technical Manual was continued. On March 25, the preparation of this manual was about $69 \%$ complete. The following five additional chapters were completed during the month, bringing the total number of chapters completed to date (except for reproduction) to fleteen:

\section{Englneering Flow Dlagrams \\ XIV. Solvent-Extraction Colums \\ XVII. Pumps and Jets \\ XXII. Shlelding \\ XXIII. Decontamination of Surfaces}

Reproduction of some of the completed chepters was initiated. A smoll emount of effort was expended or the preparation of the Uranfum Recovery TechnicnI Manuel. On March 25, the preparation of this manual was about 16\% complete.

\section{Redox Solvent Extrection Studies}

The studies in the Demonstretion Unit were devoted exclusively to Redox training of " $g$ " Division personnel during the past month and no new solvent extrection data were obtained. Flans are underwcy to resume study of the $\mathrm{MnO}_{2}$ feed sccvenging step under improved conditions of centrifugation.

\section{TBF Solvent Extraction Studies}

During the report period, 54 Furex IA, IB, and IC pulse colum runs were carried out in the 5-in. and 8-1n. diameter pulse columns.

Tho 5-in. diameter IA extraction section (I2 $\mathrm{fi}$. "pccked" helght) opercted satisfactorlly over a range of 500 to $2400 \mathrm{gal} . /$ (hr.) (sq.ft.) with waste losses in c.1I cases below $0.1 \%$ and optimum H.T.U. va.lues of approximately 1 ft.

The some 5-1n. colum opernted os a simple IB scrub section ot volume velocities of 500 to $2100 \mathrm{gal} . /(\mathrm{hr}$.$) (sq.ft.) rosulted in a minimum waste loss nt optimum$ conditions ( $1440 \mathrm{gal} . /(\mathrm{hr}$.$) (sq.ft.)) of 0.007 \%$ of IAF feed urcnium and a $1.2 \mathrm{ft}$. H.T.U. This corresponds to an uranium content of the plutonium of cbout $16 \%$.

Intt1al poor performance of the 8.5-ft. high, 8-in. IC Colum (3 to $10 \%$ waste losses, H.T.U.'s 1.6 to $3.0 \mathrm{ft}$.) hos beon markedly Improved to avernge losses of 1\% or less by Dri-filming tho pierced plete cortridge and operating by disparsing the equeous rathor then tho organic phase. The Dri-filmed "standard cartridge" (0.125-1n. holos, 2-1n. ploto specing, 23\% open aroc) wcs opernted over a range from 340 to $740 \mathrm{gr.l} . /$ (hr.) (sq.ft.) with minimum wasto losses of loss than $0.5 \%$ and optimum H.T.U. values of lass then $1.1 \mathrm{ft}$. obtrined in the rnnge of 350 to $450 \mathrm{gnl}$./(hr.)(sq.ft.). Since the crpncity of this cartridge is limited ct $800 \mathrm{gal.} /(\mathrm{hr}$.$) (sq.ft.), furthor studies woro made using Dri-filmod pierced$ 
plates with 3/16-in. dinmetor holos, 23\% free area, and a 4-1n. plate spacing. This cartrldge was oporated over a range from 450 to $1500 \mathrm{gal}$./(hr.) (sq.ft.) with a minlmum waste loss of $1.3 \%$ at 1200 volumo volooity, and an optimum H.T.U. of 1.4 ft.

321 Bu1lding Construction and Malntonance

Revisions to the B-2 Centrifuge feed systom woro completed during tho month. These revisions consisted of installation of a self-priming contrifugal pump to roplece tho fomor jet and installation of a constant-level head tank and rocording rotameter control system to permit accurate motoring nt low flow ratos.

The 8-in. IC pulsi colum was revised to permit operation with interface at the bottom of the column by relocating the interface dip tubes at the bottom of the colum and Installing a gauge glass for visual location of the Interface at the bottom. The column wes coeted with Dri-film to prevent the aqueous phase from wetting the colum, plates, and spacers.

\section{Bullalng Operations}

Tho Demonstration Unlt operated uneventfully throughout the month on Redox trainIne muns. No major maintenance was required and operation on the Redox flowsheot was in 0.11 respects satisfactiory. No attempt was made to simulate MnO scavenging, pending revisions to the B-2 Centrifuge foed systom.

The Scale-Up unlt operated on a wide variety of runs designed to pormit atudy of the Purex flowsheet in conjunction with TBP training. The columns were opercted both singly and in cascade. Most muns were made on the IA-IC cascade although several IB-IC cascade runs ond single-column runs were also mede.

The first contingent of "S" DIV1sion trainees (20 supervisors, 28 operators) completed 1ts six-weeks training assignment on March 31. A.I trajness had rotated twice through each job on both Redox and TBP columns, and, during the last two woeks of the month, operation of the Demonstration Unit on Redox operation wes turnod over to the trelnees almost entirely. Throughout this period, oonsid-erable time was devoted to shutting down and starting up the columns to glve the trainees experience in this phase of the operation.

\section{Equipmont Developmont}

Submerged Pump No. 2 completed 14 days of steady and unevontful oporation at $3450 \mathrm{rev} . / \mathrm{min}$, circulating simulated Rodox dissolver solution contcining $7 \mathrm{~g} . / 1$. of $\mathrm{MnO}_{2}$ at a discharge rate of 2.0 gnI./min. agrinst a $20 \mathrm{lb} . / \mathrm{sq} .1 \mathrm{n} . \mathrm{ga}$. pressure. The program was deslgned to test flooded oporation (no prossure ports or bearing grooves) of $n$ Stelifto No. 6 joumal and boron carbide bushing for ag. plicntion to a Hot Semiworks pump.

Peorloss 4"-IA, a four-stago decpwoll turbine pump with Grophitar No. 2 bushm Ings, complotod 73 diys of unevontful oporation at $1750 \mathrm{rov} . / \mathrm{min}$., clroulating neutralizod ond concentred $\mathrm{RAW}$ solution ot $82 \pm 2^{\circ} \mathrm{C}$. nt a dischnrgo mte of $45 \mathrm{gal} . / \mathrm{min}$. against a $15 \mathrm{ft}$. hecd.

A.t the conclusion of this period, the cloarence botwoen the shaft and the becring increcsod from $4 \mathrm{mils}$ to about $8 \mathrm{mils}$ for oach of tho six shaft boarlngs. 
Mhls woer will bo studlod furthor in Johnston Purp Co. production units.

Trgon Ilnor Materlal, for $\mathrm{Al}\left(\mathrm{NO}_{3}\right)_{3}$ solution bulk storcgo torks, was tostod by Immorsion in $\mathrm{T}_{2} \% \mathrm{AI}\left(\mathrm{NO}_{3}\right)_{3} \cdot 9 \mathrm{H}_{2} \mathrm{O}$ contcining $0.3 \% \mathrm{ENO}_{3}$ at $105^{\circ} \%$. for 34 days. The physical appoarsnoo was satisfuctory and the scmple showed a wolght galn of $0.43 \%$.

\section{Frocess Chemistry}

A study of tho propertles of noutrallzed and concentratod RAW, extending tho scopo of Information proviously reported in Document EW-18404 for the purpose of corrolnting $\mathrm{pH}$, bolling polnt, and froezing point to the dogreo of concontretion, has beon partic.lly comploted. It hes beon demonstrated that the $\mathrm{pH}$ of the concontrate and the dist1ilate w1II be within the range 11.5 to 13 aftor conoentram tion to 40,50 , or 60 per cent of the origlnal neutrallzed waste rolumo por flowshoot TBF-HW No. 4 .

The cssembly of the "Min1" counter-current mixer sottler hes boen delayod due to the unara1lab1lity of necossary parts. The design of tho batch countermcurront cxtractor has boon completed. Shop drawings aro boing prepcred. Fabrication of the other 1toms of spocic. equipmont for the 222-5 Bu1lding is continuing in tho 101 Shops.

\section{Hot Somi works}

Excovation for tho Hot Frocess Bullding, 201 C, was started on Merch 15 and 18 approximately in por cent complote. Preliminary schodulos indicato that tho first concrete pour w1Il bo mado on pril 23. Th1s w1Il bo tho baso pad. The Hot Somiworks oporating manual is approxlmetoly $48 \%$ completo.

\section{SEPARATIONS PROCESS RESEAFICH}

\section{Decontaminetion of Agod First Cyclo Supomntcints}

A briof survoy of tho removnl of rodoactivitios from cgod first cyclo supornatant: by a numbor of scovonging cgonts has been mado. Goneral conclustons which may bo drown from those oxporiments aro os follows:

1. Colcium oxelato is $n$ vory officiont agont for the removel of plutonium cnd corlum and moderatoly good for the othor rore ecrths and strontium. Hocting the solution as well as increcsing the $\mathrm{pH}$ c.ppocis to improve the strontium corrying.

2. Fuller's onrth and Attcoloy cro very offlclont carriors for plutonlum, strontiun and raro ecrthe and fair for cosium, providod tho slurry is hoated during stirring.

3. Potassium alum is c very efficiont scavonging cgont for cesium but would bo oxponsive duo to its reletivoly high solubility.

4. Forrlc hyänxido shows modoreto corrylng efficiency for plutonium and corium. but poor for strontium and cosium. Tannio acid is somewhat bottor than 
Sepnrations Technology DIvision

Iron for plutonlum, strontlum and cerlum but equally poor for ceslum.

5. Calolum phosphate $1 \mathrm{~s}$ very efflclent as c plutonium and cerlum carrier, moderate for strontium and poor for cestum, provided the calclum $1 \mathrm{~s}$ added at low $\mathrm{pH}$ (ca. O) with suhseriuent Increase in pH to rbout 12.

6. Ferrous and ferrle ferrocyanlde, particularly the former, show conslderable promise for carrying most of the oritical activities present in first cycle supernatan's. When the preclpitation is carrled out at a pH of 6 , carrying of plutonluin, corfum and ceslum 18 very good and strontium moderate.

In the above statements, very, moderate, falr and poor refer to D.F. values of greater than 100, 10-100, 2-10 and less than two, respect1voly.

Centrifugation Characteristics of $\mathrm{MnO}_{2}$

Pixperiments to determine the centrifugation characteristics of $\mathrm{MnO}$ here been Performed in a 5-1n. solld bowI centrifuge (no baffle plates) operating at 1730XG. In this apparatus (using gravity foed control) a contrifuge hold-up timo of 20 minuties did not produce cloar effluent streams; howevor, effluent streams obtalned using a hold-up time of ca. one hour wore quite satisfactory. Some difficulty wcs encountered in control of the low foed rate.

A serles of scouting runs has beon made in a clinical centrifugo using $\mathrm{MnO}_{2}-$ Filtrol and $\mathrm{MnO}_{2}$-alumine mixtures to determine the feasiblilty of improving the sottilng cheracteristios of $\mathrm{MnO}_{2}$. Of the two mixtures, the MnO2-elumina combinetion produced the botter solut1 in olaritiog and a sulstantial improvement over that produced by $\mathrm{MnO}_{2}$ elone. Settling characteristics (under one $G$ ) of $\mathrm{MnO}_{2}$ in the presence of zirconlum phosphate geve good supormetant cleritios and an appreclable reduction in the $\mathrm{MnO}$ cake rolumo. Tho presence of elumine or similar cormounds may allow rapld contrifugation of tho $\mathrm{MnO}_{2}$ produced in headend operations.

\section{Effect of Sulfete on Rodox IIA Colurm Operation}

Provious results of exporiments porformed to study the roplacomont of ferrous sulfamate in the IBX stroam by forrous amonium sulfeto and sulfemic acid soomod to be orratic and, thoreforo, obscurod finel intorprotation of tho data. In en offort to dotermine the cause of the orretic deta, plutonium distribution coefficionts were moesured as a functior of tino. Theee exporimonts showed that a vory rnpld incroose in extrcction coefficiont occurs during tho first thirty minutes of contecting. At tho ond of ono hour it cppenred as though oquilibrium wis nearly molntalnod. Two exporiments, ore in tho prosonce of forrous sulfamete and the othor in the presence of ferrous amoniurn sulfato and sulfomic acid, por.formod as a function of timo, showod no sulfnto offect as tho date from both exporlmonts were virtually the same. Tho repld incrense in the value of tho oxtraction coofficionts must be due to the oxidetion of $\mathrm{Pu}(\mathrm{IV})$ to $\mathrm{Pu}(\mathrm{VI})$. This conclusion is in alscgroomont with datc obtalned in tho prst by other workers, and furthor studios, thoroforo, are being mado to establish tho recson(s) for this conflict. 


\section{Concentiration of Redox IIBF Solutions}

Current laboretory results on the evaporation of an ANI-IIBI solution (1.14 g $\mathrm{Pu} / \mathrm{I}$ ) splked with $0.002 \mathrm{MAI}\left(\mathrm{NO}_{3}\right)_{3}$ show that th1s materlal can be evaporated by a fector of ca. $300 . .101 d^{-}$(to ce. $300 \mathrm{~g}$ Fu/I). The concentrate muat be diluted whth water or diluto nitric acld before cooling since solidiflcation takes place upon cooling to room temporeture. Ilxperiments are currently belng performed to establish a relationship between the plutonium, oluminum and attric ac1d concentrations durling the evaporation procedure.

\section{Recycle of Plutonium Feroxide Suriernatanta Solutions to Redox}

Tentatirely; laboratory experiments show that it is chomlcally feastblo to recyolo plutonlum peroxide supernetant solutions from the 231 Bulialing to the Redox plant (IIA Column). Synthet10 peroxido supermatants, after belng subjocted to peroxide k1II-off with heot, and thon diluted 1:10 with IIAFs solution, wero contacted with hexone $\left(0.5 \mathrm{M} \mathrm{ENO}_{3}\right)$. Plutonlum distribution coefflelents were found to have a value of about 7 to 8. Although plutonium distribution coefficionts in tho absence of recycle meterlal were somewhat higher (cr. 10), those data would lndi-' cate that the heat-killed peroxide supernatants might be roturnod to Redox fior recycle, other considerations permitting.

\section{Rodox Coupling Studios - Plutonlum Trlfluorlde}

Preclpitations of PuF from slmuleted Rodox IIBP solution, carrled out with AT matorial diluted to $40 \mathrm{~g} \mathrm{Pu} / 1,1.25 \mathrm{M}$ Erro 3 , ca. $0.002 \mathrm{M} \mathrm{Fot+t,} \mathrm{and} \mathrm{containing}$ $0.08 \mathrm{M} \mathrm{Al}+3$, have ylolded the forlowing addition 21 information:

1. Freclpitatos formed in the presonce of aluminum at room tomporature with $2 M E F$ settlo slowly and havo e rolativoly low bulk donsity. This is fresumbly cnused by tho Erosence of tho riluminum, sincs procipitates of Laf' 3 formed in the presence of aluminum have shown the same effect; $1.0 .$, set tie very slowly and heve a bulk density two to throe times as great as lanthanum fluorlde procipitetes prepered in the absence of aluminum.

2. A spectrochemical analysis of PuF precipitated at $70^{\circ} \mathrm{C}$, washed, and filtered in s sintered glass funnel showed that tho aluminum separation was poor $(2000 \mathrm{ppm})$. Whether this quantity of aluminum would be found in plutonium metal produced with oluminum contaminsted PuF' 3 romins to be invostigated.

3. Flutonlum (III) fluoride peptizes severly upon washing two or threo tiries with distilied wator. Use of a $2 \mathrm{M} B F-1 \mathrm{M} \mathrm{HNO}_{3}$ wash solution minimizes the peptization.

4. Flutonlurn(III) fluorldes washed with $2 \mathrm{M} \mathrm{HF-1} \mathrm{M} \mathrm{ENO}_{3}$ to remove the excess reducing agent ( $\mathrm{NH}_{3} \mathrm{OH}^{+}$) appear to bo oxIdized to PuH 4 upon heating. The Iuff 4 thus formod had a remerkably high bulk density (ca. $1 \mathrm{~g} / \mathrm{cc}$ ) and modorc. tely low solublilty $(0.5$ to $0.7 \mathrm{~g} . \mathrm{Pu} / \mathrm{l})$. Furthermore, tho conversion of $\mathrm{FuF}_{3}$ to FuF 4 by this procedure is nccompanied by a decreaso in the e.Iuminum contamination ( $2000 \mathrm{ppm}$ in PuF' 3 to $200 \mathrm{ppm}$ in PUF 4 ). This $\mathrm{FuF}_{4}$ wes dried to essontinlly constont wetght $n t 125^{\circ}$ to $220^{\circ} \mathrm{C}$. and subsequont conversion 
nt elovated temporaturoe to tho dloxide grvo $n$ welght chango whlol auggostod that tho driod FuF 4 preclpltate contalned ca. $20 \%$ Puare.

\section{Rodox Coupling Studios - Plutonlum (III) Sulfoto}

Flutonlum(III) sulfetso may bo proalpltatod by tho addition of excess sulfate to $c$ plutonlum(III) solution. Tho solid formed lo vory cry'stalifino and sottles quito rapldiy. A fow laboratory oxporiments cre being undortakon to investigate tho foosiblilty of using this preclpitato for Redox 234-5 coupling purposos. Modo of proclpitation, solid purlty and hydrofluorination experimonts wlil bo studiod.

\section{Recovory of Plutonium Irom 234-5 Slag and Cmuclule Wrstos}

A socond orrutble and sing has boon lonohod with $\mathrm{HNO}_{3}$ to recovor plutontum. LocohIng fallod ogain, due to plutonlum rotontion in the solids cnd ilitration difflcultios. Tho matoricl was locchod in six fractions resulting in dissolution of all solublo matorial and oach frnotion contelnod sizablo quantitios of tho plutionlun.

Solvont oxtraction of part of the loochings was effootod froma solution contalning $2.7 \mathrm{M} \mathrm{Cn}\left(\mathrm{NO}_{3}\right)_{2}$ and $0.6 \mathrm{M} \mathrm{HNO}_{3}$ Into $30 \% \mathrm{TBP}-\mathrm{AMSCO}$. Threo successiro contactings with $1 / 10$ volumos (orgeñ10 to cquoous) woro ermployed. Flutraction doefficionts of 37, 33 and 12 woro obtalned, looving about $3 \%$ of the plutonium unaxtractod. Thoso figures aro poorer than thoso obtainod from $2.7 \mathrm{M} \mathrm{Ca}\left(\mathrm{NO}_{3}\right) 2,1.2 \mathrm{M}_{2} \mathrm{HNO}_{3}$, suggosting that thoro is a strong $\mathrm{ENO}_{3}$ dopondenco.

Conversion of sillce in leaching solution to a fliterablo form ky heating in the presence of $5 \mathrm{M} \mathrm{FilO}_{3}$ and $0.35 \mathrm{MAI}\left(\mathrm{NO}_{3}\right)_{3}$ at $90^{\circ} \mathrm{C}$. was demonstrated. After filtering at $80^{\circ} \mathrm{C}$. and cooline, these solutlons can be extracted with $30 \%$ ITB-AMSCO without giving emulsions. Four successive 1/10 volume (organic to aqueous) extractions were performed and coefflolents of $36,35,27$ and 39 were obtalned leaving about $1 \%$ of the plutonium unextrected.

Stripping of plutonlum from the organio TBP solution can be done with hydroxylamine sulfate solution; three sliccessive $1 / 10$ volume contactings (aqueous to organic) removed $99.8 \%$ of the activity. This result is considerably better than any attained with hydroxylamine hydrochloride. The distribution coeffictents were $0.023,0.0080$ and 0.0054 .

\section{P-11 Ass 1otance Work}

The feesiblilty of returning lithium-polsoned plutonlum solutions (used in critiva?. mass studies) to the 231 Bullding for product isolation and purification has been investigated. Using slmulated 231, operetions, lithium is separated quantitatively from plutonium. The lithium content of the final dissolved plutionium peroxide cake conteined only 0.5 perts per mililion of plutonlum metel, wherees the maximum lithlum content that could be tolercted in motalilic plutonium is of the order of 100 parts per million. The product losses during the simulated 231 operations were ali nermal.

Extrection By M1xod A.krr Phosphrte Esters

The uranium extraction behavior of dethyllsobutyl phosphate (DEBF) and di-nbutylethyl phosphate (DBEP) was compered to that for TBF, because of more 
Separations Technology D171810n

SPCTris

IW-20671. Del

favorable physteal properties such as lower v1scosity and lower molocular wolght found in the mixed esters.

DBWP was synthesizec by reacting dibutylchloro phosphate with an excess of anhyw drous ethyl a.lcohol in the presence of pyridine at $15^{\circ} \mathrm{C}$. IDEP was prepared - simliarly froin dietizlohtoro phosphato.

Phys1cal proyert1es of DFBF and DBEP compared whth THP g1ve a 25/4 of 1.0209 , 0.9984 and 0.9730 respectively; a v1scosity at $25^{\circ} \mathrm{C}$ of $18.9,25.5$ and 33.2 m1IIIpolses, respectively; a B.P. at 2-4 mo Hg of 82-87, 95-101 and 127 C., respectively; and a solublility in water at $24^{\circ} \mathrm{C}$. of $14,3.4$ and $0.4 \mathrm{~g} / \mathrm{I}$, respootively,

The extraction behavior of uranyl nitrate was measured in a $0.5 \mathrm{M}$ solution of these phosphedies in carbon tetrechlorlde. A reasonably constant complexing constant, $\mathbb{K}$, wes observed by essuming the same extreotlon mechanlsm as found for TBP, where tho transferring speoles $\mathrm{Is} \mathrm{UO}_{2}\left(\mathrm{NO}_{3}\right)_{2} \cdot 2$ TBF. In pact the $\mathrm{K}$ values for DEHP and DWEF were nearly the same as observed for TRE in carbon tetrechlorlde. Thus, the uranium capectty of any of those solvents is primarily dependent on their molecular welght elnce thelr densities are precticeliy the same. The relative uranium consentretion for the same per cent saturetion of IBP, DHEP and DIHP becomes $1.8,2.1$ and 2.6 , respectively, showling a decldediy increasing rolumetrlc efflclency with a derease in molecular wolght.

Further criterle for a good solvent with respect to oolum behavlor are a low $\nabla 18 \cos 1$ ty and a low coefflolent of $\nabla 1$ cosity with increasing uranium concentration. Both of the new solvents have an apprealably lower viscosity than llBP; the Incroase In Viscosity with uranium concentration ls nearly the same as for the TBP system.

Striblilty of TBP at $105^{\circ} \mathrm{C}$.

The heterogeneous hydrolysis of TBP to POH in the presence of three and aix molicix nitric acld was measured at $105^{\circ} \mathrm{C}$. (B.P.) at two phase ratios of aqueous to organic. The reaction rate constant in tho aquoous phase is 600 times that in the organic phese. However, the solub1lity of TBF in $3 \mathrm{M} \mathrm{HNO}_{3}$ at $105^{\circ} \mathrm{C}$. Is only $0.4 \mathrm{~g} / \mathrm{I}$ and nltric acla distributes slightiy in favor of the organic phaso. Both of these propertios are such that in an equal volume misture of equeous and orgunic the docomposition of THF proceods largely in tho organia phase.

Tho temporature coofflclent was calculatod from the provlously reported rate at $76^{\circ} \mathrm{C}$. and tho now $105^{\circ} \mathrm{C}$. rate and found to be $1.77 / 10^{\circ} \mathrm{C}$. riso in tomporaturo. Tho ocleulatod $\mathrm{E}$ of roection $1 \mathrm{~s} 15,500 \mathrm{cal} / \mathrm{mole}$ TBF, comperodt to 11,000 for the moro roadliy hydroljzod monobutyl phosphorlo acld. By extrepolating tho rate data to $25^{\circ} \mathrm{C}$. the 10 If 1 ifo of tho first order ronction $1 \mathrm{~s} 180$ and 0.3 yours for organio and a moniss rnnctions, rospoctivoly. Since tho organic phaso roaction is of primnry importanco in tho storcgo of oxtratant, 1ts stability is vory setisfuctory.

Tho rato of docomposition of TEP was found to incrocso diroctly with incroasinc nitric acla concontrition. 


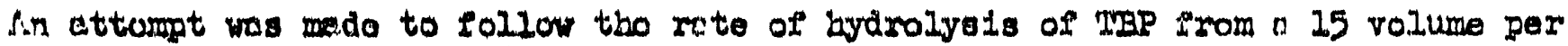

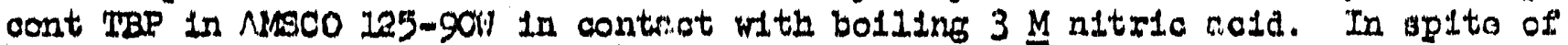
tho low aromitic and alefin conteat of thls diluent, altration was readily apperent and the nftrito actd consumed. Aftor a1x days the organlo phese was 0.9 grems-atoms/I1ter in bound inltrogen and nearly free of $\mathrm{HrO}_{3}$. About one-half of the Inftial nitric acid had dsappeared out of the reflux condenser as oxides of: nitrogen.

\section{Purex Strlpping in the Pulge Colum}

The behavior of the Purex IC Colum was followed in the 1-1n. $x$ 65-1n. pulise column under verlous types of perforated plate construction. H.T.U. and flooding velocity were determined in compound plates, simple stainless steol plates, dr1-flined atalnless atoel plates nad all plestio fluorothene plates. Studies wore largely with pletes of $0.077^{\prime \prime}$ dlameter holes, $10 \%$ open area and spaced one Inoh, but runs were also made with plates of 0.050 inch holes, 23\% open area, spacod one 1nch and plates with 0.125 inch holos, $23 \%$ open aroa and apaced two inches apart. The peed was $195 \mathrm{~g} / \mathrm{i}$ unt and $6.5 \mathrm{~g} / \mathrm{I}$ ENO 3 dissolved in 30 volumo. per cent TBP in Shall Spray Baso. The feod to tap wator extractent ratio was 1 to 1.5 .

Phase disporsion and uxanlum extraction was defindtely connectod with the wottablilty of the plates and the cholco of continuous phase, as woll as pulso froquency and omplitude. The 0.077 " diameter hole compound plates gavo tho best troublo-freo oporation as well as high flooding voloolties, 1.0.,1250 gal/ aq.ft./hr, both phasos. Flooding volooltiog woro noarly halved by tho use of simplo platos, but tho H.I.U. was also nearly bnilvod near tho flooding point whon tho simplo platos were wot by tho continuous phase.

If the simplo platos aro wot by the dlapersod pheso, sorlous chnnneling and high H.T.U. valuos woro observod at modoreto pumping ratos, but as the froquoncy and/or amplitude are incrensed, or the flow rppronches flooding, tho E.T.U. drops markedly apparontly due to "IIefin" typo disporsion.

Tho $0.125^{\prime \prime}$ holos at 85 cjolos and ono-hnlf displnoomont, arl-f1lnod and with orgaric contlmuous grvo on H.T.U. of two food at $500 \mathrm{gril} / \mathrm{sq}$.ft./hr throughplat comperad to c.n H.T.U. of 1.1 foot for tho ldontlcal plato dosign in an olght Inch dicmotor columi oporntod by tho Chomical Dovolopmont Soction. This comparison of tho ono Inch colum with tho olght inoh is probnbly questionablo sinco tho ralus retlo of 0.125 inch holos in a ono lunch column is high and wall offocts cppoar to bo sorlous.

Compound platos of 0.050 and 0.077 inch dicmotor holos wero compcrod and tho floodl11g voloclty found to bo 1000 and $1250 \mathrm{gal} / \mathrm{aq}$.ft./hr, rospoctlvely, whlle H.T.U. valuos at $500 \mathrm{gnI} / \mathrm{sq} . f . \mathrm{hr}$ woro 0.6 and 1.2 foot, respoctivoly.

Tho rosults in gonomi point to tho eroat flnxiblilty of tho pulso colum. For ony givon holght nnd diamotor a gront vrrioty of comblnation of holo sizo, plato composition, froquonoy and pulso cmplitudo and Intorfeco locotion con bo obtalinod which con roalily bo adjustod to glvo tho dosirod colurin capacity. Vartctions in tho physical proportiog of tho syuton on also bo componsotod for in a lilso mannor. 
Valvo-Aotuatod Pulso Colum

The synchronized valve-actuated pulge colum bas been applled to the stripplng of uranyl nftrate from 12 1/2\% IBP in AMSCO 125-90\%. Colum operability and extraction behavior wes first min at rocm temperature, followed by runs at 40 and $60^{\circ} \mathrm{C}$.

These experiments were not sufflolent 1 a sope to evaluate in livaling velocity or H.E.I.S. as a funotion of plate design or valve timing, but do show the effect of Increased temperature on H.H.T.S. at throughputs of $500-700 \mathrm{gal} / \mathrm{sq} . \mathrm{ft}_{\mathrm{t}} / \mathrm{hr}$. An averege H. H.T.S. of 32 1nohes at room temperature was reduced to about 22 inches at $40 \%$. under similar operating conditions. Since a fewer number of atages are needed at the higher temperature for a given waste loss (1.0., lower Hol values), the colum helght noeded at $25^{\circ}$ is twloe that for operation at $40^{\circ} \mathrm{C}$.

Preliminary data at $60^{\circ} \mathrm{C}$. Ind1cate that the H.W.T.S. Is further reduced proportlonaliy and collum operablilty is equally as good.

\section{Purex Decontamination Studies}

Studies to determine the effect of Hanford head-end treatment on subsequent decontamination in the Purex Process were continued. Decontamination of treated and untreated feeds through one extrection with 30 volume per cent IIBF-AMSCO 125 and three scrubs wlth $3.0 \mathrm{M} \mathrm{ENO}_{3}$ was determined. As previous Iy reported, sma 1 . scale exporimentp gave over-alI beta and gemme decontaminatior factors of $1.1 \mathrm{x}$ 105 and $1.4 \times 104$, respentively, for untreated feed as compared to $9 \times 105$ and $1.3 \times 106$, respectively, for a feed from whteh 97 per cent or more of tho muthenlum, nloblum and zirconlum had been removed by head-end treatment. Most of the activity extracted from the troated feod wes cerlum. Ozonolysis did not affeat the eq for ruthenlum. In an offort to obtein meaningful rosults for the behavior of zlrconium in theso studies, soveral runs have been made on a sornowhat larger scalo. Although spocific fission product analyser aro not yot avaliablo for theso mus, the following gonoril conclusions may bo drawn from tho over-ell bote end gamo docontamination sactors:

1. Ovor-all bota and gamma docontaminetion factors wore the same whothor phaso soparation wag by contrifugation or gravity.

2. The aging of non-troctod foods soems to rondor some of tho activities prosont moro oasily scmubod from the organic, resulting in highor over-all bota anci gamme docontamination ficctors. Thothor tho food was stored in glass or stainless stool appocis to havo 11 ttlo offect on this chango in extraction and scrub behavior.

3. Protroatmont of scavongod food by flow sheet procedures to assure that plutonium is in tho (IV) oxidation stato has no dotrimontal effect on. ovor-all bota and garma dacontaraination.

Dibuty. phosflato (0.05\%) In tho oxtractent hod a dotrimontal effect on docontaminetion whothor or not tho food hed boon subjoctod to hoad-end troetmont dus to tho irrevorsiblo oxtraction of zirconiur. Hond-ond troatnont improved tho 
oror-ell gamm docontarination by a factor equal to tho zirconfum docontamination factor obtalned in the treatriont.

\section{4-5 FROCESS DHVHELOPMEWII}

Dilute nitrio aold, from $0.1 \mathrm{M}$ to $4.0 \mathrm{M}$, has beon testod as a mons of dissolv1ng skull materlal. Tho groen oxide of plutonlum was obtalned whon skull.s wore troated with bolling dilute nltric acld; the reaction was fastest whon tho concontration of tho acid was $0.5 \mathrm{M}$. At th1s concontration, opproximatoly $30 \%$ of tho plutonium was found to be in solution during tho perlod tho skull bad beon converted qomplotoly to oxide. In all coses tho greon oxides obtalnod wero d1s-

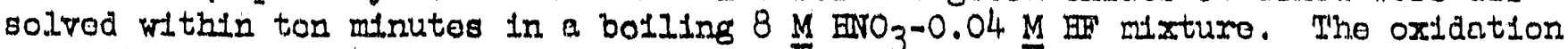
of buttons by tho bolling, diluto nitric acld was mich slowor than tho skulls bocauso tho buttons do not havo tho largo surfaco aroa offorod by tho skulls.

A program of sompling a sorios of ton plant mus eftor second cyelo poroxido calse dissolution was carried out to provlde a besls of evaluating laborntory scalo woris on tho number of poroxide oyolos requirod to obtaln buttons of the roquirod purity. Tho analytical data indicato that nine olomonts - B1, Ca, Cr, F'Q, K, In, $\mathrm{Na}, \mathrm{P}$, and $\mathrm{Fb}$... aro prosent in P-2 calso in arlounts signiflcantly highor than in tho buttons producod in tho plant. From the data avc1lablo for 234 Build1rg procossing through the oxalato procipitation stop, it is probablo that B1, La, Ca, and Fb are corriod with tho oxalate preclpitato and aro removed in the Roduotion step, whilo Fo, Cx, $\mathrm{K}$, and No aro romovod during tho oxalate procipitation by staying 1.r the spermatant and wesh solutions. The removal of $F$ is believed to occux durling hydrofluorination. It would, therefore, appear necessary to determine whether $\mathrm{Fe}, \mathrm{Cr}, \mathrm{K}$, and $\mathrm{Ne}$, present to the extent thet they are found in $\mathrm{P}-2$ cake in the Isolation Bullalng, can be edequately removed during the Reduction step. Previous work to evaluate this point was inconclusive so additional work will be done as soon as possible.

A single peroxide cycle on a flve-gram scale in the leboratory reduced the La content from $5000 \mathrm{ppm}$ in the starting solution to $20 \mathrm{ppm}$ in the cake, and to $40 \mathrm{ppm}$ when the starting solution was spiked to $0.4 \mathrm{em} / 1$ of iron. If the starting solution is splked with Ia to give a concentration of $30 \mathrm{gm} / 1$ (3 $\times 10^{6} \mathrm{ppm}$ basea on plutonium), a single peroride precipitation reduced the la content to 20,000 ppm in the precipita.te.

Assiatance wes given the P-II. Project in the preparation of a plutonium solution contalning phosphate. A fliter was constmicted to remove the MnOc formed when potasslum permarganate was added to the plutonium solution to oxidize the plutonium to Pu(VI). The solution wes filtered for the P-II Froject.

One Beduction on a one-pound basis with uranium tetrafluoride as a stand-in was made in which sulphur was used instead of lodine as the booster. Sufflclent sulphur was added to give the samo amount of heat evolved as would be obtalned If lodine were used. A normal appearing button was obtained with a yleld of 98. 9\%. Thls compares with yiolds from 99.1-99.3\%, which are usually obtalned when lodine is used. The Reduction bomb would probably not require pickling if sulphur were used irjtead of lodino. It 1s also likely that the Reduction hood could be maintianed mich cleanor if a sibstituto for lodine collid be found. 
Because of the operating difliculties that have been encountered during the production test for the recycling of the supermatant solution and washes from the oralate preclpitation in the 234 Buliding, the destruction of the oxalic acid by oxldizing agents otbor than nitrle acld bas been considered. The "S" IIvision prefers not to use permengenate in the glass-Iined equipment used to boil down the supernatant solutions. Funs in which hydrogen peroxide was used as the oxidizing agent were made with a synthetlc concentrated supernatant solution. After rePluxing for one and a half hours, over $96 \%$ of the oxallc acld wes destroyed when two moles of hydrogen peroxide were added for every mole of oxalic present at the start. The synthot1c supernatant solution did not contain any iron, so additional runs will be ade in the presence of 1ron at concentrations usually found in supernatant solutions bolied down to varying degrees.

Three finishod core pleces were returned to the production Iine by the Inspection Group during the month for fallure to meet the coating speciflcation. It was recessary to return one assembly to the matching station because of fallure to meet dimensional specifications.

Assistance was given in evaluating a new set of Pressing die punches. $\Lambda$ Model 111 plece and a 112 piece were coated with a minimu of hand cleaning. The coeted pleces were inspected after only a rough polish hed been given to them. The geps between the various thething surfaces were found to be improved over those obtalned wth provious punches.

Although the integratod alphe count at Hanford on the flnishod ploces has been consistentily Tory low (actualiy the majorlty show less than $100 \mathrm{c} / \mathrm{m}$ ), the counts on these same pleccs at IOs A.Iamos have boen consistently higher than at Hanfore. Although the situation does not appear to be bothersome at the moment, since thu counts at both sites aro well within the limit specifiod, the alpha chamber has becn tested rigorously wlth calibrated alpha sourcos. It is therofore believed thet the Hanford values are rellablo within the limits of the counting derice.

Alltoradographs wero made of approximatoly half the pioces produced during this interval. The rosults of those cxominations indicated that tho coatings wore of very good quality. Tripod points were discermible on only one piece. Vory smell spots where the coating wes slightly thin were found on four pleces. Other varlation in the coating thleloness which was obsorvod wes probably caused by work done to match tho pleces or to bring tho coating thickness to the spocifice. range.

\section{STACK GIS DISPCSAI}

A test filter contolning a one-half-inch dopth of "AA" Fiberglas at a donsity of $1.2 \mathrm{lbs}$ /cu.ft. wcs placed in tho monitoring equipment loccted in the $221-B$ pipe gellery. An eliquot of the Dissolver off-gas stream was drawn through the apparatus during a metal dissolution, chnrging, and a cocting romoval. To represent more closoly the actual Dissolvor coll conditions, provisions wero made for heating th. gas stron during its passage through the pipo ge.llory sampling systorn. A low of $1 \mathrm{scfm}$. (50 ft/min) was maintained through the experimental unit tnroughout the test porlod. The pressure drop across the 
"AA" Fibcrglas at the start of the tost was 4.0 Inchos of wator. At the conclusion of the run, tho rocorded pressuro drop was 4.1 inches of wator. Those veluos revonl thet thero was no cpproclablo deposition of sollds. Following the complotion of the run, the unit was disissomblod and tho Fibergles packines was tested with Nosslor's rocgent for tho prosonce of cmonium lon. The tost was negrtive.

During tho charging oporation "grab samples" wore talson of tho off-gas strocm to detormino the concentration of oxides of nitrogen. The results havo shown that the flushing ection of the hoatod of $x$ stroam roducos tho Non concontration from re.juas as high as $2260 \mathrm{ppm}$ at tho beginning of a charging oporation to $c$ rengo of 7 to $30 \mathrm{ppm}$ at the time of caustic cddition.

Both phesos of the 1nvestigation have indicctod that the oloveted tomperature of the DIssolver coll equipmont prevonts the formetion of lorgo quantitios of acid condensate and subsoquont cumonlum nitrato formation. A bottor dogroo of weste gas decontcmination and an approciablo scvings in the fabricction costs of future fliters can be cohlovod by tho ollminction of tho by-pess velvos. Consoquontly, It has boon recomondod that tho by-pass valvo on tho Fiborglns filter In the 3-5R Coll at $B$ plent bo locked out and tho off-gascs bo directod through tho flltor during all operctions. If thoro bes boen no unusual incrocso in resistance caross tho filtor after threo months of oporation in this nannor, it has been further rocommonded that tho by-pass velvos on the throe romaining units. also be lockod out of oporction.

A spot chock of the II3I romoral. officioncy of the 4-5I G1Ivor Recetor at B PInrt was mado on Merch 8. The offlizioney of the vintt wc.s $99.9 \%$.

\title{
INVINTIONS
}

All persons ongigod in work that might rocsorcbly bo cxpocted to rosult in invontions or discorerios edviso that, to tho best of thoir knowlodge and bellef, no invontions or discovorios woro medc in tho courso of thelr work during the perlod corored by this report oxcopt es Iistod below. Such persons fuxther adviso that, for the porlod thoroin covorod by this roport, notobook rocords, if any, kopt in the courso of their work havo boon oxrmined for possible invontions or discoverios.

\author{
Invontor \\ C. G. McCormcck and O. F. HilI \\ The Use of "Codeulonts" to Improve \\ the Sottling Chrocteristics and \\ Centrifugabilitj of $\mathrm{MnO}_{2}$. \\ P. M. Brown and W. H. Roas \\ The Use of Plutonium(III) Sulfate \\ as an Isolation Frocipitate for \\ Coupling Jclvont Extricetion \\ Soperotions to Motal Production.
}




\section{Inventor}

K. M. Harmon

J. F. Facer, W. I. IJon

J. F. Fecer, W.I. Ijon
The Preperation of Pur 4 for Metal Reduction by the oxidation of $\mathrm{PuF}_{3}$ In N1tric Acld-Erdrofluor1c Ac1d golutions.

The Preparation of a Reedily Soluble Powder from Massive Plutonlum (W-206el)

The D1ssolution of PIutonlum from Metal Processing Wasteg (W-20622)

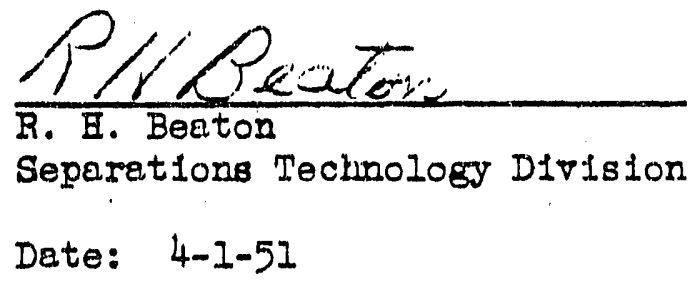




\section{TECHNICAC SERVICES DIVISION}

MARCH 1951

\section{VISITORS \& BUSINESS TRIPS}

B. M. Fry, of the A.E.C. Technlcal Information Service, Waghington, D. C., spent March 1-2 with the 300 and 700 Area Classifled Files and the Plant Technical Library.

The Commit tee of Senior Responsible Reviewers met at Hanford on March 9-10 and discussed local problems regarding classification and declassification of documents.

Dr. John Woodhouse, of the Du Pont Company, gpent March 22-23 reviewing the operation of the Classifled Files.

Dr. William Beamer, of the Dow Chemical Company, spent March 29-30, reviewIng the 300 Area Classifled Files index for documents pertinent to the new Dow project at Denver, Colo.

Business trips of Technical Services Division personnel were as follows:

E. W. Rebol spent March 1-2 at the Mallinckrodt Chemical Works, St. Louis, discussing analytical methods and inspecting facilities.

J. W. Hall spent March $1-3$ reoruiting technical personnel at the Missouri School of Mines and the University of Missouri.

R. B. Socky inspected laboratory and equipment design features at the Argonne National Laboratory on March $5-6$, and at KAPL on March $7-9$. He spent March 12-14 at the C. T. Main Co., Boston, reviewing the design criteria for the Pile Technology Bldg.

W. N. Carson, H. W. Miller and M. Lewis spent March 5-8 attending the Pittsburgh Conference on Analytical Chemlstry. They spent March 9-10 at KAPL discussing recent advances in analytical chemistry relating to Hanford processes. M. Lewis spent March 8 at the Aluminum Research Laboratorles in Pittsburgh discussing the behavior of metaliic aluninum. H. W. Miller spent March 12-13 at the Argonne Nat1onal Laboratory discussing recent advances in analytical chemistry techniques.

R. J.Hale and F. B. Quinlan spent March 12-14 at the C. T. Main Co. discussing problems related the design of the Library \& Files and P1la Technology Bldgs. While in the Fast, F. B. Quinlan spent March 15 reviewing laboratory designs at KAPL.

J. F. Gifford Vlsited the Brookhaven National Laboratory, March 12-14; KAPL, March 15-16; Oak RIdge National Iaboratory, March 20-21 and the Mounds Laboratory on March 22-23 where he inspected the latest developments in the fields of remote handling devices and cubicle degign. 
M. G. Freidank attended the A.E.C. Jolnt Conference on Document Control in Chtcago on March 15 and 16. The meeting was devoted to problems of inventory and control of classifled documents.

T. R. Cartmell spent March 22 and 23 at the Mound Laboratory reviewing electronically operated control devioes.

J. S. Stoakes visited the Radiation Laboratory at Berkeley, Calif., on March 22-23 where he discussed contamination control and waste disposal problems.

F. B. Quinlan and R. J. Hale spent March 25-27 with the Leland S. Rosener Co. In San Francisco for design llalson discussions in connection with the Radiochemistry and Radiometallurgy Bldgs.

ORGANIZATION AND PERSONNEL

Personnel totals in the several subdivisions are sumarized as follows:

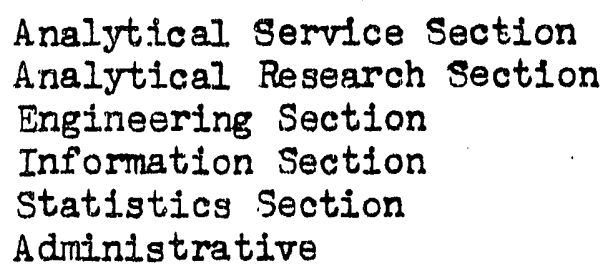

Division Totals February 28

244

43

75

73

18

3

456
March 31

2.44

45

78

71

18

3

459

ANALYTICAL SERVICE

Work Volume Btatistics

The following tabulation shows the source and volume statistics for samples on which analyses were completed.

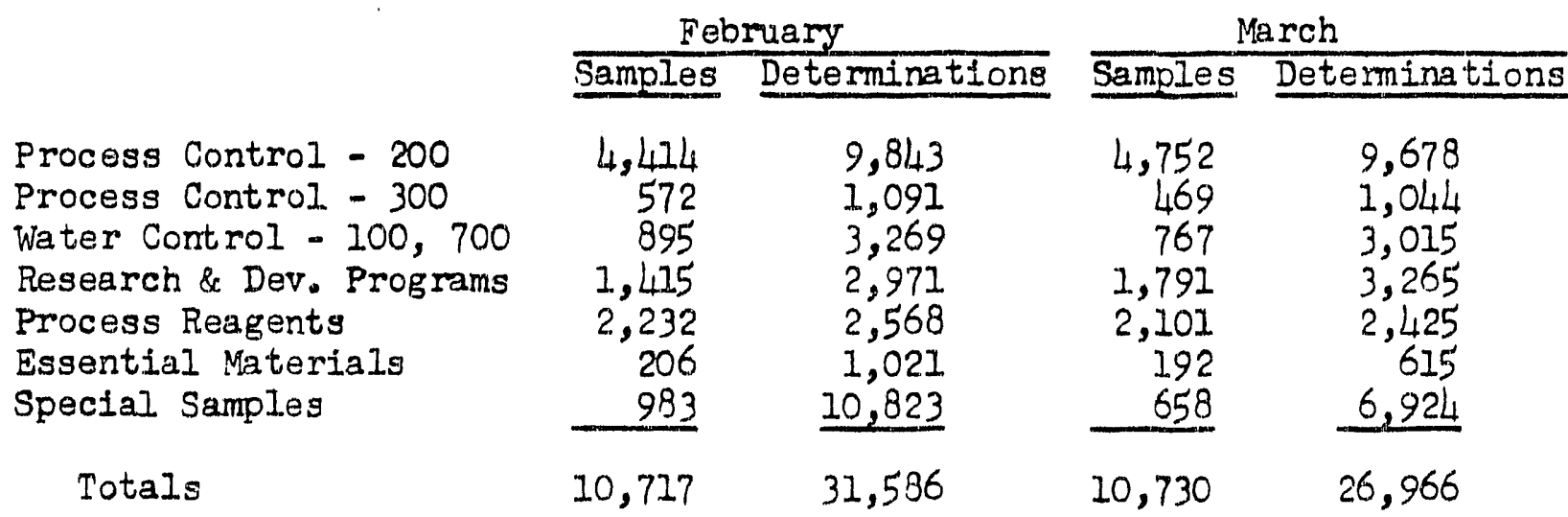

The cause for the large drop in the number of special samples (above) submitted throughout the section's laboratories is not known. Many of them required spectrog raphic analysis, and the number of deteminations dropped from about 20 reported elements per sample to 2-3 per sample, thus accounting for a decrease of roughly 2,500 determinations. Some of the charge may be 
accounted for by the fact that the out-off date for the data is the $23 \mathrm{rd}$ of the month and, hence, the Merch data is short about three days of coverIng a complete month. These two factors would also account in part for the disproportionate changes in the $200 \mathrm{Area}$ control statistics.

\section{Areas Water Control}

The refrigerant for the cold trap on the high vacuum gas analyzer used in determining gases in Naval Reactor Profect ( $P-13$ ) water samples was changed from a dry ice-trichlorethylene mixture under high vacuum to a liquid nitrogen-alcohol mixture at atmospheric pressure. This change has resulted in a saving of 24 man hours per month analytical time, and has eliminated the handling of the hazardous trichlorethylene and dry 1ce. Improvements in sampling of the Naval Reactor System water were made by adding capillary ball joint fittings to the ter sampling taps and the sample ampoules to insure air-tight fittings and eliminate possible gas traps when collecting samples.

\section{Area Control}

The sample accountability log book format the 222-B and - T Laboratories has been revised to include both operational sample data and accountability data in one book. This step eliminates the possibilities of errors or omissions in transposing sample data from the sample log book to the accountablilty $\mathrm{log}$ book. In addition, an estimated savings of approximately 30 man-hours/month will be attalned. New binders have been procured and log sheets for the book are being printed.

A sampling error test on the $E-4-R C$ tank containing material returned to the 22L-B Bullding for recycle was started on March 3. Sixteen batches of recycle material, including five relatively pure plutonium solution batches from the P-II project, were added to the tank which was sampled in triplicate after each addition. The analytical results have been forwarded to the Statistics Group for evaluation.

Two sample cans were processed for americium recovery in the 231 BIdg. on March 8 and 9. Laboratory assay work proceeded wi.thout incident.

Occasional high first decontamination cycle waste losses (14(17)-3-w9) have been observed at the 221-B Bldg. during the production test 221-B-10 (bismuth and volume reduction). As a result of an informal request from the Separations Technology Division, Am-Cm assays were performed on two of the samples in the 222-B Laboratory. The results are tabulated below:

\begin{tabular}{|c|c|c|c|}
\hline Sample & Run No. & Tota.l Alpha $\mathrm{c} / \mathrm{m} / \mathrm{m} I$ & $\mathrm{Am}-\mathrm{Cm} \quad \mathrm{c} / \mathrm{m} / \mathrm{ml}$ \\
\hline $17-3-w S$ & $B 11-D 3-F^{2}$ & $1.2 \times 10^{4}$ & $7.7 \times 10^{3}$ \\
\hline $14-3-W ;$ & $B 11-D 3-F 23$ & $1.6 \times 10^{4}$ & $1.1 \times 10^{4}$ \\
\hline
\end{tabular}

The prepared discs were then checked on the alpha energy analyzer, showing the following distribution of activity:

$$
\mathrm{Cm}^{2} 42 \quad 70-80 \%
$$




$$
\begin{array}{ll}
\mathrm{Am}^{24 \mathrm{I}} & 20-30 \% \\
\mathrm{Pu}^{239} & \text { Trace }-5 \%
\end{array}
$$

The above results indieate that very good separation of Am-Cm from plutonium was attained on this type of sample ugling the standard Ceric Oxidation Method, $C A-19 a$, and verffled the cause of the apparent high waste losses.

In an effort to expedite the adoption of stainless steel disos for routine control radi oassay procedures in the 231 Bldg. Laboratory, spare time was devoted to securling comparative $S S$ and platinum disc data on the $P-1$, CT-I-R, and AT samples. Approximately 20 such analyses were obtained on each type of sample. These data have been submitted to the Methods Control Group and the Research Section for evaluation.

As part of the overall program to improve plutonium accountability, the material balance for the separations Process was placed on a total count (TC) basis, starting with Runs BII-03-FI and TII-03-BI. With this March series of runs, routine reporting of the final product solution (AT) radioassay in terms of $\mathrm{c} / \mathrm{m} / \mathrm{ml}$ at $50.5 \%$ geometry was begun. Effective with the April serles, the accountablitity procedure will be revised to the extent that assay results w1.1I be corrected for 1sotopes according to $\mathrm{HWm} 20581$, "Revision of Isotope Correction Factor."

Selected Pyrex test tubes without rims were substituted for the Klett tubes which are used in the Fluorimetric Method for the determination of Chemical 70-58. Is addition to the advantages reported last month for this method In comparison to the Ferrocyanide Method, it is estimated that a saving of 35 man hours/month of analytical time, based on a 200 man schedule, has been realized.

A request has been recelved to determine silicon and titanium in the concentrated oxalate supernate (SN-3) samples from the $234-5$ process recovery studies. A spectrographic method for titanium and a colorimetric wet ohemical method for silicon are now being set up.

\section{Area Control and Special Services}

It has been noticed for some time that total molsture values in coal, procured from the same mine, do not correlate with the surface molsture; consequently, an investlgation of the A.S.T.M. method for moisture analysis in coal is in progress. Several coal samples, with moisture content established, are being spiked with known amounts of water to determine the accuracy of the methods for surface and total moisture.

Several samples of lone-stored ammonium sulfite, used as a reductart in the Separations Process in the $231 \mathrm{Bldg}$, were submitted to the laboratory for sulfite and sulfate analysis. Analytical data indicated that the sulfite was partially oxidized to the sulfate, either by air oxidation or by the presence of a contaminate which was acting as an oxidant. This information was given to the 200 Area Plant Assistance Group investigating the problem of low sulfite content.

The procedure for the determination of total calcium in calcium metal was reviewed and it was found that the temperature during the ignition of the 
oxalate to the oxide could be reduced from $1200^{\circ} \mathrm{C}$ to $1000^{\circ} \mathrm{C}$ 'w thout affecting the converston. It was necessary to make this slight change in procedure because the high temperature, $1200^{\circ} \mathrm{C}$, was exceeding the capacity of the muffle furnaces and continuously burnirig out the heating elements. The range of $1000^{\circ} \mathrm{C}$ is within the safe operating conditions of the muffle fumaces.

As a result of the Uranium Sample Exchange Program between Mallinokrodt Chemical Works and the Hanford Works, 1t was found that the iron and silicon as reported by Hanford are biased on the high side. In revlewting the analyt1cal methods at an inter-site quality control meeting held at Malilnckrodt Chemical Works, It was discovered that the only difference in methods is that Mallinckrodt uses metal samples and Hanford uses oxlde prepared from the metal. There was some bellef at the meeting that contamination of $F e$ and $S 1$ are plcked up from the refractory liner and heating element in the muffle furnace. The comparison of values obtained from the two types of samples is being investigatied here; in addition, a standard uranium oxide sample is being sent out by the New Brunswlck Laboratory to all sites for F'e and $S I$ analysis.

A sample of mixed acld contalning $\mathrm{HF}, \mathrm{FNO}_{3}$, and $\mathrm{Pu}$ was submitted by the Chemical Research gection for $\mathrm{HNO}_{3}$ analysis. The conventional HNO 3 Distillation Method was not feasible since $\mathrm{HF}$ interfered; consequently, the $\mathrm{HNO}_{3}$ was determined by titration with standard ferrous sulfate solution to a brown coloration.

The determination of promgthium activity in Separations Process first cycle waste streams has been requested by the Chernical Research Section in connection with a study of the feasibility of cribbing these wastes. In aged wastes, promethium can be determined by a method for total rare earths minus cerium, other rare earths excepting cerium belng negligible. However, on current wastes it is necessary to allow the prepared discs to age for approximately three weeks, after which time the 65-hour yttrium daughter of $5 r-90$ should be decayed to a negligible quantity.

In connection with the slag and crucible leaching studied by the Chemical Research Section for $234-5$ Bldg. recovery operations, TBP deteminations are necessary on organic streams containing up to $1 \mathrm{gm}$. Pu/liter. In order to use the infrared spectrometer for the determination of high concentrations of TBP, Pu must be removed since the instmanent is not set up for radioactive work. Consequently, a tentative procedure for preliminary removal of Pu from these samples is being investigated and consists of passing the organic stream through a $\mathrm{K}_{2} \mathrm{CO}_{3}$ column to absorb the $\mathrm{Pu}$.

A. new method of determining $T B P$ in aqueous streams containing low concentrations of TBF is being examined. The method consists of extracting the TBP with three passes of $\mathrm{CCI}_{4}$ and then evaporating the major part of the $\mathrm{CCI}_{4}$. The residue is then hydrolyzed with $\mathrm{H}_{2} \mathrm{SO}_{4}$ at $175-200^{\circ} \mathrm{C}$ for three minutes. After cooling the mixture is decolorized with nitric acid and ammonium persulfate, following which the $\mathrm{HNO}_{3}$ is removed. The $\mathrm{PO}_{4} \equiv$ now formed is mesured by the conventional colorimetric phosphate method. Percent recoveries using the new method varied by $12 \%$ and the old method varfed by as much as $30 \%$. 
Chemical Development Service Laboratory

Operations in this laboratory continued on a routine basis.

Methods Control Group

The falling drop apparatus was transferred from Bldg. 3706 to Bldg. 222-B for use in Separations Process density determinations, but has not as yet been ingtalled. The use of mixtures of tetrebromoethane, fuel. oll, and kerosene as the reference organic liquid was found to be satisfactory throughout the entire range of Sp.Gr. required. The Instrument Division completed the constant temperature controller using a themlstor sensing element and a saturable reactor. This regulator gave a rapld response, had high sensitivity, and was easily adjusted to the temperature desired $\left(25^{\circ} \mathrm{C}\right)$.

Weighing and analyzing the total 234 process supernate (SN-1) sample was found to give results a factor of 2.06 higher than the previously used but less precise analy'sis using a measured aliquot. There is an indication that the heel of the sn-I tank contalns some solid plutonium oxalate resulting In a build-up of plutonium in the tank; the sampling tube dips almost to the bottom of the tank whloh may also result in a non-representative sample high in plutonium belng sent to the laboratiory. It is felt that a sampling test would be very much in order at this point.

A study of the accuracy and precision of the cupferron extraction spectrographlc analysis for 19 impurities in plutonium metal was carried out at an impurity level 20 to 100 times the lower limit Imposed by sensitivity of method or contamination. A series of eight analyses on each of three samples: a Pu-free standard (prepargd by the Research Section), a plutonium metal sample, and the same metal spiked with the standard, was made by persomel of the 234-5 Bldg. Laboratory. The ranges for the eight determinations (each on a different film) on the spiked plutonium samples were a factor of f1ve for seven elements and a factor of two or less on the remaining twelve. The average recoverles were $20 \%$ for manganese, 33\% for chromium, $50 \%$ for $\mathrm{Ni}$ and $\mathrm{Ba}, 66 \%$ for $\mathrm{Cd}$, and 100\% for the remaining twelve el ements. These encouraglng data were forwarded to the Analytical Research Section for further consideration of the advantages of increasing the sample size in order to work with amounts of Impurities well above the sensitivity linits.

A study of the possibility of using specific gravity to detemine the concentration of zirconium in the zirconyl nitrate process solution indicated this method would not be feasible.

A statistical study of the presently used method for detemination of carbon and hydrogen in uranium metal, based on range of duplicates, indicated the precision of $\mathrm{C}$ determination is $\$ 55 \mathrm{ppm}$ and of $\mathrm{H}_{2}$ determination is $\$ 7.6 \mathrm{ppm}$. A similar study on the detemination of uranium by the Chromous Sulfate (RUV-2a) Method gave a preclsion of i $0.9 \%$ based on reported results.

The following items were noted in the investigation of the fluorimetric determination of uranium. On the Hanford type fluorimeter, if a high level sample or standard is measured and followed within a two-minute period by a low-level standard sample, the reading on the low-level standard will be higher than normal. The cause for this down, but a study of this 
effect Indicated it was reproductble and the instrument could be standardized on the basis of measuring a high-level standard prifor to sample measurements. A study of' the glase standards used in the Price flunrimeter Indicated the use of a higher level fluorescent glass would be preferable to the presently used low-level glass standard.

A.II A.S.P. and IDL counting Instruments in 222-T, 222-B, 231, and 3706 BIdgs. were in good agreement when tested with the same standard diso. The geometry standard in routine use in the $234 \mathrm{Bldg}$. was found to have lost a portion of the samples a new dese was losued and the off-standard condition corrected.

A similar cross oheck was run an the A.S.V.P. Lngtruments in 3706 and 31 . Bldgs. using three standard disos of known aotivity. In $3706 \mathrm{Bldg}$. \#I A.S.V.P. Instrument measured geometry and tested geometry were in good agreement. No. 2 A.S.V.P. tested goemtry was 1 , $4 \%$ low as compared to the measured geometry, but subsequently the tested geometry came lnto agreement with the measured geometry, In $231 \mathrm{Bl}$. dition while the \#2 A.S.V.P. tested geometxy was $0.7 \%$ low as compa red to the measured geometry. This Instmument has been taken out of gervice pendIng the Installation of a new low geometry attachment.

Varlous tests have shown a correlation between mica windows, low geometry attachments, and erratic results. Reports from Berkeley ( $v$ ia the Instrument Development Group, Instrument Division) indloated gimilar experience at that site. On recommendation from Berkeley, a test on matallic coated (aluinizec) mica windows is being made. In addition, further modifications in destgn of the low geometry attachment were recommended. New chambers followling the modifled design have been ordered.

Two Iron standards, used as a stand-in for the chemical titration of plutonium, were 1ssued this month, a sample of each going to the 231 BIdg. and 234 Bldg. laboratories. The only results reported to date are from the 231 Bldg. and show that for 24 analyses an average result of $12.27 \mathrm{~g} / 1$ was obtalned. This is $0.11 \mathrm{~g} / \mathrm{I}$ lower than the assigned value. A chemist has been assigned to investigate analytioal techniques and possible remedial action. It has beon determined that the equipment and reagents used are in good order.

\section{Special Hazards Control}

Over the past six monthg the routine shift surveys in the entire 231 Bldg. laboratory area have been gradually decreased in scope. This has been done on a test basis with the trend in contamination of non-regulated items beins used as an index of the adequacy of the survey work. Because there was no Increase in contamination sprsad, the routine shift surveys have been eliminated completely, thus savirig approxinately 80 man hours/month. Slmilar procedure changes will be evaluated in the other 200 Area laboratories.

The dry waste disposal crib at the 222-T Laboratory apparently became filled or partialiy caved in during the month, rendering it useless. It was estimated that the life span of this crib wes cut from ten to five years because of the incroased produotion rates; it actually lasted only two years, thus giving credence to the possiblitty of a cave-in. During construction of a 
replacement, arrangements have been made with the "igh Division to handle nomal dry wat: viader SWF oonditions.

Several High afr samples were encountered at the $234 .-5$ Bldg. Iaboratory th Rooms 134 and 148 dury.ng the week of Maroh 12-Maroh 18. Investigation of the hood exhaust dampers in these rooms revealed that two dampers were out of adfustment. The exhaust dampers were reset, and the condition thus correoted. However, it was noted that the locking set-screws installed on the shafte of all hood dampers during Febmary of 1950 had worked 100 se and were not provideng the positive ohock on damper slilppage that was intended. A better method to prevent the dampers from alipplng, such as spot welding or plinning of the danper gears to the shaft, is now being considered. In the meantime, a routine monthily chock of all hoad air flow has been initiated.

ANALYTICAL RESEA ROH

P-10 Analyt loal Studies

An automatio recorder has been Installed on the mess apeotrometer employed for the analysis of gaseous P-10 samples. Spectrum records have thus been obtatned for the 309 samples analyzed during the month. The device has beem of partioular value in that it provides a permanent and complete record of the spectrum although it offers littie in the way of time-saving for routine analysis for the normali.y sought constl.tients. The visually recorded spectra revealed the unexpeoted presence of about 2\% methane in outgas fracticns; this material was not found in gases extracted at higher temperatures.

A study deslgned to evaluate the rellabllity of different types of sampling contalners ylelded the unexpeoted conolusion that breakseai contalners are not superior to ones with stopoook olosures. In cooperation with P1.1e Technology Division personnel, a system has been devised for using metal. sampling containers. A plnch-off device l.s employed to remove successive portions of a long aluminum tube sealed onto the process line, and methods have been selected for attaohing the bulb to the analytical manifold and subsequentiy opening it.

A 50 r gection of I./4" O.D. copper tubing has been attaclied to the mass spectrometer head to allow studies of ramote sampiling as a preilminary to possible in-line use of the lnstrument. Retention of geses on the inner surface of the tube appears to be small and low backgrounds are obtained. Further studies indicate that during operation with a steady sample feed, alteration in sample composition wLII be indioated within flve seconds and that a new steady state will bo established within two to three minutes.

Analysis of additional samples with the emission spectrometer being tested for conduct of $P-i O$ analyses indicates that higher operating pressures than those initially selected may be necessary; this is in agreement with recent work at the National Bureau of Standards. Experiments deslgned to eliminate the need for flow of sample under controlled conditions during the period of exaltation proved unsuccessful; the attempted prooedure Involved an initial flushing perlod during a prej.1minary discharge and subsequent measurement under statio conditions. The sampling line has been modflied to reduoe 1to tetal. volume and to provlde more sensitive pressure and f'low control. A nerv sample system has been obtalned for stidy in preparation to design of 
a comparable metal aystem for use wh th ln-litne analyses.

Radiochemicial. Methods - (RDA $\mathbb{f l O}-1)$

Preparation has begun on a sertes of urantum oxlde samples oontalning flssion products. The separate samples will contain flasion produots havirig if ferent beta and gamma energles and whll be used to voordina te oounting tochnigues at Oak Fidge and Hanford. This program 1g paxt af a prearranged attempt to standardize urantum oxlde spectfioation anelyses for materlal produced from the Redox and Metal Recovery Processes. Detalled oonsideration Is beling g1ten to the expeoted content of $U X_{1}$ and $U X_{2}$ in the recovered oxtde slnoe the aotivity of the equilibrium concentration of these elements provldes the bas:ls for the speolfirationg. Conslderation is also being glven to the J237 content since it is possible that this constituent may be present in suffiolent quantity to Influenoo the beta activity measurements.

Final arrangements have been made for the purchase of mass gpectrometers to provide uranium 1sotopto analygis of urantum oxticlo to be produoed at Hanford. The orfginal Instrument speolfloations could not be met by any producer within the desired time. As a consequence, the lnstmant speaifloations were modifiled In ouch a way that one producer has glven agreament to a shipping date of September 1951 .

S1x separate plutonium nitrate solutions have been analyzed for pu240 with the recently ingtalled flssion counter. The results obtalined are in agreem ment with those calculated in the P1le Physics Sectlon and lend further support to recentily accumulated laboratory data lndioating that the presentiy used lootope oorrection factor for radioassay of plutonium is in error.

A flnal set of expertments deslgned to evaluate the appiliablifty of disposable stalnless ateel dises to routine radioassays has led to a procedure for use of such disos with all Intermodiate Blsmith Phosphate Process streams. The work showed that the backscattering from these discs is different from that obtalned with platinum disos so that a new backscattering oorrection must be applied.

Speotrochemioal Methods - (RDA \#TC-2)

A modifioation of the oupferron-spectrochemical procedure for the determination of Impurities in plutonium metal has been introduced into control use. The principal modifloation 1.3 the use of reference standards that have been carried through the entire extrestion prooedure, thereby tending to counteract errors inherent in the procedure. The development work in testing the modified method has shown that organio matter on the spectrographic electrodes is not a serious source of error and that appreclable discrepanciea may result: ihrough strong adherence of the impurity metal oxides to the contajners in which the samples have been processed and evaporated. It was also found that a thin grease film on the surface of the electrode wlil decrease the extent of reaction between the metal electrode and acid In the sample. Tha optios of the spectrograph were revised to produce a more intense spectrum, and optimum operating conditilons were established.

Investlgations have continued with inf rared absorption techntyues for the detorinination of carbon monoxide in the prosence of carbon dioxide. This 
work is In proparation for and in oupport of a P1Je Technology Divlsion test hole study of the reaotion of graphite in a neutron flux involving constant monitoring of geses. Good preciston has boen obtalned with the method although experfonos has shown that it lo diffioult to cement windows on the infrared oel]. In such a manrer as to make them gas-tight.

In an effort to develop a more suitable method for the determination of TBP In aqueous phase, a sertes of experiments was conduoted in which column ad.. sorption techniques were used to separate the TBP prior to dissolution of the material in an organio phase for inf rared absorption measurement. Other experlments involved direct extraction of TBP with carbon tetrachloride. Both procedures proved to be oonventent and to produce satisfactory analyseg. Experiments were also caried out to determine aromatios in Metal Recovery Process diluents. Adsorption technigues served to separate the aromatio fraction from the kerosene base. Infrared analysis showed, however, that certain al foyolic constituents of the materlal followed the arometio group. As a consequence, the technique is not yet proven to be satisfactory. Additional development work Involving the inf rared spectrometer included the investigation of methods for the detemination of TEP in plutontumi-containing solutions and the determination of diethyl. 1sobutyl phosphate. Satisfactory methods appear to hare bean developed in both cases.

A serles of short problems using the Cary spectrophotometer recelved attention during the month. These included the determination of chromate, permanganate, manganese dloxide, and $P u(I V)$ in solutions employed for critioal mass studies; the determination of permianganate and manganese dioxlde in solutions obtained during Chamloal Development Section head-end Redox studies; an Investigation of possibl" improvements in the methods for detexmination of Pu(VI) and of UNH; and the direct determination of copper in bronze bath.

\section{Miscellareous}

In support of the Pile Technology profect to study methods for lncreased flow of plie water, autable radiochemical methods for the determination of sodium, silicon, manganese, and copper have been adapted and applied for regular analyses of pile effluent water. The purpose of this work is to establish the normal concentration of these elements in the water during the present period of normal conditions and later durlng the spring pertod of high wateractivity.

A group of gludge samples obtalned during the pushing of slugs has been obtialned and will be subjeoted to chemical analysis in order to determine the nature of the sludge. Durling a trip, one of the chemists who is interested in this problem consulted with personnel of the Aluminum Research Laboratorles. Experimental. work wis desoribed which showed that higher concentrations of dichromate aoted as a corrosion inhibitor for aluminum but that dichromate contents of 100 p.pom. or less tended to accelerate pitting attack. This Iriformation was considered pertinent since 2 p.p.m. dichromate is currently added to pile cooling water.

it serles of analyses falled to reveal any unusual constituents in samples obtained from a lithiun-aluminum slug that had ruptured in the pile. The aluminuril cap and can proved to be within spocifications. The lithiummaluminum alloy was of normal purity, and the relitively large quantity af corrosion 
product proved to be aluminum hydrate, contalning no unexpected impurities.

Design work has been completed on a proposed gas analysis laboratory in Room 59 of the 3706 Bldge, and cost estinates are ourrently being obtained. ENOINEERINO SERVICES

Mechanical Shops (Eldgs. 101 and 3706)

Work volume statistios for the Mechanical Shops are as follows:

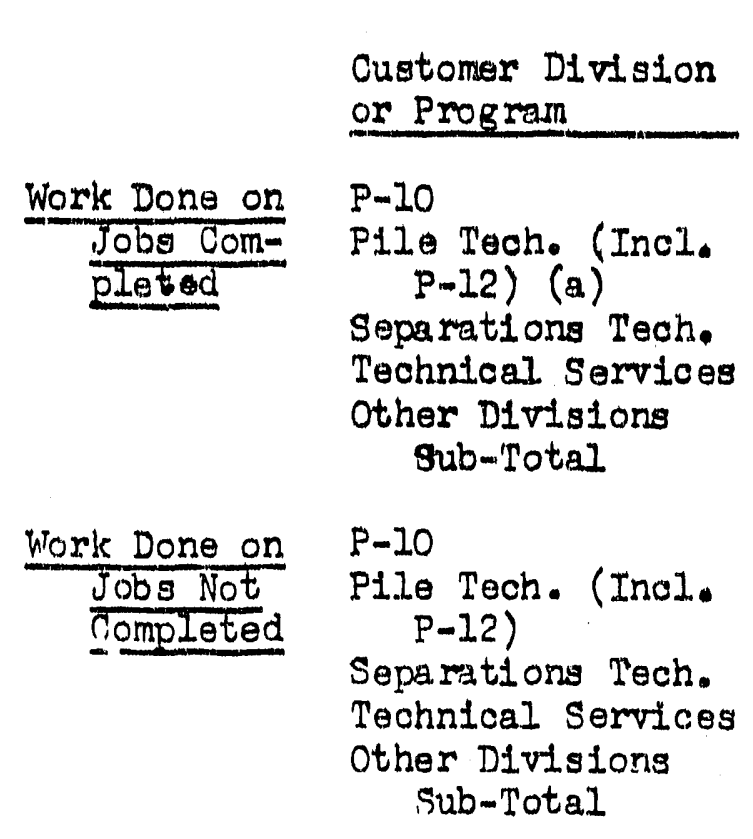

Total Work Done

Work Bercklog:

\begin{tabular}{|c|c|c|c|}
\hline \multicolumn{2}{|c|}{ February } & \multicolumn{2}{|c|}{ March } \\
\hline $\begin{array}{l}\text { No. of } \\
\text { Jobs }\end{array}$ & $\begin{array}{l}\text { Man- } \\
\text { Hour's }\end{array}$ & $\begin{array}{l}\text { No. of } \\
\text { Jobs }\end{array}$ & $\begin{array}{l}\text { Manw } \\
\text { Hours }\end{array}$ \\
\hline 16 & 391 & 19 & 501 \\
\hline $\begin{array}{r}52 \\
18 \\
35 \\
5 \\
126\end{array}$ & $\begin{array}{r}830 \\
1119 \\
295 \\
80 \\
1,715\end{array}$ & $\begin{array}{r}44 \\
17 \\
35 \\
4 \\
119\end{array}$ & $\begin{array}{r}740 \\
196 \\
513 \\
194 \\
2,144\end{array}$ \\
\hline 4 & 526 & 7 & 248 \\
\hline $\begin{array}{r}17 \\
5 \\
9 \\
3 \\
-32\end{array}$ & $\begin{array}{r}168 \\
63 \\
159 \\
68 \\
9884\end{array}$ & $\begin{array}{r}12 \\
10 \\
10 \\
2 \\
\text { पI }\end{array}$ & $\begin{array}{r}68 \\
276 \\
188 \\
52 \\
8332\end{array}$ \\
\hline
\end{tabular}

$2,699 \quad 2,976$

Man-Hours

To Complete

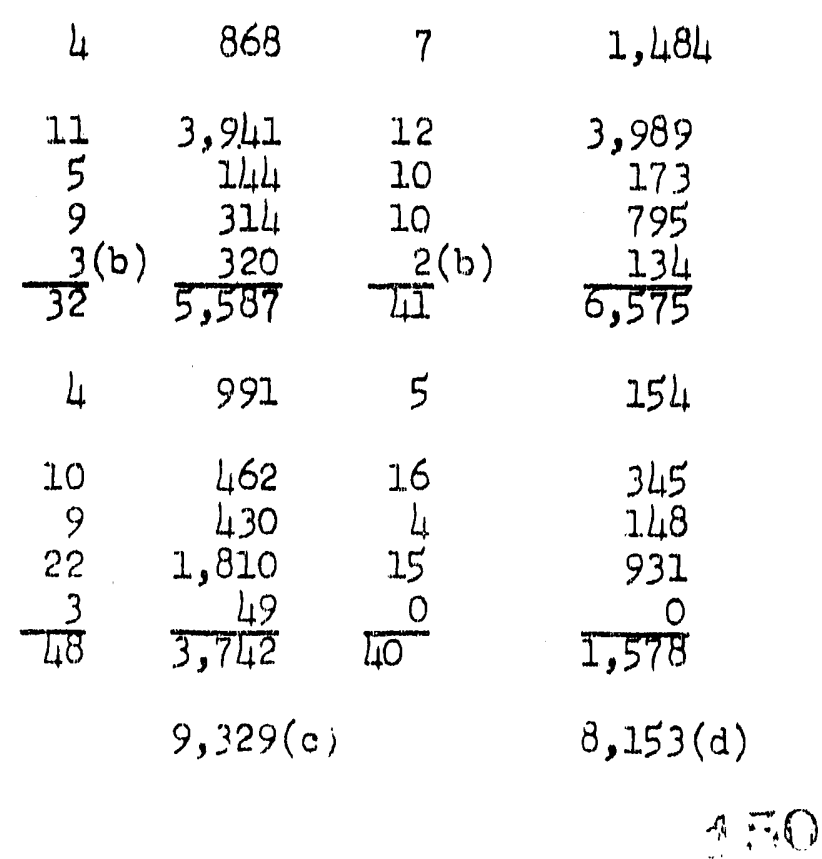

$P-10$

P1le Tech. (Inol. $P-12$ )

Separations Tech. Technical Services Other Divisions

Sub-Total.

Jobs Nct P...10

Pet Started Pile Tech. (Incl. P-12)

Separations Tech.

Technical Services

Other Divisions

Sub-Total. 
(a) P-12 designates the Exponential Pile Project.

(b) Includes ene order that is unestimated as the work is of a routine natiriso.

(c) Does not 2nclude 46 man-hours transferred to Instrument nor 686 manhours transferred to Maintenance during the month of February.

(d) Does not Include 215 mar $_{1}$-hours transferred to Inst rument, 257 manhours transferred to Maintenance, nor 16 man-hours transferred to Transportation during the month of March.

Fab rication work on the fifth set of mercury pots for P-10 was completed and the pots were delivered to Bldg. 108-B on schedule. A total of 59 has now beon completed. Shop work was completed on the fabrication of a hydrogen tube furnace for P-10 development work. Thts fumace is used in connection with the tempering of large Kovar pieces. Fabrication and assembly work on metal transfer system for P-10 was completed. Experimental work on the welding of titanium to tungsten was successfully accomplished. This work was part of an experiment to find intermediate welding components for the jolning of copper aild zirconium. Several small jobs were completed during the month for P-10, including special flanges, fittings for bellows and tools for punching slugs.

A number of specialty items for the P-12 Group were fabricated. Technical Shops personnel are continuing assistance in the erection of the exponential. plles. Installation of the actual "w" hole mock-up was completed. Fabrica.. tion of special parts and accessorles for this test is continuing. A number of varlations to the original " $I-Z$ " nozzie being fabricated for use in introducing wiring and small dlameter tubing into process tubes have been completed during the month. In order to expedite this fabrication work, a few Shops personnel worked two saturdays on an overtime basis.

There has been a marked increase in the demand for special apparatus for field work and special tests by the Pile Engineering Section. A number of specialty jobs were completed for this section during the month. A nine-tube mock-up was fabricated and installed in the Pile Engineering Section's mock-up area.

Installation and test work for one of the multicurie cell air hoists for Bldg.222--S was completed. Modifications and additional assembly work are being continued on the second air hoist. Fabrication and shop development work is continuing on special apparatus and handiling devices for Bldg. 222-S. A duplicate cone cart dolly for transporting samples to be processed in Junior Caves was completed.

The molding of neoprene gauntlets to bellows for the Junior Caves was successfully accomplished. Test results indicate a highly satisfactory product, and the molding will result in considerable savings to the project. The outslie cost of easi such 1tem is $\$ 57$ as against an approximate cost of $\$ 11$ in the Techrical stops.

The followirg new equipment was received and installed in the 101 Shops : One ten-inch Solth Bend Lathe; a 40 kVA Spot Welder and a 200 amp. Wilson Arc hielder for DC heliarc welding.

A large number of small jobs were completed in the Bldg. 3706 Sinop, principally in suppirt of Chemical Research, Analytical and Metullurgy Sections. Design 
and shop work was completed on a new film cassette for use in confunction with the X-ray equipment. Several multiple stirrers and remote control pipetters were conpietod for the Chemical Research and Analytical Sections. Work is nearing complestion on the assembly of a 10-place mixer settler, explosion-proof ijpe, for use in a gloved box. The majority of the design work in connection with this job done in the 3706 shop.

\section{Glass Shop}

Work volume statisites for the Glass Shop (exclusive of Pmlo service) are as follows:

February $\quad$ March

Jobs Completed

$\begin{array}{lcc}\text { New } & 56 & 51 \\ \text { Repairs } & 14 & 16 \\ \text { Revisions } & 14 & 18 \\ \text { Total } & 84 & 85 \\ \text { Job Backlog } & 10 & 16\end{array}$

At various times during the month, seven glass blowers were assigned full time to P-10 work at Bldg. 108-B. Three of these men were working shifts on pruduction linos, and the other four were rendering assistance in development work and glass IIne installation. Installation work on one glass line was completed during the month. In addition, a new I.R.D. Iine was fabricated and assembled.

It was hecessary to remove one glass blower from $\mathrm{P}-10$ production line work temporarily due to his being above the working limit for contamination.

The Glass Shop foreman suggested platinizing glass for use in the removal of product cylinders. Test results have indicated satisfactory use, and it is anticipated that this method will be made a part of the regular operation at 108-B.

The Glass Shop foreman has continued assisting the H. I. Divisions in the development and improverient of the present Vibrating Reed Chambers. The flrst test model has been delivered to 200-W Area for testing. One glass blower traince continued on assignment to the H. I. Biology Division in Bldg. 108-F.

Equipment I3sign

Work volume statistics for the Equipment Design Group, expressed in manhours, are summarized as follows:

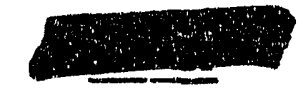




\begin{tabular}{ll} 
February & \multicolumn{2}{c}{ March } \\
Drafting & Drafting \\
\hline
\end{tabular}

P1le Technology

\begin{tabular}{|c|c|c|c|}
\hline $\begin{array}{l}\text { P-10 } \\
\text { Engineering, Section }\end{array}$ & $\begin{array}{l}32 \\
78\end{array}$ & $\begin{array}{r}35 \\
499\end{array}$ & $\begin{array}{r}16 \\
124\end{array}$ \\
\hline Physics Section & - & - & $\pi$ \\
\hline Metallungy section & 218 & - & 116 \\
\hline
\end{tabular}

Separations Tychiology

$\begin{array}{llll}\text { Chemical Resiearch Section } 189 & 105 & 164 & 43 \\ \text { Chemical Development } & & \end{array}$

Section

105

176

121

40

Techntcal Services

Engineerint Sect.

(Tech. Shops)

Analytical Sections

$28 \quad 28$

28
64

$12 \overline{2}$

104

Laboratory Equipment

$\frac{\text { Development T(EDA \#TC-5) }}{\text { Totais }} \frac{384}{1,118} \frac{387}{1,294} \frac{494}{1,147} \frac{580}{1,199}$

The following work was done for the various Technical sections, as indicated:

$\underline{P-10}$

A leak attachment fitting for a mass spectrometer was designed and a Dewar flask support was sketched.

\section{P1le Engineering}

1. Design and scoping of "M" through hole facilities continued.

2. Varlous coping studies were made and conferences held in preparation of proposals for test facilities in a 105 pile building.

3. Numerous irawlings were made or mised on such items as a strip heater, the $\mathrm{Ba}$ II 3-X clevice, a mock-up of a monoiail tube removal system, a bubble tester and various devices for pile experiments.

4. One designer continued all month on direct assignment.

Metallingy

1. Design and shop assistance continued on the slice-and-dice box, the slug breaker and the metallurgical polisher.

2. Design of an X-ray film holder was completed. 


\section{Chemical Researci}

1. Scoplne anci expediting of Junior Cave, gloved box and accessory equipment, for use in Bldg. 222-S (the Redox Analytical and Plant Assis sance iaboratory) continued. A partial shipment of gloved boxes for this bullding was received at Bldg. 101 .

2. Desigs of the tall gloved box for column use continued.

3. Various pieces of laboretory equipment were strip coated.

\section{Chemtcal Develojment}

1. Design of a fifteen-stiage batch counter current extractor continued.

2. Shop assistance was given in the construction of a miniature mixersettler desigmed at KAPL.

3. scoping and expediting of laboratory accessorles for Bldg. 222-s continued.

Analytical

1. Design and scoping of Junior Caves, gloved boxes and accessortes for Bldg. 222-S use continued. The first shipment of commercial gloved boxes was received at Bldg. $10 I$ and installation of equipment was started.

2. The assay gloved box for Bldg. 222-B was nearly completed.

3. A monoxide exhaust blower was set up for use in Bldg. 3706.

4. Drawings were made of various glass apparatus.

Laboratory Equipment Development (RDA \#TC-5)

The following work was done under this RDA:

1. Design of malticurie cell equipment continued, Development and testing of several tongs was in progress and shop assistance wa.s given in the fabrication of slare-type manipulators. These tongs and manipulators will be useful for both chemical and metallurgy cells. Tests were carried out on the :n-cell remote air hoist installed in the cell mockup. The modular pant l lifting jig was loaned to the construction forces at Bldg، 222-s for use in assembly of the cells.

2. Development of Junior Cave zccessories continued, and a recently designed tilting jaw tong was being made in the Technical Shops. it new molded neoprens manipulator gauntlet was developed in collaboration with the shops. This superior gauntlet can be molded in the Technical Shops for much less than the cost of commercial fabrication of the former model.

3. Deviopment of gloved box accessories criatinued. A new miniature 100- 
watt disc drying lamp was devised.

New Laboratory Planning

Redox Analytical and Plant Assistance Laboratory, Prof. C-187-E

Construction work on BIdg. 222-S, the Redox Analytical and Plant Assistanoe Iaboratory in the 200-W Area, is approximately 95\% complete. Based on this percentage, completion of this building is now scheduled for May 1951. Originaliy AprlI I had been planned as the occupancy date. The Inability of a subcontractor to deliver hoods on schedule is the primary cause for this delay. Other items of construction, particularly the cubicle installation, are proceeding satisfactorily.

The waste disposal facility for this new laboratory is approximately $92 \%$ complete.

Radi ochemi stry Bldg., Prof. C-381

Final plans and specifications for the Radiochemistry Bldg., one of the mafor bulldings in the new Laboratiory Area, were received from Leland $S$. Rosener on March 12. These plans were reviewed by the interested divisions and several important changes suggested. These changes were discussed with representatives of the $A-E$ on March 25-27 and are now being incorporated in the final design. It is expected that the bid assembly will be released early in April. A.E.C. Tirective HW-174, Modifisation No. 2, was received authorizing the construction of this facility, and a total project expenditure of $\$ 4,680,000$.

Plot Plan \& Utilities, Prof. C-394

The design of these facilities was estimated to be $80 \%$ complete at month end. An architectural sketch of the south gate Badge House for the Works Laboratory Area has been approved by the operating divisions. This sketch (SK 4-50060) was prepared by the E \& C Divisions, on the basis of information furnished by the Contact Engineer.

Final designs for the new parking area to be located outside the south gate are being prepared by the Leland S. Rosener Co. for review.

Radiometallurgy Bldg., Proj. C-385

Preliminary prints for this building in the new laboratory a rea were recelved and retumed to the L. S. Rosener Co. within the two weeks allowed for checking. The prints were reviewed by representatives of the Technical, Power, Safety, Maintenance and H. I. Divisions and the Contact Engineer. AlI comments were formally transmitted to the Project Engineer. The Part II Project Proposal covering the construction of this building is in preparation, with $E$ \& $C$ re-estimating the construction cost.

Mechanical Development Bldg., Proj. C-406

The Dix Steel Co. (of Spokane) broke ground for the Mechanical Development $3.1 \mathrm{dg}$. in the Works Laboratory Area, and made good progress on the 
concrete footings for this prefabricated steel structure.

The Part 2 Project Proposal covering Phase II construction of this buildIng was approved by the A \& BCormittee and forwarded to the A.E.C. Is required to assure completion of thi facility in September, A.E.C. consent was obtalned by E \& O (letter from J. E. Travis to R. E. Davison, dated March 26, 1951) for the negotiation of a Iump sum Phase II design and construction subcontract with DIx Steel. Design criterla for the Phase II interlor work are being prepared, and negotiations with $D \perp x$ can start when these criterla have been completed and revlewed by all interested parties.

The P-12 studies now being carried on in BIdg. 101 by the P1le Technology Division will be displaced in September when $E$ \& $C$ takes over the 101 Area for Project C-43I, and consideration is being given to housing P-12 in the Mechanical Development Bldg. until permanent space in the Pile Technology Bldg. becomes available. Discussions on methods of accomplishing securtty separation of this work from the main machine shop were in progress at month end.

P1le Technology Bldg., Prog. C-4.14

Many questions on detalis of piping, furniture layout, ventilation and electrical arrangements were settled in individual discussions between the Contact Engineer, E \& C personnel, and representatives of the Architect Engineer (C. T. Main Co.) during a visit to the $A-E$ offices in Bostion.

Plans were in progress at month end which would change the scope of this building profect to include excavation of that portion of the basement area previously left unexcavated. This additional space is desired by the Pile Technology Division as a permanent location for exponential pile experiments $(P-12)$ which will have to be conducted in temporary quarters after vacating Bldg. 101 early this Fall.

A request for modification of the A.E.C. Directive covering this building was submitted changing the method by which the Title III A-E services will be performed from lump sum to CPFF. This is necessary to conform with the regulations covering the administration of CPFF contracts, sinoe this A-E has been assigned other CPFF work at Hanfort.

Library \& Files BIdg., Proj. C-42I

Preliminary plans for this building were reviewed with representatives of the Chas. T. Main Co, and were accepted with minor revisions.

A modification of the $\Lambda_{\text {.E. }}$. Directive covering Title III A-E services for this building also was requested for the reasons outlined under Pile Technology Bldg., above.

Building Administration \& Services

300 irea Services

Normal Bldg. 3706 services continued routinely. Material control, stock- 
room and work order activity is summarized as follows:

\begin{tabular}{|c|c|c|}
\hline & February & March \\
\hline \multicolumn{3}{|l|}{ Purchase Requisitions } \\
\hline Total number procossed & 46 & 61 \\
\hline Number requiling special expediting & 16 & 14 \\
\hline Number requiring emergency handling & 0 & 0 \\
\hline $\begin{array}{l}\text { Stores Stock Requestg Processed } \\
\text { store Orders }\end{array}$ & 2 & 0 \\
\hline $\begin{array}{l}\text { Total number processed } \\
\text { Number requiring emergency piok-ups }\end{array}$ & 877 & 775 \\
\hline $\begin{array}{l}\text { and delfveries } \\
\text { Work Orders Processed }\end{array}$ & $\begin{array}{r}7 \\
39\end{array}$ & $\begin{array}{r}5 \\
47\end{array}$ \\
\hline
\end{tabular}

The conversion of Room 25, BIdg. 3706, from telephone service to Technical offlce space was completed March 23. Chemical Research Section and Analytical Research Section personnel started moving arrangements preparatory to occupancy.

A complete point-of-use inventory of materials and equipment controlled by this group in the 300 Area was completed during March. Transcribing to the standard forms was in progress at month end.

A work order has been issued to Maintenance for summer overhaul of the rentilating units in BIdg. 3706. This work is done routinely to maintain efficiency and prevent major breakdowns. The Health Instrument Divisions operations group in this building has been requested to check the old filters for any contamination that might have been picked up during the past year. A positive result will be considered sufficient to consider a method of control to determine time and cause for future pick-up. Past years have shown no contamination, but an increasing number of programs involving radiochemistry havo introcuced a greater potential.

A project proposal covering the design and construction of a Solvent Bullding to be located just east of Bldg. 321 in the 300 Area was prepared in cooperation with the Separations Technology and Project Eng 1neering Divisions, and was submitted to the A \& B Subcommittee on March 26. This proposed new building is designed to include (1) a laboratory for the safe conduct of process studies involving large guantities of flammable solvents, and (2) sufficient solvents storage space to meet the needs of the Technical Divisions in the 300 Area (and the stores Division, when their Caption 10 Stores are moved from the 700 Area to the 300 Area).

Efforts continued to obtain G. E. and A.E.C. Security office agreement to the use of a "Limited" status for all buildings within the present 3706-321 Exclusion Area. Answers to specific A.E.C. questions in this connection were forwarded to G. E. Security on March 27. 
Technical Bervices Division

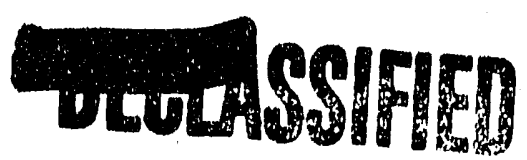

HW-20671-Lel

STATISTICAL \& COMPUTING SERVICES

Statistical Services

Further study of the exchange of uranium samples between Hanford and the Mallinckrodt Chemical Works at St. Louls revealed that systematic differences in chemical analysis were not due to sampling. At the request of the General Chemical Laboratory, the precisions of uranium bililet egg analyses made at Hanford were calculated (Doc. HW-20481).

The statistical study of the effect of aluminum cans from different vendors on the reactivity of canned uranium slugs was continued.

A mathematical equation was obtained statistically for the Metallurgy Section's use in relating the expansion of exposed alpha rolled uranium slugs to the indices of crystal orientation (Doc. HW-20557). Additional metallurgical data were analyzed from the statistically designed experiment to determine the structural operating limits on the dilatometric testing of canned uranium slugs.

A study of the frequency of autoclave failures by time of day and by canning lines was made for the 300 Area Plant Assistance Group. Statistical controls were reported on $P$ Division operational results from Machining, Plckling, Canning and Autoclave, Test Pile, and Melt Plant.

At the request of the 100 Area P1le Engineering Group, a statistical study was begun of the panellit readings for the H-10 loading to see if the mupture of P-10 Iithium-aluminum alloy slugs can be predicted and prevented.

Additional I.B.M. calculations were completed in connection with the statistical fitting of a decay curve to data from the $105-\mathrm{B}$ pile extended shut.down in December 1944.

Based upon relationships obtained to date, calculations have been made of the expected bowing of the 105-D pile at varlous exposure levels. Results are being discussed with the Pile Engineering Section and the Theoretical Physics Group.

A statistical study made in 1946 of water quality in oonnection with pile operation is beirg reviewed as a potential source of help to the Pile Engineering Section in planning the proposed new study of factors pertaining to water quality.

An attempt was made by the Analytical yections to obtain a Iinear isotope correction equation by statistical methods (F. W. Albaugh, Doc. HW-20330, and D. F. Thepard, Doc. HW-20581). The data used consisted of (1) the ratio of chemlcal assay to radioassay of Building 231 final product solution ( $\mathrm{CA} / \mathrm{RA}$ ), and (2) the ratio of total plutonium counts to tons of uranium (TPC/TU). Certain discrepancles in these data were observed by the Analytical Sections in that the statistically fitted equation obtained did not represent the majority of the data. It was concluded that the starting is otope composition (TPC/TJ) was at fault. 
Since there was some difference of opinton as to the cause of the statistical discrepanctes observed in this important S. F. accountabllity correction factor data, the Statistics Group made an extensi ve study of all data avallable. To test the hypothesis that the staxting 1sotope oorreotion was at fault, the data were grouped so that each group oontal ned only muns from the same metal solution. In this way any varlation due to error in estimation of starting 1sotope oompogition could be subatantlaliy removed, making it posstble to 1solate and measure the varlations caused by errors in the chemical assay-radioassay ratio. The varlation in CA/RA ratio when grouped according to the same starting metal solution was identical with the variation of ungrouped data for $T$ plant runs, and was very nearly identical for $B$ plant runs. This indicated that the discrepancles were che to chemical assay-radioassay ratio data.

A further study of data during an elght week perlod when the enrtohment level of the runs from both $T$ and $B$ plant were relatively stable, revealed a highly significant correlation between the varlations in chemical assay-radioassay ratio of $B$ plant and $T$ plant mins. This was further evidence that the ohemical assay-radioassay ratio varled significantly from time to time in a way that was unrelated to isotopic composition.

From this statistical study It was concluded that the chemical assay-radioassay ratio has not been sufficiently rellable to provide the data necessary to obtain a preclse statistically derlved equation. Further statistical studies of this problem are in progress.

Components of error in the sampling and assay of E-LRC samples were estimated from data provlded by a special test.

A complete list of range limits recommended for use in 200 A rea control laboratories for checking radioassays was forwarded to the Analytical Service section.

Monthly reports of Henford-Los Alamos produ ct measurement differences, ATSpecific Gravity relationship diferences, and 200 Area control laboratory rernuns were ls sued.

\section{Computing Services}

Further computations were made of expected H-10 discharge schedule.

In support of the Exponential. Plie Project (P-12), four sets of data were fitted to a three term cosine series, nineteen sets of data were processed for determination of diffusion length, and a short table of cosine values was prepared.

A preliminary investigation of the pile "boiling disease" problem has been made. It appears that this calculation can be done by machine, through an interative process. The steam table and viscosity data will be represented by empirical equations.

A table of constants for rapid computation of xenon in the field was prepared for 200 inhours of f'lattening for powers of 0 (25) 200 (10 250 (5) $550 \mathrm{MW}$. 
$550^{\circ} \mathrm{MW}$.

\section{DECLSSSFIED}

Graphite calculations are now being run on data from the 105-D p1le as we.L]. as from 105-HI and 105-F.

Routline caloulationg were made on Aquat10 Blology data for the Health Instrument Divisions, and on motal quality data in connection wi th a statistioal study.

Detailed programing was begun on the skeep thyroid oount data for the Zoology Group.

A tabulator control panel was wired to print temperature maps on standard forms from cards processed on the I. B.M. punches at 105-H and 105-DR. other quantities such as tube power oan be printed on the map, if desired.

Control panels were developed for progressive digiting on the tabulator to obtain sums, sums of squares, and sums of cross products required in statistioal studies. This 18 a very flast procedure capable of processing 1000 observations on elght varlables, ugling flve diglts in each varlable, fin less than flve hours.

A new general board was wired to acoommodate 10 diglt chanmels. This will allow faster solution of simultaneous equations, greater acouracy on serieg of al ternating signs where the early terms are large, and will allow more freedom in programing problems where the order of magnitude of the function varies.

The baok Iag of problems continues to increase at a rapid rate.

\section{IIBRARY, FILES AND CENTRA I REPORTING SERVICE}

\section{Plant Library}

Library work volume and book statisties were as follows:

Number of books on order recelved

Number of books fully cataloged

Number of bound pertodicals processed but not fully cataloged

Pamphlets added to the pamphlet flie

Miscellaneous material received, processed and routed (Including maps, photostiats, patents, otc.)

Books and periodicals clrculatod

Unclassiflad reports processed

Uruclassif1ed reports ciroulated

Reference services rendered

$\begin{array}{rr}\text { February } & \text { March } \\ 184 & 239 \\ 178 & 193 \\ 4 & 6 \\ 21 . & 141 \\ & \\ 81 . & 66 \\ 3,519 & 3,1.97 \\ 92 & 229 \\ 284 & 160 \\ 1,794 & 1,805\end{array}$

Main Library W-10 Branch 208-F Branch Total

Number of books
Number of bound periodivalo

$$
6,970
$$

4,188

2,909

0
285

531.
10,164

4,719 
Work in the plant Llbrary proceeded on a routine bas 1s, with the number of referenoe services contlnuting to cilinb teadily. A sampling of the ques. tions anowered is liated below, indleating wide we of the Itbrary referenoe resources by all Diviolons at Hanford,

Data on preseure drop (of watex) through 22 mesh soreen plaoed in a plpe. solution for oliver plating whloh do not use oyantde.

Sag and tenetion curves for $1-0$ and $4-0$ oopper wire.

Artioles on how to determine researoh oosts; when to stop spending money on a profect, eto.

Address of the Ingram Co., The Fexf1.1m Co., eto.

Sohematio diagrame for surplus Signal Corps radio set No. SCR-69. Analog oomputers of mass speotrograph data for multi-componeritg.

Aboorbling oapaolty and temporature range for best results with Amberl tite Lon exchang $₫$ r.

Composition of Duponal N.E. Dry.

Deteotion and determination of thortum in soll.

Caloulation of heat loeser in underground plpo.

Comparative costs, regeneration, and effeotivenegs of varlous drytng agents.

Composition and method of removal of Inhlbitor from methyl methaorylate monomer.

Basto prinolplas and methods used in Loniation deteotion.

Information on construction of screw oonveyors.

An older bibliography on industrlal management and problems of supervision was rovised to ref'leot the Iftrary's ourrent book holderigs f.n these f'lelds. Coples of the earlier edition of this bibllography have been distributed routinely to plant personnel taking the 40-Hour Supervisorg Tralning Course. Consideration is currently belng glven to plant.wide distribution of this booklist to supervisors.

H. W. Instructions Lattar No. 31, which ordglnally establishad (2947) a centralized control of Plant reference material through the Plant Iibrary, was revised. Draft coples were olroulated to Plant supervisi on direotly affected for review and conment before final ls suance. Revision of this Instructions Letter has also necessitated reviston of the "Requesti for" Library Procurement". form. The revised form ts receiving careful study in order that it may be as useful. a possible.

Arrangements have been completed with the Procurament Section of the A.E.C. to excess surplus coples of library perlodicals for oredit. Inasmuch as lengthy route lists for many technical perlodicals make tt nocessary for the Itbrary to oarry added subscriptions, excessing of coples beyond bindery requirements may prove very advantageous.

\section{Classtified F11es}

Wrork volume statistics for the clnssiffod Flles were as follows:

$\begin{array}{lrrr} & \text { February } & \text { Maroh } \\ \text { Doouments routed } & & \\ \text { Documents is sued } & 9,460 & 1.1,843 \\ \text { Reference services rendered } & 5,251 & 6,790 \\ & 4,425 & 4,360\end{array}$




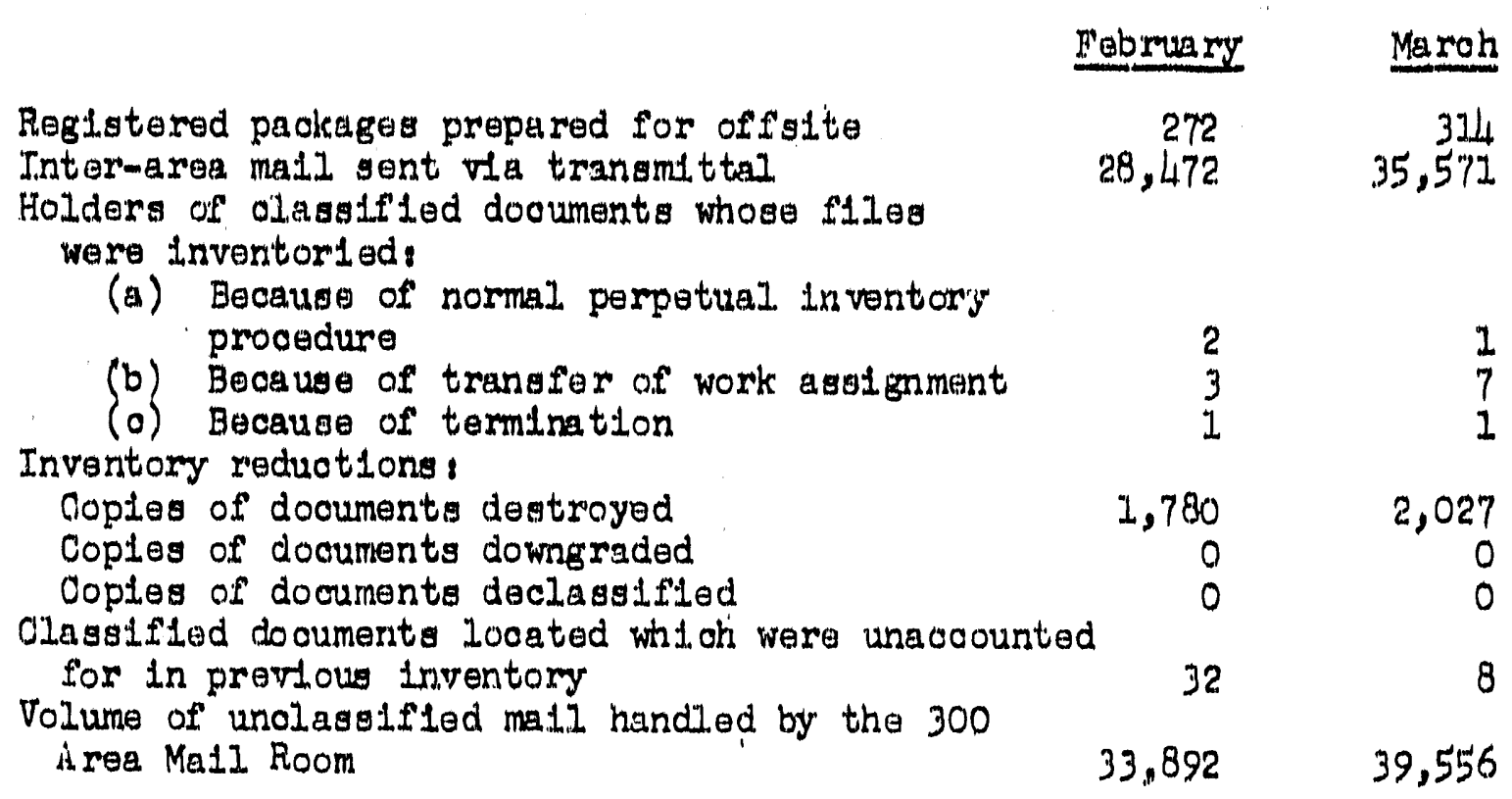

The inventory of claselfled doouments is proceeding on sohedisle. The physical Inveritory of the E \& C F1Les has now been oompleted, and the cheak of the results agalnst the basio file record cards is underway. In the 700 Area olassifled Files, the lnventory of the subject flle lo now completed and the 1nventory of the numeriogl. flle ls well started. In the 300 Area Classified Files, priforlty hes been git ven to the Inventory of the olassifled resenrch and development reports. The physloal 1nventory ias been completed and the inventory summary $1 \mathrm{~s}$ golng forward rapldiy in order to meet the June deadline egtabl.l.shed by cam-176.

Considerable time was expended on matters in conriection with the reviston of the A.E.C. Standard Distribution Ilst (M-3679) planmed for April 15, 1951. The Atomito Energy Commisgion vuggested reviston of the present MHealth and Blology" oategory into two new oategories, one concerned with reports on plant and animal experimentations where interpretations leading to porsonnel protective mensures were not Inoluded, and the other conoerned wi.th reports on personnel decontamination, personnel protective measures, operating prooedures for radionotive areas, and research and development reports relating direotily to the development of such procedures. The proposed revision, roughly paralleling the divi sion of reaponsiblilty within the H. I. Divisions, was approved for Henford with minor changes.

A second revisiton suggested by the A.E.C. Involved the elimination of the categorios "Technology-Uranium" and "Technology-Iranium Compounds, "redefinition of the oategory "Metallurgy and Cermincs, and the establishment of" a new category "Techrology-Feed Materlals" fow roports on tha preparation of larege soale amounts of urantum and lts compounds. In effect, the proposal suggested a division of the reports on uranium technology into those concerned with the derlvation of the metal from the ore, and those concemed with fts subsequent treatmont, This suggested revision was glso acoepted for Hanford with minor changes.

These changes, plus the revision of the category "Reactors" mentitoned In tho February report, involved the dovelopment of new distribution lists. Hanford 
Worke copy requlrements for the dffferent oategorles and for unolagsifted reports was reviewod and gubmitted to the Atomio nerey Commiselon. Wherever posatble, copy requitraments were lowered din order to reduce alasalfled dooument acoountablilty problems.

Plant personnel were notlfied of a speclal A.E.C. gubeldized supplement to the Journal of the Amerloan Ohemloal Boclety. Thlo 1 ssue wili be devoted to papers on the symthesis of labeled compounds, and on speotal techntques of lootope work such as 1sotope d1ssolutlon analysls, paper chromotography, eto. It is hoped that this arrangement w11. secure publioation of a large number of unpublished paperg on these subjeots orlginated with in the Commlsolon's activities. Hanford origlnated reports sultable for inolusion were solicited.

In this connection, the A.Q.0. Joint Conference on Document Control, held In Chicago on Maroh 15 and 16, deolded to expand the requiraments of $0 M-176$ to Include the Inventory of CONFIDENTIAL as well as SECRET research and development reports. Confirmation of this declaion, which wes antiolpated and provldod for in the Hanford Inventory procedure, is expented shortly from the Atomio Energy Commisalon. The Chicago meeting also brought out the fact that olght major A.E.C. Ingtallations are taking complete inventory of olassifiled documents as is belng done at Hanford.

The Sentor Responsible Reviewers met at Hanf'ord, March 9 and 10. The Chitef Ltbrartan accompanted them on a tour of the outer Areas, and attended the subsequent meeting. Where local problems of olassification and declassifioation were discussed. This meetlne highlighted agaln the cur rent Hanford practioe of applying the same Securdty controls to both CONFIDENIAI and SECRET reports. Since this practioe lo not profect wide, a study $1 \mathrm{~s}$ belng undertiken to develop the volume of CONFIDENIIAL material handled at other installations, and the procedures used to control it.

The fourth edition of CA-1927 (Bubject Headings To Be issed For the Irdexing of Technical Reports) was recelved. This adition, which now comm prises some 300 pages of detalled subject headings, is presumably the last complate revision of this document. Previous reports have indicated Hanford's contribution to this document. Baslcalily, the new edition incor porates a change from the Indsrect entry form, previously used for subleot headings, to the direct entry form. This change is lin line with the most advanced thinking on moderm lndexdng problems. The subject headings are now arranged in a stralght alphabet1cal flle, and the numbering system uged in previous editions has been abandoned. The looseleaf format used wLIl simplify the problem of future additions, deletions, partial revisions, etc. A plan is presentiy under considerntion for a meeting of abatraoters and indexers from the vartous $\Lambda$. E.C. Instalizations to discuss the application of the new edition to the revision of the classified reports index.

A number of meatings were held throughout the month on various problems on classifiud document accountability and control. A meeting of personnel from the A.E.C. Securl ty Blvision, General Electric Securtty Division, and Classified Files was held regarding an improved procedure for the handiling of classifled photographo. 
B. R. Prentioe met with personnel from the E \& 0 Classifled Flies, the Operations Olassifled Flies, and the Reprodustion Seotion, to firm up the transmittal of olassifled doouments between the Nucloonlos offioe and the General Ingineexing Laboratory in Soheneotady, and the Flles units at Hunford. Plans were complated to treat the Sohenectacty Offlce Hilo as a branoh of the Hanford Classifled Flles, wh th lood acoountability for all olassifled doouments transmitted there. Accountablilty for classifled dooumerts prevlously charged directly to scheneotady off 100 personnel from the varlous Hanford flies will be trangferred to the Schenectady Offloe Fllo. Steps are underway to establish slmlar centrelized control of alassifled doouments losued and recelved by the Ceneral Englneering Laboratory.

During hig visit to Hanford, personnel from the A.E.C. Operations office, A.E.C. Securlty, and Classtified Files met w1 th B. M. Fry, ChLef Librarian, Teohnical Information Servioe, Washington, D. O., on problems of classified document acoountablilty.

Personnel from Operations and E \& C Classified Files, and the Reproduction Section, met with the Hanford Works Sub-Committee of the Nucle onios Hecords Committee to discuss the inventory of Job 11 olassifled doouments in the possession of the Kellex Corporation in New York. It was agreed that the E \& O Classified Flles, the Reproduction Section, and the Records Control Division would handle the planned spot-cheok Inventory prior to transfer of accountablilty for elassifled documents and blueprints to Hanford as discussed in the Febmary report. It was furthor agreed that a complete inventory of this material was unnecessary, inasmuch as the accountablilty was to be re-transferred to Kellex on the basis of the Inventory Ilst submitted by Kellex. Thus, any errors appearing in the Iists would ultimately become a Kellex responsibility.

A portion of the new Records Center has been screened off for the exolugl ve use of the classified Files. It is planned to retire immediately all classified notebooks, and an acoumulntion (from August 1946) of s sertes run books progently stored in a vault in the 271-T Bldg. Plans have been made to expedite the program of classifled document retirement, supplementIng the present aotive destmation progrem which is steadily reducing the site document accountability.

Contral Reporting Service

Work volume statistics for this Unit were as follows:

\begin{tabular}{lrr} 
& February & Maroh \\
\cline { 2 - 3 } & 673 & 510 \\
Mitto masters run & 863 & 620 \\
Ditto coples prepared & 24,747 & 18,587 \\
Mimeograph copies prepared & 87,293 & 53,525 \\
Fornal Research and Development Reports issued & 10 & 11 \\
Reports abstiraoted & 357 & 475
\end{tabular}

Operations and services proceeded routinely. 
Technical Services Division

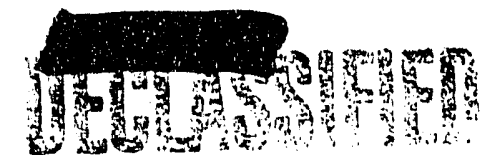

HH-2067I-Del

\section{INVITIONS}

A.1 Techical Services Division personnel engaged in work that might reasonably be expected to result in inventions or discoveries advise that, to the best of their knowledge and belief, no inventions or discoveries were made in the course of their work during March 1951. Such persons further advise that, for the perlod therein covered by this report, notebook records, if any, kept in the course of their, work have been examined for possible inventions or discovertes.

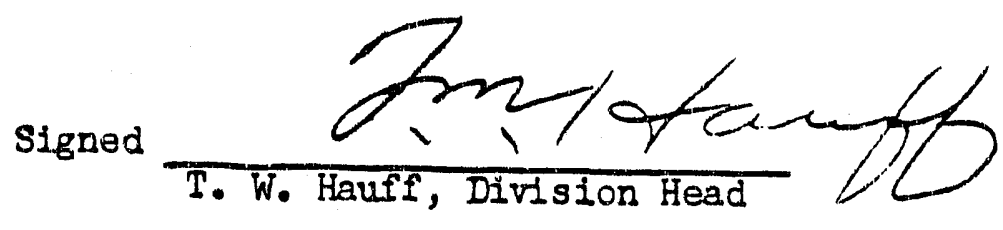

TWH : mcs 
YQEJJTCAL TITISIONS

MARCH 1951

Ceneril

Personnel Changes

The roll decreased from 288 to 282 .

Ceneral

An epidemic of influenza which reached a peak during the month has almost ended. It influenced all phases of medical activity. About $15 \%$ of the population was involved acoording to a rough estimate.

Tisits

The operating room supervisor attended a 5 day institute on Operating Room Techniques at Santa Monica, California for one week.

Dr. Herman Smith, consultant on the Kadlec Hospital construction program, was here on March 10 and 11.

Miss C. Kinney, University of Washington School of Nursing, visited the division of Fublic Health.

Industrial

imployee physical examinations increased from 2346 to 2817 . Dispensary treatments increased from 7994 to 9161 largely due to a high incidence of influenza among employees.

New equipment for the more scientific testing of hearing and seeing woo obtained and will greatly improve these phases of employee physical examinations. Four major and 14 sub-major injuries were treated as compared to 5 major and 3 sub-majors for the previous month. No major and four sub-major injuries were sustained by $G$. E. employees.

An $S$ division employee inhaled a very small amount of plutonium and was treated to ircrease the rate of elimination from the boty. The extent of plutonium left in the system can only be estimated with fair degree of accuracy after the lapse of several months.

Cancer was the health topic for the month.

Sickness absenteeism (weekly employees) for March increased by $1.49 \%$ to $3.92 \%$

while total absenteeism incroased by $1.61 \%$ to $4.65 \%$. This is the highest monthly rate of sickness absenteeism since the beginnine of operations here and was due to the epidemic of influenza, S1ckness absenteeism (monthly employees) for February increased by $.22 \%$ to $1.32 \%$, while total absenteeism increased by $.36 \%$ to $1.82 \%$. The March date is not available yet.

Kadlec Hospital

The average daily census increased from 102.3 to 112.0 (97.7 adults, 14.3 infants). The census was 36.4 a year ago. This is the hi.ghest infant census ever recorded at Kadlec, 90 deliveries being made. Daily adult census: Maximun 113, Minimum 76.

The high adult census was partially due to the epidemic of influenza. The adult occupancy rate was 9 li.9\%. The rate for the mixed serrices (all services except obstetrics) was 100\%. The very high occupancy rates for the past several months indicite a need for more adult bids at hadlec. A modification of the scope of pro. ct $r-20 \mathrm{~L} A, 3$ is b. ing raquested to allow for adding more bed spar. at radlec with thatever iunds remain after completion of the project in its prescni scope. Dr. Jurman jmith, our hospital consultant concurs in this recomnendiation. Nursing hours per patient day were 2.76 for the mixed servict and 3.06 for obstetrics. This is lower than that required for good service and was occasioned by an unexpectedly heavy patient load coupled with a high nurse turnover rate. 


\section{MEDICAL DIVISIONS}

MARCH 1951

General (Continued)

Fubiic Health

A sudden Fise in an upper respiratory type of infection was experienced. From a check of school absenteeism it was estimated that approximately $15 \%$ of the population was effected. Blood tests indicated that many of these infections were due to Influenza - Type A prime.

Measles showed a sharp increase. The division arranged for a regional meeting of the Washington State Public Health Association, w1th about 64 local and out of town people in attendance. This was the first regional meeting of this type to be held in this state and recelved commendation from the state organization.

Costs (February)

Medical Divisions' operating costs, before assessments to other divisions, were as follows:

Industrial Medicine (Oper. Div.)

Public Health

Kadlec Hospital (net)

Hospital assessments to other divisions and workmen's compensation

Subtotal - Operations - Medical Divisions

Construction Medical (Industrial R Public Health)

Total Operations and Construction

\begin{tabular}{|c|c|c|}
\hline January & February & $\begin{array}{l}\text { February } \\
\text { Budget }\end{array}$ \\
\hline $\begin{array}{l}41,401 \\
11,072 \\
24,204\end{array}$ & $\begin{array}{l}36,680 \\
10,352 \\
21,531\end{array}$ & $\begin{array}{l}\$ 40,674 \\
11,070 \\
21,959\end{array}$ \\
\hline$\frac{3,056}{79,733}$ & $\frac{2,4,46}{71,009}$ & $\frac{3,208}{76,911}$ \\
\hline$\frac{12,085}{91,818}$ & $\frac{11,406}{82,415}$ & $\frac{13,380}{90,291}$ \\
\hline
\end{tabular}

The net cost of operating the Medical Divisions, before assessments to other divisions was $\$ 82,475$, a decrease of $\$ 9,403$ and $\$ 7,876$ below the budget fierure.

The improvement resulted in large part from the (1) lower salary costs due to the shorter month, (2) decrease in transferred charges from other divisions which more than offset (a) lower assessments to other divisions and (b) a small decrease in revenue. The revenue was high because of a higher average hospital census than was anticipated. 
MEDICAL DIVISIONS

MARCH 1951

Incustrial Medical Division

Cenera?

Physical examinations increased from 2346 in February to 2817 in March.

Dispensary treatments increased also from 7894 to 9161 . Subcontractor employees sustained 4 major injuries and 10 sub-major injuries. Ceneral blectric employees sustained 4 sub-major infuries

Dr. Eckles attended Department of Labor hearings during the month and gave medtcal testimony.

New equipment for testing vision was obtained and training of personnel to perform these tests is underway.

The industrial physicians scientiflc meeting dealt with a discussion on plant and civilian defense.

The Chemical Hazards Committee met on March 29 and the findings of the survey made on metal cutting operations at the White Bluff's shops were discussed. Continued study is being made on the chemicals to be used in the Redox process.

The Health Activities Committee met on March 21st. The Health Topic on "cancer" was presented. Material on this subject was prepared for distribution to all employees. Work is being done to make the representation on this committee more effective divisionwise.

Absenteeism (weekly employees) due to all causes increased by $1.61 \%$ to $4.65 \%$, while absenteeism due to sickness increased 1.49\% to 3.92\%. Absenteej.sm (monthly employees) due to all causes increased by . $36 \%$ to $3.92 \%$, while absenteeism due to sickness increased .22\% to $1.32 \%$.

Medical treatment was given to one employee who inhalcd plutonium in dry powder form. Estimation of amounts is not yet complete but it is believed that the amount deposited will be under tolerance. Treatment was directed at increased excretion.

The net cost of operations decreased $\$ 4543$ as compared with the previous month. This was due chiefly to a shorter month, and decreased charges from othor divisions.

Industrial Medical Costs:

Administration

Household \& Property

Frofessional Services

Total Direct Expense

Accrual for Public Liability Claims

Transferred from Other Divisions

Less: Ruvenue Workmen's Compensation

Net Cost of Operation

Increase
or (Decrease)
over
Previous
Nurth
$\frac{(961)}{(199)}$
$(1254)$
$(3414)$
0
$(1229)$
78
$(179)$
$(4543)$

February

Budget

$\frac{\text { January }}{\$ 460}$

2606

24391

35957

150

5913

619

642

40759
8937

1300

26250

364.87

5130

943

700

39974 
Physical Bxaminations

Operations

Pre-employment .......................

Rehire..............................

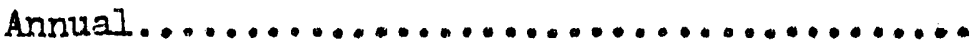

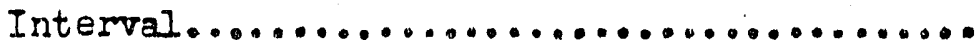

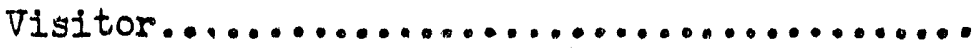

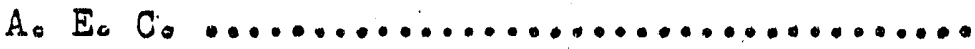

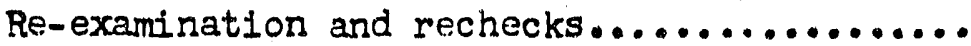

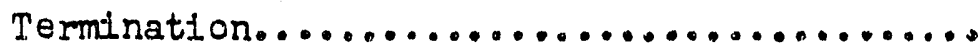

sub-total................

Sub-contractors

Fre-employment.........................

Rehire...............................

Recheck...............................

Termination \& Transfer..................n.

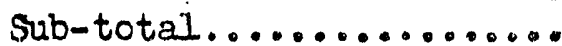

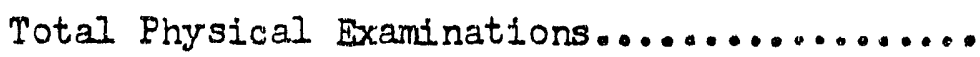

Iaboratory Examinations

Clinical Laboratory

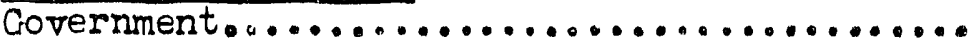

Pre-employment, termination, transfer........

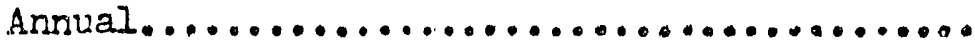

Recheck (trea).........................

Flrst Aid...............................

Clinic..............................."

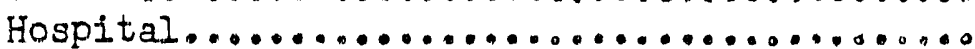

Public Health.............................

Total..................

$x$ - Ray

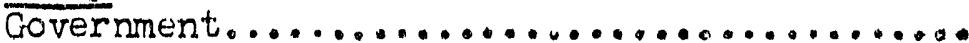

Pre-employment, termination, transfer........

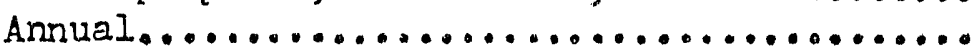

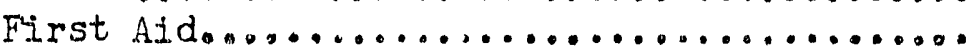

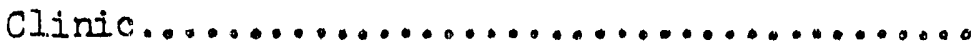

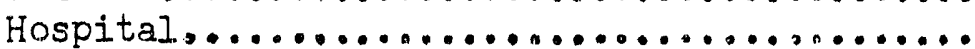

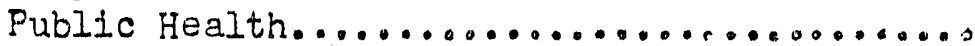

Total.................

Electrocardiographs

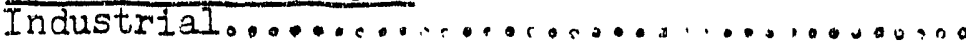

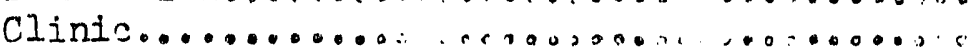

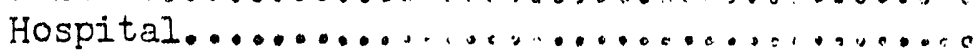

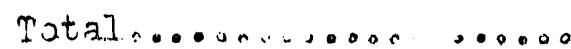

Alergy

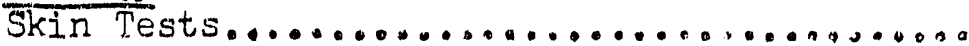

February March Year to date

761

232

85

186

.1138

231

1

25

88

142

1118

797

2

412

439

38.16

$322 \quad 344$

1073

1070

268

1673

1238

2346

$\frac{684}{1462}$

2817

4084

7900

88

5725

1617

1216

23

2804

4820

$\frac{14}{15307}$

91

209

19490

1681

1693

19

3131.

4888

20

$\overline{1.8090}$

5898

4147

49

9043

14121

53032

11

14

28

921.

1.017

112

170

141

250

$23 L$

$\frac{11}{1903}$

2.50

338

$\frac{6}{1907}$

3230

1101

471

742

806

$\frac{32}{6410}$

\begin{tabular}{rr}
20 & 25 \\
6 & 2 \\
25 & 33 \\
\hline 51 & 60
\end{tabular}

93

12

$\frac{94}{199}$

1

11 
MARCH 1951

Flrst Aid Treatments

Operations

New Occupational Cases.................... Occupational Case Retreatments............... Non-occupational Treatments............... sub-total.

Construction

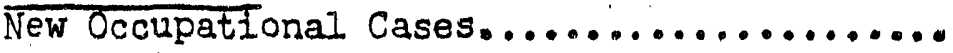
Occupational Case Retreatments............... Non-occupational Treatments................ Sub-total...............

Facility Operators...................... Total First Aid Treatments.

Major Infuries

General Electric........................ Sub-contractors.

\section{Total.}

Sub-major Injuries

Ceneral Electric...

Sub-cont ractors.

\section{Total.}

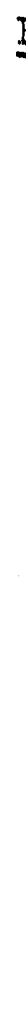

\begin{tabular}{|c|c|c|}
\hline bruary & March & Year to Dat \\
\hline $\begin{array}{r}275 \\
880 \\
2662\end{array}$ & $\begin{array}{r}230 \\
711 \\
3473\end{array}$ & $\begin{array}{r}836 \\
2664 \\
8973\end{array}$ \\
\hline 3817 & $4 \longdiv { 4 1 4 }$ & $\overline{12473}$ \\
\hline $\begin{array}{r}644 \\
2472 \\
945\end{array}$ & $\begin{array}{r}735 \\
2680 \\
1305\end{array}$ & $\begin{array}{l}2068 \\
7579 \\
3058\end{array}$ \\
\hline $\begin{array}{r}4061 \\
16 \\
7894\end{array}$ & $\begin{array}{r}4720 \\
27 \\
9161\end{array}$ & $\begin{array}{r}12705 \\
88 \\
25266\end{array}$ \\
\hline
\end{tabular}

Absenteeism Report - Weekly Employees
No. days absent due to
Male Female all causes............. $4707 \quad 2353$

$\begin{array}{ll}0 & 0 \\ \frac{5}{5} & \frac{4}{4}\end{array}$

$\frac{11}{15}$

$\begin{array}{lrr}1 & 4 & 5 \\ \frac{7}{8} & \frac{10}{14} & \frac{30}{35}\end{array}$

No. days absent due to sickness only $000000 \quad 3899 \quad 2059$

Percent

Total Absenteeism

Comparison with

Frevious Month

$4.65 \%$

$1.61 \%$ more

$3.92 \%$

Avg. days absent due to sickness by each male employee................,86 day or 860 days/1,000 employees Avg. days absent due to sickness

by each female employee.................31 days or 1,310 days/1,000 employeer. Avg. days absent due to sickness by all employees...................98 day or 980 days/1, 000 employees

Comparison of present year-to-date total absenteeism figure with the 1950 figure shows an increase of $.85 \%$

lbsenteeism (Weekly Employees) by Divisions:

Municipal, Real Estate is Generil Service............3.96\%

Empiloyee $\&$ comminity $R_{t}$ ations.......................11\%

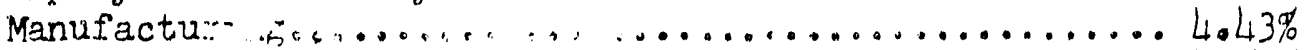
Plant secu. ty e services........................51\%

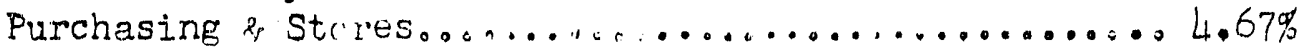

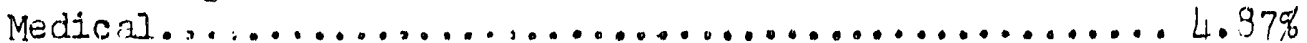
Engineering \& Constmuction...........................

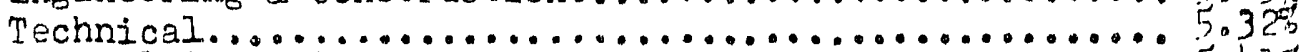

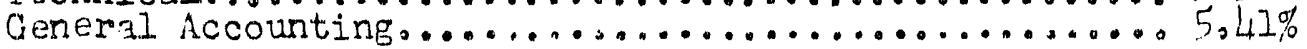

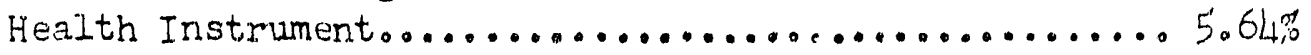




\section{MEDICAL DIVISIONS}

MARCH 1951

Absenteeism Report - Monthly Employees:

No. days absent due to

Male Female Total

all causes..............

No. days absent due to

stckmess only......... 493

683

25

Total

$1.82 \%$

Previous Month.

Avg. days absent due to sickness

by each male employee..............26 day or 260 days $/ 1,000$ employees

Avg. days absent due to sickness

by each female employee............39 day or 390 days/1,000 employees

Avg. days absent due to sickness

by all employees...............27 day or 270 days/I,000 employees

ibsenteeism (Monthly Employees) by Divisions:

Employee \& Community Relations................... .42\%

Municipal, Real Estate \& Cenexal Services.......... 1.08\%

Purchasing \& stores........................... 1.18\%

Design \& Construction....................... 1.62\%

General Administrative..................... 1.82\%

Manufacturing........................... 1.87\%

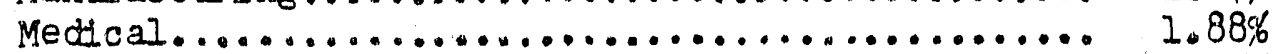

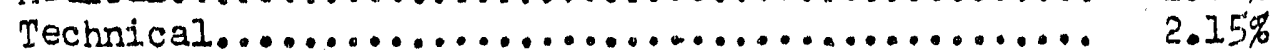

Plant Security \& Services................... 2.3I\%

Health Inst mument........................ $2.31 \%$

General Accounting........................40\%

Absenteeism Investigation

Total No. calls requested................

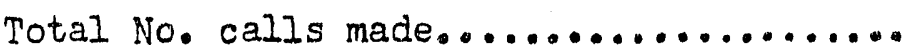

F

No. not at home when call was made.........

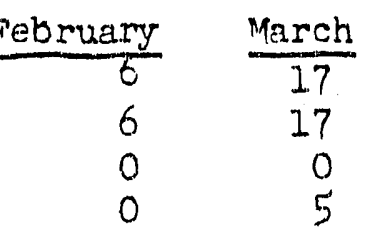

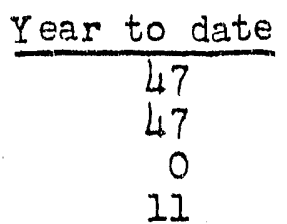


MEDICII DIVISIONS

MARCH 1951

Hospttal Division

General

The average daily adult hospital census 1ncreased f'rom 90.7 to 97.7 , as compared to 76.6 a year ago. This represents an occupancy percentage of $94.9 \%$ broken down as follows: Mixed Service (Medical, Surgical, Pediatrics) - 100.0\%; Obstetrical Service - 71.5\%. The minimun and maximum datly census during the month ranged as follows:

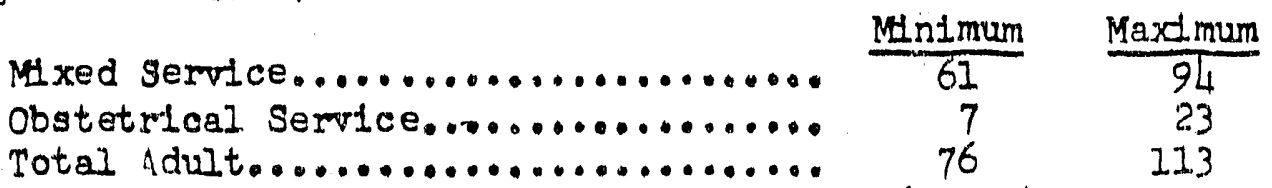

The average daily newborn census increased from 11.6 to 14.3 , as compared to 9.8 a year ago.

Nursing hours per patient per day,

Medical, Surgical, Pediatrics........ 2.76

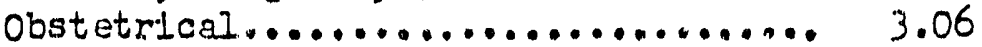

These nursing hours are lower than we intend to provide and they have resulted primarily from a combination of an unusual increase in census and the lag between requesting additional personnel and actually receiving them for duty.

The ratio of hospital employees to patients (excluding newborn) for the month of February was 1.65. When newborn are included, the ratio is 1.46.

The net expense of the Richland community medical program for Febmary, 1951 was $\$ 21,531$, as cempared to $\$ 24,204$. for January. Summary is as follows: Kadlec Hospital net expense

This is a decrease of approximately $\$ 2600$ as compared to

January. It results from a reduction in salary cost of about \$2100. and a reduction in transferred charges from other divisions of approximately \$2.200, Professional. supplies and costs decreased about 1000 ., but this was offset by a corresponding increase in payments for food and household \& property supplies. Cost reductions came about from a shorter working month. These reductions were partialiy off'set by a reduced revenue of about $\$ 1100$ and a $\$ 600$ decrease in assessments to other divisions, also from the shorter month.

No charges are made against the clinj.c because the clinic medical records work has been completed.

Miss Ruth Bridges, $R_{0} N$, attended an Institute on Operating Room Techniques from March 19 through 24. It was held at St. Joscph's Hospital, Santa Monica, California under the ouspices of te Dupartment of Surgery, School of Medicine, University of Califo:".iz.

Mr. M. J. Smith and Mr. O, E. Eakko coml leted thuir survey of hospitals in Washington and Oregoil. The data obtaincd are in the process of being summarized. 


\section{MEDIC.L DIVISIONS}

\section{MARCH 1951.}

Hospital Divison

\section{Cerseral (Continued)}

Mr. W. T. Pope, Assistant to the Manager, resigned on March 15 to accept a position elsewhere. He was succeeded by Mr. O. H. Bakko who in turn is being assisted by Mr. E. J. Quigloy. Mr. Julgley spends part of his time as Supervisor of Industrial Nursing and part of the time as assistant in personnel, maintenance and general hospital administrative work.

Dr. Herman Smith, consultant on the medical program of the Medical Divisions, visited Kadlec Hospital on the weekend of March 10 and 11. He recommended that additional beds be provided with whatever amount of money was determined left over from the present construction program and the total approved appropriation. Necessary action is being taken to follow up this recommendation.

Kadlec Hospital

Average Dajly Adult Census...................

Medical.............................

Surgleal $\ldots \ldots \ldots \ldots \ldots \ldots \ldots \ldots \ldots \ldots \ldots \ldots \ldots \ldots$

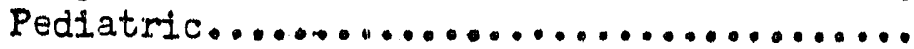

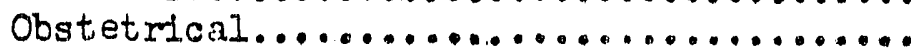

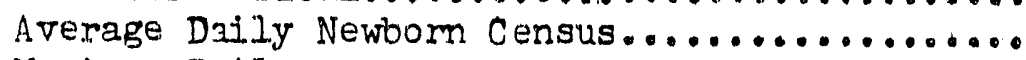

Maximum Daliy rensus:

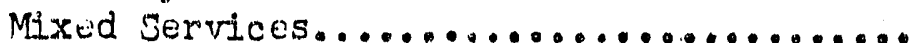

Obstetrical Service.......................

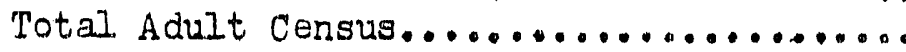

Minimum Daily Census:

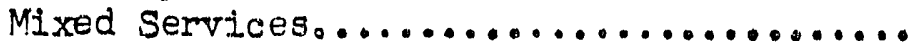

Obstetrical Service..................

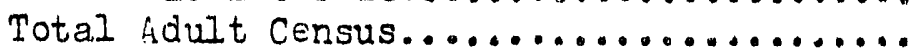

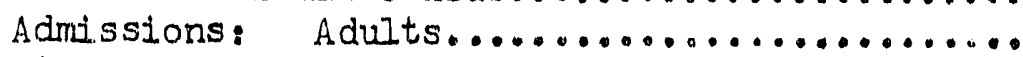

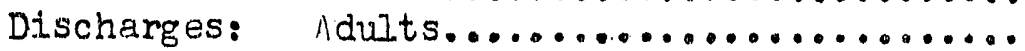

Newborn......................

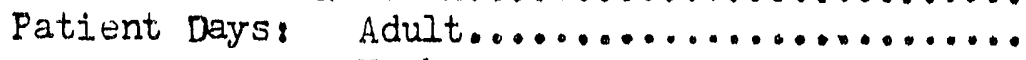

Newborn. ...................

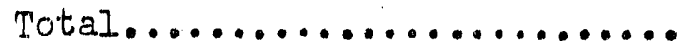

iverage Iength of Stay Adults..............

Newborn............

Occupancy Percentage:

Adults................

Newborm...............

(Occupancy Percentage based on 103 adult

beds and 14 bassinets.)

Avg. Nursing Hours per Patient Day:

Medical, Surgical, Pediatrics............

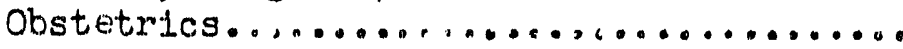

Avg. No. Employees r r Fationt

(excluding new, , r $\left.r_{1}\right) \ldots \ldots \ldots \ldots \ldots \ldots \ldots$

operations:

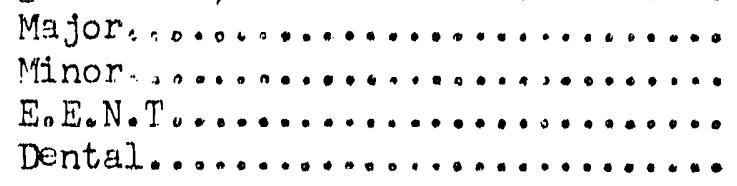

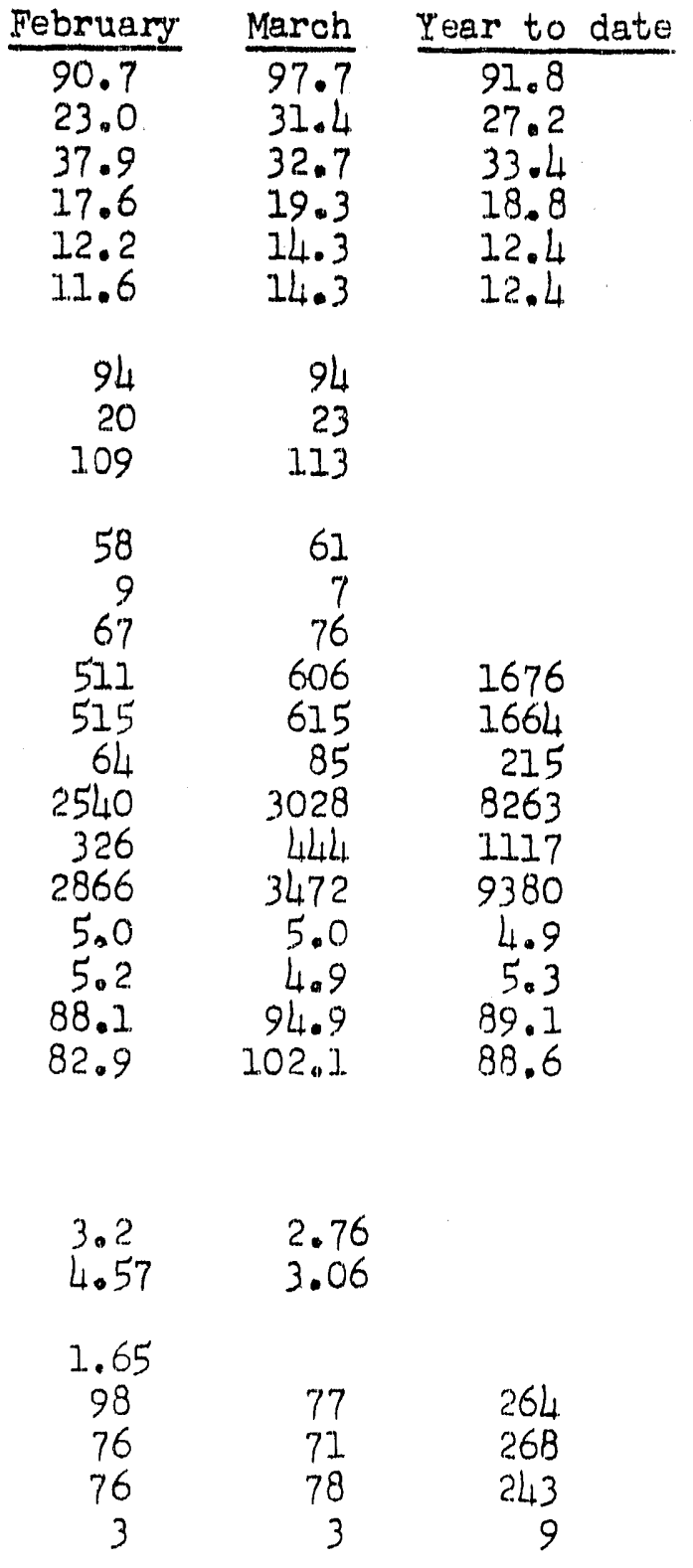




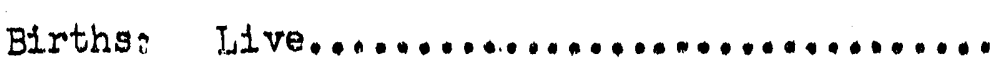

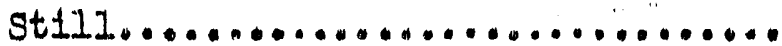

Deaths................................

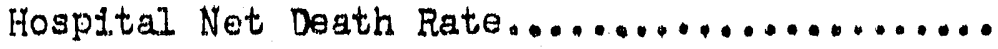

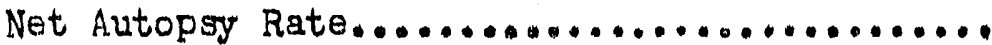
Discharged against advice................

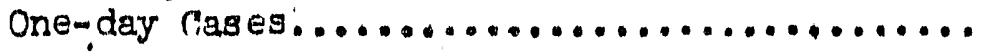

Admisston Souroe:

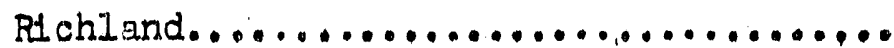

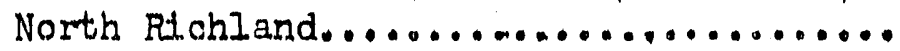

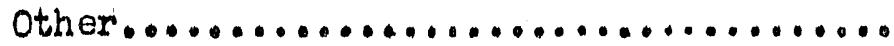
Admissions by Employment,

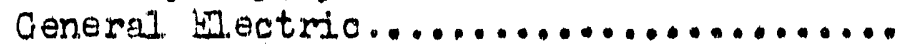

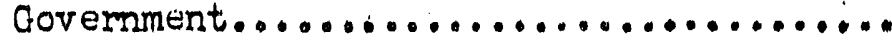

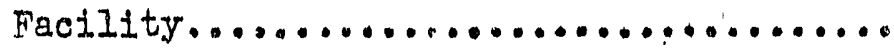

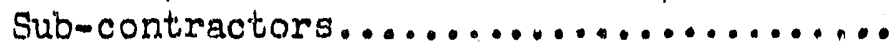

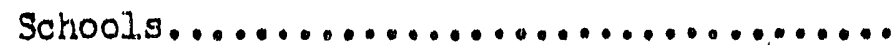

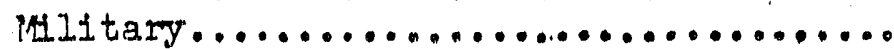

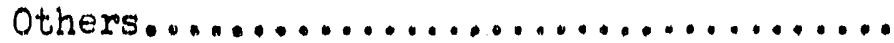

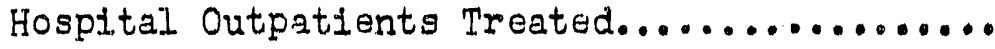

Physical. Therapy Treatments

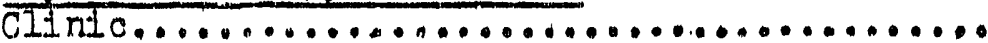

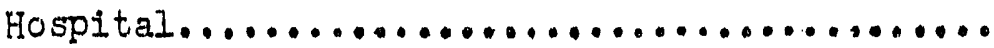
Industrlal: Flant. $\ldots \ldots \ldots \ldots \ldots \ldots \ldots \ldots \ldots \ldots \ldots$

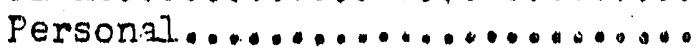

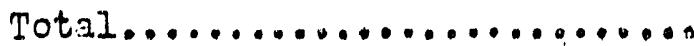

Pharmacy

No. of Prescriptions Fliled................

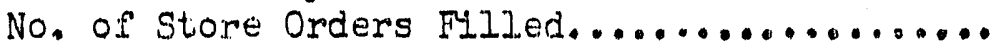

Patient Meals

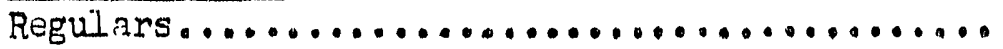

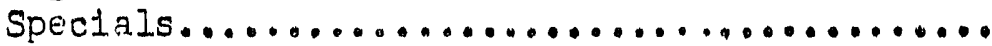

LIghts..........................

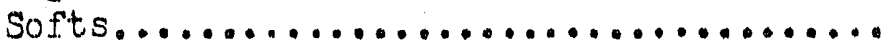

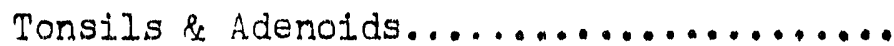

Liquids..............................

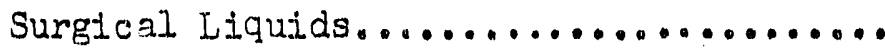

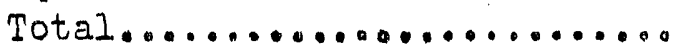

Cafeterla Meals

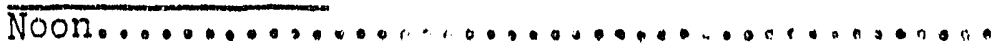
Night.

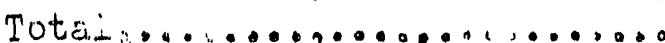

$\begin{array}{ccc}\text { February } & \frac{\text { March }}{93} & \frac{\text { Year to date }}{210} \\ 1 & 0 & 1 \\ 4 & 6 & 15 \\ .20 \% & .14 \% & .30 \% \\ 50.0 \% & 0 & 33.3 \% \\ 2 & 0 & 4 \\ 100 & 101 & 302\end{array}$

$74.2 \%$ $75.7 \%$ $75.6 \%$ $11.6 \%$ $3.2 .8 \%$ $11.9 \%$ $1.1 .5 \%$ $1.2 .4 \%$ $72.7 \%$ $2.4 \%$ $4.4 \%$ $14.9 \%$ $1.8 \%$ $2.6 \%$ $1.2 \%$ 1422

$\begin{array}{r}181 \\ 64 \\ 154 \\ 26 \\ \hline 125\end{array}$

$$
\begin{array}{r}
187 \\
62 \\
144 \\
17 \\
\hline 41.10
\end{array}
$$




\section{MEIMCAL DIVISTONS}

\section{MARCH 1.951}

Publio Health Division

deneral

A sudden rlse in an upper resplratory type of infeotion was expuritenoed. It was estimated from a chock of the school absenteal sm that approxitmattely 1.5\% of the population was affeoted. Several blood samples collooted and sent to the vima laboratory were reported as having an inorease in titre for Influenza type A prime. From this it oan be conoluded that many of our infectlons were due to this virus. Our experienoe was similar to that of the rest of the state and country. At the present time this outbreak has subsided.

Red measleg has also shown a sharp wse with all other oomunitoable disoases remalning at approxdmately the same level.

Home public health nurging vialtg inoreased mpproximately $15 \%$, refleotling the rlse in communicable disoasos and morbldity.

The Division arronged for a regional meoting of the Wasington State Publito Health Association, with approximatiely 64 local and out of town people in attendance. The state organization commended us on the success of this venture which was the flrst of its kind to be held in the state.

A santtary survey was made of the schools by this department. Rusults were very gatisfactory with but a few minor violations.

Mosquito contrnl operations have consiated essentially of cilearing and burning of ditches 1 i the rloinity of the community.

Restaurants in this area were inspected. It was necossary to degracle one restaurant because of insandtary conditions.

There has been a noticeable increase in doy bites this past month. Some dogs were impounded for observation of rabtes which ts now previlent in northeastern Washington.

The majority of cases handled by the social service counselors were problems of adolescents or pre-adolescents. Several referrals came from both the funior and the senior high schools. In most 1ncidents work was done directily with the adolescent and with his parents in an attempt to remove causes of symptomatic behavior which was disturbing to school and community. When cilreumstances did not permit direct work with the f'amliles, the teachers and school coungelors were idvised is to the methods of helplng the youngster in the school. settling.

\begin{tabular}{|c|c|c|c|}
\hline$\frac{\text { Education }}{\text { Pamphtets di stributed }}$ & February & Mareh & Year to date \\
\hline 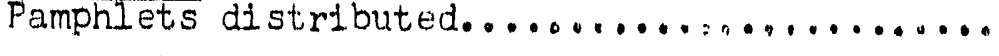 & 14,955 & $\overline{1200}$ & 30591 \\
\hline News Releases...... .......... ar ........ & 0 & 0 & 0 \\
\hline Staff Meetings..... n no, ........ n ...... & 2 & 1 & 4 \\
\hline 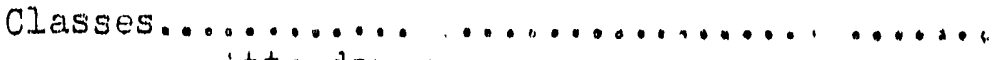 & 1 & 4 & 5 \\
\hline fittendanc $\ldots \ldots \ldots \ldots \ldots \ldots \ldots \ldots \ldots$ & 1.4 & 53 & 67 \\
\hline 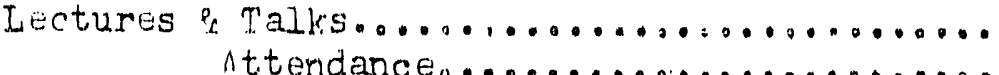 & 14 & 7 & 27 \\
\hline 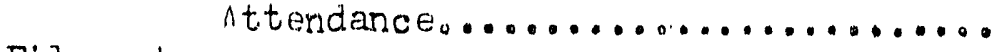 & 1.43 & 123 & 568 \\
\hline 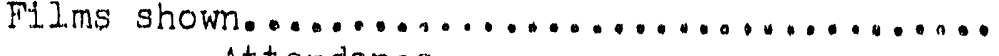 & 12 & 4 & 17 \\
\hline ttatendance. $\ldots \ldots \ldots \ldots \ldots \ldots \ldots \ldots \ldots$ & 624 & 94 & 793 \\
\hline 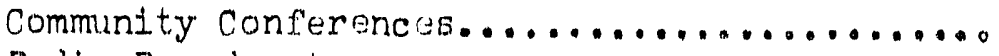 & 51 & 37 & 123 \\
\hline 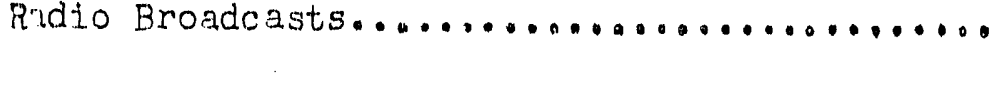 & 0 & 0 & Or \\
\hline
\end{tabular}


Immunizations

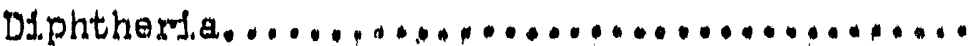

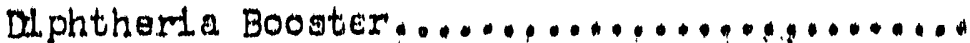

Tetanus...............................

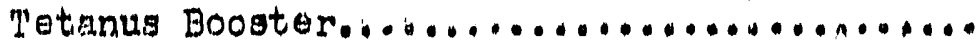

Pertuasts................................

Pertussis Booster............................

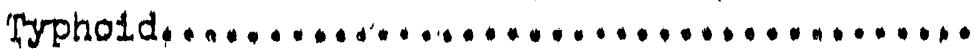

Typhotd Bnoster...........................

Smallpox............................

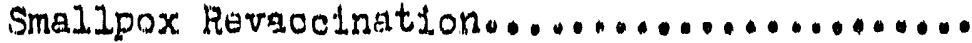

Tuberculin Test........................

Soolal Serviloe

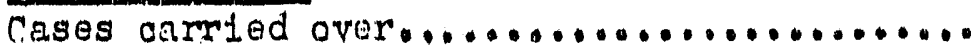

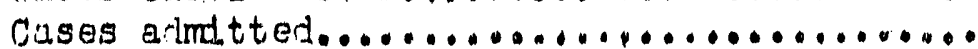

Cases olosed.............................

Remalning case load...................... Aotivities:

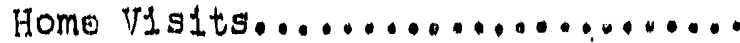
Offlce Interviews..............

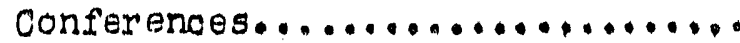
Meotilngs......................

Senitation

Inspections made...................... Conferences held.......................

Bacterlologfeal Laboratory

Treated weter sampleg.................... Milk samples (Inc. cream \& f.ce cream)........

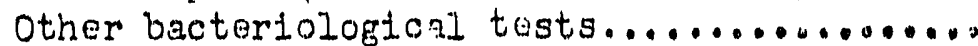

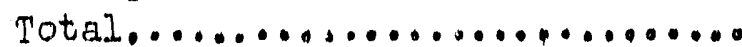

Communtcable Disugses

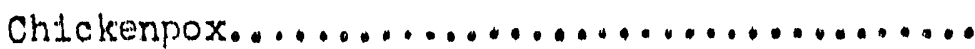

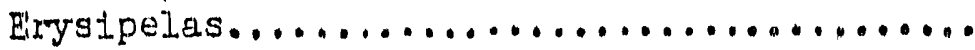

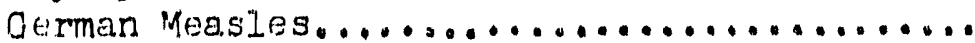

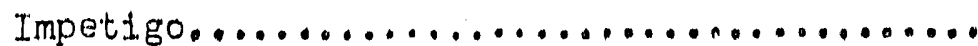

Influenza (Upper Resplratory Inftotion).....

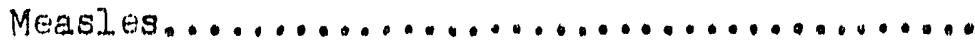

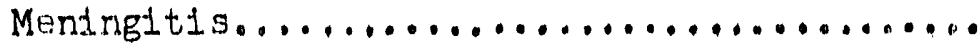

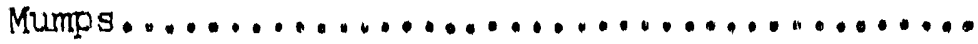

Salmonellosig.........................nn

Pinkeye...........................

Ringworm. .............................

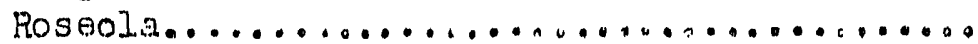

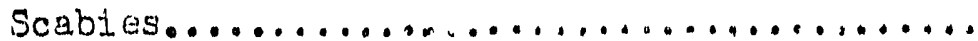

Scarlet Fever......................

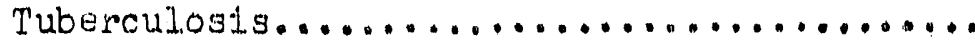

Whooplng cough.....................

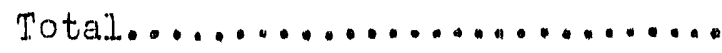

\begin{tabular}{|c|c|c|}
\hline February & Marck & Year to date \\
\hline 1 & 5 & 38 \\
\hline 65 & L & 79 \\
\hline 14 & 6 & 44.7 \\
\hline 109 & .102 & 220 \\
\hline$i$ & 2 & 11 \\
\hline 55 & 2 & 58 \\
\hline 4 & 0 & 13 \\
\hline 0 & 0 & 0 \\
\hline 2 & 1 & 14 \\
\hline 2 & 3 & 25 \\
\hline 7 & 7 & 14 \\
\hline 73 & 84 & 237 \\
\hline 20 & 19 & 52 \\
\hline 9 & 7 & 36 \\
\hline 84 & 96 & 253 \\
\hline 18 & 22 & 62 \\
\hline 219 & 233 & 678 \\
\hline 89 & 84 & 251 \\
\hline 1.1 & 15 & 45 \\
\hline 130 & 129 & 447 \\
\hline 22 & 5 & 41 \\
\hline 153 & 1.69 & 522 \\
\hline 8 & 12 & 28 \\
\hline 261 & 31.4 & 862 \\
\hline 422 & 495 & 1412 \\
\hline
\end{tabular}

\begin{tabular}{rrr}
83 & 87 & 331 \\
0 & 0 & 7 \\
10 & 19 & 29 \\
2 & 0 & 2 \\
1 & 3090 & 3091 \\
0 & 18 & 18 \\
0 & 1 & 1 \\
2 & 0 & 2 \\
1. & 1 & 2 \\
0 & 0 & 3 \\
2 & 4 & 6 \\
2 & 1 & 13 \\
0 & 1 & 2 \\
12 & 11 & 33 \\
0 & 2 & 3 \\
0 & 1 & 1 \\
\hline 115 & 3236 & 351.14
\end{tabular}

$4 \sin \cdot 6$ 


\section{MEITCAI DIVISIONS}

MAREH 2951.

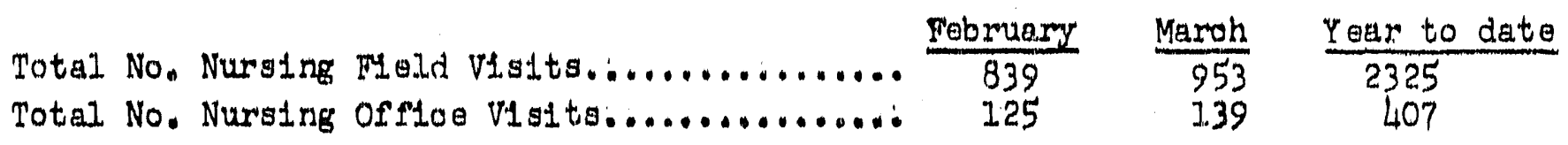




\title{
w1:asn
}

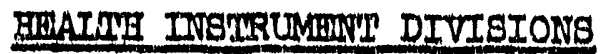

MARCE 1951

\begin{abstract}
Sumary
There were three 1nformal. 1nvestilgations and one Class I Investigation of speclal bazards incldents.

The control progxams of all the divlolons showed no result slgnilicantly different from the expected pattern, except in the Increased release and deposition of I I3I.

The development divlaton appeared to bave proved speclficaliy the production of tritium in the P-13 experiment, beyond tho concentrations suggested by the current physical constants. Further lnvestigation of this interesting problem would be outalde the responstbilitiles of the division.
\end{abstract}

The blology division reported aeverel experiments guggeat1ve of ways in whtch tritlated water may be Introduced into the body, and how it rould be utslized by the body. The flsh laboratory work tended to conflirm the previous interpretatjon that plie effluent was more toxic as a chemical polson thar as a radiological one. 


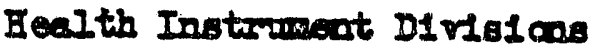

BW-20672

Fran time to time, the roparting bese of the 11 ln badge progrem has been changed to try to match rorloed pecmisalble limita. There is gtill somo unoertalinty as to whother the penindselblo whole bals surpece exposure to bote radiat1on w111 be 0.5 or 1.5 rep per woek. Tho 18suo is further con-

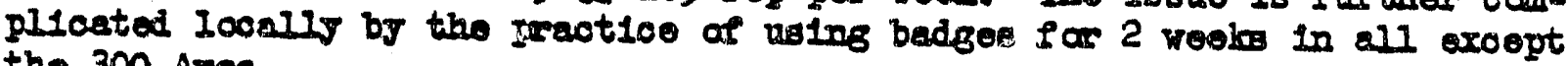
the 300 Area.

No reeds means of sorting out the reel meening af the sereral combinations of exposure in a conclise repart existe. Thooe ceses of epecial intereet will be polnted ant in the tert each month.

The follorlng trips were repcarted:

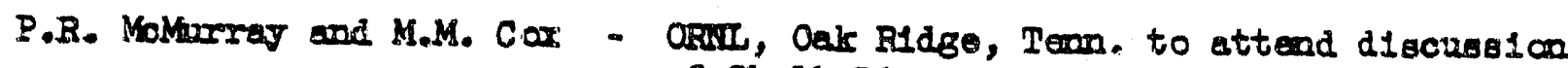

B.G. Rleck - AII, Chleago, III. of Chalk R1ver accident.

R.C. Thompon- ANL, Chicogo, III.

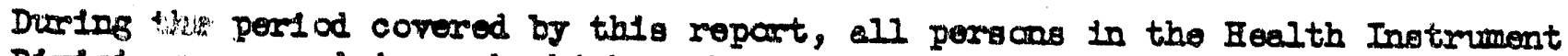

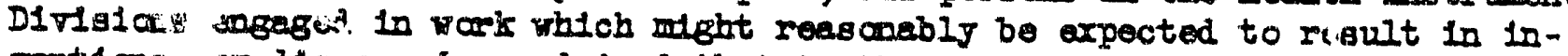
rent1ons, or discoverses, advised that to the beet of their lonowledge and beIlef, no 1orent1ons or discorerloe wero mede in the course of thelr work excopt as listad bolow. Such persans furtber adfled that for the perrod theroin covered by this report, notobook recards if eng kept in the courese of their worle have been exumined for poesible tnrentians or diocoverlea.

Inventor

R.J. Dowwart
Titlo

Apperatus for Mresuring Absorption of Redioect1re Cernee. 
Eesith Instrument Divisions

\section{DECLASSPIFD}

OPERATIONAL DIVISION

100 Areas

Generel Stat1atics

\begin{tabular}{|c|c|c|c|c|c|c|c|c|c|c|c|}
\hline & \multicolumn{4}{|c|}{ February } & \multicolumn{6}{|c|}{ March } & To $D E$ \\
\hline & $\underline{B}$ & $\underline{D}$ & $\underline{\mathbb{P}}$ & 豆 & Total & B & $\underline{D}$ & $\underline{F}$ & $\underline{E}$ & Total & \\
\hline $\begin{array}{l}\text { pec1al lork Permits } \\
\text { out1ne C Spec,Surveys } \\
\text { atent1oin Bsin } \\
\text { ir Monttorinc samples }\end{array}$ & $\begin{array}{r}685 \\
607 \\
84 \\
160\end{array}$ & $\begin{array}{l}1150 \\
717 \\
219 \\
262\end{array}$ & $\begin{array}{r}743 \\
572 \\
84 \\
117 \\
\end{array}$ & $\begin{array}{r}1720 \\
684 \\
86 \\
103\end{array}$ & $\begin{array}{l}3698 \\
2544 \\
465 \\
103\end{array}$ & $\begin{array}{r}619 \\
584 \\
72 \\
135\end{array}$ & $\begin{array}{l}959 \\
637 \\
164 \\
179\end{array}$ & $\begin{array}{r}635 \\
513 \\
82 \\
125\end{array}$ & $\begin{array}{r}776 \\
504 \\
100 \\
92\end{array}$ & $\begin{array}{r}2989 \\
2202 \\
418 \\
525\end{array}$ & $\begin{array}{l}9896 \\
6661 \\
1318 \\
1632\end{array}$ \\
\hline
\end{tabular}

Retention Besin Frelient

The actirity of the rater leaving the retention basin ias as follows:

Pover Level (M:I)

$\frac{100-B}{415}, \frac{100-D}{3300}, \frac{100-D R}{480-520} \frac{100-E}{380-400} \frac{100-B}{505}$

Average beta donace-rate (mrep/hr)

2.9

2.9

1.9

3.93 .6

5.6

Averacje total dosace-rate (mrep/hr)

5.45 .5

8.5

4.9

2.3

Average interrated dose in 24 hrs.

132

204

6.8

4.6

106

254

163

226

6.9

Maximum intecrated dose in 24 hrs. (mrep) I34

$166^{\circ}$

254

226

166

206 1951

$100-$ B Area

P1le aid Associated Duildings

Radiation conditions vere normal.

P10 Operation - 108 Bulldinc

Tro employees gave urine samples shoving greater than $20 \mu \mathrm{c} /$ iter of tritium oxide; the maximum sasple vas 37 uc/I1ter. Activity density of the urine of the employee involved in the Class 2 incident last month fell from $407 \mathrm{uc} / 1$ ter to $9 \mathrm{uc} / 1$ ter.

Metallur 1cal Laboratory - 111 isulidina

The entire tracsfer area vas cortami nated durint vork oil the mptured slur

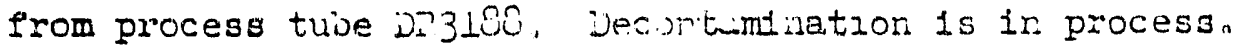




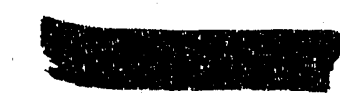

HW-20671

Health Instrument D1F1s10ns

100-D Area

105-D P1le and Assoclated Brildings

A beam was discovered coming from the "B" experimentel bole as a result of improper replacement of shlelding; dosege-rates of $1.5 \mathrm{r} / \mathrm{hr}$ and $560 \mathrm{mrem} / \mathrm{hr}$ at three feot were reported.

\section{5-DR P1le and Aseoclated Bullalings}

On two $\propto c a s 10 n$ s the process tubes were purged with the plis at a reduced power level. The purze water was diverted to the emergency trench. Although the purge material becamo highly radloact1ve, no unueuel hazards problem resulted.

$100-$ F Aree

P1le and Associated Bulldings

No unueual oondition was reportedduring th1s perlod.

\section{B10logy Fuc111t1es}

Exposure-rates up to $1.5 \mathrm{r} / \mathrm{hr}$ and $1.5 \mathrm{mep} / \mathrm{hr}$ were encountered in the proparation of II31 and $P^{32}$ solutions, respect1rel.y. Plents assoclated with the $\mathrm{P}^{32}$ experiment showed surpace dosage-rates up to I rep/hr. No overexposure to persannel wes indicated.

\section{$\underline{P-11}$}

Twenty-three of the 40 alr agmples taken were above $10^{-11} \mu \mathrm{Pu} / \mathrm{cc}$. Tre meximum gemple was $6.4 \times 10^{-10} \mu \mathrm{Pu} / \mathrm{cc}$, taken from a hood ventllating duct during handing of pocess olution inside the hood.

Two Incident of contamination apread occurred when emall quantlilea of process solution were spliled on the Ploor. Decontamination efforts were successful.

\section{0-H Area}

\section{P1le and Assoclated Bulldings}

A mptured P-10 plece was removed fram tube \#3483 wlthout inc1dent. The maximum expoeure-rate encountered wae $15 \mathrm{r} / \mathrm{hr}$ durlng discharge of the tube. No overexposure was reported. 
Bealth Instrumant DIVIsIons

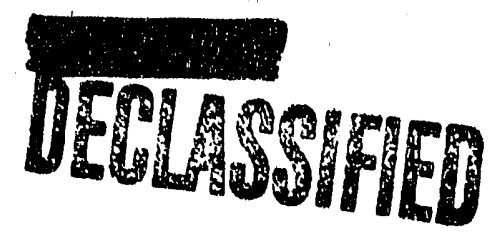

BW-20671

200 Areas - $T$ and B Plants

eneral Statfotics

Spec1al Work Permits

Routine \& Spec,Surveys

Alr Mont torling Semples

\begin{tabular}{rrrrrr}
\multicolumn{5}{c}{ February } \\
I & 231 & 235 & B & Total \\
355 & 31 & 249 & 320 & 9.55 \\
481 & 390 & 575 & 520 & 1966 \\
417 & 565 & 1247 & 557 & 2786 \\
75 & - & - & 27 & 102
\end{tabular}

Thyro1d Checks

75

\section{Cenyon Bullalins}

In the T Plant, canymi deck contamination resulted when a 14 -4 sample was spliled, with exposure rates up to $22 \mathrm{rep} / \mathrm{hr}$ Including $2 \mathrm{r} / \mathrm{hr}$ reported. However, decontanfination efforts were successful w1th no overexposure reported. An apparent faulty seating of the 75 ton crane cab fliter permitted the exposure of the occupants for a short time to atwospheres contalinting $3 \times 10^{-9}$ uc fop./cc。

Fortymine of 177 air samples showed results above $10^{-12} \mu \mathrm{g} P u / c c$, with a miximum of $2.4 \times 10^{-10} \mu \mathrm{g} \mathrm{Pu} / \mathrm{cc}$ durling crane work in the canyen; 137 samples were above 10-10 $\mu \mathrm{c}$ f.p./ce, w1th the maxtmum of $7.6 \times 10^{-8}$ ye f.p./cc.

In the B Plant, 102 of 257 alr samples showed results aivcre $10^{-12}$ yg Pu/cc, w1th a maxclum of $1.7 \times 10^{-9} \mu \mathrm{Pu} / \mathrm{cc}$ taken durlng crane wick; 93 samples were above

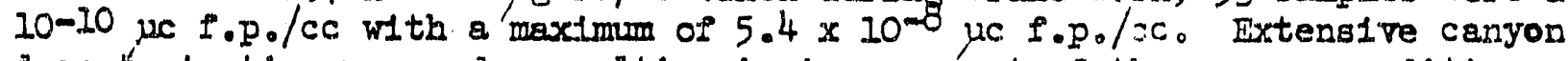
decontamination was made resulting in improvement of tip canyon conditicn.

\section{Concentration Bulladings}

Cell roof rents Indfated the following average discharge rates:

CeII Vent

A
$B$
C
D

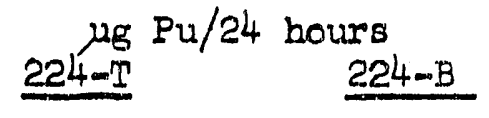

$\begin{array}{rr}50 & 30 \\ 44 & 45 \\ 46 & 45\end{array}$

Waste Areas

In the B Plant, the ahe re grum. je: gabembly fror tile $702-B X$ tailk to 103-BX

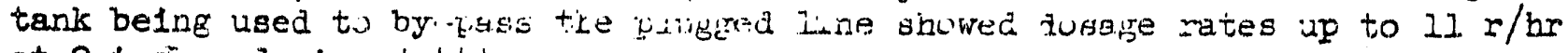
at 2 1nciges during jetting. 


\section{Plant Iaunary}

Five of the 43 air samples showed positive results, with a maximum of $6 \times 10^{-12} \mu \mathrm{g}$ Pu/ce obtalned. while processing Isolation and Purification Butlaing clothing.

\section{General}

All thyroid checks were below the waming level.

\section{Isolation Builaing}

One hundred and seven of 627 a1 samples taken were above 10-12 $\mu \mathrm{g} \mathrm{Pu} / \mathrm{cc}$; the maximum of $3 \times 10^{-10}$ ug Pu/ce was obtalned on the 903 duct system. Elghty-elght unregulated 1 tems and two floor locations vere found contaminated. The maxisum level of gama rediation encountered was $120 \mathrm{mr} / \mathrm{hr}$ on PR containers.

\section{Puriflcation: Butizaing}

\section{Alr Sample Results}

Two hundred and ninetymive of 1327 air semples were cbove 12 ug Pu/cc; the maximum sample of $3.7 \times 10^{-8} \mathrm{ug} \mathrm{Pu} / \mathrm{cc}$ was obtained in the ducts after the Pelmary Filter.

\section{Bullainc - Operating Sections}

Grosi face, head ond hand contamination resulted th an employee who was examining the contents of a waste carton. Postive binmassay results were obtained in confurction with this incldent; howeve's, i'urther data are necessary before the extent of the body deposition of Pu can be established. This Incident was formaliy inrest1 gated as CIass $I$.

\section{Bullalizg - Operating Section}

Contamination spread Involving approximately $25 \mu g$ of Pu occurred in room 231 when an Inadequate hand survey was made upor witheraval from a ruptured hood glove.

\section{Genergl Bullaing}

The plutonium concentrat 10 in the discharge alr for the 26 inch vacuum exhaust areraged $2.8 \mathrm{x}, \cdots, \cdots, \mathrm{r}, \mathrm{g} / \mathrm{cc}$ 。 
Health Instrument Divisions

200 Area Control Laboratories

$\begin{array}{lrrrr} & \text { T } & \text { B } & 231 & \frac{234}{2} \\ \text { Items contaminated - not reprilated } & 246 & 110 & 228 & 132 \\ \text { Slda contamination - alpha } & 1 & 2 & 6 & 0 \\ \text { Skdn contamination - beta } & 4 & 2 & - & - \\ \text { Contaminated floor locations } & 16 & 59 & 16 & 49\end{array}$

In the T Plant, monttoring assistance was furnished whtle muning 17 process samples. The underground dry waste plt appeared to bave fliled with waste necessitatins the higher level waste to be boxed for disposal to the aren burlal ground.

In the B Flant, a faulty stirrer caused splashing of active materlal on the face and face shild of the laboratory asslstant. Th1s Incldent was Investigated Informally.

In the Isolation Bullaing, several instances of floor contamliation occurred as a resuit of dropped samples and discs. Mecroprane of plutonium vere spread in an Inclient when the stopper popped out of a contalner, apparently due to pressure billi u.p in that cortainer.

In the Purlfication Billaling, a plutoniun als conien'sation of $4.1 \times 10^{\circ} 10$ $\mu \mathrm{B}$ Pu/cc was obtalined in roכm 134 over a 24 hour jer'lod as a result of Inadequate air flow throuch the hood caused by tise dimper sllppluif.

Particulate contemiracion in particles per 1CON ar is meters was as follows:

Location

$222-1$ Outs1de Hallway Room 7

222mE Outside Hallivay Room 7
Pebruary

65

78

320

110

98

410

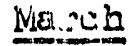

28

58

450

19

35

735

300 Area

General Statistics

Special irork Permits Fibruar March

1951 to Date Routine i Spec. Surveys 102

246 149 Alr Samples 


\section{BVI-20671}

Eealth Insturment DIvlsions

Metal Fabrication Plant

Forty-one of 10I alr samples were above $5 \times 10^{-5} \mathrm{ug} \mathrm{V} / \mathrm{cc}$; the maxtmum of $9.8 \times 10^{-3}$ ug U/cc was obtained in a freicht car while unloedtng rods.

Test P1je Butidings

Radiation conditions were normal.

Technical Builaing

Dosace rates on special slugs recelved to be bubble tested were up to $50 \mathrm{r} / \mathrm{hr}$. Inspection of the alugs indlcated they vere inproperly canned. Teating and inspection were done with a maxtmun exposure rate of $2000 \mathrm{mr} / \mathrm{hr}$.

Hand Score Siumary

There were 38,865 alphe and 42,369 bete scores reported. About 0.08 percent of the alpha and ebout 0.07 percent of the beta acores vrere htgh. No at.tempted reciuction $1 \varepsilon_{B}$ indicated on one high bete score from the 100-H Area. Where decontnmination was attempted, it was succedafu' in all cases reportad. 


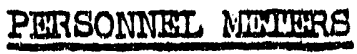

Pencils

\begin{tabular}{|c|c|c|c|c|c|c|c|c|c|}
\hline & $700-B$ & $100 \mathrm{ND}$ & $100-\pi$ & $100-\mathrm{II}$ & 200 & $\begin{array}{l}200-i l \\
\text { Cunst.* } \\
200-I 1\end{array}$ & 300 & Totel & $\begin{array}{c}1951 \\
\text { to } \\
\text { Date }\end{array}$ \\
\hline $\begin{array}{l}\text { Pencli1s Read } \\
\text { Sincle Readincs }\end{array}$ & 17,650 & 16,548 & 14,817 & 9,582 & 23,382 & $\begin{array}{c}34,0613 \\
13 *\end{array}$ & 37,531 & 163,482 & 468,318 \\
\hline $\begin{array}{l}\text { (100 to } 280 \mathrm{mr}) \\
\text { Paired Read1ncs }\end{array}$ & 23 & 28 & 17 & 13 & 22 & 52 & 39 & 207 & 596 \\
\hline $\begin{array}{l}\text { (100 to } 280 \mathrm{mr}) \\
\text { single Readings }\end{array}$ & 0 & 0 & 0 & 0 & 0 & $\begin{array}{c}0 \\
22^{*}\end{array}$ & 1 & 1 & \\
\hline $\begin{array}{c}\text { (over } 280 \mathrm{MR}) \\
\text { Palred Readings }\end{array}$ & 20 & 8 & 18 & 11 & 16 & 27 & 40 & 162 & \\
\hline $\begin{array}{l}\text { (over } 280 \text { r) } \\
\text { Lost Readincs }\end{array}$ & $\begin{array}{l}0 \\
3\end{array}$ & $\begin{array}{l}0 \\
0\end{array}$ & $\begin{array}{l}0 \\
0\end{array}$ & $\frac{1}{0}$ & $\frac{1}{0}$ & $\begin{array}{l}0 \\
1\end{array}$ & $\frac{11}{0}$ & $\begin{array}{r}13 \\
4\end{array}$ & \\
\hline
\end{tabular}

Of the fourteen rjejlicicant pencll readings reported, tro were conflmed by badge results but ald Let constituice an overexposure.

Investlgation of Iost readings Indfcated no posalbliltiy of an overexposure.

Badges

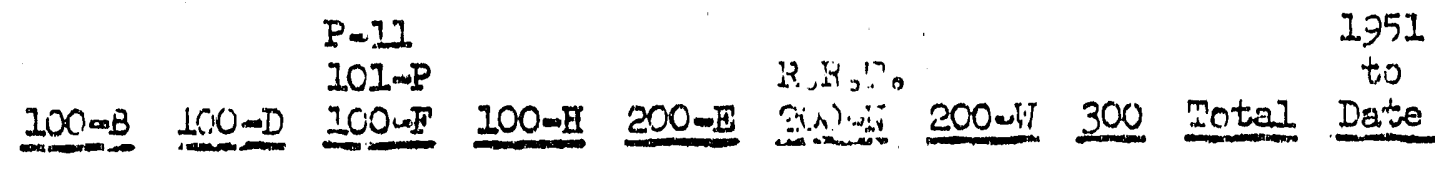

Badges Processed $2,854 \quad 2,679 \quad 2,635 \quad 1,219 \quad 3,333 \quad$ Ui ! $\quad 3,9978,226 \quad 26,33074,443$

Tlumber Readings

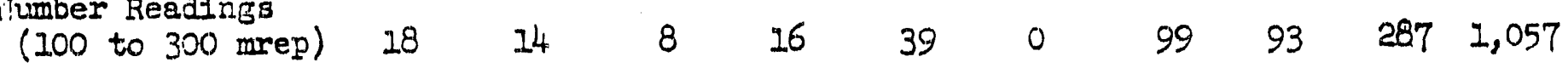

Number Readincs

( 300 to 500 mep)

Number Readinrs

(500 to 1000 map)

Muiber Readinge

(Over 1000 mep)

Lost Readings

1000140

1. 366

of the elght readings reported between 300 - 1000 mrep, only one vas above 300

for garma.

Lost readings were accounted fer as follows:

$\begin{array}{cc}\text { Badge lost in area } & 3 \\ \text { Lost in processing } & 2 \\ \text { Light struck } & 3 \\ \text { Packet lost in area } & -\frac{3}{7} \\ & \text { Total }\end{array}$

Investigation of the above lost readings indicated no possibility of an overexpesure. 
BVI-20671

Health Ingtrument DIVlolons

Badge Resune, Corstruction Areas

200-Iy Const. 200-E Const. Total To Dat

\begin{tabular}{|c|c|c|c|c|}
\hline $\begin{array}{l}\text { Badges Processed } \\
\text { Number Roadincs }\end{array}$ & 3,719 & 2,798 & 6,517 & 18,530 \\
\hline (100 to 300 mrep) & 27 & 3 & 30 & 75 \\
\hline Number Readincs & & & & \\
\hline (300 to 500 mrep) & 11 & 0 & 11i- & 21 \\
\hline Number Reedings & & & & \\
\hline $\begin{array}{l}\text { (500 to } 1000 \text { nirep) } \\
\text { Number Readincs }\end{array}$ & 0 & 0 & 0 & 10 \\
\hline $\begin{array}{l}\text { (Over } 1000 \text { mrep) } \\
\text { Lost Readints }\end{array}$ & $\infty$ & $\begin{array}{l}0 \\
2^{*}\end{array}$ & $\begin{array}{l}0 \\
2\end{array}$ & 3 \\
\hline
\end{tabular}

*open rlndiw ex=ueed to X-ray in badge bus.

Total badges prunessed 1951, Operation 74,443

Construction 18,530

rotal $=92,973$

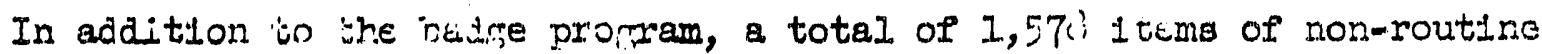
nature was procengai, iring the month.

Slow Neutron Fenct I Sumary

1951

100-B 100 100D IDI IJn-F 100-H Dotal TO Date

Number of pairs 1ssued

ilumber of signiflcant readings

Number of signiflcant readincs

$34 \quad 203 \quad 116$

$\begin{array}{rrrrr}216 & 103 & 222 & 578 & 1,720 \\ 3 & 3 & 46 & 47 & 71 \\ 0 & 0 & 0 & 0 & 1\end{array}$

(above 50 mrem)

Neutron F11m

1951

Badges Processed 100-9 100-D 100-F 200-H 200-U Total To Date

Persciunel

Special

$20 \quad 205$

$2 \quad 32$

32

84

56

29

870

25

112 
CONIROL AND DEVELCPMENT DIVISION

CONTRUS GROUPS

\section{S1to Surver}

There was no unusual finding in monttioring for redioective contamination in drinking water. The actirity density of bota emitters in the Columb1a R1Ver did not diffor Pram the averase lerelo af last manth; the maximum activity density measured was $7.7 \times 10^{-6} \mathrm{\mu c} / \mathrm{cc}$ in a samplo taken noar Henford; tho avorage of ten samples taken erbm the river at MoNary Dam wes $6.5 \times 10^{-7}$

$\mu / c 0$. Sediments flitered fram backwesh water of the Paroo Water Plarificatican Plant averazed ebout $2.4 \times 10^{-3} \mathrm{\mu c} /$ gram of bote omitters; the activity density of the filtrate was about $4.3 \times 10^{-8} \mu \mathrm{c} / 00$.

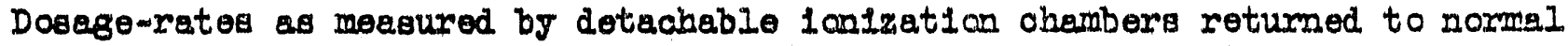
wh1s mantb; the number af active pext1cleo measuised in the atmosphere were also within the expected range this month. These findings tend to cont'1 rm the Increase noted last manth whlah wee belloved to be the results of atamle ex-

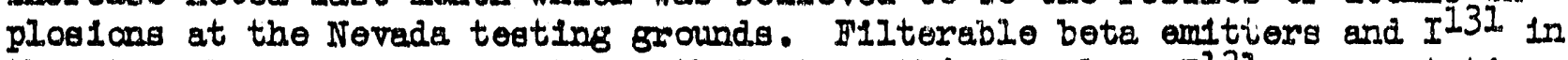
the atmoephere wero compareblo with last monthis levels. Il31 on regetation continued to decreese during the oarly part of Maroh, but after March 14 or 15

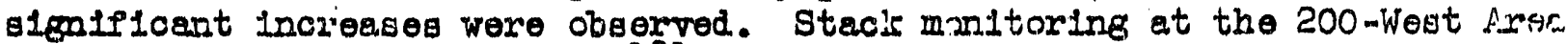
Ind1cated that the amount of Il31 emitted. Prom the 200 Weat Aree atacle during the latter part of March Increased by a factor of abnut 10 over the early part of the month, due to a planned reduction In cooling timo. This inorease ras reflected by the increase noted for deposited II3I on regetati an toward the end of the month. Increases approsching a factor of 5 wero obeerved on vecetation in the Tri-City Area and by about 10 near the Soparat1ons Area. The maximum activity denelty of II3I measured was $2.1 \times 10^{-2} \mu \mathrm{c} / \mathrm{gram}$ at tho 200 West Area gate; the maximum in the Tr1-01ty Area was $2.5 \times 10^{-4} \mu \mathrm{c} / \mathrm{gram}$ mea.sured in a sample taken from the Kennew1ck H1ghlends. The averace In the TriC1ty Araa was about $1.5 \times 10^{-5} \mu \mathrm{c} / \mathrm{gram}$. Off-ares sampling which Inciluded. spolsane, Lewlation, and Pendlet 6 , Iridicated $<3 \times 10^{-6} \mathrm{\mu c} / \mathrm{gram}$.

Monltoring resulti for radioect1ve wastes in the 100, 200 and 300 Area waste ejetems were withtn expected levels.

\section{B10agsay}

FItre hundred and foxty $n$ ino urino amplea were analyzed for plutonlum; olghtyone aplked and blank urino semples wero processed as controla. Measurementa for plutanlum in these urine samples using the present T.T.A. procedure ind 1cated an average of $0.03 \mathrm{~d} 1 \mathrm{~g} / \mathrm{mtn}$; the averege in the forty-ane blank aamples processed was $0.04 \mathrm{dls} / \mathrm{mtn}$. The averege recovery yleld durling the manth was ninety-ane percent. No routine urine sample processed excoeded the detect10n. limit of $0.33 \mathrm{dls} / \mathrm{min}$; but postive results were obtalned in urine semplea on one omployee known by provious hiatory to be a positive crese, and from an er.. ploye Involved in a apeclal hezards inoldant in the 234-5 Building. An ext:mation of body depoeition besed on urlnaxy plutonlum measuremente in the lett cr 
EW-20672.

Hoelth Inotrument D171s10as

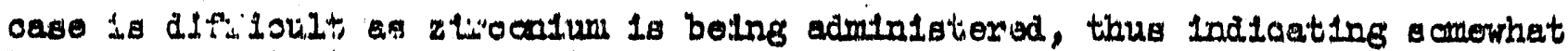
bighar sonssntrations ar plutculum in the urtao.

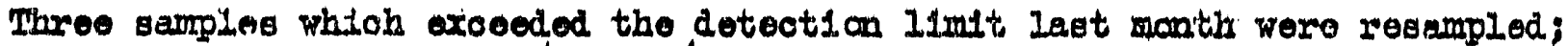

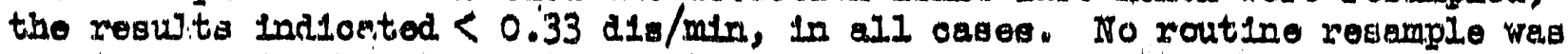
required durtug Marob due to exratio or low J1ellow.

A total of tireo hundred and ten splife and blente samples was proceseod by tho

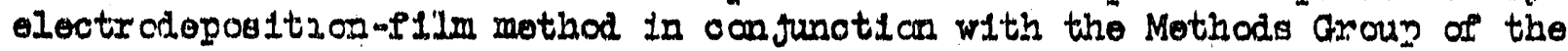
Dovelopment I1rle10a. The reaults wero promilalng and ind Losto that this mothod for low level plutanlum analyalo in urine will be adopted by the Bloessay group in the neer future. Inodequate tao1litios in the present bullding may tand to rotari the tranaltion period.

F'ivo hundred and seventy-e1x urino semplos wore rralyzod for flesion produot

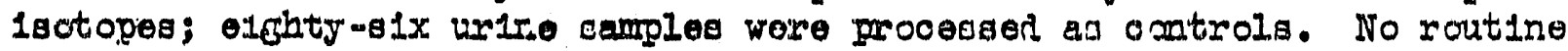
semplea exceoded the reporting level of 10 oounts por minute; of soren speclel Incldent samples, four samples indicated $12,15,23$, and 16 counts per minuto, respeotively. These individuals woro resemplod and the analyses aro in prooses.

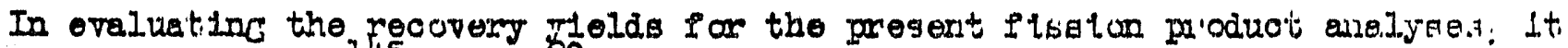
was found that $00^{145}$ and sy 90 are net loot in tho discarded aupernater of tino

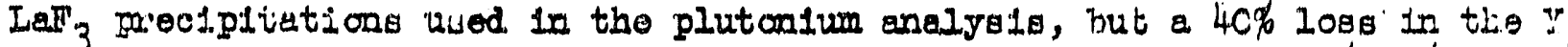

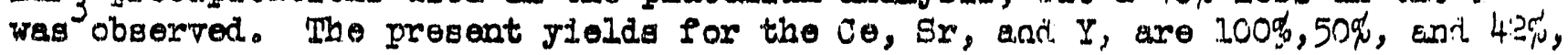
reapeit1vol.j.

One hundred and inety urine samples wero analyzor $f$ uranium. Urino samples are taken after 4 days of exposure on the job (Friday), and then agaln after 2 days of no expoeupt (wookend); a sumery of the resvitis of andiyses of these aemples for urentum by the fluorophotomoter method folliows:

IMVD 4 TH DAY OF ERPOSURT

Job

Description Me/2iter

Avorese Meximm

Cannine

Machining

Melt plent

Materlal Handing

Inspootion

Car unjoading

305 Bullalnes

Clertcel

Rendom

10

22

2

5

8

2

6

1
57

94

3

30

3

10

2
ENDD ENDD DAY, NO EXPOSUEE

Averefies/11ter

TOTAI

NUMBERR

SAMPILES

Avoreze

3
7
12
2
3
2
2
4
$\cdots$

8
4
41
4
14
13
3
6
.-

45

23

11

4.

15

56

11

22 


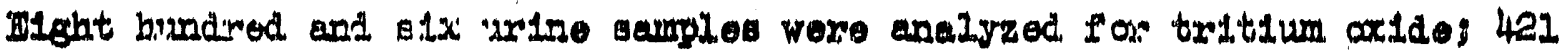

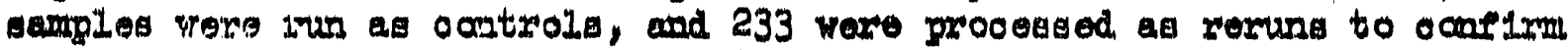
values of ariblinal analjsos. The table bolor howe a datributian of tho reaulta!

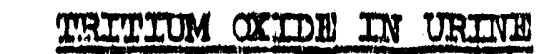

$$
\mu 0 \sqrt{1 \text { tex }}
$$

\begin{tabular}{|c|c|c|c|c|}
\hline Oanoentiation frollp & $<5$ & $5-20$ & $10-20$ & $20-50$ \\
\hline Number of semples & 725 & 34 & 28 & 12 \\
\hline
\end{tabular}

Analytioal-Conirol Iaboratory

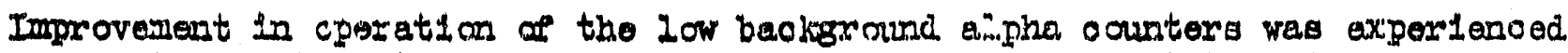

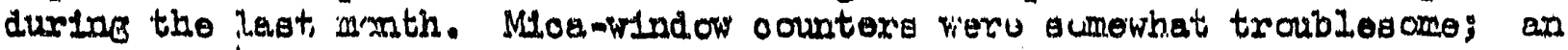
arerege of 4.5 hours por ot per dey was lust dus to fultty tubes. The PS $-2 A$

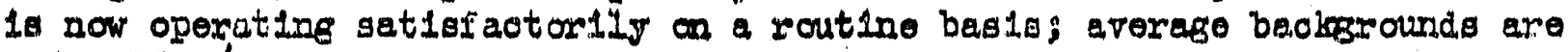
$<0.05 \% / \mathrm{m}$.

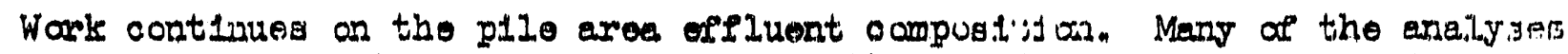

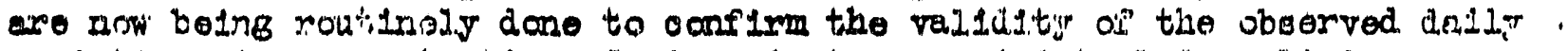
rerlation.s in oonsentxation of glven 1aotopes. A diataliou preliminary weport,

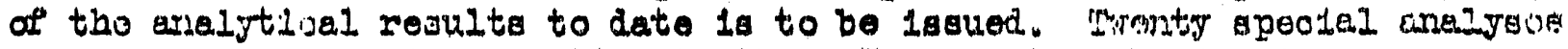

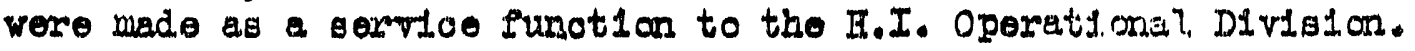

A aumary of the semples analjzed and oounting roum mongunementa made folj.0ws:

\section{Laboratory}

Type Sample
Vegetation
Water
Soldda
Fiucrophotomotor
Spoolal Surves Anelysos
Alr Semple Analysea
Total

Counting Boom

\section{Typo Samplo}

Beta measurementa (rocounts Included) 6694 Alphe mereurements (recounta inoluded) 2930

Control polnts (bota and alpha)

Docay curve polnts

Absorption curre polnts Total

\begin{tabular}{l} 
No. of Teate \\
Mexch 1251 \\
\hline 1413 \\
1549 \\
313 \\
771 \\
20 \\
122 \\
4188
\end{tabular}

1951.

$$
\begin{array}{r}
\text { To Date } \\
\hline 4320 \\
5032 \\
954 \\
2124 \\
85 \\
486 \\
\hline 13001
\end{array}
$$




\section{Quldbrations}

Number af Rout1ne Oal1brations

\begin{tabular}{|c|c|c|c|}
\hline Rad Ium os librat1 ons: & Pobmuary & Maroh & $\begin{array}{r}1951 . \\
\text { To Date } \\
\end{array}$ \\
\hline Fixod. Inotrumeats & 242 & 327 & 833 \\
\hline 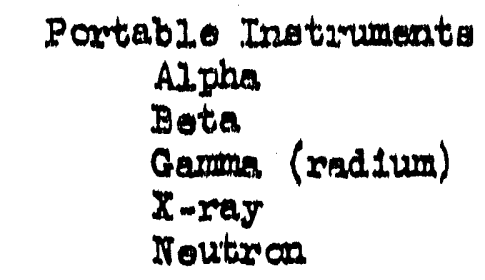 & $\begin{array}{r}248 \\
549 \\
1,003 \\
4 \\
2 \\
\end{array}$ & $\begin{array}{r}354 \\
697 \\
2,310 \\
3 \\
3 \\
\end{array}$ & $\begin{array}{r}902 \\
1,870 \\
3,462 \\
7 \\
6 \\
\end{array}$ \\
\hline Total & 1,806 & 2,367 & 6,247 \\
\hline $\begin{array}{l}\text { Pors canel Metors } \\
\text { Beta } \\
\text { Geurm (radium) } \\
x-r a y \\
\text { Noutron }\end{array}$ & $\begin{array}{r}756 \\
6,658 \\
5,786 \\
11 \\
\end{array}$ & $\begin{array}{r}778 \\
5,860 \\
3,023 \\
59 \\
\end{array}$ & $\begin{array}{r}2,409 \\
22,008 \\
10,999 \\
90 \\
\end{array}$ \\
\hline Total & 13,211 & 9,720 & 35,506 \\
\hline Grand Total & 15,259 & 12,1414 & 42,586 \\
\hline
\end{tabular}

Eyzopt 10 Met ooralogy

Forecesta

Productian

24-hour

Speolal
March 1952

Number made Percent Rellabllity

$\begin{array}{ll}93 & 82.8 \\ 62 & 83.6 \\ 21 & 90.5\end{array}$

The avereze tamperature during the manth wes 40.1 degroes wh1ch is the coldest record for the manth of Marah. The lowert temporature of $22^{\circ}$ occury:d on the 7 th and the 9th, and the h1ghest was $65^{\circ}$ an the 25 th. There was a total of 4.2 1nches of onow whlch was aleo a reoord. This was actually more snow then was observed in Maroh for the I'lve prortous jeare oomblned. Total procipitat ion amounted to 0.46 Lnches. There were numexoue deys with cansiderable wind, the maximum guet of 51 mph wea observod at the 50-ft. Levol on the 15th af March. 


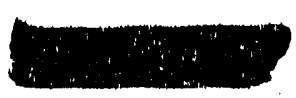

ENW-20677

Holth Instrument Divialone

\section{DECLASSIFIED}

\section{DEVEROPMRAN GROURS}

\section{Ixperimental Metoorologr}

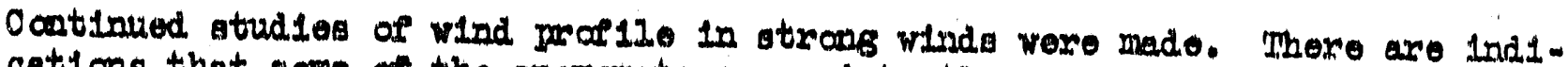
catlons that some the anomomoters canslettently read hlgh while omo read too low. It ls plannod to Interohange instrumeate to determine what oomeotian
feotors are nooded.

A repart descrlbing the techniques euployed in the trejectory asalyses was

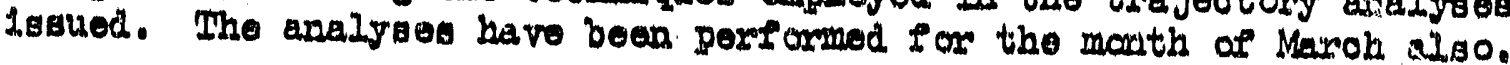

\section{Induatrifal Hrelene}

A atudy of Hersey boe I1ters mado in cooperation w1th the 300 Area H.in. Oporatlanal D17islon wes ocmploted during Meroh. Porformance teats wero conduoted on the two pliot unito whloh operate in serles as alr oloenors In the process oxhaust rent1lation aystem for tho Bumout and Fumeos rooms.

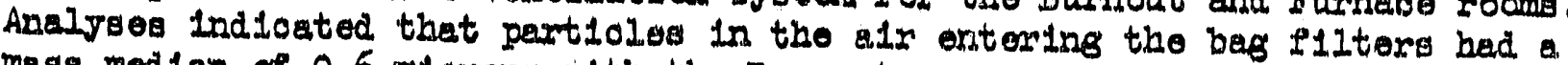
mass modien of 0.6 mlorens with the Burnout xoam alono 1nvolved, and 1.2 mlorane wlth the Burnout and Fumaco roome cambined. Tho standard deviatians

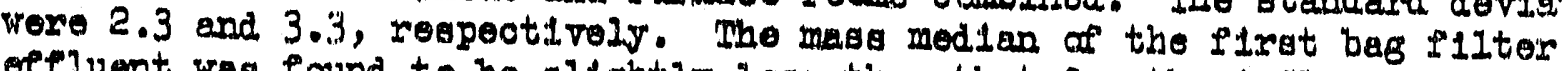
of fluent was found to be aldghtig lese than that for tho lnfluant alz". The oftlolenog of a alnglo unlt ranged from $90.8 \%$ to $98.7 \%$. Tlie overail off 101 ency with two unite in sexied was $99.7 \%$ to $99.99 \%$.

The date wh10h were oompllod from the oooperat1ve otudy w1th the Bloassay Group on cortaln workers in the 303 Area wero analyzed; and it was found that no pos1t1ve camelation was orident between oxposure to oontaminated a1s and urinary exoret 1on urantum. Two worleres wore followed for a periad af one Wook with alr samples bolng taken from the broathing zonos duiling the entire wook and urine samples wore oollootod at the beglnnine and end of ooch shlet.

\section{Goologey}

Ground water oontamination levels in the 200 Areas dis not oharge algniflcant27 , al though thero wero minor fluctuat1ans. The alpha activity donoltios in the wolls in and around tho 300 Aree lncreased olightig during this poriod. Sampling the $108 \mathrm{mB}$ wolls followlng dincharge of activity to the orlo revoalod no olgnifloant eot1Fity.

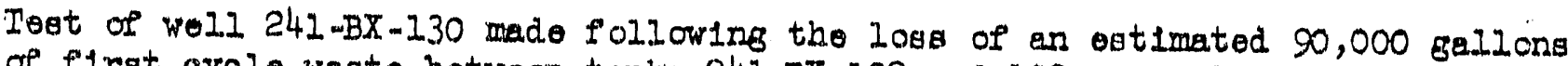
of f'Irat oyclo waste botwoen tanke $241-\mathrm{BX}-102$ and 103 , rovoaled rediat 1 on lovole hlegh enough to jam the oounter uaed. None of the other teat welle or water tables in tho violinity had oloniflcant act 1 vity. 
Hoalth Instrument Divisions

\section{SolI Solonee}

The cation exchange capac1's of oamplee from woll 219-5-2 was determined w1th rosults rangling botween 2.5 and 8.0 miliequivalents per 100 grams of 0011. Meneurenente on oloy sueporslons from those samples gave values botwoen 24 and 36 millequivalento per 100 grams. Th1s 5 to 10 fold increase ind loater that the olay fraction 18 renpansible $f$ or the major part of the exchange capecity of the whole soll.

A rough petrographle etuds of a nample from woll 219-5-2 was mado by the USDA persannol at Bolterille, Margland. They found the followling minerale: querta, feldaper, aug1to, al1-ino, mice (mostlo blototo), calcito, and numerour accessory minerels in small amounto; opatito, tourmaline, opidoto, opeques and aggrogates.

\section{Mothods Derelopment}

The results of the teat of the new oloctrodeposition-nuclear film procedure in the Blossagy laboratory have boen encouraging. An oxact value for the j10 $\theta^{2}$ is difflcult to quote bocause of variations in the sizes of semples with the prosent plating cells and unexplained variations in the rosponse of IIIm to a standard disc, but the ylold, we judeed by 70 eamplee, lo almost certainly Greater than $90 \%$. The atandard deviation of the results 10 about 15\%, which 1s In exceas of the thooretioal expocted from the total number of tracks moasured $(r . .4 \%)$. Twenty-s1x blank samples processed at the same time averaged $0.04 \mathrm{~d} / \mathrm{m}$ with a standand dorlatlon of $0.08 \mathrm{~d} / \mathrm{m}$. Twenty blank plat so oxposed to the fIIm averaged only $0.011 \mathrm{~d} / \mathrm{m}$ with a etandard devlation of $0.009 \mathrm{~d} / \mathrm{m}$. The response of the $111 \mathrm{~m}$ to a standerd source exposed for a lenown langth of timo indicated an arerage j10ld of $48.9 \%$ (rat10 of tho numbor of tracks to the number of disintegrations) with again a high standard deviation of $15 \%$.

New polystyrene plating celle with a definite plating area are now in use but no reeulto are iva1lablo. The valuo of tho blank samplo appears to have docreased about to the f1Im backeround on seroral recent sote of data where separate g.leseware lo used for the blenk and aplked semplo. An ad justable stop has been placed an the mleramoter stage to ellow meesurement of lown lengths of strips on the film without conetant reference to the rernier gcele. A new holder tior expoeing the rilm is belng deolgned to allow precles positianing.

Some works wes done on contralling roltages on the hydrogen counter to allow a more precise setting of the sensitirity on the quench elrcult. The pereconnel usins this equipment for routine samples were tralned, and timo was apent asslating with tho unit during troublosomo perlods.

Poeltire identiflcation of the activity in the P-13 reclrculated water as tritium was ootalned in cooperation with the cintrol laboratory. It wes ahown that the actirity followe in the distilation of the water, in the regeneration of calclum hydraxide produced fram the water, and that the apecific activity af the hydrogen drops by a factor of abnut I'Iro on olectroljeis as expected iram results on douterium. 
A mantfold was designed and bullt to allow fliling of Golgor tuber with different mixtures. The desien of the tubes was patternod af ter those used by I1bby at Argonne. Revults on the flret f11110n with aloabol-argon indicated good counting aharactoristios. Th1s unit 1s to bo used in en attempt to oal1brate seroral samples of tritlated water.

Tho Iracoriab windorlose flow Gelger Coutor bas given erratic results. A different quench c1roust w111 bo tried in an attempt to obtain brod operatian. The secmotry of cane of the off-area alr monltars wes moesured and the effect of souroo aree noted.

Tests of the solf-ecattor of beta part1010s foom thin precipltater bare glven little erldence of such a phencomenon with $5 r^{90}-y^{90}$ and leed oulphate. Procedures for the electroplating or load aro bolas investlgated so that unif orm ources bey bo propared, thus eliminating the effeots of uneven opread.

Work was started on Invost1gation of qualitat1vo and quantititivo mothods of anelysis $f$ or varlous rediolsotopes. Tho thorlum analys1s procedure has rooolved Into removing diffloultios with interfering 100 s.

A new problem on the dilut1on of the 107 wastor in the Columbla R17or was etarted this month in conperation with the S1to Survoy group. Solection and marking of the locations at which traverees are to be mado has been carrled out. Preliminary soundings to obtain the river contours at these locations bavo been mado and the sampling equipment has been derigned and terted. Soveral trarersen havo been mun neer the 100-I Area and volocity measuremente made. Diffloulty 1s ant101pated in etudjing 100-B and 100-F Axeas because of the lack of docketng and grealng faollitios for tho boat at any location except Hanford.

\section{Phyg108}

Rango apoctra have beon ocnetructed for the PO-B, POmB and Ra.Bo eources. The flrst two spectre groe well with thoee obtalned by other investagat mes, but the Re-Be apectrum 1s radically different fram that moasured by one other worker and resembles Instead Po-Be opectrum. Beoduse of this difference, the study wes continued for appraximately double the number of tracks with substantialis the same reault.

Some calculations were made to determine the energy deperdence of ateol walled argan-f1lled chembers for the Technical D1rlolons.

A syatem of using sleaves of rarlous thlckeseses of polyethylene, aluminum and copper w1tk a V1ctorean 1885 GM tuke wae worked out for malting onersy meesurements of low energy same radlat lar. In the range fram $10 \mathrm{Ker}$ to $100 \mathrm{KeV}$. Th1s has been particularly useful in determining the energ19s which are mot in the 234-5 process.

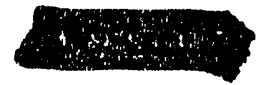


Health Instrument Divialone.

Instrument Derelopment

A now filter system Par manttoring alrborno ocatamination was developed. It consists of co scalor and ohronolog reglater, two flitiors, counters and pumps and a nowly doveloped owltching sjotem. In operation, alr lo filtered altornately through oech af the probes vith an adjustable perlod of the order af hours, and the flitere are monltared alternately $f$ or 10 minutes. Iho system has boen fairly ouccosaful but is not jot roeds for flold trial.

The game scintillation counter has boen turned over to Mothods group tor te日t-

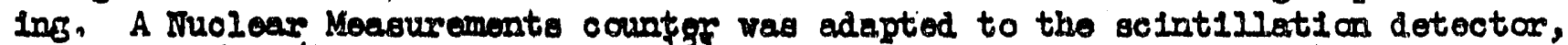
and gave $260 \mathrm{c} / \mathrm{m}$ far a $0.009 \mu \mathrm{c} \mathrm{I}^{131}$ source at about $2 \mathrm{~cm}$. Upon ovaluation as a river monltar, thls oounter will be tried as a human thyrold manitor. Moanwh1lo, a new probe has boen deslomed for moro proolse thyrold work. The alphe acintliliation survoy probe continued to operate satiafactorily in 234-5 operations with all complaints belng besed an tho unwioldiness of the probe compared. to a poppy probo. With the 1ntention af orereoming part of these, a new probe using a IFRI photomultipiler has boen designed and Is under construction.

Tho Inhaled trit1um absonption monltoring apperatus was comploted and ad justed appraximatels under fleld conditlans. an proliminary setting-up, the over-all system would detect a differenco in concentration of tritium betwoen the inhalod and oxhalod atr of 1/10\%, whloh 1s nct soneit1ve onough. The complote apparatus is bolng studied and Improved by interested Blology and Instrment Devolopment pooplo. An 1an-ohomber tor monftoring tritium uptake by enzymos was doelened and ls bolng ocanstructed.

For Meteorological experimentation, a rough preliminary test of oll fog tluoresenco under ultre-violet Irradiation was mun with encouraging rosulta. If the syetem can bo developed as Intended, it will bo froo from a large part of the orror introduced by alrborno dust in light absorbing or scattering aystams.

Final cleanup of the partable $\mathrm{BF}_{3}$ counter was campleted, and the fintehed model 1s now in service. All blueprinte, lajoute, and photagraphs, havo been camploted and rorlsed where necosears. A final repart and malntenanco manual 18 belng propered. 


\section{QESA ISSSFIFD}

EW -20672

Health Instrument Div1sions

\section{BIOLCGY DIVISION}

Analrsos Group

\section{Radioectivity in Carcasses}

Analjses of duplicate allquots of prorlously analyzed samples confirmod roproduclbillty of mothods to bo ueed.

2. Alphe and Bota Anal rees of Organic Matorlal

Derelogment work on the analysis of 1 argo arganlo samples for radiolodine vaing fursion in $\mathrm{Na}_{2} \mathrm{CO}_{3}$ followed by silver lodide procipitation and counting was completed. The mothod has boen incorporeted into routine use.

Worle continued on the devolopment of mothods for tho determination of trace amounts of $\mathrm{Pu}$ and $\mathrm{Cm}$ in rat carcasses.

\section{Radioe lements in Organiams in P1lo prepluent}

Itro Iargo algae samples from the river wore anelyzed for zadioact1vo canstituente. The bete emitters wero primarlly composed of leotoles of $\mathrm{Cu}$ and $\mathrm{P}$ with traces of Na, Fe, the rare earths, and Al 18otopes. Poesiblo trace amounts of Pu ( $2 \mathrm{~d} / \mathrm{m} / \mathrm{g})$ were obverved.

4. Phyalcal Procosues Affect1ng Mothods for Isotope Use

To determine the efflclency of the vibrating reed electromoters when ueed for measuring tritlum, two samples of tritium gas were divided into allquots of lown volumo, temperature, and pressure; tho al1 quots quantitat1vely canverted to the axide, diluted, and measured as outlined in Elv-17257. An averaze y10ld of $60 \%$ I $4 \%$ was obtained, indlcatine prevlous work to bo valid. Further stondardizat lons will be mado.

Proliminary experimente using the Tracerlab windowlese flow counter to count Ilquid amples contalning tritlum oxlde wore wun with promising resulte. Fifty

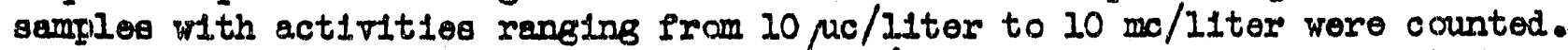
A plot ar counting rate vo. eotivity lotel (as determined by the ribrating roed electrometer) ylelded a etralght line w1th a slopo showing $0.44 \mathrm{c} / \mathrm{m} \mathrm{re-}$ cordiod for each $\mu \mathrm{c} /$ IItor of the sample. All samples but ane fell inside tho comblned expected counting orror and the vibrating reed standardization erroc.

5. Westo D1sposal Mothods for B10l.oglcal Spoclmeng

\section{Inact1re.}

6. Physical Chemlcal Mothods for Dosimetry due to Deposited Isotopes

Inective. 
Bealth Inotrument Divisions

\section{Sorvioes}

Analjticel services to other blology groups Increased about $15 \%$ orer lagt manth. Aquatic Blology Group

1. Hefoct of P1le Hefluent Water on Aquatic Organiams

The chinook selman monltoring etudiles were contlnued wlthout unuaual lacldent. Cumilative mortality among the control 11 sh 1 s nominel at $4.3 \%$. No signifloent affect has sppeared at the $2 \%$ concentration of ans of the experimental waters. At 5\% concentrations, there has been a retardation of Browth but only sl1eht increese in mortelity. With the exception of the cooled area effluent, mortalItiog in the $10 \%$ concentrat 10as ox experimental waters have risen to near $50 \%$. Growth and mortality pattorns aro ossentlalis tho samo in comparable dilut lons of pile influent and pilo of Iluent water indicating that radioectivity lo not a jor factor contributing to the eflects observed.

\section{Blological Chains}

The ectivity density of jearling ralnbow trout held in $5 \%$ pile offluent is currentis about 7 times thet of controls. Cantinued low water temperature with arsoclated anorexia has depressed the actlolty denglty of the flah recolving radioet1ve algao in their diet to about the same level as those on on uncontaminated diet. Vexy fow af the femalo tleh appear to be maturing and it may be neceseary to continue this atudy for another jear in order to evaluate the effect of the effluent on spawaling.

\section{Red1ob1olog1cal-Ecological Survey of the Columbla R1-rer}

The river helght remalned relatively atable during tho manth permitting sampling for actifity density determinations. Established areas for the collection of quentitative samples remained out of reach, however. Algal Growth appeered on same of the floeting collectors. Prellminary attempts with the boat to drodge bottom strata for blological sempling showed promising results. Equlpment was adapted and dereloped for plankt on collecting from the bout.

Act1rity deno1t1es of arganisms in the river romalned at about the levels observed lagt month. In the ricinity of Henford, everage figuree amounted to $1.7 \times 10^{-2} \mathrm{\mu c} / \mathrm{gm}$ in plankt on for a now blgh, and $6.5 \times 10^{-5} \mathrm{\mu c} / \mathrm{gm}$ in amall Iloh, a minlmum $f \circ$ the seasan. Bottom algee and invertebrate forms were in-

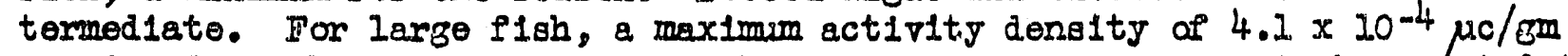
was found in the bone of a whitefigh; the maximum velue for flesh amounted to only $3.0 \times 10^{-5}$ puc/gm.

4. Control of AlBee in 207 Retent1on Bag1ns

No progrese. The brend of anti-fouling peint desired for the test in the 10\%-3 retention basin seems unobtalnable. An alternate brand may have to be used. 
Health Instrument D1visions

\section{BDochemistry Group}

1. Relative Blolog10al Hefocts Fia Blochomical Systems

A suboptimel culture modium for I. Cesel was deroloped. Satisfactory growth occure at $30^{\circ} \mathrm{C}$, provided the poriod of Inoubation ls exterided to appraximately 40 hours. It was found that tho growth response in tubes containing $0.16 \mu \mathrm{B}$ of ribafievis plus 500 jio a tritium axide is approximately oquivalent to the Browth reaponeo in tubes cantalning onls $0.10 \mathrm{\mu s}$ af ribaflavin and no rad 101sotope. It ras estimated that during the Incubation pertod of 40 houre a total of $29 \mathrm{kllorep \theta} \mathrm{rea}$ delivered to the modium. Since the growth of I. Cese1 is directis proportional to the concentration of the riborlavin in the culture tuber, it is orldent that only $62 \%$ of the expected srowth occurred in the presence of the radiolsotope.

2. Absorption of $\mathrm{Pu}$ from the G.I. Treot

The dally oral adminletration of plutonium continued. Both the experimontal and the control rats appeared to be in good hoelth. The alphe activity on the oplked counting plates propered delly has remalised constant, substantlatins the adequate removel of short-ilved contamtnante of the plutonlum.

3. P-10 Biolog1cal Hazards Invest1gat1ons

Ninety days after the last intraperitoneel injoction of tritium axide in mico, no actloity wes detectablo in body weter; the biolobical half-ilfe of the bound tritium remalning in the tiseues wes of the arder of 60 dajs. ApproxilnatelJ $0.02 \%$ of the actirity orlginalis injected ot1ll romalned in the body at this timo.

Fifty-three dajs after the administration of tritium oxide to rats, the body wator activity continued to decrease with a halp-119e of 3.0 to 3.5 deys. The blaloglcal balf-time for bound tritium in fat, musele, and brain in the rat during the Intervel botweon tho 32 nd and $53 \mathrm{rd}$ day foliowing the tritium axide adminlatration was approximatoly 30 days. On a dry welght bas1s, tho act1vity in fat, maclo, skin, and brain was about 3 times as great as in the other t1soues being sampled.

The drled carcasees of rate whloh hed boen injected with tritium oxide are boing hydralyzed in an attempt to 18olate frections which may contain tritlated compounds.

A proliminary exporiment sarried out in cooporation with the Phyolology group soemed to Indicate that the rotention of Inhaled tritiun gea by tho rat 1s less than $0.1 \%$ af the adminlatered dose. This confirmod results reported by Los Alamos.

The percutanious absorption of tritium oxide in 22 reta exposed for one holr 


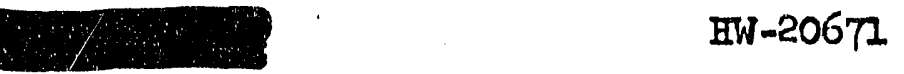

Hoelth Instriment D171010ns

to the vapors of tritium oride at levelo of $150 \mathrm{mo} / \mathrm{co}$ of water has been found

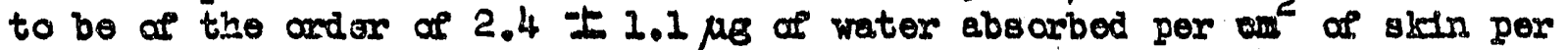
minute. IInAe values wore obtained by anelyzing blood semples immodiately followlng the exposure. When body-water samples yere anelyzed, the velues found wore 2.7 I $1.3 \mu \mathrm{g}$ of water absorbed per om of aktn per minute. Seven additional rata were exposed for ano hour durlag four coneecutive dajs to the seme concentration of tritium oride vapor. Whon blood samples wore analyzed 1mmodiately ofter each exposure, the averege percutaneous aboorptlon wes $f$ ound

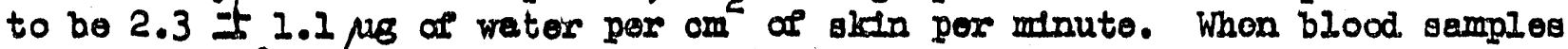
were taken 18 hours after each exposure and values were corrected to and of exposure lovels using a blologlcal half-timo of 3.1 ders, the absorption ralues wore found to be $4.2 \pm 1.2 \mu \mathrm{s}$. When body-water wes analyzed 18 hours efter the last expoeur', tho absorption was caloulated to bero reeched $5.3 \pm 1.2$ pB of weter per $\mathrm{cm}^{2}$ af skin per minute. The higher values for percutaneous absorp.tion obtalned 18 houm after the and of the expoeures are attributed to the fact that during this perlod of time the tritium oxide which has permeeted through the sletn has bocome fully distributed in the body fluids, thus also raleing actifity lerels in the blood. Moreover, sinco the akin is known to act as a reservoly of water in the body, the porticn which has been exposed to the tritium oxide rapor may act as a continuous source or radiolsotopo oven after actual exposures are finlshed.

The abdaminal sktn of four joung pupples wes expoeed to the vapors of trittum oxtde for one bour at a level of $1.5 \mathrm{curles} / \mathrm{cc}$ af water. The average porcu. taneous absorption found was $2.2 \mu s$ of water per om of $3 \mathrm{kln}$ per minute based on analyses of blood semples imodiately following the exposure.

The abdominal skin of 2 adult doge wes exposed to the repors of tritium oxide at a level of 1.5 curles/ce of water for ane hour durine 5 cansecutive deys. By analyzing samples of blood taken imodlately after each expoeure, tho pexcutaneous absorption was found to be $2.5 \mu \mathrm{g}$ of water per cme cf skin per minute.

Equipment for investifating the percutaneous absorption of tritium gas is now beling aesembled.

\section{Servicen}

Durine Merch, the B1ologlcal Services laboratory performed 983 blochemlcal and 996 hematologlcal determiriat1ons. Data accumilated in the past year aro belng treneferred to I.B.M. cards.

In support of the Animal Farm program, 160 blood semples were analyzed for protaln-bound lodino as well co for inorgenlo lodino levels. 


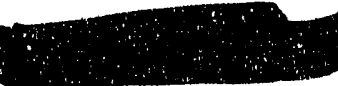

$\mathrm{BW}-20672$

Health Inotrument Diviaicas

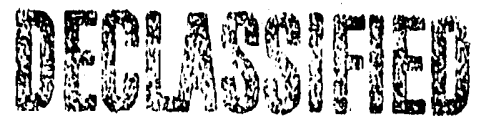

\section{Botany Group}

\section{Agriou?turel F1ald Station}

The averagu act1ifts density of 19 s011 semples taken erom the treatment plots vas $1.9 \times 10^{-5} \mu \mathrm{c} / \mathrm{s}$; activit1es ranged from $1.2 \times 10^{-5}$ to $3.9 \times 10^{-5} \mathrm{\mu c} / \mathrm{s}$.

\section{Pranslxation of Red loolements in Plants}

The uptake af $\mathrm{Sx}$ from nutrlent solution of pH 6.0 by red kldrey boen plents was founil to be diroctly proportional to the concontration af $\mathrm{Sr}$ in the range of 0.0001 to $100 \mathrm{p} . \mathrm{p} . \mathrm{m}$. of Sx. The concentration of Sr within tho trifoliate leares of bean plente grom four dere in these nutrient soluticons was 50-100 times that of the orlginel nutriont solution.

A phroem injection study showed that the pH af the nutrient solution (root modium) had no olfmifloant offoct on the tranolocat1on of Sr from the injocted leap to other perts of the plant. In contrast, the translocation of Sr was increesed in othor exporimonts whon the of was hold constant and Ca and MB were removed soperately from tho nutriont oolution (root modium). It 1o cancluded that $C a$ and $M_{B}$ inhiblt the tranglocation of Sx. The inhibitory effect of MB wes less pronounced then that of $\mathrm{Ca}$.

\section{P-10 gotantcal Invest1gation}

Work an the rato of Incorparation of tritium into the water and organic matter of red leldney bean plants exposed to 11ght or darkness and grown in nutrient olution containing tritium axlde showed that the tritium content of these fractions Increasea vory rapld $2 \mathrm{y}$ up to 24 hours after exposure. Data are not jet extens1ro encigh to seo whothex the uptake ras amenable to treatment as a almplo thematical blophysical exerolso.

The contents of tritium in the water and orcanlo matter of plants exposed to light were higher than in the same Practions of plants kept 1id the dark. After 24 hours, the concentraticne of tritium in the water and organic matter of plants expoes to Ilght were $70 \%$ and $5 \%$, respectively, of that in the nutrient solution. In the carrosponding fractions of plants kopt in darkness, the cancentrations of tritium wore $23 \%$ and $0.9 \%$, reepectivels, of that in tho autriont solution.

ChIcrolla po were exposed to tritlum oxide (In nutrient solut1on) in the presence of Ilgint for 5 and 15 minutes. At the and of these per1ode, the organic mater of the algae had a total tritium content of $0.1-0.5 \%$ of the total tritium to whlch they wero exposed. The major portion of the tritiated cellular conetituente wore soluble in hot alcohol.

Further teste on the chloroplast fraction active in splitting tritiated water in photosynithegis have shown that activity is lost through precipitation wit:. diarane on by a solution in dreft (0.1\% or 1.0\%). Thus more eridence is addut? which polnte to the presence af proteln and chlorophyll in the active compcnent of chloroplasto. 


\section{Health Instrumeat. DIFlatone}

Sallim pumareto and potassium altrate did not act as hydrogen accoptors for the hydrogenses syotion of Azotobacter 'Tineland 11. Howeror, when a compound such as mothyleno bluo was Introduced into the ejoteen, hydrogen was traneforrod to fumarate and altrate. It appears that the axldation potent1al difforonce botwoen these comporinds and hydrogenase weo too large for the reaction to procoed by a singlo atop, but when a compoum of intexmodiate axidatica potentiel wes introauced into the systam, the reection proceeded in two steps.

In co exporimoni Azotobeoter Finoland11 cosvarted tritium gas to the axide at the rato of $1.4 \mathrm{~kg} / \mathrm{mg}$ proteln $\mathrm{N} / \mathrm{hr}$. when air containing $50 \mathrm{mc}$ of tritium per

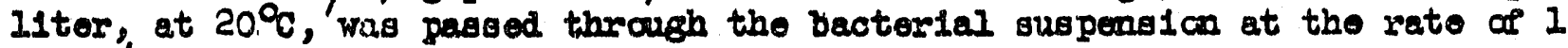
11tor/hr. In anoither experiment in whlch a statlonery gas was used, approxImately $90 \mathrm{mc}$ of gas wes converted to the axide in 20 hourg ircm $0.5 \mathrm{C}$ af tritIum. In an alr rolume of approrimately 2 liters. At the ond of the experiment, appraximitely 3.5 mo were present in the Lacterlal colla. Whether the latter ectlpity developed through becterlal motabollam of the $f$ armed arido or the direct incorporation af tritlium 1s dobatablo, al though the former possibllity Beeme more probeble.

4. EPPects of Radiation on Plent Life

The growth of D. Coli was approximately $30 \%$ 1088 than that of controls in 24 hours when the celle wore grown in a medium cantaining appraximatels 0.2 on of carrier phosphorous and $1,000 \mu \mathrm{c}$ af $\mathrm{p} 32$ per litor of alution.

The uptake of phosphate lons in 2 hours by exclsed barloy roote was oleniflcantiv lose in solutions containting 0.1 mo of $\mathrm{P} 32 / 11$ ter of solution than the upteks by controls. At 1 mo of $\mathrm{P} 32 / 1$ itor of solut1on, the uptake of the lon wres approximately 30 times lese than that by control roots exposed to 2 po of $\mathrm{p}^{3} 2$ per liter of solution.

An experimont has boen completed on tho offect of varying levels of $\mathrm{p}^{32}$ an the growth and absorption of $100 \mathrm{~s}$ by bean plants.

\section{Phye10losy Group}

\section{Blologlcal Hefects of Active Perticles}

INo progress.

\section{Bane Motaboliam of Radloelements}

A successful $r 1 b$ resect1os was pertormed on one af the antmals freviously bled Into a comprnsatos: bone marrow hycomplasia. Thlo antmal is down about onethird hla normal hemoglobin cuntent and had about cno-half hls normenl number of erythrocyios.

Tho normal antmal whose $\mathrm{rlb}$ was prerlously reaected bas boen the reciplent of 
twro milligrems of Pu239, siting a conoontration of about $0.12 \mu \mathrm{g}$ Pu/B body volght, The maturial wes administered by roln. About $0.3 \%$ had boon oliminated In the firet dey's urine.

3. Teohniques in Autorad legraphy

No repport.

\section{th. P-10 Hazards MLlogical Intest1gatian.}

An instrment des.ened to mousure directis the tritlum content of a gaseous intrture before anc aftor adminletration to an animal has not proven sat1aPactary. Attempts are belng made to modify the epparatus for auccosaful opere"tion.

The offects of forced flulde (1.5 times the 24 hour urine output) on the helfIffe of tritifum in the dog are being inveatigated on two antmals where the halfI1fo under normal conditions is alreedy mown. Phyolologio seline solution is administered by roin, the tritium content of the urine beins assayod dulij.

\section{Services}

Servicer Inoluded 230 tiseue proparations for the Zoology Group on routino slides and preparation of bone for axamination of mamow and bonj materlal, and routine autoradlagraphy and photograph.

\section{I0gy Group}

1. Blologinal Monitoring

\section{Waterr'owl}

Manthly census showed a slight decrease in total numbers of watersowl on the pojoct as the number fluctuated whth the arrivel and departure of migranta. Appraxtmately ane thousend blrds woro counted, of which $48 \%$ were mellards (Increase over last month), and $41 \%$ were Canaca geese. The goose population 18 nearingstablilty with the onset of nesting and a total sount is difficult to obtaln, due to thoir secretive hablts at this timo.

No samplo was analyzed for actirity denelties.

\section{Upland Wildifife}

Rabblice takan in ihe rloinity of Henford and the highway intersection oast of

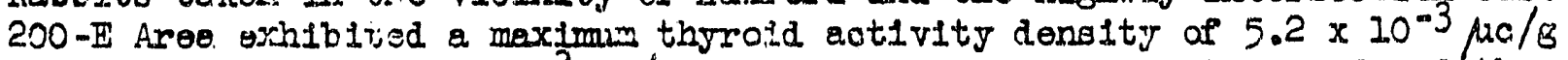
and a mintmis of $1.9 \times 10^{-3}$ Mo, 8 . Maximum activity denelty was found three milos east of the intersection. 
The westo ditch at 200 North 8 Area has been rosurveyed to Indicate the advise-

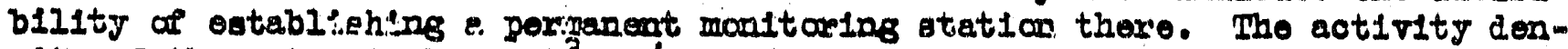
olty of the water $137 \times 10^{-3} \mathrm{mc} /$ liter. Inmoreod regetation and the wood co treos growing tharo hare actitlty densities 1,000 and 100 times hlgher, rospectivels, then that of wator.

An experiment cancerning the uptake and ocnsentration of radioeotivity by animal and recetibls tioanes bolled in file effluent weter hes beon comploted. Tho data will be jresentol in a separate rejort.

2. Toxicology of $I^{131}$ in Stock Antmalo

Six of tho atro ram lambs proviously placed on a foeding regimen ocotaining $480 \mathrm{pc}$ of I $131 / \mathrm{ram} / \mathrm{dar}$ havo orldenced thrreldal camogo a detected by a drop In 6xtermel coun'ting rate. The Blochemf stry group dotiormined the relative quantity of prototn-bound 1odino, radiouct 1vo pretsin-bound 1odine, and rad 10act170 Inorganto Iodine, in the serum of blood taken from those animals at frequeat intervals. Preliminary data reveal promileling correlatians betweon rat loo of rarlous lodine trastions and externel threcld count.

Two owe lambe in the 240 pro group axplred duririce this perlad. Both of these animais exhiblted enaclation, lethargy, macular woekness, and Incoordination, difflculty in prehenelon, a rough wool coat with moderate alopeole. This alopecia Included a region up to $3 \mathrm{~cm}$ in diamoter on the lablum maxiliare and lablum infertus. Necropsy revealed oplthellal denudaticin in tho mouth. There was aiso osophegerl and minor gartric involvement, one of the owo lamber beoame blind as both oyeo derelopod corneal ulceration. Just prior to explra. tIon, keratorihoxis occurryd. 
GHWHRAL ACCOUTMING DIVISION

VONITHL REPORT

March 1951

GBHERALL

Volume of work handled In the Accounts Payable Section during March 1.951 exceeded that handled during any month since decentralization of the Accounting Div1s1ons in 1948. In splte of the shortage of personnel, all Involces were pald when due and were promptiy audited and forwarded to AEC for final approval. As of March 31, 1951, total rouchers on hand and in process, Including those paid and unpald, numbered 1 513. Th1s represents approximately $58 \%$ of the number currently recelved in one month. Final audit of approximately 20000 purchase arder folders whlch contain information as to quantities recelved and amounts rald is being deferred until adaltional personnel is made avellable. This audit is necessary before these Piles can be farwarded to permanent storage.

Revision of budgets for FY 1952 and preparation of budgets for FY 1953 progressed auring the month. As budget date was recelved from division heads and coordinated by the Budget Accounting Section, a close working arrangement was maintained with the ABC Budget OPflce. As a result, AEC reconmen-dations and questlons were consldered as the work progressed and preliminary approval wos obtained on a considerable amount of completed work.

As a result of the incorporetion of Project ingineering with Engineering and Construction DIVIsions, besis of all assessment studies were thoroughiy revlewed and revislons were made where necessary.

Arrangements were made for the segregation of work and selection of employees who are to be transferred to Technical, Englneering and Construction Div1sions. Work substantially cornplses compling, analyzing and reporting Technical operating and research and development costs and related budgets. A total of seven employees ( 3 from cost, 2 from Budget Accounting and 2 from Accounts Payeble) are to be transferred.

Plant Accounting personnel is in process of reviewing depreclation rates of several classes of plant and equipment. Rates were established at the time of the plant appraisal in June 1949, and in many instances it has become apparent that revisions to rates or 1 ginally established should be made. Plans were nearing completion relative to the assignment of Plant Accounting personnel to the areas where they will be responsible for coordinating work in connection w1th plant accounting. Continuing physical inventories of certain types of equipment are also to be conducted by these employees.

Internal Auditors started work on two new audit prograns in March; namely, Standardization of Inventory Sub-Accounts and Physical Inventory and Booking of Special Mater1als. The followl.ng audits are currently in progress: Timekeeping Procedures, Hospital and Bus Revenue, Receiving and Shipping, State Excise Tax, Physical Inventory Procedures and Study of Termiration Clearance Procedure. Audits were completed and reports 1ssued on Review of Proposal to Purchase Marine Inswrance Pollcy and Revenue and Change Funds of School of Nuclear Englneering. 
Request for relmbursement authorization covering the hergency Loan Plan for Ill or Iaid-off Pension Participants was transmitted to the Cormission on Fobruary 28, 1951, and Relmbursement Authorlzation No. 142 dated March 26, 1951, was 1ssued by the Atomic Energy Camission approving the plan for relmbursement effective February 1, 1951. Hanford Works Instruction Letter No. 166 was issued in March covering the provistons of the plan, which was placed in effect as of February 1, 1951 on a company-wide basis.

Payroll deductions for Red Cross contributions amounted to $\$ 5,388.85$. Deductions were wade in March from salaries of 1 l22 weekly paid enployees and 603 monthly paid exployees. A check covering these collections will be iasued to American Red Cross and forwarded to the chaiman of the Nucleonics Department Red Cross Drive.

The retroactive partion of the $3 \%$ General Salary Increase (ninimurn $4 \phi$ per hour) applicable to JuIy 2, 1950 rates, effective September 18, 1950 for employes 8 represented by the H.A.M.T.C. and for employees represented by Iocal 20I, Bullding Trades Service Eriployees UnIon, was paid during the month of March. The retroactive poyment covered the period septeniber 18, 1950 through February 11, 1951. amounted to $\$ 147,894.74$ and was paid to 3332 ermployees.

There are 135 employees, as of March 31, 1951, who have left the Company to enter the Armed Forces of the United States. Military Duty fillowance equivalent to one month's salary has been pald to 36 weekly pald exployees and i? monthly paid employees totaling $\$ 11,431.52$ as of March 31, 1951.

The hlgh percentage of absenteeism during March was al.so reflected in an increase in the number of disability clains processed under the G. E. Insurance Plan. Absences of paysoll personnel in March and the high percentage of absenteeism in all divisions, which increased the work load in the Weekly Payroll, made it necessary to reschedule nany of the statistical reports and related payroll work in order to complete calculation and distribution of payrolis according to nomal schedules. 
Advances from AEC 1ncreased from $\$ 5000000$ as of Febmary 28, 1951 to $\$ 6500000$ as of March 31, 1951. Advances are accounted for as followr:

Cash in Bank Contract Accounts Cash in Bank - Balerry Accounts Cash in Transit Advances to Subcontractors Travel Advance Funds

Tote.
March

$\$ 5596364$ 50000 428636 300000 125000

$\$ 6500000$
February

$\$ 4470490$ 50000 79.510 300000 100000

$\$ 5000000$

Hanford Works cesh disbursements and cash recelpts, excluding advances from Atamic Energy Comission for the month of March 1951 as compared wth February 1951 may be summarlzed as follows:

March

February

Disbursements

Material and Frelght - CE

Payrolls - GE (ivet)

Paymants to Subcontractors

Pension Trust Fund - Company Portion

Payroll Tax

Generel Administrative Expenses

Stock Bonus Plan - Employers Contribution

U. 8. Savings Bonds

Others

\begin{tabular}{rrrrrr}
$\$ 2$ & 360070 & $\$ 2$ & 353 & 419 \\
2 & 530 & 812 & 1 & 972 & 441 \\
4 & 015 & 533 & & 311 & 335 \\
& $-0-$ & 1 & 213 & 300 \\
396 & 907 & & 434 & 035 \\
200 & 000 & & 200 & 000 \\
168 & 451 & & & -0 \\
140 & 325 & & 143 & 156 \\
409 & 811 & & 364 & 775 \\
\hline 10 & 241 & 909 & $\$ 10$ & 292 & 461
\end{tabular}

Tota].

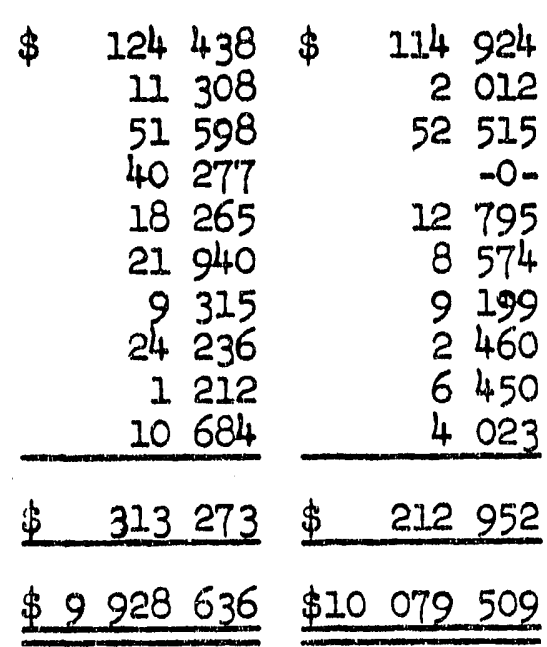

Total

Net DIsbursements

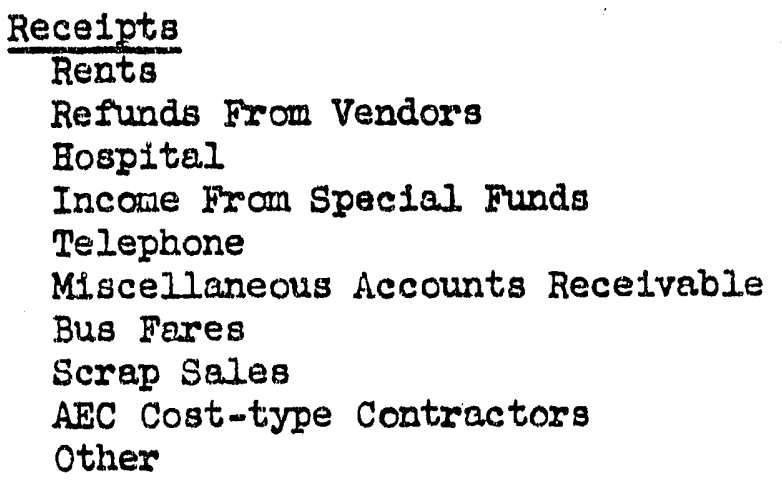


Generel Accounting Division

STATISTICS

Pumployees and Parroll

tuployees on Payroll at beginning of month

Total

Monthly

Payro11

Additions and transfers in

Removals and trensiers out

7990
287
$(226)$

Transfers from Weokly to Monthly Payroli

Transfers from Monthly to Weekly Payroll

Emplogees on Paysoll at end of month

Number of Amployees

BargainIng Group - HAMEC

Bargaining Group - Bullding Services

Other weekly

Two platoon firemen

Brecut1ve, adminlatrat1vo and operating

Protessional.

Other monthiy

Total

Numiter of Amployees

Menufacturing

Fingineering and construction

Munfclpel

Real Estate ard General Services

Techrical

HeaIth Instrument

Mrployee and Community Relations

Plant Security and Services

Purchasinfs and Stores

Medical

General Account ing

General Adminlstrat Ivo

Total

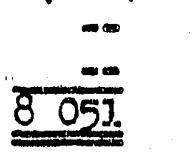

18

(24!

22

(I)

1955

March

3099

69

2928

57

1295

564

39

8051

Weokly

$\frac{\text { Parro11 }}{6050}$

269

(202)

(22)

6096

February

3077

69

2904

59

1275

562

44

7990

3232

869

230

425

822

434

105

1037

373

279

183

$\frac{56}{051}$

3215 (1)

863

234

428

815

425

100

1005

369

288

189

59

7990

Overt Ime Peyments

Weelply Paid Fmplojees

Monthly Pald Employees Total

$\$ 110418$

$28 \quad 221$ (2)

$\$ 86541$

$\$ 136709$

$\$ 110 \frac{23}{423}$

Number of Changes in Selary Rates and Job Classifications

1058

1251

(1) February stat1st1cs recast to reflect the transfer of 197 Project EnglneerIng employees from Manufacturing Divisions to EngIneering \& Construction Divisions effective March I, 195.L.

(2) Payments covor por'1od from 16 th of provious month to 15 th of current month, except that in the case of Engineering and Construction Divisions, peyments cover period February 1, 1951 to February 28, 1951.

(3) Payments cover period from I6th or previous month to 15 th of current month, except that in the case of inginooring and Construction Divisions, peyments cover period January 1, 1.951 to January 31, 1951.

4 . 
Genoral Accounting Divlsion

Gross Amount of Payroll

Manufacturing

Inginoering and Construction

Munlclpal, Real Estate and Goneral Services

Other

Total

Annual Golng Rate of Payroll

Bege

Orext 1 mo

Isolation Pay

Shift Differential

other

Total

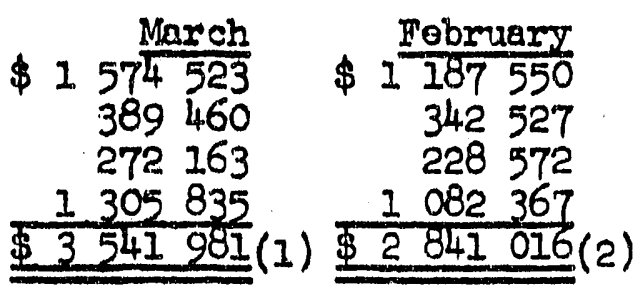

$\$ 33746807$

I 588608

1038613

406441

47389

$\$ 36827858$
$\$ 33556227$

1382405

1033968

411. 834

55817

(3) $\$ 36440251$

Averase Hourly ase Rates

Bergaining group - EANTC

Bergaining group - Building Services

1.947

1.495

$1: 947$

Other weekly

1.610

1.494

Two platoon firemen (monthly rate +173.9 hours)

1.883

1.619

Execut 1ve, administrat Ive and operet ine

Professional

Other monthly

Total

2.783

1.847

2.702

2.798

2.150

2.680

2.067

2.182

Averege Earnings Rate Per Bour (4)

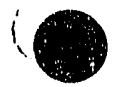

Menufacturing

$\begin{array}{ccc}\frac{\text { March }}{\text { Wogkly }} & \text { Monthly } & \text { Total } \\ \$ 2.115 & \frac{10.807}{2.233} \\ 1.666 & 2.881 & 2.130\end{array}$

$\frac{\text { February (5) }}{\text { WookIy Monthly Total }}$

Enginoering \& Construct Ion $\begin{array}{rrr}2.115 & \$ 2.807 & \$ 2.233 \\ 1.666 & 2.881 & 2.130\end{array}$

$\$ 2.120$

$\$ 2.808 \div 2.237$

Munlclpel, Real Estatio \& General Services

Othor

$\begin{array}{lll}1.867 & 2.373 \quad 2.026\end{array}$

1.670

2. $878 \quad 2.140$

Total

$\frac{1.710}{\$ 1.893} \frac{2.681}{\$ 2.721} \frac{1.942}{12.086}$

$\begin{array}{r}1.876 \\ 1.717 \\ 1.898 \\ \hline\end{array}$

$2.367 \quad 2.029$

$\frac{\text { March }}{3.93}$

$\frac{5.73}{4.70}$

$\frac{2.74}{4.06}$ $\begin{array}{ll}2.367 & 2.029 \\ 2.677 & 1.946\end{array}$

$\$ 2.721 \frac{1.091}{\$ 2.091}$

Fobruary
3.89

3.06

1.82

2.76

(1) Includes payments for the five (5) week perlod ended March 25, 1951 in the cave of Weekly Pald employees.

(2) Includes peyments for the four (4) weok period ended February 18, 1951 in the case of Weokly Pald employeer. Salary increaser, effect1ve September 18, 1950 of $3 \%$ (minlmum of ht per hour) on July 2, 1950 rates, were paid on a current bas1s effect1ve February 12, 1951 to 3,100 employeer represented by unions.

(3) Includes now rates after fiving effect to General Salary Adjustmont as Indicated in note (2) above.

(4) Includes shift differential and Isolation Pay. Excludes overtime premiums, conmissions, sucgestion awards, etc.

(5) Fobruary statistics recast to reflect the transfor of 197 Froject Engineoring employeos from Manufacturing Divisions to Engineerine and Construction Diviafons effective Merch 1, 1951. 
Employee Benefit Plans

Pension Plon

Numbor part lclpating at boglnning of month

New part lcipants and transfers in

Removals and transfers out

Number part lolpating at ond of month

of of ellatblo employeos part 1clpat ing

\section{Hoyees Ret 1red}

Number

Aggregate Annial Pensions Including

Supplemental Pajments

Amount contrlbuted by employees retirod

(a- Includes 6 employees who died after reaching optional retirement age but before actual ret lrement. Iump sum settlements of doeth bonelits were pald to beneplofarles in these cases.

(b- Amount before commation of pensions in those cases of employees who recelved lump sum settloment.

\section{Insurunce Plan (1)}

Personel Coverage

Number part1cipating at boginning of month

New participants and transfers in

Cancieliations

Remuvals and transfers out

Number part1clpating at ond of month

कof ellatble exployees particlpating

Dependent Coverage

Iumber part lcipating at beginning of month

Additions and trensfers in

Cancollations

Removals and transfers out

Number participating at ond of month

Claims - Disabli1ty Benef1ts (2)

INumber of clajns pald by insurance campany:

Innloyee Benefits

Weoly. J Sickness and Accident

Da1ly Hosp1tal Expense Benefits

Speclal Hospltal Services

Surgicel Operations Benefits

Dependont Benofits

Daily Hospital Ixponse Bonefits

Special Hospital Sorvices

Surgical Operations Bonefits

Amount of claims paid by inaurance company:

Imployee Benefits

Dependent Jenofits

$$
\text { Tota.I }
$$

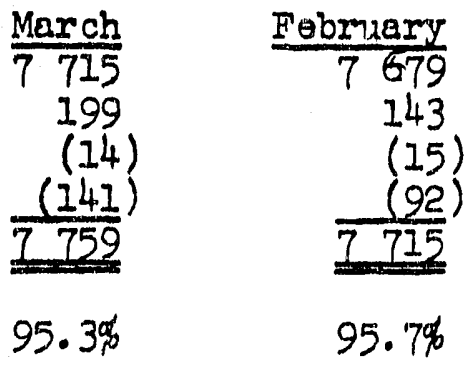

5029

89

(6)
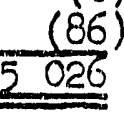

(90)

494

$95.6 \%$

March Total to Date

160-a)

1. 560

1510

\$38 044-b)

25199

\begin{tabular}{|c|c|}
\hline $\begin{array}{r}\text { March } \\
530 \\
54 \\
(90) \\
6494\end{array}$ & $\begin{array}{r}\text { Fobruary } \\
554 \\
45 \\
(69) \\
6530\end{array}$ \\
\hline $95.6 \%$ & $95.8 \%$ \\
\hline$\frac{\text { March }}{4}$ & $\frac{\text { Total to Date }}{160-8}$ \\
\hline $\begin{array}{r}560 \\
1510\end{array}$ & $\begin{array}{rl}\$ 38 & 044-b \\
25 & 199\end{array}$ \\
\hline
\end{tabular}


General Accornting Division

\author{
Employee Bener1t Plans (cont inued) \\ Inowence Plan (cont inued) \\ Cla1ms - Death Beneflts (1) \\ Number \\ Amount
}

\author{
$\frac{\text { March Total to Dete }}{4}$ \\ $\$ 20985 \quad \$ 314312$
}

\title{
Group IIfe Insurance
}

The Group Ilfe Insurance Plan was disccatinued November 30, 1950. As of March 31, 1951, 22 employees who are absent with continuous service are st1Il part1clpating in the Group LIfo Insurance Plan. They were not actively at work an December 1, 1950, and therefore were not elifible to perticipate in the new Insurance Plan. However, they w1Il becone eligible upon their return to works.

Group Disab1lity Insurance

The Groxp Dlsablilty Inourance Plan was discont Inued November 30, 1949 for all omployees actively at work. However, nne employee who has boen absent from work since September 15, 1949, is st11. insured under the Group Disablilty Insurance Plan.

\section{Group Hoaj.th Insurance}

The Group Health Insurance Plan was made effectlve Decomber 1, 1949 and was discont Inued on November 30, 1950, As of March 31, 1951, 10 employoes who are absent with continuous service are still participating in the Group Eealth Insurance Plan. They were not actively at work on December .., 1950, and therefure were not elielble to participete in the new Insurance Plan. Howover, they wlll becomo elifible upon the ir return to work. During March, 83 checke in payment of benefits of $\$ 5,182$ on 59 Group Health Insurance clains were recelved from Metropolitan Life Insurance Conpany.

\section{Vecation Plan}

Number of employees grented permission to defer one week of their 1951 vecation to 1952

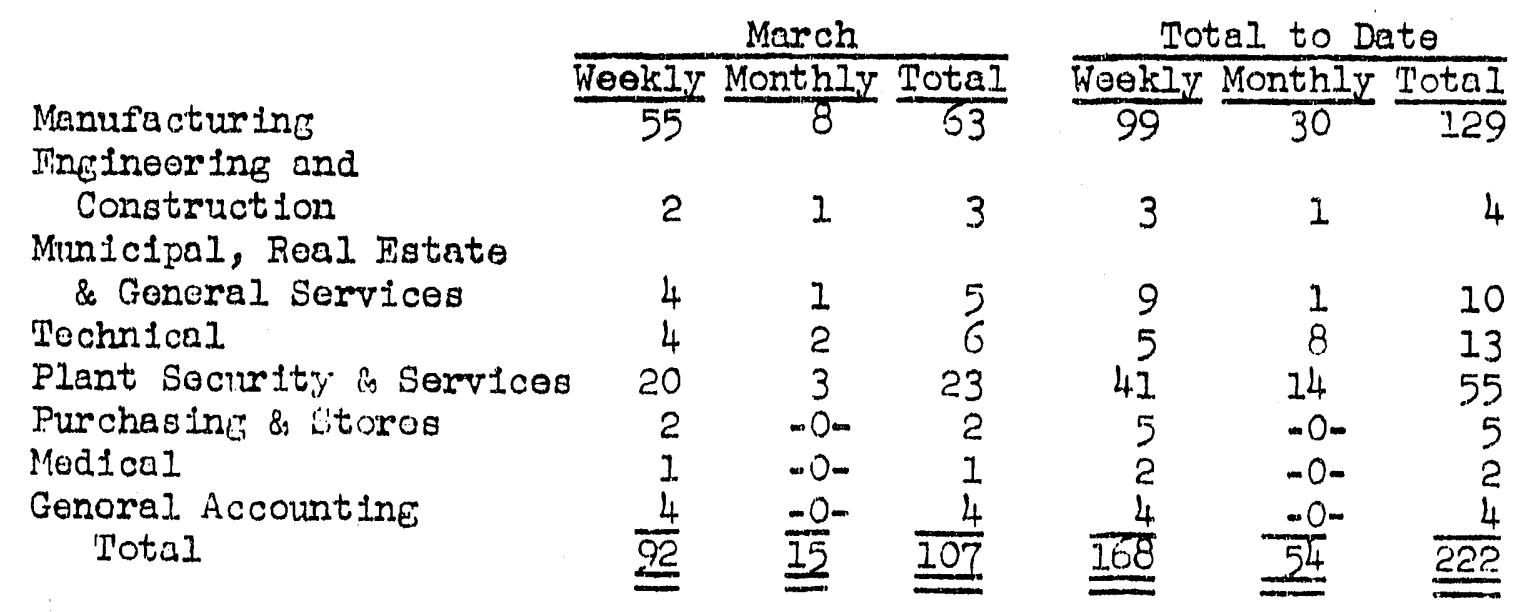

(1) Total to date includes two deaths which resultod from accidental injury. Total to date includes all clnms under the old and now Insurance Plans. 
Geveral Accounting DIfialon

Theroe Benerit Plang (Cont Inued)

ர. S. Savings Bonde Number particlpating at beglaning of month

New authorlzatlons

Voluntary cancellations

Removals and tranefors out

Trensfers in

Number part1cipating at ond of month

\% Partiolpating

G.I. Thplojeos Sevioge and Stock Bonus Plan

G.E. Sarings Plan

Both Plans

Bonds Isaued

Maturity Value

Number

Refrunds lasued

Revialons in authorizat Ions

Annuel going rate of deduct Ions

G.I. Eroloyees Savings

and Stock Bonus Plan

G. D. Savings Plan. Total
$\$ 600837$

213061

$\$ 813898$
Municlpal,

Real: Eatate

Enginearing \& \& General
Other Total 1625

(117) 13

$40.7 \%$

$12.0 \%$

$46.6 \%$ Construction Services

1349

3494
(3)

109

$\frac{246-274}{4}$

$\left.\begin{array}{ll}3) & (3) \\ 6 & \\ 1\end{array}\right)$

350

1

269

(1)

(1)

(39)

(23)

124<smiles>CC</smiles>

1310

$35.2 \%$
$8.3 \%$
$40.3 \%$

$36.5 \%$

$41.1 \%$

$35.1 \%$

$39.8 \%$

$3434 \quad 43 \%$

$\$ 80750$
1667
41

41
27

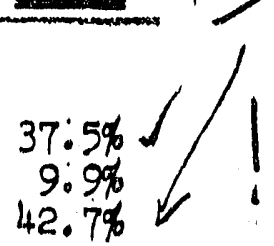

Annuity Certif 1cater (For duPont Service) Nurnber 1ssued

Susizest1on Awards Nurmber of awards

Total amount of awards

Employee Sales Plan

Certiflcates 1ssued

Certiflcates rolded

Selary Checks Depos 1ted

RIchland Branch - Seattlo Firat NatIonal Jank

North Richland Area offlco Seattle Firat Nat Ional Bank

Rlchland Branch - Natlonal Bank of Commerce

Out of atate banks (Schenectacy staff) Total

* Week onded 3-18-51

$\frac{\text { March }}{-O-}$

44

$\$ 505$

March

$\begin{array}{ccc}\text { Major } & \text { March } \\ \frac{\text { Traflic }}{4.1} & \frac{\text { Appliances }}{215} & \frac{\text { Total }}{256} \\ 4 & \frac{5}{4} & \end{array}$

March Weokly Monthly

Febmary

\begin{tabular}{|c|c|c|c|}
\hline$\theta A$ & Monthiy & Weokly & Monthly \\
\hline 698 & 836 & 706 & 843 \\
\hline 13 & 7 & 14 & 6 \\
\hline 251 & 189 & 236 & 179 \\
\hline$\overline{962^{*}}$ & $\frac{3}{2035}$ & $\overline{956}^{* *}$ & $\begin{array}{r}2 \\
1030 \\
\end{array}$ \\
\hline
\end{tabular}

941

$\$ 15300$ 5

**Week ended 2-18-51

Speclal Absence Allowence Requerts Number submitted to Penalon Barra

$\frac{\text { Absenteelom (Weokly Fald Imployeer) }}{\text { Janiuary I to March }}$

$\begin{array}{ll}\frac{\text { March }}{5} & \frac{\text { February }}{9} \\ 3.44 \% & \frac{1957}{2.63 \%}\end{array}$


General Accounting Division

FYHSONNHEL AND ORGANIZATION

Number of Irmployees

On Payrolis at beginning of month

Merch

188

(11)

Removels and tranefers out

Additlons and transfers in

Humber at and of month

Net increase (or decrease) during month

\% of terminations and transfers out

\% of abrenteo1am
12

189

1

$5.8 \%$

$5.42 \%$
February

188

(I)

Changes by division in number of Accounting D17laton emplogees during March 1951 were as follows:

General: Increase of one employeo One transfor from Plat Security and Services

Name

Accounte Payable: No Change

Cost: Increase of three employees

Throe ner hilres

Edno B. Footer

General Accounta: No Change

Plant Accounting: Increase of three emplogees Five new hires

A. B. Adeline

J. W. Nelson

Dorothy J. Toppin

One trangfer to Manufacturing Maintenance

One employee entered Military Service

Weekly Payroll: Decrease of flve employees

Two new hlres

One tranefer to Purchasing and stores

One exployeo entered Military Service

One 11 Iness removel

Four terminetions

Monthly Payro11: Decrease of one employee

One new hire

Two terminat ions

B. P. Burr

Ethel B. Clarke

D. C. Easton

E. Heintz

R. A. Launor

Betty C. RIdders

S. F. Casteel

Charlene R. Calkins

Marlan B. Hendr1cks on

Loulse M. Blakely

J. E. KIrkpatrick

Gladyr E. Frlend

Ruth D. Bender

INeIen I. MIIburn

Betty B. Pesce

Betty J. Rouse

P. D. Sutton

Helon C. Wellgure

Hazel H. W1Illams

Special Aselmment: No Change

Budgets: No Change

Internal Audit: No Change

Infurfes

Meajor

Sub-ma,jor

Mineri:

\begin{tabular}{cc} 
March & Februery \\
\hline$-0-$ & $-0-$ \\
$-0-$ & $-0-$ \\
1 & $-0-$
\end{tabular}

9. 
General Accounting Divielon

PIRRSONIULL AND ORGANIZATION (Continued)

Number of Accounting Diviston employees as of March 31, 1951. were as follows:

General

Accounts Pegrable

Cost

General Accounts

Plant Accounting

Woekly Payroll

Monthly Payroll

Speclal Alsigriment

Budgets

Intermal Audit

Total
Nhaber of Himployees

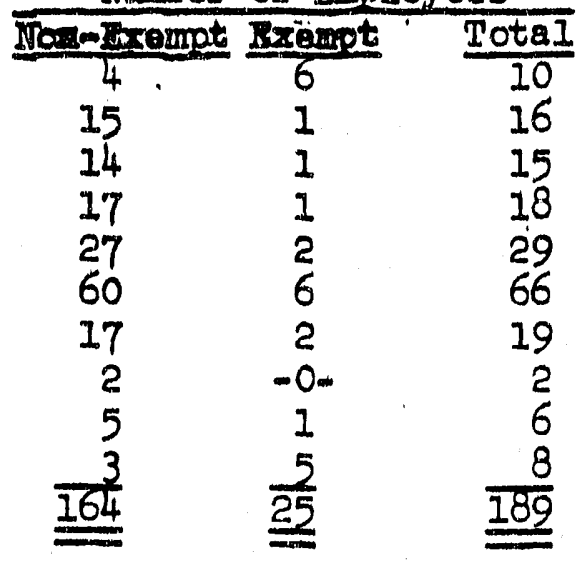

Ion-aromt employees may be sumarlzed as follows:

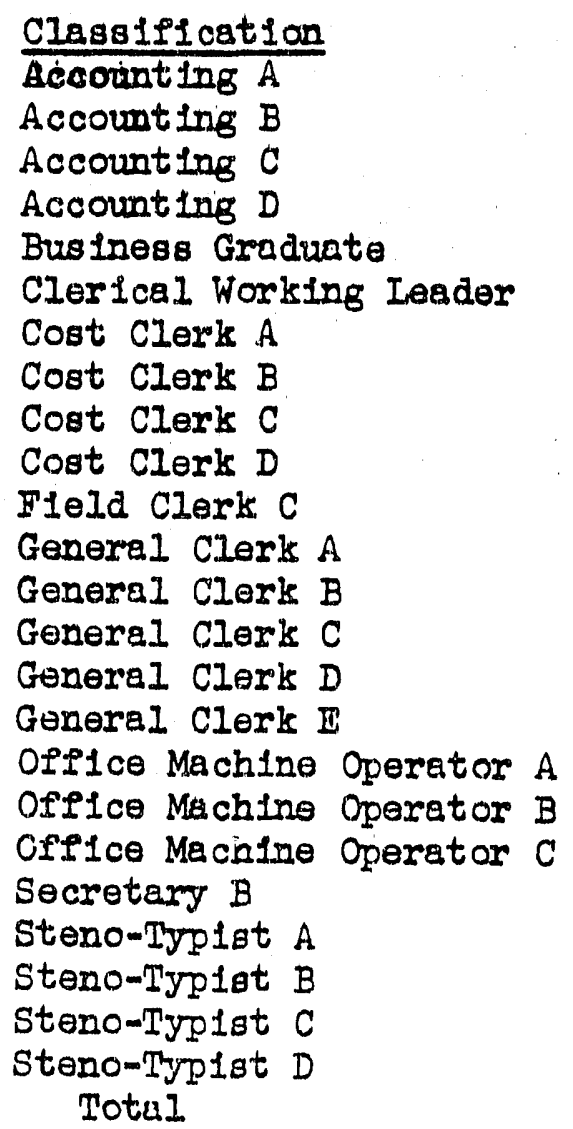

\begin{tabular}{cc}
\multicolumn{2}{c}{ Number as of } \\
\hline $3-31-51$ & $\frac{2-28-51}{2}$ \\
\hline 2 & 2 \\
3 & 7 \\
7 & 7 \\
10 & 13 \\
12 & 8 \\
9 & $-0-$ \\
1 & -0 \\
1 & 1 \\
1 & 1 \\
3 & 2 \\
2 & 19 \\
19 & 42 \\
37 & 21 \\
19 & 9 \\
9 & 1 \\
1 & 8 \\
7 & 6 \\
6 & 1 \\
1 & 1 \\
1 & 2 \\
3 & 6 \\
6 & 3 \\
3 & 1 \\
1 & 163 \\
164 & $=1$ \\
\hline 1 &
\end{tabular}

Open employment requests as of March 31, 1951 were as follows:

Account Ing $B$

Accolunting $C$

Accorating D

2

Business Graduates

Cost Clerk C

Cost Cleris D

General. Clerk B

General Clerk D

Total

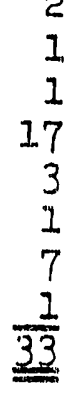


Generel Accounting Division

\section{Accounts Payablew Balsmce at Beflnning of Month \\ Vouchers Bhtiered \\ Casb D1 sbursements \\ Cash Recelpts \\ Belance at end of month \\ Number of Vouchers intered \\ Number of Checks Issued \\ Number of Frelght BIIIs Pald \\ Amount of Freight Blils Pald \\ Inumber of Purchase Orders Recelved \\ Value of Purabese arders Recelved \\ Cash D1sbursements \\ Wurlolpal, Real Estate \& Cenerel Services Tngineering \& Construction \\ Genera' \\ Manufacturing}

Tota].

Material and Mrelght

Lump Sum and Unit Price Subcontrects

CPHF Subcontracts

Labor

Others

Payrolls (Net)

Payroll Taxes

U. \& Savings Bonds

Income Fram Spectal Funds

General \& Adminlotrative Expenses

Stock Bonus Plan - Employers Contribution 1950

Pension Trust Fund - Fmployers Contribution A.I Othes

Total
March

$\$ 71794$

I 502347

1482560

1269

$\$ 2850$

2577

1484

$\$ \quad 6133$

1113

$\$ 451450$

\$ 288637

5201137

4153697 598438

$\$ 10241.909$

$\$$
2380070 489917

2 767076 758540

2530812 396907

140325

40277

200000

168451

- 0 on

369534

$\$ 10241909$
Febsurary

$\$ 98721$

2423930

2451584

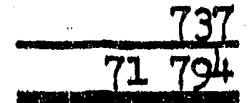

2036

I. 223

$\$ \quad 4326$

1229

$\$ 510814$

\$ 209775

4799656

4567181 715849

$\$ 10292461$

$\$ 2353419$

508192

2 467687 635456

1972441 434035

143156

-0 -

200000

$\infty$

1213300 364775

$\$ 10292461$

Cash Recile1pts Muldispal, Real Estate \& General Services Englneering \& Construction

\$ 217216

51009 General

11203333

Manufacturing

*General Divisions Only 
Detall of Cash Recelpts Advances Irom AEC

\section{Renta}

Hospital

Telephone

Scrap Sales

Bus Fares

Miscellaneous Accounts Recelvable

A.I.C. Cost-type Contractors Accounts Recelvable

Refunds from Vendors

Employee Sales

Educational Program

Refund of Advances to Subcontractors (Kellex)

Expendit tures - Disallowed by A.I. .C.

Income F: Special Funds

All Other

\section{Total}

Number of Checks Written

Munlcipal, Real Estate \& General Services Desion \& Construction

Ceneral

Manufacturing

Total

Benk Balances At End of Month

Chemlcal Bank \& Trust Jompany - New York Contrect Account

seattle Flrst Natinnal Benk - Rlchjand

Contract Account

U. S. Sev1ngs Bond Account

Selary Account No. 1

Salary Account Nn. 2

Trevel Advance Account

Seattle Firat National Bank - Seattle Escrow Account

Nat Lonal Bank of Commerce - Rlchland Contract Account - Manufacturing

Contract Account - Municlpal, Real Estate \& General Services

Total

Travel Advances $\varepsilon$.nd Exfense Accounts

Cash Advance balonce at end of month*

Cash Advance balance outationding

over one month*

Traveling and Itving Expenses:

Pald Employees

Bllled to Government

Balance in Variation account at end of month *General Divisions only
March

$\$ 11079510$

124438

51598

18265

24236

9315

21940

1212

11. 308

1171

1219

-0 -

$=0$ -

40277

8394

$\$ 14392783$

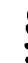

February

$\$ 11428657$ 114924

52515

12795

2 460

9199

8574

6450

2012

831

1509

100000

10619

$-0$.

1683

$\$ 11752228$

283

817

1484

810

216

649

1223

654

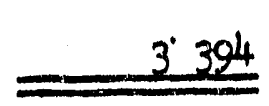

2.742

\$ 3034783

$\$ 1539648$

1823656

2 256467

186919

201912

20000

20000

30000

$30 \quad 000$

50925

1.8868

31685

31. 685

701562

$584 \quad 151$

$36 \quad 363$

$90 \quad 225$

$\$ 5915893$

$\$ 4772956$

$\$ \quad 41343 \$ 50313$

21126

4021

38866

26215

$34301 \quad 23976$

21 625 Dx. 17 061 Dr. 
Cenerel Accounting Division

Hogpital Aocounting

Accounts Recelvable

Balance at Beginning of Month

Involces Issued

Refunds

Caoh Recelpts

Paysol1 Deductions

Bad Debts Witten off

Adjustments

Balance at Fad of Month

March

Tebruary

\$ $128789 \quad \$ \quad 128047$

$73558 \quad 57991$

$639 \quad 1114$

51598 cr. 525.15 or.

5523 ar. 5657 cr.

-0- $\quad 175$ or.

$85 \mathrm{cr} . \quad 16 \mathrm{cr}$.

$\$ 145780 \$ 128789$

March

Total to Date

Scrap sales

(a) number of seles

(b) Revenue (Mot Including

Sales Tax)

Revenue to G.E.

Revenue to ABC (sale of

Iract Houses)

Total Revenue

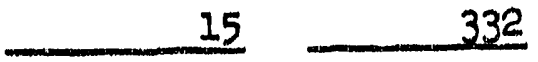

\$ $24236 \$ 336690$

$600 \quad 40778$

$\$ \quad 24836 \$ 377468$ 
Genersal Accounting Divlsion"

ACCOUNIS PATABTE

The number of rouchers booked In March wes 2577 amounting to $\$ 1502347$ 8s compared to 2036 in Doburuary amounting to $\$ 2423930$. This volume represents the greatest number of vouchers processed threugh this office in any one month eince decentrallzation of the Accounting D1v1aion in 1948 and continues the steady Increase in volume evident over the perlod of the last $81 x$ months.

The number of checks 1ssued in March was 1484 as compered with 1223 in February. This is the greatest number of checks 1saued by this off1ce in any ane month sInce decentralizetion of the Accounting Division in 1948. Deta1la for Marah are as follows:

$\begin{array}{lll} & \text { Merch } & \text { February } \\ \text { Chemical Bank Mruat Co. } & 484 & 459 \\ \text { Beattio-FIrat Nat1onal Bank } & 1000 & 764 \\ \text { Totel } & 1484 & 1223\end{array}$

A total of 2540 vouchers were paid in March, averaging 1.70 vouchers per check, the higheat average attained to dete and compares with an average of 1.66 in Febmuary.

On March 31 there were I 513 rouchers on hand requiring additional supporting data before they could be forwarded to AEC for final audit. Detalls, compared with Febmuary, are as follows:

\begin{tabular}{|c|c|c|}
\hline & March & February \\
\hline $\begin{array}{l}\text { Number on hond - Pafd } \\
\text { Number on band - Unpaid }\end{array}$ & $\begin{array}{r}469 \\
1044 \\
\end{array}$ & $\begin{array}{r}413 \\
1024 \\
\end{array}$ \\
\hline TotaI & 1513 & 1437 \\
\hline
\end{tabular}

Number of freight b1118 pald 10 March was 375 amounting to $\$ 6125$ as compared with 326 in February amounting to $\$ 4153$.

The General. Ledger Accounts Payable balance on March 31 was $\$ 92,849.85$. Detalls of thls balance by wonths, compared with February, are as follows:

\begin{abstract}
August
Octcber

November

Decenher

Jenuary

Febmuary

March
\end{abstract}

$$
\begin{array}{rr}
\frac{\text { March }}{.0 .} & \frac{\text { Febmunry }}{3.60} \mathrm{Dr} . \\
3.21 \mathrm{Dr} . & 2,307.75 \mathrm{Dr} . \\
35.44 \mathrm{Dr} . & 117.62 \mathrm{Dr} . \\
113.14 \mathrm{Dr} . & 97.70 \mathrm{Dr} . \\
964.67 \mathrm{Dr} . & 10,747.42 \\
93,567.23 \\
966.29 & \\
\hline
\end{array}
$$

TotaI 
Ceneral Accounting Divlsion

ACCOUNMS PATABLE (CONWD.)

New pirchase crders 1asued in March applying to Genexal DIv1s1ons totaled I 113 emounting to \$451 450 as compared with I, 229 1n Februery amounting to $\$ 510814$. The value of material being purchased in Mexch, although lowex than in Februmey, still is higher than in any other month pricr to February since decentrailzation of the Accounting DIVIsion. The bolk of purchases in March (58\%) were for stcres Iriventories accountis, Plant and Equipment I tems accounted for $18 \%$.

\section{BUDGETARY CONTROC}

Durling the farepart of the month, budget amounts as determined by the fourth quarter budget revlew were tabulated and oubmittied to the cost section for Inclusion on operating reports. Effort during the balance of the month was concentrated on work relating to preparation of the budget for FY 1953 and revision of the budget for FY 1952.

DIv1sion heads submitted 1temized detell on budgets for Property In service Bquipment (lncluding offlce Furnture and Equipment) for FY 1952 and FY 1953. These schedules were revlewed and summarlzed by the Budget Accounting section. This budget was completed and forwarded to AgC for preliminary revlew.

Budget schedules for 1952 and FY 1953 for Construction Projects were also completed and forwardiad to ABC for preiliminary review.

Tentatlve schedules of estimated FY 1952 and FY 1953 personnel requirements were completed and forwarded to ABC.

During the latter part of the month workelng schedules were completed on Cash Workelng Capital and Inventor'ses and were ferwarded to concerned divlsions tcgether with letters of instruction.

Considergivle tinf was spent during the month on divisional operating Cost Budgets. As worling schedules were retumed by div1s1on beads, they were revlewed and analyzed by Budget Accounting personnel and the caloulation of monetary amounts was completed by use of payroll and other cost stat1stics.

Wuring the month, continual personal contact wes malntalned with all divielon budget representatives in order to assist them in uniform prepara. tion of data for their FI 1952 and. FY 1953 budgets.

At the close of uhe month, work was progressing satisfactorily on the budget fer FY 1953 and revision of the budget for FY 1952 and deadilnes which had been previous Iy established are expected to be met.

$\cos T$

General D1"uglons Operating Reports for the month of February were issued on March Ij, 195.. Detajled reports of Research and Development Costs for Technical and Heal.th Instrument DIv1sions programs were 1ssued on March 20, and the Consolidated Summary of Costs report was issued March 28, 1951. 
General Accounting Divis100

cosT (Conid.)

Cost analyses letters were 1ssued to mansgers of each General Division showlng a sumary of February costs and a comparison with budgeted costis. Explanations of slepiflcant changes in coste from the provlous month ware polnted out in the letters.

The bases of all assessment studles were thoroughly revlewed and adjustments made where necessary to reflect the Consolidation of Froject Bngineering with the molneering and Construction Divisions.

In arder to provlde a more accurate segregation of costs as incurred by the varlous control groups of Health Inetrument Divisions, the present cost coding system wes enlarged by means of a decimal system whereby costs of these control groups will be accumulated by function or by area in which the service is rendered. The new segregation will provide a much better cost control and w117. Freatly facliltate the preperation of the Hea.Ith Instru- . ment DIV1alons' budget. The system to be used and the cost breakdown Ior the Health Instrument Divisions was evolved after considerable goint effort on the part of the Cost Section and the Health Instrument Divislons.

As a result of the transfer of P-10 Program - Slug Fabrication, to the Manufacturing DIvlalons, Inventories of Aluminum and $\mathrm{Z}$ Metal were also trensferred from Generel Divisions books to Manufacturing Divisions books in March.

Charges by the Electricel and Power Divisions for site preperation in connection with the new wing of the 703 Bullding were reviewed and arrengements were made to segregate these charges at the source for transfer to Plant Accounting in order that they may be reviewed for determination as to whether they are cost Iterns or of a capital nature.

Further effort wes expended on the basic discrepancles that arise in preparation of the Consolidated Summary of Costs Report. Considerable detall. wark was done to determine the various methods of hariding similar itrams by the respective Cost sections and recommendations were made as to the best method to be used in arder to facliltate the prepajation of the Consolldated Sumery of Costs Report.

In connection with the merger of Englneering and Construction Divisions with the Technical Divisions, personnel of the General Cost Section have been designated to be transferred to the newly formed Technical, Engineering and Construction Divisions to handle the necessary Technicel Divisions cost accounting. At the present time these persons are engaged in a concentrated training program encompassing all phases of cost accountinfs for the Technical Divisions.

Arrangements were made with the Surplus, Salvage and Scrap Section of Purchasing and Stores DIvisions to accumulate all the necessary information regarding overtime costs arising from the shipment of lumber on a specific AEC shlpping order. Considerable overtime was necessary to complete this shipment on the stipulated date and detailed records were necessary in order to accurately charge AIC for the cost of the service rendered. 
General Accounting Division

GENIERAI, ACCOUNTS

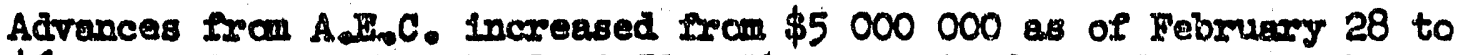
$\$ 6500000$ as of March 31, 1951. The amount adranced as of February 28 may be compered with that of March 31, 1951 as follows:

Cash in Benk - Contract Accounts

Cash in inansit

Cash in Berok - Saleny Accounts

Iravel Advance Funds

Adrances to Subcontrectora

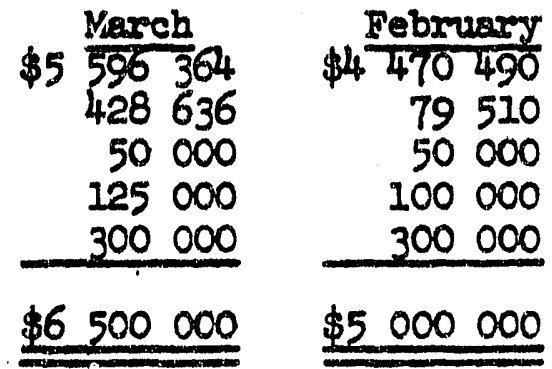

Due to the continued increase in travel activity., the Travel Advance Funds a count was increased $\$ 25000$ this month.

In comparing February disbursements of $\$ 4567$ 181 with those of March in the amount of $\$ 4153697$, a decrease of $\$ 413484$ is noted. This decrease Is due to the payment in February of the company's contribution to the 1950 Pension Mrsat Fund in the emount of $\$ 1213300$.

During March, 197 travel expense reporta were processed as campared with 110 last month. Treveling employees spent $\$ 28507$ and reimbursement was recelved from the Atomic mergy Commission for $\$ 26716$. The balance of $\$ 1791$ was charged to the Travel and Ifrlng Expense Varlation Account.

The Travel and IIving Expense Variation Account has been charged wi.th $\$ 21625$ (AII DIvislons), flscal year to date. A total of $\$ 4564$ was charged this month, for which $\$ 1705$ wes entertainment expenses and $\$ 2859$ the difference between expenses incurred by employees and the amount billed the A.E.C.

General Ledger Trial Belances were recelved from all Accounting Divislons by noon, March 14, 1951. Hanford Works Flnanclal Statements and the Consolidated Financial Statements were completed on March 16, and March 20, 1951, respectively. All accounting reports for February were completed by March 26.

The Financial Statements Group spent considerable time during the month on the development of a revised Application of Funds report.

Memorandum billings were recelved from Knolls Atomic Power Laboratory covering General Englneering Laboratory Assistance to Hanford in the amount of $\$ 140409$. KAPL Ass1stance to Hanford of $\$ 1978$, and Research Laboratory Assistance of $\$ 33$.

27. 
General Accounting Division.

IFIHERTAL AUDTTINTG

Drrelng March,-1951, two audits were begun covering (I) Standardization of Inventory Sub-Accounts and (2) Physlcal Inventory and Booking of Special Materielo:"

Inventory abbaccounts are belug atudied far the purpose of establishing a standard list of Inventory subuccounts, camprehensive, yet descriptive enough to be used with all plant inventory accounts In accordance with the provlstons of Atcomic Energy Comission Bulletin GM-179. At present, the same type of material 18 being carried under differeat-named inventory submaccounts and by different Inventory sub-account numbers under the several General Iedger Inventory accounts:

In conjuretion wh the Finance Branch of the Atanle Fnergy Camission, a study is being made of records and control of platinum and other spectal materlals, with a Vlew of recomending standard procedures and records for use by" all divisions using spectal materials in accordance with the provisions of AIFC Bulletin GM-179.

The following audits are in various stages of completion: (1) Tlmekeeplng, (2) Boopital Revenue (3) Bus Revenue, (4) Receiving and Shipping, (5) State Business and Occupational Taxes, (6) Physical Inventory Procedures, (7) Revlew of Feserve Far Mircellaneous Inventory Adjustmo nts, Account 10.30, and (8) Study of Termination Clearances Procedure.

During the month, an auditor essiated Stares Division personnel in effecting changes in control desk activitles and in reconciling monthly inventory subaccounts required by revised procecures.

A follow unp in the Pleld was made of an audit of Memo Employee Sales toapprafse the system used by the several divisions in controling directcharge materials, supplies, equipment, and articles of protective clothing and to determine the extent and accuracy with which the divislons are malntaining records for control in accordance with the provisions of H.W. Instructions Letter No. 49. Special attention was given to direct-charge Items being withdrawn from the Stares Divislon Memo mployee Seles account.

Aud1t reports were completed and lsaued in March covering: (1) Review of Proposal to Purchase Marine Insurance Pollcy for Hanford Works and (2) Audit of Revemue and Cash Change Fund of School of Muclear Englneering.

\section{PIANT ACCOUIVIJNA}

The review of depreclation rates which were established at the time of the plant appreisal on June 30,1949 continued during the month of March. This review is belng made as rates on certaln accounts are obviously too hlgh. New estimated service lives are being established, and it w1Il be recomended that depreclation rates be adjusted accordingly. 
Genergl Accounting Division

PLANT ACOOUNWIIS (COANDD)

Representatives of this Gection revlewed the revised budget for flscal yeer 1952 and the buaget for f1scel. year 1953 with the Profect inglneering Divis1on. Expenditures were classifled as to Investment ar expense.- No attempt was made to gegregate Investment costs between the equifment budget and new construction.

As a result of a revlew of the spexe parts account, it was found that equipment relued at approximately $\$ 260000$ should be capitalized. A new account, Spare Equipment Beld in Stcrage, was established and arrangements were made for the transfer of capital equipment which bas been included in the spizere parte accounti.

Maps which funploh extent, Installation date, location, ete., of plant utlilties are being revised to reccod changes resulting from projects sompleted since June 30,1949 .

Fleld clerks continued the Inventary of certain Plant and Equipment Accounts. Inventorles were completed covering all refrigerators, ranges, water heaters, drinkeing fountains, household and Industrial vecuum cleaners located in the manufacturing areas and cafeteria equipment located in the Kadlec Hospital. These Items have, in the past, been Included in the Comunity fiurnishings and Equipment Account and designated as Commity Facilities. As a result of this inventary, coryections to Plant Records are being made. The water heaters, drinking fountains, etc., will be charged to the bullding in which used as Butlding Service Equipment and the balance of the equipment will be transfermed to the appropriate facility account.

As a result of recent discussions with representatives of the Atomle Fnergy Ccomisslon:s office of Flnance regarding plant accounting adjustments resulting from physicel inventary, the Atomic Energy Comission Issued a letter stating the policy to be followed. This letter stated "Items added or eliminated from Plant Accounts, as the result of physical inventaries which are determined to be adjustments of the Plant Appraisal as of June 30, 1949, shall be applied to the Plant Appralsal Adjustment Account; Items which cannot be so ldentifled shall be credited to the reserve applicable to the plant Account to which it applies".

\section{MEDTCAI ACCOUNTING}

The belance in Accounts Receivable increased $\$ 16991$ during the month; from $\$ 128789$ in Febmiary to $\$ 145780$ in March. Sales increased by $\$ 15566$ to a new hlgh of $\$ 73557$ during the month. Cash payments decreased $\$ 917$ and payro11 deductions decreased $\$ 134$ from the previous month.

$$
\text { - }
$$

Out-patien't Involces numbered 2549 and amounted to $\$ 17701$ as compared to 2101 involces amounting to $\$ 9598$ in February. This represents an increase of 448 Involees totaling $\$ 8103$ of which $\$ 5005$ was billed to Waale-Complan Company during the month for premenployment physical excminations given to their ermployees. 
Generail Accounting Division

MEDICAI ACCOUNYIITO CCONWD.L

In-patient revenue 1noreased $\$ 7463$ over February. The adult patlent day census increesed from 90.7 to a now blgh of 97.7 in Marcil.

A total of 31 claims in the amount of $\$ 2303$ were submitted thls montb to Fort Lews for services rendered Milltaxy Personnel: Relmbursement on 86 claims in the amount of $\$ 3655$ on mor months blilings was recelved cuming the month:

Blue Cross clatms pald during the month numbered 28 and amounted to $\$ 1995^{\circ}$

Listed below Is a smony of activity to date on accounts submitted to Tolesma Adjustment Service for collection:

\begin{tabular}{|c|c|c|}
\hline & Number & Amount \\
\hline $\begin{array}{l}\text { Accounts submitted } \\
\text { Accounts returned as uncollectible } \\
\text { Collections by Iakelma Adjustment Service } \\
\text { Accounts recalled } \\
\text { Account at } 3-31-51\end{array}$ & $\begin{array}{c}169 \\
29 \\
47 * \\
6 \\
107\end{array}$ & $\begin{array}{rl}\$ 29 & 467 \\
7 & 017 \\
2 & 428 \\
1 & 456 \\
18 & 566\end{array}$ \\
\hline
\end{tabular}

*Includes 27 accounts pald in full and 20 accounta partially collected."

Medical Divisions budget for FI 1953 and revialon of budget for FI 1952 provides for an over-all 1ncrease in net costs of $8.8 \%$ in 1952 and $3.9 \%$ in 1953.

The Fublic Eealth and Industriel Medical portions of the budget remain fairly constant showling a slight increase in costs.

Badlec Hospital Costa and revenue raflect the major changes in the budget: The Increase in budgeted costs is due prinuarily to the addition of nurses. to meet Amarican Hospital Assoclation aursing requirements. It is expected that the nursing staff whll remaln at a constant level during 1952 and 1953. A recomended upward revis1 on of rocm rates is expected to go Into effect in January 1952. This revision w1ll result in increased revenue of approximately $27 \%$ far the last belf of FY 1952 and the full year of FY I953.

During the month the Doctors in the cinic bullaing opened a Clinical Leboratory. It is expected that this will reduce hospital revenue by approximately $\$ 1500$ a month.

20. 
General Accounting Division

\section{PATROTIS}

During the month of March there were 226 removels fram payroll, inoluding 1 leave of absence and 1 transfor to another unit of the Company. Thero wore 287 additions to the payroll including 29 employees re-engaged with continuous service. There wore 5 transfors from othor units of the Company. The result is a net increase of GI exployeas on the payroll.

$* * * * * * * *$

Appro imately 350 man houre were expended in connection with a spoolal payroll a.0aligils.

$$
* * * * * * * *
$$

The Salary Record Card used in Monthly Payroll to rocord personnel and payroll data of each montbly pald exployee was revised to provido space for recording Information necessary for record purposes in ocmnection with the new salary plans whlch became effect1ve December 1, 1950. Two cards were deslgned, one for use under the Brecutive, Administrative and operating Plan and the other for use under the Professlonal Plan. Data has been transcribed to the new Selary Record Cards from the cards used prior to Inauguration of the new salary plans. Th1s work was started early thls year and was completed during March.

$$
\text { ********* }
$$

Request for reimbursement authorization covering the Phergency Ioan Plen for III or Iald-Off Pension Partiolpents was transmitted to tho Comission on February 28, 1951, and Relmbursement Authorlzat1 on No. 142, dated March 26, 1951 was 18sued. by the Atamic Hersy Comise1on approving the Plan for relmbursement effect 1ve February 1, 1951. Hanford Works Instruct 1ons Letter No. 166 was 1saued in March covering the provlalons of the Plan whlch was placed in effect as of February 1 , 1951 on a Compang-w1de basis.

$$
\text { ********* }
$$

During the month of March, charts of Hiployee anc Payroll stat1atice were extended on a current basis for use of management.

$$
\text { ********* }
$$

The retroactive portion of the 3\% General Salary Increase (minimum $4 \phi$ per hour) applicable to July 2, 1950 rates, effect1ve September 18, 1950 for employees represented by the H.A.M.T.C. and for employees represented by Local 201, Bu1lding Trades Service Imployees Unlon, was pald durlng the month of March. The rotroact1ve payment, covering the perlod September 18, 1950 through Februery 11, 1951, amounted to $\$ 147,894.74$ and was pald to 3,332 employeer, including 197 employe日s not reglatered on the payroll at the date of payment but who had been on the payroll for a portion of the per1od September 18, 1950 through February 11, 1951. 
Miltary Duty Allowance equivalent to ono month's oalary was pald during March to six weelly pald employees who entered the Armed Forcos. The grose payment to these employees amounted to $\$ 1,743.22$. A tatal of $\$ 11,481.52$ has been paid to 36 weekly pald employees and 2 monthis pald emploge日 for Mliltaxy Duty Allowance as of. Marah 31, 1951.

There were 135 emploge日e as of Maroh 31, 1951 who had left the Company to enter the Armed Forces of the United States as follows:

\begin{tabular}{|c|c|c|}
\hline & $\begin{array}{l}\text { Called to } \\
\text { Duty }\end{array}$ & $\begin{array}{l}\text { Volunteered } \\
\text { For Duty }\end{array}$ \\
\hline $\begin{array}{l}\text { Reserve Olflcers } \\
\text { Wnlloted Reservo } \\
\text { National Guard } \\
\text { Selective Service }\end{array}$ & $\begin{array}{r}6 \\
32 \\
1 \\
34 \\
73 \\
\end{array}$ & $\begin{array}{c}3 \\
4 \\
-0- \\
55 \\
62\end{array}$ \\
\hline
\end{tabular}

Appraximately 7,900 mploge日 Benef1t Plans Letters showing status in the princlpal beneflt plans were mallod to employees on March 9, 1951. Approximately 250 inquirles were recelved from amployeen concerning the letters.

********

Peyroll deductions for Red Crose contributione whlch amounted to $\$ 5,388.85$ were made in March from salarles of 1,122 weekly pald emplojees and 603 monthly paid employees. A check for this amount will be lasued to American Red Cross and forwarded to the chelrman of the Nucleonlcs Department Rod Cross Drive.

********

New authorlzat1on cards for check-of: of Unfon Dues were recelved for 12 employee members of 5 unlons afflilated with Hanford Atomlc Metal Trades Counc1.1. Seven members of the International Chemlcal Worlsers Union, Local. 369 each algned a revised card authorlzing deduction of union dues in the amount of $\$ 3.00$ per month instead of $\$ 2.00$.

Check-off of union dues is in effect for 862 employee members of 12 unions afflliated with the Hanford Atomic Motal Trades Counc1l, and 19 employeo mombers of the Bullaing Service Fmployees International Union, Locel 201.

********

Payrolls Divisions discontinued ovext lme work during March and returned to a normal 40-hour schedule. 
There were 22 time carde recelved late in payroll during; the month of March, as Pollows:

\begin{tabular}{cr} 
Woek inded & Nhumber \\
\hline $3-4-51$ & 3 \\
$3-11-51$ & 11 \\
$3-18-51$ & 1 \\
$3-25-51$ & $\frac{1}{22}$ \\
Total &.
\end{tabular}

Late time carde cause cansiderable extra rork in Pajroll as it is necessary to calculate the amount of selaries and propare pey ohocks separately in such caser. In some cases, specle, arrangements for distribution of checks mast be de so that employe日e concexmed will recolve tholr alary chock an the regular payday.

In addition to regular payroli addressograph worls, approximately 112,720 1tems were addressographed for other divisions in March.

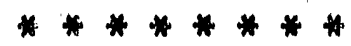

One garnlehment served on the Company had not been dismiseed February 28, 1951. One garnishment wes served on the Company during March. These two cases ware demisegd during Maroh by Court oxder, one witb payment to the Court, and one without payment to the Court. There were no cases panding at March 31, 1951.

$* * * * * * * *$

Three salary checks were reported lost during March and two were subsequent Iy located by the employe日s. "There wes one lost salary check not relssued as of March 31, 1951.

Approximately 780 employees are autborlzed to plck up salery ohecls, U. S. Savings Bonds and Custody Recelpts. During March, 28 employees were added to the 11at of Individusis so authorlzed.

*********

During the month of March, 1,300 U. S. Sevings Bonda having a maturity value of $\$ 61,425$ were wlthdrawn frar the G. E. Fmployees Savinge and Stock Bonus Plan by 151 particlpating employees. U. S. Savings Bonds and Custody Recelpts having a maturity value of $\$ 202,650$. covering purchases by employees through payroll deductions in February were delfvered to employees on Merch 30, 1951. There "vere 739 U. S. Sevings Bonds and 2,870 Custody Recelpts delivered.

Three Henford Works employees reported the 1008 of 3 Custody Recelpts and request was made for replacemonts during the month.

Checks representing income for the years 1949 and 1950 on General Electric common atock credited to their accounte were delivered to 88 participants in the $G$. $E$. Employees Sevings and Stock Bonus Plan who, during tho year 1951, withdrew U. S. Savings Bonds purchased in 1948 or 1949.

23. 
G. IH. Imployeas Serings arut Stock Bacius Plan statements of accounts, as of December 31, 1950 were deIlverod to approximately 3,500 amployees who were on the payroll at Maroh 30, 1951. Statements of accowts vere ma1led to approximatels 200 amplogeos who were not actively at work. Copy of Gworal Hlectr10 Company'a emual report for 1950 and a lotter from R. J. Cordinex, Frealdent, were inaludod with oach atatement.

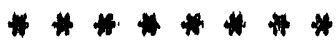

Report of the study and anelorelo of our payroll prectice end procedure belng prepered by a representetivo of I. B.M. has not yot been recelved.

\section{$* * * * * * * *$}

Authorfzetions for deductions from paysoll for the; purchese of gafety shoes were recelved trom 189 exployees in March.

$* * * * * * * *$

There were 6,327 Iteme deducted tram salarles of Weekly Peld Hmployeen In March for rent and telephone charger as follows:

$\begin{array}{lr}\text { House Rents } & 3,242 \\ \text { Dormitory Rents } & 686 \\ \text { Treiler Rents } & 126 \\ \text { Berraoks Rents } & 43 \\ \text { Telephone Accounts } \\ \text { Total }\end{array}$

During March, preferentlel retes were eliminated in 15 casen where employees were transferred or reclaselfled. In July 1948, when all weekly pald employoer were reclasalfled, apprarimatel, 4,550 employees had preferentlal rater. As of March 31, 1951, there were approximtely 1,100 employees having preferent 1al rates.

*********

A total of 317 weekly pald employees were scheduled to begin their 1951 vacation In March. Dirision Menagers or the1r author1zed representat 1ves approved deferment of one week of the 1951 vacation to 1952 for 92 weekly paid employees and 15 monthly pald employeos. As of March 31, 1951, I68 weekly pald employeen and 54 monthly pald employees had deferred one weok of the 1951 vacetion to 1952.

$$
\text { ******** }
$$

Under the G. E. Penalon Plan, 64 weokly peld employees became ellg1ble for particlpation in March. Enroliment carde were recelved from 38 of these employees and 23 elected not to part iclpate in the plan. Thre日 of the newly e.l1gtble employees bave not roturned elthor an enrollment card or a "walver card". 
The high percentage of absentealam during March was reflected in an inoreare in the number of d1seb1lity elatw processed under the G. B. Insmance Plan. Absencer of payroll persconnol in Maxch and the hifh percentage of absentealate in

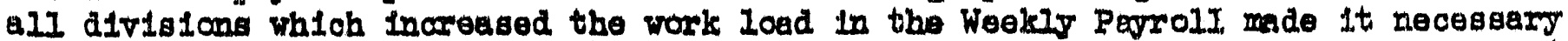
to resahedule many of the statistloel reports and related peyroll work in order to complete caloulation and dietribution of paysolis according to normal sohodules.

During Merch, 802 alsablifty olalm were proceseed and forwarded to Metropolitan Lifo Insurance Company. This is the large日t number of digoblilty clalms aldbmitted. to the insurance ocmpany in any ane month since the G. E. Ineurance Plans became effective September I, 1946. In Maroh, 799 ohouks totaling $\$ 48,871$ fox 622 . clatms were recolved from the insurance campany and forwarded to elnployees or to hoopltals and aurgeons in accardance with authoriations of the employees.

The fallowing bank recomoll lations were complote at February 28, 1951:

Woekly Salary through \#237, weok ended March II, 1951 Weekly Salaxy Vacetion $\#$-237, week onded March 11, 1951 Bond Account - January Monthly Payroll \#54, Fobruary 1951 


\section{SIJMMARY}

There were no major infurles during the month. The major infury frequenoy rate was further reduced to 0.25 for the year to date.

The Hanford Works of the Ceneral Electric Company was declared the winrer of the AEC Safety Improvement Contest for Group I in 1950 .

There were no Industrial fires during Maroh.

Laundry volume deoreased slightly in the plant laundry and remalned approximately the same in the 700 Area Laundry.

Volume of work demanded of the Clerical Servilces group continued to Inorease.

All records have now been transferred from $712-\mathrm{A}$ and $7.12-\mathrm{B}$ Hutments to the Records Service Center.

Methods and forms oontrol activities resulted in estimated savings of ,inl6.734 of which i14,308 will be on a recurring annual basis.

A fornt AEC - GE soourlty educational program was begun this month. 


\section{HONIHIY REPORT - MAROH 1952}

ORGANIZATION AND PERSONNEL

Number of employees on payroll:

Beginning of

Month

\section{Staff}

Patrol and Seourity

Safety \& FIre Protection

Office Servioes

(General iervices, Clerical

Servioes, Records Control and Offloo Nethods)

TOTAIS

NET INCREASE, 18

(a) - Patrol and Seourity

26 - New Hires

4 - Returned irom Leave of ibsence

1 - Transferred from iunufacturing Accounting

2 - Rernoved from Roll due to Leave of Absence

5 - Trangferred to other Divisions

13 - Terminations

(b) - Safety and live Protection

6 - New Hires

1 - Iransferred from Instrument Division

1. - Transferred to Instrument livision

3 - Terminations

(c) - General Servitoes

11. - New Mires

2 - Returned from Leave of boence

' 1 - Removed from Roll due to Leave of' absence

4 - Terminations

Clerioal Servioes

5 - New ilites

5 - Trunsferred to other ilvisions

3 - Removed froin Roll due to Leave of Absence

1 - Termination
End of

Month Inorease Decrease

630

11 (a)

3 (b)

4(c)

18 
Plant Beourity and Services Diviations

SAFETY AND FIRE PROTEOTION

Infury Statistiog

Days sinoe last major infury

Acoumulated Exposure Hours since last major injury

Major Injury trequenoy Rate (1-1-44t through 3-31-5I)

$2,591,697$

0.78

Febmaary March

Comparative

Major Injuries

Sub-Major Infurtes

itinor Injuries

Exposure Hours

Major Injury $F / R$

Wajor Infury $s / \Omega$

Mtnon Injury $E / R$

$\begin{array}{cc}0 & 0 \\ 1 & 4 \\ 260 & 277 \\ 1,215,640 & 1,376,057 \\ 0.00 & 0.00 \\ 0.00 & 0.00 \\ 2.13 & 2.01\end{array}$

$\begin{array}{cc}1 & 1 \\ 5 & 11 \\ 824 & 948 \\ 3,927,037 & 3,658,997 \\ 0.25 & 0.27 \\ 0.08 & 0.002 \\ 2.10 & 2.59\end{array}$

Sub-itajor Injury No. 194

On March 7, In the 100-H Area, a llaintenance employee and two Transportation riggers were in the act of removing a radiation shield from its location when a stand support, fabricated from channel iron, flipped and fell on the left foot of the Malntenance employee resulting in a cominuted fracture, distal phalanx, left great toe. He was not wearing sacety shoes at the time of the accident, although he normally did so.

Sub-ilajor Injury No. 195

On March 9, an employee of the Worth Richland Realty Section of the Engineering Construotion jervices Division, reported to "lirst lid that he sprained his right ankle when he stepped on a rock on laxoh 7. He had oarried a small trash can of paper out of a barracks and after setting it down, turned to walk away at whloh time he claims he stepped on the rock. He turned his ankle, which resulted in a fracture, right tibia.

Sub-iajor Injury i10. 196

On March 9, ar employee of the North Richland realty Section of the Engineering Construction Services Division sustained a compound fracture of the distal phalanx of the left middle finger when it was caught between the door and jamb of a barracies. A very strong gust of wind slamed the door shut as she was passing through, and she lost control of the door.

Sub-Mrjor Injury No. 197

On Maroh 18, during a routine check of compressed gas cylinders in storage, 100-D Area, a cylincer wis tipped over and struck the saiety cap of an employee's left shoe, cmushing the cap and causing a fracture of the distal phalanx of the

left great too. Fimployee was a member of the P Division. 
Plant Sequrity and Services Divisions

Safety iotivities

The Hanford warke of the General Ilectrio dompany (Produotion) was declared the winner of the AfC eafety improvement conteat, Group 1. A bronze plaque was presented on 'arch 30, 1951 by $A E C$ General ilanager Hoyer. The speaker's platform and 1 ts deocration was completed by the safety Mivision.

Two-year safety award plns have been distributed to all elfatblo employees In the 200-East and Hanford iroas.

An extensive study is being conducted on the use of Oarbon Tetranohloride and use of a substitute material seems very likely.

The 100-F Area is oonducting a safety quiz on the Who, Why, when and inere of Safety.

The style and design of the Safety Topic of the onth vas changed and the new design set up for printing.

A special pamphlet wcs designed covering jafety of those employees assigned activities "off the plant" such as traveling inspectors and expeditors sent off the plent on Company business. The printing section will have these ready for distribution curing the early port of the month.

A surver is in pragress to review the scfety coverage on all construction safety activitios to determine the fenslbility of recommonding any ohanges.

A rewly prepored and deslgned employees' Safety Booklet has been completed and turned over to Employee iielations Diviaion for release.

Fire Protection Division: fotivities

Filre otection surveys ware completed on Buildings 11-B, 151-B, 224-B, and 3746 .

A fire alsm system demonstration was given to members of tho P-10 Group. A fire extinguisher demongtration was given to mombers of tie p Division in the 1:00-D wrea.

The Laundry garsonnel was given a demonstration of the irst ild fire appliances in thoir butlding.

The 300 .rea laintcuance Division was given a talk on "yacts and Fire Safety".

A survey of fire extinguishors is in prosress in c.ll nreas. NII vaporizing liquid fire extinguishers are bolng removed from all pl nt operating buildings. There the nced exists for an cxtinguisher for Clisg $\mathrm{D}$ or $\mathrm{C}$ fires, the ciry compound extinguisher is boing iristolled.

The heat devector fire $67 . \cdots m$ systen in the $2724-j$ tindrur Building was tested. The tost was satisfactory except thi.t the evacuation signi.]. sounds whon the master box is rosot. This will be corrected by chenging the control switch in the supervisory panel. 
Plant Security and Services Divisions

Elro Proteotion Activities (Contin)

A fire evacuation procedure wes writton for the Laundry.

The Iocations for fire extingtishers in the new 222-s Loboratory Building are being developed in conjunction th the Technteal Division.

A list of questions was prepered for the $S$ Division concerning the hindling of the solvent in Redox. The questions wcre discussed with the manufacturer of the solvent.

The prints and specifications for incio Cheinistry were reviowed and commonts submitted.

Prelimincry prints for the Radio :Letollurgy Building wore reviswed and corments submitted.

¿de specifications for $105-C$ elevators and sever 1 othor small jobs wore reviowed.

A fire protaction review was made of $\mathrm{P}-10$.

There were no industrial firos during the month of inrch.

OFIICE SIRVICES DIVISIONS

General Services

Plant Loundry (Building 2723)

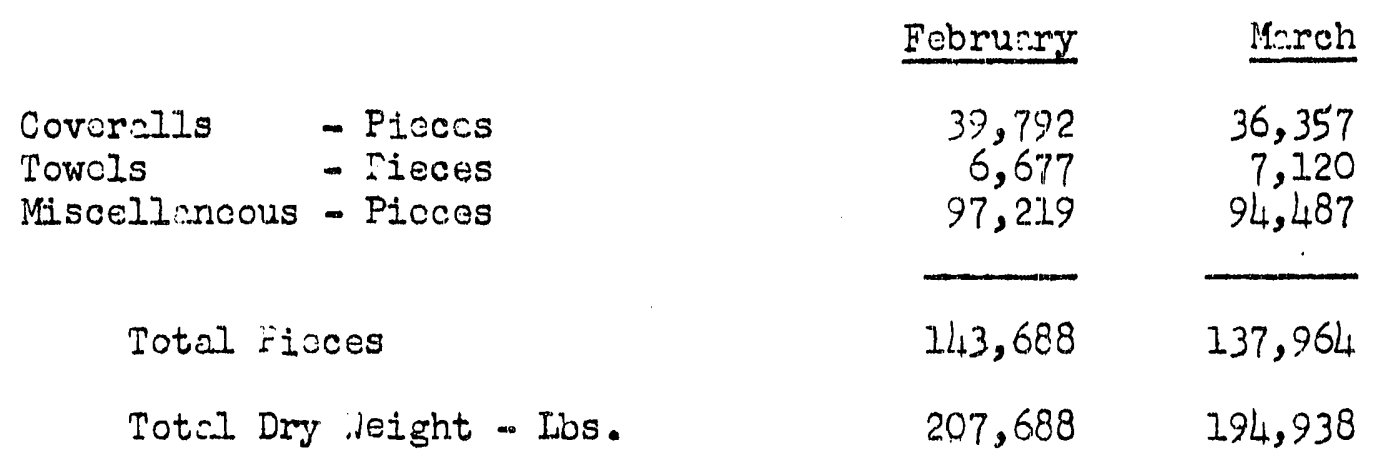

Richland Laundry (Building 723)

Ilittwork - Pounds

Rough Bry - iounds

Finished - Pounds

\begin{tabular}{cc}
50,253 & $\begin{array}{r}58,331 \frac{1}{2} \\
18,010 \frac{1}{2} \\
2,132\end{array}$ \\
\hline $\begin{array}{c}2,097 \frac{1}{2} \\
2,502\end{array}$ \\
\hline 105,187 & 104,709 \\
$80,295 \frac{1}{2}$ & 79,931
\end{tabular}

Er imated + ieces

Tot:al Dry leight - Los.

$80,295 \frac{1}{2} \quad 79,931$ 
Plant Security and Services Divisions

Monitoring Section (P]nt Laundry)

Poppy Check - Pleces

Scaler Check - Pleces

Tebruary:

March

Total. Pieces

103,247

114,364

147,200

129,593

250,447

243,957

Clerical jervices

Iail Room

February

larch

Pieces of intermal mail handled

Pieces of postal mail handled

Pieces of registered mail handled

Pleces of insured inail handled

510,239

64,863

923

277

Pieces of special delivery mail handled

289

596,034

96,364

1,163

353

322

Total mail handled

576,489

694,236

Total amount of postage used

. $1,623.96$

\$2,368.73

Total teletypes handled

6,622

8,750

Office Equipment Section

Office iachines repaired in shop

iebruary

March

Office Machines service calls

266

291

453

510

Total ilachines Serviced

719

801

Printing Section

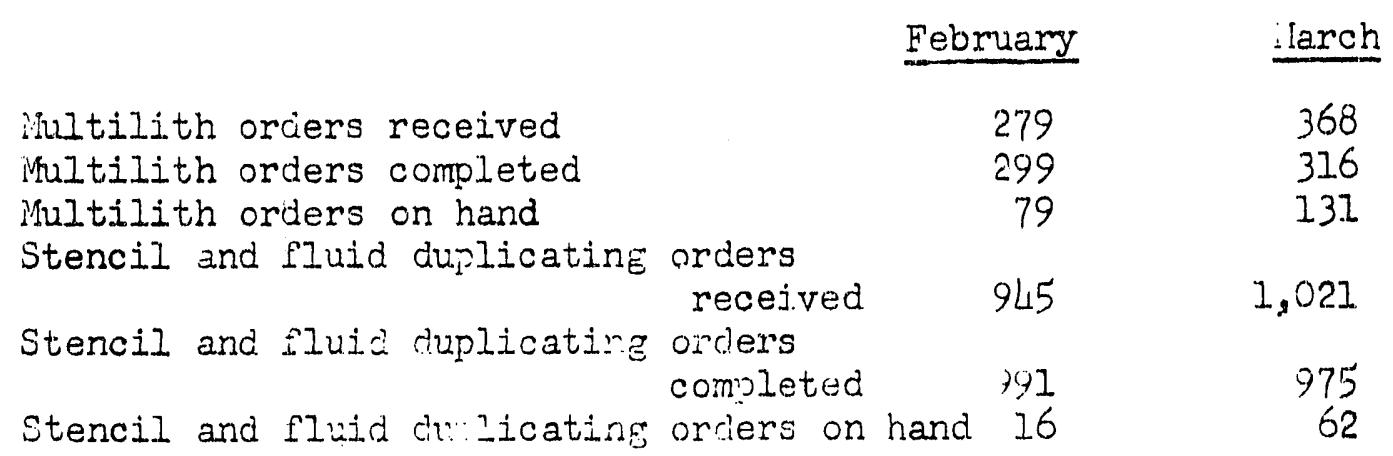


Plant Security and Services Divisions

Stenographic Sorvices Section

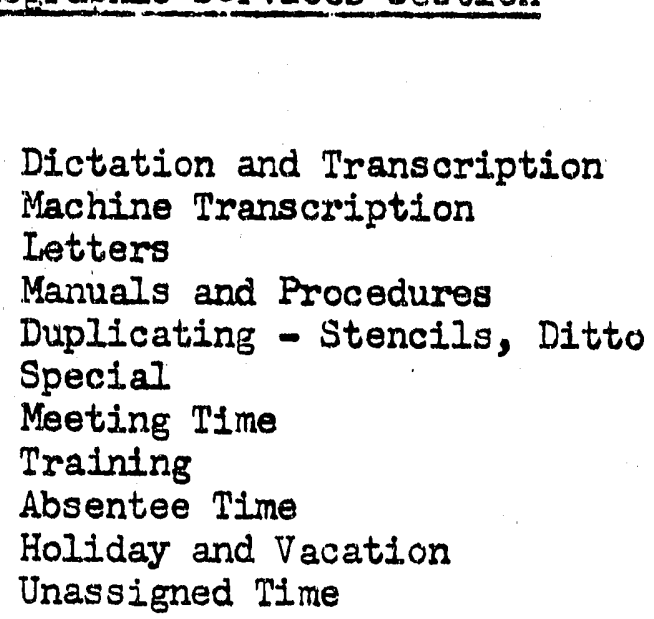

Total

Employees loaned to other Divisions

Total Hours Available

\begin{tabular}{|c|c|}
\hline$\frac{\text { February }}{\text { Hours }}$ & $\frac{\text { March }}{\text { Hours }}$ \\
\hline $\begin{array}{r}33: 00 \\
60: 00 \\
105: 15 \\
117: 00 \\
224: 00 \\
753: 15 \\
: 00 \\
29: 30 \\
8: 00 \\
112: 00 \\
75: 00\end{array}$ & $\begin{array}{r}28: 45 \\
99: 15 \\
142: 15 \\
112: 45 \\
266: 50 \\
544: 55 \\
2: 00 \\
95: 15 \\
24: 00 \\
: 00 \\
23: 00\end{array}$ \\
\hline $1,517: 00$ & $1,339: 00$ \\
\hline $692: 45$ & $1,044: 30$ \\
\hline $2,209: 45$ & $2,383: 30$ \\
\hline
\end{tabular}

\section{Records Control Division}

Quantj.ty of records received, processed and stored:

Electrical Division

Engineering and Construction Divisions

Employee is Commity Relations Divisions

General Accounting Division

Health Instrument - Operational

Instrument Division

Mainterance Division

Manufacturing Accounting Division

redical Division

itunicipal, Real Estate and General Services

Power Division

Purchasing Division

Stores Division

Subcontractors:

Kellex Corporation

iorrison-Knudsen

Technical services Division

Technical Separations Division

Transportation Division

\begin{tabular}{rccc}
2 & Standard & 3torage & Cartons \\
88 & 11 & 11 & 11 \\
27 & 11 & 11 & 11 \\
61 & 11 & 11 & 11 \\
19 & 11 & 11 & 11 \\
7 & 11 & 11 & 11 \\
2 & 11 & 11 & 11 \\
4 & 11 & 11 & 11 \\
20 & 11 & 11 & 11 \\
8 & 11 & 11 & 11 \\
4 & 11 & 11 & 11 \\
29 & 11 & 11 \\
4 & 11 & 11 & 11 \\
13 & 11 & 11 & 11 \\
1 & 11 & 11 & 11 \\
2 & 11 & & 11 \\
2 & 11 & 11 & 11 \\
7 & & 11 & 11 \\
\hline
\end{tabular}

Total

200 Standard Storace Cartons 
Plant Security and Services Divisions

Records Control (Contin)

Persons provided records service:

Records Cartons issued:

Records reboxed:

Records destroyed:

Fliling service provided Purchasing

and Stores Division

449

408 Standard Cartons

200 Standard Cartons

81 Iinear feet of duplicate nonrecord material.

172 Pieces filed in with records already in storage

Approximately 10,000 boxes of records were moved from $712-A$ and $B$ Hutments to the Records Service Center. This move required six working days and is complete.

Segregated storage area was provided to Classified I'iles Section with capacity of 900 boxes of records.

Ten selected offices were spot checked for yollow file survey.

The surrey of file ratorial to be microfilmed was completed for Employee and Community Relations Division, Health Instrument Division, Medical Division, Law Division, engineering and Construction Division, and part of the Technical Divisions.

The Supervisor of the Rocords Control Division visited the Kellex Corporation, New York City, and the C. T. Mein Company, Boston, to inventory sub-contractor records and discuss the matter of transfor of subcontractor records to Richiand when the subcontractor records becams inactive.

Copies of the Record Flow Schodules were mailed to all Divisions except Employee and Commanity. Relations and Plant Security and Scrvices.

Office liethods Division

Printing Orders received Printing Orders cancelled New numbers assigned Forms designed

\begin{tabular}{cr} 
Fobruary & March \\
\hline 563 & 438 \\
46 & 36 \\
99 & 121 \\
53 & 39
\end{tabular}

As a result of the reorganization program throughout Engineering and Construction Divisions, this office has been called upon to assist in revising their procedures where papor filow is involvod.

Many of the reports used by Ingineering and Construction which deal with the scheduling of material, equipmont, drawings, manpower, ctc. range in sizes from $17^{\prime \prime} x$. II" to $19 " x$ II". In tho past, master copics of these reports were prepared on tracing papor and renrodiced by the $\mathrm{Oz}: \mathrm{Iid}$ process at a cost of $4 \phi$ per square foot. A nrocess has ..ow bcon doveloned vinercby the inaster copies of these rer, nts ar, prop ned b. using forms printid on standard white paper

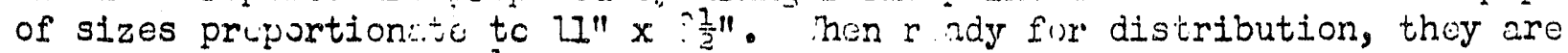
reduced down to $11 " x$ " $8 \frac{1}{2}$ " by phu'ost:t. Tho photostate negative is then used to exposc a sensitizcd papor plicc for roproduction on a small multiliti. 
Plant Security and Services Division

Office Kethods (Contin)

The cost of this process is $29 \phi$ for the first ten copies and $35 \phi$ per hundred thereafter. Copy requirements on these reports range from 30 to 50 copies. On one report alone, Material and Equipment List, averaging 150 sheets, 37 copies each per week, a savings has been achieved in reproduction cost alone amounting to approximately 1,13,750 per year. Additional savings are to be realized through less need for filing space and a nore convenient size report.

This procedure is being adopted throughout Engineering and Construction as standard policy in reproducing copies of all reports that originate in sizes larger than $11^{n} \times 8 \frac{7}{2} "$ and where copy requirements are greater than can be provided by one typing operation. It is estimated that after all of their larger reports have been converted to this method of reproduction, there will be a potential annual saving of close to $\$ 50,000$.

Other divisions are now reviewing this reproduction method with considerable interest.

Miscellaneous savings created during March as a result of forms design and forms control have amounted to $\$ 2,934$.

Total estimated savings were $\$ 16,734$, of which $\$ 14,308$ will be on a recurring annual basis.

\section{PATROL AND SECURITY}

There were 120 Generil Electric employees given orientation talks which dealt with plant salety and security rules, also a brief resume of plans and policies of the general Electric Company for its employees.

There were 296 Security meotings held and attended by 4,152 General Electric employees.

A representative of the Security Mivision showed the film on the subject of Communism at one showing to 25 employees.

A representative of the Security Division showed the film "On Guard" at nine security meetings to 153 employees, and the film "Iltting 'U' Into jecurity" at five meetings to 95 employees.

The Security films "On Guard" and "Fitting 'U' Into Security", which were made at Hanford Works, were shtpped to the Bendix Corporation, Kansas Dity, Missouri; Knolls Itomic Power Laboratory, Schenectady, and the Kellex Corporation, New Y'srk City, for use in their security education programs during the month of April.

A memorandum was issued by the security Dirision to all exempt personnel. entitled "Conpletics of nuesti nnaira Form, imerican Chemical society". Instructions for filling cut tris form according to Atomic Energy Instructions were contained in this lutter, dated "larch $: 8,1951$.

There were 11.3 employees of the General Electric Company who receivod a "Q" oricntation talk from a representative of the security Division during the month of ilarch. 
Plant Securlty and Services Diviaions

Patrol and Security (Contin)

Practice evacuations were held as follows:

$\begin{array}{lrl}100-B & 2: 38 \text { P.M. } & 3-5-51 \\ 100-H & 10: 10 \text { A.M. } & 3-8-51 \\ 100-D & 10: 17 \text { A.M. } & 3-20-51 \\ 100-B & 1: 30 \text { P.M. } & 3-23-51 \\ 100-\mathrm{F} & 11: 05 \text { A.M. } & 3-27-51\end{array}$

Practice Blackouts were held as follows:

$\begin{array}{lrl}100-D & 2: 02 \text { A.M. } & 3-1-51 \\ 100-B & 10: 01 \text { P.M. } & 3-4-51 \\ 100-D & 10: 02 \text { P.M. } & 3-4-51 \\ 100-F & 10: 01 \text { P.M. } & 3-4-51 \\ 200-\mathrm{E} & 10: 02 \text { P.M. } & 3-4-51 \\ 200-\mathrm{W} & 10: 02 \text { P.M. } & 3-4-51 \\ 100-\mathrm{F} & 9: 15 \text { P.M. } & 3-11-51 \\ 100-\mathrm{B} & 8: 55 \text { P.M. } & 3-13-51 \\ 100-\mathrm{B} & 10: 35 \text { P.M. } & 3-16-51 \\ 100-\mathrm{D} & 9: 32 \text { P.M. } & 3-16-51 \\ 100-\mathrm{D} & 3: 31 \text { A.M. } & 3-19-51 \\ 200-\mathrm{E} & 2: 15 \text { A.M. } & 3-19-51 \\ 100-\mathrm{H} & 10: 08 \text { P.M. } & 3-20-51 \\ 100-\mathrm{D} & 9: 15 \text { P.M. } & 3-26-51 \\ 100-\mathrm{B} & 10: 05 \text { P.M. } & 3-27-51 \\ 100-\mathrm{D} & 1: 32 \text { A.M. } & 3-27-51 \\ 100-\mathrm{F} & 9: 20 \text { P.M. } & 3-27-51 \\ 100-\mathrm{H} & 10: 20 \text { P.M. } & 3-31-51\end{array}$

Practice mobilizations were held as follows:

$\begin{array}{llrl}100-B & \text { Plan D } & 9: 26 \text { P.M. } & 3-19-51 \\ & \text { PIan A } & 10: 18 \text { P.M. } & 3-24-51 \\ 100-D & & & \\ & \text { Plan A } & 1: 35 \text { A.M. } & 3-1-51 \\ & \text { Plan A } & 4: 50 \text { A.M. } & 3-4-51 \\ & \text { PIan D } & 9: 37 \text { P.M. } & 3-19-51 \\ & \text { Plan A } & 9: 37 \text { P.M. } & 3-20-51 \\ & \text { PIan A } & 9: 50 \text { P.M. } & 3-31-51 \\ & & & \\ 100-F & \text { PIan A } & 1: 35 \text { A.M. } & 3-1-51 \\ & \text { PIan B } & 4: 51 \text { A.M. } & 3-4-51 \\ & \text { Plan D } & 9: 38 \text { P.M. } & 3-20-51 \\ & \text { Plan A } & 9: 44 \text { P.M. } & 3-26-51 \\ & \text { PIan A } & 9: 49 \text { P.M. } & 3-31-51\end{array}$


Plant Security and Servioes Divisions

Practice ilobilizations (Contin)

\begin{tabular}{|c|c|c|}
\hline 100-H & $\begin{array}{l}\text { Plan A } \\
\text { Plan B } \\
\text { Plan A }\end{array}$ & $\begin{array}{ll}I: 35 & \text { A.M. } \\
4: 55 & \text { A.M. } \\
9: 44 & \text { P.M. }\end{array}$ \\
\hline $200-E$ & $\begin{array}{l}\text { Plan A } \\
\text { Plan A } \\
\text { Plan A } \\
\text { Plan A } \\
\text { Plan A } \\
\text { Plan D }\end{array}$ & $\begin{array}{r}10: 00 \text { A.M. } \\
4: 50 \text { A.M. } \\
9: 20 \text { A.M. } \\
\text { 5:10 A.M. } \\
\text { 9:40 A.M. } \\
\text { 9:33 A.M. }\end{array}$ \\
\hline $200-W$ & $\begin{array}{l}\text { Plan A } \\
\text { Plan A } \\
\text { Plan A }\end{array}$ & $\begin{array}{l}9: 21 \text { A.M. } \\
5: 11 \text { A.M. } \\
9: 50 \text { P.M. }\end{array}$ \\
\hline 300 & $\begin{array}{l}P l \text { an } \\
\text { Plan } A\end{array}$ & $\begin{array}{l}5: 35 \text { P.M. } \\
\text { 5:44 P.M. }\end{array}$ \\
\hline
\end{tabular}

The Blackout Procedure for the 200-lv Operitions wrea was revised and issued during the month of March to all personnel concerned.

A joint Atomic Energy Commission - General Electric education program was begun this reporting period with the following material issueds

On Wlarch 5, "Be A Badger" posters were posted in the following designated places:

250 posters $1611 \times 20^{\prime \prime}$ in the industrial areas

100 posters $11^{\prime \prime} \times 17^{\prime \prime}$ in the work areas

Two hundred copies of a poster entitled "It's Baloney" were posted in the Richland and North kichland cormercial facility buildings on March 5 .

On llarch 5, 10,000 copies of a security cartoon letter "I Thought You Knew Him" were distributed among Atomic Energy Commission and General Ilectric parsonnel, as well as a limited number of subcontractor personnel.

On March 12, 7,000 copies di a security cartoon letter entitled "Gossip, Too, is jabotage" were mailed to the home address of project employees.

Effective larch 6, the hot semi-works construction area vithin the 200-E Operations irea, was established as a "Controlled" area, and construction work was started at that time. i'his area has been fenced out of the 200-E Area proper:

A project proposal was piesentes to the sproriutions end sucget Comittee on larch 7 For an arition to the 2J0-i ${ }_{12}$ rea líain Badge House. 
Plant Seourity and Servioes DLvisions

Patrol and Seourity (Contin)

Operations Order No. I-240, Pevision 4, was 1ssued March 8, which established the procedure for admitting sub-contractor owned vehicles into Operations and Constmaction Areas. Vehicles of this type must have a properly stenolied "CE" number.

The 303-K Pcst, 300 Area, was discontinued on the No. $I$ and No. $3^{\circ}$ shifts. However, the man formerly assigned to this post will now be asslgned to the post of Roving Area Patrol as of March 9.

During the perlod of March 13 through 16, the Charles T. Matn, Inoorporated, facility in Boston, Massachusetts, was visited by a member of the Security Division for the purpose of surveying security requirements in confunction with its new contract for performing off-sita wark.

Instructions were issued March 20 to the Transportation Division to ditch the areas adjacent to the perimeter fence gates to prevent unwuthorized vehicles from entering the "iontrolled" area.

On ilarch 21, a memorandum was issued by the Security Division establishing one part of the 2J2-S Building as an "exclusion" area beginning hpril 15, 1951. An additional section will be restricted spril 30, 1951.

On March 23, the National Labor Relations Board held a representation election of all Henford guards including Security Patrol, North Riohland and Richland Police Departments. The tabulation was 272 "yes", 243 not in favor if' representation by the International Guard Union and 46 eligible voters did not vote.

$\therefore$ magneto telephone was installed on a stea." line pole near the southwest corner of the 321 Building, 300 irea, for tho conventence of Ditrol in calling Headquarters when making checks of this portion of the 300 drea. This install ation was made on ilarch 25.

A total of 716 pat searches were made during the nonth. Escorts handled totalled 343.

The Patrol Division made 34 ambulance runs for the Medical Division during the month.

iatrol mraining Sohool ictivitiss

The trining courses conducted during the month of Varch were as follows:

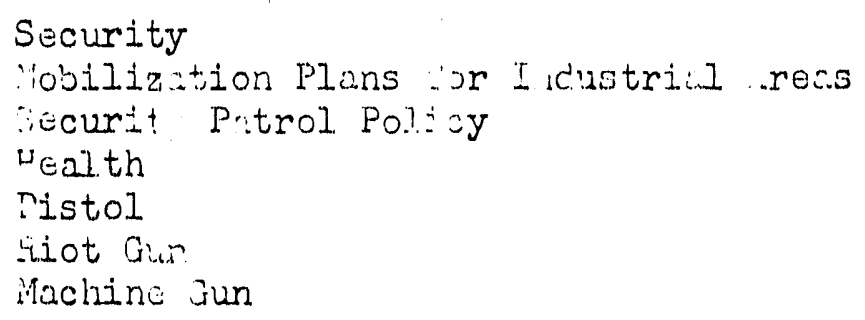


Plant Beourity and Services DHvislons

Seourity Field Inspeotion aotivities:

Investigations conducted of documents mishandled, oto. and reports written:

Porsonal contacts in rogard to missing documents: 130

Physical soarahes conducted for missing documents: lo

ilssing documents located during the month: $5 \%$

Porsons notifiud of ovordue file oombination ohangos: 103

Comblnations of file cabincts ohanged during the month: 29

\section{Cloaranoes}

There were 2,757 badge transactions comploted during Maroh including "Al", "B", "C" and teiporary type badges. 


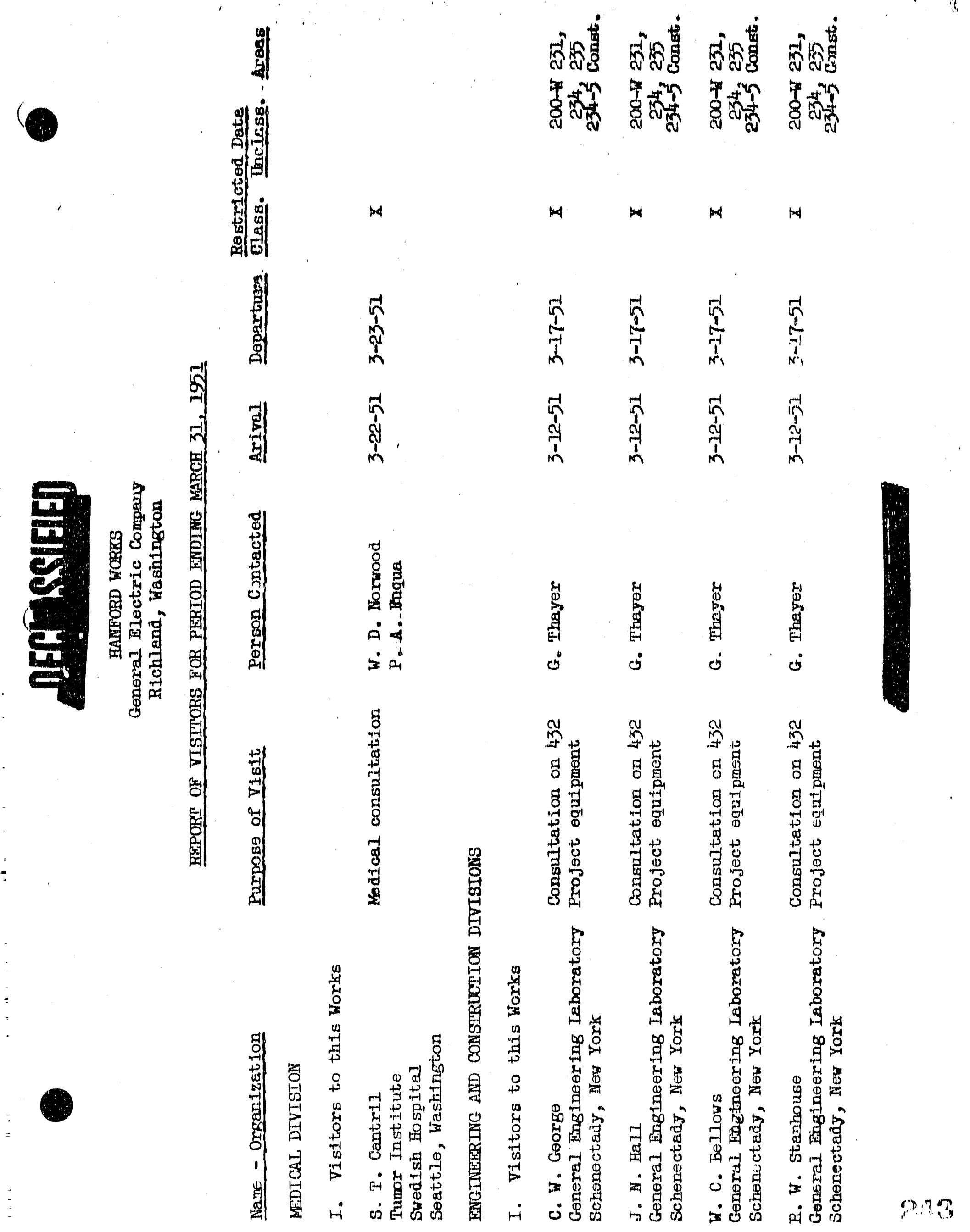




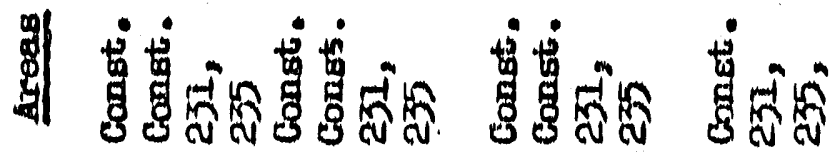

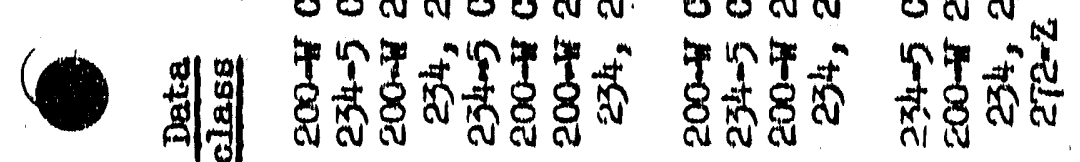

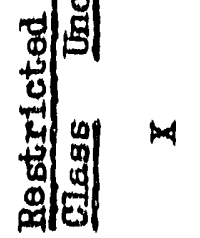

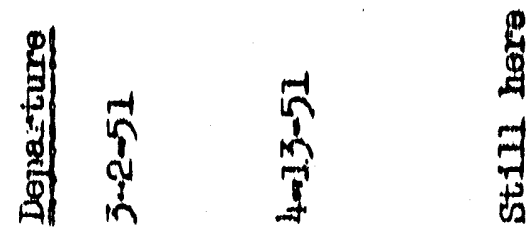

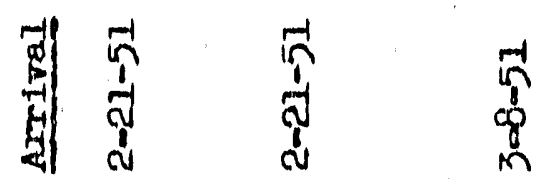

in
禀 晸

4

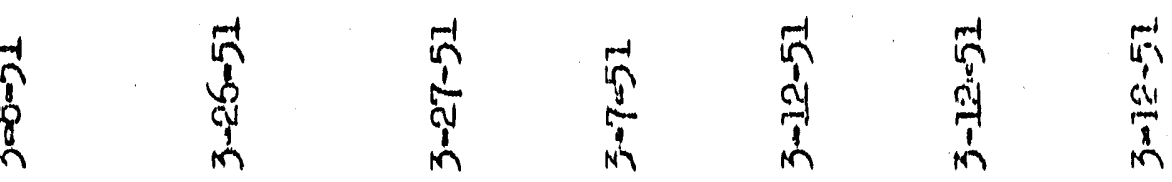

尔

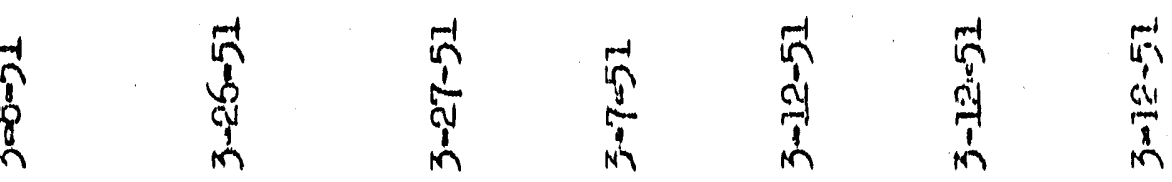

塄

兽

点

m

占

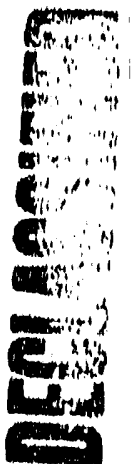

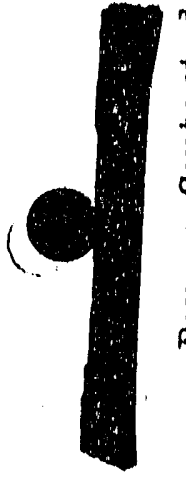

戛

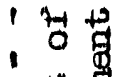
告揰

|-1

范苚 댕해

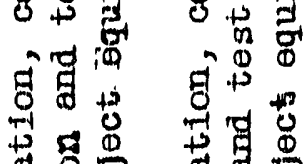

起品

की 명 현

紫等

莺焗哭

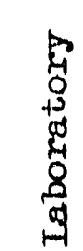

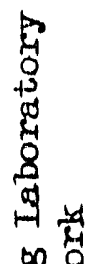

영

峉

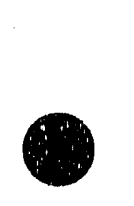

कै

क⿺

$9=2$

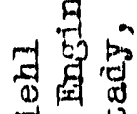

मी

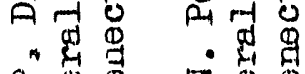

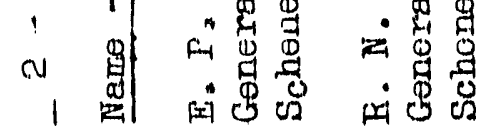

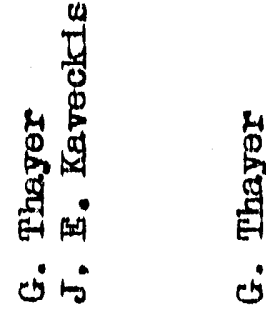

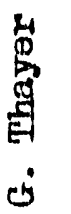

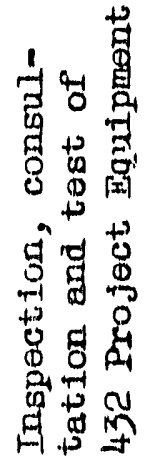

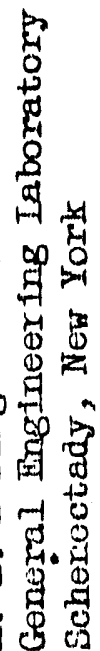

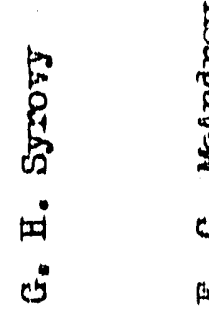

量

为定

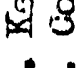

विं

.

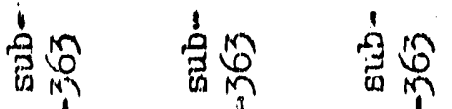

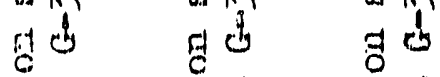

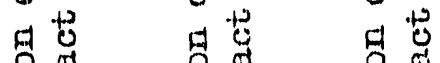

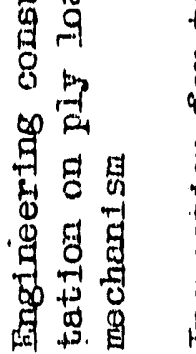

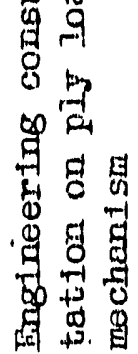

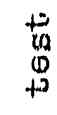
告
照

青公

量尊等
要各

8 策

第占
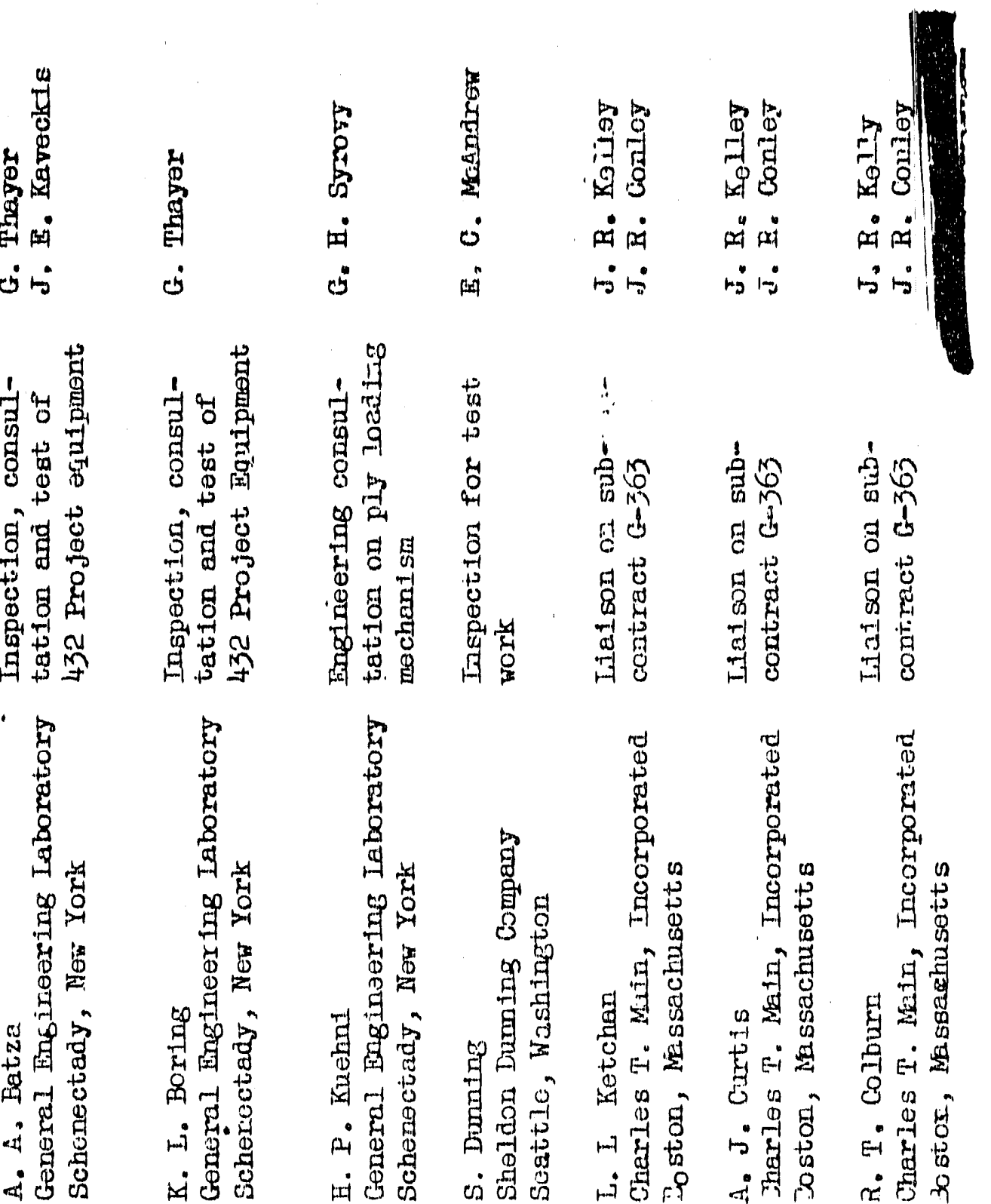

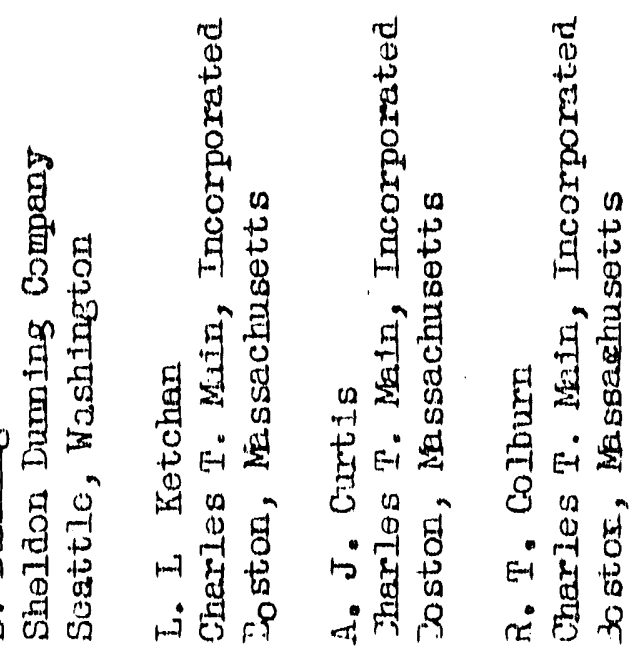




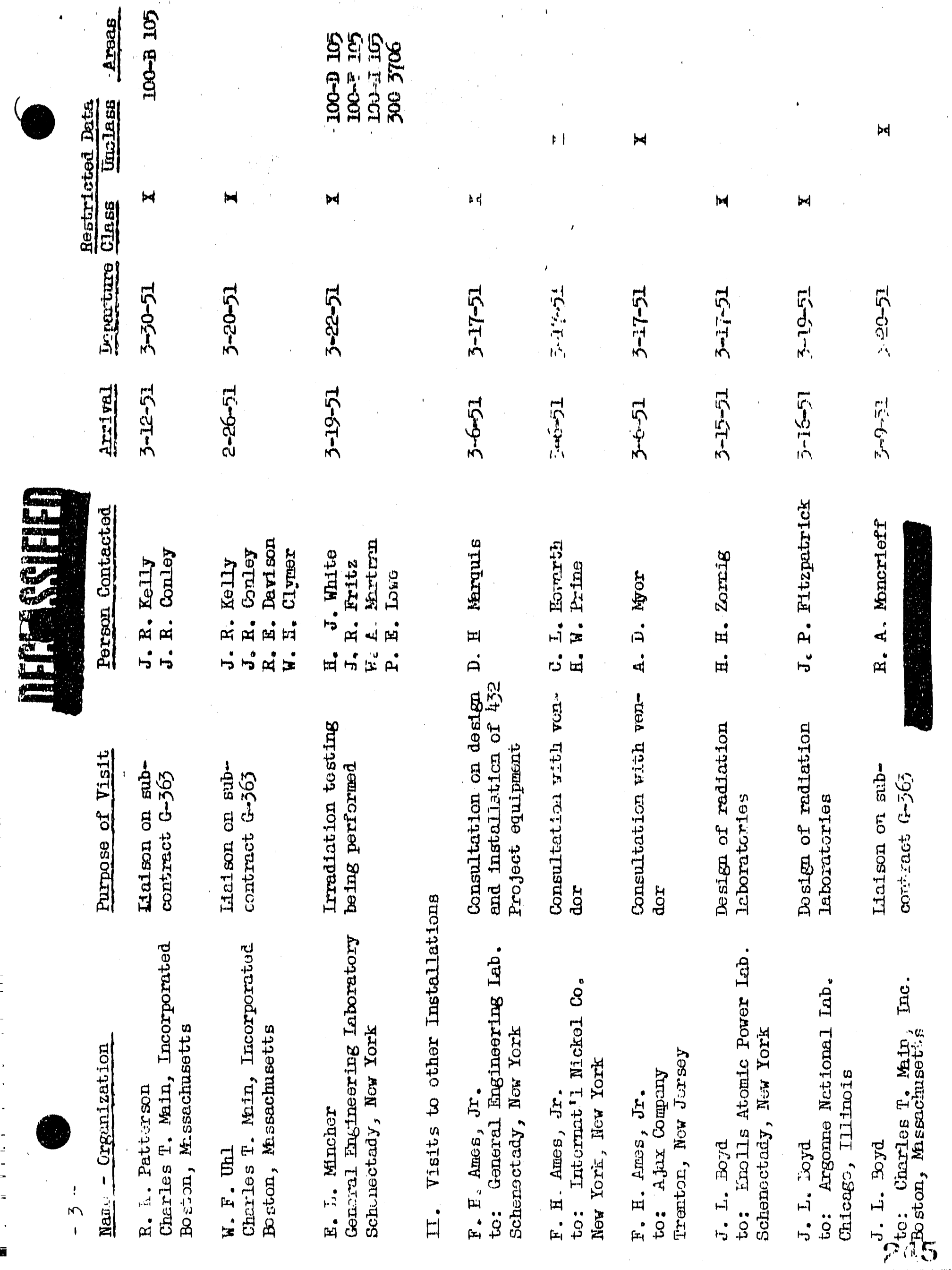




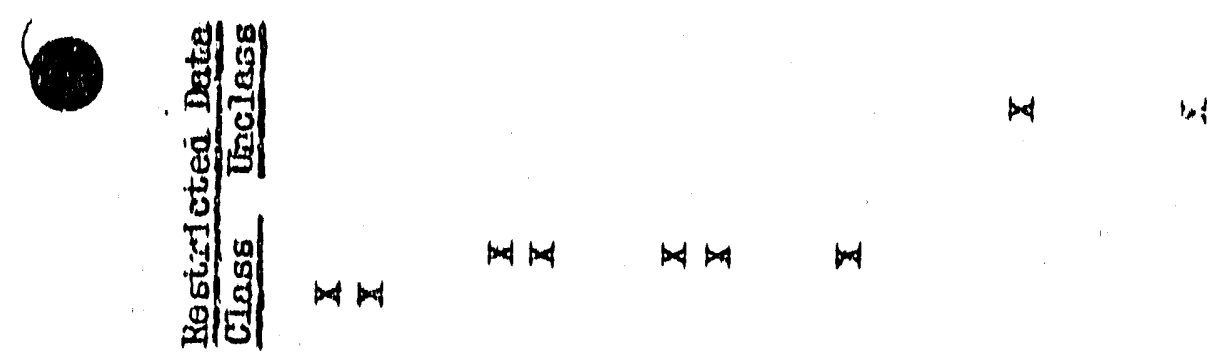

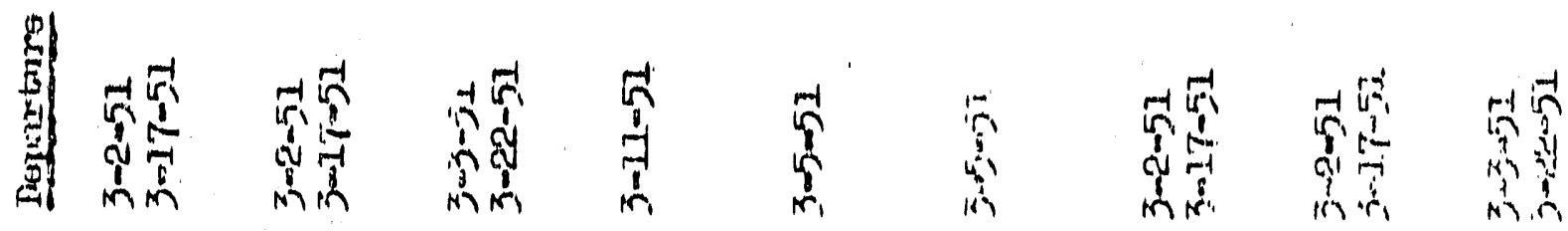

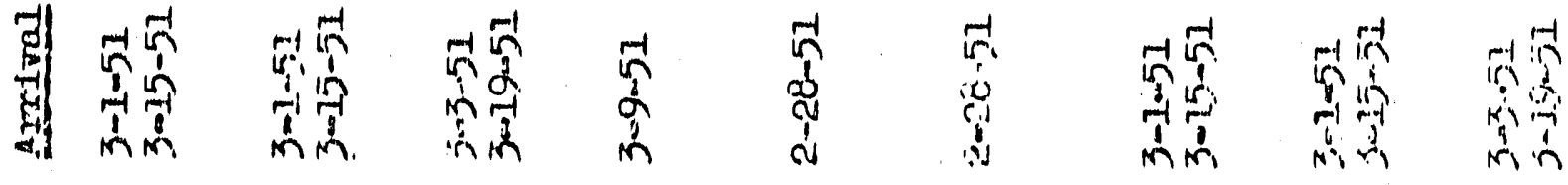

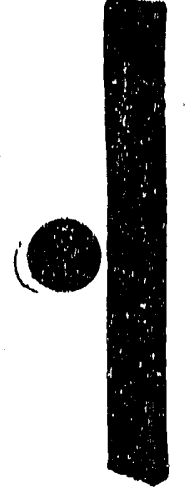

'd

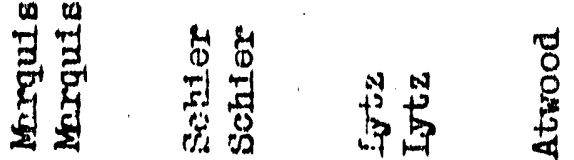

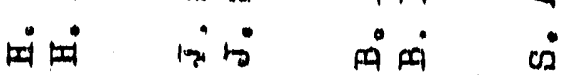

की $\dot{A} \dot{A}$ व्यंति मिं में

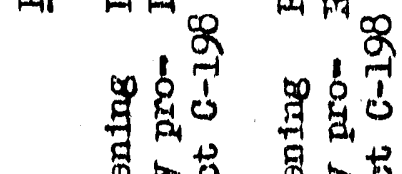

남

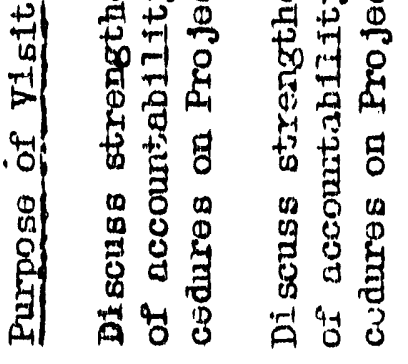

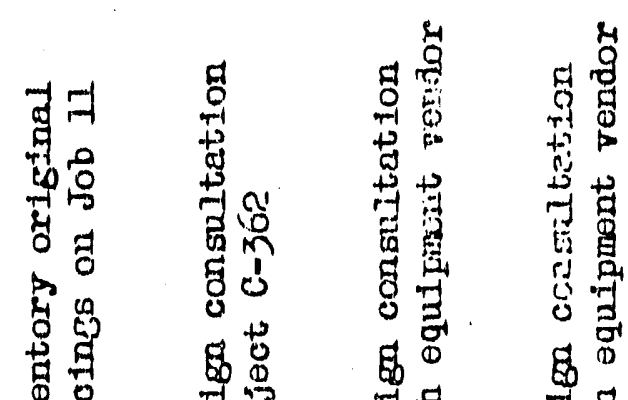

焉

范

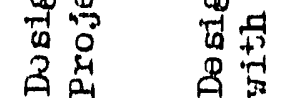

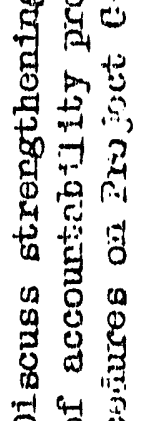

至

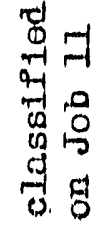

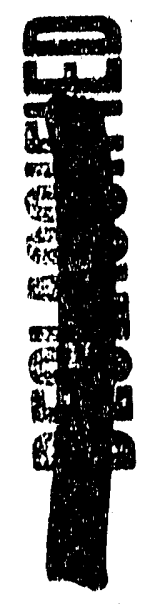

量 䓪

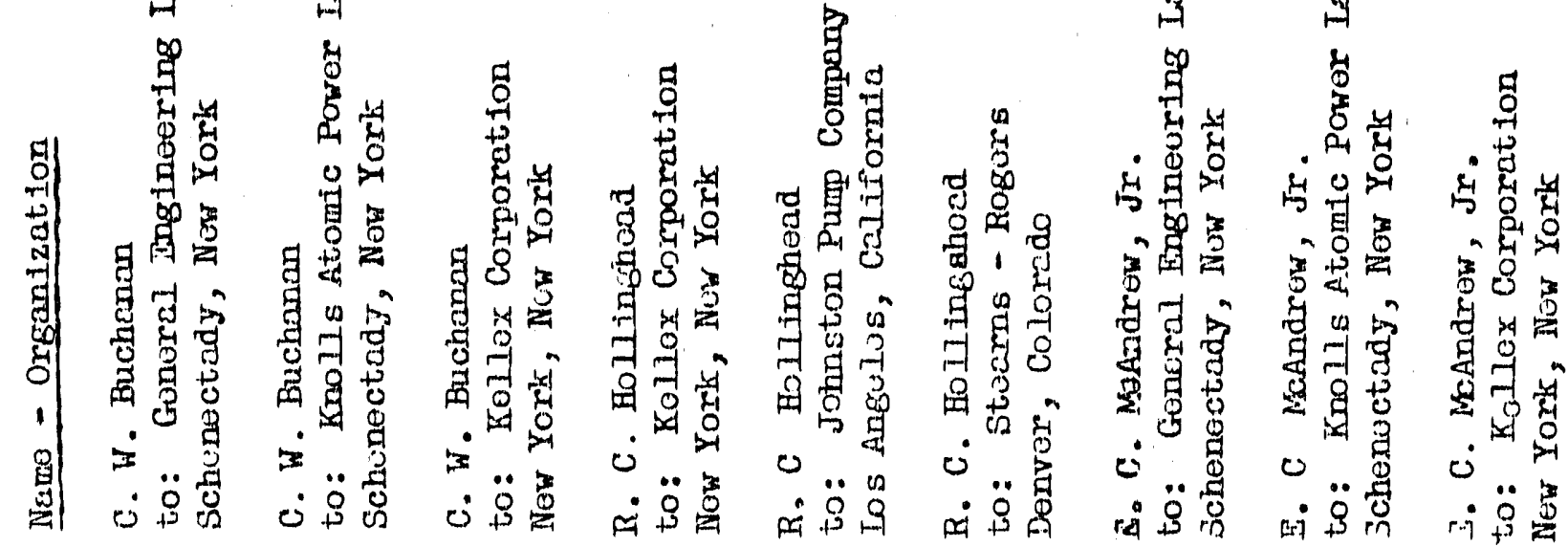

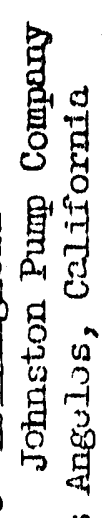

तิ 


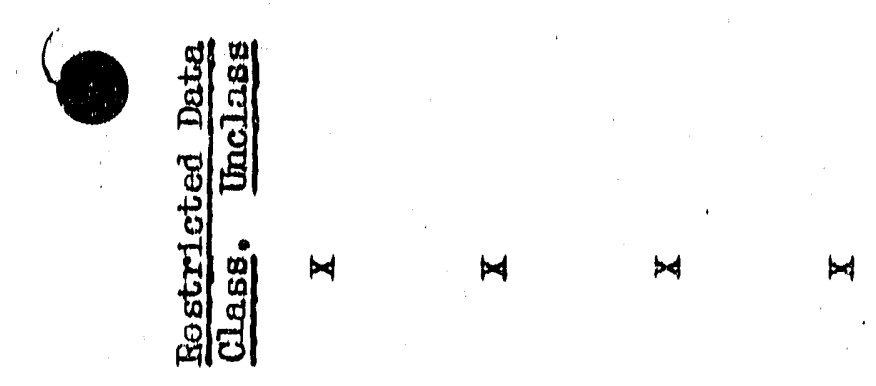

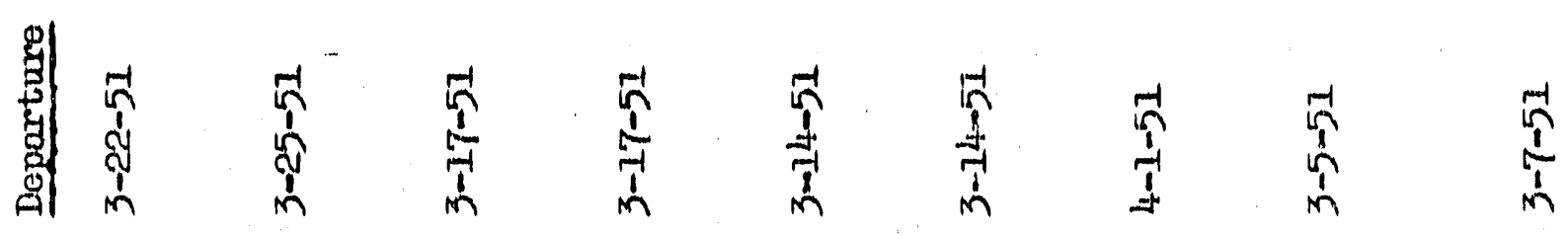

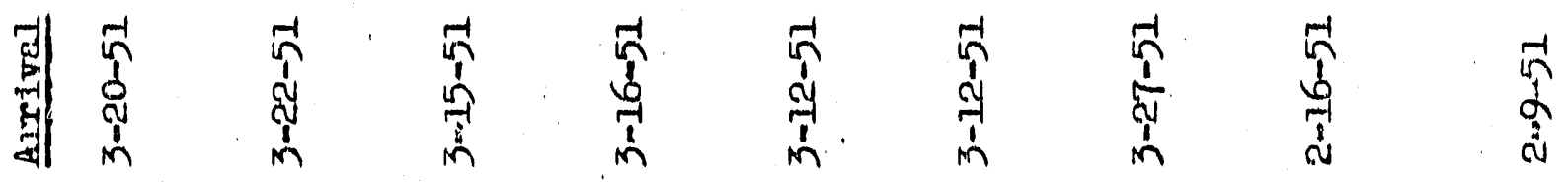

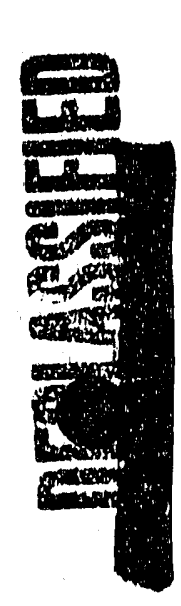

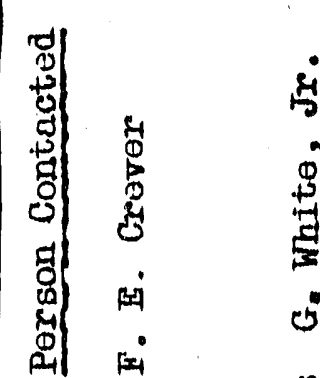
is

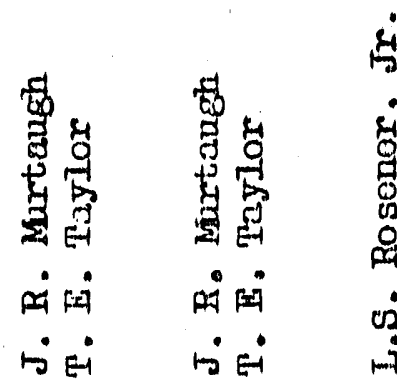
造
बं

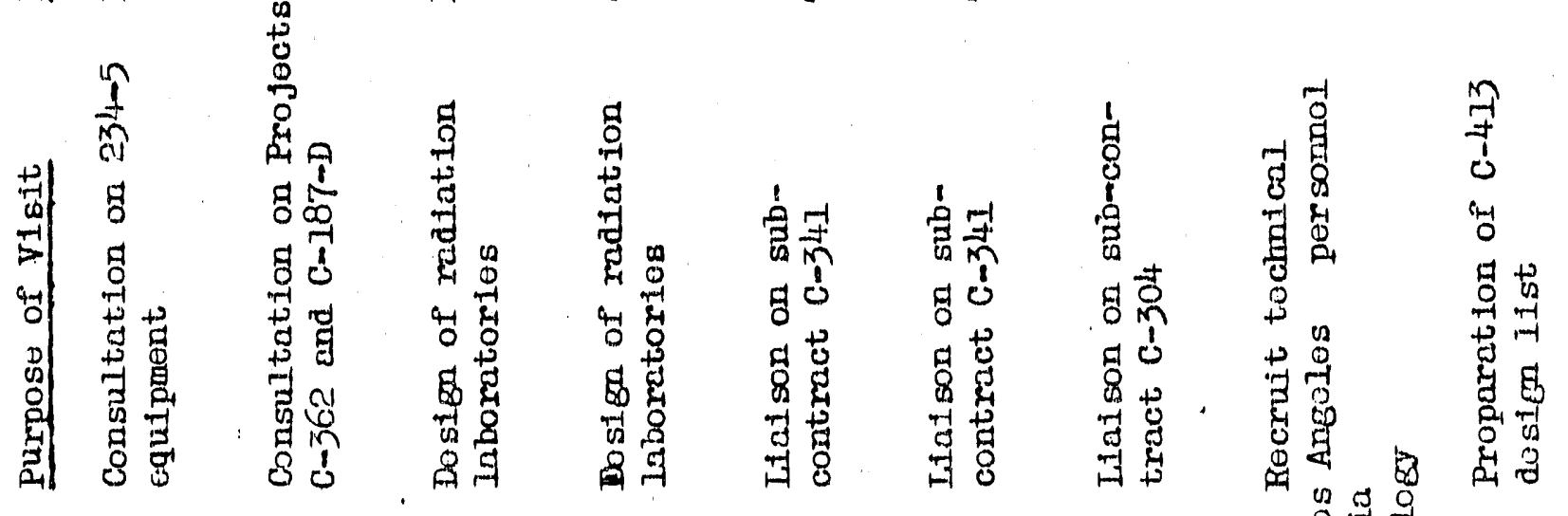<smiles>[CH]CC</smiles>

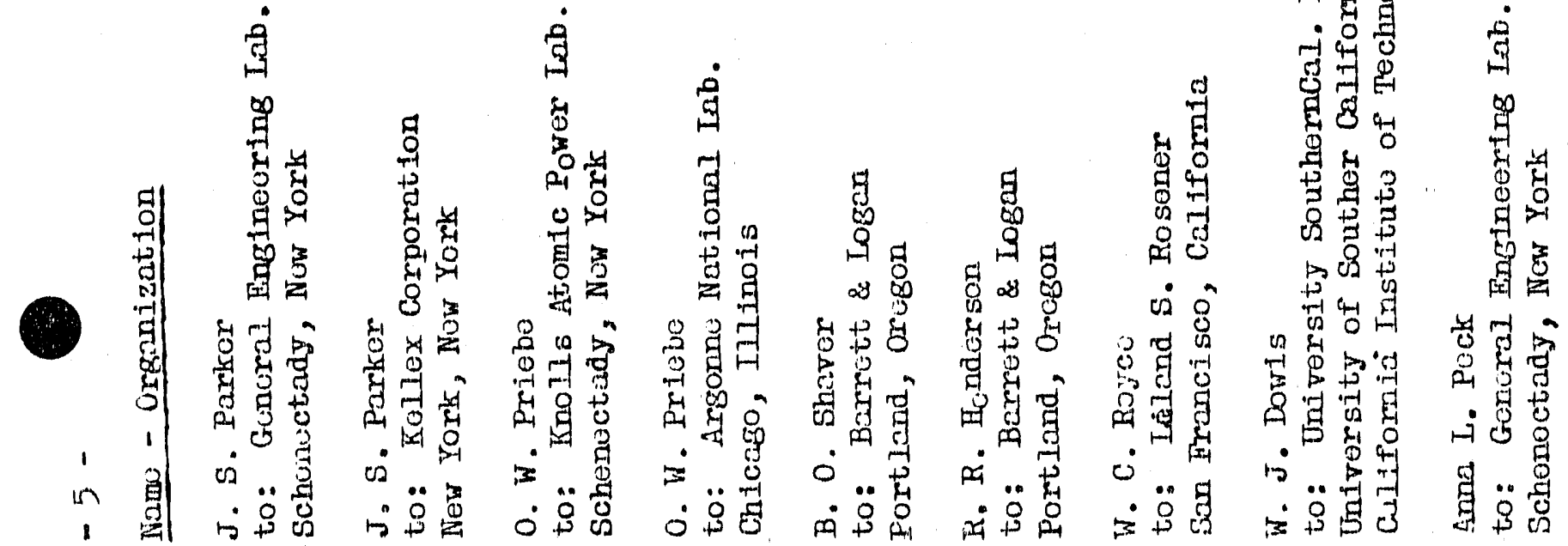

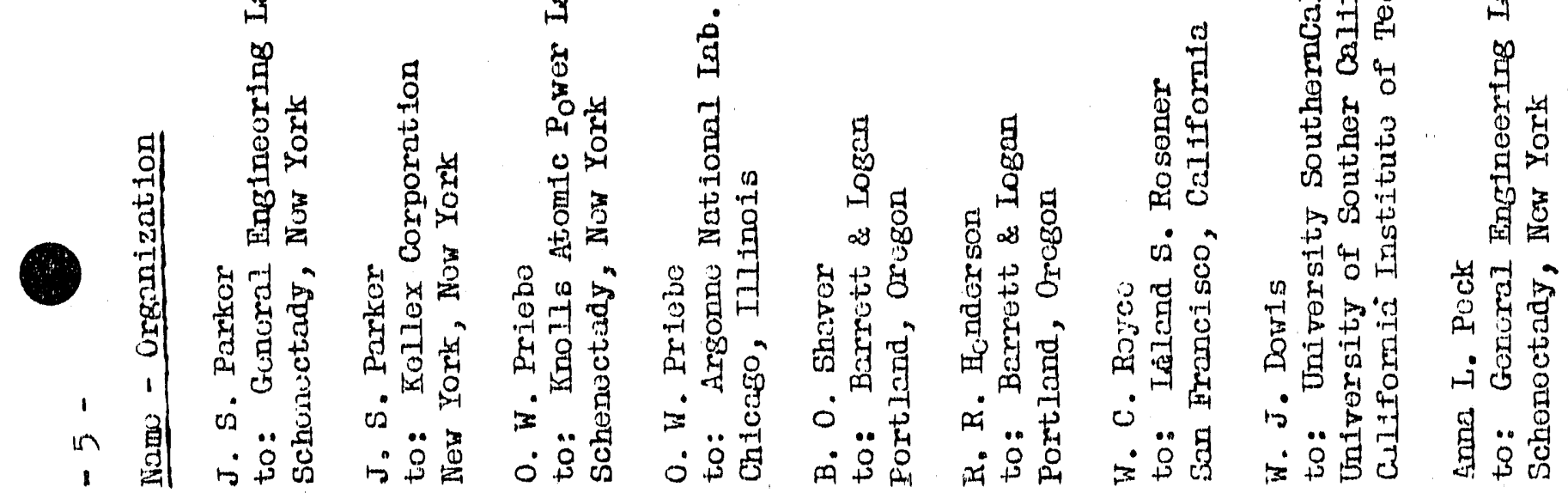


:

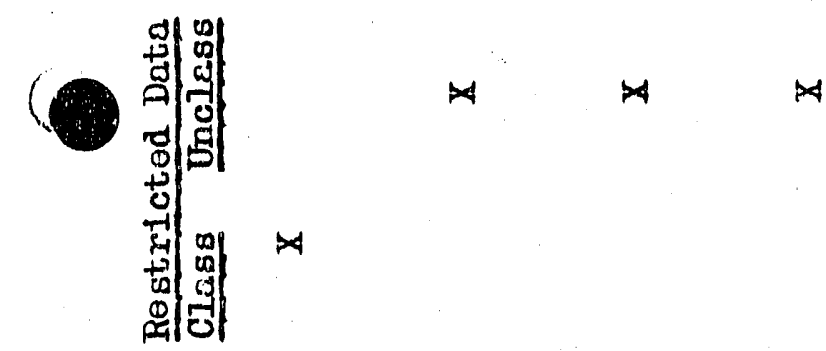

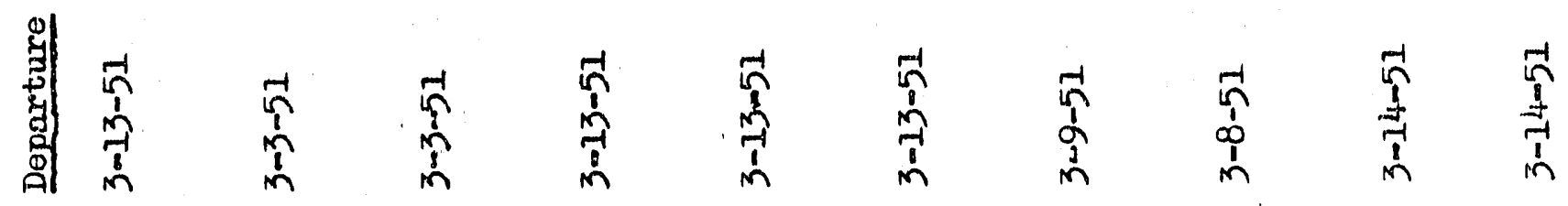

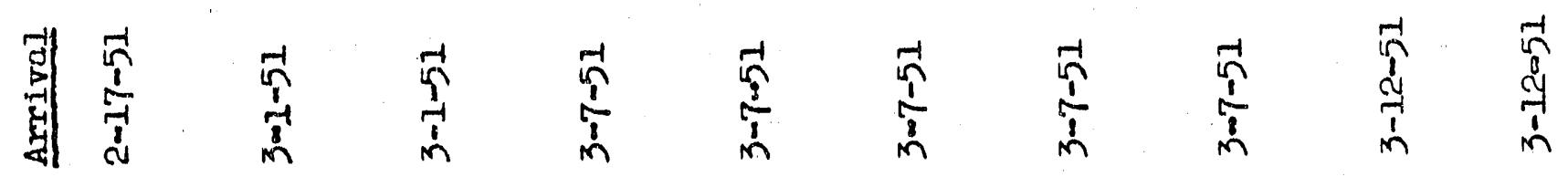

4

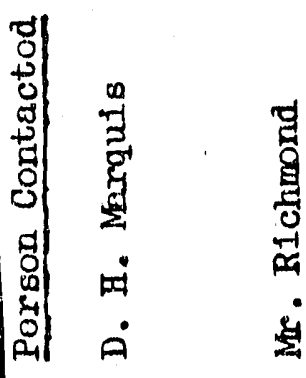

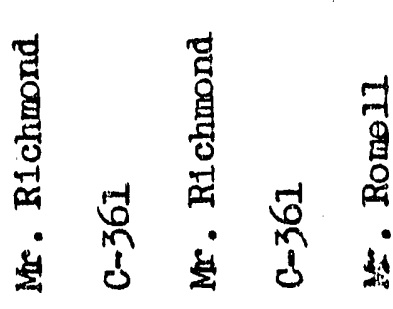

要

运

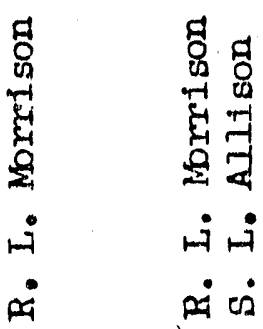

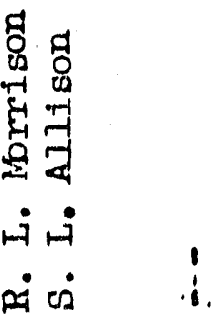

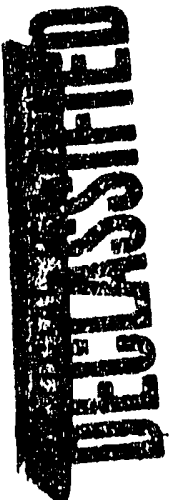

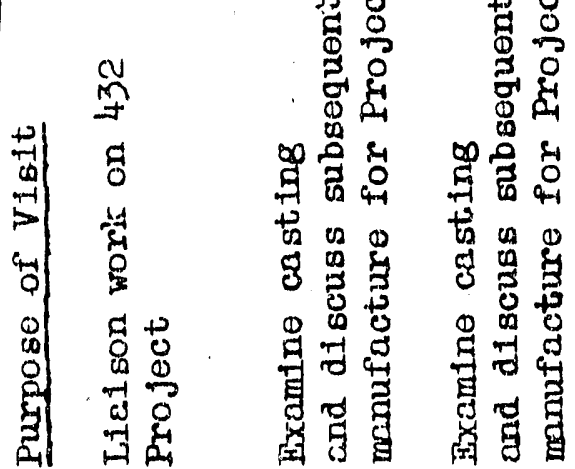

명 효 영

章

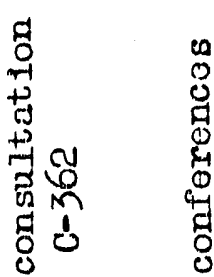

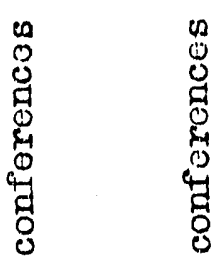

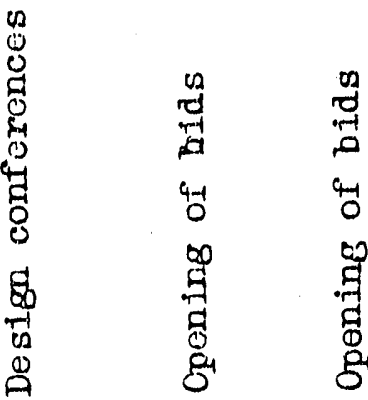

运

整密

密 量

告

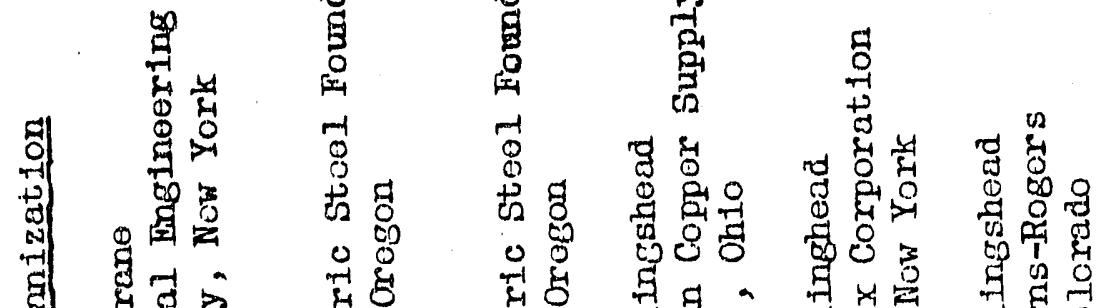

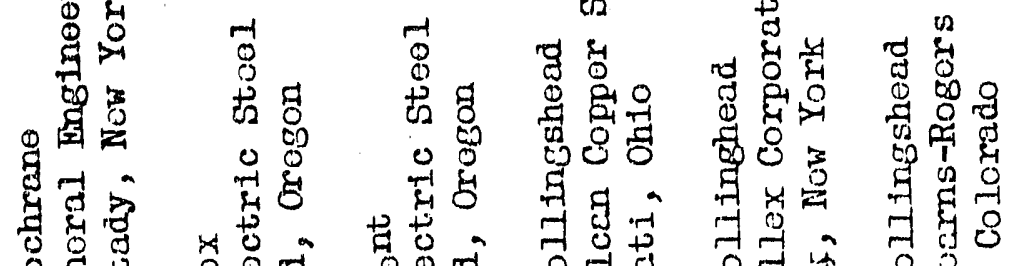

点

究常

뎡

要 留

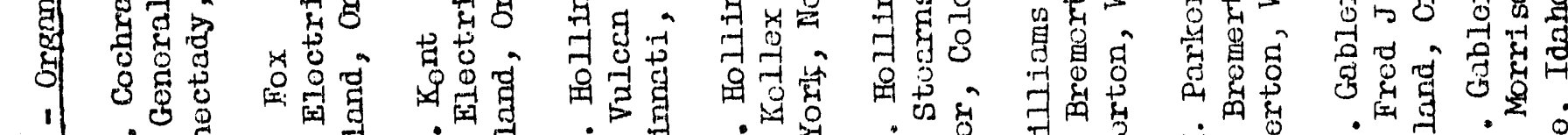

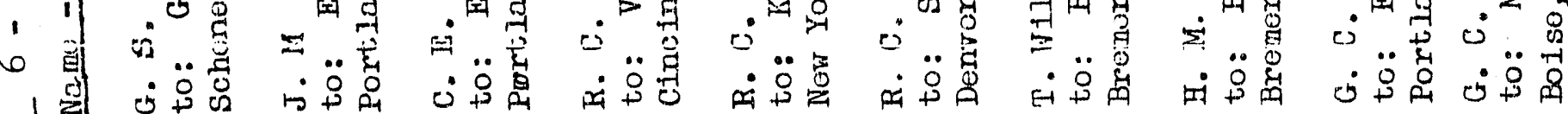

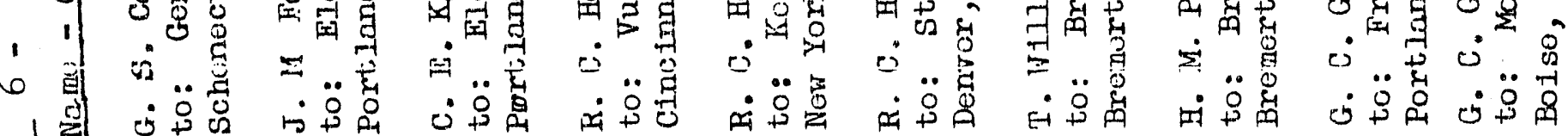


罗

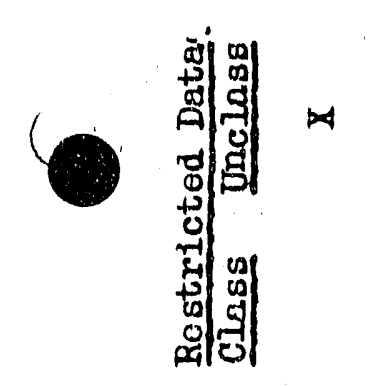

$\star \Delta \quad \infty \quad \infty$

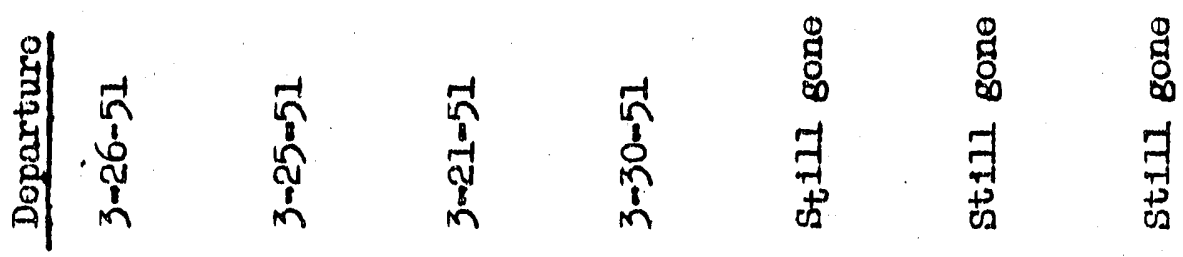

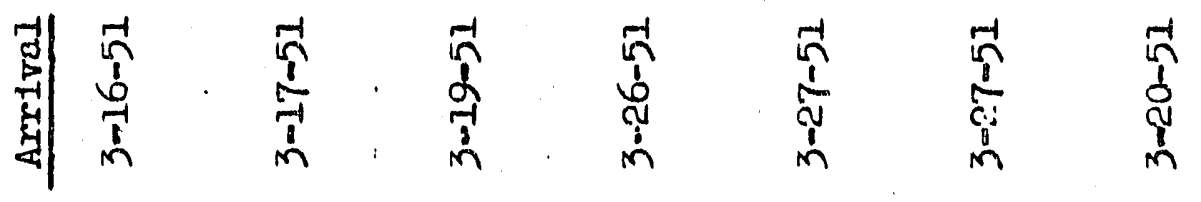

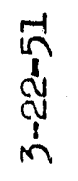

$n$
1
$\frac{1}{n}$
$n$
$n$

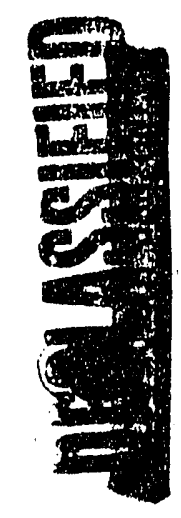

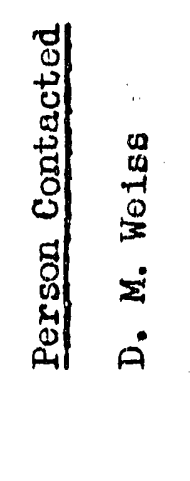

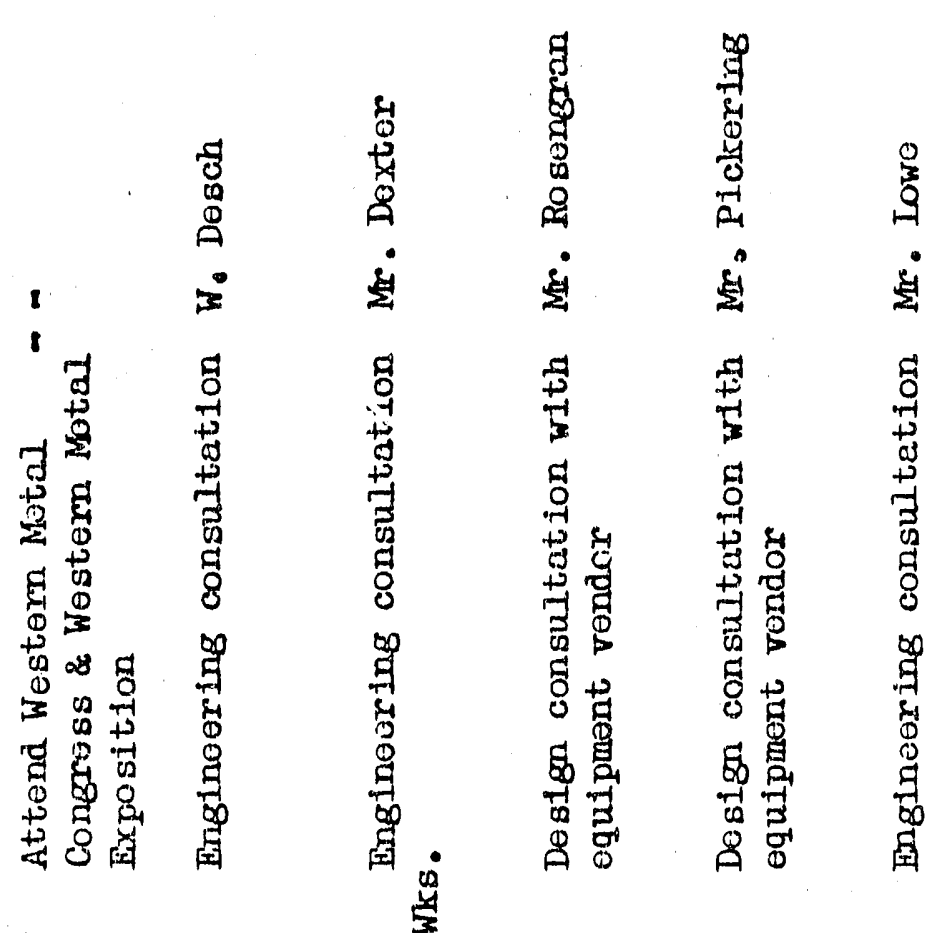

这

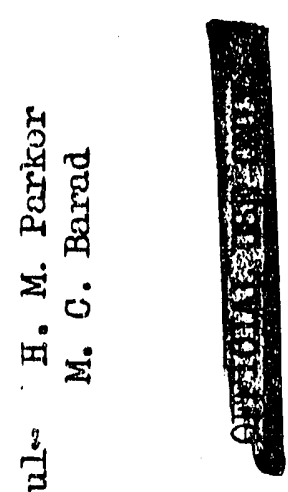

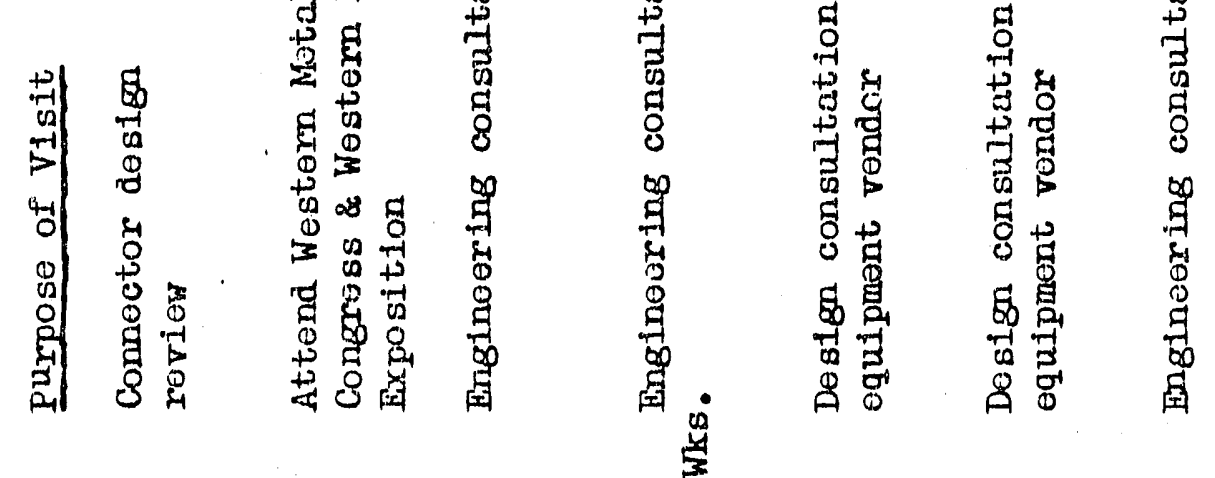

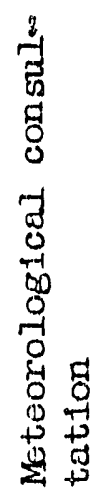

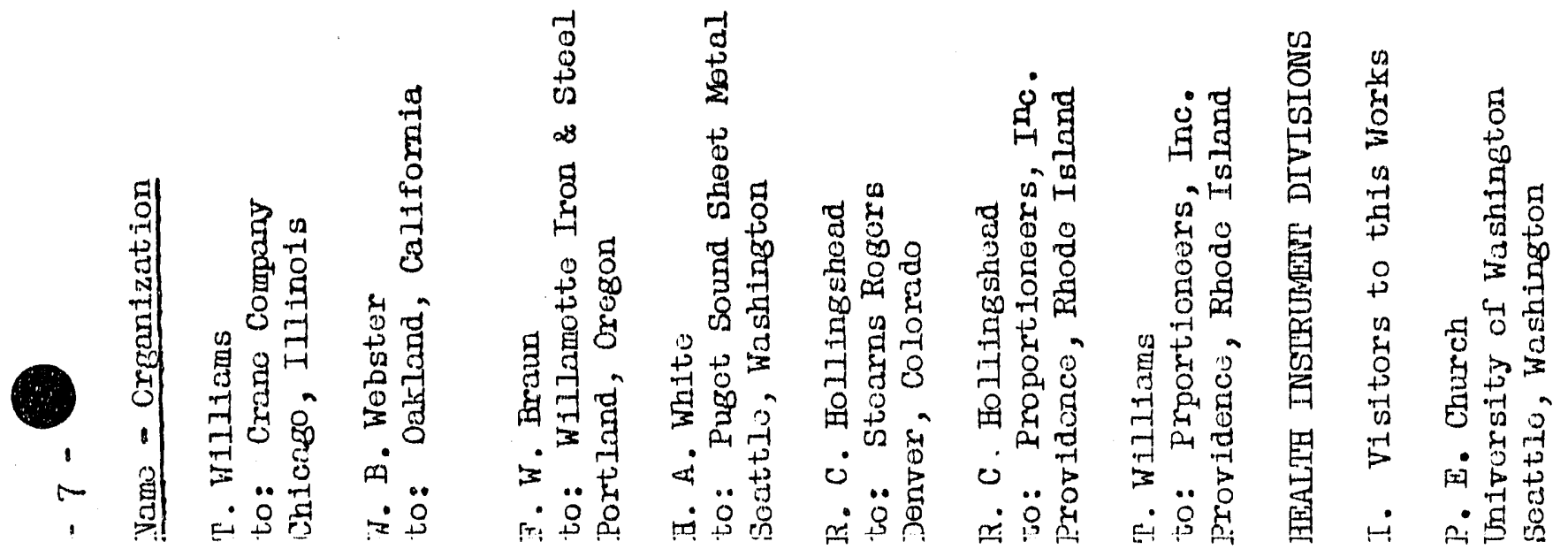




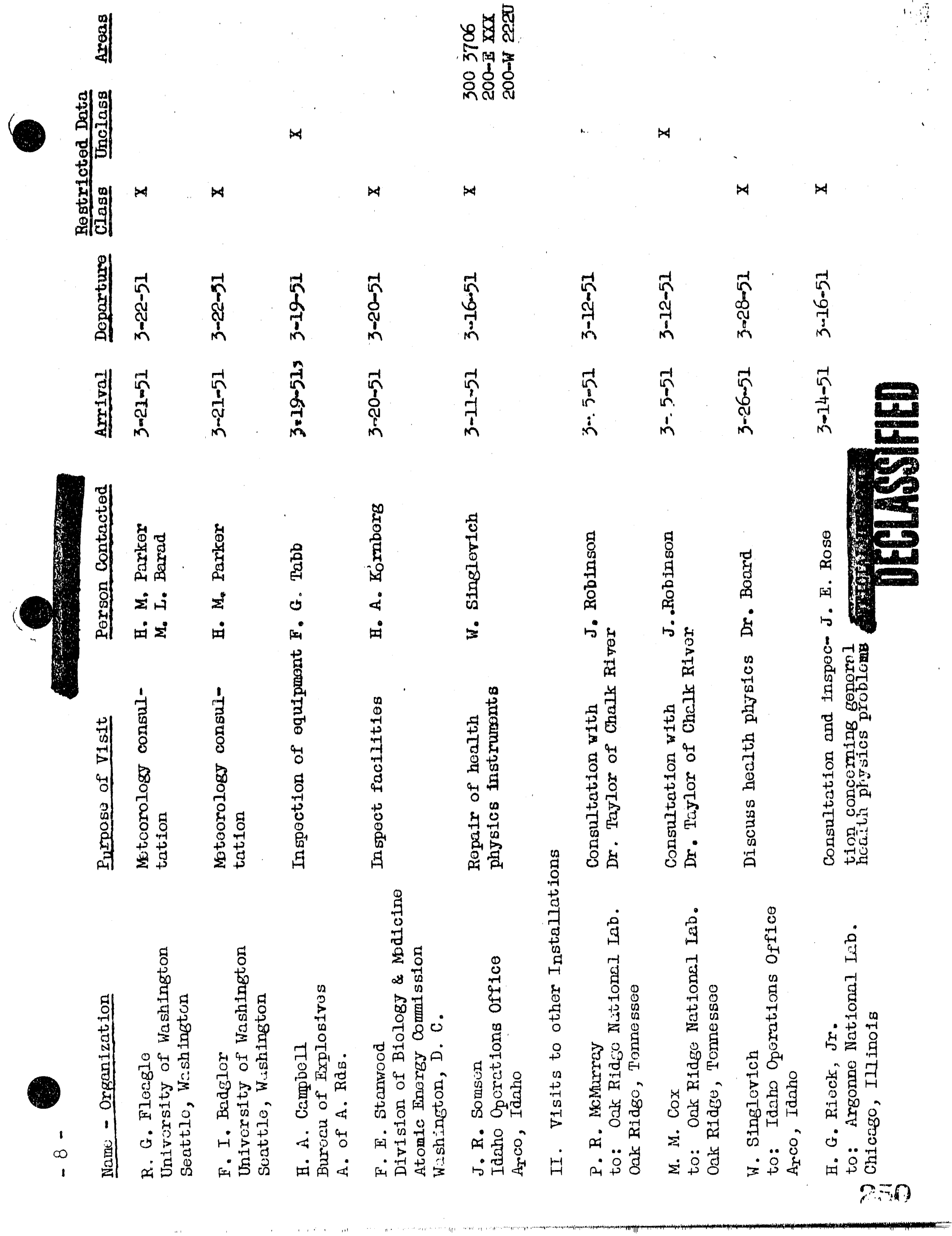



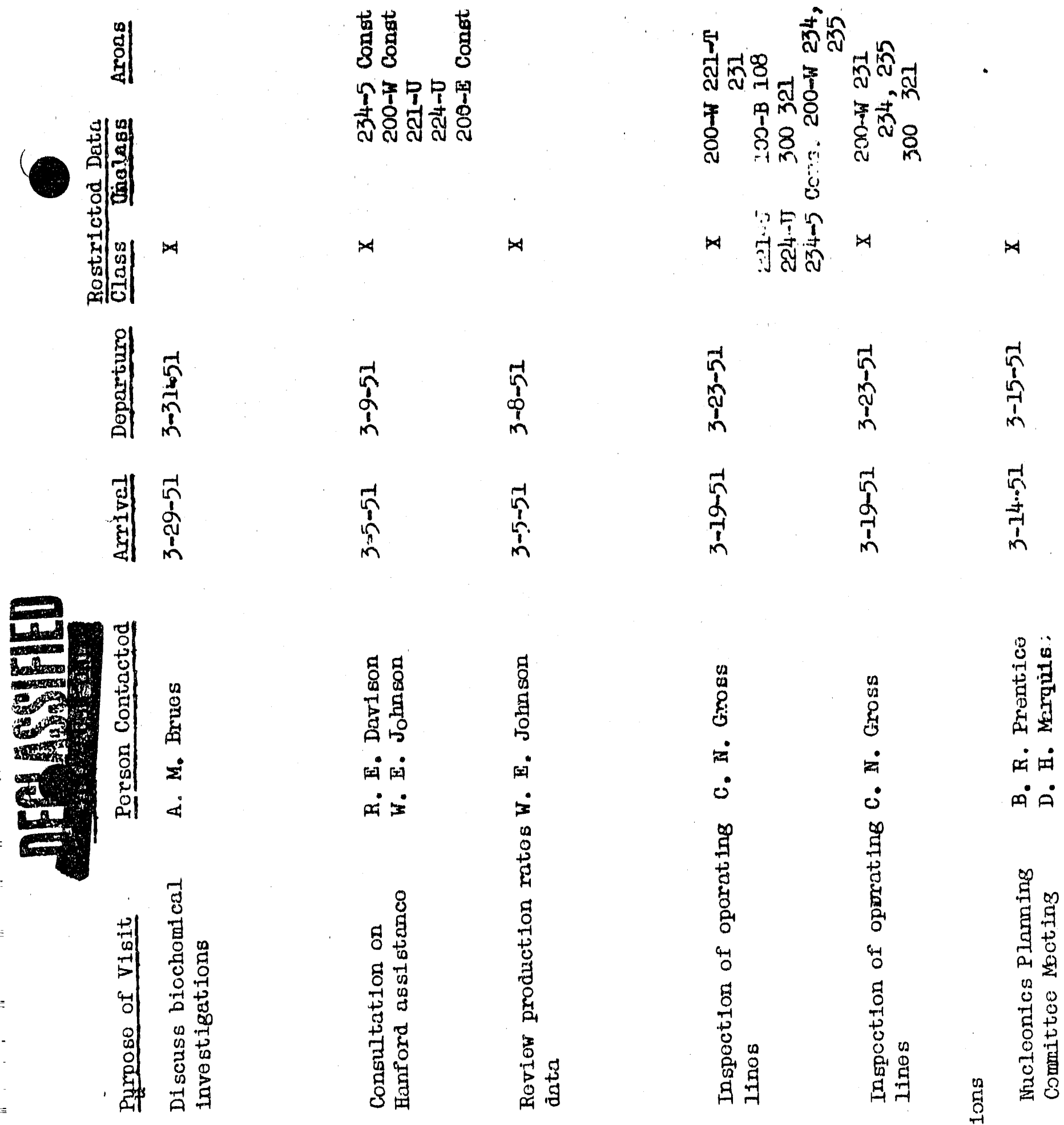

我 $1 x$

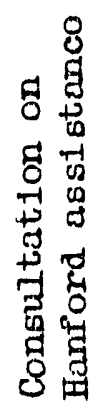

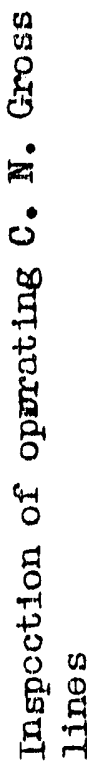

乎的

$\dot{\oplus \dot{A}}$

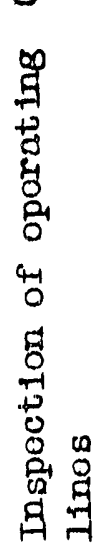

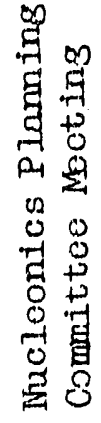

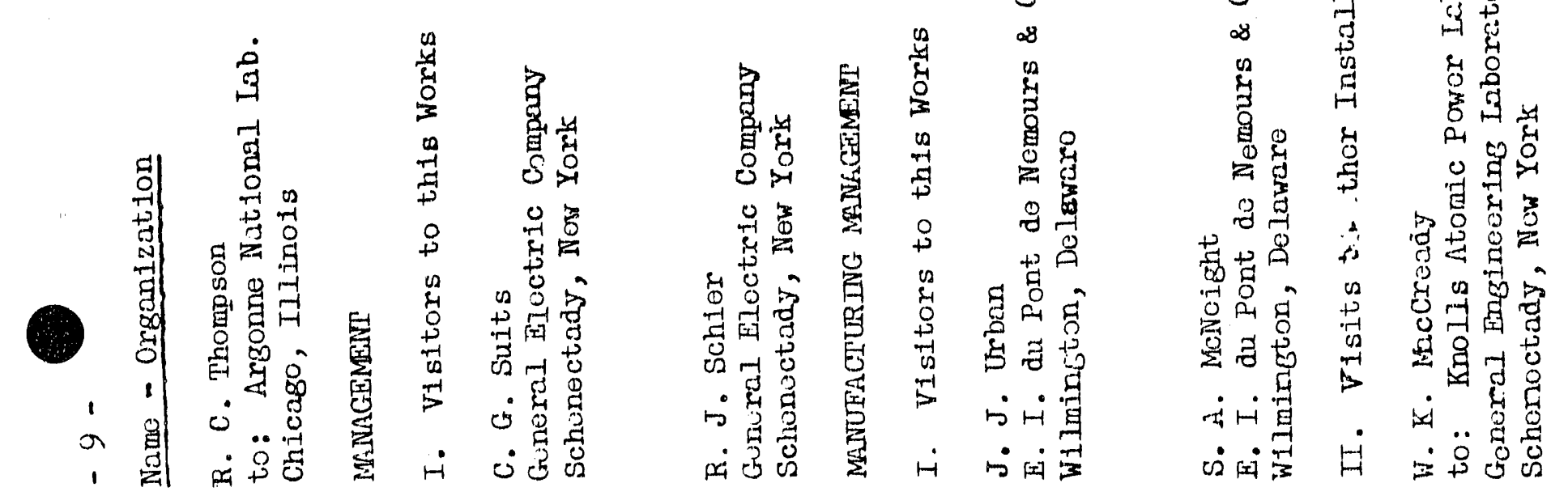




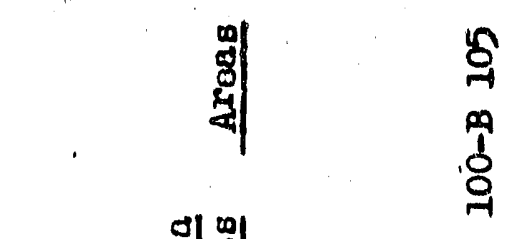

密
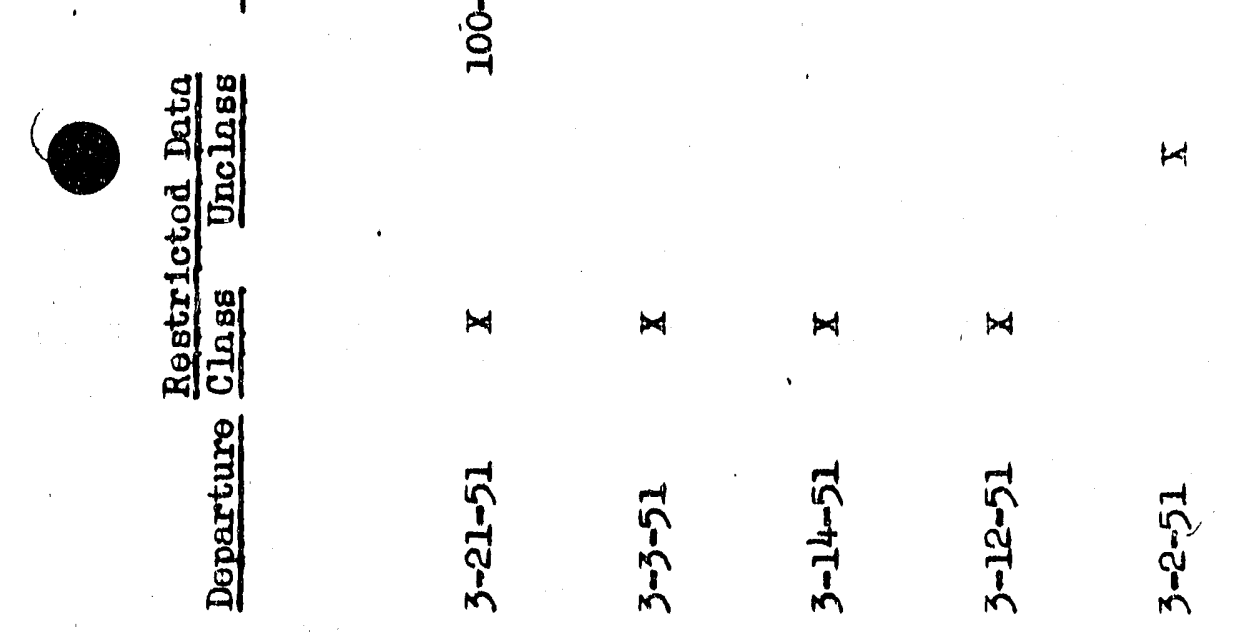

우운

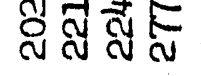

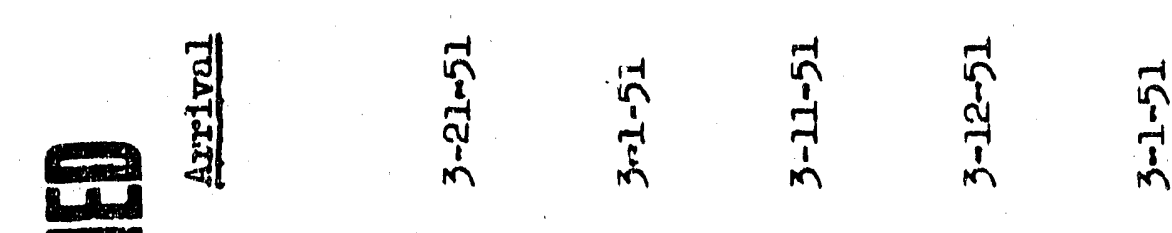

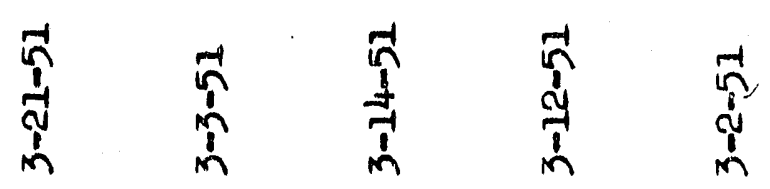

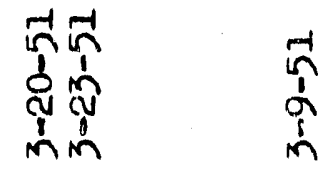

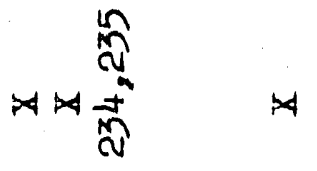

\&્द्य

ণิ

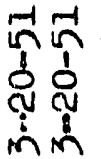

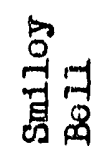

$\begin{array}{ll}8 & 8 \\ 8 & 8 \\ 0 & 8 \\ 0 & 8\end{array}$

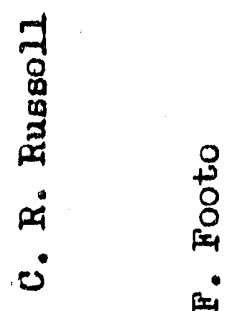

$\frac{1}{3}$

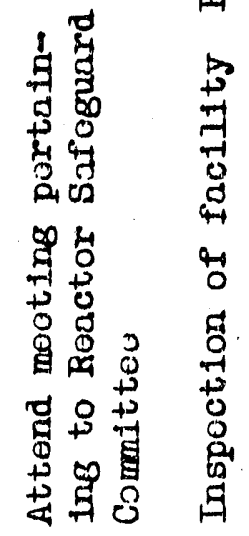

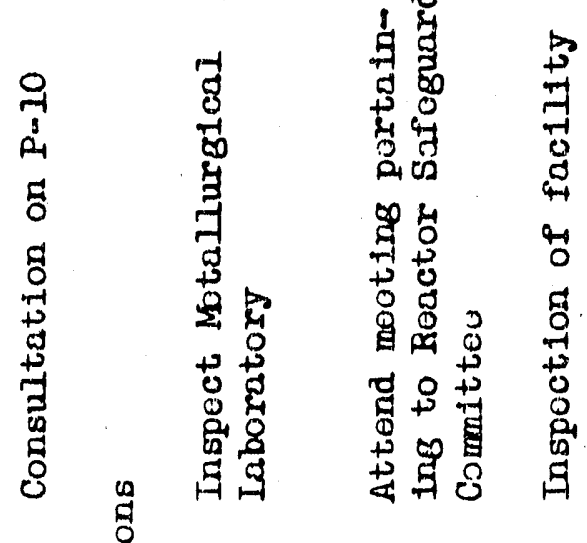

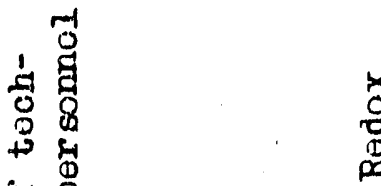

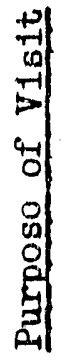

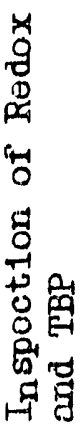

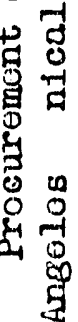

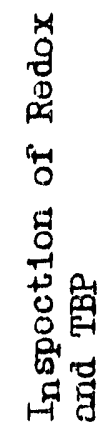

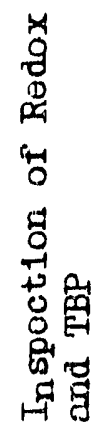

ค่

نं

$\frac{n}{n}$

$\forall$ क ज

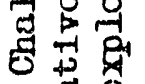

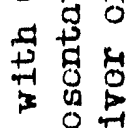

몽

क्ष

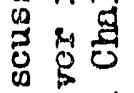

吾学

떠몀 영

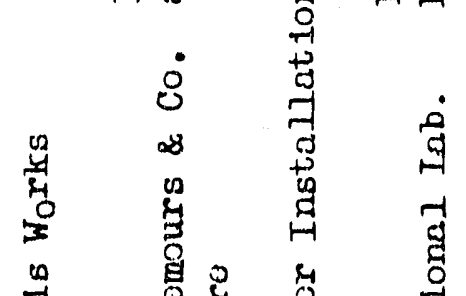

䒹藏 


\section{罗}

\section{- 疃}

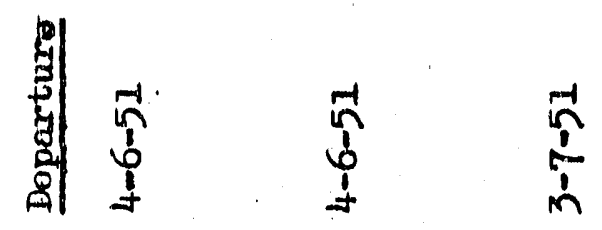

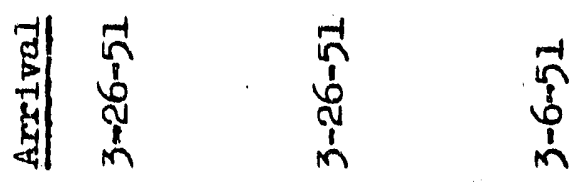
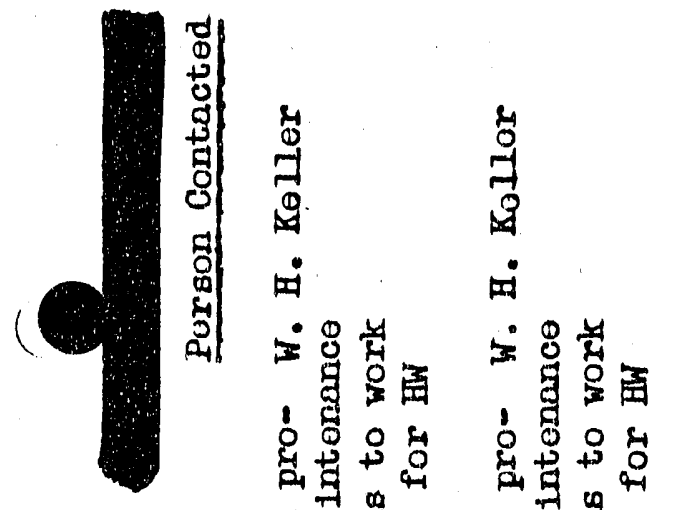

4
7
3
3

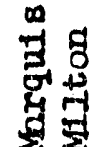

영

- 四 的的

贾通

웡영

$\therefore \dot{0}$

$\stackrel{1}{1}$

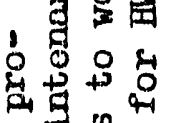

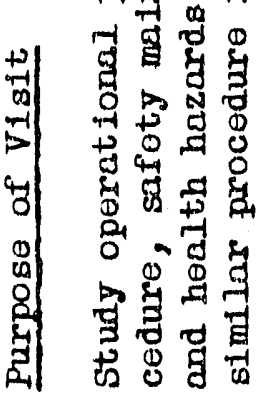

要早

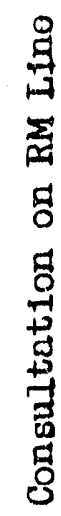

o

ज证

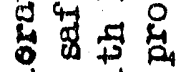

वे की

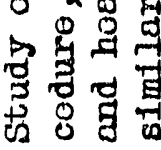

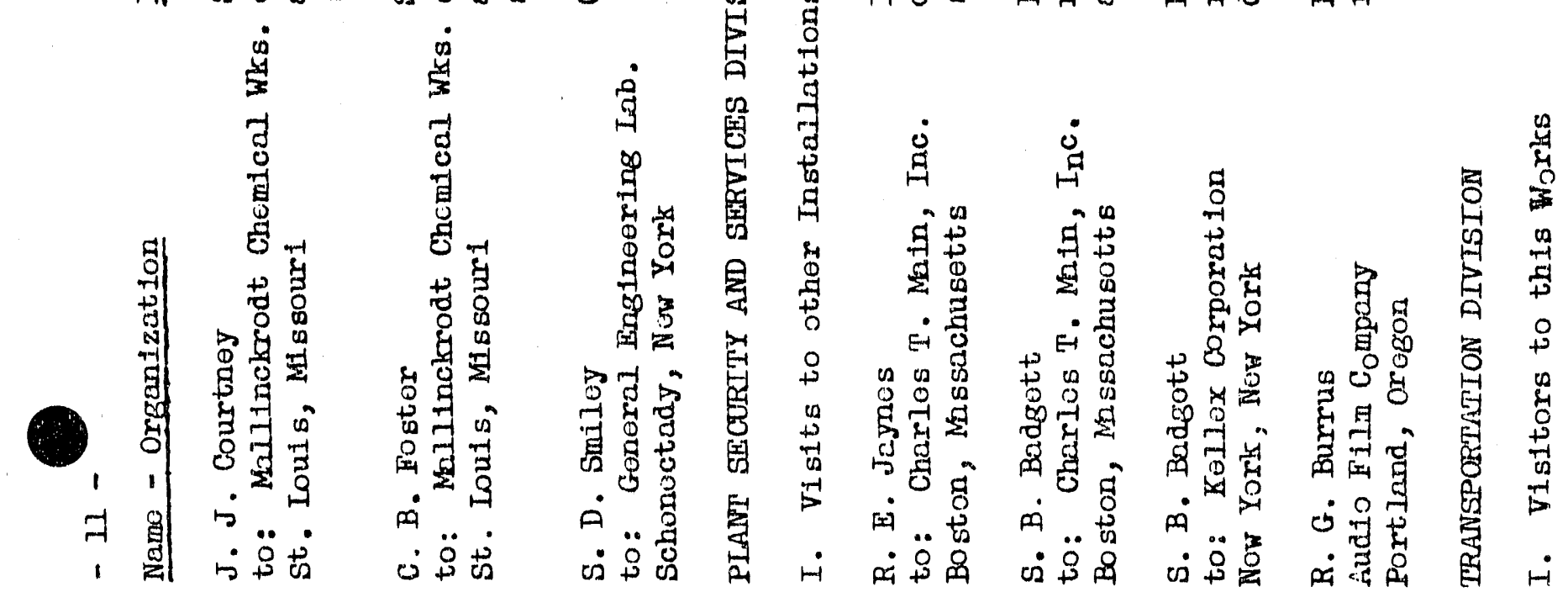

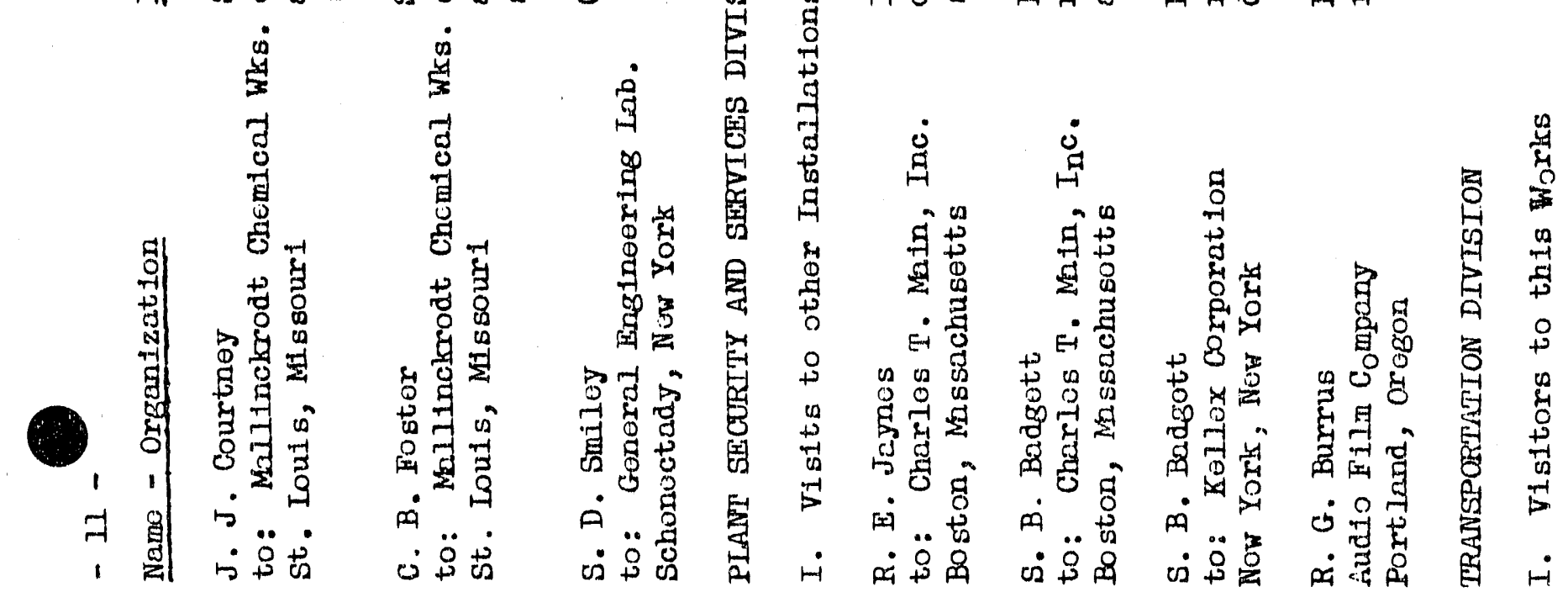

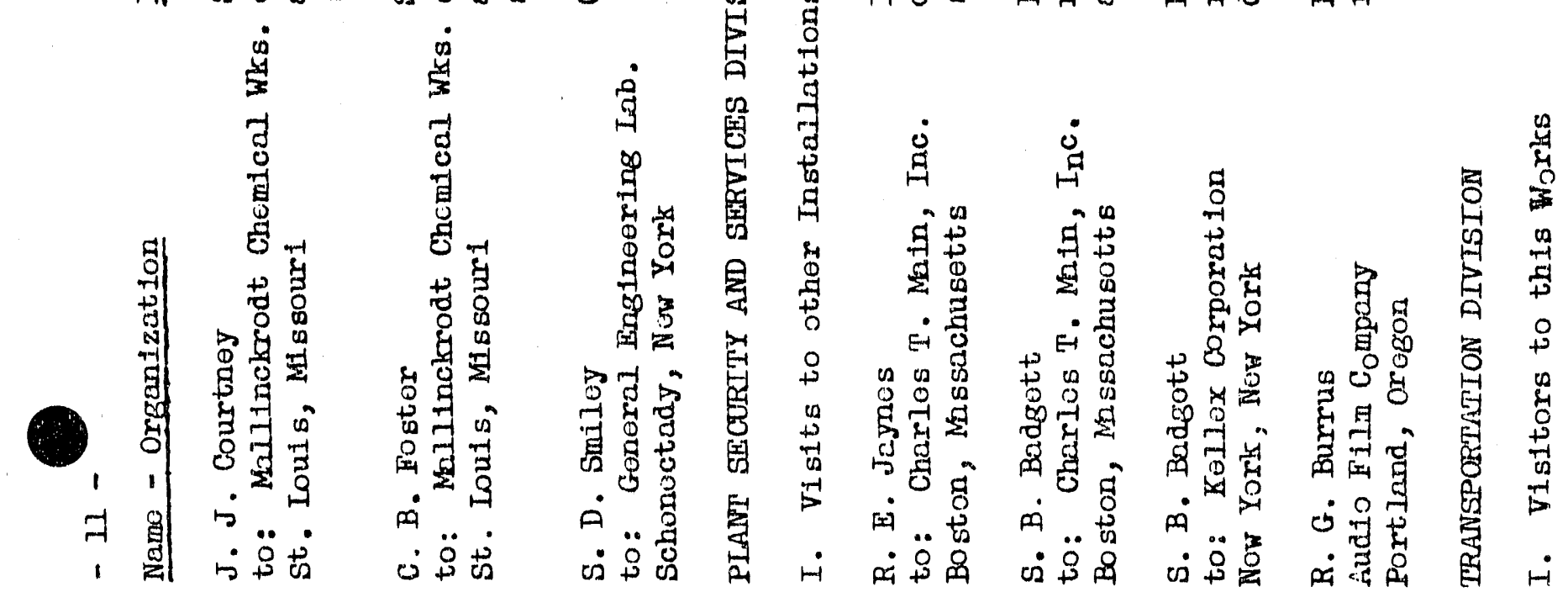

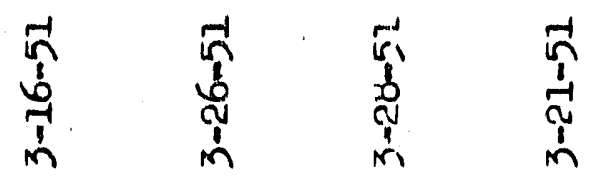

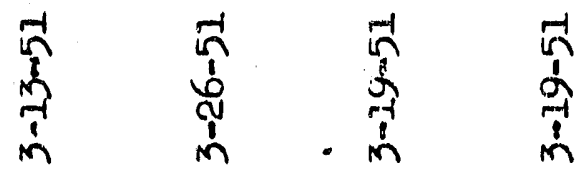

骂 鄫

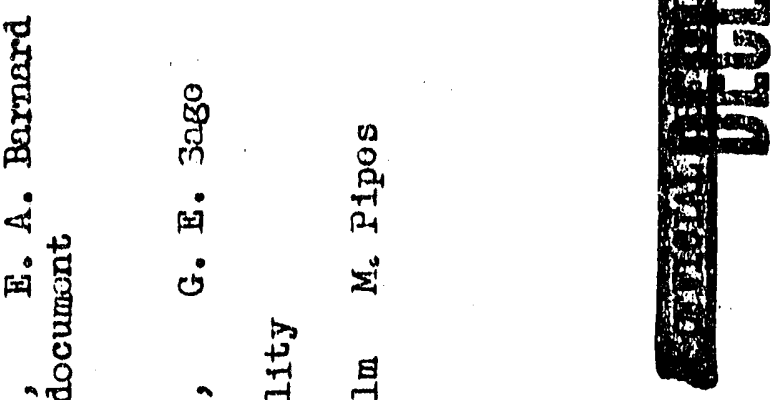

竞

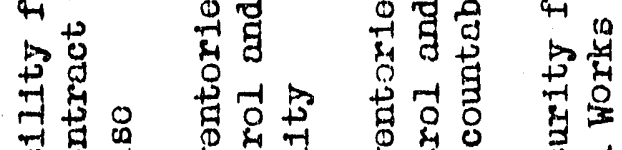

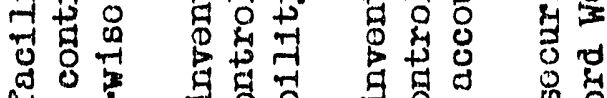

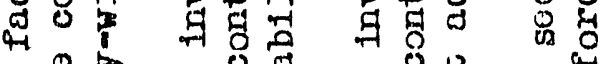

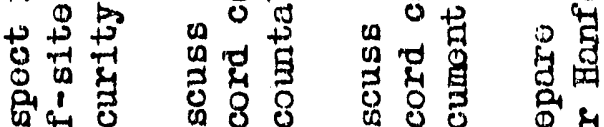

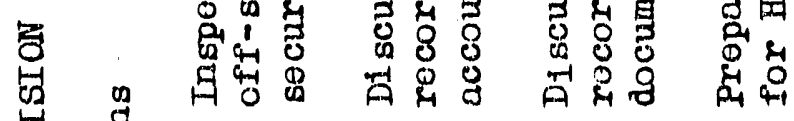

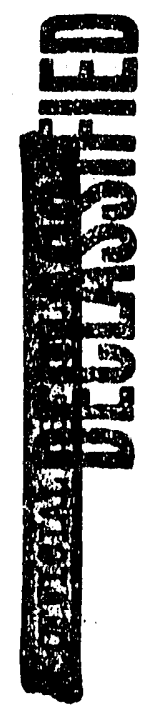




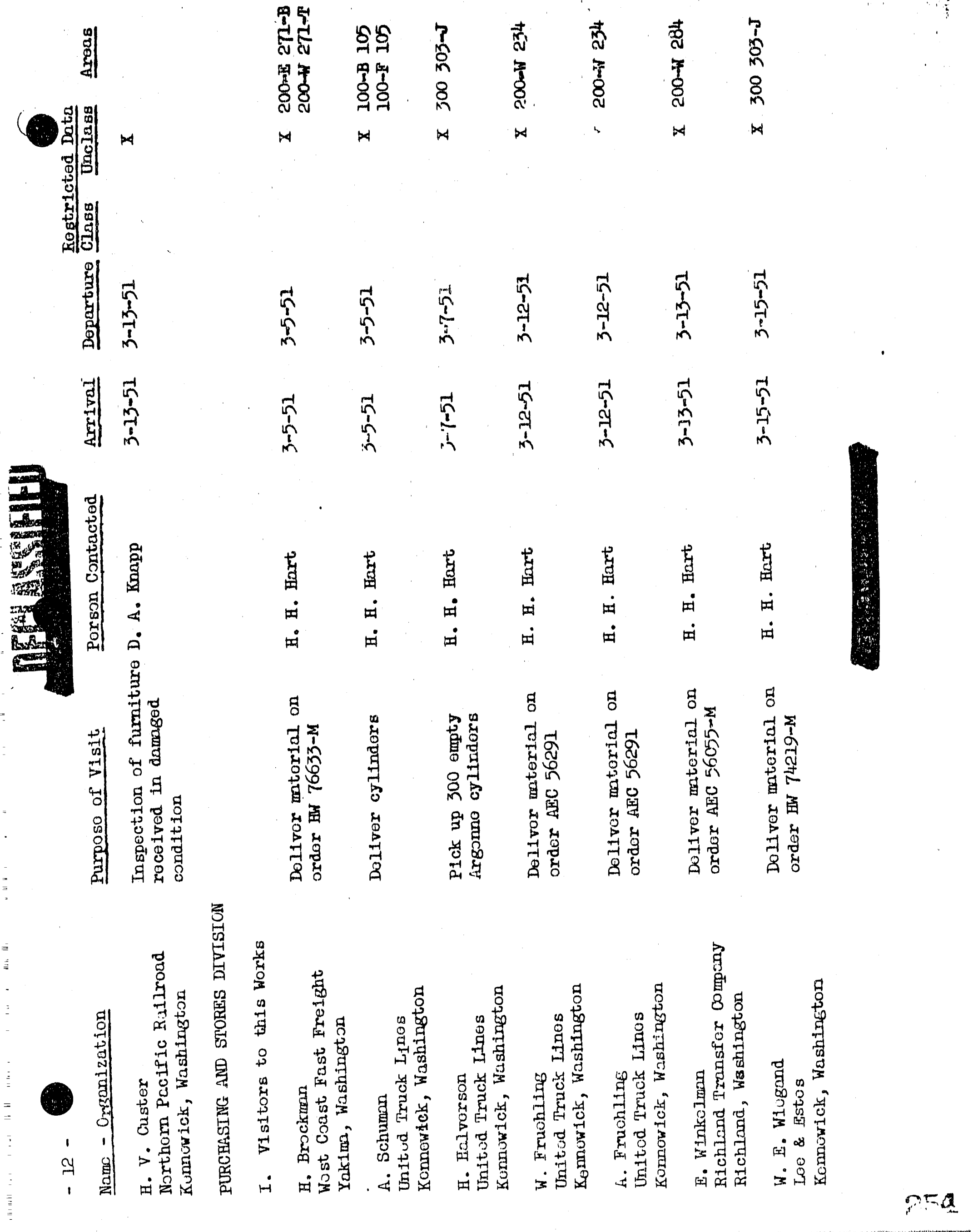




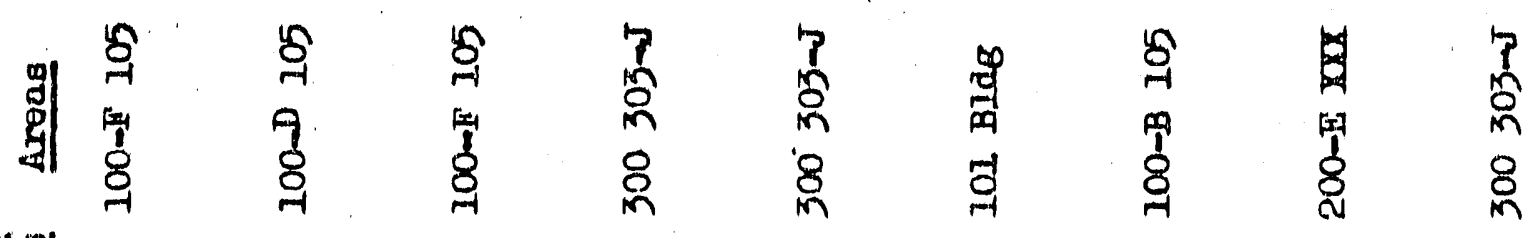

- 됀.

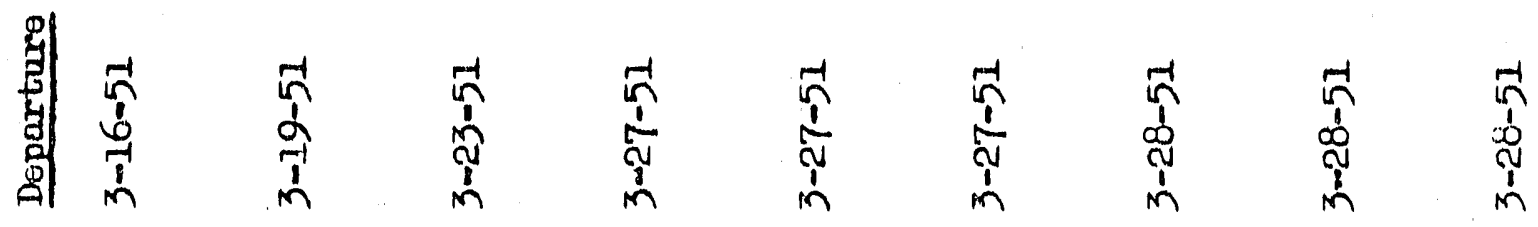

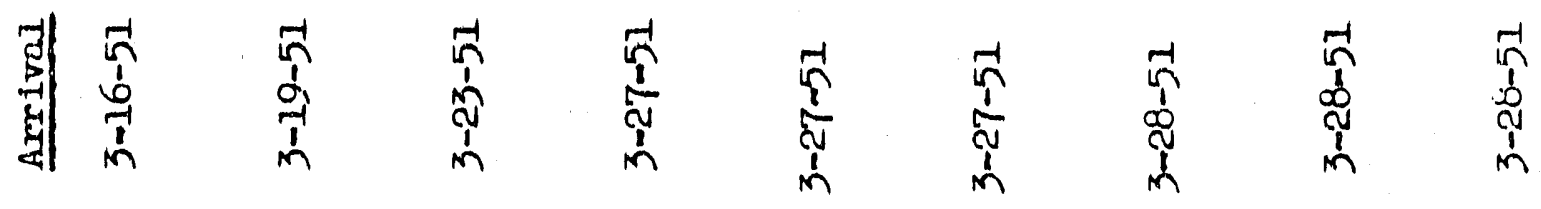

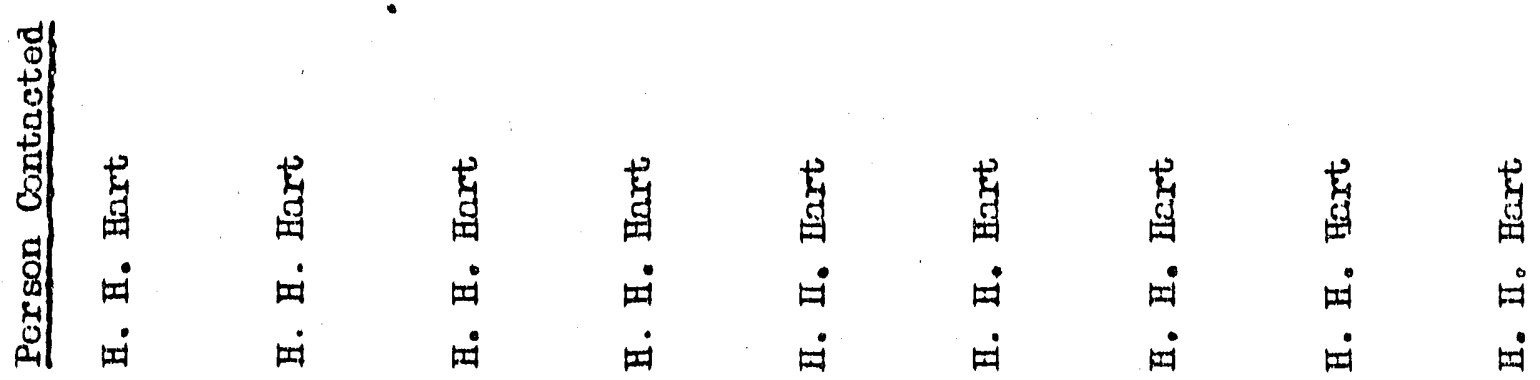

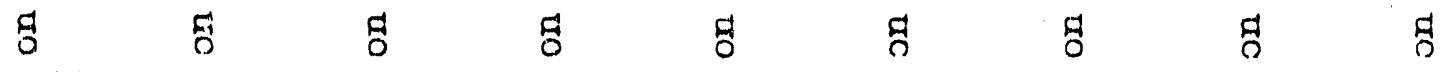

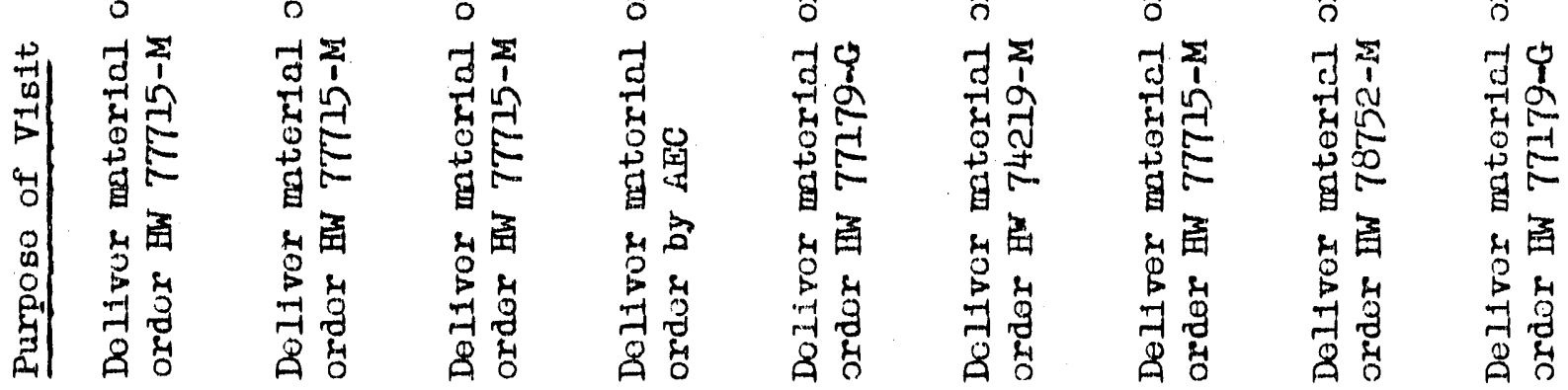

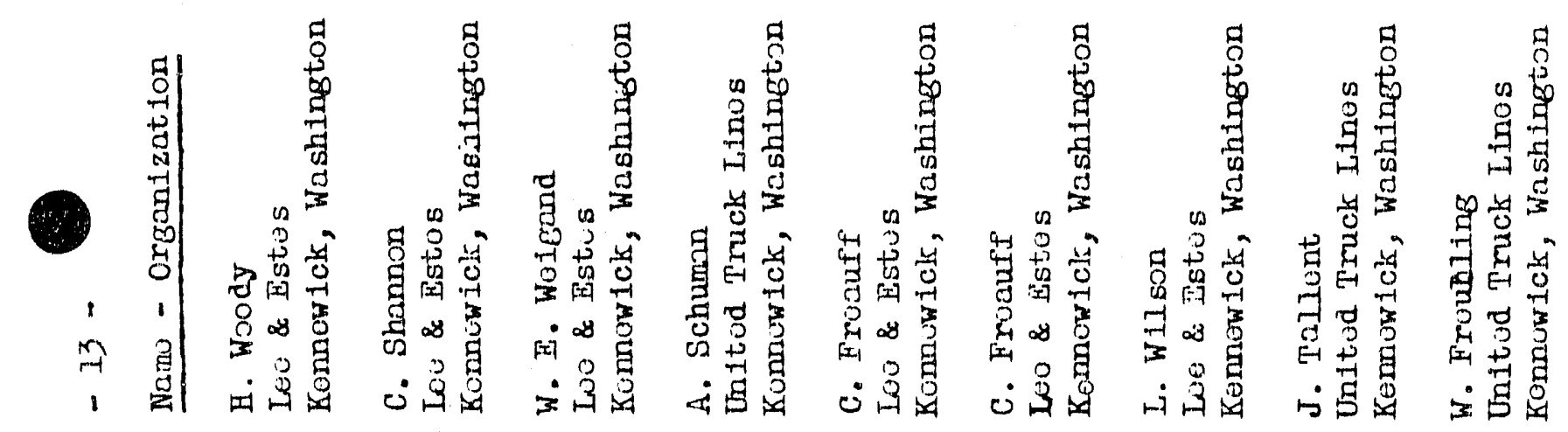




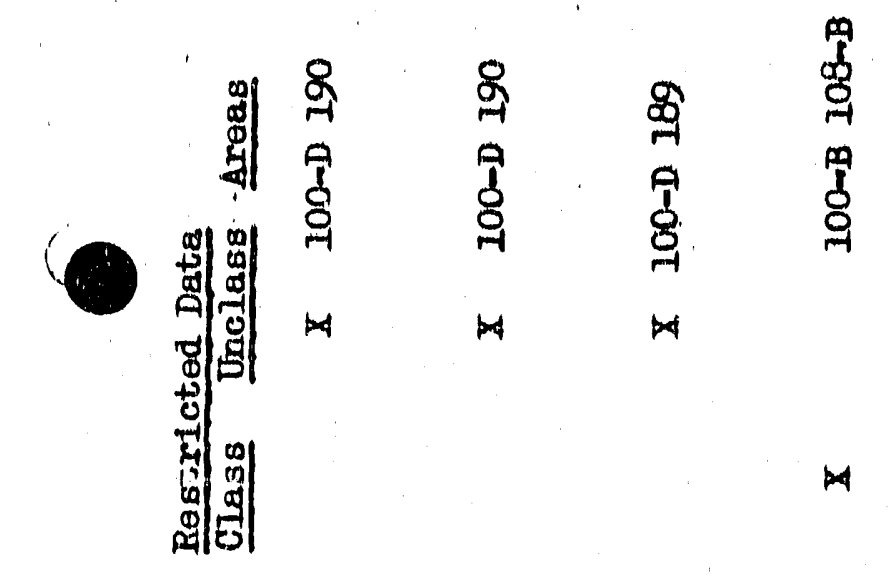

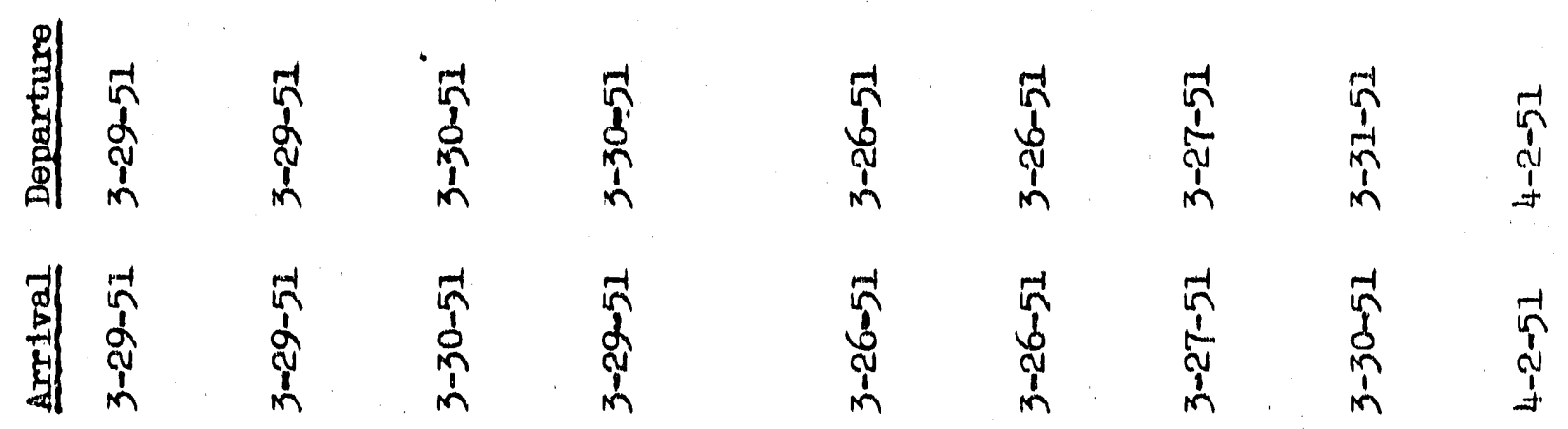

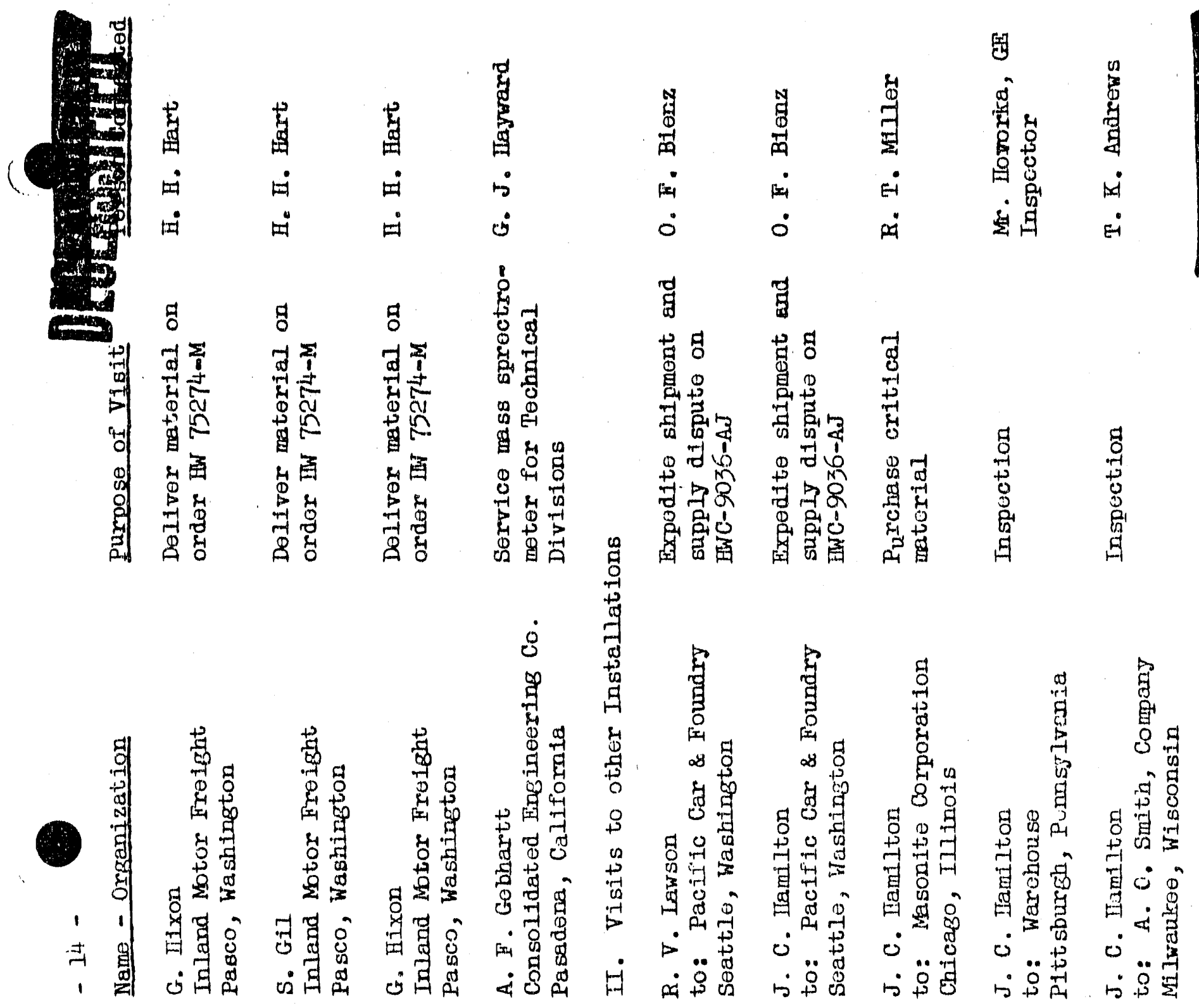




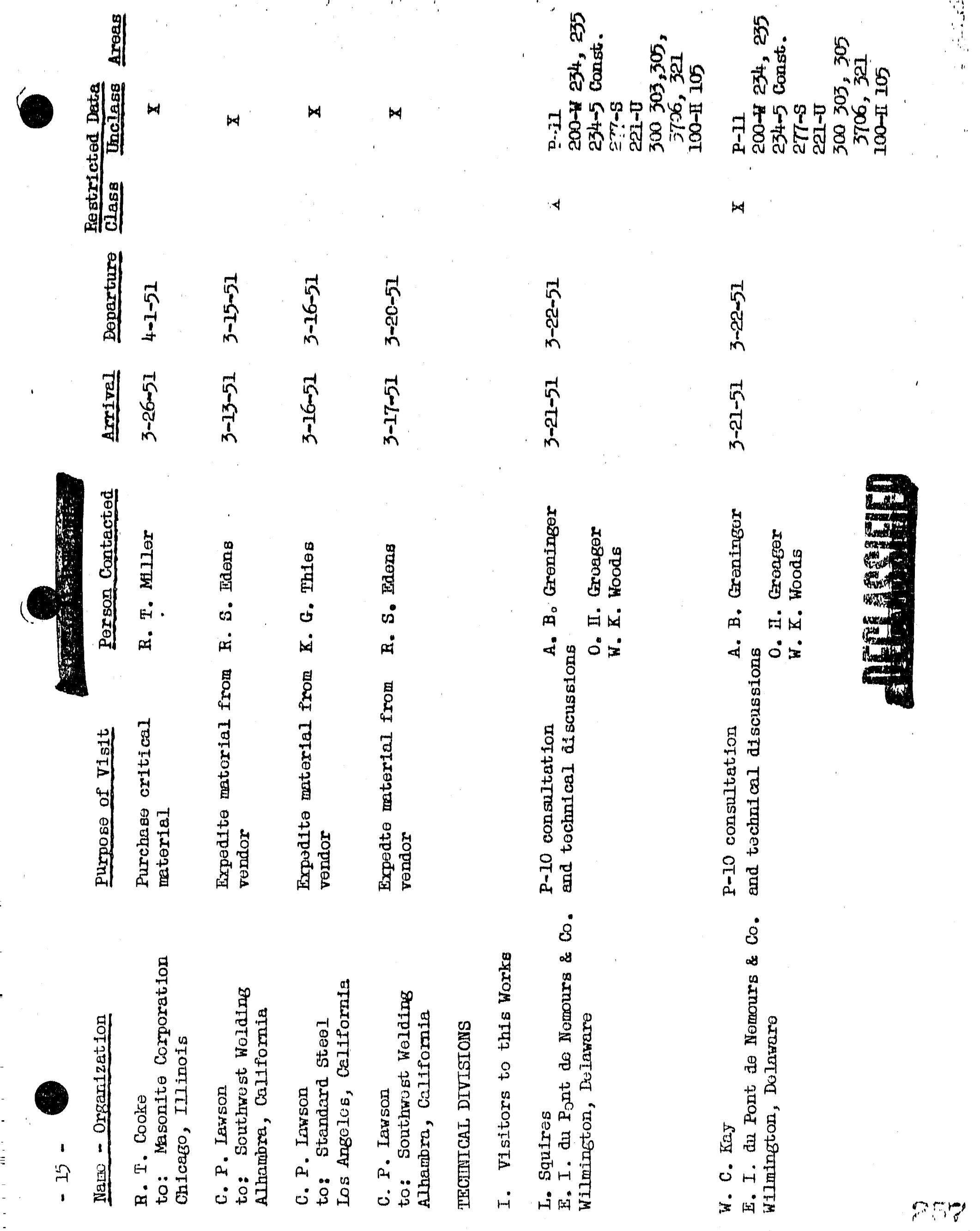




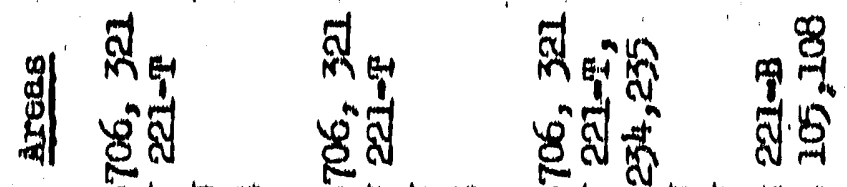

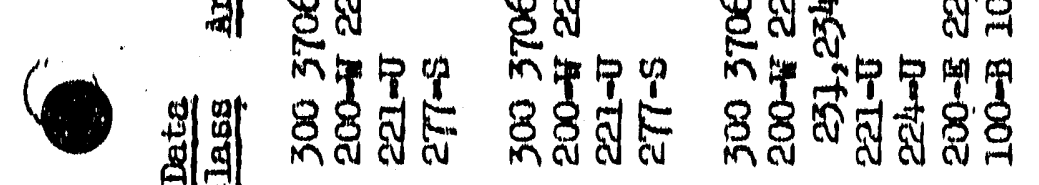

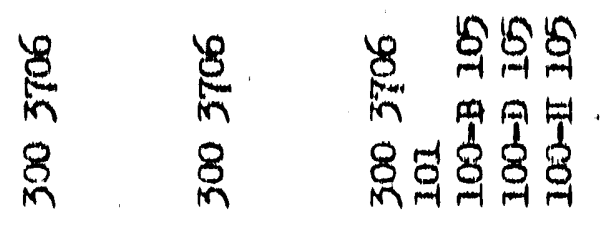

部的

咅

蒂蒡

等

蒂旁蒂

步葶

索

के

告

年

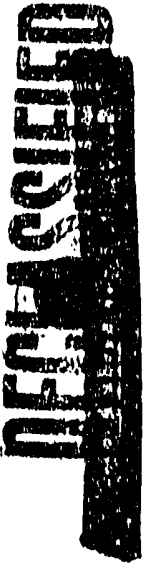

总

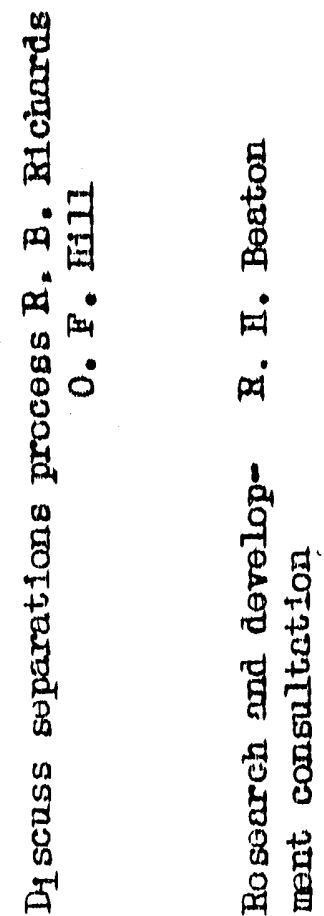

की

员

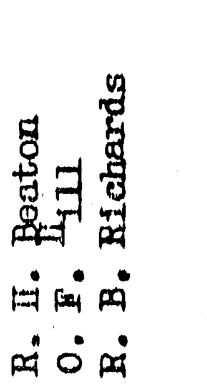

究究

武|

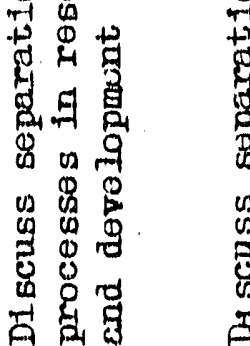

要

章

䧈
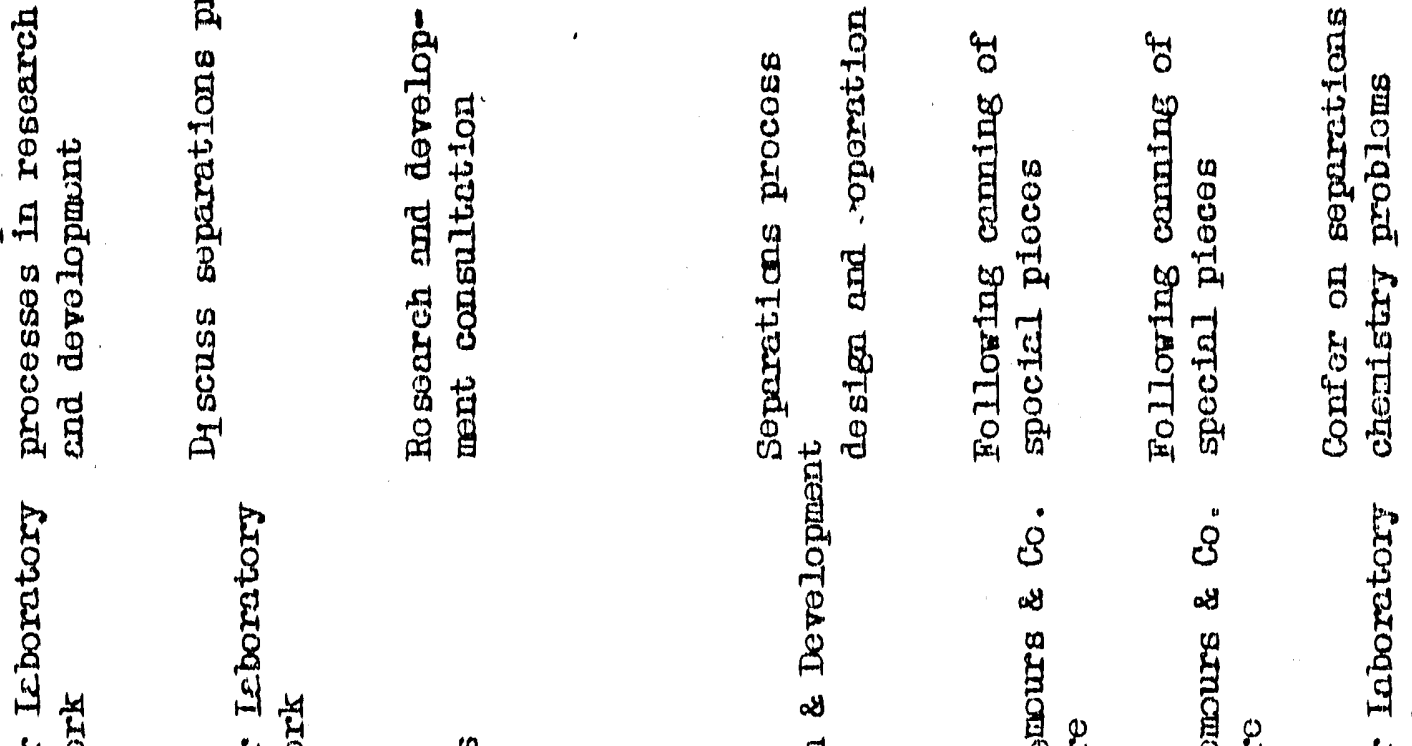

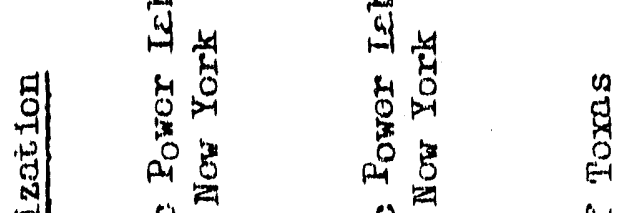

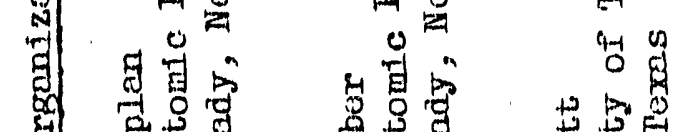

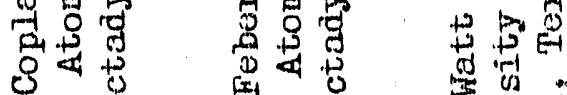

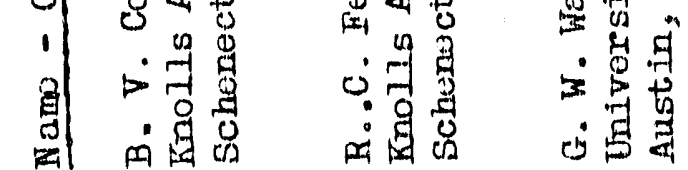

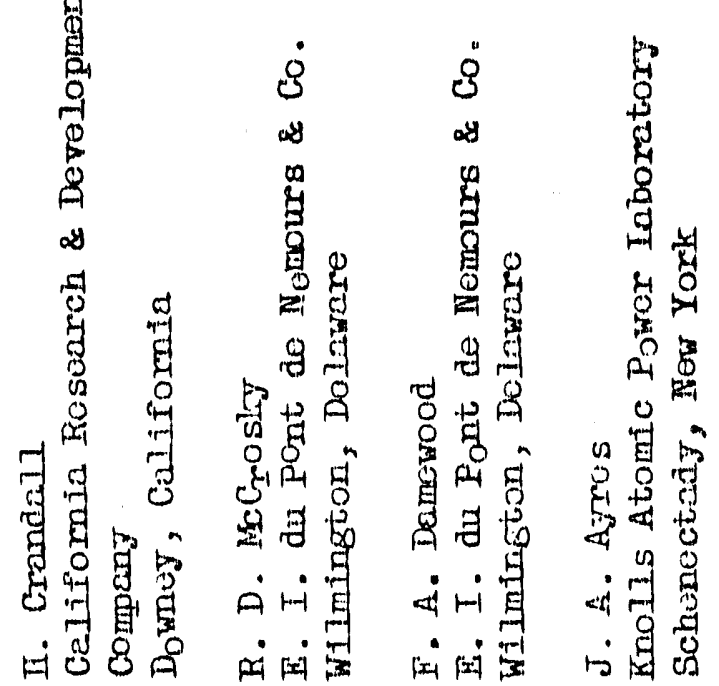




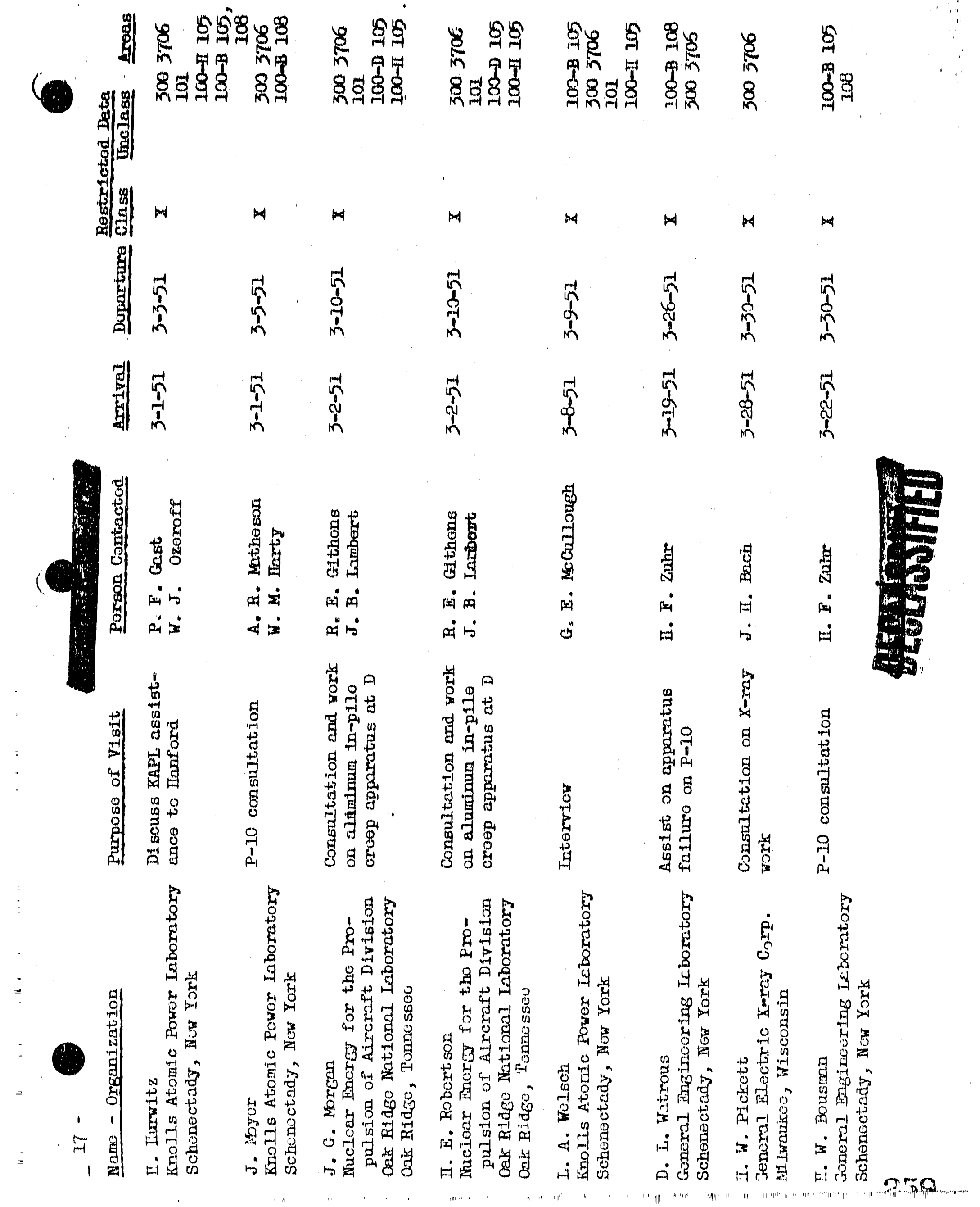




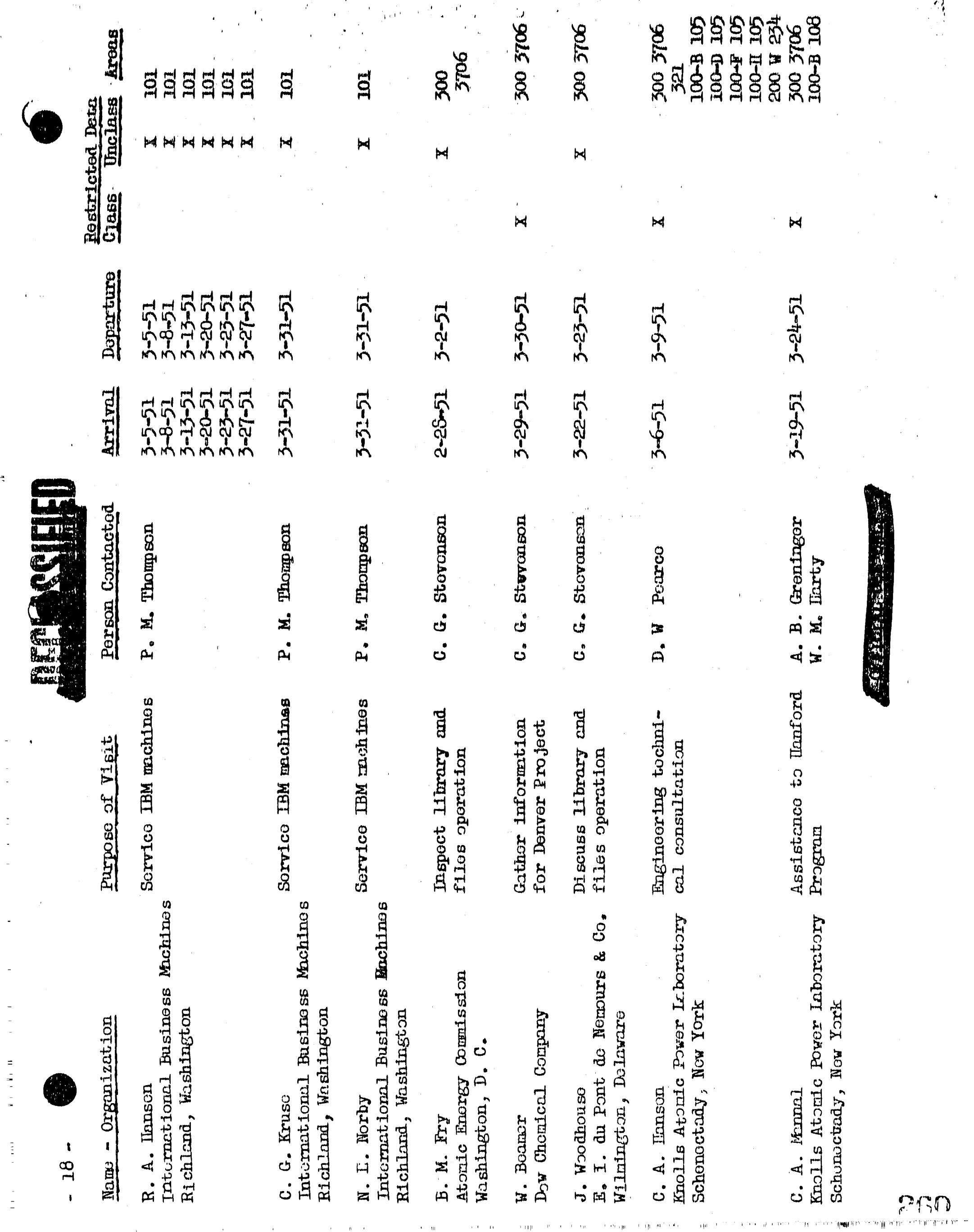




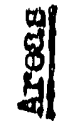

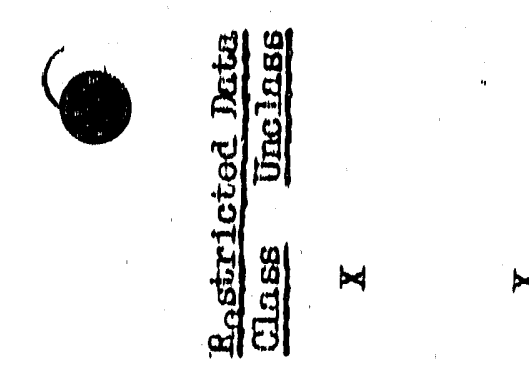

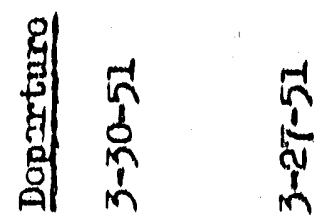

की

के

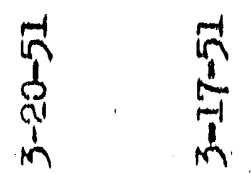

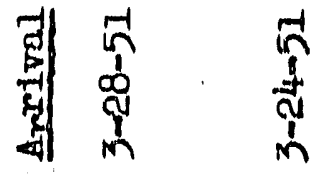

की

ڤ్t

की

हึ

ấ

$\frac{-1}{5}$
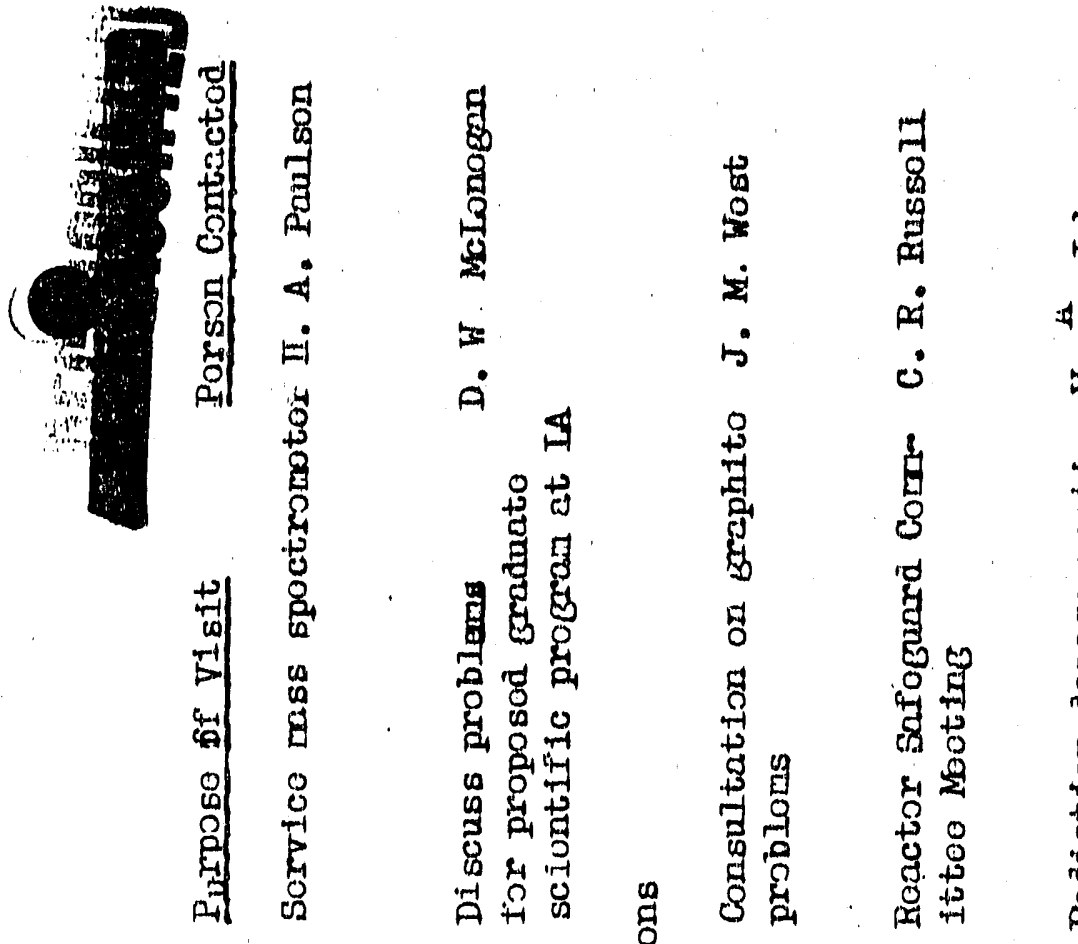

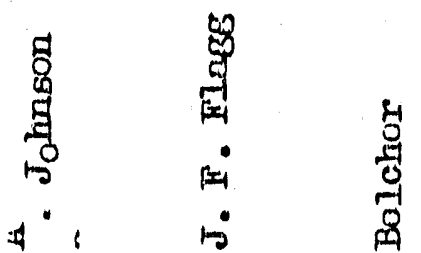

告

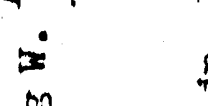

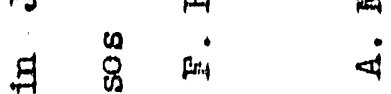

营

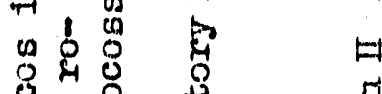

尊憵

気

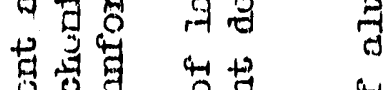

题总息等

연

a.

弯

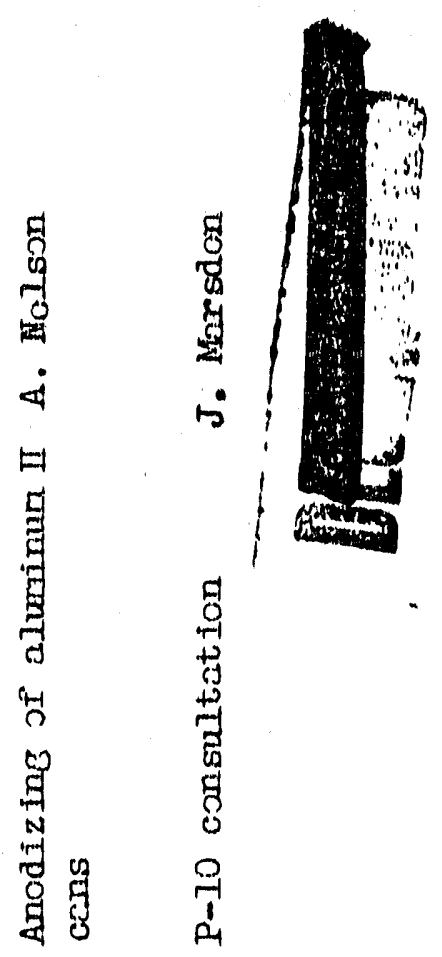

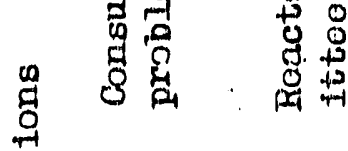

考出莒

分角等<smiles>C1CCCCCCCCCC1</smiles>

苟

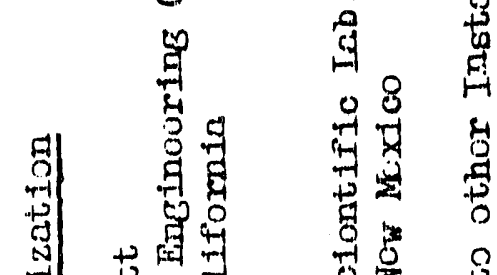

昌

赵

$=$

की

है

昌苟 总

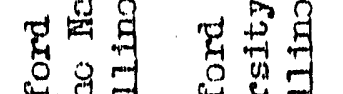

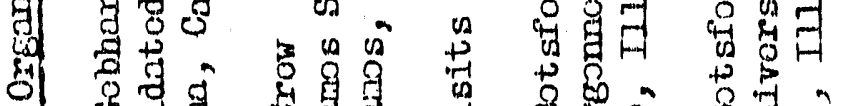

总兽

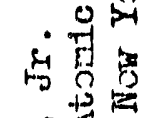

臂

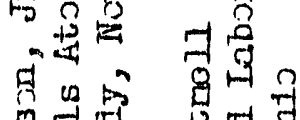

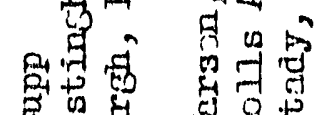

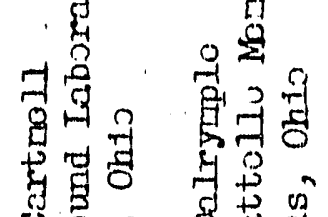

窎

品 क क

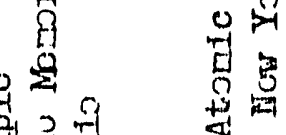

o

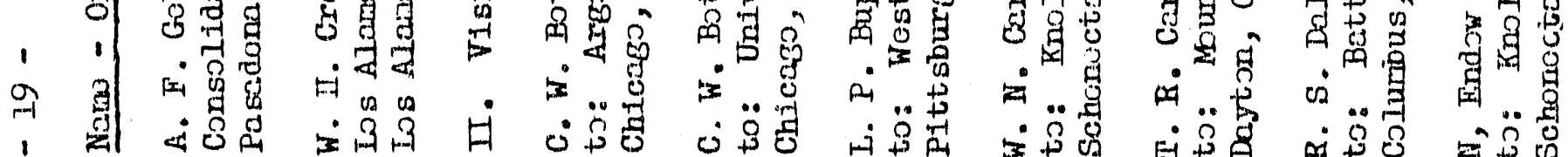




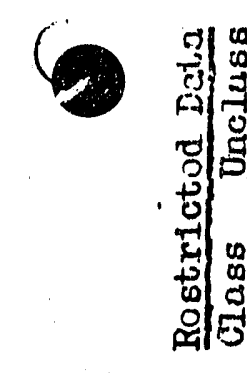

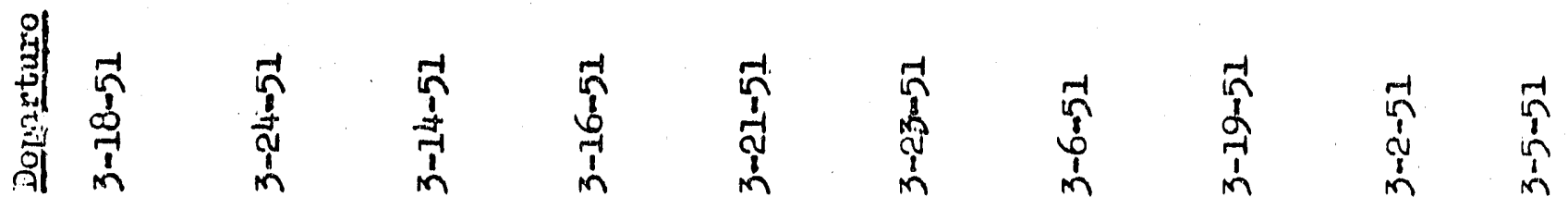

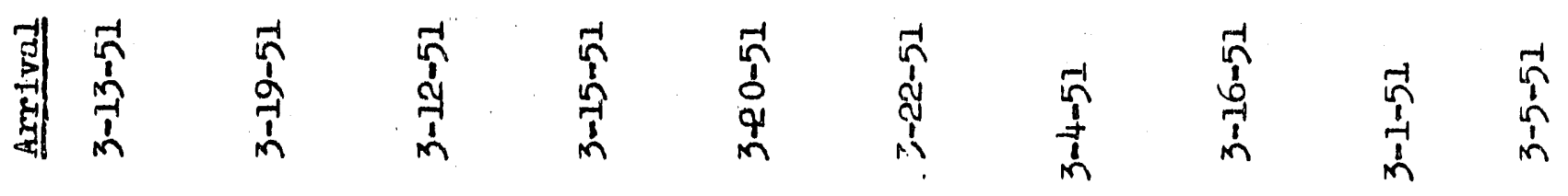

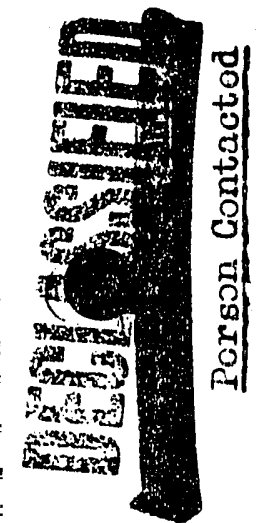

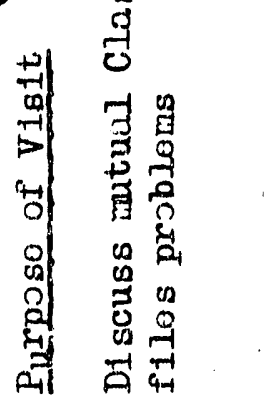

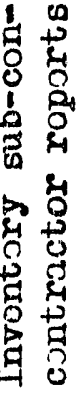

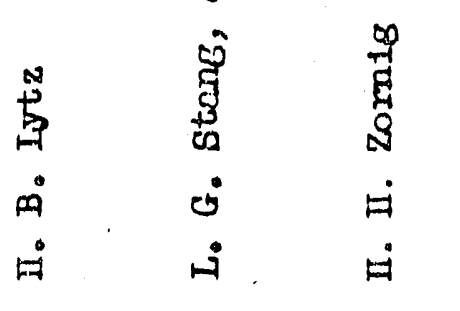

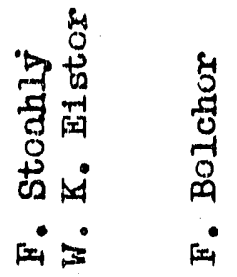

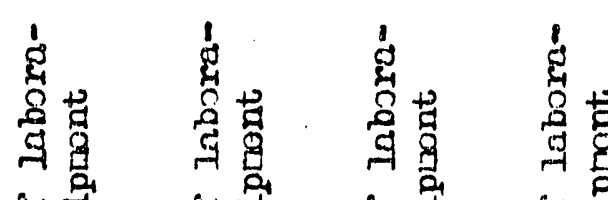

4

मै न

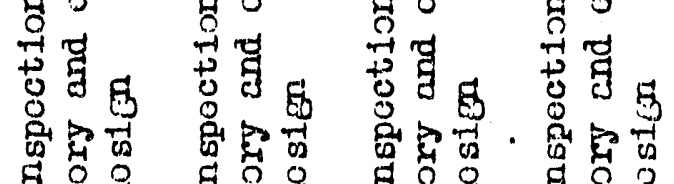
总象皆

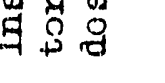

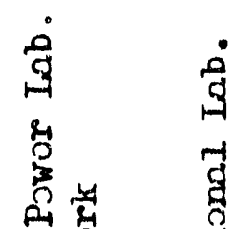

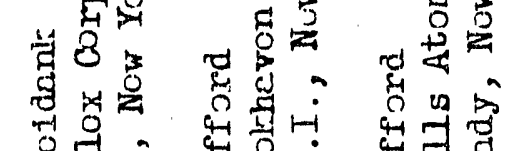

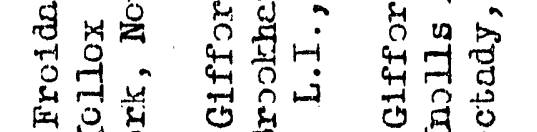

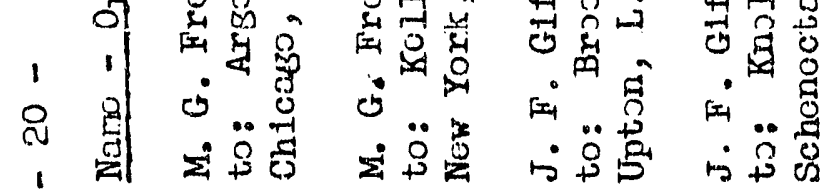

$\dot{1} \ddot{3}$ 费

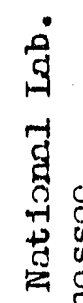

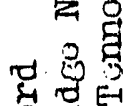

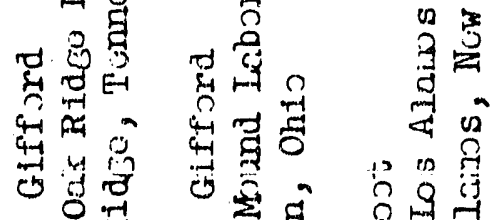

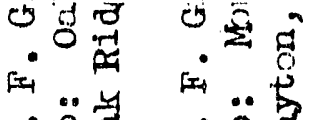

॰ $\ddot{\circ}$ है

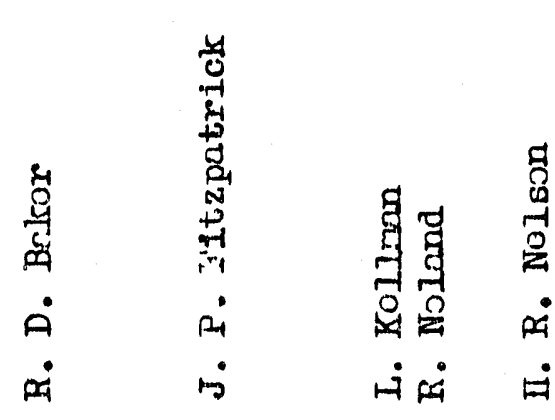

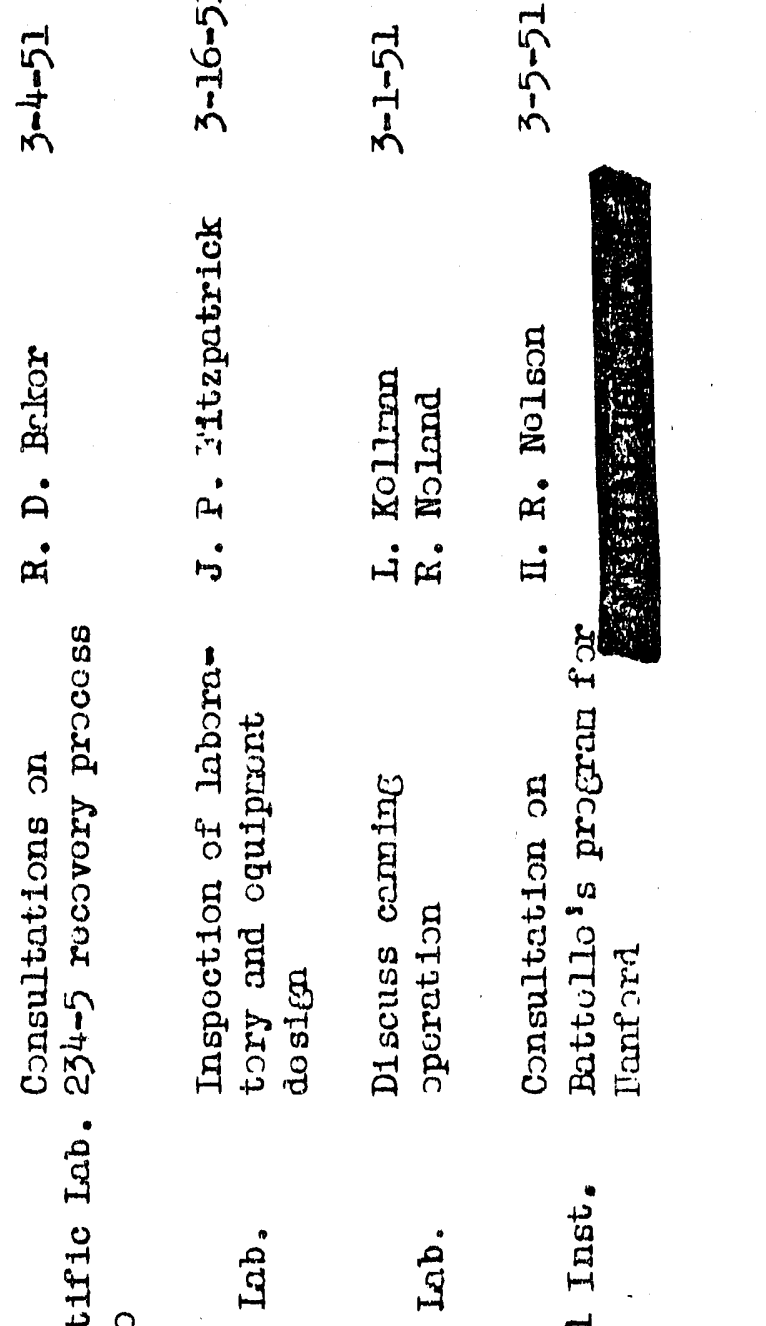

家

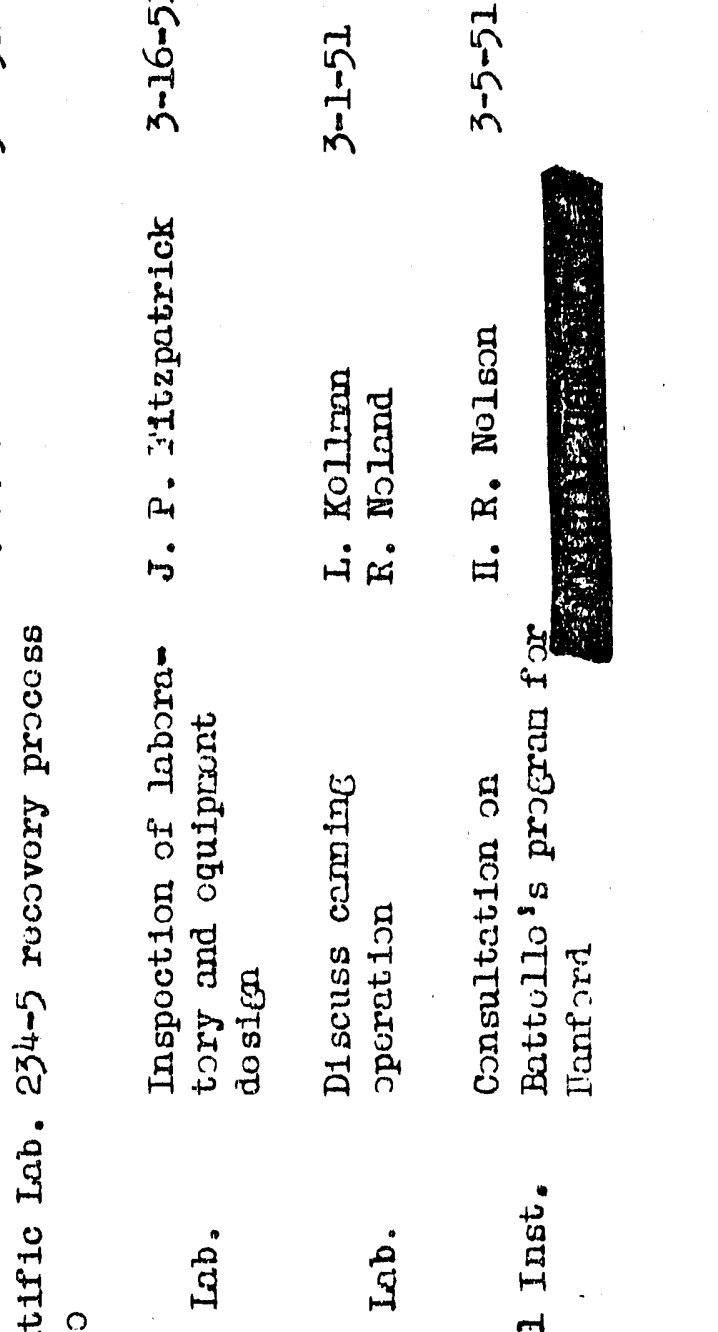

至造 न

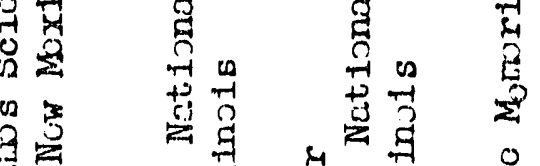

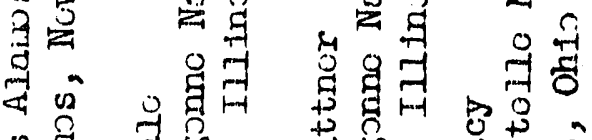

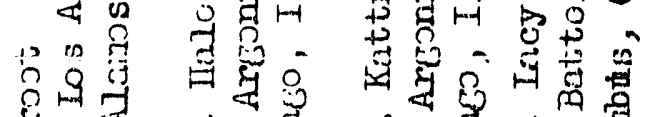
$\therefore$ द्यु

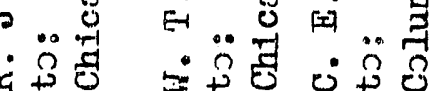




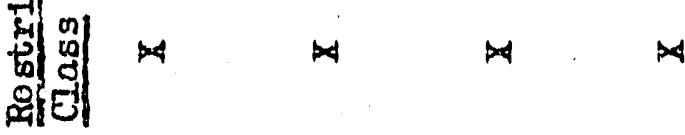

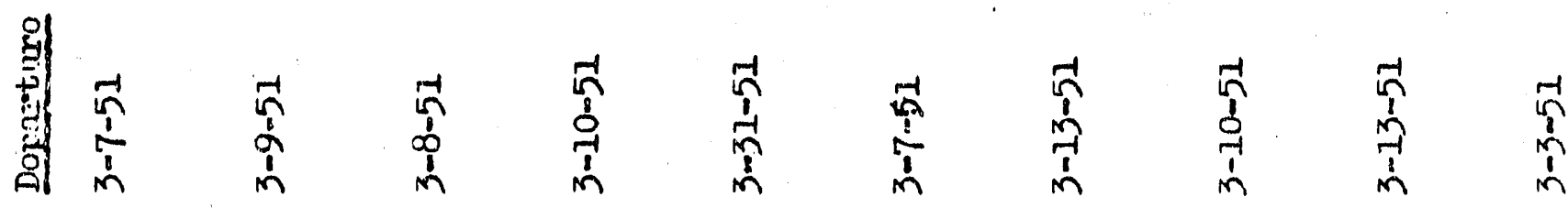

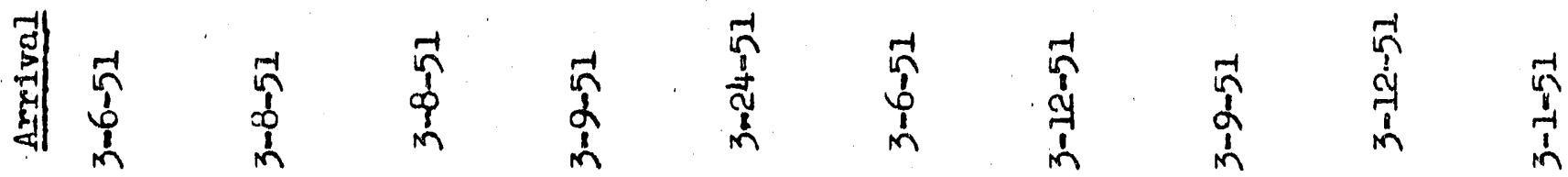

崖

(1)

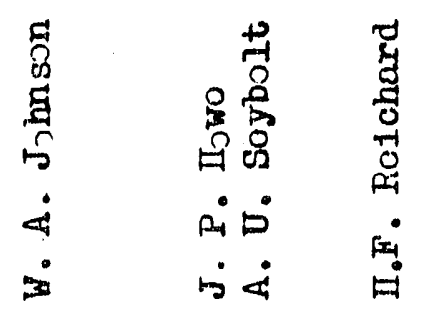

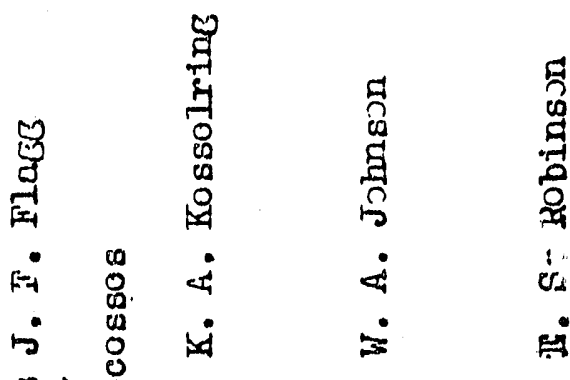

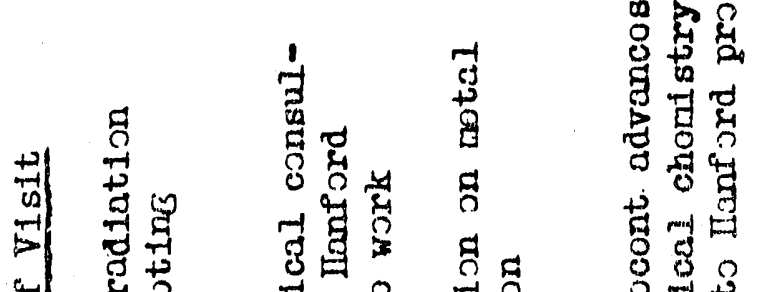

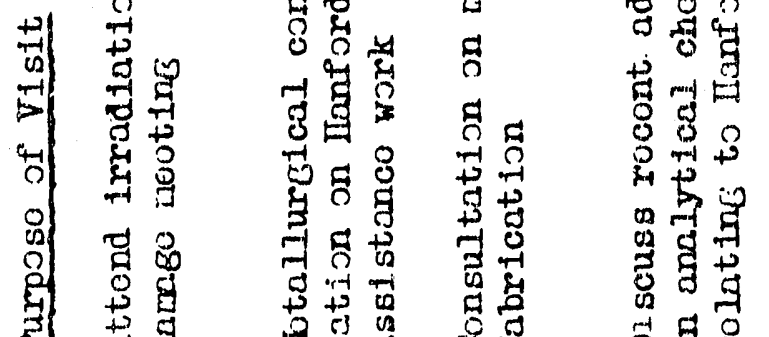

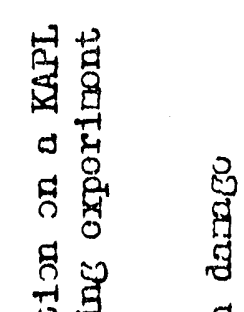

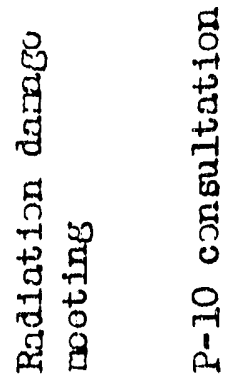

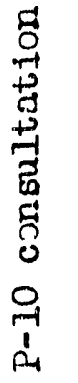

营

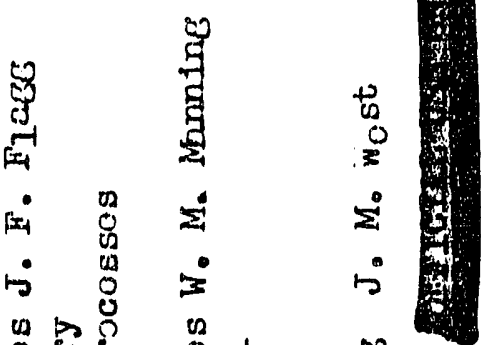

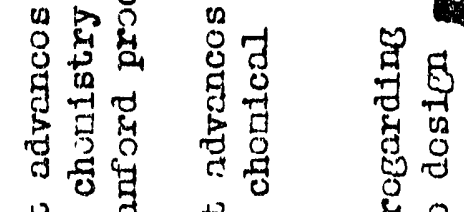

若垫

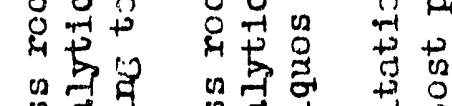

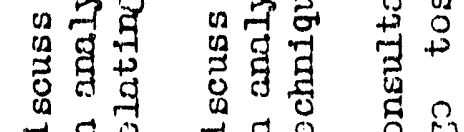

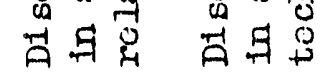

हु ริ

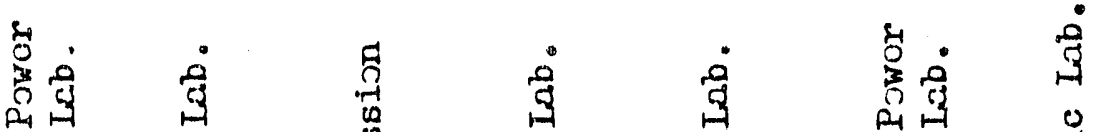

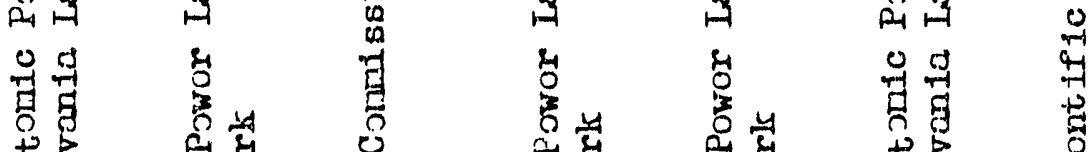

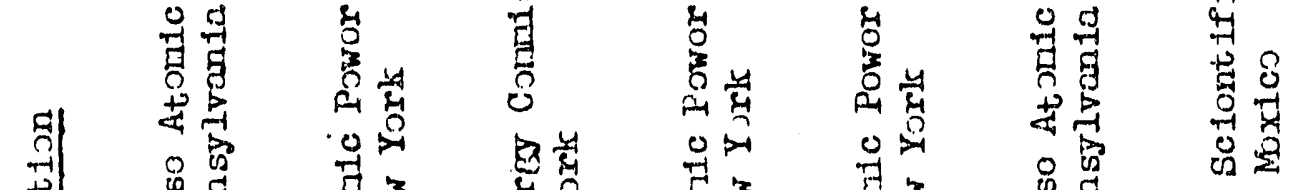

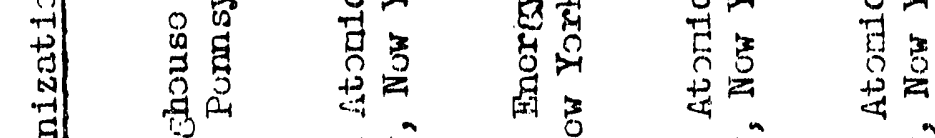

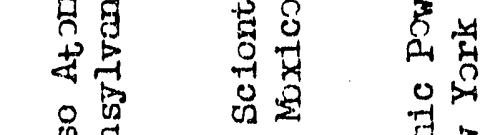

家

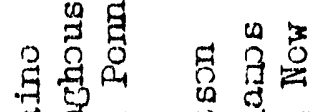

要要

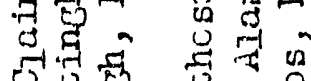

乎品害

造要

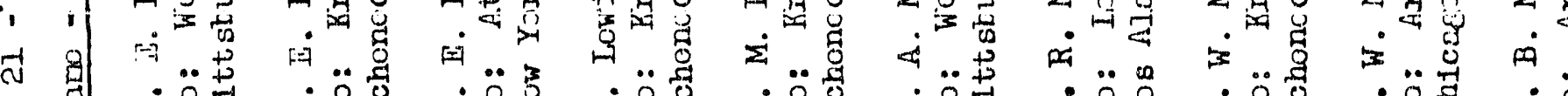

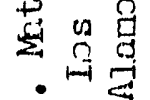

से दे

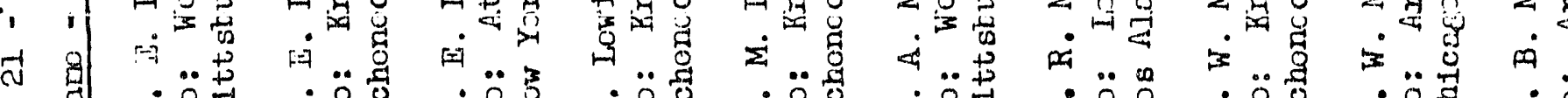

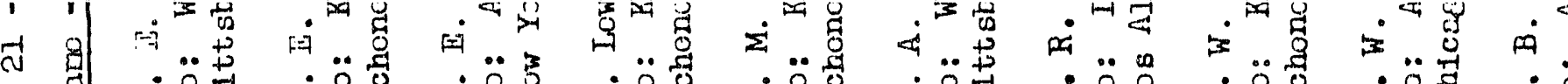

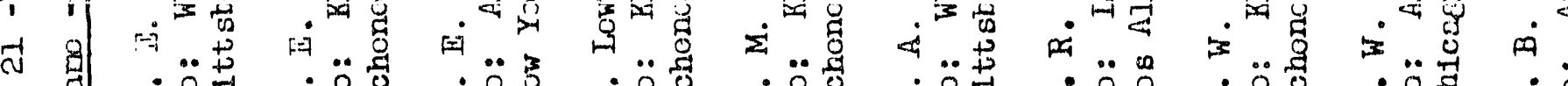

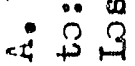

$\dot{0} \ddot{\circ}$

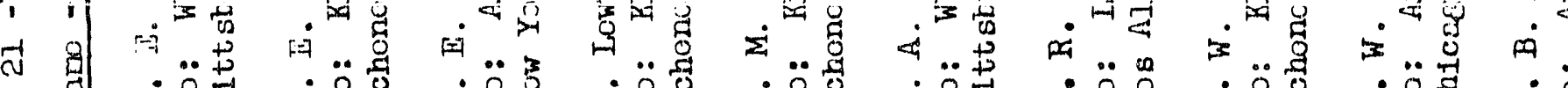

家

है

䓪

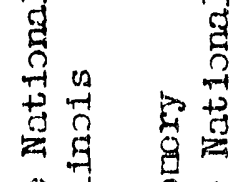

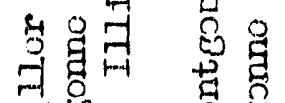

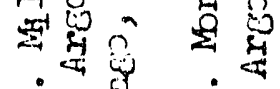


罗

(2) 矛苟

它

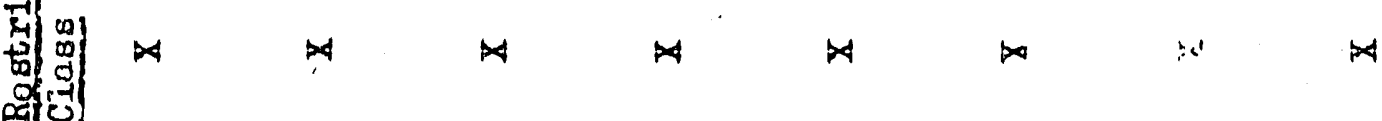

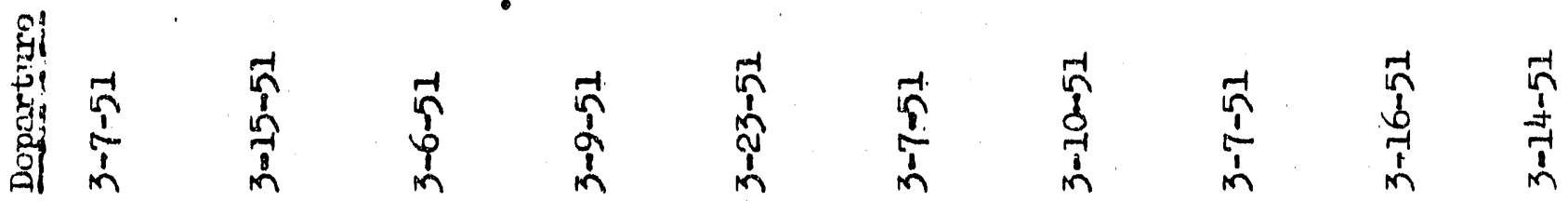

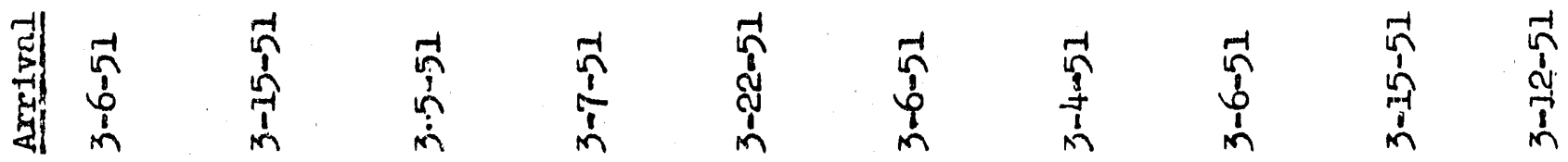
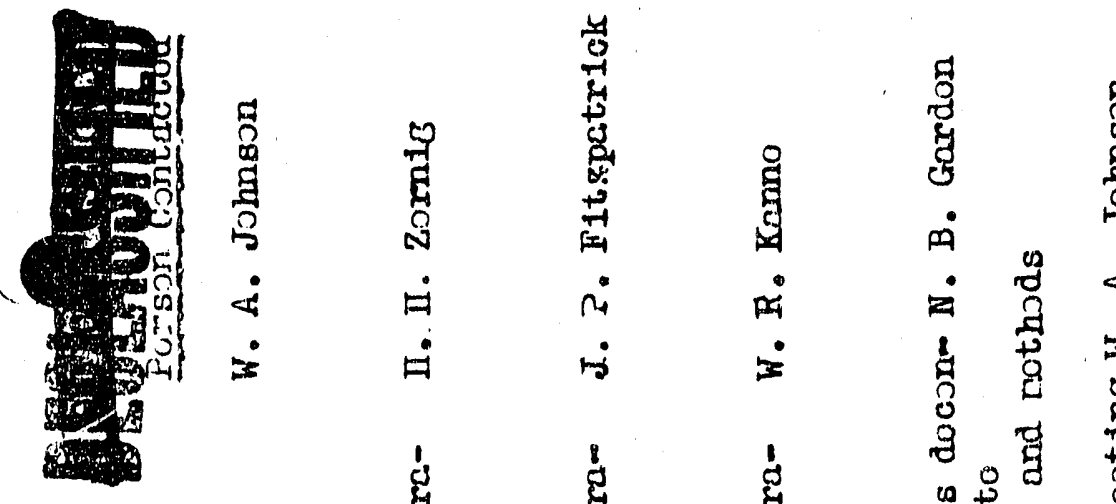

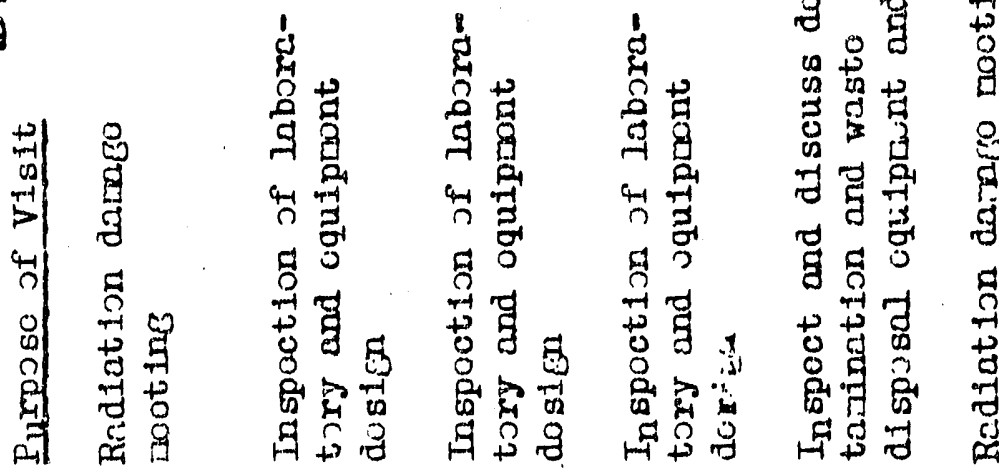

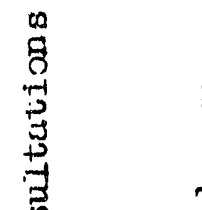

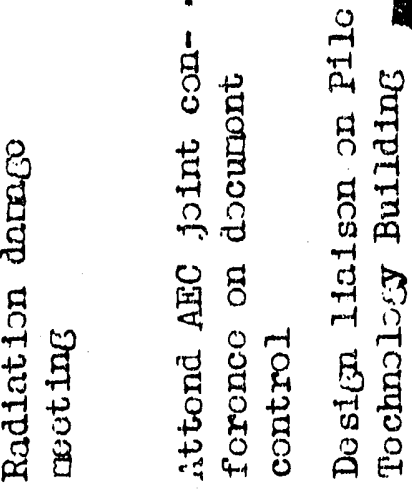

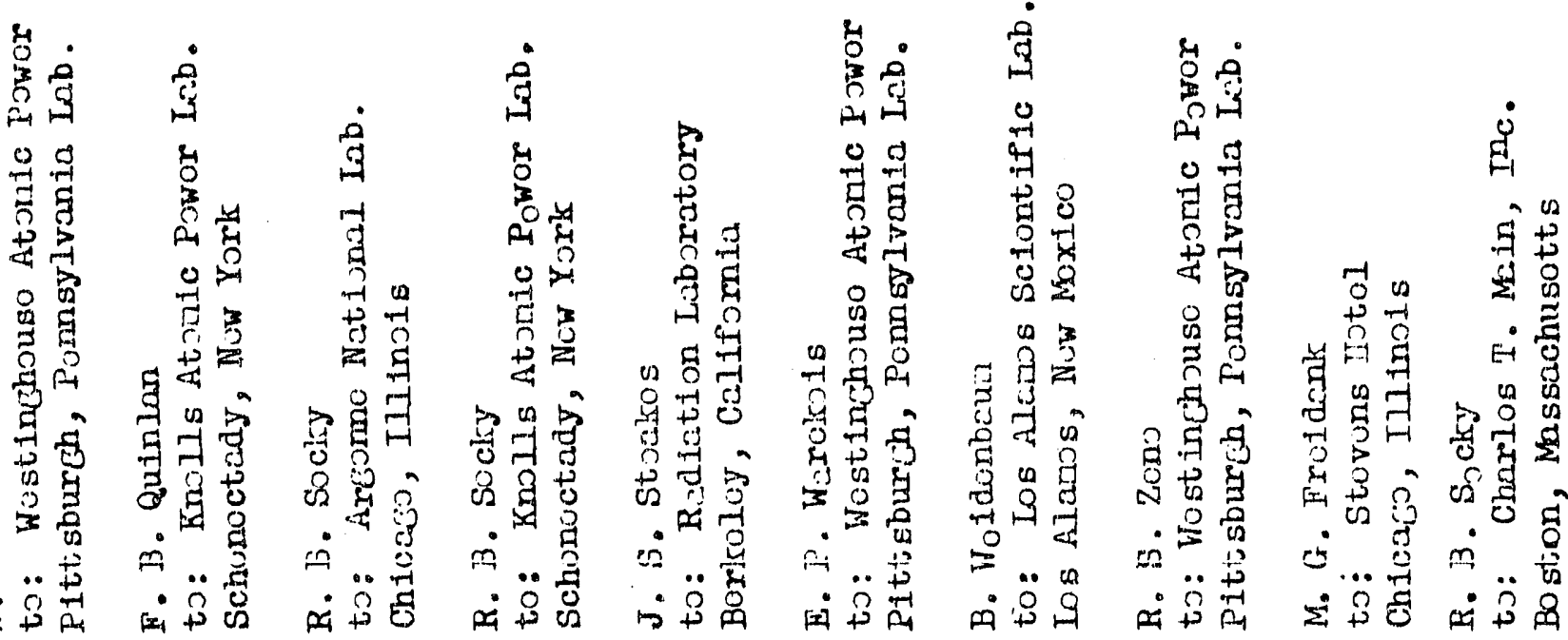




\section{!}

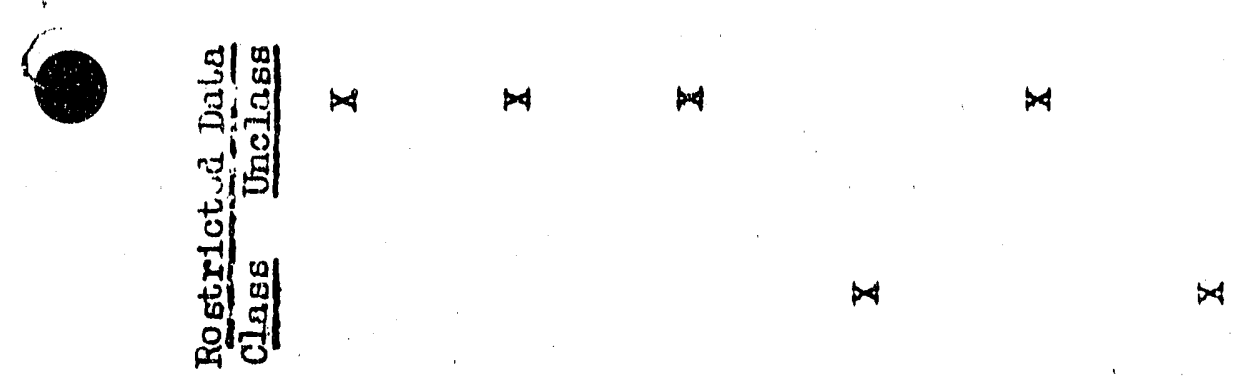

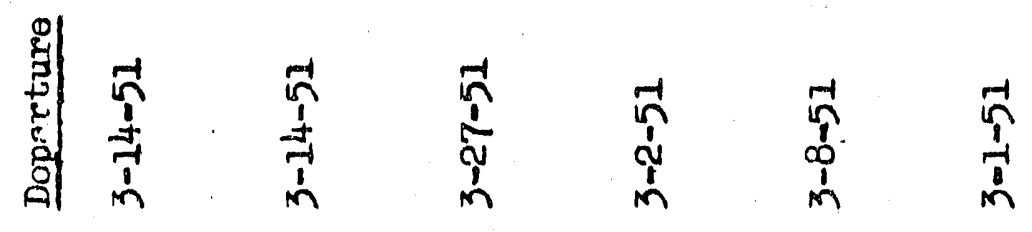

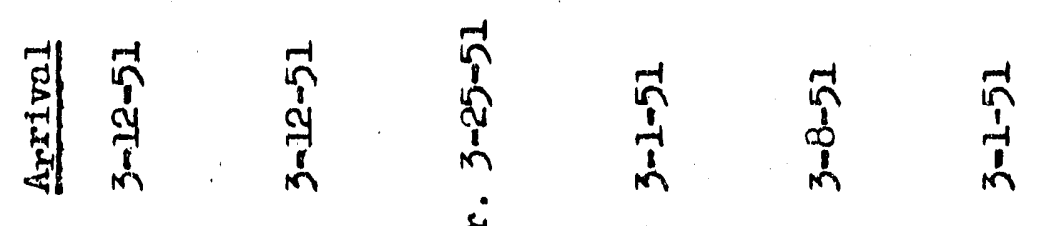

1

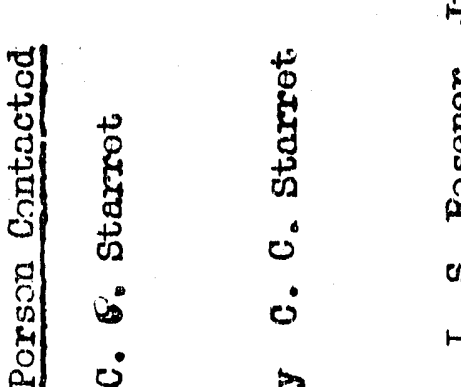

क्ष

密

告

茴

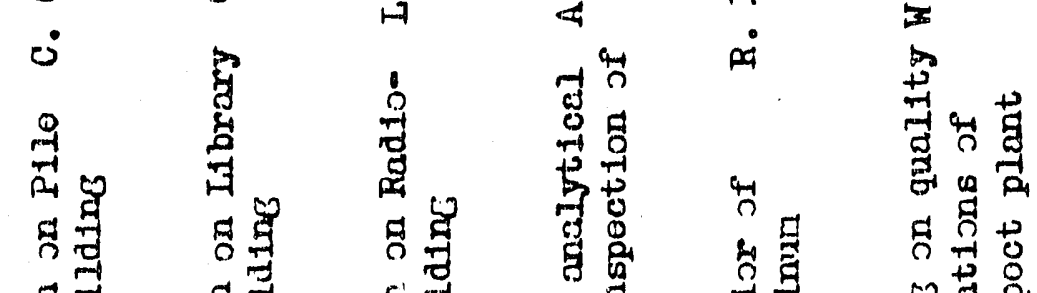

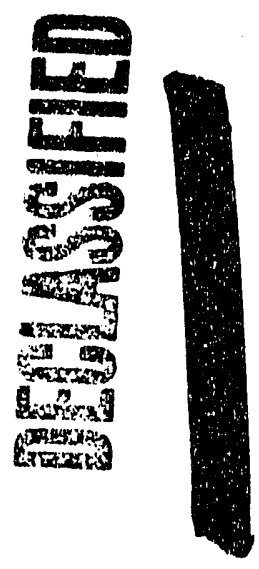

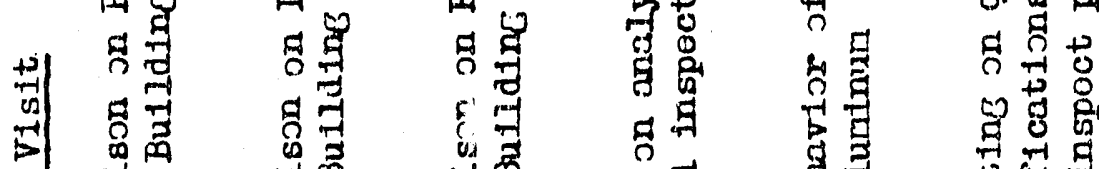

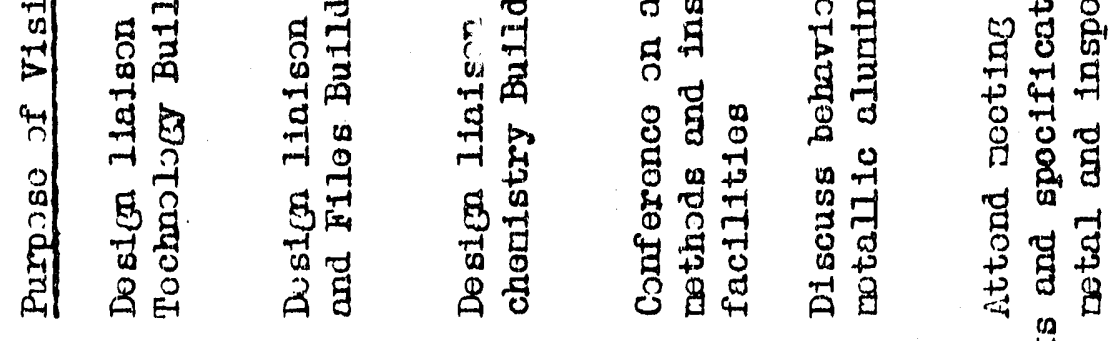

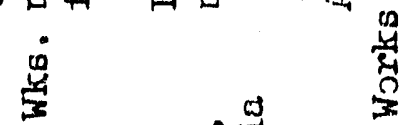

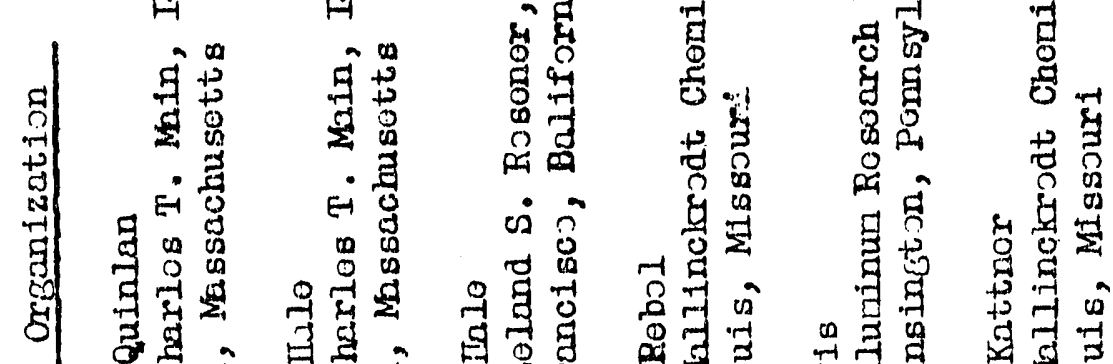

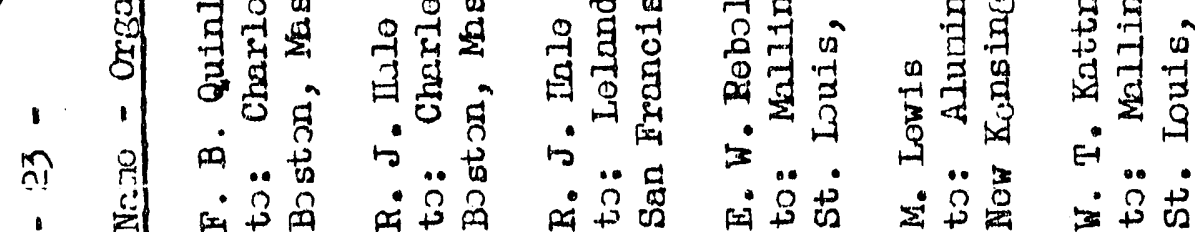

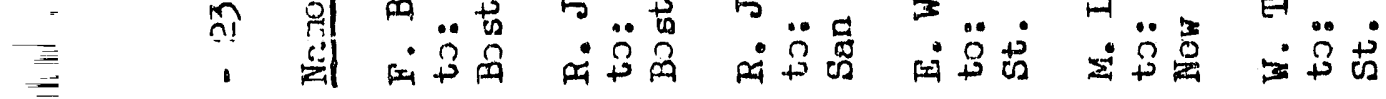




\section{PURCHASINO AND STORES DIVISIONS}

\section{SUMMARY}

MARCH, 1951

Personnel of the Purchesing and Stores Divisions showed a net tncrease of five as indicatud by the tabulation below:

Total Personnol as of $2-28-51$
Total Personinel

as of $3-31-51$

82

$\frac{290}{372}$
Not Change

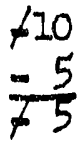

The work Ioad in the Purchasing Division increased substantially during the month.

3,900 purchase requisitions were recelved and assigned as compared with 2,848 in the previous month.

The dollar value of orders placed during the month amountud to $\$ 2,794,475.18$ as compared to last month' $\$ 2,397,876.82$.

Alterations to purchase orders as a result of design changes and material substitutions incraased 35\% during the month. It was necessary to requisition additional personiel to handle this increased work load.

Claims from vundors totaling $\$ 150,000$ as a rusult of design changes were received, At month end, a thorough reviuw and analysis of these claims was underway.

The Initial requisitions for Project $C-431$ wre roceivcd and orders negotiated for all of tho masonite and relnforcing steel requirementis and a portion of the structural steel requirements.

Because of Ifmited funds approved for Project $\mathrm{C}-43 \mathrm{I}_{2}$ tho Iurchasing Division arranged to submit a daily report of commitments to respective Technical, Enginoering and Coostruction Divisions! Managers.

An order originally placed by the University of California for 300 vacuum tanks was taken over by the General Electric Company for the P-lo Program.

Contracts were awarded for our requirements of oxygen and acetylene gas.

Escalation clauses in coal contracts wero invoked by the suppliers due to increased wages effective Fubruary:.. 1951. As a result, the Continental Coal Company contract was carce. ...id and pri increases allowed to the Bair-Collins Company and the Kemmor crial Co pany,

The inspection work lead cuntinued to be vory heavy on fabricated equipment for the Redox and IBP Programs。 
It was necessary to place additional bulk ordors for stalnless steel. for Projects C-36I and C-362 due to Pallure of the Kellex Orrporation to make complete takem offs at the tine the initial orders were pleced.

The work load with respect to priorities and allocations increased substantially. Several of the more critical materlals are now under allocation which necessitatus keeping detalled riecords in accordance with NPA Regulations.

3,383 purchase requisitions were processed through soreening with the risult that 2,545 items wero supplied from project inventories thus obviating the necessity of expenditure uf new funds by purchasing from outside sources.

86 items of stainless steel not immedlatuly available on the opcn market wero supplied to uur fabricaturs frum project inventories to expedite delivery of critical vessels.

Maintenance materials and supplies ralued at $\$ 262,451.15$ were disbursed from operations inventuries.

Materials and equipment valued at $\$ 215,891.79$ were disbursed to cunstruction forces frum inventories of Construction Materials Held fur Pussible Future Uso. In addition, materials valued at $\$ 31,177.60$ wero disbursed fur use in operatiuns and matorials valued at $\$ 72,770.62$ wore declared excess from this same accunt.

Material and equipment valued at $\$ 80,085.14$ ware withdrawn from excess inventories for use on the project, of this amount, $\$ 75,962.46$ was fur construction,

$5,054,512$ buard feet of excess lumber was shippod from the project at the directiun of the Commissiun.

Decision was reached by the Comission that they wiuld handle the contracts for construction of the new Central Warohuuse Fasilitios and at month end they wer $\theta$ negotiating an architectwengineuring cuntrect covering functional study and final design.

30 represtntatives of the govcrnment and private business were escortul through our warehcuses and sarap yards for the purpose of nogotiating sales of scrap and trensfer of surplus property.

Scrap sale revunue for the munth was $\$ 24,564.93$.

The wisk lond in the Traffic Jivision continued tu increase due largely to lrm creasing movement uf constructiun materials to the project.

The Union Pacific Railroad changid their time of delivery to the project thereby providing an adutiunal 24 burs ace time frir luading and unloading cars.

The Intorstate Comerce Chimissi in, on "arch 74 , grantul the railroads a freight

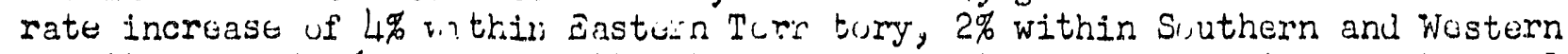
Territory, and $2 \%$ incurturitirialiy aming the throe torritories which resulted in a maximum incrcase on coal of 6 cunts per ton, effective April 4, 1951.

As a result if rate ruluctions obtained frum carriers, a tutal scivings of freight ratc charges for the month amounting ti, $\$ 16,145.28$ was effected.

2. 


\section{PURCHASING AND STORES DIVISIONS}

STAFH SECTION

MARCH, 1951

\section{GENERAL}

Office furniture and equipment requirements for FY 1952 and FY 1953 were submitted to the Office Services Division. Additional requirements were composed almost exclusirely of furniture and equipnent needed by the purchasing Division due to 1 ts increased procurement activity.

Personnel Iiquidation detalls for the FY 1952 and FY 1953 operating cost budget were submitted to the General Accounting Division with a schedule of average number of employees and estimated average work week. Estimates of telephone and telegraph expense and travel expense were made to assist the General Accounting Division in complifing other Within Division Costs for the Purchasing Division。

A review and audit of Purchasing Division records of bulk stainless steel held in the Pittsburgh, Pennsylvania, warehouse was completed March 31, 1951.

Memo Employee Sales procedure was reviewed and methods for a more economical operation are being developed.

Physical inventory, audit, and reconciliation of Captions 903-2, 5, 7, 906 and 912 have been completed.

PERSONNEL

As of $2-28.51$ Ex. Non Ex. Total

$$
\text { As of } 3-31-51
$$
Ex: Non- Ex. Total Ex. Non-Ex. TotaI

Cost, Budget Control Methods - Procedures, Inventory and Audit TOTALS
1

$\frac{2}{3} \quad \frac{13}{13} \quad \frac{15}{16} \quad \frac{2}{3} \quad \frac{11}{11} \quad \frac{13}{4} \quad \frac{0}{0} \quad \frac{-2}{-2} \quad \frac{2}{-2}$

SAFETY AND SECURITY

Saf'ety and Security meetings scheduled - 1 Number attending -.nnom 17 


\section{PURCHASING AND STORES DIVISIONS}

PURCHASING DIVISION

MARCH, 1951

The number of purchase requisitions processed by the division increased con3iderably during the month of March. 3,900 purchase requisitions were recelved and assigned as compared with 2,848 in February. Orders and alterations placod totaled 2,793 as compared with 2,277 the previous month. Requisitions on hand at the end of the month totaled 1, 119 compared to 1,096 on February 28.

The dollar value of orders and alterations placed during March amounted to $\$ 2,794,475.18$ of which $\$ 1,274,764.93$ was for naw construction materials. of tho 577 new construction purchase orders placed during the month, 60 were for Projects C-187-D and E, 172 for Projeot C-362, 15 for Project C-36I and 27 for Projects $C-431-A$ and $B$. The balance of the construction purchase orders were placed for construction MS Stores material and miscellaneous TE\&C Projects.

Alterations to purchase orders increased $35 \%$ due largely to design changes and material gubstitutions requested and authorized by the Engineering and Con struction Dirlsions. It was necessary to requisition additional personnel to handle this increased work load.

Vendorsi claims for additional money as a result of desion changes, material substitutions, etc., totaled \$150,000. A thorough review and analysis of these claims is underway in order to determine whether or not they are in order.

The Initial group of purchase requisitions for material and equipment for Project C-43I were received from the TE\&C Divisions. Orders were negotiated for all of the masonite and reinforcing steel and a portion of the structural steel.

Because of the Iimited funds appropriated for Projects C-431-A and $B$, the Purchasing Division agreed to submit a dally report of commitments to the respective TE\&C Managers.

An order which had been placed by the University of California for 300 . vacuum tanks to bo used in the P-10 Program was replaced by a General Electric Company purchase order. This finalized negotiations which have beon in process sinco yovember 1950 .

Delivory of special extrawlength rubber gloves uscd in $234-5$ operations was temporarily stopped by the failure of the porcelain molds used in producing the gloves. The porcelain molds which wure the property of Los Alamos are being replaced with a permanent type aluminum mold purchased by ceneral Electric Company. These molds will be midie available to los Alamos for the procurement of their rubber gloves. In the mearitime, an order was placed for gloves with an alternate supplier and an aisequate supply of gloves will be maintained. 


\title{
PURCHASING AND STORES DIVISIONS
}

\author{
PUROHASING DIVISION
}

Contracts were awarded to Industrlal Air Products Company and National Oylinder Qus Company for our yearly requirements of axyen and acetylene respectively.

Escalation olauses In contraots with Continental Coal Company and the BairCollins Company were invoked by these compantes following an increase in wages to the United Mine Workers of Amerioa on February 1, 1951. The price increase requested by Continental Coal Company, was $\$ 0.42$ per ton f.0.b. the mine -this was refused and the remainder of the contract cancelled. The Bair-Collins Company requested an escalation of $\$ 0.23$ per ton foob. the mine. Inasmuch as this is the only coal that can be delivered to the plant via the OMSTP\&P Railway, this escalation was granted. Coal for the remainder of the contract period will be furnished by the Batr-Colitins Company for delivery to Hanford via the CMSTP\&P and the Kummerer Coal. Company for dellvery to Richland, Washington vla the UP Railroad,

The Inspection work Ioad was heavy during the month as a rusult of fabricators completing vessels and equipment for C-187-D. The relaxation on tolerances has permitted accoptance of vessels which formerly wero refected and held for rework. Two extra engineurs will be employed and assigned to work in the inspection office. These additional engineers are needed to handle the review of verutor clatms and outgoing specifications and to prepare instructions for fleld inspectors.

Three field expediturs were employed and assigned geographical areas in which to operate. One additional field expediter will report for work in April.

Expediting 1ssued Its first status repert on open General Eleotric Company orders on Project C-187-D and E. This ruport will be 1ssued twice a month as well as open order status roports on Project C-36I, C-362, C-43I-A, and C-43I-B.

Six additional bulk stainless steel, orders were placed during the month of March for Projocts $\mathrm{C}-361$ and $\mathrm{C}-362$.

Final shipplng instructions have beon issued on $95 \%$ of the fabrication ordors on which the Goneral. Electrio Company is to furmish the stainless steel. The balance of shipping instructions are hold pending changes in maturial requirements due to design modifications.

A breakdown of bulk stainless ste 1 orderg indicating the steel ordered for equipment fabrication and lile stuj crierud for field use was completed. Shipping instructions have buen isshir, to tho Pittsburgh warthouse to ship fleld allocatud stoe to to infort. 
PURCIHASING AND STORES DIVISIONS

PUROHISING DIVISION

Trends during the month have been toward the development of the National Production Authority Controlled Materials Plan which is still in the offing for July 1, 195.1. Developments along this Iine inolude the requirement of NPA allocations for purcheses of tungsten and molybdenum. Nllooations are now required for the procurement of ferrocolumblum, ferrotantalum and ferrocolumbium-tantalum by the producers of columbium bearing stainless stoels.

End use certifioation is now required for proouroment of columbium bearing stainless steris.

Prlorlty rating DO-43 was extended durirg the month to throe vendors in reply to their requests for priority assistance. Standard Stiel Company was authorized to apply DO-43 to procurament of plant additions up to $\$ 15,000.00$, Charles T. Main Co. $\$ 5,000$ and Fastorn Industries $\$ 6,454.94$.

PERSONNEL

1s of $2-28-51$

As of $3-31-51$

ijet Change

Ex.Non-Ex.Total Ex.Non-Ex.Total Ex. Non-Ex.Total

Administrative

Purohasing

Dxpoditing

14.1

1
24
11

10

Inspection

Clerical

Priorities

TOTsLS

24

124

$\frac{1}{51} \quad \frac{4}{69}$

$\begin{array}{cr}2 & 1 \\ 38 & 15 \\ 21 & 14 \\ 29 * & 30 \\ 25 & 0 \\ 5 & 1 \\ 120+ & \frac{1}{61}\end{array}$

$\begin{array}{rr}2 & 3 \\ 27 & 42\end{array}$

1327

$7 \% \quad 37 *$

$24 \quad 24$

$\begin{array}{lll} & +1 & +1 \\ +1 & +3 & +4 \\ +4 & t 2 & +6 \\ 66 & 12 & +8 \\ -1 & & -1\end{array}$

$77 * 138 *$

40

48

* The above figures do not include 6 rotational trainees assigned to Inspuction.

\section{S.FETY LND SECURITY}

Safety and Security Meetings Schedule Number of employees attending

Minor Injuries 


\section{STIRTISTIOS}

Requisitions on hand $3-1-51$

(Inoludes 111 assigned to Gow't.)

Requisitions assigned during Maroh

Requisitions placed during March

Roquisitions on hand 3-30-51

(Inoludes 67 assigned to Gov't.)
832

3010

2980

772

NUMBER

$\begin{array}{rr} & 1817 \\ 228 \\ \text { Total } & 2045 \\ & \\ & 577 \\ \text { Total } & \frac{171}{748}\end{array}$

AEC Orders Plaoed

DC Orders Placed

Gov't Tranefers

Return Orders Isøued a.

D TOTAL

$\begin{array}{ll}264 & 1096 \\ 890 & 3900 \\ 797 & 3777 \\ 347 & 1119\end{array}$

ViLUE

$\$ 1,149,811 \cdot 21$

$\frac{35,046.28}{\mathrm{ar}} \mathrm{Cr}$.

$\$ 1,623,956.27$

$55,753.98$

$\$ 1,679,710.25$

157
68

\$ $101,101.9 .9$

$52,848.21$

$\frac{O R}{I} \quad \frac{O R C}{I} \quad \frac{\text { TOTAL }}{1}$

Dollar Value of ordors to date to which Priority Rating was applied: Ist Quarter 1951. 2nd Quartor 1951. 3rd Quarter 195: 4th Quarter 1951

DO $=40 \quad \$ 1,832,836.90 \quad \$ 1,07.1,635.40 \quad \$ \quad 206,006.81 \quad \$ \quad 143,341.08$

D0. 41 it $\quad 8,775,919.69$

* Includes Contract Section. Trec Divisions

OPEN ORDERS

iTW Orders $\quad 1888$

ITWC Orders $\quad 1.199$

Clovernment $\quad 106$

Number of New Orders requeling insp . titin during month

Number of orders roquiring traspeotion coiplutod durlng month

INMBER

Number of Orders outstanding requiring inwicetion at months and 495

Number of HW Orders oxpediteil (routine) 900

Number of HW Orders expodited (Spocial. Rrqurosts) 430

Number of HWC Orders oxpeditod

1000

* Includos 91 Sub-vendor orders. 


\section{FUROHASING AND STORIS DIV "TS TONS"}

STORTS DIVISTON

VARCL, 2951

\section{GENGRAL}

3383 purohase requisit1 on were prooessod through soreaning and 25461 tems wore furnished from plant souroos. 86 1tems of stalnleas steol not immedim ately arallable on the open market were furnished to fabrioutors from. plant linvertortes.

Mainten ano matiorial and supplior dis bur sod from aotive Irventoriea were valued at ;,262, 451.15.

Rooolpts of 1nooming ohipments durlng the month reoohed an all time high, as 5779 reoelving reports were lssued.

Mat orial and equipent valued at $215,891.79$ involving 22 oaptions in the 10.20 Aocount (Donst motion Held Meterials) were disbursed to oonstriotion foroes during the month. In addytion to the foregolng, materials valued at ;31, 177.60 were withdrawn for use by operations' foroes, and matertals valued at $72,770.62$ were deolared exoess.

Material and equipment valued at $80,085.14$ were withdrawn from Aooount 10.10 (Exoess) and returned for use on the Projeat. Of this amount, oonstruotion foroes' withdrawals were valued at ill $75,962,46$.

At month ond, inventories of matorials and supplies in the oustodr of vart ous operating divis ions were being reoolved. In some instances, the inventory lists were inoomplete due to the omission of the divis ion's thirty day requil rement or insuffiolont nomenolature for proper identifioation. Suoh lists were f'orthwith returned to those divisions.

A. total af 5,054,512 FBM of lumber was shipped from the Projeot during the month as direoted by the Commission. This shipment roquired the us $\theta$ of 82 reil 0 ars and 163 semi-trailers. In addition to the foregoing, 20 shipping doouments ralued at "i $90,778.62$ for exoess materials wore prooersed and sitpped.

During the month, the Commission proposed that they enter into lump sum oontraots for arohiteot engineoring sorvious and for construotion of the propos ed Contral Stores Tar ehouse (Projeot Proposal C-390-R-2). At month ond, the Comulssion was nocotiating : controct for f unotional study and final design with the flm of "offat, $\mathrm{H}$. hol \& Tayler, Ingineors, Portiland, oregon.

30 reprosontatives of erernment on il iveto businossos woro asoorted through our warehous as and sorep yords for tho purpose of nogotiatirf tho salo of sorap and tho transfor of oxooss propurty. Sortap sale rovonuo for tho month was 憋4, 564.93。 
POROTASING AND SMORTS DIVISIONS

STORTS' DIVISIOI

PDRSO NINEIL

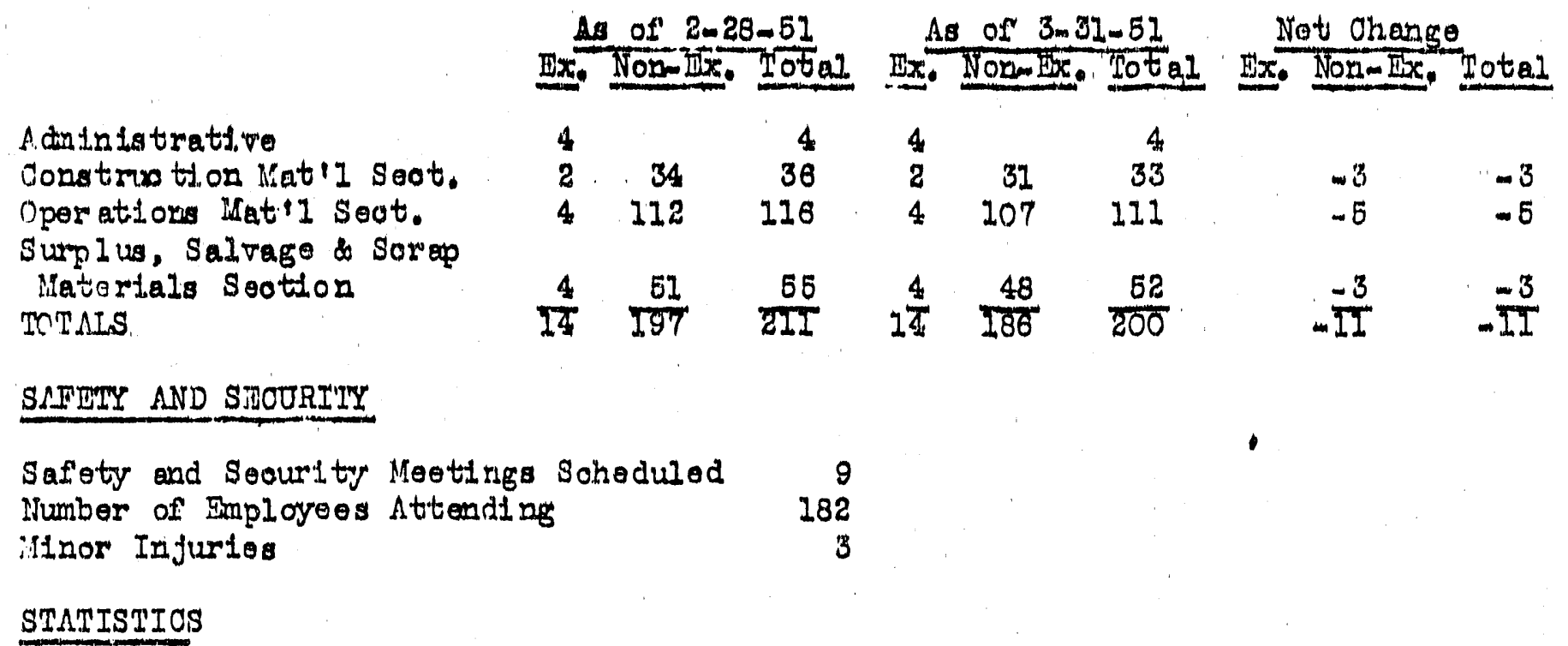

Construation liatiorials Section

Items in stores Stook

Items Added to Stook

43,778

324

697
3,676

Items Complately Llquidated From stook

stiore Orders Posted (Items)

654

Nunber of Requisitions Soreoned - AoJ.

6,294

Number of Items Soreonod - G. $\pi_{0}+$

844

Value of Disbursements

Invent ory Valuation at Month End - Materials

$247,069.39 *$

Value of Materials Shipped

Value of lifaterials Reoeived

$7,204,736.94$

$13,615,90$

$19,022.92$

Value of Materials Deolared Exoess

$72,770.62$

*Inoludes $215,891.79$ dis bursed to Construetion \& CPFF Suboontraotors

Operations Materials Seotion

ivmber of Itoms Added to Stores stook

Number of Items Deleted from Stores Stook

Items in Stores stook at Month End

Store Orders Posted

Number of Requisitions Soreenod This i.onth - G. E.

20,760

Number of Items Furnished from Flnnt Souroes This ilonth

2,729

Inventory Val lation at :'onth. Ind (303-1.11 Captions, 906 \& 912)

1,701

Invent ory Val uation at "inti: and (jpers Perts)

Inventory Valuation s.t irnith Ind (jpecial ifatirials)

Total Value Invent ory Aooo'nts

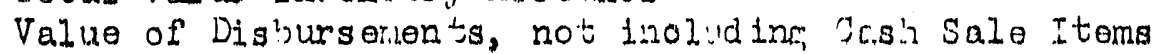

Value of Cash Sales

Volite of Sales, Peyroll Deduotion

$\$ 1,339,041.17$

$1,648,465.43$

$3,161,218.54$

$6,148,71.5 .14$

$262,451.15$

973.87

$1,828.67$ 
FU ROESSING AND STOR'IS DIVIS IONS

SIORTIS DIVI SION

STATISTIOS (Oontinued)

Value of Materiala Deolared Exoess

Value of Materlals Roturned to Stores stook for Oredit

*Inoludes $\$ 32,810.71$ disbursed to dons truotion and OPTS Sulvoontractors

Surplus, Snlvage is Sarap Matori als Sootion

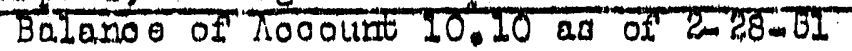

$36,341,872,50$

Reoelpts 2-28-51 to 3-30-61

Lumbor
Autamotive Equipment
Offloo Furniture
ifateriel and Supplios
Mis ool loneo us Iquipment
Laohine Tools and Fquipment
Hous ohold. Furniture

$$
\begin{array}{r}
64.68 \\
12,314.24 \\
1,235.95 \\
70,323.55 \\
4,528.31 \\
2,258.29 \\
53.50 \\
\hline
\end{array}
$$

267.176

$13,807.62$

djustments - Classos and Curront Markot Prioos

Dis bursoments $2-28.51$ to $3.50-51$

$\frac{\text { On Projoot }}{\text { Liumber }}$

Automotiv e Equi pment

liachine Tools is Equipanent

offtoo Furn iture

Matorial and Bupplios

Ilsoollanoous iquipment

Trans fer to 10.20 Aoo ount

Stores Material Transfors

Off Profoot

Lumber

Automot 1vo rquement

Offio Furmiture

Matorial and Supplios

:1soollaneous iquipmont

$$
\begin{array}{r}
8,614.33 \\
12,207.33 \\
850.16 \\
1,343.33 \\
50,500.62 \\
6,569.35 \\
\hline
\end{array}
$$

90.778 .62

$\frac{5,4.17 \cdot 24}{6,438,268.35}$

Balano $\theta$ of Aocount 10.10 as of $3-30-51$

* Inoludes DAsbursamonto to Consiruotion $775,962.46$

Total Rooolpts to Dato

Total Disbursamento to Dato

137.16

$544,142.08$

$3,4.95 .02$

$16,1,85.08$

$27,858.05$

$591,818.29$
$672,036.12$

$45,706,132.23$

$34,768.427 .16$

$29,002,294.93$

Sorap and Snlrage Disbursod
Sorap Snlos Complotod
Sorap scilos in Prooos
12
1

Sorap Salos Rovoutuo for month of Mroh

Total sorn.p Snlos Rovonuo to Dato

$$
\begin{array}{r}
24,564.93 \\
35,390.64
\end{array}
$$

20. 
FURCHASING AND STORES DIVIS IONS

STORTS DIVIS JOIN

STATISTIOS (Cont1 nued)

WAIFHOUSING, RTCEIVING, DIS BURSING \& SEIPPING SECTIONS

Construoti on Matorials Sootion

Storo Orders pilled

Number of Itoms Reoeirod

Itoms Filied for Shipping

Items Exoessod

Oporations Matorials Seotion

Rooeiving Reports Issued

Ine rgenoy Store Orders Filled

Shipmonts Frocossod (Containors \& Matorials)

Shipments Rocoirod

Store Ordors Rogistered

- Surplus, Sclivage Si Scrap Matorials Sootion

storo Orders Fillod

Truck loads of liatorial Shippod

5,396

324

1,015

87

Carloads of Matoriel Sinippod

5,779

1

326

5,380

24,241

634

184

106

DEC CONSTRUCTION STO RES

1000 ant 10.16 as of Maroh 31, 1951

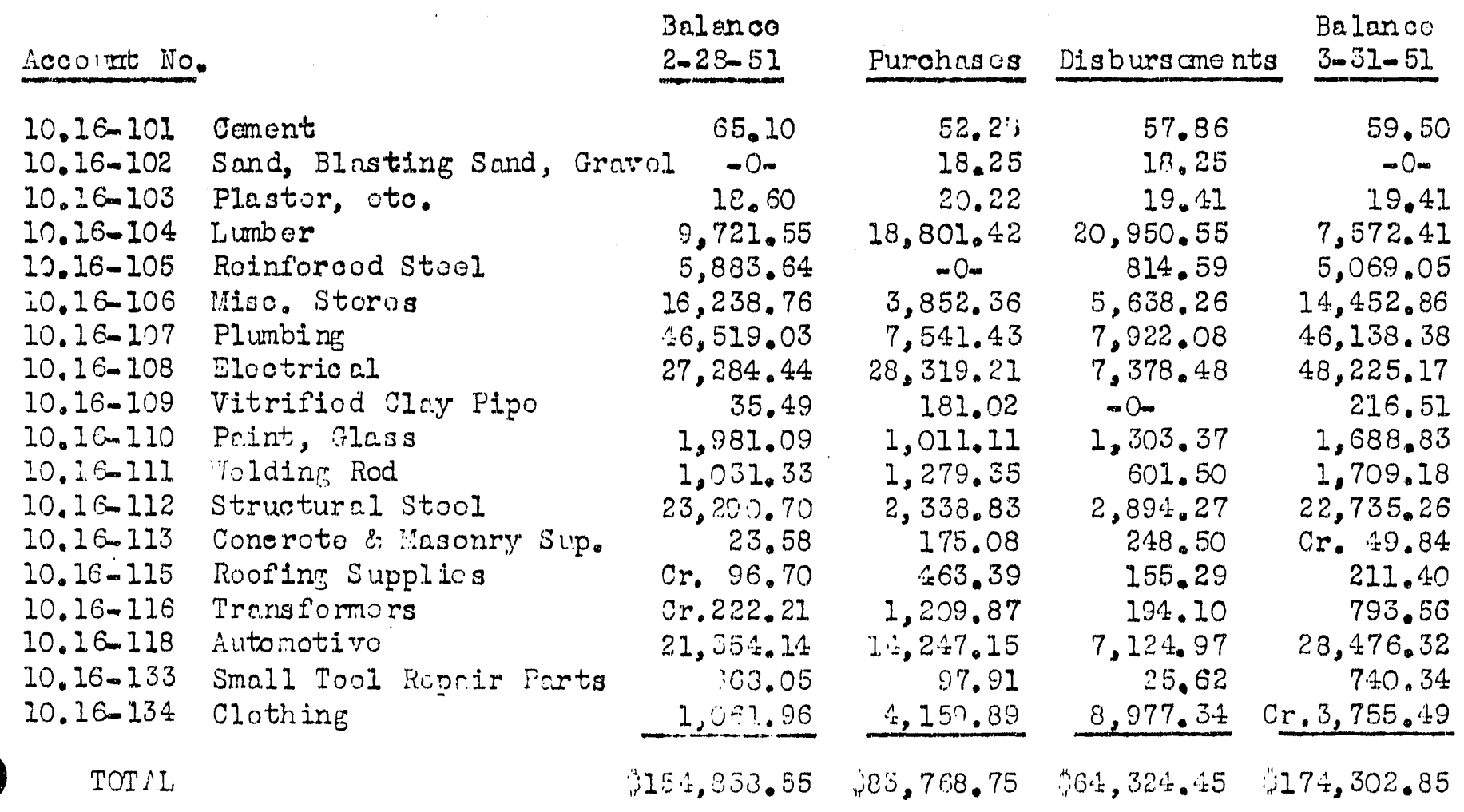


PURCHA IIVG AIND STORES DIVLSI IIS

IRATTIS DITISION

MARCH, 1951

GEVIERAL

Tho work load of the Irafic LIfision showod an Incruase ovar the previous inonth.

The Union facific Rallroad on diarch 5 changed their time ef dellvery to the proj6et and w1ll arsin at vorth Kicnland lards shortly after 7:00 Aul. This change wlIl provide an additional 24 hours of free tine for unloading and loading cars.

wfective viarch 21 the Kaflway ixpress Agency Increased the AIr Express rates up to 20 percent, based on weight and distance, and the minimum charge fram "1.50 to 2.50 per shipinent.

Due to the high loss ratio which the Home Insuranca Company hava experienced on the coverage of household goods.moving to and f'rom tha project, they projused amendments to the policy to reduce their liability and greatly increase their rates. jur nin-compliance to the anencinents would compel them to retire from the policy.

After considerable negotiations, it was a reed to continue the prese.t coverage with reasonable increased rates, and endursements have been received accomplishing this agreement wh.ch will become effective April 1, 1951.

The Interstate Commerse Commission on March 14 issued its report and granted the railroaas an emergency general freight rate increase of 4 percent within Eastern Territory, 2 percent with n voutiern enc Nestern Territories, and 2 percent interterritorially among the three teritoriss, with a maxinum increase on coal of 6 cents per ton. The i.zcreascd rates will become effective on April 4, 1951.

As a result of rate reductions obtained from the carriers, there was a total savings in freight charges for the month of larch anounting to $16,145.28$. This nakes a total savings from jeptember 1,1946 to date of $1,487,741.74$.

$\underline{P-R O O M T N L}$

Total Personnel

Total Personnel

as if $2-28-51$

as of $3-31-51$.

Net Change

Exempt

Non-Exempt

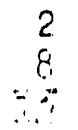

$\begin{array}{r}2 \\ 2 \\ \hline 11\end{array}$

0
+1
+1

DAFLTY A.D OLCUKETI

Safety and jecurity reetings scheauled I

iheetin $s$ held

1

،inor Injuries

0

12. 


\section{SUECHAOING AUVE STOKES DIVISLNO \\ TRAFFIC DIVIOION \\ MARCH, 1951}

\section{STATISTICS}

javings Report

1. Rate ductions obtained from the Carriers:

$\begin{array}{ll}\text { Comnodity } & \text { Oxigin } \\ \text { Coal } & \text { kemmerer, Wyo. } \\ \text { Coal } & \text { Roundup, Mont. } \\ \text { Iime } & \text { Evans, Wash. } \\ \text { Phosphoric Acid } & \text { rewark, Cal. } \\ \text { Phosphoric Acld } & \text { South Gate, Cal. } \\ \text { Caustic Joda } & \text { Tacoma, wash. } \\ \text { Caustic Soda } & \text { willbridge, Ore. } \\ \text { Soda Ash } & \text { Trona, Cal. } \\ \text { Rajlway ixpress } & \text { Various }\end{array}$

2. Freight Bill hidit

3. Loss and Lamage and Jver-Charge

$$
\text { Clains }
$$

4. Tioket kefund Claims

5. Household Goods Claims

Work Volume Keport

Reservations lade

Kail 160

Hir $\quad 137$

Hotel 122

Expense Accounts Shecked

268

13.
Savings for vavings 9-1-46 Total savings March thru Feb. 1951 9-1-46 to c'ate
$\$ 4,510.56$

$6,065.56$ 400.18

$1,124.32$ 956.64 402.79

$1,597.28$

606.00

481.95

$\$ 16,1 1 5 . 2 8 \longdiv { 1 , 4 7 1 , 5 9 6 . 4 6 \quad \$ 1 , 4 8 7 , 7 4 1 . 7 4 }$

$3,134.20$

$58,802.52$

$61,936.72$

967.10

$103,592.54$

$104,659.04$

$798.19 \quad 12,509.62$

$13,307.81$

$\frac{35.97}{1,61,080.74} \frac{14,402.86}{1,064.00} \frac{14,498.83}{1,682,144.74}$ tiousehold Goods * Automobiles

Ticket Refund Claims

Movements Arranged Inbound

Movements Arranged Outbound.

Insuranve Hiciers Issued

Insurance jills $A_{i}$ pr ved

Furniture repaid srders

roquests for Claim illing

icins riled

Ii ins C.Ilected - number

lie ims C.ILEcted - .nu unt

ri.led

Collected - imber

Colleoted - Anount
13

5

11

9

3

12

2

.35 .97

44
27 
PURSHASING AND =TORIS LIVIS-OISS

THAFFIC DIVISI AN WARCA, 195I

STATISTISS (C.JTINUED)

reight jlaims

Filed

13

Collected - Number

14

Collected - Anount

$\$ 967.10$

Over and shorts frocessed

16

Demaje Reports rocessed

15

Freight 111 Audit vavings

$* 3,134.20$

Freight Shipments Iraced

113

Quotations

Freight hates

252

Lioutes

351

Bills Approved

Air Frelght

Air tixpress

Toat

Carloading

5

30

ixpreas

Ràl

Truck

1.56

547

410

Returr Urders Proeessed

Carload infipincnts

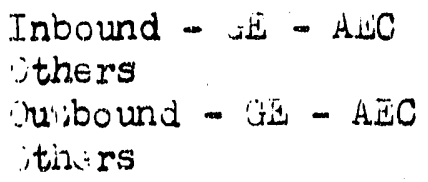

Report of Carloads ileceived

Ceneral blectric Company

Acic, vitric and sulphuric

Aluninum sulphate

Ammoniun vilico Fluoride

Caustic Potash

Caves, Junior

Liquid Chlorine

CoEl

Drums, Sterl

Ferric sulphate

Hydrofluoric heid

Infusorial warth

Iron Ore

iron Plumbing Goods

Laboratory Tabl. 3

Gydrated Lime

vitrate of ioda

N1tric Acid

Phosphoric Aicid

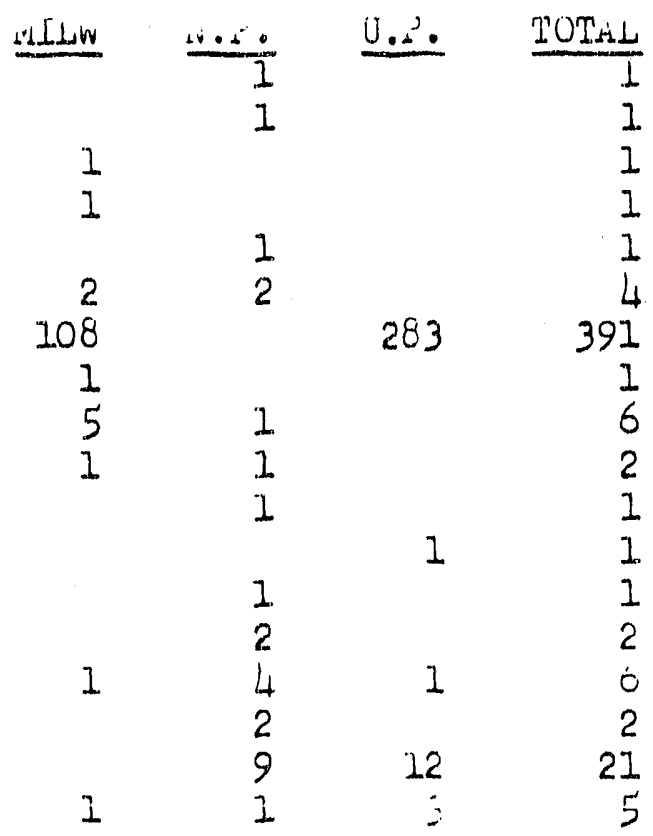


PUROHADIVU AND STOKLS LIVISIOANS

TEHFFIC DIVISION

WARCH, 1951

\section{STATISTICS (CONTINUED)}

Report of Carloads Hecelved (Oontinued)

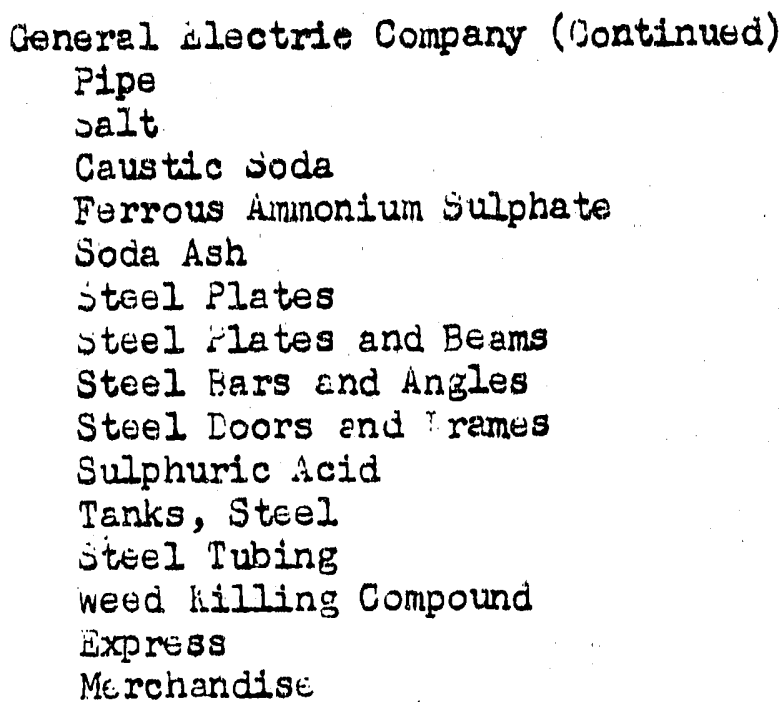

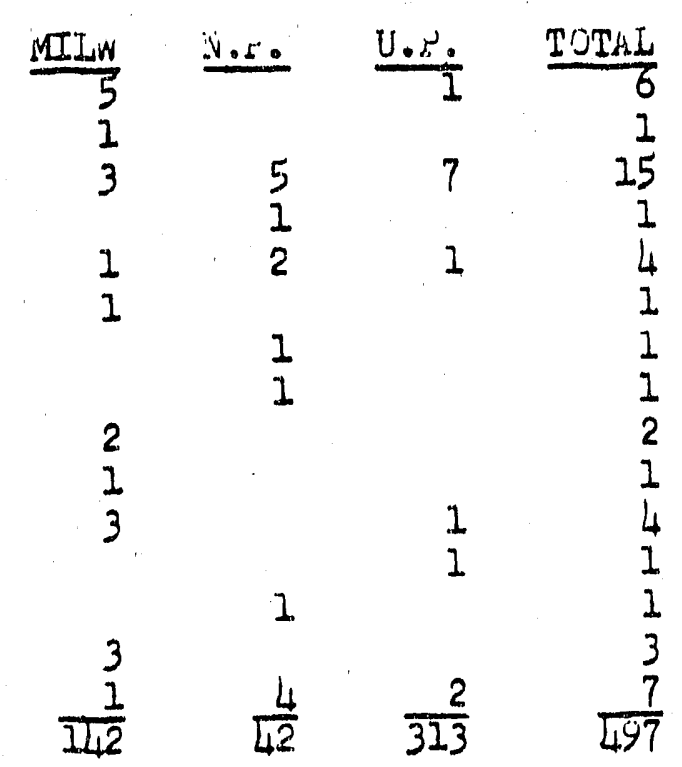

A. i. C.

Automobiles

Cabinets, Steel

Chumicals

TUTAJ

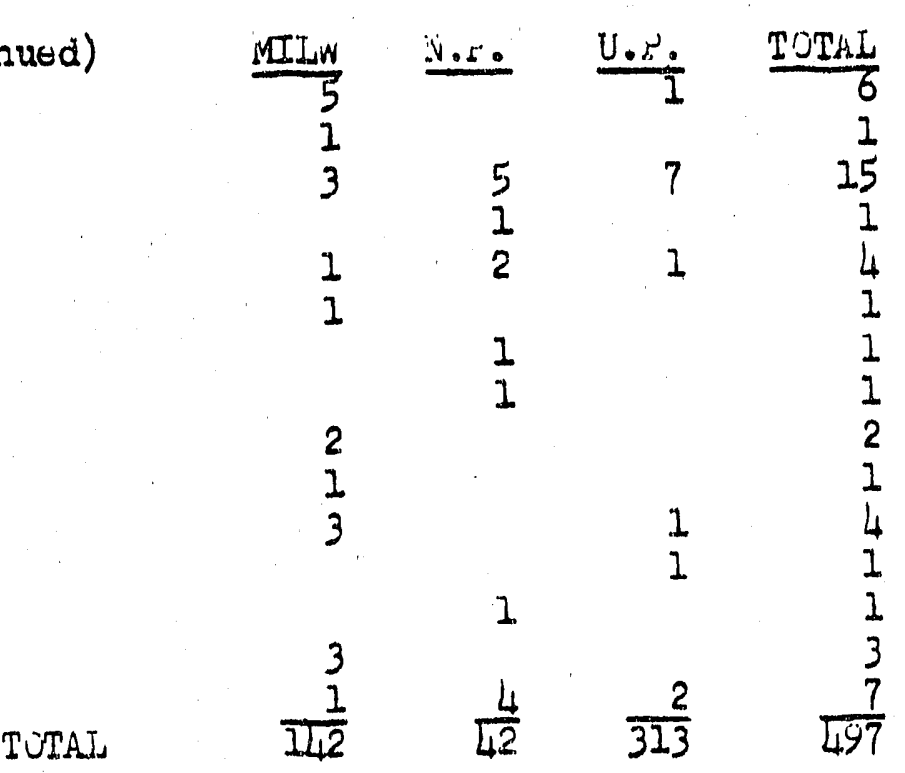

Lumber

Iywood

Merchandiso

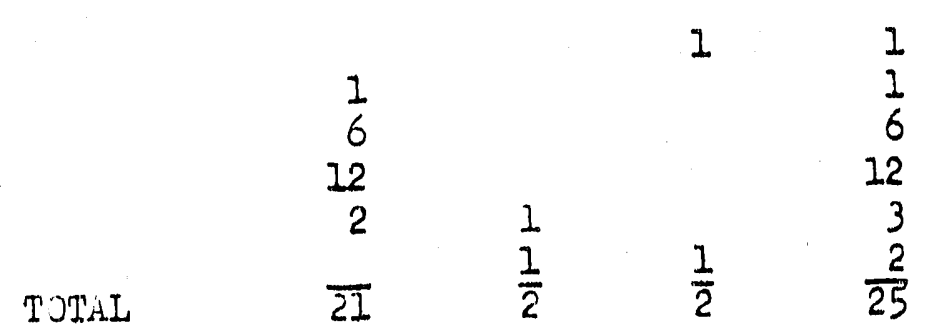

A.tiknson \& Jones Construction Conpany

Asphalt

Cement

Insuletion

Lockers

Mine ral nool

Pipe Conduit

Pipe

sand

Silica Sand

Steel Plates and Pipe

steel Bars

otructural jtet

Steel Tanks

Track Bumpers

T J.A

Tubing, Copper

Nierchandise

$\begin{array}{rrrrr}2 & & & 2 \\ 1 & 26 & & 27 \\ 1 & & 1 & 1 \\ 1 & & & 1 \\ 1 & & & 1 \\ 3 & 1 & & 4 \\ 1 & 3 & & 3 \\ & 2 & 1 & & 3 \\ \text { TOTAL } & 4 & 1 & & 4 \\ & & 1 & 1 & 1 \\ & \frac{1}{25} & \overline{33} & \overline{2} & \frac{8}{60}\end{array}$

2. F. liauserman Conpany

Pertitions

15.

TOTAL

$\frac{1}{1} \quad \frac{1}{1}$ 
PIRCHASING ANL STORIS IIVISIONS

TRAFIC DIVISION IARCH, 1951

STATISTICS (CONTIIVUED)

Report of Carloads Received (Continued)

Haigan \& wolff, Incoxporated

Plaster

TOTAL

West Coast Heating \& Punbing Company Pipe

TOTAL

WILW NIP. U.P. $\frac{\text { TOTAL }}{\frac{I}{I}}$

$\frac{1}{1}$

$\frac{1}{1}$

Roof service, Incorporated Asbestos jiding

T:JAL

$\frac{1}{1}$

$\frac{1}{I}$

Elactric Smith Company Pipe

TOTAL

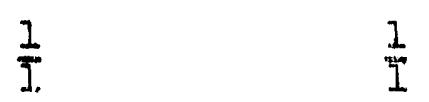

TOTAI - SUBCONTRACTORS

40

47

16

103

TOTAL ENTIFL PROJECT

203

$91 \quad 331$

625 


\section{EMPLOYHE AND COMMUNITY REIATIONS DIVISIONS}

\section{SUMMARY - MARCE, 1951}

The number of anjlicants intervlewed decreased from 1,934 in February to 1,671 in March. Of these applioants, 712 were Individuals who applied for employment with the Goneral Ilectric Company ior the first time. In add1tIon, 821 new applicants aubmitted applications through the mall. Open, nonexempt, nontechnical requisitions increesed from 548 at the beginning of the month to 621 at month end. Total plant roll increased from 8,027 to 8,080 . Turnover rate 1ncreased from $1.73 \%$ in February to $2.38 \%$ in March. During Nirch, 70 new requesta for transfers to other type uf work were recelved by the Employment Off1ce, and 63 transfers were effected. During March the Employment Off1ce again remained open on Saturdays, with the result of 375 appiloants being interviewed on those days, of whioh 206 were now applioants. Of these, 79 were pleced in process and 30 others are under conslderation. During March advertisements were placed in 17 Paciflc Northwest nerssapers on 15 different dates, and spot radio announoements were given oror 14 local rilio stations five times weekly. Fleld recruitment was conducted in Portiund, Oregon, for draftsmen and deslgners, and for oost anc accunt1ne lerks on MPrch 19, 20 and 21. There were 255 applicants interviered, ff which. 20 wore mede offers and 36 are being glven active consideration. Iower Columbla Junior College, Lorgriew, Washington, was vialted on March 22, 1951, and 5 laboratory assistant candidates were interviewed. offers were made to 2 and the others are belng considered.

During March, four employee deaths oosurred and four employees retired. Two hu udred and five visita were made to employees confined at Kadlec Hosp1tal, and 67 selary chocks were delivered to omployeos either confined at the hospltal or at home. The plant Red Cross Drive was completed on March 16, with employees at Hanford Works contributing $114.8 \%$ of the $\$ 13,650$ quota established by the County Chatrman. During the month, 54 letters were written to employees relative to the new ruling of the Pension Buard concerning the survivorship options. At the end of March, there were 737 employees registered under the selective service Act and 653 military reservists on the rolli. Silce August 1, 2950, 117 omployees have terminated to enter military jervice. At month end, participation in the Pension Plan was $95.5 \%$, the Insurance Plan $95.3 \%$, and the Employee Savings and Stock Bonus PIan $37.5 \%$.

A total of 23 supervisors attended the LO-Hour Training Program during March. FMS Groups 13, 14, 15 and 16 met dung March. The 8-Hour iNonexempt Training Program was held cn March 9, 1951, with eleven "S" Division employees in attendance. Duilig the months of February and Narch, a total. of 228 meetings, or 76 compute series of conferences, on "How Our Business System Operates" was m. de available at Hunford ivorks. A total of 785 people, or 4 . 3: , part. ipated in the three-session program. A sche-

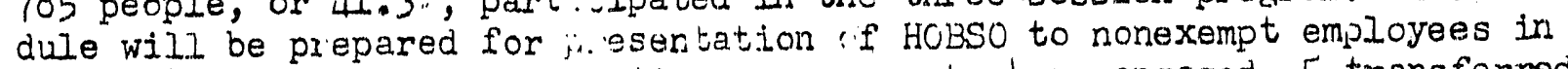

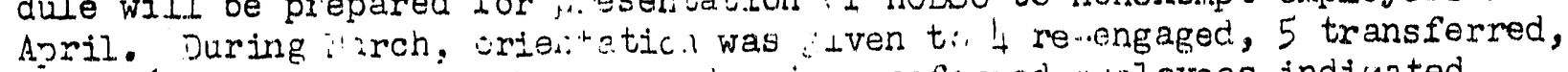

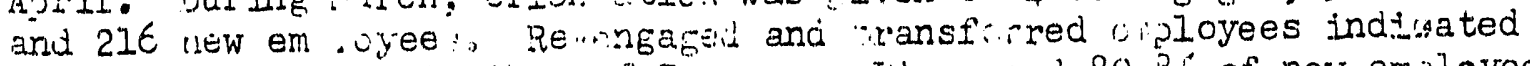
100\% paricipar.ng 1." the 
Employee and Community Relations Summary

signed to partioipate. A net of 16 copies of the Supervisor's Handbook on Employee Relations were distributed during March. Thirty-twe Handbooks were tumed in and re-issued. Seotion 1.7 was revised and distributed to Handb ok holders during the month of March. Twenty-four coples of the book, MEN AND VOLTS were sold. "Let's Talk It Over" disoussions were held at the time of Annual Ratings with exempt members of the Training Staff

A total of 90 news releases were written and distributed curing Matu, 63 of which were sent to the "local list", and 27 were sent to the "daily 11st". During the month of February, 360 column inches were printed of news conceming Hanford Works in newspapers throughout the Northwest.

An instruction letter defining the responsibility for the release of information at Hanford iorks was distributed.

A riagazine article about the Health Instrument Division, with photographs, was sent to the NONORRAM, and will. appear in all early issue.

A survey was coinducted during the montil to determine whether or not Richland businessmen and minister and educators would like to recelve a "Community News Letter," to be put out by Comminity Relations. Of the 30 per cent returne from the survey, the majority indicated that they would desire to receive the newslettor, which will be produced and distributed rsgularly in the near future.

The News Bureau Supervisor, Editor of the works lNews, and the somnunity Relations Supervisor addressed journalism students at Columbia High School on the subject "Joumalism's Part in Employee and Public Relations." Ar invitation was extended for students to visit the Comnunity and Public Relations Division, in the noar future, and put out a section of the works ivews.

During the month a mecting, was held with presidents of the local kiwanis, Rotary, and Lions Clubs to outline a suggested procedure for presenting HOESO t: Richland residents.

Civil defense information was released to residents through local newspap $\in$ rs, rudio statiuns, and the Jorks News.

Five spesches wure delivered durizg the month by $G-E$ employees. Twentyone hand prints and II glass slides were prepared for two of the specches.

Arrangements wire cc"npletid during the nont!i for the employe and Community Relations Divisions Manager's pracentation of HOBSO before three groups in Fort!nd. 
Thployee and Ocmmunity Relatians

Summary

In an NLRI conductod tioction on March 23, 1951, tho Riacliand and North Richland Police and Plant Sucurlty Guards votud in favor of ropresentation by by the Intomational Guards Union in colluctive ba gaining mattars. Tho NLRB gave notice on Maroh 7 that proposed union shop elootion had becn postponed. A hearing was soheduled in the case of the Village Firomen for April 4. The HAMTC-OE Contract was not reopened.

On March 22, tho Davis Panol requested furthur nogotiatilns at the loeal Ievel on the isolation pay 1ssue. Negotiations with Painturs concluded Maroh 14, granting ton conts an hour effoctivo Ducember 9, 1950, and sevon cents an hour effoctivo May 1, 1951. A now promium of fiftoen conts an hour was agrood upon for work on Swinging Scaffold or Boatswains Chair. It is roportod that tho Toamstors will hold roprosentation and union authorization elections in the near future. Puget Sound shcot Metal (Soattlo), Atkinson-Jonos vundor, is f'.cud with tho possibility of a strike on dpril 2. Thoy are to furnish and crcet 19 tanks. This office is preparod to assist in the ovent an actual work stoppago ocours.

Compilod data of the Nortiwest Survoy was complotud and sent to Priating. Also complutod was tho spocial Paci ic Coast Dusign and Drafting Wage liate Survey. A caso was propared for prusuntation to lago Stabilization Board for increased rates for Designurs and Dr iftsmon, the classification of Chlorinator Sorvicuman, and a plan for granting merit incroasos to Designers. The survey of non-unit clorical jobs in the Medical Division was complotod. 


\section{MAROE, 1951}

\section{ORGANIZATION AND PHRSONAEI.}

\section{Employment and Hhop loyee Serv1008}

Effeot17e March 2, 1951, a General Clork "D" was engagied and assigned to the Inrestigation and Fliles Group to replace a General Clork "D" who transferred to Fealth Instrument Blology DIVIs1on on Merch 9, 195..

Effective Maroh 9, 1951, a Messenger wes engaged and asglgned to the Inrestigation and Files Group.

Hefeotive Maroh 12, 1951, a General Olerls "D" was engaged and asalgned to the Investigation and Files Group.

Effect1ve March 26, 1951, an Hoployment Intervlewer and Investigator "B" wa engaged and assigned to the Procurement Group.

\section{Training and Program Devolopment}

Effuctivo March 23, 1951, a Fidid Clork "A" was ongagod to roplace an employoe who had bocn promoted to Training Instruotor.

Community and Public Rolntions

Effcetive March 19, 1951, ono Steno-Typist "C" was upgraded to Genoral C.lirk "C".

\section{Union Relations}

Effcetive March 12, 1951, a Stunowypist "D" was transfurred to Maintenance. On March 12, 1951, a Steno-Typist "D" was engaged to repluce thu one, who was transf'errod.

$\begin{array}{cc}\text { Numbor of Employocs on Payroli } & \text { March, 1951 } \\ \text { Begianine of month } & 101 \\ \text { End of month } & 105 \\ \text { li t Incronso } & -4\end{array}$




\section{Employee and Oommunity Relations}

Summary

Publ10 Funotions boaked three G.H. films and 4 University of Washingtion films for a looal group.

Arrangements were made for use of the AEC Securjty darkeroom on a temporary basls by one umployee of the Photo House unt1l more spaos is made avallable. The congestion th the Photo House darloroom was thus relieved sufficlentiy to allow handiling of the lnoreased volume of requests for servioes being, recoived from Hanford Workes Divisions.

Black and white photogrephs, $16 \mathrm{~mm}$ color motion piotures and $35 \mathrm{~mm}$ oolor slides were made of the AEC Safety Award Ceremony.

One hundred three general photo assignments were completed during the month, involving the production of a total. of 7,298 prints.

Services by Special Programs to Union Rolations inoluded a lettar to all H.W. patrolmen and RIchland policemen ooncornine the ropresentation eliction; ind the Works News columu, "Union Relations News," which appared twioe.

A 12-page booklet, "Let's Got loquadnted," was produced for distribution to hospital pationts by Kadloo Hospital.

A publio rolations outilino to accompany the ourrent construction and improvoment program at Kadleo Hospital was drawn up and put into effect. It includus mual tray oards, insorts for the now patients' booklot, a four-color hospital floor plan for the lobby showing the Improvements being made, and a newspapur photo of the "ground breaktng ouromonies."

Publicity carried in the iNorks Nows includod: Rod Cross Drive, motering of electrictty in lichland, the noed for rooms in homes of employees to house new employees, ojvil definso activitios, employee benefit plins, s"restion system, and the noed for cortatin clessifications of employees at Hanford Works.

Four womon's pages appearod in the Hanford Works Nows during the month. They fuaturod tho YiVA Supper Club, reoipes, Spring fashion forocast, and spring housucleaning.

The womin's activitivs fuavure writer suppliod a foaturo story with pic.tures for the jorks Nows on the nuw North Richland teen-ago center. This writor also comploted a dodble pagc foature for an April issue of the Works Nurs on the nuw iecords Survice Cunter in the 700 Area. 
Truployeo and Commulty Relatlone D1v1810no

ACUIVIIIES

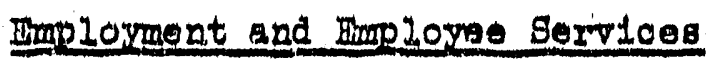

Eviployment:

February, 1951 Nerobe 1951

Applicants 1atervleved

1,934

1,671

712 of the above applicants Intervlewed during Marob were 1ndividualo who applied for employment with the Compeny for the first time. In addition, 821 now applications were recelved through the mall.

open requisitione

Dxempt

Nonexempt
Tebruary, 1951 Maroh, 1951

4
548

of tile 549 open, nonexempt, nontechnical reyulaitions at the beginning of the month, 440 were covered by interim comitments. Of the 621 open, nonexempt, nonteopnical requisitions at morth ond, 481 were covered by interim comiltments Durlag March, 190 now requisitlone were recelved requeating the employment of 310 nonexempt employeer.

February, 1951 March, 1951

Employees added to the rol.1s

Employees removed from the rolls

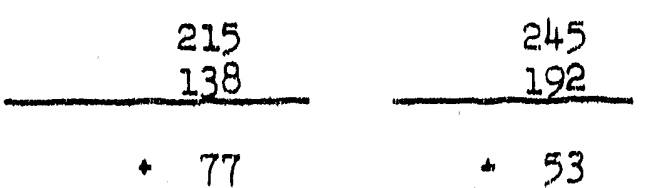

Net Gain or IOE

$+77$

$+53$

Of the 192 employees removed from the rolls, ro:le were removed due to lack of work

Turnover:

February, 195 : Mele Feina 1e

March, 2951

Excluding employees latd off for lack of work

$\quad 2.83 \% \quad 2.56 \% \quad 2.96 \% \quad 4.03 \%$

Over-al1 Turnover:

February, 195! March, 1951

Excludine employees laid of for lack of work

\section{$1.73 \%$}

$2.38 \%$

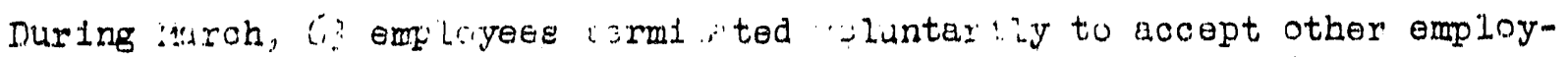
ment, 23 torminited = lea thd: richaty, ar: 13 terminated to enter military sorv10:. 
At the end of Mab, there were 52 employees in laok of work utatus, divided lato the rollowlas oetagorieas

Tebruary, 2951, March, 1251

Nonbargalning undt eurployees

Bargainlag unft omployees

20

17

$44 \quad 34$

\section{Transer Data}

Acoummulatire total of requesta for transfer reoelved since $1-1-51 \quad 167$

No. of requesta for transfer recelved during Marob 70

No, Interviewed in roh, 1ncluding promotional transfers 78

Tranofers effeoted in Maroh, inoluding promationel transfers 63

Trans efeoted to date alnoe 1-1-51. 1noluding promotlonal transfers 132

Tranefer requeats aotive at month end

Trans, effected in Mrob, for employeen given lay off notioes

Trans, effected since 1-I-51, for employees given lay off notioes. 0

No, of stenographers transferred out of steno. Pool in Maroh

Durlag March, 10 people whose contlaulty of service was broken wh1lo in an inective status were so informed by letter.

During Mroh, the Procurement Group cont1nued the reorultment program through advertiolng for instrument mechanics, designors and lraftamen, production operators, laboratory asslatants, nurses, stenographers, cost and account1ns olerks, power operators, oumptometar and I.B.M. operators, and vendor lapectora. These advertianenta were placed in 17 Pacific Northwest newepapers on March $8,9,10,24,15,16,17,21,22,23,24,28$, 29,30 , and 31. Spot radio announcements were given flve times weekly over 14 local radio stations. As the result of the combined nowapaper and radio advortialng, 519 replies were recalved during the month of March.

Also during the month of March, enployous wers asked to recomond possible ond ldates for employment to tho Procurement Group through artioles placed in the Works News. As a result of these articles, 66 replies wore recelved, recommending 88 peopl.e.

On Maroh 19, 20 and 21, two representatives of the Employment liroup and two represontatives of the Plant Englneering Division, visited the Portland, Oregon, Employment Socurity office on a fleld recruitment trip, primarily to reorult designers and draftamen, and cost and acoounting clerks. On these dates 255 applicants were lntervlewed, of whlch 20 were made offers and 36 offers are pending.

On March 22, 1951, a reprcentat1ve contactad tho Jower Columbia Junior

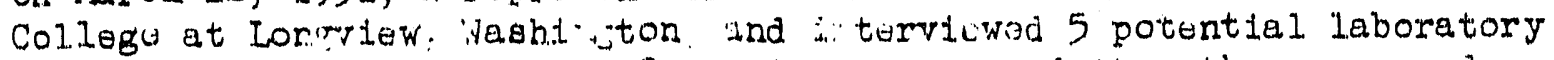

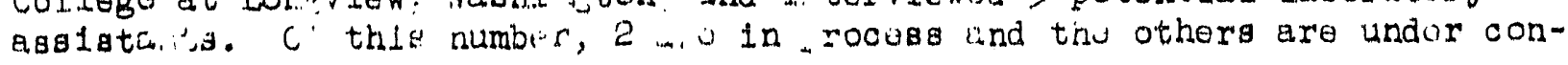
Bl.doration. 


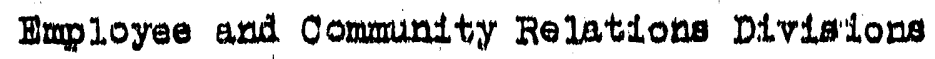

The loyment offloe remalned open on the P1ve Saturdays in Maroh to araiot the recrultmant program. On these Saturdays, 375 applicants wero laterviowed, of which 206 were now applicants. As a result of these interviews, 79 applicants were pleced In process and 30 are under astive oonsideration.

A representative of the throloymont offloe spoke at a meating of the comer. olal Olub of Columbla High Sohool, on the aubject of "What is texpocted of H1gh Sohool Graduates in Industry". This group conslated of Jumiors and sentors who are joring in oomercial subjeots. In addition the ceneral Bleotr10 \#mployee Benaflt Plans, descriptions of types of fobs and rates, and our syatom of promotion were disoussed.

Employment Statiotios:

$2-28-1951 \quad 3-31-1951$

Number of employees on rolls

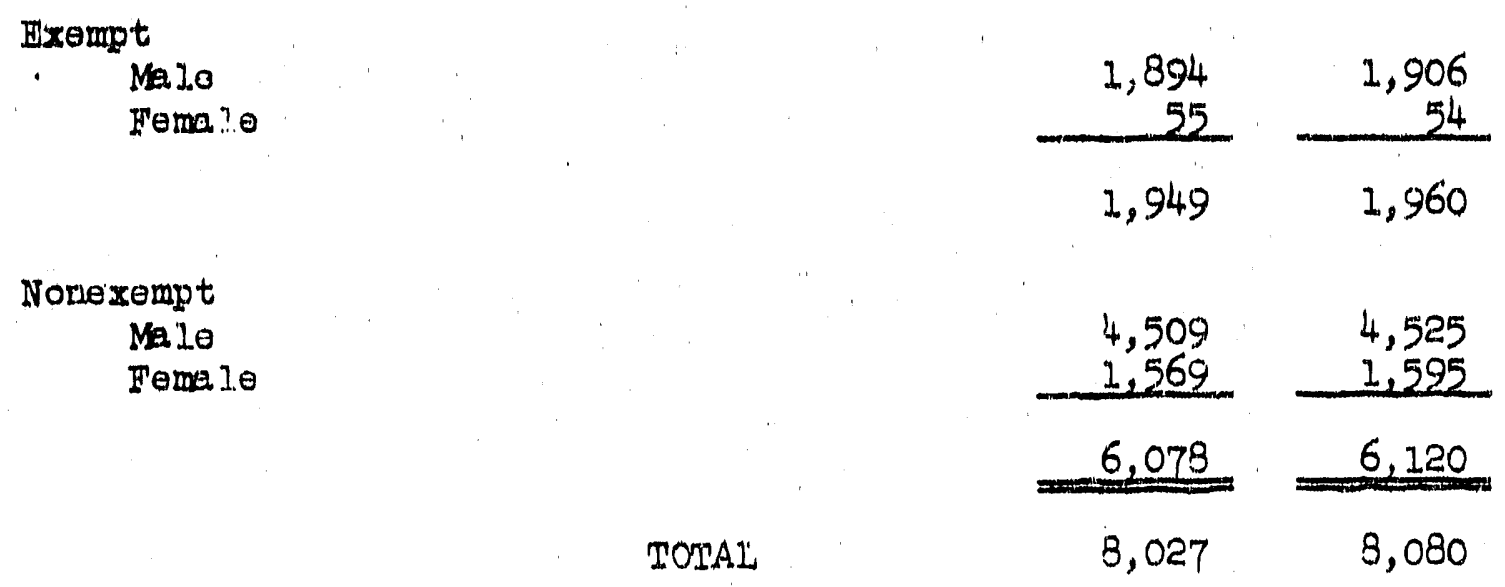

ADDITIONS TO THE ROLIS

Now HLIre日

Ro-engaged

Retetivations

Transfors (from othor plants)

Aotilial. add 1 wions

Payrol. exohanges

GROSS ADDITIONS
Exempt Nonoxompt Total

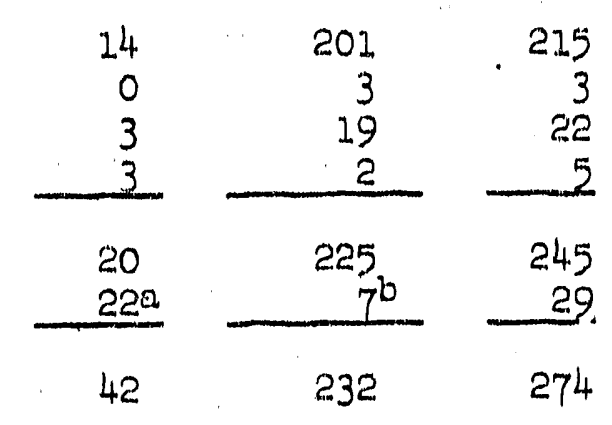

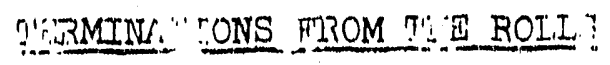

Actual Th.rrainat.ing

Removales Erom tij rois.s (du litivitions)

Payrol1. Eurshangals

\begin{tabular}{rrr}
22 & 132 & 154 \\
2 & 36 & 38 \\
70 & $22^{d}$ & 29 \\
\hline 31 & 190
\end{tabular}




\section{GIHTHRAI}

\begin{tabular}{|c|c|c|}
\hline & $2-1951$ & $3-1951$ \\
\hline $\begin{array}{l}\text { Applicents interviewed } \\
\text { Photographe taken } \\
\text { Flngerprint 1mpressions (taken in duplicate) }\end{array}$ & $\begin{array}{r}1,934 \\
302 \\
485\end{array}$ & $\begin{array}{r}1,671 \\
371 \\
554\end{array}$ \\
\hline$\frac{\text { ABSEMVIEEISM STATISTICS }}{(\text { WeakIy Salar' RoI1日 })^{\theta}}$ & & \\
\hline $\begin{array}{l}\text { Nale } \\
\text { Female } \\
\text { Total plant average }\end{array}$ & $\begin{array}{l}2.84 \% \\
4.03 \\
3.14\end{array}$ & $\begin{array}{l}4.26 \% \\
6.39 \\
4.55\end{array}$ \\
\hline
\end{tabular}

INVESTIGATION STATISTICS

$\begin{array}{lrr}\text { Cases received furing tho month } & 534 & 316 \\ \text { Cases closed } & 244 & 237 \\ \text { Cases found satisfactory for omployment } & 523 & 767 \\ \text { Cases found unsatisfactory for employment } & 21 & 19 \\ \text { Clses closed before investigations completed } & 23 & 16 \\ \text { Special investigations conducted } & 11 & 23\end{array}$

a Transferred from Veekly Payroll

b Transferred from Monthiy Payroll

c Transferred to Weekly Payroll

d Traneferred to Monthly Payrol.2

a Statist1cs Purnished by Wuekly Payroll Division

Emp loyes Services:

The foliowing visits were mde with employees during the past month by a representative of the Employee Sorvicus Group:

$\begin{array}{lr}\text { Employees visited at Kadlec Hospital } & 205 \\ \text { Salary chocks delivored to employees in hospital } & 52 \\ \text { Salary checks deliverod to employees confinod } & 15 \\ \text { at home } & \end{array}$

The Red Cross Drive was completed during March, with the result of Hanford Works employees contrlbuting $174.8 \%$ of the $\$ 13,650$ quota established for Hanford Woriss by the County Chairman. The Employeo Services Group was rasponsible for assisting the plant Chairman in all phoses of this campaign.

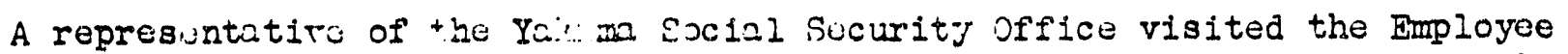
Services Group wice turine Marc. in o:-lor to ubtain information to complete paymont a ben. ¿cia."es o. ducu jed unlloyees.

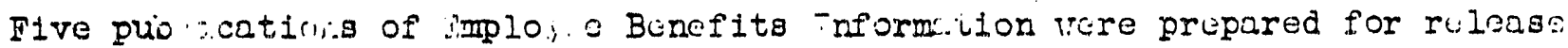
in the Works Nows during Mulch. 


\section{Employee and Communteg Relations Dirlolon}

As of the end of Merch, participation in Compeng Bonefit Plans was as follows:

Pension Plan

Life and Boblth Insurance

Employee Sevings and stock Bonus Plan
$95.5 \%$

95.3

37.5

Four employee deaths occurred durlng Narch, namely:

Randolph H. Long, Reel. Fstate Housing Divis1on;

Ruth J. Davison, Technical Service Diviaion;

Dellart Bergen, Jr., "S" Division; and

Floyd Stech*, Mintenance Division.

*This employee's continulty of service bad been broken on Junc 10, 1949 , but h1s coverage under the Iife Insurence Plen continue 1 under the disebility clause of this plan.

In the past month, 33 letters were writtan to members of deceased employed's pamilies and laturested perties concerning payment of moneys due them from tho comeny, as well. as answering other questions recelved from them.

During March, a representative of this Group contacted the Walla Walla General Hospital, St. Mary's Hospital and the Veterans' Administration Hospital in Walla Wallo to discuss the benofits for omployees under the new Insurance plan, $2 s$ well as to loave forms for use by employees who way bo hospitallzod at tbose hospitals.

Four employecs retired during March, namely:

Iaura Gowlng, Purchasing DIviaion (Optional);

Mercl E. Smith, Plant Security \& Survices Division (Optional);

William J. LaVelle, Municipal Divisions (Optional); and

John W. Doude, Power Division.

During March, 29 letters were written to rotirod omployees giving them information of a general nature which affects them. In addition, 54 letters were written to omployees rolative to the now ruling of the Punsion Board on survivorship options.

Military Roserve and Selective Servico:

The otatistics with respect to employees rogistered under the Solective Service Act are as follows:

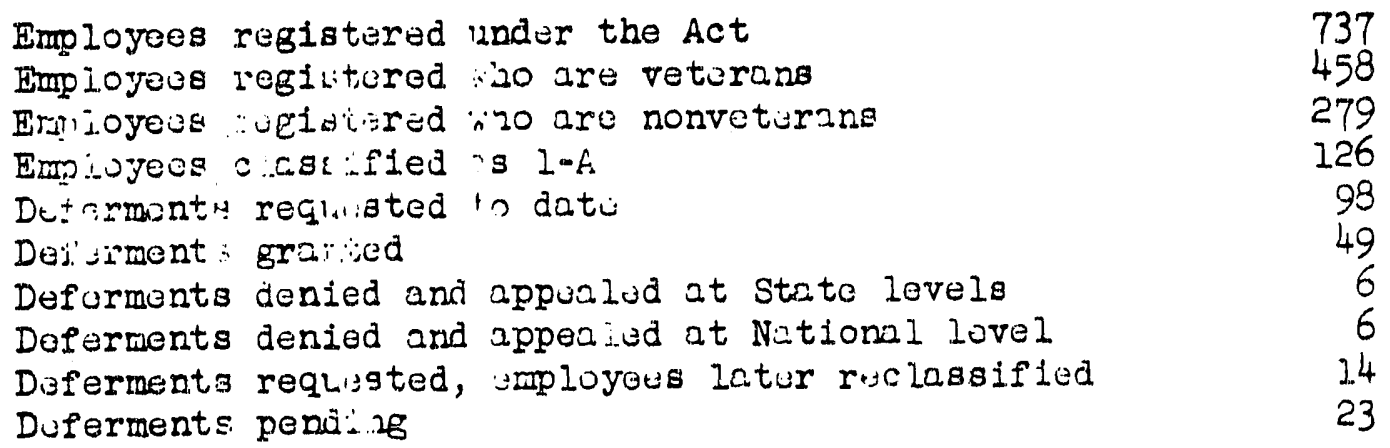


Bup' Oyeo and Communte Reletions DIflsions

Statiatice with reapect to employees who are members of the military reserve are as follows:

Number of reserviats on roll

Number who bave returned to active duty to date Nlumber who returned to act1ve duty in March Deferments requested to date

Deferments granted.

Deferments pending

653

50

Military terminations since 8-1-1950 are as follows:

Reservisto recalled

Fema io employees enilsted 


\section{TRAINING AND PROCRARI DEVISOPNENT}

The Supervisors' 40-Hour Tralning Progrem was held during the week of March 12-16. A total of 23 members of supervilsory-management were onrolled by H1ve major divisions. Iuncheon was held at noon on Fridas of tho program week, at which time the members of the group, together whth flve mabers of senfor management of Hanford Woriss, mot togother for an Informal luncheon. A survey questlonnalre conpleted by partielpating meinbers of the group indicated that this program had been of desinite assistance to them as supervisors.

PMS Groups 13, 14, 15, and 16, met during the month of March. The supervisors onrolied in these four groups are regularly scheduled to work on shifts, therefore, each group meets on Friday and Nonday mornIngs whilo' on days. Appraximately 15 supervisors have been enrolled in oach group, making a total of approximately 60 supervisors attending PMS in these sessions. To date, approximatelo 240 supervisors have completed PMS at Hanford Works.

On Maxch 9, a special moeting was held at the request of "Sit DIvisd on to present the 8-Hour Nan-exempt Training Program to eloven operators in the 200-W Area. An anonymous survoy questionnaire completed by the members participating in this program indicate that the discussion of the many subjects throughout this 8-Howr Program is proving a successful mothod of disseminating information and discussion of polley problems to achievo better attitude and higher morale.

During the months of Fobruary and March, a total of 228 meetings, or 76 complete series of conferences on "HOW OUR BUSINESS SYSTEM OPERATIS"I were made avatlable at Hanford Works. All members of excempt personnel throughout the Works'were invited to participate in these meetings. A total of 785 persons, or $41.3 \%$, actualig participated in the threemsession program. A survey was conducted by the Training Staff members to determine the reason for such low attendance. Results of the survey indicate that the major reasons for lack of attendance were due to: (1) supervisors waiting to be scheduled to attend meetings, (2) lack of interest of upper levels. of supervision in the program, or their not encouraging others to attend, and (3) supervisors feeling that they couldnit spere this much time awey from the fob. An additional survey was conducted regarding presentation of HOBSO to non-exempt employees with results indicating that the program should be presented, but that three sessions could not be justifled in timing for non-exempt personnel. The greatest number of persons surveyed indicated that the program should be presented in one ( 1 t hour) session. A spocial presentation was made with a test group on this basts on March 27. Approximatels 35 nonarexempt employees wore present, at which time the appreciation version was presented, and asproxdmate 15 twanty minutes takon for discussian, making a total of approximately $1 \frac{1}{2}$ hours for $t+\cdots$ meeting. A suhedilie will be prepared for presentation of HOBSO to nor. - zxarpt employees bc ginning in April.

During the month of Maruh, (ritentation was gives to four re-engaged, Are transferred, and 226 new employees; a total of 225 . Re-engaged and transferred employees indioated $100 \%$ participation in the $G-\mathbb{E}$ Insurance Plan, and $89.8 \%$ of the new employees elected to participate 
Employrs and Comanity Relations Dirisions

TRAINING AND PROGRAM DEVETOPMENT

in the Plan. It present, the booklot, Wou and General Electric At Henford. Works" is boing rempinted, and will be distributed to those now employees now jointing the organization when coples are avaliable. The stock of this booklot was depleted in February.

In response to letters of Inquiry to Superintendents and Division Heads, a net of 16 copies of the Supervisor's Handbook on mployoe Relations were distributed. There were 32 Handbooks turned in and re-issued cluring the month of March. Fach of the Handbooks were brought up-todate in revisions and accuracy of content. Of the total of 1,500 copies of Handbooks orighnaly prepared for distribution to supervisors at Hanford Works, 1474 have boen 1ssued to date. A rovised Section 1.7 of the Supervisor's Handbook was distributed in March to all Handbook holders. Additional revislons will be prepared and distributed to keop the Handbook current.

A new employee, David V. Smith, reported on roll March 22, 1951, as Fleld Olerk "A" of Trafoing and Program Development. Mr. Smith replaces Mr. Adair who was romoted to Training Instructor.

Twenty-four coples of the book, NIMN AND VOLTS, were sold during March. The cash for this sale was turned in to the G-E Cashler, and a roceipt is maintained in Training Dividion flies.

W. W. Chamberlatin of the Training Staff is continuing to present ENFECTIVE PRESENTATION at the G-E School of Nuclear Fingineering.

Let's. TaIk It Over discussions were held at the time of reviewing annual ratings with exompt members of tho Training Staff during Iarch. 
Employee and Community Relations Dirisions

Community and Public Relations Division

PUBIIC RNFCRMATICN - News Bureau

\section{Interviews}

R. Lucas, editor of both Yaldima papers, interviewed G. R. Prout before his speech to the Yaictme Rotary Club. The News Bureau and Public Functions supervisors accompanied Nir. Prout on the trip to Yaki:na. Cien C. Lee, editor of Tri-City HERALD spoke to the Yalima Rotary Club earlier this year.

\section{Meetings}

News Bureau Supervisor talked to two journalism classes at Columbia High School about the "Need for Journalisin in Public Relations rork."

\section{Requests}

Several booklets and copies of releases concerning operation of the Community were given to the AEC at their request for forwarding to the state Real Istate Board.

The following requests for information were received from the Tri-City HERALD or Columbia Basin NEWS and releases were made: costs per square foot of Carmichael and Spalding schools; the finding of mastadon bones in white Bluffs; the possibility of a 4 per cent wage increase; the need for rabies shots; and the charge that GE prevented a union shop election.

\section{Spectal Projects}

An instruction letter defining the responsibility for the release of information at Hanford viorks was distributed.

A magazine article about $t$ e Tealth Instrument Division, with photographs, was sent to the MONOCRAll. It will appear in an early issue.

Special emphasis was given to a series of stories and photographs about the installation of meters, establishilent of the Hanford works Laboratory, civil defense, and a concert by the linnesingers.

\section{Coverage}

A total of yo releases were ritten and distributed during Narch. Of these, 63 were sent to the "local list" which includes: Columbia iasin NEWS, Tri-City "ERALI, Lind IEADER, Yakima Sorning HERALD, Nalla walla UNION-BULIETI", Works NEviS, Spokane CHYONICLE and ra io stations K'KW, KWII, KAIJ, KREW and KIT. The rest were sent to approximately 75 daily newspapers and wire services throug lout the porthwest. Following is a sampling of news subjects du' ${ }_{2}$ the montis.

Construction - Fourteen news stories were cistributed that concerned invitations to birl, bid openings and award of contracts for construction work in the plants and the commurity. 
Recreation - Twenty-ight news stories, radio spot announcements and photoFraphs which publicized C.E.'s recreation program were released.

Utilities - Ten releases concerned installation of electric meters, power outages, and the fencing of the irrigation ditch.

Housing - Residents were unged to rent rooms in their homes. The procedure for applying to nove to the houses now under construction was explained.

Fire and safety - Releases pointed out the procedures for burning trash, the danger of cleaning with gasoline and the presentatiin of the AEC's 1950 Safety Trophy to G.E.

Hanford Works Laboratory - A news story anc. a 3000 worc feature story were distributed concerning the seven-building laboratory to be built here.

Medical - Residents were warned of an increasin number of measle cases. Another release urged residents to have dogs innoculated for rabies.

Personnel - A luncheon for employees with 25 years or more of service was publicized. A story was released on the number of employees fom the entire Company and from Hanford Norks who $h=v e$ entered the armed forces.

SFeakers - Publicity was released concerning four out-of-town speeches by Hanford :jorks personnel.

Employee Benefit Plans - It was pointed out that taxpayers were saved almost 1100,000 last year by employees of fanford jorks throush the Susgestion systern.

Union Activities - Three releases were made concerning statements by a CIO representative.

Organization Changes - Pine stories were released ccncerning organization changes.

Space Report - See last page of this report.

PUEIIC INFO. AATION - Community Relations

A survey to determine interest in receiving a Community NEWSLITTER, regularly, was conductec amone ifchland ministers, educators, and businessmen. A letter to these community leaders sugeested that subjects such as the facts involved in rumors about company activities; information about the Hanford Works employment situation; and information about employee programs and activities might be discussed in the NEWSLETTER. Leaders were invited to use an enclosfer, self-addressed postal card to indicate their interest in a NDIEITYM and their orefurinces as to subjects that might be discussed. Ovor 30 ur cent of tine milisters, educators, and businessinen surveyed returnec tinc sostal cards. The vast majorit said they would appreciate receiv -ivg a "WISTTER, realarly. It is planned to produce and distribute a NEicismen in tho ncar future. 
The Encyclopedia Americana was furntshed information about North Rlchland for inclusion in the next edition of the publication. The editor requested the information furnished.

A letter requesting the taking of a public opinion survey in Richland was witten to the AIC for the sisnature of the Employee and Commuity Relations Divisions llanager. The letter, which proposes a survey among $G-E$ employees and tri-city residents, is currentiy being edited by the Manager of the Community and Public Relations Division.

Local hish school journalism students were eddressed on the subject, "Journallsm's Part in Imployee and Public Relations." The llews Bureau Supervisor, Works NIWS Editor, and Community Relations Supervisor spoke to the students. The talks were well rocolved, and the journalism instructor was profuse in her thanks to the speakers. An invitation was extended for students to visit the Commity and lublic Relations Division, in the near future, and put out a section of the Norks NEwS.

The G.E. Supervisors Association membership drive was publicized by the Communty Relations supervisor. Pictures and news stories were published in local papers ano the works NDWS. Two letters about the organization and its membcrship drive were written and sent to each $G-E$ supervisor.

The monthly safety meeting of the Employee and Community Relations Divisions was planned and conducted by the Community Relations supervisor.

A suggested procedure for presentirg HOBSO to adult, Richland residents was outlined and discussed at 3 evening neet in $\vec{E}^{\prime}$ with presidents of the local Klwanis, Lions, and Rotary Clubs, the three sponsoring or ganizations in Richland. A "HOBSO Action Committeell composed of members of the sponsoring groups has been appointed.

Civil Defense information was released to residents through local newspapers, radio stations, and the works liEvs. 'The arrival of Richland's air raid sirens was publicized, as were the activities of the Civil. Defense Technical Defense Group.

Recommendations relative to the Public Administration Services rejort were reviewed and suggestions for improvement offered, at the request of the ianater, :unicipal, Real Estate and Concral Sorvices Divisions.

PUBLIC IIFOLI ATION - Public Functions

Papers and speakers

Jim Figenshau demonstrated and explaines "Re lote Control Tools Used in Atomic Energy" before the issonic "Grotto" in Yalima, Washin ton.

C. A. Bennett spoke on "The 1 pplication of Several Tests for Randomness to Cherical Problems" in Zostor: "ass.

C. I. licCullough delivered L.s lecture on "Concostration of Radioactive Legend by Evaporation" to mininiton State Collete and "niversity of Idaho AICE in Noscow. 
Employee and Comminty Relations Dtots ons

G. P. Tracy spoke to the ACS in Eoston on "Safety in the Laboratory."

W. E. Johnson's talk, "Design Engineering. - A Job Desoription for the Guidance of Engfneering students," was sint to Schenectady for review.

The General Manager spoke before members of the Yakima hotary Club on "The Hanford Project. in.

Arrangements were completed for the Divisions lianaser's presentation of HOBSO before the members of the Baker Convention, the Tast ulde Commercial Club, and Sales Managers Association--all three appearances to be made in Portland.

\section{Filins}

Three G.E. fllins and four University of Washington films were booked by a local group.

$\underline{\text { Radio }}$

Employment spot announcements werê written and placed for broadcast with 14 radio stations located in Washington, Idaho and Oregon. A total of 280 sixty-second spots were requisitioned.

Five one-minute interview-type spot announcements were developed for the Campfire Cirls leacership recruiting callpaign and birtinday celebration. These announcencnts were tape recorded in one of the local racin station studios and broadcast locally.

A ten-minute radi: show was produced for the Campfire Girls.

One sixty-cend spot announcement was written for the Civil Defense Authority and placed for broacicast over all local stations.

A professionally produced health series was aucited by this group with the Public liealth officer.

Three sixty-second spot announcements, advertising the ininesinger concert, were produced for the iews Rureau.

Arraneinents were made with IWIE for the live broadcast of the presentation by AdC Ceneral Manager, $T$. W. Boyer, of AEC's 1950 Safety Trophy plaques to iellex Corporation, the local AIC office, and Ceneral Eleotric Company's operations personnell at hanford works. Public address, tape recordine, photorraphic and incidental services also were furnished for the outdoor presentation cerenonies.

Program Deve lopment

The newly appointed fssistar: Cenerel Mann er w presented to the members of the Supervisors Associati na their reglar eeting this month. 
Bmployee and Community Relations Divisions

Photo Youse

Ose of the AEC Security derisroom on a temporary basis until additional space is made available was begun this month. One employee was assigned to this borrowed darkrooin, thus pertielly relieving the congestion present in the Photo!!ouse darkroom.

"The King of $K i n_{E} s, "$ a three-hour $16 \mathrm{~mm}$ motion jicture, was projected by the Photo House Supervisor in Columbia $\mathrm{High}$ School Aucitorium as a comunity ser vice.

Black and white photographs, $16 \mathrm{~mm}$ color motion jictures and $35 \mathrm{~mm}$ color slides were made of the AEC Safety Award Ceremony.

Photographs were made to illustrate the conditions under which Richland firemen live durin duty hours.

Twenty-one hand jrints and Il glass slides were prepared for the presentations of Dr. D. W. Pearce and G. P. Tracy in Boston.

Photograjhs of details involved in an automobile accident were photographed for the Police Department.

Unusual process conditions were photographed for the Nanufacturing Control Division and the cesirec resilts accomplished for them.

Black and white slicies were made at the request of the General Manager and Assistant to the General Hanager on Technical and Educational latters.

I'orty-two special 81" $\times 1011$ prints we prepared for the Transportation Division to be used in a yearly lionograjh re,ort booklet being prepared by" theme

One hundred three general assignments were comjleted curing the month, involving the production of a total of 7,298 prints.

Artwork completed during the month: cover and pages of "You and $G . \pi$. at Hanford Works !" and illustrations; the lay issue of the Richland Telephone Directory-front cover; outside back cover of a safety booklet; inside back page of a fire painglet and page 2 of a security publication; a hospital card and \& patients' booklet insert; safety booklet dummy wes redesigned; 1llustrations for the lonthly Health Eulletin; civil defense poster.

ENPLOYEE IIFOP: ATION - Special Programs

Classified ac's were placed in 12 daily newspapers in the ivorthwest each week in larch announcing that the imployment oficice would be open on Saturday. Nine disferent clr. iifications were dvertised for. A total of 451 witten inquiries were resived ouring the rinth, anc 375 job applicani: were interviewed on the five isturdajs as a resil.t of the newspaper and radio advertising. A specia. ad in the two portland papers netted 255 inquiries. 


\section{Employee and Community Relations Dirisions}

The attendance award plan got rolling as purchase requisitions for 2400 pins--plus an additional 1000 inserts-and 500 certificates were issued.

Services furnished by Special' Programs to Union Relations included a letter to all H.W. Patrolinen and RIchland policemen concernint their representation election, and preparation of the Works NISWS column, "Union Relations News," which appeared twice.

Civil Defense cur cards and posters were produced.

"Let's Get Acquainted," a 12-page, two-color booklet for hospltal patients was produced for $\mathrm{Ka}$.lec Hospital.

A public relations outine to accompany the ourrent construction and improvement at Kadlec Hospital was drawn up and put into effect. It includes patients' meal tray cards, inserts for the new patients' booklet, a fourcolor hosjital floor plan for the lobby showing the inprovements, and a newspaper photo of the "ground breaking ceremonies."

Services given the Health Activities Committee included the preparation of the health bulletin for lay, with the accompanyini discussion leaders' guide, and the preparation of a story synopsis and picture outline of a Medical Divisionsi sound-film strip.

Stories were prepared and released for Public Health concerning the Washington State Public Fealth regional meeting in $\mathrm{A}^{*}$. vhland, the presence of rabies in the state, and the sudden increase of led measles in Richland.

ENIPIOYEE INFORPIATION-- WOTKS NEWS

Special services performed during the month by the Works NEWS, and programs and activities which were publicized within the plant and community are as follows:

Red Cross Drive received intensive pronotion in each issue for the month. Material used to publicize tha Jirive included lead stories, an editorial, an editorial cartoon, a full page mat, plctures, anci a full page feature.

A full-page feature was devoted to the voluntary action by employees in the Purchasin $n_{b}$ and Stores Divisions and the baintenance Division in donating blood and working at the Blood center.

A special editorial was writtion for publication over the signatures of the $A E C$ and C.T. Managers, pointine out the valuable work being performed by tine Red Cross.

Community inforination of interest to employees was pullished which concerned opportunitry to weve 1.. o new homes being constructed, announcement of metering of elsctnicitr, .... the need ior rocms in homes of employees to house new einplorees. 
Employee and Commity ielations Divisions

Special. Service was performed for housewives by the inclusion of a certificate of registration which is required by sales representatives to sell in Richland homes. It was published following inquirles made at the Works NEWS office as to whether such certificates were necessary.

Civil Defense activities within the plant and community were publioized. Special emphasis was give to an announcement af tests being mace in the Areas of defense plans. Follow up stories were published concerning the results obtalned. Arrival of sirens for the community was announced.

Benefit plans information was included on the Pension plan explaining the Survivorship Option, and that energency loans can be granted to active members in the Plan. Publicity was given to distribution of personal. reports for each employee advisine thein of their status in each plan.

Suggestion System report of activities during the past year for the Company and the Nucleonios Department were included. One out of four suggestions being adopted at Hanford Works was pointed out to be oomparable to average in all industry. Promotion messages were published.

Employment needs were published regularly. A form for employee recruitiag was designed for repeated publication at the request of the Employment Divis:on.

Safety news, in addition to the regular "Iifeline" column included a banner headline, lead story of award given byr the AIC to operations personnel of (7.. . for their improvenent in the reduction of disabling injuries durinb 2950 over the previous year.

special features during the month of interest to, or about employrees, included North Richland Club for teen-ajers, Red Cross : Iood Prosram, and einployees who make their own furniture.

Special services included a talk by the editor before two journalism classes in the Columbia High School in which all phases of the works NESS operation were explainer. Arrangencints have been made to have some members of the class work a ay in the Works "EWS office.

At the request of the Red Cross a news article was included telline how First Aid certificates may be renewed for peo lie whose cards have expired.

One ten and one twelve page paper were published during the month.

Two new columns were introduced in the Works NEWS during the month: "To Your Health," and "Union Relations News," both written by Special Prograins.

EUPLOYEE IIFORMATION -- WOMEn's Activities

Four women's pages ajpeored ; the Vanfors works Nitis during tize month of March, 1951. On arch 2, iht Y.N.C.A. Eupper Club was featured. This organization has been createj for wonen who wort, and who are under 35 
years of age. "Jinier in a Dish," with photograins anc recipes from the National Cotton Counc1 I was featured on March 9. "Spring Fashion Forecast" with line cuts of fashions firsts was the feature on the women's page on arch 16. An article on spring cleaning, includini Consumer's Institute hurry-u. meals for busgr cleaning days, appeared on i.arch 30.

Twenty-five stories were written for the Parks and Recreation Division concerning activities at Columbia Playfield and the Community liouse. Incluced was promotion on the kite tournament, the square dance contest, and the lilinnesingers concert. This promotion publicity included photo captions, and radio spots.

A special feature was written for the Horks NEWS on the new "orth Richland teen-age center. Pictures of the opening of the center ware included with the story. A Works ?EWS-only story was written promoting the women's Amateur Basketbal. Association tournament. on Varch 9. "Ilector is a Climber," another special feature, was written to publicize the play equipment at Barth Playlot. Work was completed on a double pase feature concerning the "ew Records Service Center in the 700 Area for publication in April.

The "What's Doin $n_{B}$ " column included information on the Allied Arts Association exhibit, the A.A.U.W. art exhibit, the Dormitory Club, the kite tournesient and the Y.T.C.A. Supper Club. 


\section{DIVISIONS}

INGIN. \& CONSTRUCTION Project Engineering North Richland Rec.

EIPIOYEE \& COMMTNITI RIIATICNS

Employee Relations Commuity Relations News Bureau

Special Programs iNor'is N"WW

Public Functions

HEAITH INSTRUMENT

MANUTACTURING DIVS.

Reproduction

Transportation

Naintenance

Instrument

Blue Print

MEDICAL DIVISIONS

Public Health

MUNICIPAL, REAL ESTATE

\&. GENIERAL SERVICES

Public Safety

Parks \& Recreation

Police

Safety \&. Fire

STAFF ORGAMIIZATION

Rotational Training

TECHNICAL DIVISIONS

Pile Technology

MISCELIANEOUS

A.E.C. Safety

Civil Defense

TOTAI

Total Prints

Total Negatives

Total Assignments

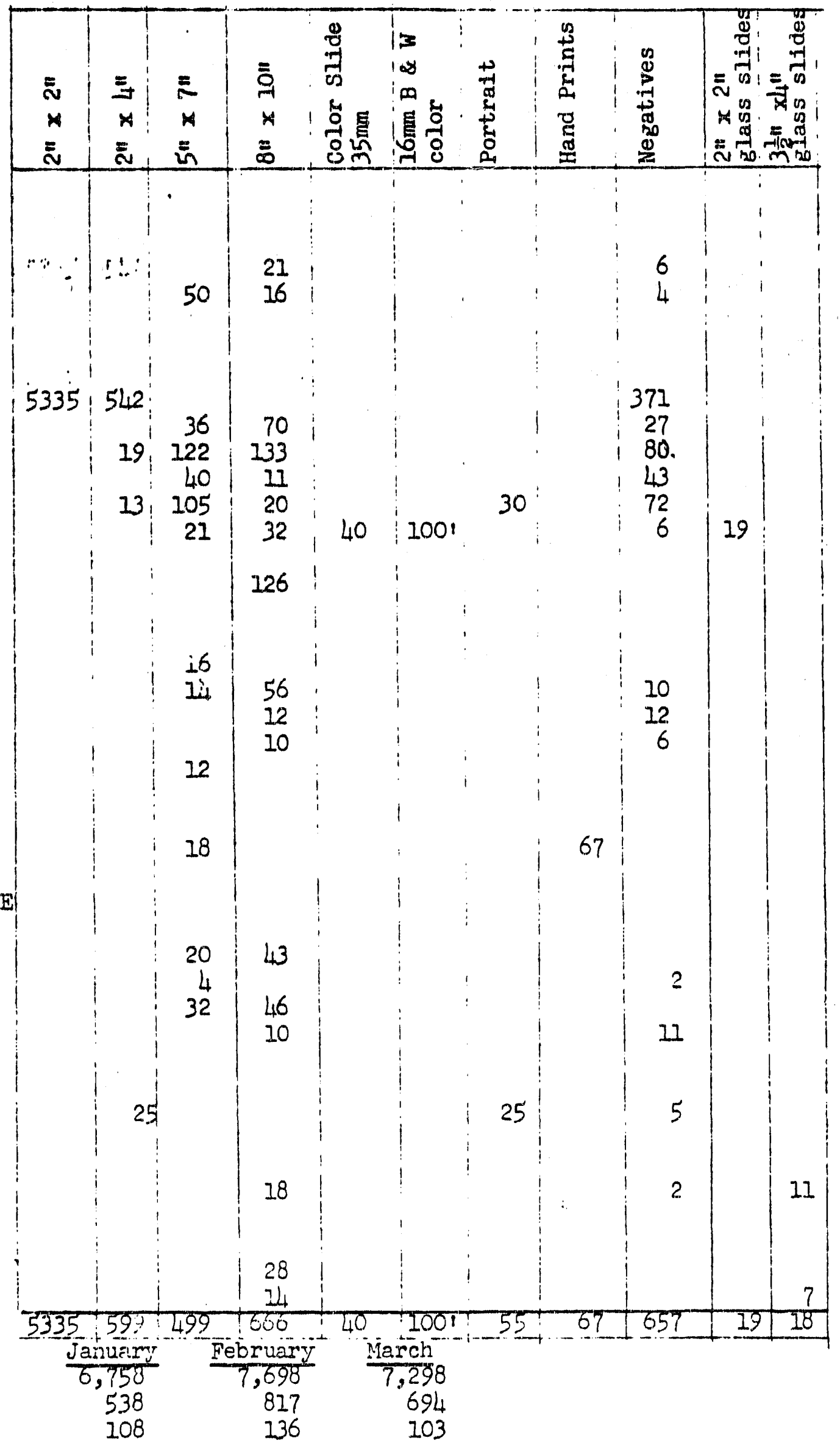




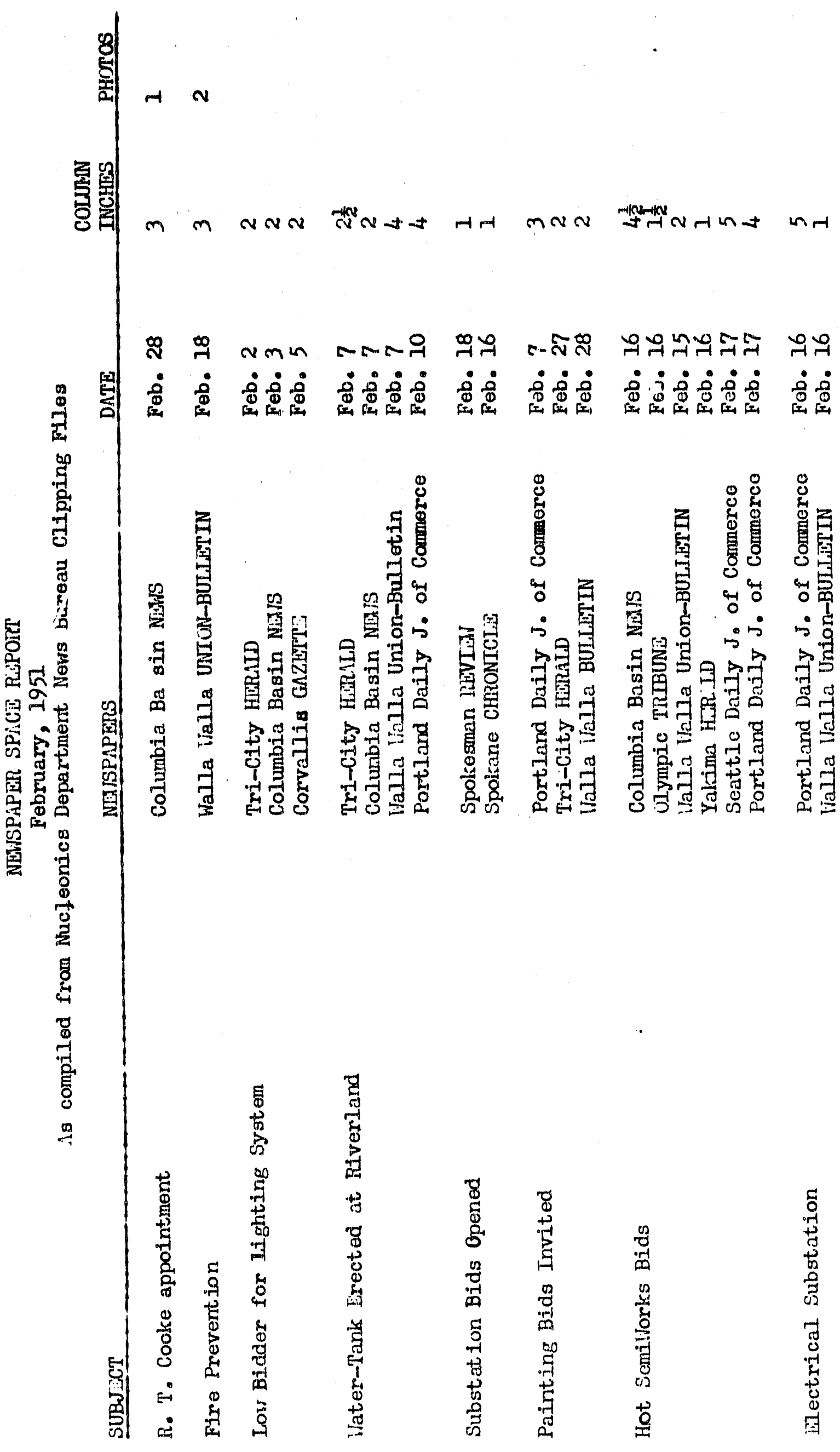




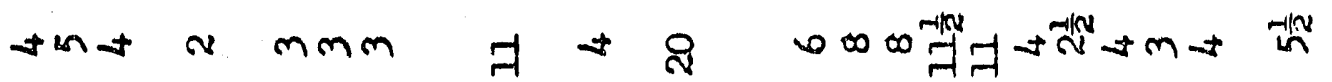

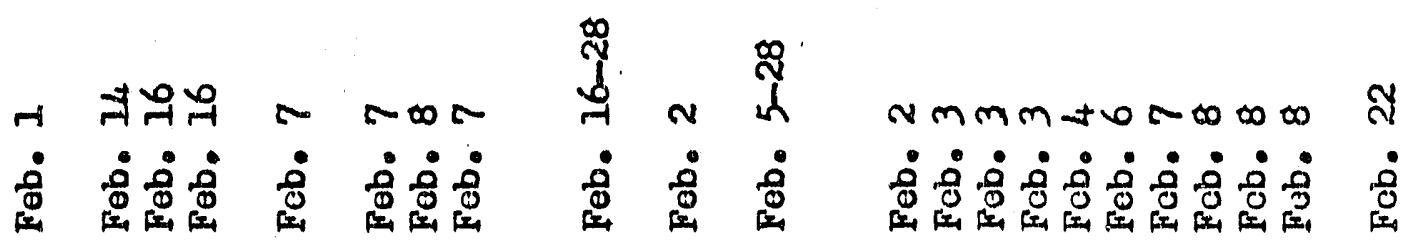
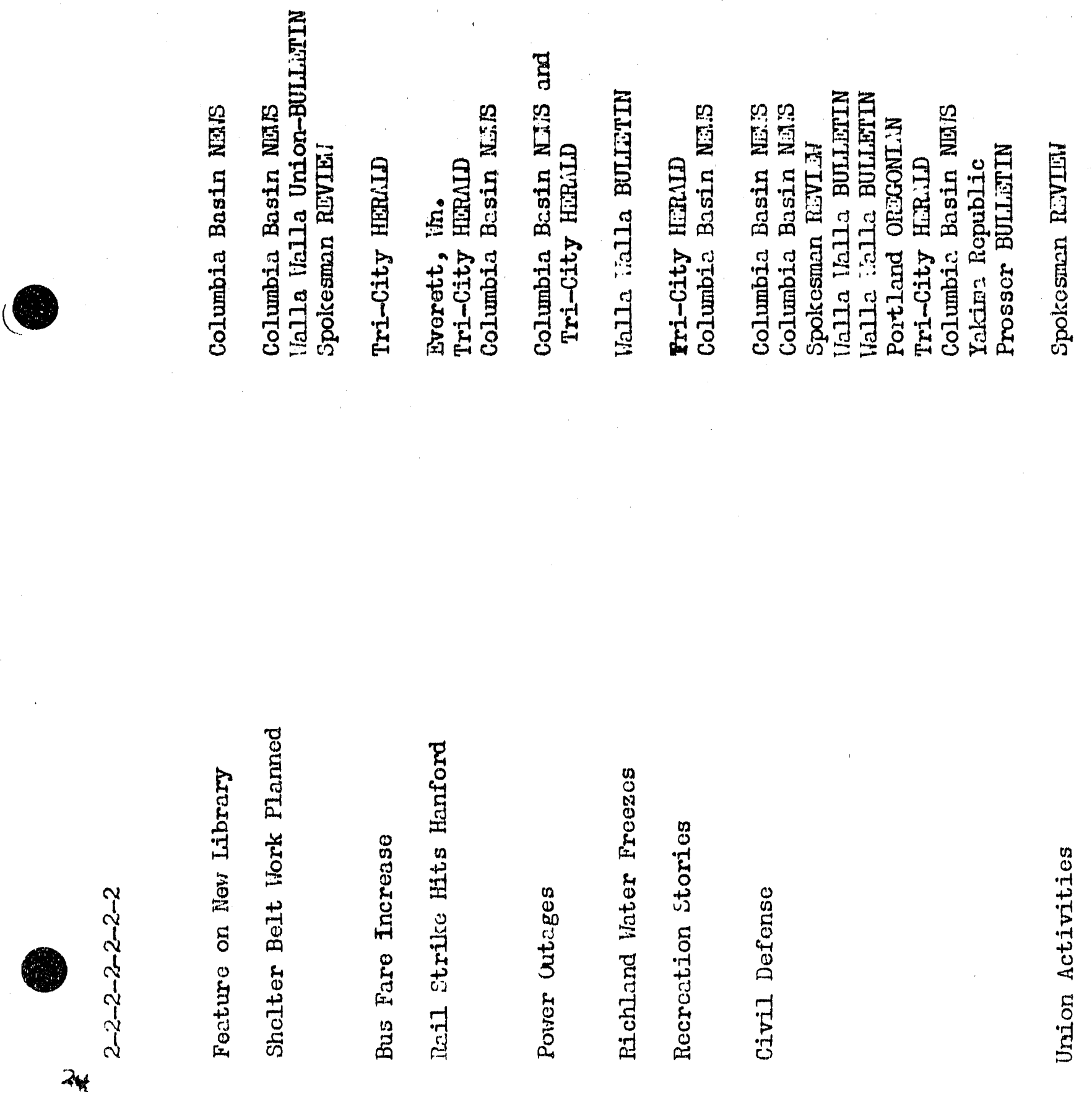
- 4 म ल

m

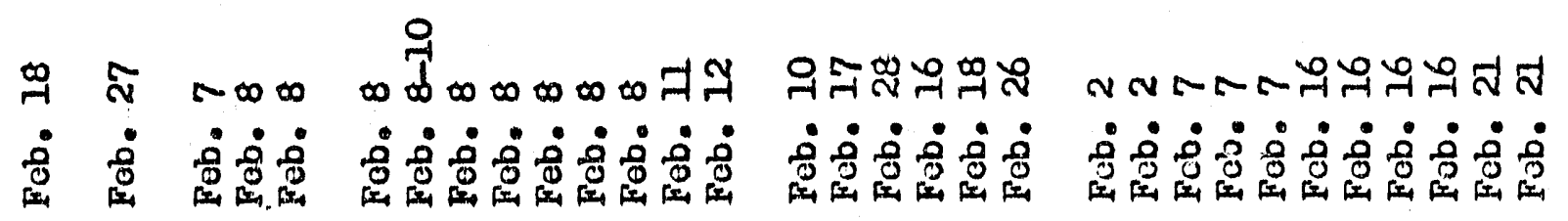

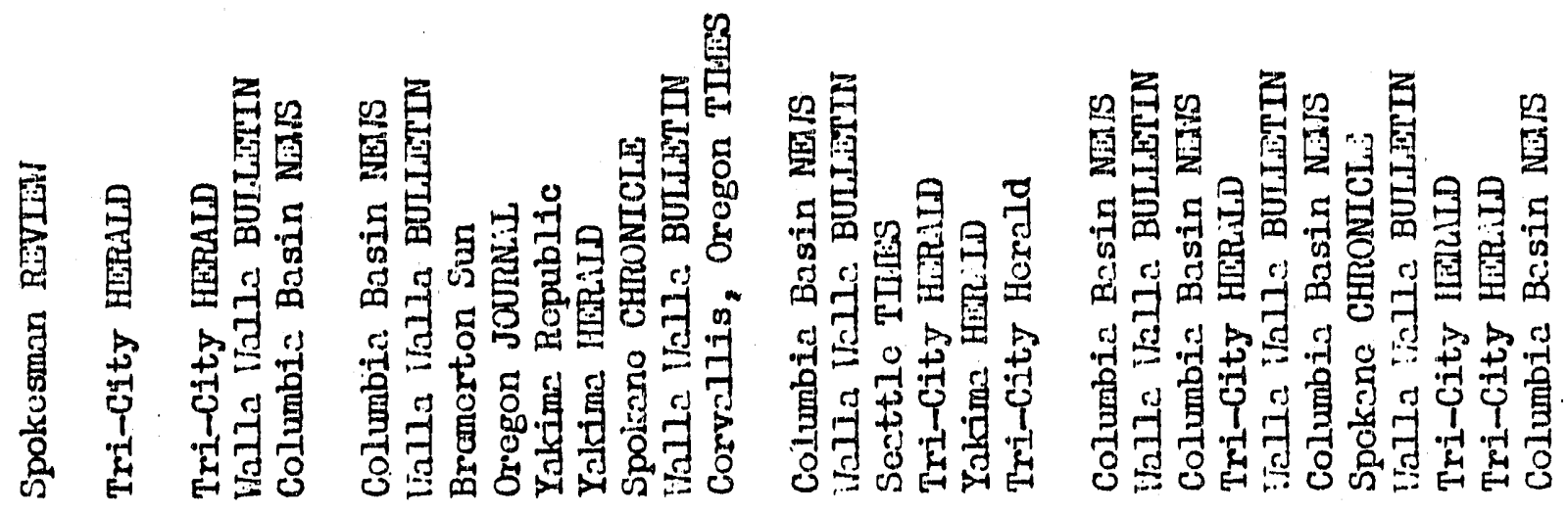

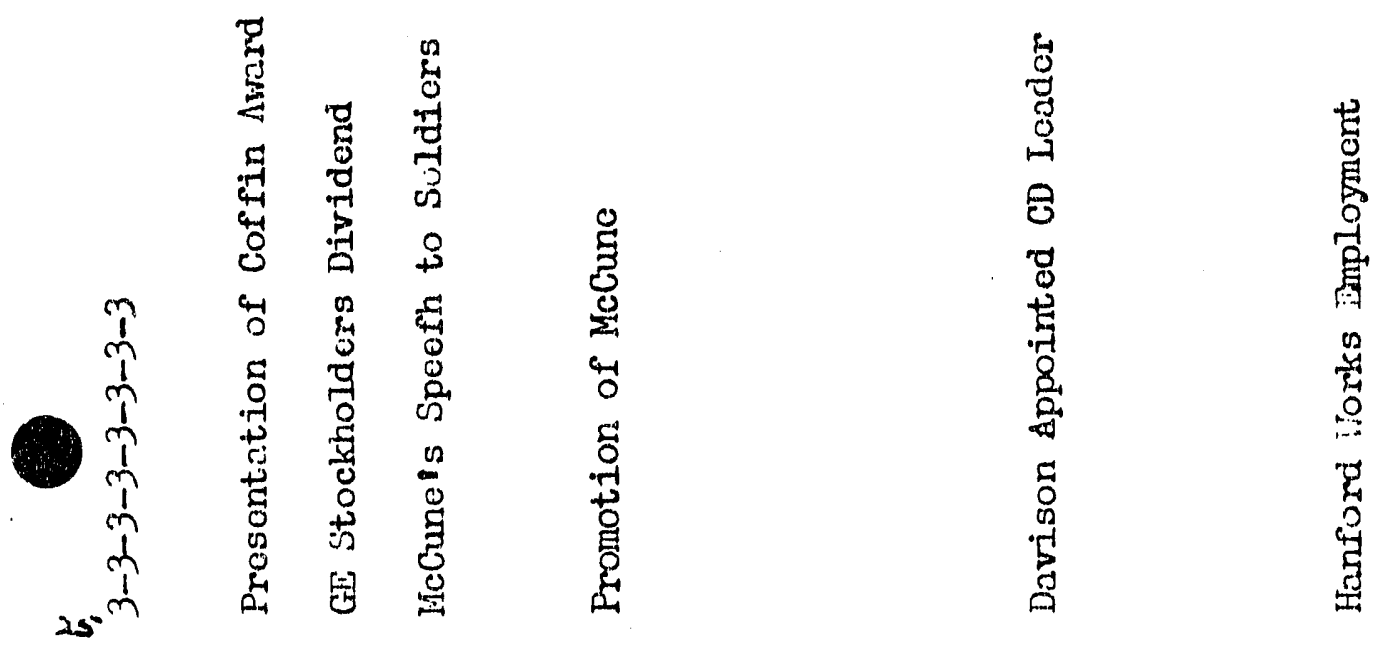


\begin{tabular}{l|l}
-1 & 9
\end{tabular}

$\bullet$

$\infty n+n$ tmm

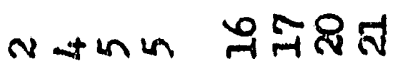

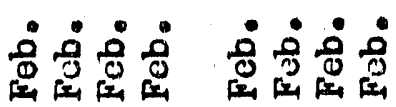

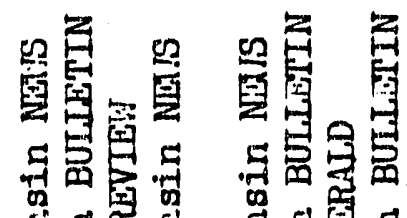

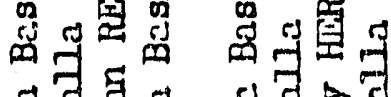

ง

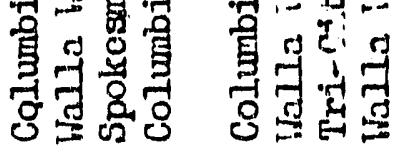

淟

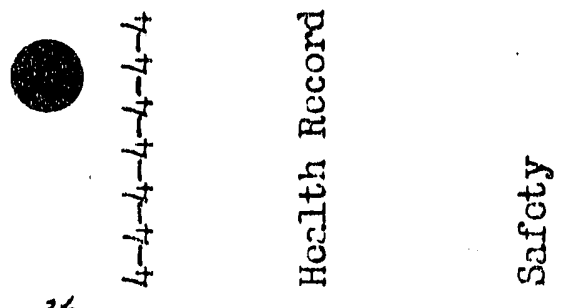


Employee and Community Relations Divisions

Inton Relations \& Wage Rates DIvision

Union Relations - Operations Personnel:

The Nat1onal Labor Relations Boerd conducted an election on March 23, 1951, to determine whether Rlchland and North R1chland Pollce and Plant Securlty Guards should be represented in collective bargaining matters by the International Guards Union of America. The results of the election are as follows:

$\begin{array}{ll}\text { Eligible voters } & 561 \\ \text { Votes for } & 272 \\ \text { Votes ggalnst } & 243\end{array}$

It was significant that the number of non-voters, 46 , was sufflclent to control. the outcome since the union was successful by only 29 votes. At month-end, the Compeny had not recelved appropriate notice of certification from the NLFB conflrming the Guards Union as the bargaining agent.

The Company roceived notice from the NLRB on March 7 that the proposed union shop election, requested by the BAMIC, hao been Indefinitely postponed. This action wes prompted by the NIRB's heving recelved a petition for recognition from the CIO. An examiner spent some time during the month verifying the slgnatures on this petition but at this writing, the Compeny has recelved no offlcial word that the petition wes a valid document.

The NLRB also adrised the Company that they desired a hearing in the case of Village Firemen seeking to be represented by the EAMTC. This heering w1II be conducted on April 4, 1951.

Neither the Company nor the BAMIC served notice of their desire to revise or modify their Agreement prior to the establjshed deadine date of March 16. However, the Council did notify the Company on February 12 of $1 \mathrm{ts}$ desire to open the Contract for wage discussions. No meeting dates have been set.

The Company wes successful in resolving a problem Involving the Painters' Local, that posed serlous complications. The Painters had gone on record as refusing to consider job assignments during any hours except the regular day shift. The Company has two situations where it is necessary that some malntenance painting be accomplished on a swing shift schedule. The Councll had been aslied to concur in this shift arrangement but their inftial action was one of refusel. After two meetings, the Compeny was able to convince the EAMTC that any maintenance craft might be required to work during swing or graveyard shifts but that $1 t$ was our intent to keep such shift work at a minimun. It was also polnted out that production at this plant should not be handfcapped by the refusal. of maintenance forces to perform certain essential work during hours that production $1 \mathrm{~s}$ shut down. It was indicated that if maintenance crafts were to categorlcally refuse to accept job assignments outside of tho day shift, the Company mieht be forced to subcontract such work with the result that a layo": of plant personnel might become imminent. After due considoration, the Painters' Union acquiesced to the temporary swing shift schedule. 
Imployee and Communtty Relat1ons D171sions

\section{Grievance Stat1st1cs:}

Fourteen grlevances wore recelved during the month, bringing the totel recelved this year to 31 .

Grievances were sent in this month from the followlng divisions:

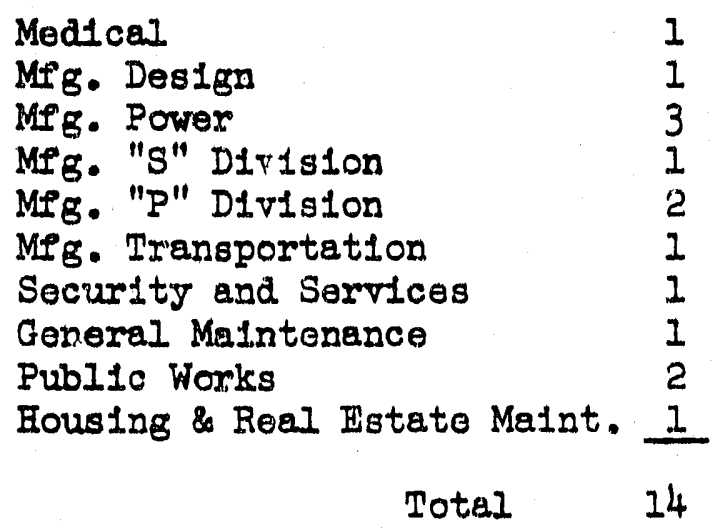

Employee grievence reports recelved were regerding the following subjects:

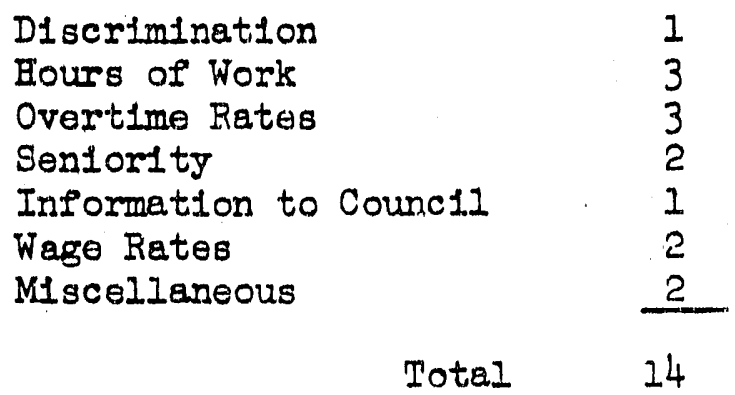

The status of grievances recelved In 1951 as compared to those recelved during the seme period in 1950 is as follows:

$\begin{array}{lcc} & 1951 & 1950 \\ \text { Recelved In March } & 14 & 25 \\ \text { Recelved through March } & 31 & 65 \\ \text { Settled sat1"factorily, Step I in Mar. } & 8 & 10 \\ \text { Pending Step II through March } & 21^{*} & 38 \\ \text { Settled at Step II, through March } & 6 & 17 \\ \text { At arbltration } & 3 & -\ldots \\ \text { *Includes grievances received In 1950. } & \\ & \end{array}$

There were no grlevance meotings held during the month. 
Emplojee and Community Relations Divisions

\section{Union Relations - Subcontractor Personnel:}

Regarding 1solation pay, the Davis Panel requested on March 22, 1951, that the perties attempt to settle the matter by further negotlations at the local level. The Panel further requested a jolnt report of progress on negotiations by April 6, 1951. Negotiations have been tentatively scheduled in Portland on April 5, and 6.

The dispute between Atklinson-Jones and the Operating Englneers regarding two working rules is considered by Atkinson-Jones to be settled on the basls of their letter to the Opereting Englneors outlining company policy. This dispute was orlginally scheduled to be heard by the Dav1s Panel; howevor, at a meeting in New Iork prior to the Panel hearing, it wes declded the matter could be settled at the local level.

Negotiations with the Palnters were concluded on March 14, A tentative agreement was reached granting ten cents an hour effect1ve December 9, 1950, and seven cents an hour effective May I, 1951 (slight varlation in speclalty classifications). A new premtum of flfteen cents an hour was agreed upon for work on swingling scaffold or boatswaln cha1r.

Representatives of Atkinson-Jones and General Electric had a conference in Seattle w1th Wage and Hour author1ties on March 7, 1951; at that time arrangements were established wheroby we were assured prompt decisions on past and future problems. Many questiois remalned unanswered and Atkinson-Jones, for the Contractor's' Negotiat:.ing Ccomittee, agreed to araft a letter incorporating those questions and setting forth all increases granted recently with the request that the Boerd ronder an opinion as to their validitiy under Wage Stabilization Board. regulations.

Manual workers' (Atklnson-Jones) voluntary quits remainod unusually high for the month of March. Below ls the average quits per weels per 1,000 employed:

\begin{tabular}{|c|c|c|c|c|c|}
\hline & $\begin{array}{l}\text { Av. } 8-1-50 \\
\text { to } 2-1-51 \\
\end{array}$ & $\begin{array}{l}\text { Av. Wk. } \\
\text { Enälng } \\
3-9-51\end{array}$ & $\begin{array}{l}\text { Av. Wk. } \\
\text { Ending } \\
3-16-51\end{array}$ & $\begin{array}{l}\text { Av.Wk. } \\
\text { Ending } \\
3-23-51\end{array}$ & $\begin{array}{l}\text { Av. Wh. } \\
\text { Ending } \\
3-30-51\end{array}$ \\
\hline $\begin{array}{l}\text { All crafts } \\
\text { Ironworkors } \\
\text { Sheot Motal Workers }\end{array}$ & $\begin{array}{r}6.5 \\
8.5 \\
10.0\end{array}$ & $\begin{array}{r}15.2 \\
34.7 \\
5.1\end{array}$ & $\begin{array}{l}11.9 \\
14.5 \\
25.6\end{array}$ & $\begin{array}{l}15.9 \\
39.7 \\
15.8\end{array}$ & $\begin{array}{l}17.5 \\
18.5 \\
26.7\end{array}$ \\
\hline $\begin{array}{l}\text { Plumbers and Stoam- } \\
\text { Iltters }\end{array}$ & 6.3 & 20.9 & 14.3 & 25.8 & 16.4 \\
\hline
\end{tabular}

On September 11, 1950, Atkinson-Jonos (on advice of counsel) refused to comply with the NLRB ordor relative to the Hewes' case. The NLRB, by letter on March 13, 1951, to tho Ninth Circult Court of Appoals, has set machinery in motion to onforco ccmpliance.

It has been reported that the Teamster's will hold representation and union authorlzation elections in the noar future. 
Thmplojeo and Communtty Relations Div1sions

Requests for Relmbursement Authorlzations handled during tho month:

1. Asbestos Workers - Wages (G.E. has withheld recomendation for

2. Carpenters - Wagos

3. Ironworkers - Wages

4. Roofers - Premium Pay for P1tch or Other Irritable B1tuminous Matorfal

Reimbursement Authorlzations recelved during the month:

1. Carpenters - Weges

2. Ironworkers - Wages

Work Stoppages - Actual or Threatened:

The Plumbers' refusal to handle material for Farly Company on the basls of (I) plpe fabricated by men pald less than prevalling on the Project, and (2) I1ttings fabricated by non-union shop, continued in March. Upon request of Monterey (Tarly plping subcontractor) the Local Jolnt Board heard this matter on March 2. Their decision was that the refusal was correct, the men were not to handle the plpe.

Nozzles fabrlcated by the U.S. PIpe and Supply were declared "hot" by the Plumbers' Business Agent on March 7. This refusal to handle was based on the allegation that fabrication was performed by men paid wages Jess than those provaling hero on the Project. On March 7, Early Company compromtsod the matter with the U.A., and on March 8, the Business Agent released the fittings, pipe and nozzles. Terms of the compromise were:

(a) "... on any future 1toma under U.A. jurisdiction that can be fabricated on the job and at ou option wo elect to have fabricated elsewhere, we wil.I send a U.A. member at Union. travol pay, wages and expensos, to superviso fabrication."

(b) "We will not fabricate in our Oakland or Torrance Shop any naterlal for this job unless we use Pasco U.A. local men."

(c) "In the event wo contract for any additlonel tank farm work in Hanford....above shell apply."

On March 28, Plumbers walked off the Early job because of certain work belng assigned to the Bollermakers. They returned to work on March 30, the Bollermakers continuing the work.

On March 9, 1951, Stocmfittors employod by Hanley \& Compeny refused to handle hood bases, etc. Ficrcoils advancod: (1) hoods woro fabrlcated in Portland at wages less than thoso provaline on tho Projoct, and (2) fabricated by Machinists rather than Fitters. The Jolnt Bsard heard this matter on March 16 and decided: (1) the Fittors would install hood basos, and ( 2 ) in the future, the piping on such units will. have to bo done on the Project. 
Bay Company (mechenical subcontractor of Hoffman Company) is antlolpating difficulty with the Plumbers Union over certaln stainless ateel pipo currently belng febrlcated by Western Plpe and Engineoring, San Francisco, on a Generel Electrle Purchase Order. In a call to this off1co on March 19, the Plumber's Businoss Agent objected to "G.T. pollcy" of utlilizing vendors on the basis of: (1) violation of Dav1s-Bacon, (2) violation of the terms of the Washington State Agreement, and (3) violation of furisdiction between Bullding Trades and Metal Trades Un1ons." The att1tude of the local offlce of the U.A. regarding Installation of ulpIng, eto. fabrlcated elsewhere, is of such magnitude and potential seriousness that this offlce is making every effort to bring about a satisfactory solution as expeditiously as possiblo.

On Merch 5, 1951, oleven Operating Englneers omployed by Atkinson-Jonos Minor Construction on the $24 I-U$ tank farm refused to comply with an order to remain in the area during working perlods. A work stoppege resulted, and the Operators were teminated by the contractor. Through their Business Agent, these men llstod conditions as necessary for a return to work: (1) the order bo resclinded, (2) payment for lost time as a result of the dispute, and (3) the crew not be split ip. A resumption of work was accomplished on March 8 by the transfor of Operators from other jobs to the tank farm. Orlginally, AtkinsonJones beld that they had exorolsed a management prerogative in discharging these men and refused to resolnd the order or make paynent for time not workod. But on March 13, It was agreed that the eleven wen Involved would be put back to work and Atkinson-Jones further agreed to hendle the clalms of the eleven men under the Disputes Article of the contract. (This offlce has insisted to Atkinson-Jones that the atter is not subject to the Disputas Article).

During March, the Cement Finishers Union refused to furnish men on AtkinsonJones' requisition. Reason set forth by the Union for this action was Atkinson-Jones' refusal to rocognize January 1 as the effoctive date for their increase from $\$ 2.20$ to $\$ 2.40$ an hour. Atkinson-Jonos has been dilatory in bandling this matter, and is bolng pressed by General Electric to conclude 1 t.

A comparable situation occurrod with the Ironworkers Unton. They refused to furnlsh men unt1l agreed-to increases were actually placod into effect. Atkinson-Jones has been diletory in handling this metter, and is being pressed by Genera: Eloctric to conclude 1 t.

Atkinson-Jories has been Informed by the Puget Sound Sheet Metal Works, Seattle, that there is strong possiblilty of a strike developing in the Metal Trade Industrles beginning Apr11 2. Two crefts, Bollemakers and Welders, who very probably will be involved, are employed in this shop. This Atkinson-Jones' vendor is to furnish material and erect 19 tanks. This offlco is prepared to assist in the event an actual work stoppage occurs.

A threatened strike with the Rocfors on March 1 wes sucessfully avolded by Atimson-Jones. Rucicon for the Union's action wais bocause thoy were fallines to recelve a higher rato whlla applying hot pltch rooflng matorlal. AtkinsonJones conducted a survey regardine this hieher rate, and a Request for Roimbursoment Authorlzation for $\$ 2.50$ an hour while handling pitch or other irritable bituminous material was rocelved from Atkinson-Jonos on March 2.2 and forwarded to the Comission March 26, 1951, with this off'1ce's recommendation for approval theroof. 
throloyee and Comiminty Relations DIVIsLons

\section{Wage Rates:}

The annual Northwest Area Wage Rate Survey was conpleted. The report 1Ilus. trating the results of this survey 1s belag printed as of this date for distribution to the particlpating firms in approximately one week.

A special survey to obtain rates pald Designers and Draftsmen throughout the Pac1f1c Coast area was completed during this month. The survey included thirty-s1x established architecturel englneerlng firms. Th1s report indicated that General Hiectrlo Company rates are out of line with area rates. As a result of this study, steps are being taken to obtain approval of the Wage Stablization Board to increase the rates of Design and Draftsman classlfica. t1ons. The reliet is being sought under Generel Wage Regulation 176 as a "rare and unusual case."

In this connection, a Fislt wes made to Seatti, offices of the Wage Hour and Publ1c Contract D1V1sion, Department of Labor, to confer with officlals regarding wage stablilzation problems. A certiflcation wes obtained from the Department of Employment Securlty that a serlous menpower shortage exists in this area and that the General Electric Company should have rate rellef for Draftsmen and Designers.

As a supplemental effort to alleviate the rate diffioulties in these olessiflcations, a request for a ruling by the Wage Stabilization Board as to the exlstence of a plan on January 25, 1951, for granting merit increases to Designers.

In cooperation with the Techn1cal. Personnel office, classiflcations and rates were established for a new program involving the employment of college junlors during the sumer months. Under the program, these studonts would be hired for the sumer months at the starting rate of elthor Laboratory Assistant "A" or Englneering Assistant " $B$ ", doponding upon their asslgmment.

A request for approval of a new classiffcation, Chlorinator Serviceman, was prepared for submission to the Wage Stablilization Boord. This proposed classlification has the concurrence of the HAMTC and 15 dosigned to proporly classify the men servicing chlorinating equipment.

Rovised job description manuels reflecting the $3 \%$ hortzontal increase of September 18, 1950, for all unit personnol were 1ssued durling the month.

The study of all non-unit clerical jobs in the Medical Division has been completed. In a fow Instances whore personnel change日 were under Imodiate consideration, recommendations were acted upon. Other recommended reclassiflcations will be acted upon shortly.

Negotlations with roprecentatlvos of the HAMIC rognrding Instrument Speclallst work was conducted periodically jurlne tho month. Write-ups of all work performed by oraftsmen in the Instrument Iilvision were submitted by foremen and reviewed by HAMTC roprosentatives, Wage Rate and Instrument Division supervision.

Information was assembled concorning petrol personnel for use in checking the Rlchland and North Rlchland Pollce and Plant Securlty Patrolmen in connection with the election conducted by the National Labor Relations Board on March 23. 
Imoloyee and Commulty Relations Divisions

Insurance, Workmen's Compensation and Suggestion System :

Suggest1on System

Total Since

February, 1951 March, 1951

$7-15-47$

Suggest1ons Recelved

$\begin{array}{cc}124 & 168 \\ 160 & 103 \\ 45 & 22 \\ \$ 410.00 & \$ 220.00 \\ 2,043.08 & 1,854.12\end{array}$

6415

Invest1gation Reports Completed

Awards granted by Suggestion Comitteo

Cash Awards

Ist Imated Sevings

$2,043.08$

$1,854.12$

The largest single award made during the month of March was to an employeo in the Eleotrical DIv1sion for h1s suggestion concerning a grease cun filled. With Aquadag to be used in the installation of the electric heater ellements on Hood 19 furnaces. The proposed method saves on labor and is an improvement in the workmanshlp of the job.

\section{Iife Insurence}

Code Information which is known only to Home Offlce Iffe Underwriters Assoclat1on has been furnished 58 insurance companies and Invest1gation agencies during the month of March, 1951. Th1s is in accordance with an arrengement whth the Underwriters whereby employees on this project might be Insurod on the same basis as those working elsewhere.

Insurance Statistics

$$
\text { February, 1951 March, 1951 } \frac{9-1-46}{2}
$$

Claims reported to the

Departinent of Labor

and Industries

57

135

4215

Claims reported to

Travelers Insurance Co.

7

$5 *$

490

* Of the above clalms reported during March to the Travelers Insurance Company, all were property damage clalms. 
MUNICIPAC, REAL ESTAIM AND CHWVERAI GMRVICES ACCOUNMING DIVISION

MOPIHIY REPOEMI FOR MARCH, 1951

ORGANIZATIION

Mrmployees - Beglnning of month
Transfers In
Transfers out
New Hires
Texminat Ions
Total end of month
Renns

House Leases Processed

Merch

February

Total actlve leases begtrinting of month

Brempt

Male

10

1

$\frac{27}{32}$

Femele

$\frac{22}{32}$

1

32

New leases

$\begin{array}{r}5,722 \\ 85 \\ 128 \\ \hline\end{array}$

5,715

Oancellat1ons

Total active house leases and of month

5,689

67

Modffloat1ons

15

5,722

16

Dormitory

Total occupancy beginntag of month

1,020

988

New as algoments

Removelis

161

136

123

91

Total occupancy end of month

1,045

1,020

Rental Reverue was as follows:

Equipment
Houses
Bas1c Rent
Electrlc1ty
Water
Steam
Bormltory
Fac1lity
Baslc Rent
Blectrlc1ty
Water
Steam -
Ut1lit1es - Electrical

$\$ \quad 18.80$

$\$ \quad 18.80$

$196,605.90$

$48,300.20$

$7,986.16$

$1,861.08$

$14,113.05$

$26,392.56$

$3,433.92$ 490.00

$7,053.15$

$1,808,28$

$198,292.79$

$48,554.66$

$8,039.70$

$1,780.80$

$13,967.86$

$\$ 308,063.10$

$29,636.55$

$3,433.92$

490.00

$6,724.69$

$1,837.73$

$\$ 3.12,777.50$

TEILPEONE

Number of work orders processed

Number of worictug telephones 
ORGANTZATION AND PIERSONINEL

Number of employees on roll:

Bes. of Month End of Month

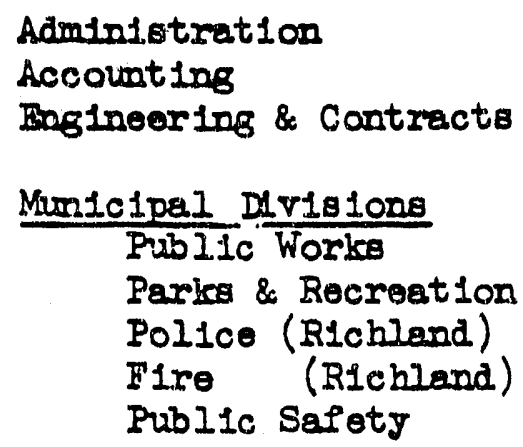

12

13

32

34

32

34

(zotal 226)

Real Eatate Divisions (Total 217) Eousing \& Real Estate Meintenance Commercie]. \& Other Property

(Total 217)

(Total 129)

Steam \& General Maintenance

Patrol (North Richland)

Fire (North Richland)

\begin{tabular}{rr}
79 & 77 \\
19 & 20 \\
34 & 32 \\
\hline 600 & 2.51
\end{tabular}

There was a decresse of aine employees in the Divisions during the manth of March, 1951.

\section{GENERAI}

The Richland Investment Compend building comenced operation on March 30 , 1951, with the following usinesses as sub-lessees; McKay's Varlety store, The Wren House, Wlley's Shoe Repair Store and an optometry office operated ij Dr. Cherles A. MoCartiney.

Total Housing applications pending - 508 .

EARoot/jak

$4 / 11 / 51$ 
Nunlcipal, Real Estate and Ceneral

Services Accounting Division

MISCELIANTEOUS

March

February

Involces prepared durlag month

Revenue derlvod from Involces
$\$ \quad 6,115.26$
346
$\$ 6,344.67$

\section{GEMVRAL}

Sixty-one collection letters were wrltten resulting in the collection of fifty-nine delinquent accounts were colsucted.

Yakime Adjustment Servlce

\begin{tabular}{|c|c|c|}
\hline $\begin{array}{l}\text { Previously submitted } 47 \text { accounts } \\
\text { Submitted in March } \\
\text { Collected by Yaktma Adjustment Service } \\
\text { Collected by General Electric Company }\end{array}$ & $\$$ & $\begin{array}{r}732.65 \\
-0 .- \\
58.68 \\
87.84 \\
\end{array}$ \\
\hline Balance Agency Accounts & $\$$ & 586.13 \\
\hline
\end{tabular}

Fifty-four of the seventy-three active telephone accounts delinquent thirty days or more as of February 28, 1951, were paid during the month,

\section{ACCOUNTS PAYABLE}

Stat1st1cs

Accounts payable vouchers

Freight B1lis processed

Purchase orders recelved

Net amount of purchase orders

Recelving Reports recelved

Total net:amount disbursed

Number of checks 1ssued

A sumary of Active Subcontracts 1s shown below:

Subcontractor

Newland Cafeterla

RIchland Maintenance Co. West Coast Painters Co

Assoclated Engineers

Grant, Algot $C$.

Pachard P1pe \& Pump Co.

C\&E Construction CO.

F. O. Repine Co.

Pasco Electric Co.

Erwen, Edmund $P$.

Baldwin-Dunham Co.

Roof Service, Inc.

Commerclal Paint. \& Dec. Co.

Patton \& H1II
Subcon. Amount

Number Awarded

$\begin{array}{rr}-\cdots-. & 170.30 \\ \cdots-.- & 167,898.18 \\ G-219 & 63,037.91 \\ G-305 & 126,133.65 \\ G-318 & 26,956.59 \\ G-326 & 12,336.00 \\ G-328 & 173,575.45 \\ G-329 & 29,263.00 \\ G-331 & 7,035.70 \\ G-334 & 16,000.00 \\ G-343 & 652,080.00 \\ G-350 & 59,879.00 \\ G-353 & 19,600.00 \\ G-360 & 8,100.00\end{array}$

$G-353$
March

372

27

126

$\$ 33,21.1 .17$

$288,637.22$

270
February

$27 \varepsilon$
22
92
$\$ 20,937.78$
126
$209,775.10$
210

Paid Thas Month

$$
\begin{gathered}
11.80 \\
7,189.58 \\
4,291.64 \\
22,434.16 \\
-0- \\
3,807.00 \\
-0- \\
-0- \\
351.79 \\
-0-
\end{gathered}
$$

$185,285.14$

$3,848.49$

$-0-$

$-0-$

$1,362,065.78$
Total

Amount

Pald Retalned

$$
\begin{array}{r}
170.30 \\
167,898.18 \\
63,037.91 \\
136,017.76 \\
23,100.54 \\
5,976.22 \\
165,644.44 \\
3,950.50 \\
7,035.70 \\
-0- \\
350,157.72 \\
3,848.49 \\
-0 . \\
-0-
\end{array}
$$

$-0-$

$-0-$

$-0-$

$7,158.83$

615.00

664.03

$8,678.77$

438.95

$-0-$

$-0-$

$32,604.00$

427.61

$-0-$

$-0-$ 
Mantcipal, Real Estate and General

Services Account1og DIvisicn

$\underline{\cos T}$

Reports

The February Operating Report was 1ssued March 19. 1951. The Comptroller Approprlation Report and Supplenental Report were 1ssued on March 15, 1951. The February Ut1lities Report was 1ssued Narch 27, 1951. The Construction Budget Status Report was 1ssued March 16, 1951.

Budget

Meetings were held with DIv1sion Managers, AEC Offlce of the Budget and the AEC Office of Communty Management concerning each detalled Divisional Budget. This method of approsching the budget, approving as it is complled has been very beneflicial to Budget preparation.

Service Orders

QUANTITY (A) IABOR COSTS

Code Feb. Mar. Feb. Mar.

11,375

2 2,922

3533

$\begin{array}{rrr}4 & 4 & 5 \\ 5 & 274 & 278\end{array}$

358

$\frac{15}{4811}$

$$
1,272
$$

2,665

$\$ 2,616.95$

$3,374.30$

$1,180.79$

3.32

735.21

901.95

73.85

$\$ 8,886.37$
$\$ 2,489.05$

$3,056.42$ 724.10

4.50

630.21

$1,179.50$

$\$ \frac{31.85}{115.63}$
MATERTAL COSTS

Feb. Mar.
TOTAL COSTS

Feb. Mar.

Difference $(B)-517$

Average Cost (C)

1.62

$-770.74$

$\$ 2,101.69$

$4,571.02$

$\$ 2,360.01$

$4,545.10$

946.31

-0 -

$-0-$

1.554 .45

$1,081.93$

548.52

325.92

$\frac{50.62}{\$ 9,786.11}$

11.84

$\$ 4,718.64 \$ 14,849.06$.

$7,945.327,601.52$

$2,363.20 \quad 1,670.41$

3.32

$$
4.50
$$

$2,289.66 \quad 1,712.14$

$1,2,7.87 \quad 1,728.02$

$124.47 \quad 43.63$

$\$ 9,493.71$

$\$ 18,672.48 \$ 17,609.34$

$-292.40$

$1.79 \quad 1.91$

3.41

$-1,063.14$

1.63

(A) Quantity covers the number of Service Charges made since each Service Order

3.54 often Includes several charges.

(B) Over $(f)$ or Under (-) Previous month.

(C) Average material cost increased even though the actual service order count was lower than previous month.

1 Plumbing

2 Electrlcal
3 Heat \& Vent.

4 Glazing $\begin{array}{ll}5 & \text { Iock \& Key } \\ 6 & \text { Carpentry }\end{array}$
9 Sheetmetal

(n)
Work Orders

\begin{tabular}{lcccc}
\hline & January & February & March & Net Change \\
\cline { 2 - 2 } & 285 & 288 & 286 & -2 \\
Active Normal & $\frac{2,920}{3,205}$ & $\frac{2,974}{3,262}$ & $\frac{2,610}{2,896}$ & $\frac{-364}{-366}$ \\
& $1,44: 0$ & 1,578 & 1,289 \\
W. O. Recelved & $\frac{1,548}{-108}$ & $\frac{1,521}{57}$ & $\frac{1,655}{-366}$ \\
W. 0. Completed & $\frac{1}{57}$ &
\end{tabular}

GENEFAI LEDGER

No. Debit

Second Class Involces Received

Şecond Ciass Invaices Issued
78

97
$\$ 486,895.05$

$245,614.97$
$\$ 228,827.85$

$95,998.76$ 


\section{ENGINEERING AND CONTRACTS DIVISION \\ MONTEILY REPORI \\ MARCH 1951}

ORGANIZATION AND PERSONNEL

Number of employees on payroll

Exempt Non-Exempt Total

Febmuary 28, 1951

March 31, 1951

18

16

34

$20 \quad 1.4 \quad 34$

ENGINEERTNG SECTION

Report on extended engineering service requests:

Completied during March

ESR-97-CH Electrical and struotural inspeotions

ESR-98-CH Alteration inspections

ESR-118 $\mathrm{CH}$ Aprerove alteration permits

ESR-1.59-CH Survey work to check tenant drainage

$$
\begin{aligned}
& 5 \\
& 2 \\
& 4 \\
& 1
\end{aligned}
$$

The following engineering service requests were completed and closed out:

ESR No. Title and Remariks

402-FW Wright Avenue from Thompson to Duportail: Closed out 3-26-51.

453-CF Recreation Hall Alterations

474-PR Hrating System - 1125 Warahouse

476-CF Heating -- Seattle First National Bank

477-RM Relocation of Access Panels in $U$ and $V$ Houses

486-RM Relocation of Partition in Housing office

490-RM Ranch House Roofs

508-RM Prefab Rehabilitation -- Part I.I

520-RC Study Veterinary Site: Closed out 3-30-51.

533-MU Grade for Sewer Iine, Men's Dorms: Closed out 3-9-51.

535-MM Surface Treatment -- Goethals Drive between Giliespie \& Knight:

Closed out $3-26-51$.

Progress report on ESRs that w1ll become projects:

ESR No. Title and Remarks

112-CH Study Sagging Floors in $M, Q, R$, and $S$ Houses: Temporarily deferred for other work. $75 \%$ complete.

262-CA Water and Sewer to Assembly of God Church: This has been combined with Chief Joseph Sahool fire protection; however, since these projects are from two different budget items, it was decided to separate the projects. Marager's approval is being prepared by Riblic Works.

303-CH Study Excessive Settlement of Precut Houses -- Floors: Temporarily deferred for other work. $40 \%$ complete.

314-CH Rewiring Tract House I-901: Information requested from Housing Division 3-26-5I. 40\% complete. 
Engineering and Contracts Division (continued)

ESR No. Pitle and Remarks

341-SS Roads and Walks - 700 Area: Project proposal and cost estimate prepared.

458-SS Floors, Foundations, Load Factors in 700 Area Buildings: Work progressing. 25\% complete.

468-sS Ilghting Study - 703 Bullding: 90\% complete. Project proposal, cost estimate, and results of survey have been prepared.

479-PW Fire Protection for Chlef Joseph School: Approved by Manager, Municipal, Real Estate and General Services Divisions; also by the A \& B Committee. It has been subritted to the AEC for approval.

484-SS Sprinkler and Fire Alarm System -- 703 Building: 98\% complote. Recommendation roport being reproduced and assembled.

492-MF New Central Fire Station - Englneering and Design: Decision to continue this work to be made by A. J. Delong.

500-RM Exterior House Painting - Divisions II, III and Ranch Houses: Deferred for other work.

506-RM Vent Covers, $U$ and V Houses: Doferred for other work.

509-MS Fire Prevention Protection Survey, Dormitories M-9 thru M-1l.: $50 \%$ complete. Work progressing.

524-SS Addition to 721. Building: Work progressing. 5\% complete.

525-SS Remove Building 720 and 720 Hutment: Work progressing. 25\% complete.

526-SS Floor Covering for All Permanent Buildings in 700 Area: Scheduled for $6-20-51$.

527-SS Permanent Iighting - 700 Area Permanent Buildings: Preliminary investigation started. $1 \%$ complete.

531-RC Heating Depot Cafe - Bus Depot: Study scheduled for completion $5-3-51$.

538-SS Remodeling 712-A Bullding: 75\% complate. Project proposal submitted 3-19-51. Plans and specifications completed.

543-RC Removal of Pre-School Nursery Building: Scheduled for rompletion $4-12-51$.

Private Construction Progress Report (Plans were reviewed and regular field inspections were made in compiance with building permit requirements.)

Catholic Church Site: Awaiting information. 
Engineering and Contracts Division (continuert)

Reorganized IDS Church: $75 \%$ complete. Work progressing slowly.

Northwest United Protestant Churoh: 95\% complete. Work progressing slowly. Westside United Protestant Church: 30\% complete. Work progressing slowly. Assembly of Cod Church: T\% complete. Work progressing slowly.

First Baptist Church: 2\% complete. Construction temporarily stopped.

Episconal Church: Awaiting information.

Redeemer Iutheran Church: 90\% complete. Work progressing.

Ohristian Science Society: Awaiting information.

Richland Laundry and Cleaners Addition: 99\% complete. Final Inspuction to be made.

Addition to Masonic Temple: $90 \%$ complete. Work progressing.

Outdoor Roller Rink: 21\% complete. Construction started again 3-26-51.

Free Methodist Church: Avaiting information.

Richland Lutheran Church Front Addition: Comnents transmitted to A. J. Delong $1-3-51$.

Richland Investment Company Building: 95\% complete. Work progressing.

Recreation Hall: 100\% complete. Final inspection held 3-20-51.

Desert Inn (Improvement Fund): Plans are being reviewed.

Status of "C" Type Projects (Over $\$ 20,000$ ) is as follows:

C-232 Contractor has resumed work on area: patching, spot seeding and routine

Pt. 2 watering. The area near the school on the southeast side was damaged by a water line break on the fire loop. This area will be reconditioned by project forces. (Carmichael Junior High School)

C-282-R Crass Seeding - Columbia Playfield: Contractor has resumed work on area and will proceed with lawn seeding. Contract time may necessarily have to be extended if cool weather continuos and retards growth of grass stand. Site grading in this area complete with exception of small section around the pump house, which will be done when the fence around the pump house is changed.

C-351 Irrigation of Pub-ic Grounds:

A. Frankfort Playground: Irrigation system is complete with the exception of lowering heads. 


\section{Einglneering and Contracts Division (continued)}

B. Hiverside Park: Irrigation system 1o complete and is being operated. Contractor"s work complete except balancing and adjusting gr stem.

C. Marcus Whitman Grade School: Irrigation system complote axcept for balanoing and adjustment of system and lowering of heads.

C-356 Recreational Facilities and Equtument for Sniools and Iriblite Grounds:

A. Restroom-Memorial Park: Construction started 3-2.3-51. 5\% complete。

B. Recreation Enulument (Prefabrioated): Instailation $90 \%$ crmplete.

C. Reoreation Equipment (Fleld Construction): 75\% completa.

C-363 Rehabliltation of Puefabs: Construotion 75\% complete. Revised cost estimate prepared for 633 prefabs.

C-382 Well 1700-D, Duke Well Fleld: Work by subcontractor hes not boen resumed since it wes requcsted that same be nuspe:neded 0.2 2-8-5I due io change in size of pump eguipment to be instailei. Tho large $2000 \mathrm{gm}$ furp and motor whtich ary furnished by the contractor irere recelved diarIng this pariod. The construction of the rechaige bastn for this project was completed. The work was performed by the General Eloctric Construction Division. Work will be resumed by the subcontractur as soon as negotiations can be completed by the Contract Section with the subcontractor on the adjustment of price increase for installaticn of larger equipment. A directive modiflcation requesting extension of time has boen pr spared.

C-387 Interior Painting of 16 Dormitories: Work started 3-1-51; appraximately $14 \%$ oomplete. Modiflcation of directive requested to extend time.

C-400 Ro-roofing, Siding, Painting - 700 Area Bulidings: Work started $3-21-51.5 \%$ complete.

C-408 Additional Erosiun Control and Shelturbelt, Planting: Troti at sewage disposal planc $30 \%$ complece. Plens and specificaticias on vileiterbelt aro in the hande of the Contract section, reasj for processing and letting of bids. 'Tapping of mains and claaring site of terporary construstion will be started cluring tize munth of April.

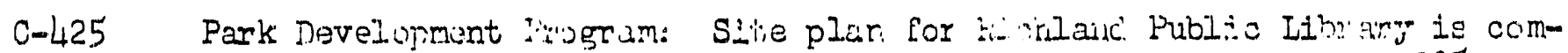

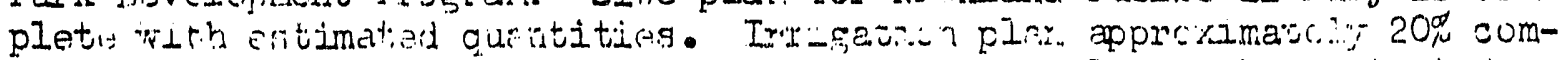

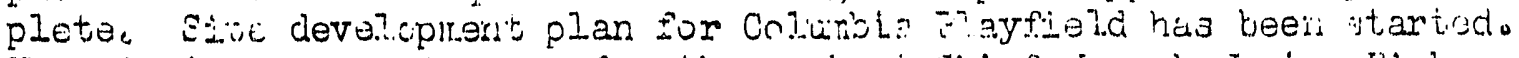

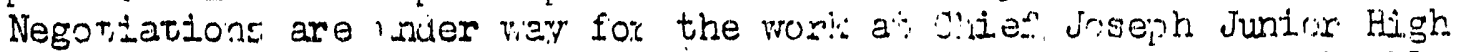
Schorl. Preliminciry planting studios ilava ojen compluted on Richlard Public Iibrary, Spalding Playground, Marsus Whitman Flayground, Frank-

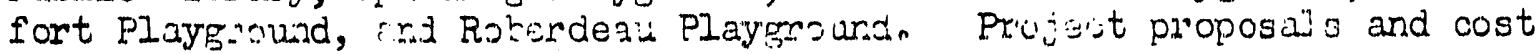
estinatus hrote bifen propined.

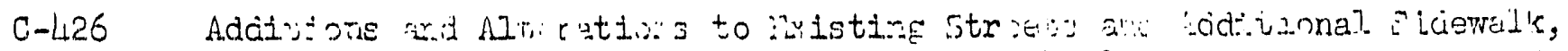

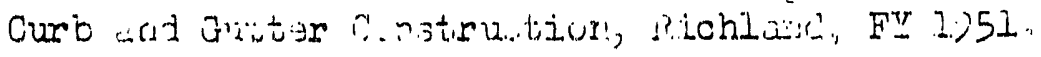

A. Van Gieien: Iesign complnted with exception of fow elevations to be Ironed cut. Illans lave bcen approved by the Maniapal Divisions. 
Engineering and Contracts Division (oontinued)

B. Wright Avenues Design wark completed wath exception of cheaking and approvals.

C. Symons Street: Topog and oross sections plutted.

D. Ceorge Waikingtion Way (South): Fleld work under progrese; plans and proflle completed. Oross sections 70\% plotted. Bularice cf' work be... ing processed.

E. Swift Boulevard: Topog and oross sections plotted.

F. George Washtni, ton Wily (North): Field roties Leing procesecd.

G. Chief Juseph Junior High School; Topog plotted.

C-436 Rehabilitation of 380 Prefabs: Foundation replacements and water sorvice alterations started. Letter requesting transfer of funds written and request for directive modification prepared. Cost estimates prepared.

C-437 Rehabilitation of 328 Prefabs: Cost estimatiss prepared.

The status of "g" projects $(\$ 5,000$ to $\$ 20,000)$ is as follows:

\section{S-255-B Grass Seoding}

A. Frankfort Playground: Reseeding will be necessary in a large prrtion of the area.

B. Marcus Whitman: Site grading $95 \%$ complete. Lawn seeding will be done the first ten days in April.

S-299 Radio Commication System for Fire Department: Contract sent to Motorola for approval.

S-321 Steam Pits to Dormitories: Plens bat.ng rerised.

S-333 Air Conditioning in Dormitories: 100\% comilete. Construction compittion notice issued 3-19-51.

S-350 Improvement of Iighting in 70; Builuting; ifiterial scheduled for deIivero 4-5-5.

S-362 Waten Service Altaration to Prufabs: 100\% comiste. Construction uomploti in acitice to be issusd. Letter requesting irangfor of iunds prepared.

S-379 Interion Fainting of Prefabs: Specificatiors cumlete. Iist of bid items to be issued $3-j 0-j z$.

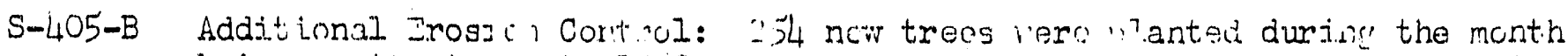
bringirg tirs toin to I vo. with tis adraice sí erowing weatier, it in probale thats this work will be curtailed before the end of April.

$$
-5-
$$


Enginearing and Contraots Division (continued)

S-415 Hosp1tal Soft Water System: B1ds were opened 3-7-51. It was dotermined after opening of bids that adequate funds vrere not approprlated for construotion of the project. The awarding of this contract is being held up pending approval of additional funcis.

S-443 Repair of Docks and Outside Statrs - 700 Srea Butldings: Project prom posal and cost estimate preparod.

S-450 New Fencing - Riverside Park: Preparing plans and specifications.

S-469 Site Preparation - 703 Building: Project proposal preparc and submitted to B. R. Hennigar.

Tho status of "I" projects $(\$ 2,000$ to $\$ 5,000)$ is as follows:

I-017 Renovation of Tract House NN-1040: Fleld Release \#I issued 3-22-51.

I-307 811 Tator Iine, Guthrio-williams: Bids opened 3-7-51. It wes de'uerminud after opening of bids that adequate funda rero not appropriated for construction. The arrarding of this cuntract is heing held up pending approval of additional funds.

I-330 Heating "T" Typo Houses: Rough draft of specifications transmitted to 1i. T. Binns 3-23-51.

I-483 Fire Damage Repair - 1313 Potter: Field Reloase \#I is sued 1-31-51. Plons and spesic'ications complete.

I-51.2 Humphreys Street 811 Water Main -. Wright to Wirslow: This project has been completed and final inspection reports submittod.

The status of "K" projects (under $\$ 2,000$ ) is as follows:

K-535 Sirface Treatment - Goethals Drive: Fiold Release \#1 iscued 3-12-51.

Review of plans and specifications for $\lfloor$ EC and other divigions is as follows:

ESR-50I-fEC Jason Lee Elamentary School: 95it complote. Some contract work to be done. Staked biliting line and elevation.

ESR-541-EC NCw Pio-Assay Laboritory Construction irrwings: Plans ruviewed $3 m .30-5 \mathrm{~L}$. 
Englneering and Contracts Division (oontinued)

\section{CONTRAOT SEOTION}

0-356 Fence and Backstop, Oolumbin Playfield: Specifications rertged. Bld opening soheduled approximately 5-10-51.

C-356-R Columbia Blayflold Iighting System: Notfoo to prooeaci givon Witzig Elootric Company 3-27-51.

0-357 Additional Capasity - Sewago Lift Station: Partial shipmert of material schedu".ed for arritral 4-9-51.

C-353 Rehabilitution of Prefabs: Work hns progresserl to anproxinlately 80\%

C-436 of completion. Modification to include .80 units approved by AEC 3-23-51 and subocmeractor is proparing suhedulo.

Water service alteration approved 3-16-51, HW DIrective No, 228, Nod1floation \#1, and is bing added to Assoozated Hrginears: contract.

C-372 Exturior Painting of Houses: Contract suspendod until 4-19-51.

C-382 We11 1100-D, Duke We11 F101d: Negotiatine with subountractor for lump sum price adjustment.

C-407 Bathtub, Tiloboard, and Iinoloum Installation - Conventional Typo Houses: Bid oponting postponed until 4-6-5i.

S-24h Fencing - Wright to Van Giosens Specifications revised. Bid opening will be held approximately 5-10-51.

S-321 Steam Pits to Dormitories: Request for bids delayed pending review for adequacy of funds,

S-366 Exterior Painting Hosnital, Modical-Dontis Building, inunicipal Builaing: Contract and rocuest for aword trorsmitted to fEJ ana recommencisd for award to Colizins \& Babrook, "rrosser, iTashingto"?.

S-379 Interjor Fainting Approximately 675 Preiabs: Contract services requested 4-4-51. Bid cpontng schoduled for 4-ci-51.

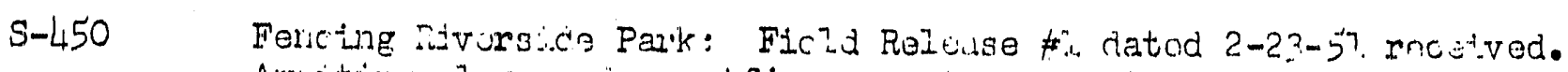

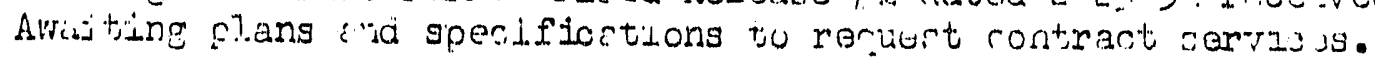

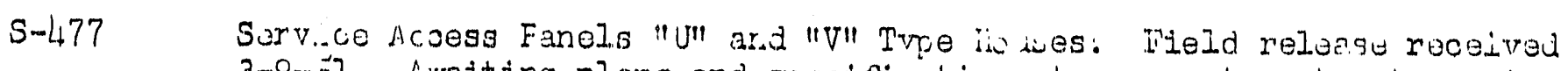
3-9-jl. Awating plans and specifications to roquest contract services.

S-485 Exterior Paintire; - 2i.3 Holsus: Bids ard to b s opered 4-17.-51.

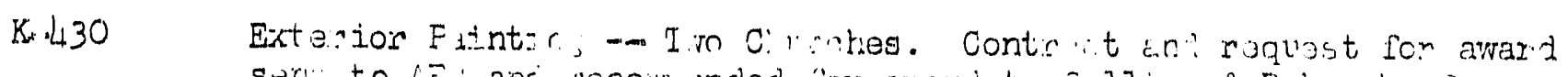

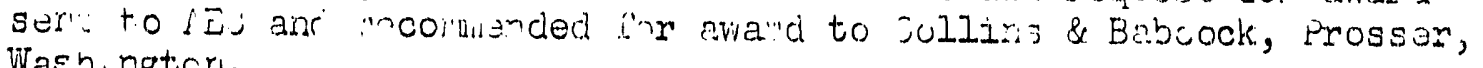
Washngtcr. 
Englnooring and Contracts DIvision (continuod)

Im-312 Humphies 8n Wator Matn - Wright to Van Glosens Flold roloase dated 1-26-51 recelved. Contract of Assooluted Engineers beling modifled to inolude this work.

I-330 Heatling Equipment in "T" Type Housea: Flold release datod :-26-51 recuived. Awalting plans and speolfioations to requeut coritract services.

I-353 Resurface Tennis Courts: Fleld release datod 3-19-51. recelved. Awating plans and spocific aitions to recilost cuntrac serva ies.

ImLO4 Fenoling Barth Flaylot: Specifleations rorisod. B1d opentne will be held appr oxtmatuly $5-10-51$.

Durtidg the month of Merch, six o voontraotors vrere engaged in wark in Ritohland and payments to suboontractorg during the month totaled approximatciy $\$ 220,018,22$. 


\section{MUNIOIPALI DIVISIONS}

\section{STRMAARY}

NARCH, 1951

ORGANIZATION AND PERSONNEL!

\section{BEGINNTNG OF MONTH}

Eximpt Non-Exempt Exerapt Non-Exempt

\begin{tabular}{lcccc} 
Flie & 53 & 1 & 53 & 1 \\
Parks \& Focieation & 13 & 20 & 13 & 19 \\
Pollos & 16 & 25 & 16 & 24 \\
Public Workg & 19 & 85 & 16 & 81 \\
Pablic Saiety & 2 & 1 & -2 & 1 \\
\hline & 103 & 132 & 100 & 126
\end{tabular}

Since the establishment of the Muniolpal Divisions in September, 1950, at which time 280 assigned employees were working in the Municipal Divilions, a gradual concentration of improving operating efficiency has taken place until at the present time there are 226 employees. This has been accomplished oven thuugh there have been additional responstbilities added to the operation, such as the Library, which n'w empluys seven poople, and there are three empl yees on a full-timo basis loaned to the Civil Defense Organization, which was resrganized in Fobruary.

The present number of employees will constitute our permanent force unless further reductions can be satisfict irily accomplishog. Seasonal grounds maintenance work and twice a week waste collection wil tend to increase the number if personnel employed during the summer months. 
ORCANIZATION AND FERSONNEEL

Preceding Month

Number of Employees on Roll:

Beglnning of Month

New Hires

Transfers In

Terminations

Transfers Out

End of Month
104

1

8

3

13

97
103

2

1

1

1

104

SANITATION

Collection and disposal of garbage and trash was performed accordIng to schedule throughout March. This section has been relleved of the responsibility of picklng up discarded paper and other litter in the commerclal, real estate, and park properties in the down-town and up-town areas, and has reduced its force by one employee through elimination of this duty.

Total weight of waste material collected during March was 889.8 tons, as compared to 841 tons collected in February.

Plans have been completed for re-scheduling of residential collections to a twioe-weels ly basis on May lst, and these plans permit equalization of the time interval between collections on a.11. routes.

EROSION CONTROL

A total of 254 new street trees were set this month, and 302 replacement trees were planted for the Real Estate Division. Burning $c$ if weeds along the drainage ditches and well percolation basin was started and is st111 in process when weather conditions allow. This work is part of the Mosquito Control Program and is at the cost of tree Public Health Division. Sprayine of American In etreet trees vas also star ted this month and cont lnues when wind conditirns permit. Tris conservation program is at the cosi of Fal Ertate Divisions. 
Miniolpai" - Publio Worla

ROADS AND STREETS

Average daytime temperaturea are now conduclve to efflolent workIng of cold-patch bituminous compounds, and crews have started a concentrated program on patching of potholes in streat pavaments.

Removal of excess stone chips from streets that had a seal-coat application in 1950 is now in process and will be completed in April.

Replacement of 10 street markers and 101 traffic control signs was completed during March.

The major part of materlals required for the pedestrian-aotuated traffic signal at the Recreation Hall cross-walk has been dellvered, but installation is awaiting receipt of the push-button box and switches.

Olearance distances under all traffic slgnals have been checked, and those algnals that were lower than accepted standards have been raised to allow a minimum olearance of $14^{\prime}-6^{\prime \prime}$.

Routine maintenance of streets, sidewalks, and storm and surface drainage systems, and street sweeping, continued according to sohedules.

\section{DOMESTIO WATER}

Norma 1 operations continued during March, and average daily water consumption was 5.39 militon gallons per day. This daily consumption is .45 milition gallons higher than February averages, and is an anticipated seasonal increase.

Well 1100-8 was overhauled and returned to service, and Wells 3000-A and $E$ vere overhauled and re-installed. However, a test mun on the 3000-E Well resulted in extremely excessive heating of the rotor of the $2300 \mathrm{~V}$. motor. The entire motor has been removed and sent to the 200-E area motor shop for tests and possible repair.

Water was mun into the 3000 Area Well Field percolation basin on $3-22-51$, and a raise of 10 feet in the water table has been eff'ected by $3-28-51$.

The Richland well field re-charge basin has been cleaned and scraped for more efficient perculation, and this work wes performed in such a manner trist tide basin will also provide a boating and fishine area for children ifter the water has been run in and the resulting lake surscked with fich. 
Municipal - Public Works

DOMESTIC NATER (CONTINUED)

The old hog-wire fence along the west side of Wellsian Way has been removed and it will be replaced by a string of posts which will provide a line of demarcation between the road and the lake area.

Water mains have been tapped and isolation valves installed at several locations to provide water service to new mains installed hy a sub-contractor on the Fourth Housing Addition Project.

\section{Domestic Water System}

Well Production

Million Galions

Richland

North Richlend

Columbia Field 300 Area

$$
23.4100
$$

17.4640

5.7846

\section{Avg. Daily}

Production

Totals

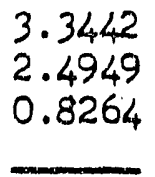

6.6655
Total Consumption Million Galions

32.5548

9.0117

5.6421

47.2086
Avg. Daily

Consumption

4.6507

1.2874

$\underline{0.8060}$

6.7441

\section{SEWERAGE SYSTEM}

Ro atine operation of the Treatment Plants was continued during March. The sludge pump has been packed with rawhide in an attempt to eliminate considerable gland maintenance that has been required on this pump. The control point of the wet well high level alarm has been lowered to allow operators a longer time interval in which to investigate and correct a failure at this point.

The wet well at the Sewage Lift Station which receives sewage from the Swift Boulevard trunk line has been altered to lower the back-up level in this line. This was done to promote a better flow in this trunk line and to elininate development of septic sewrge.

A program for control of root growth in sewer lines through use of copper-sulphate, (which is flushed into the lines from residence toilets), was started this month, and treatment was completed at 450 locetions in Division I.

Approximately $170^{\prime}$ of sewer main and 2 man-holes were installed west of Dormitory $M-G$. This new line and the man-holes replace an old line that vas torn out $b_{i}$ a sub-contractor working on the Fourth Housing iddition. 
Municipal - Public Works

SEWERAGE SYSTEM (CONTINUED)

\begin{tabular}{|c|c|c|}
\hline \multicolumn{3}{|c|}{ Sewerges } \\
\hline $\begin{array}{c}\text { Total Sewage } \\
\text { Flow } \\
\text { Million Gallons }\end{array}$ & $\begin{array}{l}\text { Averagc } D a i l y \\
\text { Flow } \\
\text { Million G. P. D. }\end{array}$ & $\begin{array}{c}\text { Average Rate } \\
\text { Flow } \\
\text { Galse Pur Mine }\end{array}$ \\
\hline $\begin{array}{r}6.460 \\
11.852 \\
\end{array}$ & $\begin{array}{l}0.922 \\
1.693 \\
\end{array}$ & $\begin{array}{r}641 \\
1.176 \\
\end{array}$ \\
\hline 18.312 & 2.615 & 1,817 \\
\hline
\end{tabular}

\section{IRRIGATION SYSTEM}

Water was turned into the canals to the "Penstock" and to North Richlard on 3-22-51, and will be brought into Richland on 4-4-5I.

A $10^{\prime}$ Cyclone fence was installed from the toe of the hill southeast of Carmichael School to the effluent end of the irrigation canal culvert just south of the school, and thence along the west bank of the open canal to a point south of the Masonic Hall. The posts for this fence had been set some time ago, ana completion was accomp lished through a work order to the Minur Constmuction Division. Further protection on the west side of this same canal was provided by installation of a $5^{\prime}$ hog-wire temporary fence from the cyclone fence termination to a point about $100^{\prime}$ south of Sanford Street extended.

AIl pumps and motors in the Irrigation Pumphouses have been serviced and are ready for operation. Testing of the distribution grids will begin as soon as water reaches the pumps, and each system will be placed in service when repairs to lines and risers have been completed. It is anticipated that all pumphouses and grids will be operating by the first part of May. 
MONTEIYY REPORT

PARKS AND RECREATION TIIVISION

March, 1951

ORGANIZATION AND PERSONNEL
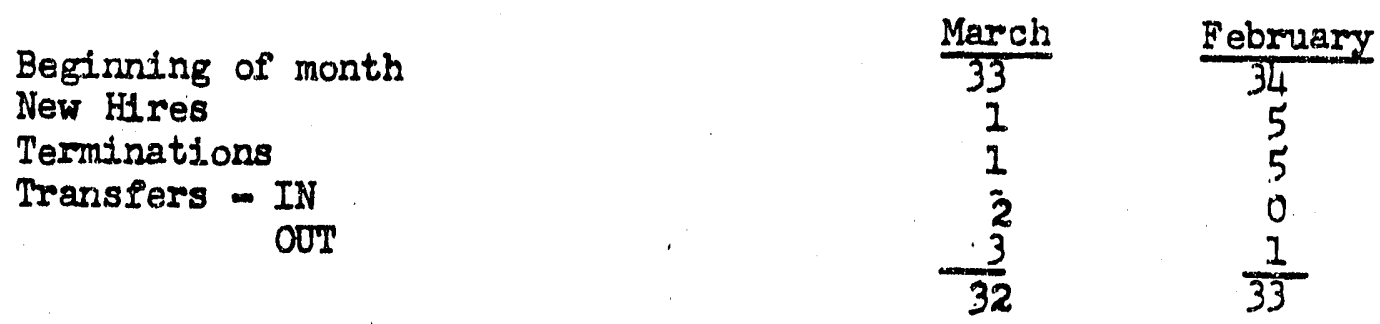

SCHOOLS

The following is a tabulation of full-time paid School District \#400 personnel as of March 31, 1951:

Administration

Principals \& Supervicors $\quad 1.5$

Clertcal 24

Teachers 244

Health Audiometer I

Building Custodians 39

Cooks 40

Nursery School \& Extended Day Care I1

Bus Drivers

Farm Manager

\section{CLUBS AND ORGANIZS.TIONS}

As of February 28, 1951, organizations' personnel, exclustve of those included in the Real Estate-Commercial Facilities Division report, include:

$\begin{array}{lr}\text { Youth Council - Chest } & 1 \\ \text { Boy Scouts } & 1 \\ \text { Camp Fire Girls } & 2 \\ \text { Hi-Spot Club } & 2 \\ \text { Girl Scouts } & 2 \\ \text { Justice of the Peace } & 1 \\ \text { Y.W.C.A. } & \frac{2}{1 I}\end{array}$

The Parks and Recreation Board held its monthly meeting on Thursday, March 8 , 1951, in the reception room of Building $W-20$. The Board recommended that the Y.W.C.A.., as an agency of the Community Chest and co-sponsor of programs with the Parks and Recreation Division, should receive free use of the Community House for activities. The proposed treffic courtesy notice as prepared by the Parks and Recreation Div sion was approved. In order to observe the Community House programs and due to spring vecation it was decided to hold the April meting on March 2:, 1951, in the conference room of the Community House. At this meeting the Wellsian Way Lake boating regulations were approved. 
Parks and Recreation Division

On March 16, 17, and 18, the Women's Tr1-State Amateur Basketbal工 Tournament was held in the gyms at the Columbia High School. The team from Whitworth College of Spokane, Washington was the winner of the Tournament.

The United Churches of Richland held a Sunrise Easter Service in the Bomber Bowl on March 25, 1951. The Parks and Recreation Division arranged for the loan of 200 folding chairs and an amplification system to be used in the Easter Service.

On Friday, March 30, 1951, Safety $/$ wards were presented by Mr. Marion W. Boyer, General Manager for the Atomic Energy Comission to the f.E.C.., General Electric Company, and the Keller Corporation for honors earned among national Atomic Energy Commission contractors in five safety records. The awards were made on the Plaza north of the Post Office Building with the Park Maintenance group providing the temporary platform.

On Saturday, March 30, 1951, the Richland little League members began the installation of cyclone fencing on the Jefferson Playground area. The Parks and Recreation Division arranged for the loan of a government truck equipped with post hole digger for use in erecting the fence.

The number and types of organizations presently served by the Parks and Recreation Division include:

$\begin{array}{lr}\text { Business and Professional Clubs } & 20 \\ \text { Churches \& Church organizations } & 27 \\ \text { Clvlc organizations } & 5 \\ \text { Fraternal organizations } & 24 \\ \text { Music \& Art associations } & 8 \\ \text { Recreation and Hobby groups } & 44 \\ \text { School \& Parent Teachers assoc. } & 13 \\ \text { Social Clubs and organizations } & 17 \\ \text { Veteran \& Military organizations } & 12 \\ \text { Welfare } & 6 \\ \text { Youth Boy Scouts } & 20 \\ & 36 \\ & 49 \\ \quad \text { Girl Scouts } & 10 \\ \text { Miscellaneous } & 9 \\ & 294\end{array}$

RECREATION

Final arrangements were made for the Minnesingers' Spring Concert to be held April 6, 1951, at the Carmichael Jurior High School.

The annual Kite Contest, sponsored by the Parks and Recreation Division, was held at Columbia Playfield at 2:00 PM, Saturday, March 10. Siward certificates 
Parks and Recreation Division

were presented first, second and third place winners in the following events:

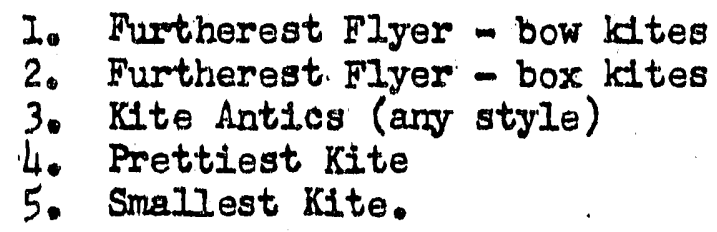

KIte making instructions were given at the Community House Saturday, March 3, at $9: 00 \mathrm{AM}$.

The annuel Easter Egg Hunt was held at Riverside Park on March 25, at 2800 PM. Boys and girls were divided into two age groups; $3-5$, and $5-6$. Twenty-two of the 1,080 eggs were numbered and received prizes. Numbers 1 - 12 received large, fancy decorated chocolate eggs and numbers $13-22$ received 10 tickets each for free rides at the local Mmusement Park.

Eggs were provided by the Riabland Villagers, Ine, Both Camp Fire Girls and Bluebirds participated in fyeing eggs. Boy Scout Troop \#147 patroled the grounds and gave valuable assistance.

The Community House Supervisor surveyed Community Houses in Seattle on March 19.

The Recreation Clerk (female) at Community House was transferred to the Technical Division on March 26, 1951. \& temporary replacement from the Real Estate Division will serve in this capacity until a permenent female worker is employed. It is felt that this should be accomplished by $\Lambda$ pril 16, 1951.

A youth square dance contest ended square dancing until next fall. The activity was held at Lewis and Clark Grade School March 31, for both elementary and junior high school. Award certificates were given to both groups in the Virginia Reel, Waltz, Mixer, Best Set, Varsouvierne, and Shottische.

Attendance figures for the Month of March were as follows:

Community House

Games Room (27 days)

Marionettes ( 5 days)

Juvenile Art (5 days)

Open Craft ( 4 days)

Fly Tying ( 4 days)

Photography (2 days)

Dramatics (5 days)

Servicemen's Center

Columbia Playfield

Kite Contest

\begin{tabular}{rrrr} 
Boys & Girls & Total & Sub-total \\
\cline { 2 - 3 } 3047 & 744 & 3785 & \\
28 & 11 & 39 & \\
9 & 19 & 28 & \\
45 & 10 & 55 & \\
77 & 3 & 80 & \\
49 & $\frac{11}{24}$ & 60 & \\
25 & $\frac{24}{322}$ & $\frac{49}{4096}$ & 4096 \\
3274 & & & 907
\end{tabular}

Particlpants Spectetors

82. 150

232 
Parks and Recreation

Spalding Program

Total Attendance

Sub-total

Badmintion ( 3 sessions)

Co-Recreation ( 3 sessions)

Mens Recreation ( 3 sessions)

Womens Recreation ( 3 sessions)

Fencing ( 4 sessions)

94

78

23

28

279

279

Boys Girls Total

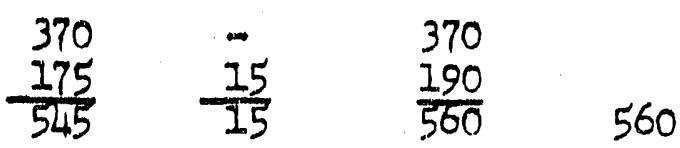

Riverside Park

Egg Hunt - 400 Spectators

Lewls \& Clark SahooI - Square Dancing

Adult Spectators

$3 / 3 / 51$

48

27

53

28

48

27

23

18

$3 / 31 / 51$

10

70
155

300

300

1,000

1,000

$36 \frac{90}{2}$

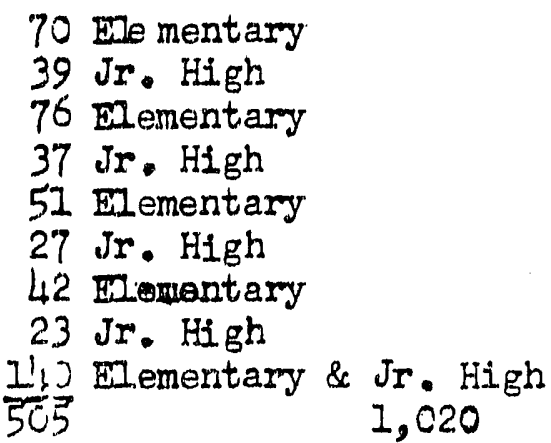

Other scheduled booklngs at Community House for the Month of March show the following useage:

$\begin{array}{rrr}\frac{\text { Booktngs Made }}{23} & \frac{\text { Sttendance }}{3,881} & 3,881 \\ \text { GREND RECRENIION TOTAI } & 11,975\end{array}$

PARK MFINTENLNCE

AlI work assigned to the Parks Mintenance Division on Projects S-255-B and C-351, regrading and sewding Marcus vinitman and Frankfort Playground areas, was completed during March.

Cleaning of the dining room at the Community House was comploted by the Maintenm ance Division in March. Repainting has been scheduled for July, 1951. 
Parks and Recreation Division

The fertllizing and re-geeding of Townsend Court Playground area has been completed.

During the month 13,350 pounds of commerclal fertilizer wes dispensed on the seeded areas of the Parks and Playgrounds.

Irrigation hoses and sprinklers were distributed throughout the Prok and

Playground areas in preparat1 on for the 1951 1rrigation season.

Rout1ne Maintenance of the Parks and Recreation Division baseball and softball. diamonds commenced during the month.

Six Work Orders were issued during the month.

Proposed Work

Percentage Completed

1. SITE DEVELOPMENT
a. Columbla Playfleld (Project I-255)
b. Marcus Whitman Playground (Project S-255-B)
$90 \%$
$9 P \%$

2. IRRIGATION INSTALIATION
a. Riverside Park (Profect C-351)
b. Columbia Playfield (Project C-35I)
c. Carmichael Playground Project (-376)
d. Marcus Wh1tman Playground (Projeot C-35I)
e. Frankfort Playground (Project C-35I)

3. GRSSS SEEDING

$\begin{array}{ll}\text { a. Camichale Playground (Project 332) } & 90 \% \\ \text { b. Frankf ort Playground (Project 255-B) } & 90 \%\end{array}$

4. PRRKING LOT

a. Columbia Playfield (Projoct 255-D) 92\%

5. PLIYGROUND EQUIPMENT

a. Equipment Installed (Project 356-R) 20\%

6. ILYOUT PLANS - Total 31 - 10 COMPLETE

a. Riverside Perk

$15 \%$

\section{PUBLIC LIBRIRY}

In exhibit of Northwest Painters was held by the A.h.U.W. in the North Hall of the Library Building from March 1, to March 12. Severel hundred visitors viewed the exhibit.

The L.tomic Energy exhibit which is to be on display for the opening of the Library, has been installed. 
Parks and Recreation Division

Spproximately two-thirds of the adult books recelved have been processed and one-third of the childrens books on hand have also been processed and are on the shelves in order.

One steno-typlst terminated curing the month.

The Ilbrary Bullding has been released to General Electrio Company with the exception of the attle lighting and welk.

The regular monthly meeting of the ILbrary Board was held on wednesday, March 7.

MAJOR L.CTIVITIES DURING TEE MONTH

March 16-17-18 Women's Basketball Tournament 25 United Churches of Richland, Sunrise Service 25 Farks \& Recreation Easter Egg Hunt

26 Safety Award Presentation

Columbia High Sch. Bomber Bowl

R1verside Park

Plaza 


\section{MUNICIPAL UIVISTONS}

RICHTAND FIRE

March 1951

\section{ORGANIZANIONS AND PERSONIEI}

Present
Month

Number of Employees on Roll

Begirning of the Month
New Hires
Terminations
Transfers In
Transfer's Out
Return From Leare of Absence

$\begin{array}{rr}54 & 55 \\ 0 & 0 \\ -1 & 0 \\ 0 & 0 \\ 0 & -1 \\ \frac{1}{54} & -\frac{0}{54}\end{array}$

\section{FIRE PROTECTION -}

$\begin{array}{llrr}\text { Response To Alarms } & . & 15 & 18 \\ \text { Fire Ioss (Estimatod) } & \text { Ilanforl Works } & \$ 1,181.00 & \$ 39.34 \\ & \text { Personal } & .265 .00 & 0.00 \\ \text { Tctal } & \$ 1,446.00 & \$ 39.34 \\ \text { Investigation of Minor Fires and Incidents } & 18 & 9 \\ \text { Safety Meetings } & 8 & 8 \\ \text { Security Neetings } & 4 & 4 \\ \text { Outside Drills } & 40 & 47 \\ \text { Inside Drills } & 48 & 48 \\ \text { Fire Alarm Boxes Tested } & 184 & 1814\end{array}$

Grass truck dispatched Mirch Ist and 28th to stand by for controlled buming

Grass truck dispatched March 2nd to fill tank at Sewage Disposal Plant. On March 4th one fireman checked an averheated furnace at 1205 Swift.

Two adults and sixteen chizdren from Lrop-A-Tot Nursery conducted on a tour of Fire station N. 1.

Captain gavo fire prevention talk on March 5til to Red Cross class for ten Public Health nurses.

On March $16 t h$ Lieutenant ran pump test at 1131 Garage on Plant fire truck.

On March 2lst twe ...n cilpatched with crnss timek to flush spilled weedkiller solution from liarchouse 6 joading ramp.

Boy Scout exarined for Firemanship merit badge on March 28th. 
Brownie Iroop 8 and three adult leaders conduoted on a tour of Fire Station No. 1 on Maroh 28th.

Assistant Fire Chief and Ileuteriant ohecked heat Indicator at Kadlec Hospltal an March 30th.

S1X offlcer attended HOBSO sessions.

\section{EIRP PREVENTION}

Fire Inspeotions:

700 Area Buildings

1100 Area Bulldirigs

Real Estate Buildings

Municipal Butldings

AEC Airport Buildings

Public Schools

Miscellaneous Inspoction Total.

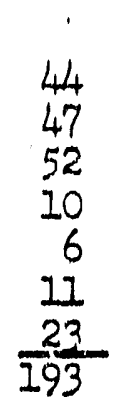

Fire Extinguishers:

Inspected

Refilled

Installed

Relocated

403

11

3

Flre Hose Standplpes:

Inspected

21

Sprinkler Systems:

Inspected

11

Inspection Reports Submitted:

Real Estate

700 Area

$-32$

Municipal

Schools

AEC Airport

1.

Meetings and Demonstrations:

Conducted fire extinguisher demonstration for 14 Real Estate ilaintenance omployces.

Assistant Fire Marshal attended Trafiflc Safety Conmittee meeting.

Fire Marshal attendod 700 Area Civil Defonse meeting in an advisory capacity.

Miscellaneous Activities:

Ey use of adaptiors, National Standard throad fire hos installod throughout Recreation Hall and Community House.

All buildings equipped with fire hose standplpos and sprinkler systerns inspected to obtain data un size of water lines sorving this equipment. Information roport $2 d$ to Accounting Division for cost study.

Special report anbitted on two comnercial ficilities in which managor. tempcrarily refue od to corrent hazards.

Rules drafted permitting residonts to burn yord trash and after approval, submitted copy to ifews Burcau for publication. 
Arranged with Commity and Public Relations DLviaion to provide cortaln photo's of Rlohland's 1950 Fire Prevontion Weok campalgn requeated for publication in "Tosted Activitieg" manual by Fodoration of Mutual. Firo Irisurarsoo Companios.

Quarterly Inspeotion of all R10hland publito sohools rovealod unusua?.1.y good conditions.

Immediate corrections obtained on serious f'lre hazards encountered in old kitohon of Recreation $\mathrm{FIII}$.

Instaliation of cellotex for colings and walls of 712-A Bullading, oontrary to A.E.C. standerda, reported to Plant Safety DIVIsion.

Recommendations submitted for removal or ropair of combustible insulation hanging I0ose undor Rocroation Hall and other butldings.

Bluoprints for renovation of 703 Buflding alarm system and for Instalination of fire dopartment connections on aprinkler systems revilewed by fitiro Marsha].

Recommendations made to Kadloc Hospltal adminiotrator for uso of alternato exits for arargency evacuation. This was necessery because of main exits blocked by prosent construation work.

Automatic exhaust fan recomended for romoving oxplosivo fumed from central ditto rrom in 703 Buildinf.

At request of the bark managar, surroyed National Bank of Commerce for firo oxtinguishor requiramonts.

Advised Installation of standpipe fire hose in Churel of Christ at Swift and Thayer. 
MUNICIPAL DIVISIONS

RIOHEAND POLICD DOPARTMENI

MARCH, 1951

ORGANIZATION AND PEIRSOMNER

Number of Employees on Roll:

Beginning of Month

New Blres

Terminations

Transfers in

\begin{tabular}{l} 
Preceding \\
Month \\
\hline
\end{tabular}

This

Month

44

41

Transfers out

1

1

0

i.

Eind of Month

$\begin{array}{rr}0 & 0 \\ 4 & 1 \\ 41 & 40\end{array}$

GENDEIRAT

Beglnoling Monday, March 5, a representatlve of the Washington State Patrol w1.1. be In RIchland on Mondays and Thesdays from 1 to 9 P. M. to renew and Issue drivers 11censes. In the pest this service has been avallable only on Mondays.

On March 19 the responalbility for the money escort service for the Wurks cashler was transferred to the plant Security and Services D1v1s1on.

On March 26 a group of Cub Scouts was taken on a tour of the Pollce Station.

During the month, the "Patrol" neon olgn on the 770 Bullalng was changed to read "Pol1ce." This is in accord with the cluenge in departmental title.

Organization of the Police Athletic League 1s progiesalng rapidiy. Election of officers was held, and the followlng were elected: President - J. S. Jobnson, Vice President - J. C. Glover, Secretary - A. I. RelI, Treasurer - R. I. Jones, Manager - A. I. Novotny. Coaches from each shlft were also appolnted. A Committee has been appointed to draft By-Laws and a Constitution for the P. A. I. Uniforms were purchased and were recelved the latter part of the month. Iry outs for the team w1ll be held next month.

Durling the month, a temporary pout was establiahed near the Coordinate club to regulate the traffic approaching the Balley Brldge at shift change time.

Durling the month, 264 traffic violation reports were recelved. These consisted mainly of 11 legel parkine and speedine. A total of 110 other reports were recelved. These consigted mainiy of larcery, invertigation and malicious mischief cases.

Durlins the month, a total of 225 letters were recelved, compered to 192 last month. These conglated of 2.11 inquiries on arreats and 1.4 requests for assistance.

Durine the month, 23 prisoners were processed through the Richland Jall. Elever. of these were from North Rlchlard. 


\title{
Rlobland Pollce Department - Contlnued
}

\author{
Durling the month, 29 gun reglstrations were recorded.
}

During the month, 87 bleycle reglstrations were recorded.

\section{TRAFTIC}

The Trafflo Section recorded 25 reportable accldents for Richland for the month of March. Thls amount shows an increase of nine over the preceding month and an Increase of 12 for tho same month last year. No traffle accident fatialitiles occurred within the communtify linits, however, thers were two najor influrles and three ininor Infuries as a result of traffic acclilents. Two of the infurles, one minor and one major, were pedestrians which were strucle by automotiles. One minor lafury was a oblla struck by a car whlle ridins a blcycle. Durling the preceding month, only three minor infurles were caused and for the samo month last year, only two minor injuries occurrod.

Causes of the 25 above accilents were: negligent driving - 7, fallure to yteld rlght of way - 0, following too closely - 5, improper oacking - 4, improper ptising - 1 .

Total property demage was $\$ 3,544,65$. Property danage caused by traffic accldents decreased from an average of \$231 per accident for last month to an averege of $\$ 141$ per accldent this month.

A trafflc safety lecture was given to the Realty Division on March 3 at Dorm W-20 by Ptm. D. F. Metz. A simliar lecture was givun to the Weekly and Monthly Payroll Division groups on March 30.

Meetings with the School Boy Patrol were conducted by Ptm. D. F. Metz at three of the Rlchland grade schools at whlch time new patrol caps and belts were issued to a number of the patrol boys. Frequent checks of the School Boy Patrol's operation were mede during the month. A.60, frequent checks were mede of the tritftc condition around the Columbia High School throughout the month.

A survey was made of all the croscwalks around the priblic gchools and in the downtown area, and en orter was placed to have sowe 80 srosswalks repaintar. Also, the stop lines wero to be repalnted at Williams Boulevard and Goothais Dritre.

The trafilc Ilghts were re-synchronized on both Georee Waskington Way and Goethuls, Drive to give a continuous f'IDW of traffic with a sDe.ed of $20 \mathrm{M}$. P. H, on a green 1.ght in both directicns nurtis anr. soltt:. The same synchronization whs done on

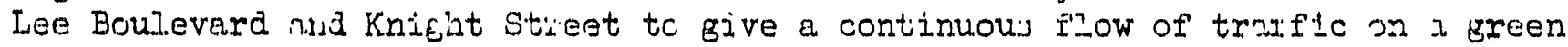

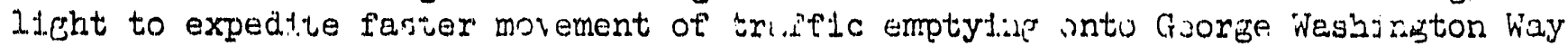
and Goethals Dive. Iine roilining of the light has at run very satisfactosy rosults.

Traffic slgns were placed alung the soutih end of the 762 Buliding parking lot to set up a one hour parrilel farkine zone Thlo also serves as an of'f-street drive for persons to plok uf or discharte pesiengers. Tha tiro hou purking zone within the lot was remeved. Also, ho twe hour parkf: aig ar irer romured from the park-

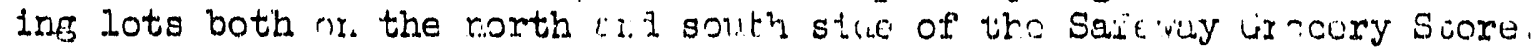

The "Wo Parking - Louding Eone" signs on the south side of the Downtown Thrifty Drug Store were also removed.

Some 47 other traffic signg were lepalr d and replaced throughout the c1.ty. Th1rty seven street miker algas were found 1 n kad repair ard are on order to be replaced. 
R1chland Pol1ce Department - Continued

Four new stop slgns were placed along Wright Avenue where new streets are belng cut through. Thro new pedestrian slgns were placed on each alde of the crossweik on George Washington Way between W1IIlams Boulevard and Symons Street.

A barrlcade of steel posta was placed along Thayer Drive just south of Long Avenue to prevent trafflc from puli1ng upon Thayer Drive over the steep grede to the rear of the Columb19 H1gli School.

\section{TRAIIIING}

Subjects covered in the lieutenant's trafining clasces for the month wero as follows:

$$
\begin{aligned}
& \text { Department Operations } \\
& \text { Observation Tactics } \\
& \text { Pollce Patrolling }
\end{aligned}
$$

Advance training at the small arns range for the pexlod in fleld instruction was as follows:

$$
\text { Plstol } 2 \text { hours }
$$

zualirications on the Army-L Course were as follows:

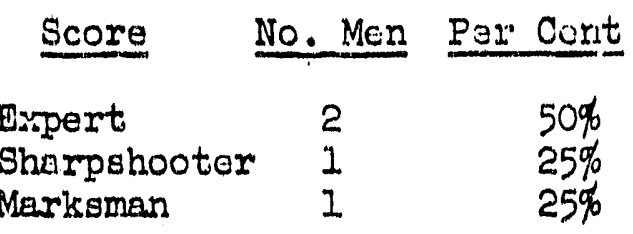

A total of four men reported to the Range for training.

ACIIVITIES AND SERVICES

Doors \& windows found open

Jenuary Februc.ry Narch

Chlldren lost or found

Anibulance runs asolsted

Ambulance driver provided

Dogs, cats reportod lost or found

Dog, cat, loose stocli complaints

Persons infurec by degs

Bonk escorts 8; deta..Is

Fires Investigatod

Miscelilaneous escorts

Complaints investigated

Deaths reported

Articles lost or fourad

Records inqulates

Low enforcoment agenclos is alstec

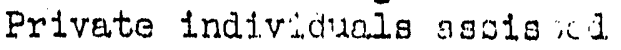

Plant divisione ussioted

Emergency messages delivered

Totals

\begin{tabular}{rrr}
39 & 27 & 32 \\
12 & 6 & 19 \\
29 & 30 & 31 \\
2 & 2 & 4 \\
9 & 9 & 22 \\
65 & 15 & 25 \\
5 & 11 & 30 \\
1.0 & 19 & 12 \\
26 & 20 & 19 \\
19 & 21 & 16 \\
35 & 48 & 44 \\
6 & 1 & 0 \\
31 & 39 & 30 \\
330 & 280 & 372 \\
-1.5 & 6 & 16 \\
10 & 16 & 10 \\
24 & 14 & 20 \\
58 & 67 & 31 \\
\hline 699 & 631 & 723
\end{tabular}




\begin{tabular}{|c|c|c|c|c|}
\hline OFFENSES & KnOWN & UתNOUUNDED & $\begin{array}{l}\text { CLETREST } \\
\text { ARRTSTS }\end{array}$ & $\begin{array}{l}\text { CIRIRRED } \\
\text { OTHER* }\end{array}$ \\
\hline $\begin{array}{l}\text { P.ART I } \\
\text { 1. Murder } \\
\text { 2. Rape } \\
\text { 3. Robbery } \\
\text { 4. Aggravated Asslt. } \\
\text { 5. Burglary-Brk. \& Hint. } \\
\text { 6. Larceny-Over } \$ 50.00 \\
\because \text { Larcent-Under } \$ 50.00 \\
\text { Bike Thert } \\
\text { 7. Euto Theft }\end{array}$ & $\begin{array}{r}0 \\
0 \\
0 \\
0 \\
5 \\
2 \\
15 \\
20 \\
2 \\
\end{array}$ & $\begin{array}{l}0 \\
0 \\
0 \\
0 \\
1 \\
0 \\
0 \\
0 \\
1 \\
\end{array}$ & $\begin{array}{l}0 \\
0 \\
0 \\
0 \\
1 \\
0 \\
5 \\
0 \\
0 \\
\end{array}$ & $\begin{array}{r}0 \\
0 \\
0 \\
0 \\
0 \\
0 \\
3 \\
20 \\
1 \\
\end{array}$ \\
\hline TOTAL PART I CASES & 44 & 2 & 6 & 24 \\
\hline 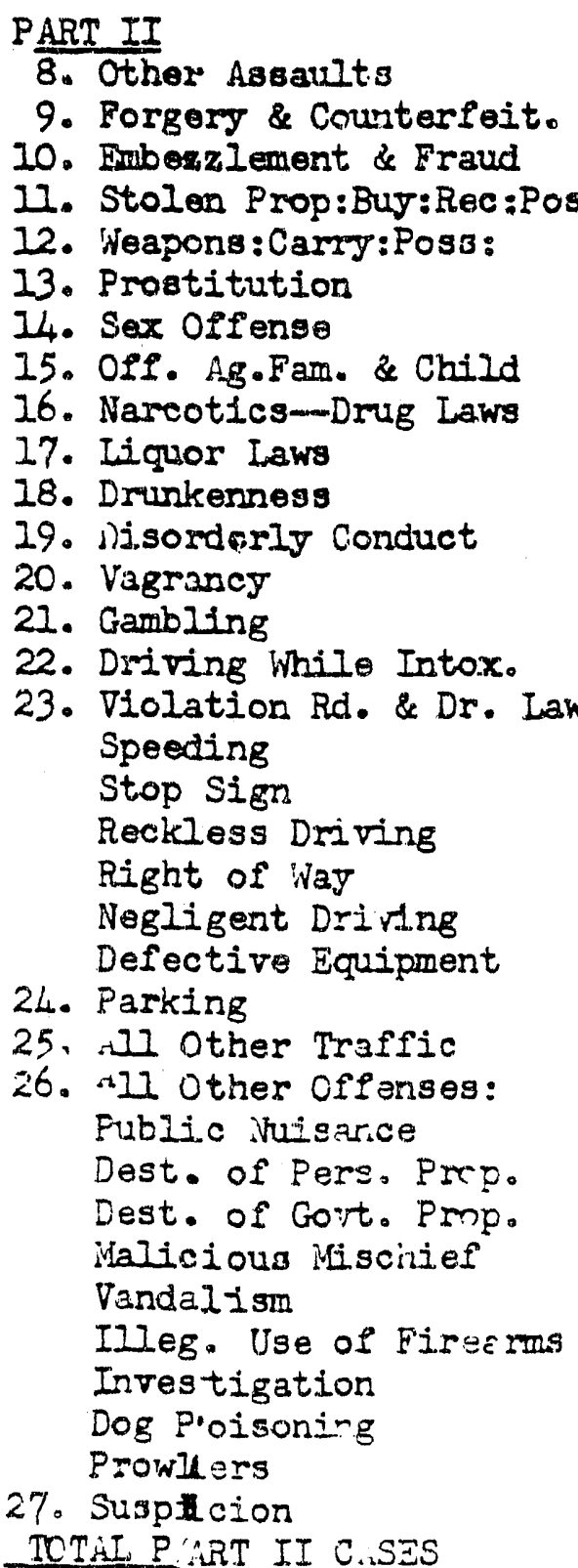 & $\begin{array}{r}1 \\
0 \\
0 \\
3.0 \\
0 \\
0 \\
2 \\
1 \\
0 \\
0 \\
3 \\
6 \\
0 \\
0 \\
2 \\
18 \\
18 \\
5 \\
3 \\
5 \\
19 \\
3 \\
242 \\
26 \\
\\
3 \\
3 \\
1 \\
12 \\
9 \\
1 \\
4 \\
1 \\
5 \\
1 \\
282\end{array}$ & $\begin{array}{l}0 \\
0 \\
0 \\
0 \\
0 \\
0 \\
0 \\
0 \\
0 \\
0 \\
0 \\
0 \\
0 \\
0 \\
0 \\
0 \\
0 \\
0 \\
0 \\
0 \\
0 \\
0 \\
0 \\
0 \\
0 \\
0 \\
0 \\
0 \\
0\end{array}$ & 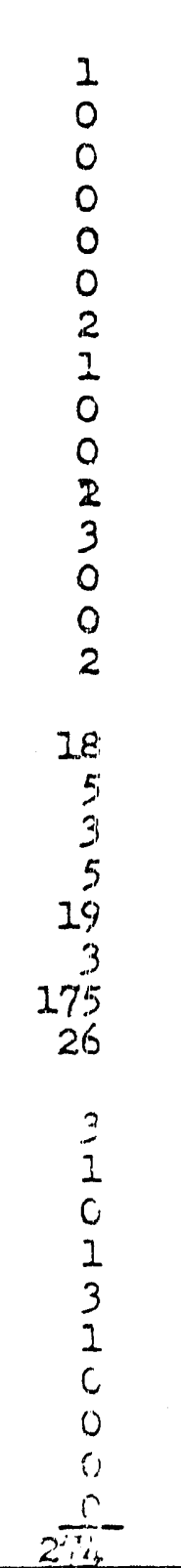 & $\begin{array}{r}0 \\
0 \\
0 \\
0 \\
0 \\
0 \\
0 \\
0 \\
0 \\
0 \\
0 \\
1 \\
3 \\
0 \\
0 \\
0 \\
0 \\
0 \\
0 \\
0 \\
0 \\
0 \\
0 \\
0 \\
07 \\
0 \\
0 \\
0 \\
0 \\
0 \\
4 \\
4 \\
2 \\
0 \\
0 \\
4 \\
0 \\
0\end{array}$ \\
\hline
\end{tabular}
(Cont. on Page Twe) 


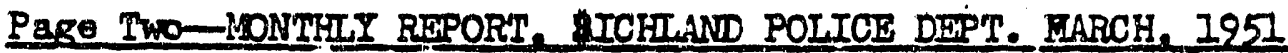

\section{OFFENSES}

KNOWN UNFOUNDED

\section{PART III}

\section{Kissing Persons}

Iost Persons

Lost inimals

Lost Property

29. Found Persons

Found inimels

Found Property

\begin{tabular}{rr}
7 & 0 \\
13 & 0 \\
8 & 0 \\
7 & 0 \\
3 & 0 \\
5 & 0 \\
19 & 0 \\
\hline
\end{tabular}

\begin{tabular}{rr}
0 & 7 \\
0 & 13 \\
0 & 8 \\
0 & 7 \\
0 & 3 \\
0 & 5 \\
0 & 12 \\
\hline
\end{tabular}

TOT.I PART IIT C.SES

62

0

0

62

P.RT IV

30. Fatal Mot。Veh.Traf.icc. O

31. Pers.Inj.Mot.Veh. Traf..cc。 4

32. Prop.Dam.Kot.Veh.f.ce. 21

33. Other Traffic icc。

0

34. Public Necidents

35. Home lecidents

36. Occupational iccidents

37. Firearms Accidents

38. Dog Bites

39. Suicides

40. Suicide littempts

$\rightarrow$ No Accurate Record Kept.

47. Sudden Death \& Bodies Fd.

42. Stck $C$ ared For

43. Mental Cases

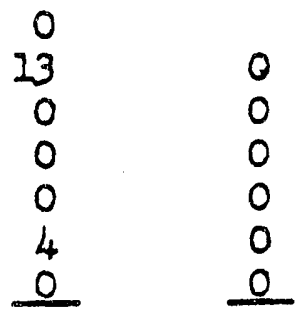

0

13

0

0

0

42

COMP.OSITE TOTAIS

PARTSS I.II. III, IV C.SSES 430

0

2

0

0

0

0

ㅇ.

0

0

0

4

0

* Cases Visted under "Cleared Other" aro those cleared by varlotis means other than arrest such as: orders from prosecutor, juvenile probation offlcer or other

slutuations in which a mutual agreement is obtalned. Thay are definitely "cleareci"

cases and differ from the arrest colum only in that thore were no arrests.

Property Reported Stolen During Month. . \$ 7113.87 (\$500.00 bikes)

Property Recovercd During Month........\$\$ 800.00 ( $\$ 500.00$ bikes)

SEE PAGE THREE FOR JUVENIIES INVOLVED. 


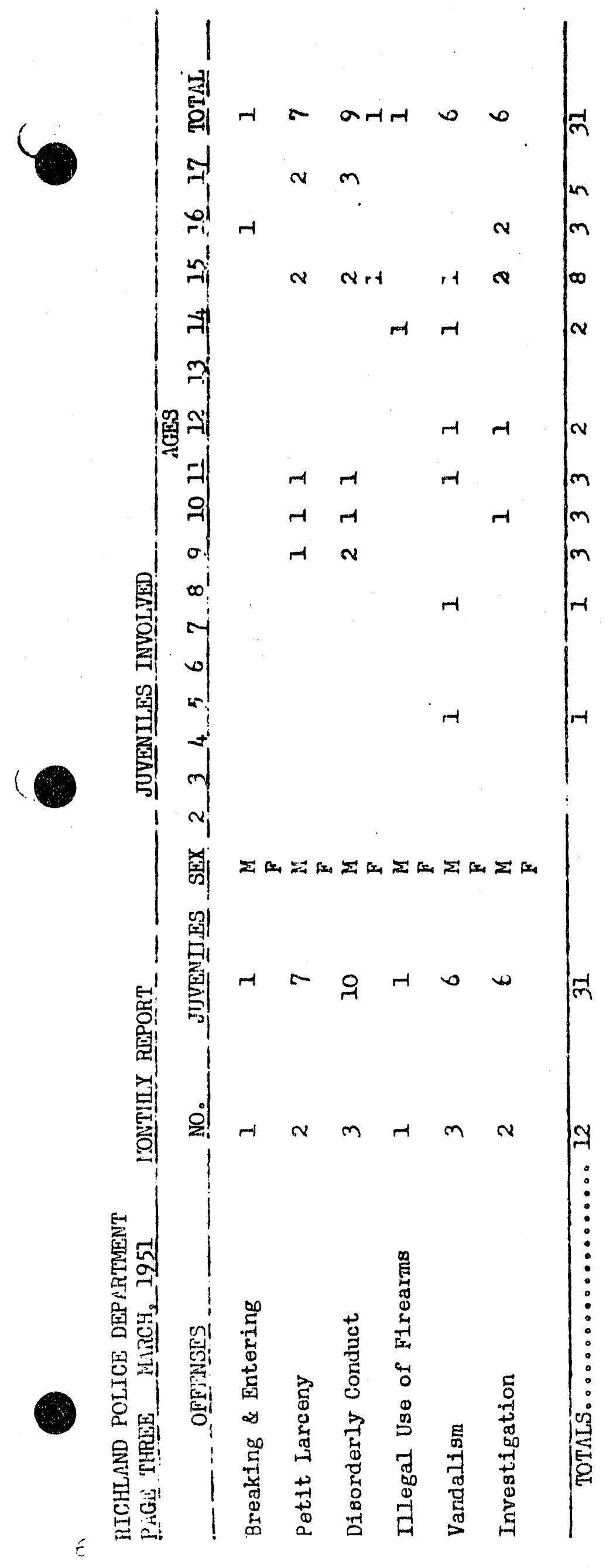


Number of offenses known to polfce per 25,000 inhabitants in cities of 25,000 persons:

Wash. Oregon \& Calif. One Month Six Months (Jan-June 1.950) Average

\begin{tabular}{lcc}
\hline Rurder & .49 & .08 \\
Robbery & 14.3 & 2.3 \\
Agg. Asslt. & 10.3 & 1.7 \\
Burglary & 90.6 & 15.1 \\
Larceny & 269.6 & 44.9 \\
Auto Thert & 37.3 & 6.2
\end{tabular}

Richland

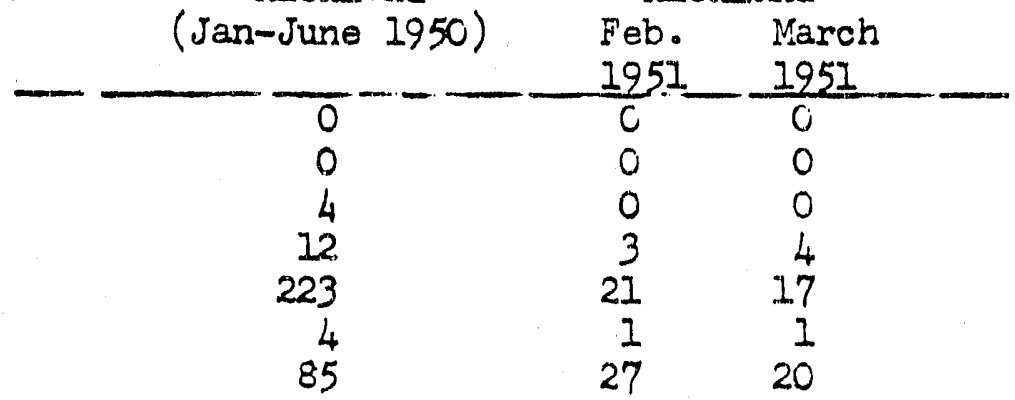

Number of offenses known to police per 25,000 inhabitants regardless of whether offenses occurred in cities or muril districts:

State of Weshingtion One Monih Six Kionths(Jan-June 1950) Average

Murder

Robbery

agg. Asslt.

Burglary

Larceny

suto Thept

Bike Theft

.53 .08

10.9

2.7

80.3

236.1

30.9

1.8
13.4
39.3
5.1

Richland (Jan-June 1950)
Richland

Feb. March $1951 \quad 1951$

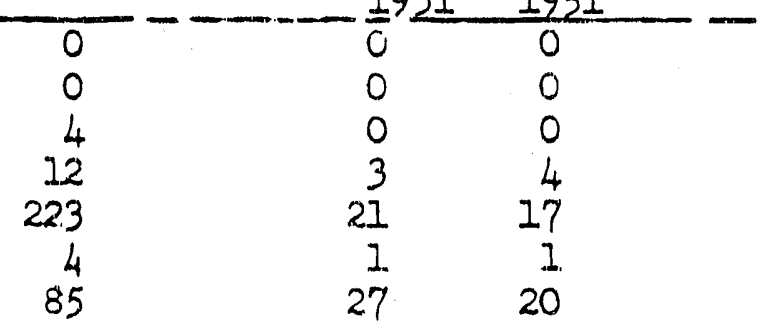

The portion of offenses comitted by persons under the age of 25 grs. is shown:

National Average(Percentage) Wash.Oregon,Cal.(Actual) Richland Richland (Jan-June 1950) of Cases) (Jan-June 1950) Cases) (Jan-June 1950) Feb. liarch

\begin{tabular}{lrrrrr}
\hline Robbery & 55.4 & & & 1.951 & 1951 \\
Burglary & 63.0 & 57.0 & 0 & 0 & 0 \\
Larceng & 46.7 & 125.9 & 2 & 1 & 1 \\
iuto Theft & 68.7 & 25.6 & 57 & 5 & 2 \\
ito & & 0 & 0 & 0
\end{tabular}

Note: Statistics of juvenile offenses throughout the United States were taken from the Uniform Crine Report published by the iederal Bureau of Investigation, which states:"It should be remberad that the limber of arrests recorded is doubtless incomplate in the luwer ginup becausc of the practjce of some jurisdictions net to fingerprint ycuttiful offeldors."s 


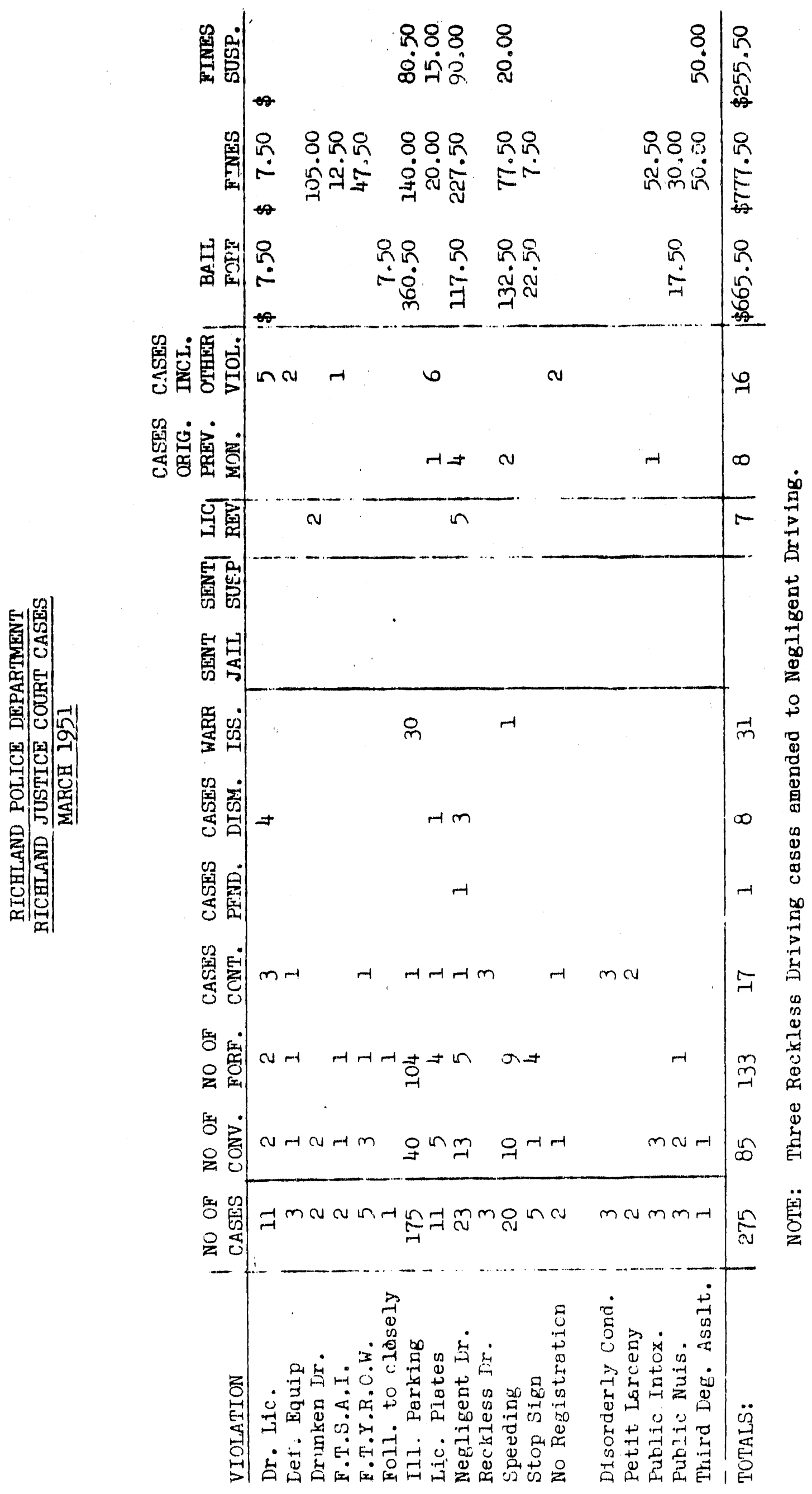



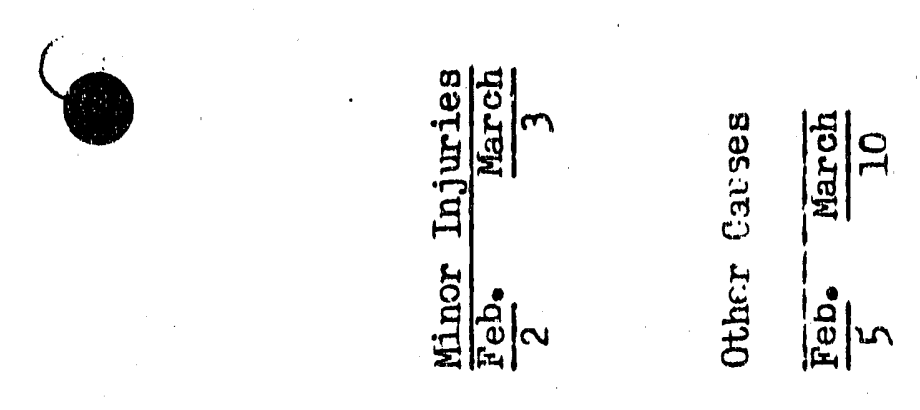

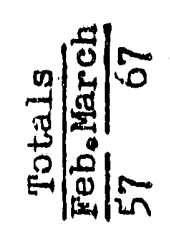
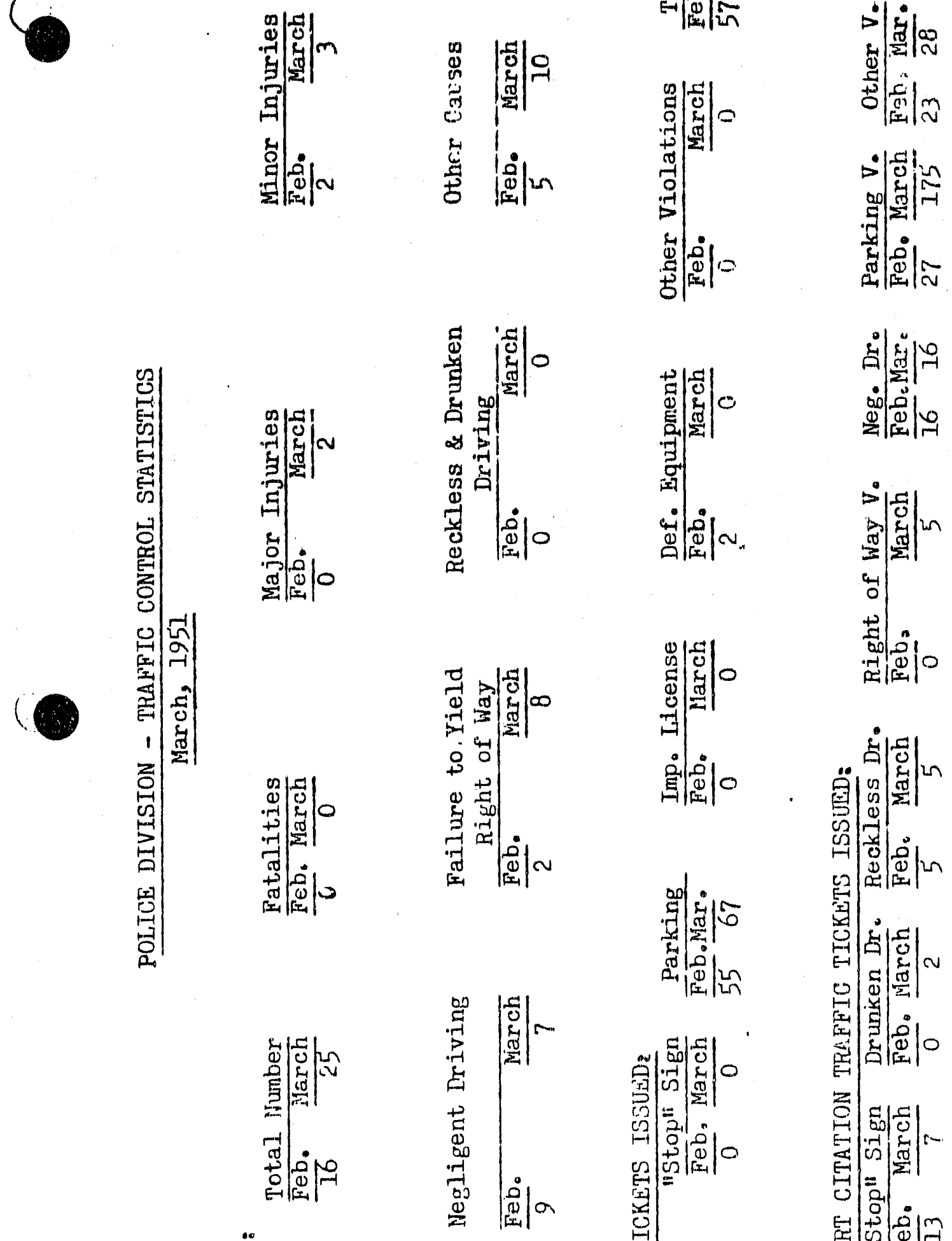

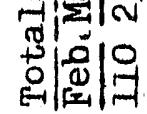
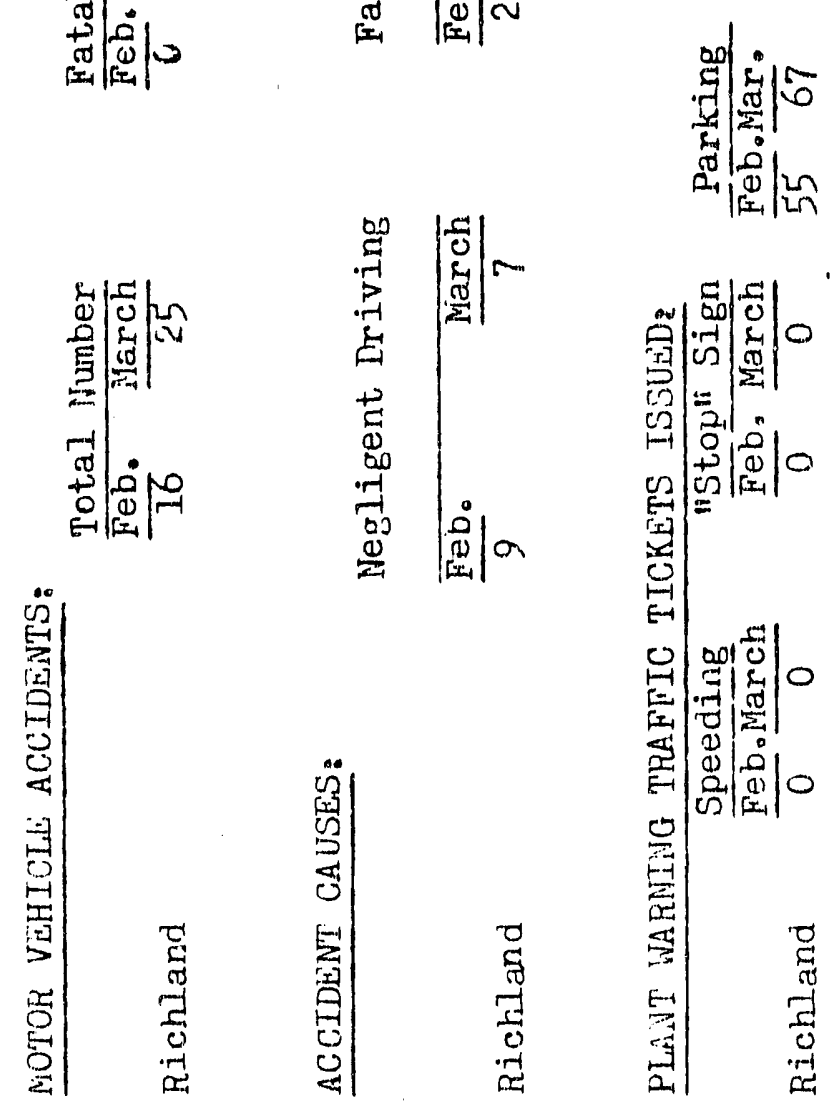


\section{MUNICIPAI DIVISIONS}

\section{PUBLIC SAFETY DIVISION}

March 1951

ORGANIZATION AND PERSONNEL,

Number of employees on roll:

Preceding month

Beginning of month

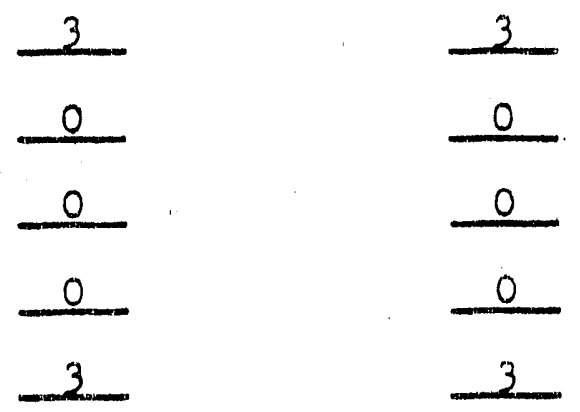

End of month

\section{STATISTICAL AND GENERAL}

The National Safety theme for the month of March, Motor Manners", has been extensively publicizec with various newspaper articles, giving a coverage of 192 column inches.

Four very interesting radio interviews involving the current theme were tape recorded and broadcast by members of organizations represented in the Richland Safety Council. These safety interviews were erititled "Discourtesy Can Mean Disaster", "Courtesy Can Save Your Lif'e", "Accidents Are Highway Robbery" and "Danger At the Cross Street". Several spot announcements were sent to the three local radio stations pertaining to the safety theme of the month.

This office sent notices of traffic safety films available at this office to fifty local clubs and organizations, which has resulted in a larger audience for these safety films. This month's films, which had an attendance of 1247 were:

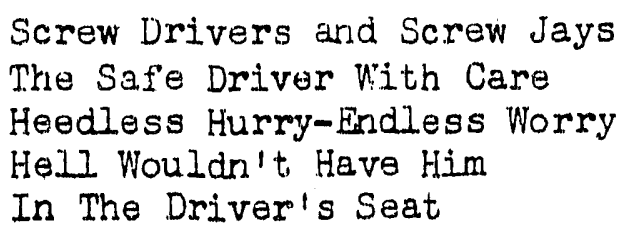

A Closed Book

\author{
Wanton Murder \\ Uncle Jim. Tells 1 Em \\ Fatal Saconds \\ Live and Let Live \\ When You know
}

One outstanding traffic safety fizm, "A Closed Book", has been purchased by this office for the use of organizations and all interested groups.

A Traffic Safety Flyer, sponsored by the Police Department, Fichland Safety Council and the Public Saf'ety Division was mailed to every home in the village, urging drivers to use their "Motor Manners" and drive safely. 
Richland's entries in the National Inventory of Treffic Safety and the A.A.A's. Pedestrian Safety Contest were completed and sent in for judging.

The Traffic Control Committee met March 27. Several recommendations were made for traffic improvements and studies are now being made on these projects.

Two 24 sheet posters, which tie in with the schools' April Safety Program, will be posted today, bearing the imprint "Sponsored by the Student-Parent Counc1l."

This office is assisting the Parent-Student Council in coordinating plans for the April "Child Pedestrian and Bicycle Safety campaign. A number of the "Man-to-man" and "Dad-to-daughter" Good Driving Agreements have been ordered, under sponsorship of the Central P.T.A., for use during the child safoty campaign. 
SUMMARY

MARCH

ORGANIZATION AND PERSONNEH:

Commercial \& Other Property Divisions
BEGINNING OF MONTH

\section{Exempt}

7

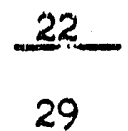

29
Non-Exempt

5

$\frac{181}{186}$

END OF MONTH

Exempt Non-Exempt

7

6

Housing \& Real Estate MaIntenance Division

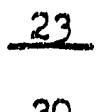

30
181

187

Net Increase of employees for the month of March _.

\section{GENERAL}

The Richland Investment Company building commenced operation on March 30, 1.95.1, with the following businesses as sub-lessees; McKay's Varlety Store, The Wren House, Wiley'g Shoe Repalr Store and an optometry office operated by Dr. Charles A. McCartney.

Dormitory W-17 was opened for Men employees on March 12, 1951. 
MUNJ.OIPAL, REAL ESTATE AND GHENERAL SHRVIOES DIVISIONS

HOUSING AND REAL ESTATE MATNTENANCE DIVISION

March, 1951

ORGANIZATION AND PHRSONNEH

Number of employees on payroll.

Maroh

Beglining of morth

22 exempt enployeos

181. non-exempt employees

203

203

End of month

23 exempt employees

181 non-exempt employees

204

204.

\section{RICHTAND HOUSING}

Housing Utilization as of Month End

Conven

Houses Occupled by Family Groups tional

Block I Pre Ranch

Pro

G. E. Employees

Commercial Facilities

$21.97 \quad 261 \quad 8 \quad 376 \quad 328$

Community Activities

Medioal Facilities

Post Office

A. E. C. and Other Government

Sohool District

Kellex Corporation

Atkinson-Jones

Newberry Neon

Vemita Orchards

J. G. Tumbull

Fred J. Early

V. S. Jenkins

Hanley Company

Total Houges Occupled

91

$\begin{array}{rrrrr}91 & 8 & 2 & 29 & 72 \\ 9 & - & - & 1\end{array}$

$5 \quad 14 \quad 2$

$\begin{array}{rrr}7 & 1 & 1 \\ 96 & 29 & 15\end{array}$

$\begin{array}{llll}96 & 29 & 15 & 36\end{array}$

Eav Aot Tract Tetal

43

7

$9 \quad 14 \quad 4 \quad 11$

$\begin{array}{llll}1151 & 55 & 38 & 4914\end{array}$

$31-1$ -

Houses Assigned - Leases written

Houses Assl.gned - Leaves not wrltten 17

Houses available for assignment

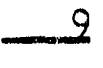

Total Houges

2500

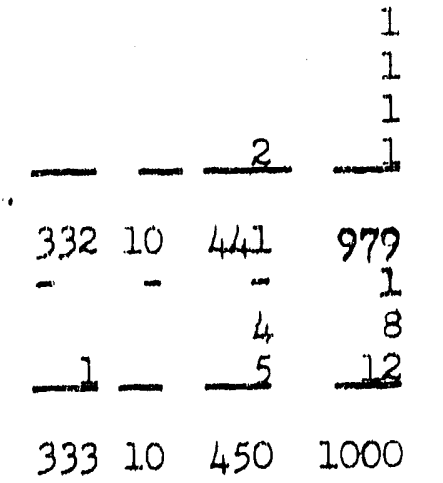

$\begin{array}{llll}65 & 5 & 5 & 277\end{array}$

$3-120$

122

$10 \quad 3 \quad 24$

$20 \quad 4 \quad 4 \quad 204$

491.110

2127

4. 2

44
6

4

1.

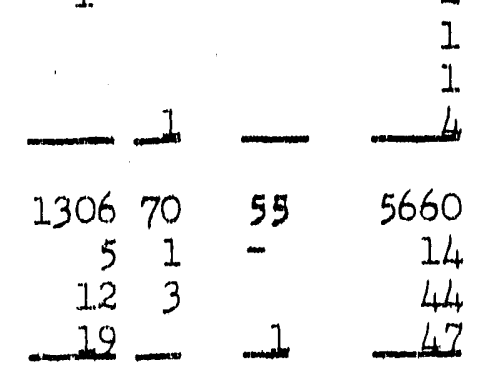

$134274 \quad 56 \quad 5765$ 
Housing and Real Estato Maintenanco DIvIaLon

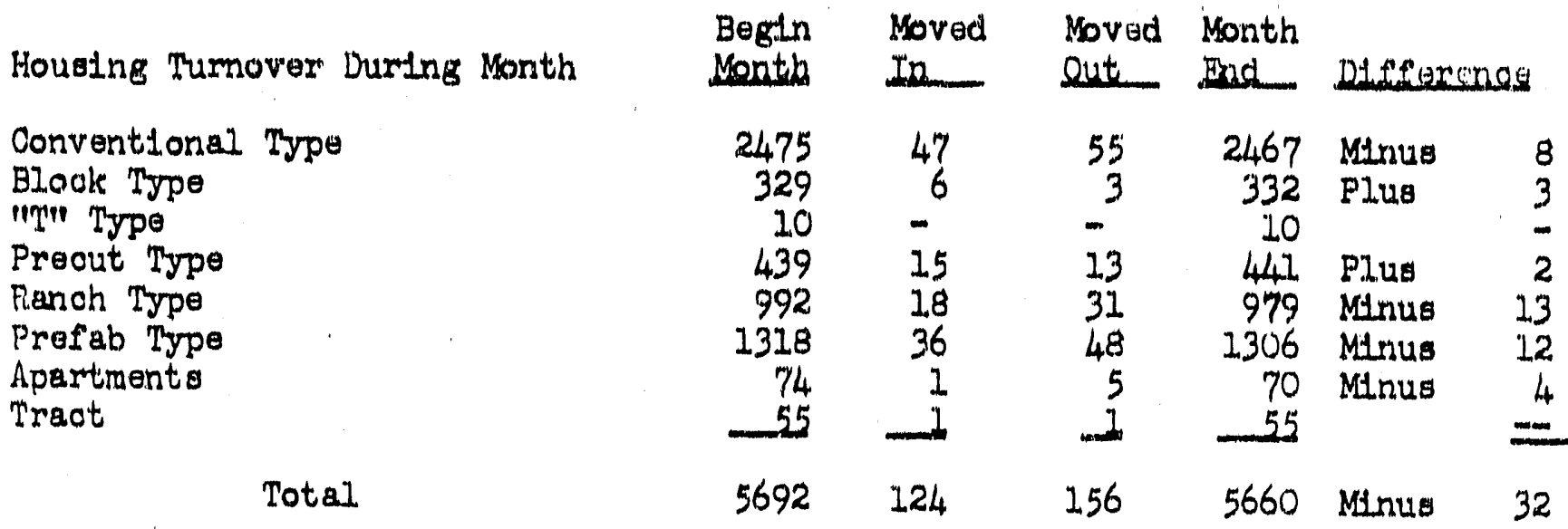

\section{DORMTTOAY STATISTICS}

Dormitorles:

Qecupants Vroangieg 'Totgil Beds

*616

$-$

616

Men Ocoupled 14

Men Unoccupled

Women Oocupled 12

Women Unoocupied 1

**1447

34

481

Women's Dormitories

ocoupled by:

$\begin{array}{lr}\text { G. E. Office } & 2 \\ \text { Education } & 1 \\ \text { Apartments } & \frac{1}{31}\end{array}$

* Ihis inclides 50 beds in W-17. This dormitory was opened for Men employees on March 12, 1951.

* This Includes space of 4 beds in W-9 used for supply rooms and dormitory offices.

There are 35 men employees waitting for dornitory rooms in Rtohland.

\section{SENERAL}

Houses Allocated to new tenants Exchanger Houses

Moves (Within tlie vilidage

Turnovers

Total. Leases Signed

Terminations

Total. Cancelilations

Applications Pending

$\begin{aligned} & \text { Aldocation Section Statistics } \\ 51 & \text { Voluntary Terminations } \\ 53 & \text { R. O. F. } \\ 28 & \text { Discharige } \\ 2 & \text { Transfers } \\ 12 / 4 & \text { Retiremunt } \\ 53 & \text { Housug Astignod "hs Is" } \\ 156 & \text { Move Of'f' Profect } \\ 508 & \text { Houses sent to renovation }\end{aligned}$

53

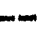

1.

11.

$-$

1.0

29

80 


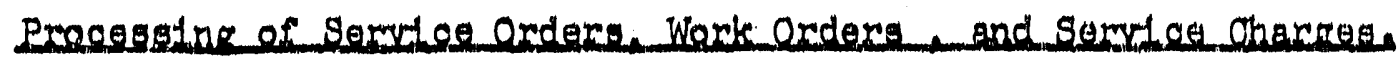

Service Orders Work Orderg

Service Onarges

Orders Incomplete
An of Feb. 28 . 1951
$\begin{gathered}191 \\ 3790 \\ 21\end{gathered}$

Ertinctosl work Onder Iosd

Incomplete 68 of

Tebruary 28, 1251

Laundry Tub Replacement

Bathroom Renovation (Tub-

Linom TIle)

TIlobourd Only" (Bathroom)

Kit chen Cablriet IInoloum

Kitotien Floor Innoleum

Orders Issued
Eab 28 to March 31
2258
831
231

Total Orders

Incomplate As of

Maroh 31 . 1951

220

3233

\section{WQRKL QBDERS COMPLETED DURTNG THE_MONTH OF_MARCH}

84 Bathtubs were instialled

137 Innoleum repals jobs were completed.

5 Blaoktop sidewalks were replaced.

1.6 Steps were repaired with blacktop

15 Hot water heaters were replaced

1 Parking compound graded and fllled with gravel.

14. Touch up paint jobs (Interfor) were completed.

30 Loads of tumble weets were ploked up and dlsposed of.

24 Loads af top soll were delivered.

Alteration Permits Issued during the Month of March totaled 100 oompared to 70 in February.

$\begin{array}{ll}\text { Arbor } & 1 \\ \text { Garden Wall } & 1 \\ \text { Olothes poles } & 6 \\ \text { Driveway } & 4 \\ \text { Feverse range \& refirlgerator } & 1 \\ \text { Oll bumer oonversion } & 1 \\ \text { Coal stoker } & 2 \\ \text { Move kitohen supboards } & 1 \\ \text { Front poroh } & 2 \\ \text { Clothes dryer } & 2 \\ \text { Back door } & 2 \\ \text { Change hot alr register } & 2 \\ \text { Trelils } & 1\end{array}$

$\begin{array}{lr}\text { Automatic washers } & 21 \\ \text { Fenceg } & 34 \\ \text { Basement partition } & 1 \\ \text { Electrioal wirling } & 3 \\ \text { Patlo } & 3 \\ \text { Refintsh floors } & 1 \\ \text { Alr conditioner } & 2 \\ \text { Remove broom closet } & 2 \\ \text { Paint extertor of house } & 1 \\ \text { Basement excavation } & 3 \\ \text { Rcmove cablnets } & 1 \\ \text { Irrigation riser in yard } & 1 \\ \text { Tool ghed } & 2\end{array}$


1644 Inspections were made during the Wonth of March as comparart to 1409 made during February.

Alteration Permits
Cupboards
Driving on Grass
Grass Seed
Jaok and Shim
Linoloum
Palnt
Soreen Doors
Shower Stalls
Sinks
Tollet Seats
Now Tenant ( Show house)
Renovation
Windows

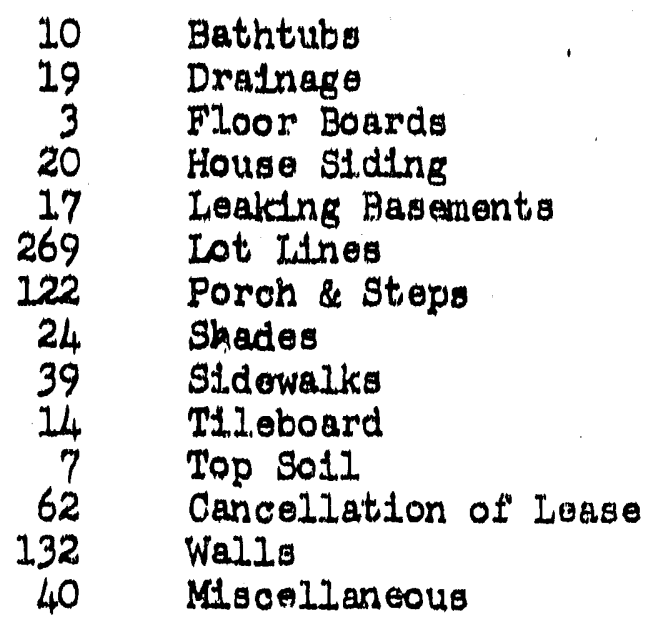

Windows

MATNTENANCE( HOUSTINC AND BEAT ESTATE) EOR MONTH OE MARCH

HEAVY MAINTHENANOE STATISTIOS

Man-Hour Backlog Man-Hour Backlog Non-Routine Boutioe

\section{Uraft}

Carpenters, Upholsterers Trainees and Drivers

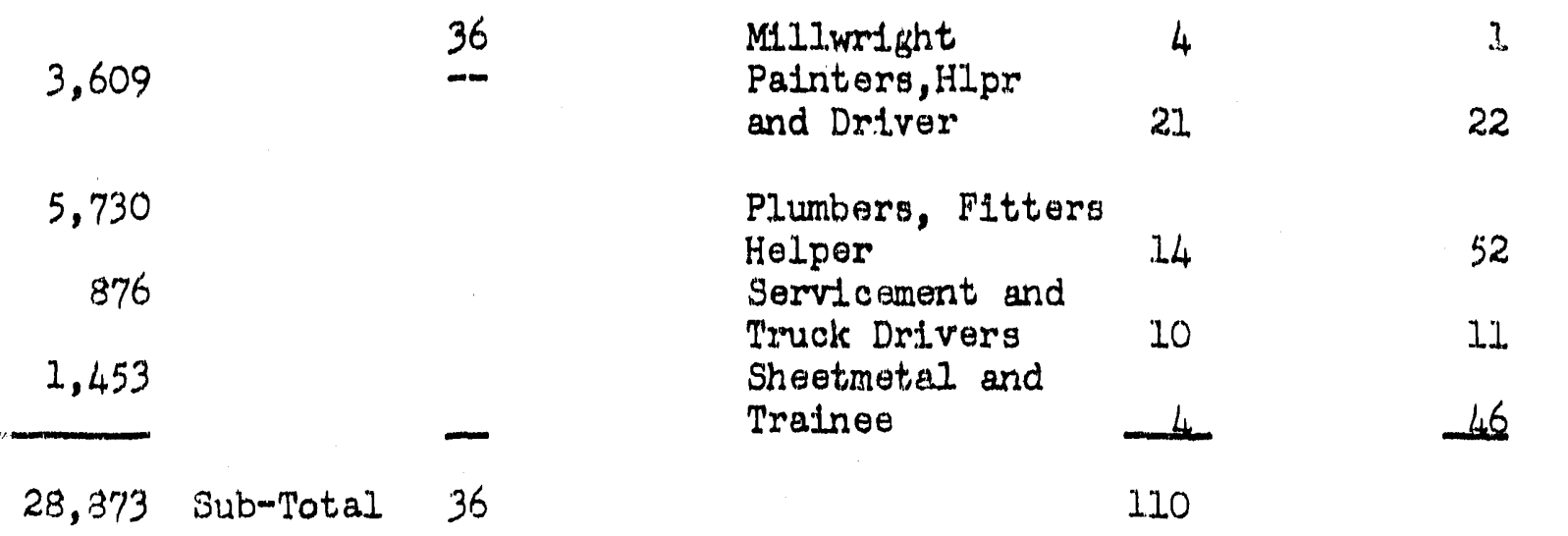

RENOYATION_STATISTTCS

3,312 Sub-Total.

$\begin{array}{lr}\text { Carpenters } & 1 \\ \text { Painters } & 14 \\ \text { Truck Drivers } & 1 \\ \text { Jan tresses } & -\frac{3}{19}\end{array}$


MATNMENANOE (HOUSTNG AND BFAT BSTANE) FOR MONTH OF MARAH(continuEd)

SEAYTLOH ORDER STATTSTLTOS

Man-Hour Backlog Non-Routine

32,185

270 Sub-Total
Man-Hour Backlog

Boutine

36

arparters

Fileatrdolans

Locksmith

Plumbers
Oraift

Non-Exempt

Manpower

Orew Dara

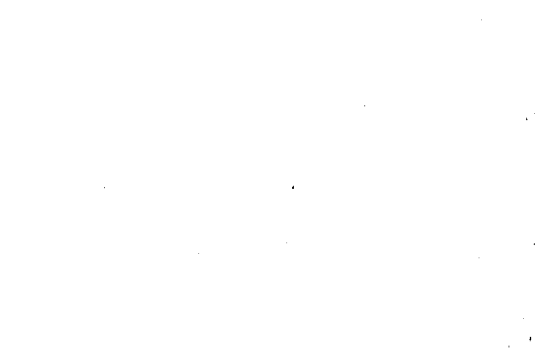

32,455 Sub-Total

HETPEHRS-TRATNEESS-ETC.

143
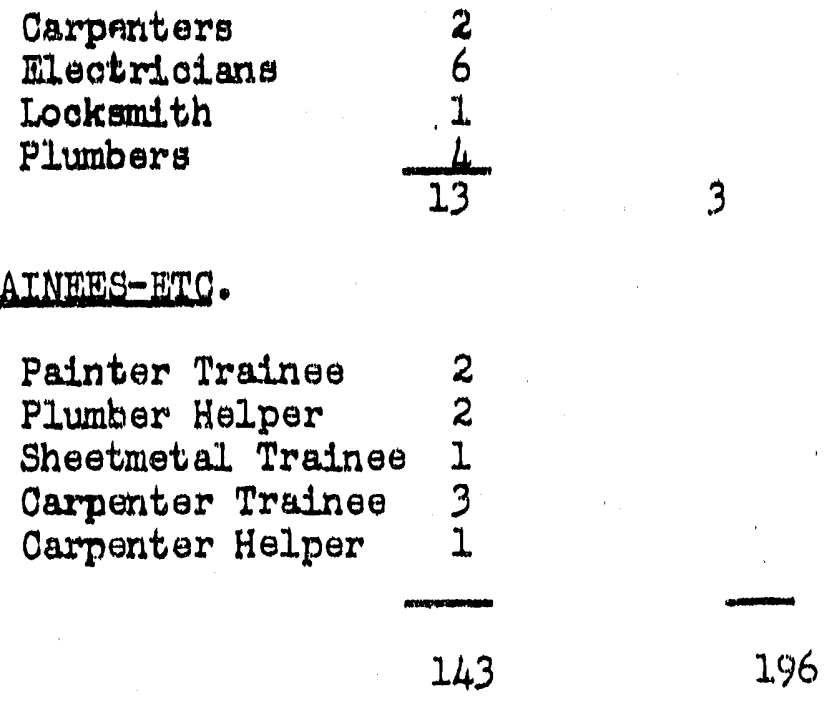

MAINTENANCE TRANSPORTATION FAOITLTIES

Truck Type

$1 \frac{1}{2}$ Ton Flatbed

$3 / 4$ Ton Power Wagon

$\frac{1}{2}$ Ton Plokup Cushman Scooter

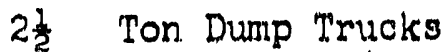

1) Ton Flatbed(Hyd. Lift) 1

ह Ton Pickups

it Ton Flatbed (Chain HoI st)

$\frac{1}{2}$ Ton Plckupg

$3 / 4$ Walk-In

3. Ton Top Panels

it Ton Flatbed(Chain Holst)

t) Ton Pickup

Ton Pickups

$3 / 4$ Ton Pickups

Ton Panel Number In Pogergston

HEAVY MATNTENANCE

10

1

7

1

2

$\frac{1}{2}$

II

in

"

Labor

Labor

Labor
Croft

Requl stioned for Roplacement,

Carpenter:s

Millwrights

Millwrights

Mil. wrights

Palnters

Painters

Painters

Plumbers

Plumbers

Sheetmetal

2. Walk-In Type 
MAINDENANCE TRANSPORTADTON FACIIITIES (contInued

RENOVATIONS

29 Passenger Bus Cher. Carryall $\frac{1}{2}$ Ton Pickup Sub-Total $\frac{1}{1}$
$\frac{2}{4}$
Painters

Painters and Janitresses Carpenters

SERVICE ORDER

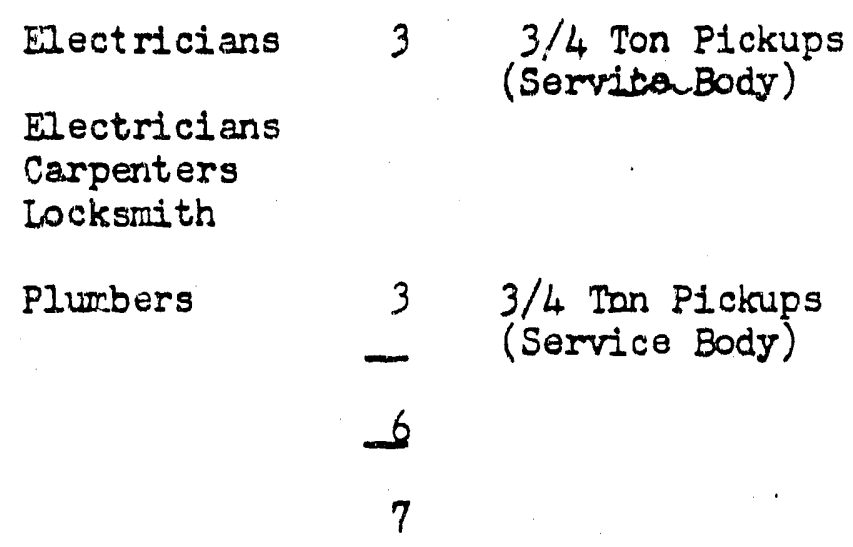

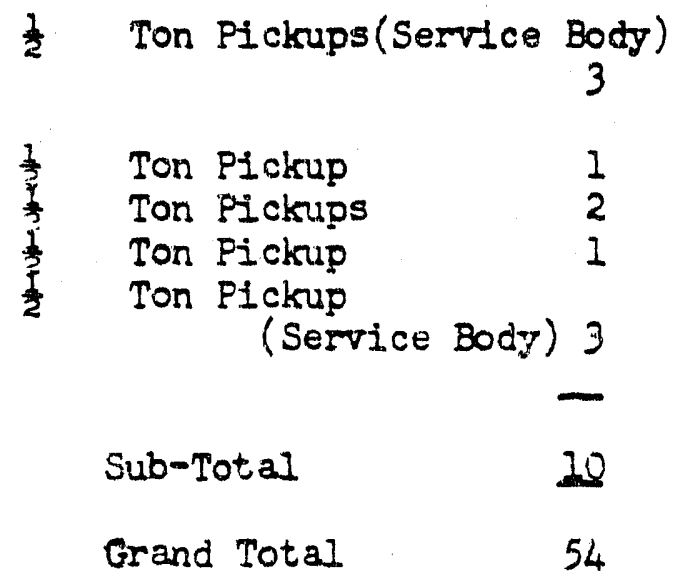

6 


\section{BATWUENANCE NARRATIVE FOR, MARCH 1251}

The following is a sumary of general items completed during the month of March along with ifscellaneous corments.

All repalrs, which were the responsibility of Housing and Real Estate Maintenance, to the 633 prefabs, Project $a-3630$, have been completed.

Interior repairs have been completed to the 10 dormitories in preparation for contract painters.

Fifty prefabs have been leveled and rotted posts have been replaced. This work was done on an individual order basis and not part of the rehabilitation program.

Carpenters repairs have been completed on a total number of 87 bath tubs and 137 linoloum floor replacements. 107 linoleum table top replacements, 120 bathroom tileboard installations, 20 screen doors were repaired, 28 roofs were repaired, I daveno wes recovered, 11 KC chatrs were recovered, I KV chair was recovered, $10 \mathrm{kV}$ chairs were repaired, $7 \mathrm{~A}$ \& $\mathrm{J}$ houses were jacked and shimmed, 102 sinks were sealed with chempoint, and 9 precuts were jacked and shimmed.

Carpenters prepared Klopfenstein's leaking basenent for manufacturers installation of water-proof paint. This work was done on a work order and will be recorded as a sample installation.

A total number of 45 houses were renovated during the month of March, 1951, of which 35 were permanent type houses and 10 were prefabs. This work included carpentry, complete paint jobs, linoleurn work, sheetmetal, plumbing and electrical and the cleaning of stoves, floors, siaks, and etc.

A total of 2,258 service orders were completed by the service order crew during the month of March. Approximately $93 \%$ of these orders were for Housing, $4 \%$ for the Dorms, 1 for Commerclal Facilities and the remainder for various other divisions.

The following is a status report of service orders:

On hand at beginning of month

Service orders received during month

Service orders completed during month

On hand at end of month
191

2258

2229

220

Arrangements have been made with the General Services Division to transfer a glazler to the Housing and Real Estate Maintenance Section effective April 2, 1951.

Therevere 39 conventional houses painted on the interior painting cycle during the month of March along with necessary carpenter repairs for these units.

Fourteen A \& J kitchens were ename ed, 58 bathrooms were enameled in part or in entirety, 14 miscellaneous paint joes ire completed. There were 11 renovation paint jobs completed by pairting roof's.

Eighty-one shower installations were fabricated and installed in prefabs. $\hat{s}$ general repair and lubrication on equipment and furnaces continued. 
A total of 84 bath tubs were installed by the plumbing crew, 25 hot water heaters, 7 yard drains, 1 septic tank drain field, a total of 7 sewer lines were cleaned and repaired, Installed 81 shower valves in prefabs, completed 86 bathroom faucet repairs, completed 164 Inoleum repalrs such as replacing kitchen sink and faucets.

Where Iinoleum men were working in bathrooms, the tollets were taken up and reinstalled, completed 16 miscellaneous plumbing repair work orders, completed three and one-half dorms - overhauling steam system, completed 37 miscellaneous steam work orders.

Inspection of the Commerclal Facilities was made one day per week for steam leaks. Inspection of dorms and apartments were made one day a week for checking steam leaks and hot water tanks.

Routine, daily, weeklg, and semi-monthly work by the labor section. Coal was delivered to 12 vacant houses, trash was picked up at vacant houses (80), pleked up and disposed of waste oil from the $81 \mathrm{x}$ service stations semi-monthly. Hauled ashes from the 784 Building once per week, pumped the settling basing at 784 and $784-A$ Buildings each week. Pumped three grease traps at the Mart each week, cleaned grease traps at Thrifty Drugs, Bus Depot, and V1llage Pharmacy each week.

The following is a sumery of non-routine work by the labor section:

Plles of tumble weeds picked up (30), raised sod and backfilled for new walks (16). Sixteen sets of black top steps were replaced. Five black top walks were rcnaired or excavated and backfliled at 3 pard drains. Excavated and backfilled four oil tanks, excavated and backfilled four sewers, excavated and backfilled three water systems. Delivered top solil on 24 work orders, five trees were removed on work orders, widened and repaired the parking space around the 722 Hangar, repatred and re-seeded lawns torn up by sub-contractors at 703, 705, 707, and 709 Comstock. Plckod up and disposed of excess dirt, and cleaned up rubbish in cemetary as needed. Excavated and bockfilled septic tank and drain field at Tract House $\mathrm{K}-744$. Hauled surplus equipment from the Racriation Hall dining room and kitchen to salvage. This crew has approximately 1500 man hours of backlog work for the Installation of black top walks and replacement. 


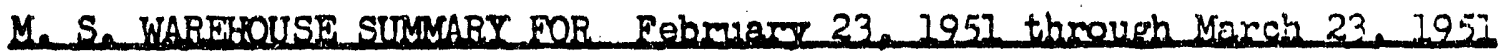

TOTAL INV. \$108,926,11

INVENTORY ITEMS AMOUNT \$\$65.892.21

\begin{tabular}{lrr} 
RECETYED IN INVENTIORY & CORE & \multicolumn{1}{c}{ AMOUNT } \\
ON STORE ORDERS & & $\$ 408.03$ \\
ON PURCHASE ORDERS & & $1,415.46$ \\
FROM HOUSING & $61-20$ & 1.47 \\
FROM DORMS & $64-20$ & 22.50 \\
FROM HOUSING FURNITURE & $61-20$ & 646.86 \\
FROM DORMS FURNITURE & $64-20$ & 12.55
\end{tabular}

TOTAL RECETPTS \$2.506,87

INVENTOBY DISBURSED

MISCELIANDOUS CHARGES

444.88

FREE ISSUE

$61-20 \quad 910.24$

CASH ITEMS

$61-20 \quad 90.65$

DORM SUPPLIES

$64-20 \quad 522.60$

DORM LINENS

$64-20 \quad 1,863.24$

DORM SHADES \& REFLECTOR

$64-20 \quad 26.68$

DORM FURNITURE

$64-20 \quad 3,963.45$

WHSI SUPPLIES

$63-20 \quad 40.18$

TOTAL DISBURSED \$2.861.92

INVENTORY ITEMS BALANCE \$60.544.16

PLANT ITEMS AMOUNT \$43,026.90

RECEIVED

CODE AMOUNT $1,467.53$

DISBURSED

$2,121.67$

PISNT ITEMS BALANCE \$12,372.76

TRHND TOTAL INVENTORY \$102,916.92

DORM FURNITURE EXCHANGE RANGES EXCHANGED REFRIGERATORS EXCHANGED PRE FAB HEATERS EX. SENT TO MAINTENANCE RECEIVED FROM MAINTENANCE PIECES 
DORMATDEY RERERT FOR February 23, through March 23, 1951

129. MINOR REPAIRS TO FUSES, PLUMBING, ETC.

35 WORK ORDERS STEAM, GLASS, EQUIPMENT, ETC.

65 PIECES OF FURNITURE REPAIRED

60 HOUSEKREEPING CONTACTS

486 LICHT GLOBES REPLACED

56 ROOMS VACATED

\section{IINENS IAUNDERED}

$8,103 \quad$ SHEETS

4,182 PIIIOW CASES

137 BED SPREADS

33 BED PADS

247 SHOWER CURTAINS

REMARBS

The inside painting program has been started this month. The lobbies of women's dormitories have been re-finished this month. 
DIVISTONAI PIRSONLHL:

Number of Imployees on Payroll:

March

Boginning of month 12

Ind of month 13

Net increase $I$

COMIDRCIAI AND NONCOM ERCIII PIRSONNEL:

Number of imployees on Payrolls:

Cormerctal Loncommercial Total

$\begin{array}{lrrr}\text { Fobruary } & 1,089 & 81 & 1,170 \\ \text { March } & 1,085 & 87 & 1,172 \\ \text { Iot increase } & & & 2\end{array}$

SUICARY OF ROUTIV TIEIS PROCESSDD:

$\begin{array}{lrrr}\text { Vork Orders } & 37 & 4 & 41 \\ \text { Back Charges } & 1 & 0 & 1 \\ \text { Service Orders } & 18 & 2 & 20\end{array}$

COMTRACTS AND NTEGOTIATIONS:

A. Cormerciaj:

1. Mssignment of Agrement:

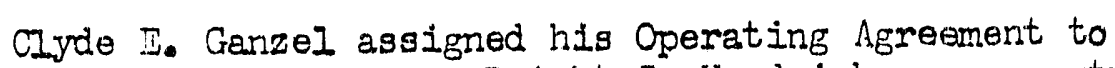
liessrs. Leo Azure and Dwight C. Hendricks, a copartnership, who will continue operation of the barber shop.

2. Letters of Authorization:

(a) Vance Properties, Inc. was authorized to irstall a ir conditioning wcuiprent in the central section and south wing oi the Desert Irn.

(b) The Richland Irvegtment Company was authorized to sublet space, approximately 000 square ieet of floor area, in its new bu.ilding to Charles A. lic Cartney for the operation of an optometry office. 
(c) The Richland Invegtment Company was authorized to sublet space, approximately 800 square feet of floor area, to Mesdames Wren illison and Mesjine F. NicCartney for the operation of a maternity wear shop.

(d) Mr. I. C. Folsy was authorized to sublet spece In the Recreation Center building to liwood Hamiltion for the operation of a barber shop.

B. Noncomercial:

1. Letters of Authorization:

(a) IJorthwest United Protestant Church was authorized to lease an additional plot of land; desoribed as Parcel "ir2, adjacent to Parcel $\eta^{\prime \prime}+1$, to provide for off-stre日t parking.

(b) Church of Jesus Ohrist of Latter Day Saints was author ized to construct an additional buildine on its leased premtses for use as a welfare storehouse.

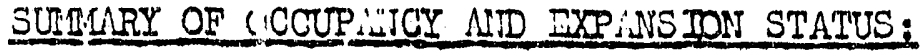

1. Commercial:

1. ivumer of Government-omed bulldings

(a) lumber of businesses operated by prime lessees

(b) Number of businesses operated by sublessees

(c) Total businesses operatine in Govemment-owned buildings

2. Number of privately-owned buildings

(a) Number of businesses operated by prime lessees

(b) Number of businesses operated by sublessees

(c) Total businesses operating in privatelymowned buildings

3. Total number of businesses in operation

4. Doctors and dentists in private proctice, leasing space in Coremment-owned kuildings

5. Privately-owned buildingy uriar construction
Febmuary March

37

37

$41 \quad 41$

$13 \quad 13$

$54 \quad 54$

$39 \quad 40$

$37 \quad 37$

$63 \quad 67$

$217 \quad 121$

21

21

2

\section{1}


B. Noncomerotal:

\section{February lanch}

1. Covernmentwormod butidings
(a) Churches
(b) Clubs and organizations
(c) Govermment agencies

$\begin{array}{rr}4 & 4 \\ 10 & 10 \\ 3 & 3 \\ 17 & 17\end{array}$

2. Privatolj-ormed buildings

(a) Completed and in use

(b) Under construction

(c) Sites tentatively allocated or leases

in process of negotiation

Total

3. Pasture Land Assignments

GiNTRAT:

A. Commercial:

1. Richland Investment Compariv:

(a) Noliays Variety Store commenced operation under the managemerit of IIr. Harold Kinnerr.

(b) The Wren House comenced oporation of a matemity woar shop under the manaement of liesdames /ren Fillison and laxine F. licCartiney.

(c) Villey's shoe Repalr Store commenced operation under the manageneiat of lir. Willey Dickson.

(c) Dr. Charles A. licCartney commenced operation of an optometry shop.

2. Hanson Interprises, Inc.: - Radio Station KAIJ moved its business office from the Spencer-rirlcpatrick building to a subleased porof the Young liorld Shop.

3. Lettors of Inquiry: - Letterg were written to business applicants, whose names are oil file in this offlce, for the purpose of establishing current ex prosolons of interost in constructing privately-orrad buildires in Richland. 


\section{B. Noncomeralal:}

Property Irrentorios: - Final inventorles of the Covermontormed fixtures and equipment locater in the followlng-named faclitites wore taken as a prelininary to the sale of all, or any portion deaired, of such property to the respective facilitios:

All Saints! Iplscopal Church RIchland Riders Club Association of U.S. Employees, Inc. Sacajewer Riflo and Platol Club Rodeomer Iutheran Churoh Richland Iutheran Church U. S. Vetorans Administration Amerioan Rod Cross

COMNRCIAI PROSPECTS:

A number of applicants, the majorlty of whom were not interested in constmucting privately-ownod buildings, expressed an interest during the month to establish and operate businasses in Richland. Inquiries wero rocoived covering the following types of ostabl ishments:

Bowling inloy

Food Store

Fuel oif Distributorsh ip
Self-Service Station

Service Station

Roller Skating Rink 
ORGANIZATION AND FERSONNEL

Number of Employees on Roll:

North Richland Patrol Division

North Richinnd Fire Division

Maintenanse \& Operation DIrIsion

TOTAL

Pergonnel Changes Durtng Month:

Transfer to Electrical DIviaton

Transfer to Instrument DIvision

Transfer to Muniolpal Divisions

Transfer from Munioipal Divisions

Tranafer from Plant Security \& Services

Terminations

New Hire
Beginriting of Month Non-

Exempt Exermpt Total
End of Menth

Non-

Dxcompt Tocempt Tota1

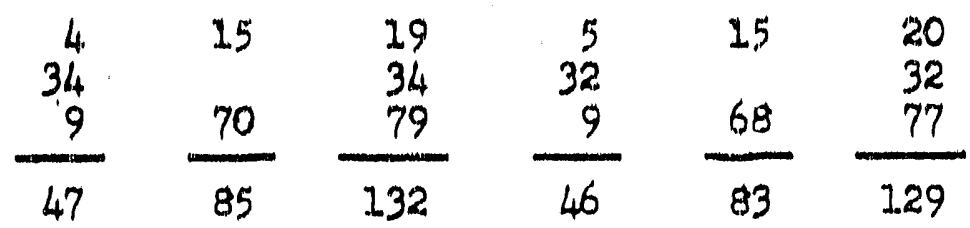

\section{Exempt Non-Exampt}

1

1

1

1

1

1

2

1

S'TEAM AND GENERAL MAINTENANCE DIVISION

Generel Maintenrnoe:

Requisitions are now open for 1 El Eectrician Journeyman, 1 Carpenter Traineo, replaco ment for Painter Journeymen, 5 Servioemen, for glumer lawn work, and 1 Servioenan, replac ement.

Treated timbers for 761 and 762 Buildings arrived on March 16. Inataliation of treated timbers and louvers is about $75 \%$ complet $\theta$. Repalr of exdt steps on 703 Bullding is $50 \%$ complete.

Five Hausermen partitions were ineteliled and one relocated in 703 Building.

ixxcesg work consisted of preparing for shipment 6 cars of equipment, 8 oars of lumber, 8.1 trucks of lumber and approximately 40 crater of miscellaneous items.

The electrical group rebuilt 11 ranges, overhauled 8 irrigation pump motors and changed out 3 fractions $L$ H.P. motors, installed 10 fluorescent fixtures, relocated 12 bethroom switches, and completed 68 trouble calls.

Interior pointing in 700 Area is progressing shead of schedule.

Slgn Shop processed Monthly Health Bul.letins, approximately 25 name plates, 10 large Scotch-litte signs for Security. $420 "$ x 24 " signs for "One Way Treffic", several miscellaneous signs for 300 rirea. Real Estiate Divisions and the Hospltal. Lettered and numbered bins in 712 Building, numbered doors in 760 Building. Made call boerd with twelve nemes for Engineerlig and Contract Division, and made one L' $x$, blackboard for A.E.C.

One hundred and twenty-one sections of shelving were moved from 712-B to 712 Buildirg. Thirty-three sectlons were completely dismantied and banded for storage. 
Ganoral Malritonanoe Oont 1 .

Five flro hose boxes in 750 Ares are 85\% oomplete. 700 Aroe cooler overthaul work is $40 \%$ completen

Clean-up ot" attios of 700 Aras bulldinge is $80 \%$ complute.

Condersate metars were Installed at Hgh Sohool. Paint Shop and Nursory.

Routine work conslsted of generel oleanm up of 700 Area grounda; general malntenanco if 700 Area Steam Syatems general malntanance of 700 Area plumbing; ateam arid other repalrs at Hospltal and Fublio Health Bulldingy repatr and Inepeotion of madn stioam IInes: and melntenance of boliers and equipment at 784, 784m A and Lil31 BuLlidinge.

Power Operation:

Three bollers were in gorvloe until Merah 1.9, when decreesed ateam requtrements perm mitted two-boiler operation, which was ountinued for the remelnder of the month.

On March 5, all shift operation changed from overlapping shift to non overlapplng shifit. Greater anployee and slipervisory sintiafaction is resulting firom this ohenge.

Car-mover was placed in operetion and is performing satisfactorily. One Coal. Handler was up-graded to Miscelilanoaus Power Operator and trensferred to Munictpal Publio Works Division.

Steam operations at 1131 Aree wore normal for the month, whth decreaglne reculfroments as a rosult of warmer weather.

Steam generated - 28,495.2 M. Ibs.: steam leaving plant - 24,249.1 M. Ibs; stearu delivered - 22,619.7 M. Lbs.; coal consumed - 2,191.97 net tons; water softened $3,563,900$ gallong.

NORTH RICHLAND FIRE DIVTSION

A.Iarm

No. Response to Alarive

257 th \& "C"

26 Hospital, 5th and "M"

27 "F" between 2nd and 3rd

29 Berlen Rcad, $\frac{1}{2}$ mile of Gun Club

29 Car in fist of Post ofizice

30 Trailer at 102. "I"

i]. North of isapital, off $6 \mathrm{th}$

32 Near Food Ltnes, Inc.

Date Investigetions

$3-5-51$
$3-6-51$

Barracks 214-B. Rm. ?'i, provable moker's careleseness.

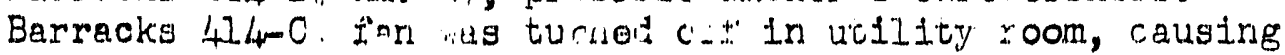
excessiva heat irom radiat.. whin set off sprinkler head.

$3-i=51$ Bremerten holise at 918 "C". Left burner of stcre on and coffee pot overterted.
Cause for AJarms

False Alarm

Accldental filarm

Overheatied washing machine

Uncontrolized burning

Smokers i carelegsness

Orerheated oll stove

Smokers careleseness

Snckers' carelessnesis

3-8-51 Barreoks 236-A, Rm. 8, smoker ${ }^{4}$ carelesaness.

Ranc nived By

Box Phone

1

1

1

1

1.

1

1

1

Personal. Lass

\$ 5.21 
North Flohland Flre DIvlelon Conted.

Dato Invost1gattong

Porsonal

(3.11-5l Nomthengtiof Logs

3-11-5I Northeast of Trailor Camp along rivor, ayparsitily from controliled burning.

3-19-5.1 Barracks 246-By Fin. 15, amoker's oarelosanesa.

3-22-5" Bramerton house at 330 "CH. Improperly operated oll stove. $\$ 22.61$

Higoellanoous Aotivitied:

Total Persomal. Loss

$\$ 44.82$

Four Safety and Socurity moetings were hel.d durling month.

Twenty-four Inside drilla and flve outside drilla were oonduoted.

Seventy-four flre alarm boxed wore testad.

Twelve FIrst Ald olasges were held.

Bomb sholter at Jahn Ball Sohoul was Ingpested.

Red Cross film shown to Flre Division employees.

Tanker sent out as otand.by at Irrigetion ditoh, between Sterens Irive and "W" Avenue for contioliled burning on Maroh 7.

Tanker stand-by, on Maroly 8, at lat and "Q", and stand-by at Stoam Plant on March 20. Installed master box card holders on Engines 2908, 2609, 2549 and 2513.

New tellephone was ingtalled in fire station ( $N-14442)$.

Ropairod $2 \frac{1}{2}$ gallion foam urackeli on truok $25 \mathrm{~L} 3$.

Emergenoy water system was inspected.

$\therefore$ group of Cub Scoutg visited Fire Station.

Severi men reported to hospttal for annual physioal examinations.

Emergency Fire connection on $81 x$-Inch woter main ot Steam Plant was inspected.

NORIH RICHLAND PATROL DIVISION

\section{Generel:}

Sixteen Inquiries regerding former lj amp cyyed personnel were answored. These inquiries carne from the $\mathrm{l}$. S. Nery, U. S. irmy, Clvil Service commigaton and E. I. du Pont de Nemours Comprily.

Thirteon treffic violationg were recelved during the month. Four of theoe were stop sign violations, one for speeding, three for no operator's license, four for 1llegal parking violations and one 11 legal pasaling violation. 
North RIohland Patrol Q1vision Cont id.

A survey was made of the North Richland Area for forelgn lidonse plates. On el.1. oare bearing forelgn plates a card was placed on the windshiold, which gtated the

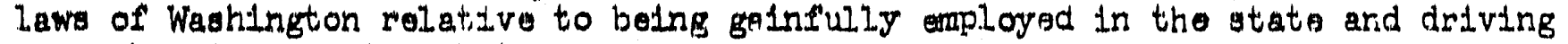
a car bearing forulign plates.

A total of 117 traftic warning tiokets wore 1ssued by North R1ohland Patrol, dur1ng the month. These trefflo violations oonstated ainly of 1 llegal parieing.

There were five automoblle accldents in the North Richland Aroa.

Al1 facllities, warehouses, butldings and the John Ball sobol were cheoked daily on the number 1 and 3 shifts and on all shifts on Sundays and Holldays.

Ten monthly hours and 30 weekly hours were spent on the bank money escort from Pasoo. AlI flre, safety and trafflo hazardo observed by North Richland Patrol were reported to the proper authorities.

On Thursday's at 7:00 p.m. an appearance offloor, assigned to Judge E. W. Brown's court, appeared against pergons oited to court by North Richland Patrol.

Twelve persons were incaroerated in the Riohland fail during the month. Five for public intoxication, three for publto nuiasnce, one for vagranoy, one for drirken driving and two for theft of automoblie.

Ten employees attended politoe school on "In Service Training" in Pasco.

A Cub Scout Troop from the John Ball. School was conducted on a tour of Patrol Hoadquarters. Some of the Patrol duties were explained.

A staff meeting was held on March 23.

Patrol acted as egcort for 5 wide and high loads coming to ind from the Riohland berrioado.

On March 6 the U. S. Army acqujred the hospital. In North Richland, with the exception of the Firgt Aid wing.

On four occasions patrolmen assisted ambulance drivers.

Five firearns were reglstered with the Arsenel office. These firearms belong to persous living in North Richland.

Seventy-elght "Courte日y Cardg"were 1ssued during the month. Thege cards were placod on vehioleg that were in violotion of the parking regulations.

All trafflo control poinis were cover ed juring the hourg of heaviost traffic.

North Rlohland populatiun is as follows: Jremerton Houses - 637: Trailer Camp 3,126; Men's Barracks - 1,28\%: Women's Briracks - 45: Total Population - 5,095. There are 1.1 .17 occupled tralier lots and 186 occupled Bremertion Houses. There was a population increase of 55 pergons durlng the month.

There are five fixed posts and five reposts in the North Richland Area. 
North Riohliard Patrol Diviajon Cont id.

\section{Unusual. Inojdent Reports}

Publio Intoxioat1on-m-

- Publiza Nutsancom Family Disturbance Automobll. Theft Misplaced or Stolen Billfold Negil.gent DrivingReokl eas Driving Negligent Driving and no Operstor's Permit
Theft of Rfngm- 1 Drunkar Drtving 1 Vagranoy-_m_-1 1 Potilt Laroony-m-m-1 1 Automoblio Aocldent (1 Privato Oar)- 3 Alutomoblie Aooldent (2 Private Cars)- 1 Fallure to stop and Identify-mam- 1

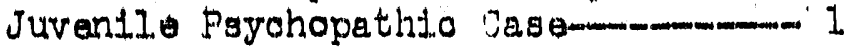

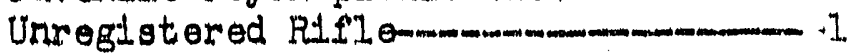
Removal of Sldewalk and Dooking-m-m 1 Theft of Jacket (Unfounded)-_... I

\section{Spectal Services Performed}

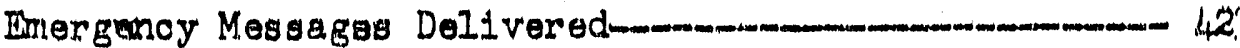

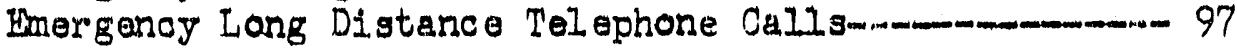

Wootiern Union and Pacifio Telegrams-10 10

Fireg (S1g. 12)

Filse Fire Alarms-_-_m_-_m 2

Unusual conditions reported to Malntenancom-man- 13

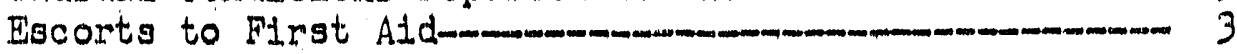

Btcycles Roported Missing 3

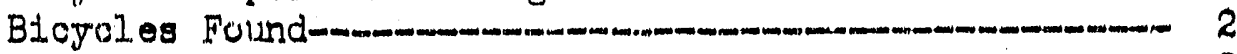

Bloycles Returned to Owner-m-2

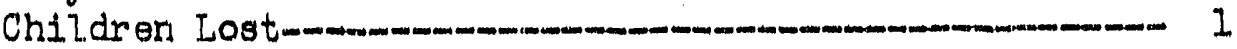

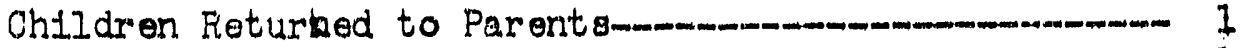

Children Bitten by Dogmann 1

Man B1tten by Dog-_an- 1

Personnel Locked out of Rooms-m-_o 1.0

Automobiles Impounded it North Richland Patrol Hdqrs.- 3

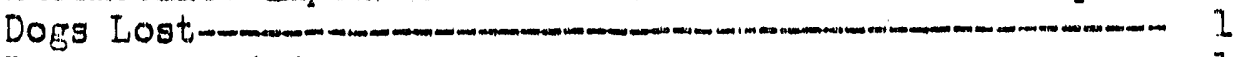

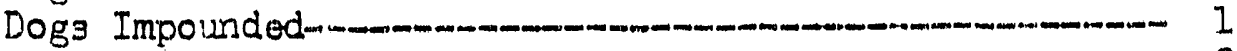

Complaints on Dogs In Triller Camp-_...

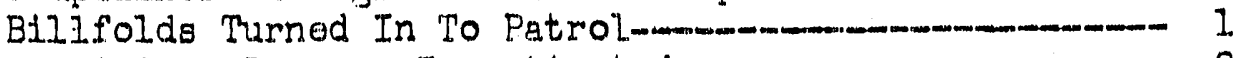

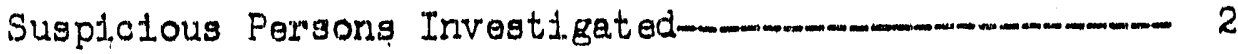

\section{Complaints}

Grand Larceny-1 1

Petit Larceny-an- 3

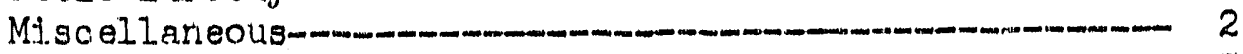

Cages Cleared-anom

Cases Unfounded-_nn 1 


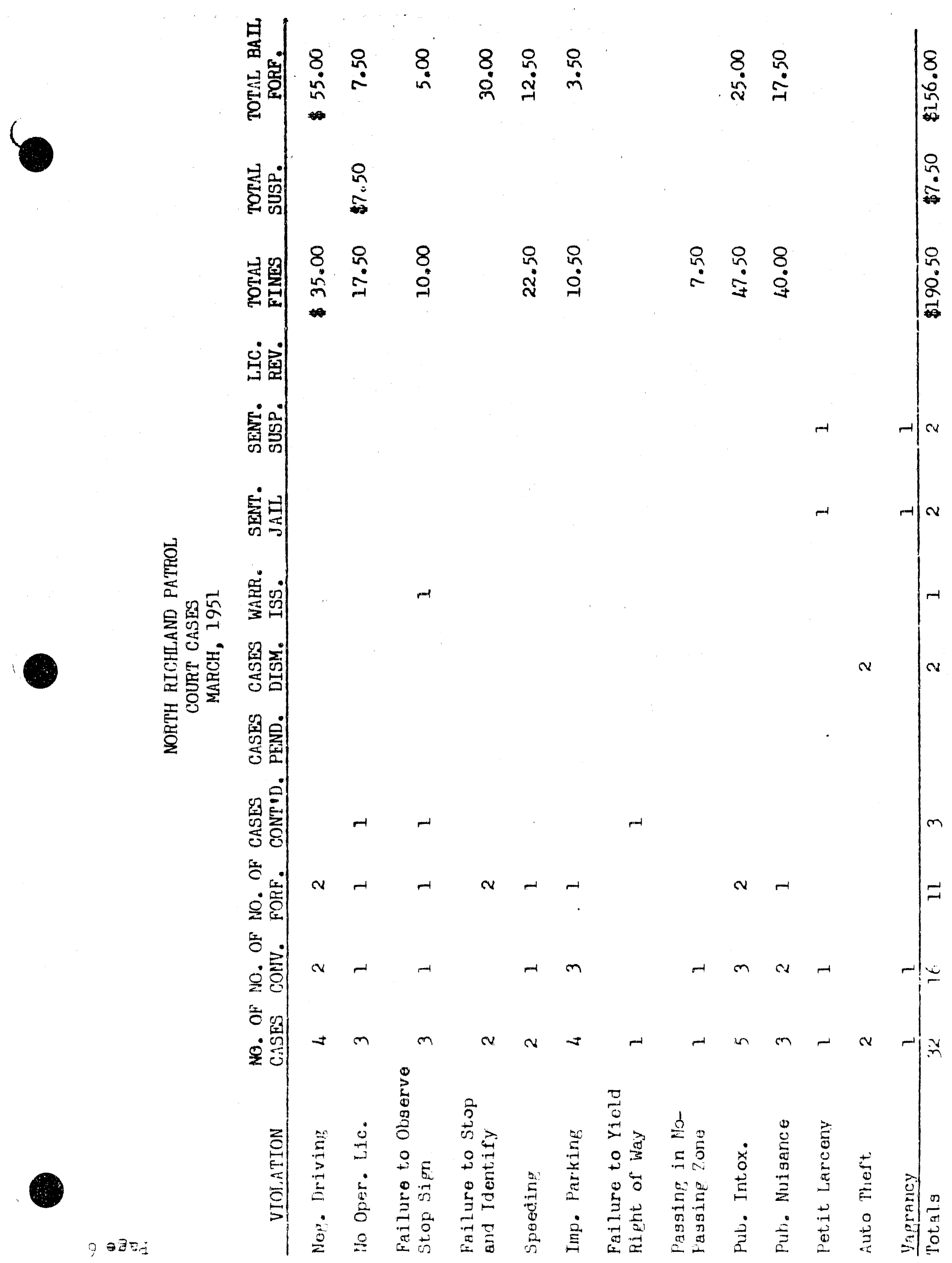




\section{WHIIISCOHED}

in-206n-Del

ENGTNEWTING $\triangle N D$ CONSTRUCTION DIVISIONS

I. QRGLIZCIITS $\perp$ ND FERSONELI

Exployeos on Payroll

$\frac{\text { Bequning }}{669} \quad \frac{\frac{\text { March }}{\text { Bad }}}{893^{*}} \quad \frac{\text { Net Change }}{7224}$

Inployees on Loan fron Instrument Division Purchosine \& Storos Schenectady

\begin{tabular}{rr}
7 & 9 \\
1 & 1 \\
$\frac{4}{12}$ & -4 \\
\hline 4
\end{tabular}

Total ERC Divisions $68 I$

907

* Includes 25 Personnol transferred to Entincoring and Construction by consolici. 10.n of Project Engincoring and Design and Construction Divisions.

II. INVENTIONS AND DISCOVERIES

171 persons angaged in rork that alght reasonably te expected to result in inventions or discovories have advised that, to the best of their knowledge and bellef, no inventions or discoverios noro rade in the course of thoir work during the pertor! covered by this report, excopt as listed below. Such persons further advise thet for the poriod thorein covered by this report, notebook recorils if any kept in the courso of their rork, have boen oxsnined for such inventions or discoverles.

NOIE 


\section{STMMARY}

Considerablo time has boen spent in compling a set of construction cost codos which will be unfform and standard for all Divisions and subcontractors of the Englnoering and Construction Divisions. It is expected these codos rill bo in effect by May 1, 1951.

Dwo to the increasod rolume of Fork load in the construction oost soction, it ras docldod to adopt machine posting. Five Burroughs Bookkoeping machines havo been ordered and it is oxpected that threo of thoso machinos $\quad 111$ bo instulled and ready for use about April 20, 1951.

\section{STATISTICAI SND GEMTERAI}

Total cash disbursed during the month of March was $\$ 5,201,136$ compared Tith \$4,799,656 disbursod during Febrangy.

Sccounts Payablo Distribution Sumary follows:

\author{
Gonoral Eloctric Purchasos \\ Roimburscmont - Ltkelnson-Jonos \\ CPFF Subcontract - Construction \\ Refribisis semont - Litlinson-Jonos \\ CFrir Subcontract - Sorvico \\ Roimbursomont - Othor CPFF Subcontracts \\ (Architoct Enginecrs) \\ Partia.l Paymonts to Iurm Sum Subcontracts \\ Travol (Ganoral Eloctric) \\ Uits cc.llanoous
}

Total Croditod to Lccounts Payablo

\section{March}

$$
\begin{array}{r}
1,484,775 \\
3,178,580 \\
230,791 \\
447,381 \\
214,614 \\
5,020 \\
121,720 \\
\hline 5,770,881 \\
\hline
\end{array}
$$

Larch

Lrorace number of omployecs roported

by CPFT Subcontractors (Inoluding

Sorvico Contract)

5451

CPFT Construction Subcontractors Payrolls

CPFT Sorvico Contract Payrolls

Lrchitect Engincor Payrolls

Total CPFF Payrolls

世2,106,349

234,807

$36 \% .809$

$2,708,265$

Lwercgo por rook (4 rook poriod excludine irchitect Enginecrs)

$\$ 505,289$

$\$ 107.37$

Lvorego Teukly Iernings

During tho month a rofund oi 17,202 mes recoivod from tho E. I. du Pont do Nemours and Compeny to covor oxcess of rolmbursoment for work under Subcontract G-174. 
Subcontract G-157 with C. C. Mooro and Co. was flnanclally completod.

in audit is currentis boing mado to dotomino the amount of proporty chargod to Profoet C-300, which should be capitalizod. Propor accourit adjustmonts will bo mado to rofloct capitalfzation of those assots.

III. PERSONNTEI

Employoos on payroll:

$\frac{\text { Boginning }}{73} \frac{\frac{\text { MARCH }}{73}}{\frac{\text { Not Change }}{0}}$




\section{CONDRSCT DIVISION}

\section{SUMHARY}

Subcontract G-343, Baldrin-Drunham Company - Modiflcation \#l approvod by the Cormission 3-23-51 addod 380 Profabs to oxlsting contract.

Sddondum No. I to Invitation to BId on B-11I olfminatod additional Viasto Storago Facllitios for 24I-BZ (200E).

Modiflcation proparod on rostatoment of CPFF Subcontract Gm 133 Lthinson-Jonos.

Hogotintions with the Kollox Corporation havo boon succossfully complotod covoring dosign of a portion of tho $100 \mathrm{C} \mathrm{FC.cilitilios.} \mathrm{Contract}$ documont has boon oxooutod by all partios.

\section{STITISTICLI AND GENTERLI.}

Elnvon contract itons showling an incroaso of $2,375,194.67$ wore complotod in Mirrch.

Trolvo othor contract itoms nore disposed of which did not involvo monoy.

III. BERSONNEL

Enployoos on payroll:

$$
\begin{aligned}
& \frac{\text { Boglnning }}{3 I} \frac{\frac{\text { MaCII }}{30^{*}}}{\frac{\text { End }}{-1}} \text { Not Chango } \\
& \text { * Inclucios ono opployoo on loan to another Division. }
\end{aligned}
$$




\section{SOMMARY}

Effective March 22 there Is established the Minor Construction DIvision of the Engineering and Construction DIrisions, comprising the previously designated Construction Division of the Englneering and Construction Divisions. Mre. J. H. Heffner is appointed Manager; Vice Ur. V. D. Nixon.

New work asslghkante, (1) fabricate, assemble for test and install process hood and oquitumint - 234-5 Dullding, (2) temporary constmaction electrical supy ty. fur I. Bullding, Projeot C-257, (3) site survey for Project C-43, (4) Layout work for MechanjenI Development Buflding Projoct C-406, (5) elootrolcal installation 24.1-Tr, 115 tank, Project C-362, (6) layout service for Project C-204-B, (7) InstaI1 13.8 KV IIne and T. C. Substation, construct temporary raliroad spur, coistisuction of concrete monuments, Project 241-TY, Project $0-418$, (8) seplace rotted wood posts - 380 prefabs, (9) repair box s111s on 6 prefabs, (10) temporary electrical for laboratory center - Project C-381, (11) temporary fonce at Aquatic DIology Iaboratory, Project G-364, (12) provido water sorvico and drainago facilities - Pile Technology Divisio!.

\section{STATISTICAI AND CENERAI}

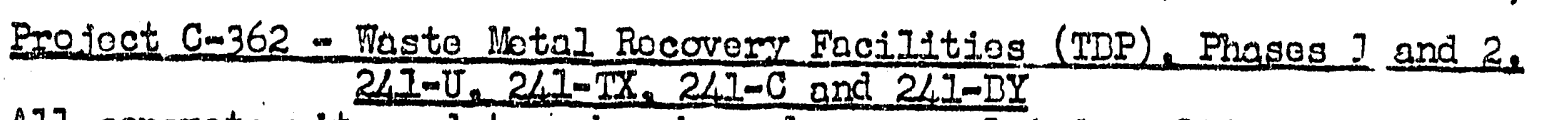
$\$ I I$ concrete pits and tronches havo been completod on 101 cascade. Coro drilling for hool pit holo is in progress on second cascado. Excavation for pits and tronches on third cascade $75 \%$ complete. Excavation in progross on $24 I-D Y$ and $C$. Tank farm 24I-U t1e-in comploted.

Projoct C-198 - 234-5 Duilding Program

Mifscollaneous rork itons, partitions, sorvico piping, etc. are being performed.

Projoct C-416 - Minor Construction Division Fabricating Shops. Fork on shop buildings and romodoling is approximately $80 ;$ complete. Equipmont installation to start as soon as equipmont is availablo.

Projoct C-4I8 - Tani Farm 24I-TY

Tork starting on tomporary fenco, mater Iine and Inyout and survering.

Richland Civil Dofonso suthority

Work on Defonso Control Contor is progrossing. Soron fences along canal at Camichrol school comploto, foncos at pumplng stction and domestic
wator woll punphouso startod.

RDL-E\&C-No, 1 Work on charging rachine and varlous othor tests and installations now
in progross. 


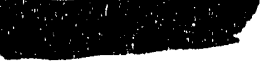

HIT-20671-x)el

Altorations to 712-4 Ifutmont - 700 Aros

Worke progrossing and complotion expocted Warch 31, with the excoption of pipo and plumbling work. Considoration is boing given to lotting a lump sum contract for the pipe and plumbing portion of the job.

Eloctrical Iine Crews

Ifno crows have boon porforming rork as requostod by Projoct Enginoering, on transformor bank for C-423, IIne instaliations for tho bruy at 200 East, 200-Most, P-II, Fhito Bluffs and 300 irea.

Safoty

Safoty inspoctions wero mado in a.ll aroas. Contacts with foromon row garding mon roporting infurios woro mado. Safoty and firo oquipriont locatod whoro nocossars.

Minor injuries

Lost Tino Injurios

Lccicionts (automotivo)

Fires

Offico Engineoring

Farohouso addition and storago yard now complotod; matorlals, small

tools and oqujpmont parts now boing centraliy locatod.

III. PERSOMNEI

Gonoral Eloctric

$\frac{\text { Degtnning }}{32} \frac{\text { End }}{33} \quad \frac{\text { Net Change }}{71}$

Sub \& Subcon-

tractors

Non-linnual

Ianual. 


\section{ENGINEHEIRING AND CONSTRTJOTION SFERIIOES DIVISION}

\section{SUMMARY}

Sone shifting of Supervisory Personnel continued this nonth. One supervisor regigned.

The moric load in all Sections contimes to be heavy, considerable Saturday and sone night rork belng necessary to koep up with requirements. The new uultigraph nochine is proving out as an oxcellont reproducer for ruany docments and forms. Costs in some cases have boon reduced 60\%. Considerublo bettor quality rork is belng turned out than was formerly by the Ozalid and meograph and ditto procosses.

Closor accountablilty has boon effected betreen this plant and the Kollex Corporation's New York office for job records and tho Sohenectady offico of Genoral Ilectric Company for noliting procedures of shipping dosien information by $C$. T. Brehanan at their offlces.

The recinutitiont of drafting porsonnel and ostablishnont of a trainfing program for beglnnine draftamon has boen coordinated by D. A. Conley.

\section{STATISTICAI AND CEIVERSL}

\section{Northli Ridehland Canp \\ Population*}

Trajlors

Darracks

Housog

Total
$3 ; 123$

1,326

$\frac{.635}{1004}$

Not Inoreaso 118

* Noter This doos not inviude U. S. Arry personnol.

Gonoral

Constmiction Work at the John Ball School and the hospital has been conplotod.

Work has started to provide switches bolor ecch sories circuit station covorine the operation of stroot Ilehts.

Fobmury 27, 1951 at 8:45 L.1\% an explosion of coal dust or feas occurred in the Numbor 3 silo at tho Stoan Plant. Thoro voro no injuries but considerablo danace rosultoc. Partial repales heve boon offocted.

Tho rator notor at the Pump Station has boon rocallbratod and adjustmonts macio to usace reporto.

Mintonanco

Goneral and scasonal maintonanco rork and vacating of bulldings for Amyr uso aro nov boing carrlod on. 
Stoan Cenometinc Plant

$\begin{array}{lr}\text { Stoam gonoratod, MI Ibs. } & 53,529.00 \\ \text { O1I consumod, gallons } & 17,238.00 \\ \text { Coal consuriod, tons } & 3,720.89 \\ \text { Bollor of flcloncy, avorago \% } & 75.69\end{array}$

Stoan cost, por II Ibs. \$.774

Wator consurption for the wonth was 4\%,805,600 or an avergge daily consunption of $1,593,520$ gallons.

Comperaial Facilitios

Thero ware sixtoon conteralal faclittios operating in North RIchland.

Rocomondations for changos to torns and conditions of Iiconse agreem nonts affecting soven oporators havo boon devoloped.

Cormunity detivitios

The rocroation progran for the sunner secson is getting underway. Some additional equipnont has beon ordored. Voluntary leadershlp is bolng souglit as the School Distriat will bo financialli unablo to prom viclo this sorvice.

Suporv1sors aro attending a district National. Rocroation dssociation Conforonco in Viloscors, Idaho.

Thero wore olghtymatght rolfglous and soventy-six soclal neotings conductod during the nonth.

\section{Offico Sorviticos}

Duo to tho consolidation of Tochnical and Project Inginooring Divisions Fitl F\&C, additional survoys aro boing nado to locate office space in tho 3000 droa for the additional people roquirod in sccounting, Iurp Sur Subcontractors, otc.

Socurity

Statistical information

During tho month, 392 nootines wore hold at which Socurity topics were discussed. Those nootines woro attonded by 11,300 erployeos. Three Socurity Bullotins roro issuod.

Mior constmuction oquirmont

Total oquipmort assignod to LiseJ and IR\&C 2002

Total shop oquiprant assignod to dseJ and G.E. $\quad 760$

Safotir

Construction Injurios

Nejor Injurios

Sub-linjor Injurios

Iilinor Injurios

\section{Controctors}

$535^{\circ}$

\section{Civ11 Dof'ongo}

The Civil Dofonso procrer activitios havo incroasod. Evacuation plans in tho aroas, orjetion and distribution of oquipront and instructions aro undormay. School bliliding ovccuation drills aro bolne conductod. Cortain nobilo oquipront hes boon located for use. Locctions for cachos of nodical supplios, nursos' alds, onorgoncy wator supply and trans- 
portatio are ving studied.

Drating Soction

Drafting Production:

Nav Drawinge

339

Procilanocus

Drawing Rovisions

245

Drawlings officlonoy index, nan-days/crawling 4.5

Estipatine and Standarde Soction

Estinnting:

Estinates sabodulod

Estinates corpIoted

20

Estiontes to be cormplatod

10

Total estlacited raluse

10

Dinlt Costs:

Studios contirad on Profoct Cus 187-D and C-362

Staudies contimued on G. E. Construction

Unitlzation of North If ahland Canp and Construction Lron

Reproduction Soction

Broduction Group Activitys

OrfeInals Handlod

Prints Producod

Squaro Foot of Papor

Avorage Squaro Feot Per Fryloyeo

$20 ; 939$

213;711

647.222

38,072

Personnol, Recorda and History Bect1on

Securfty Clearancos Processed:

Requests fur Aroa Badges, Cancollations, Lecess Authorizations and linterlal and Puakage Passos

Esc Porrol1 Ldditions. Terninationg and Transfors:

Idditions

Texrinations

Transfors withen E\&C Divisions

Transfors out of E\&C DIFIslons

32

8

9

Socret and Conficiontial Docuronts Procassed:

Docurnonts Issued, Routod or Dostroyed 3391

Procodures Issued:

Instructions Issued 22

Status of Historios:

Histories Issuod

Roady for Issuod

Others in Procoss 
Oeftoo Sorwiogs

Numbor of Tolotippos Sont

Number of Telotjpos Rocolvod

Number of Coptos of Ditto Reproducod

Nuabor of Copilas of Stonolis Roproduood

Number of Pleses of Inooning MalI

Number of Plooes of Proglstered and Insured Ma11 (Outgolng)

Anount of Fostage Used

Nurber of Store Ordais Written (Stationery)

246,981

Nurber of Speatal Mossenger Dellverles

Prolect Cost and Proeress Analvals Sootton

Forecasts, charts, ana.Iyses and reports vere doveloped and 1ssuod to shor status of I\&C Projeots.

Migoe 11anoous:

Coordinnted preparation of 1951, 52, 53 Buclget force fluuros for Englneering Sorviloos.

Mr. H. F. Scott devoted sone $75 \%$ of his time to Clv1lian Defense Nork.

III. PERSONNEL

Number of employees on paysoll:

$\frac{\text { Beginning }}{305} \quad \frac{\frac{\text { Munch }}{301}}{\text { End }} \quad \frac{\text { Not Change }}{-4}$




\section{ENGINEERING \& CONSTRUCTION SERVICES DIVISION \\ Drafting Section}

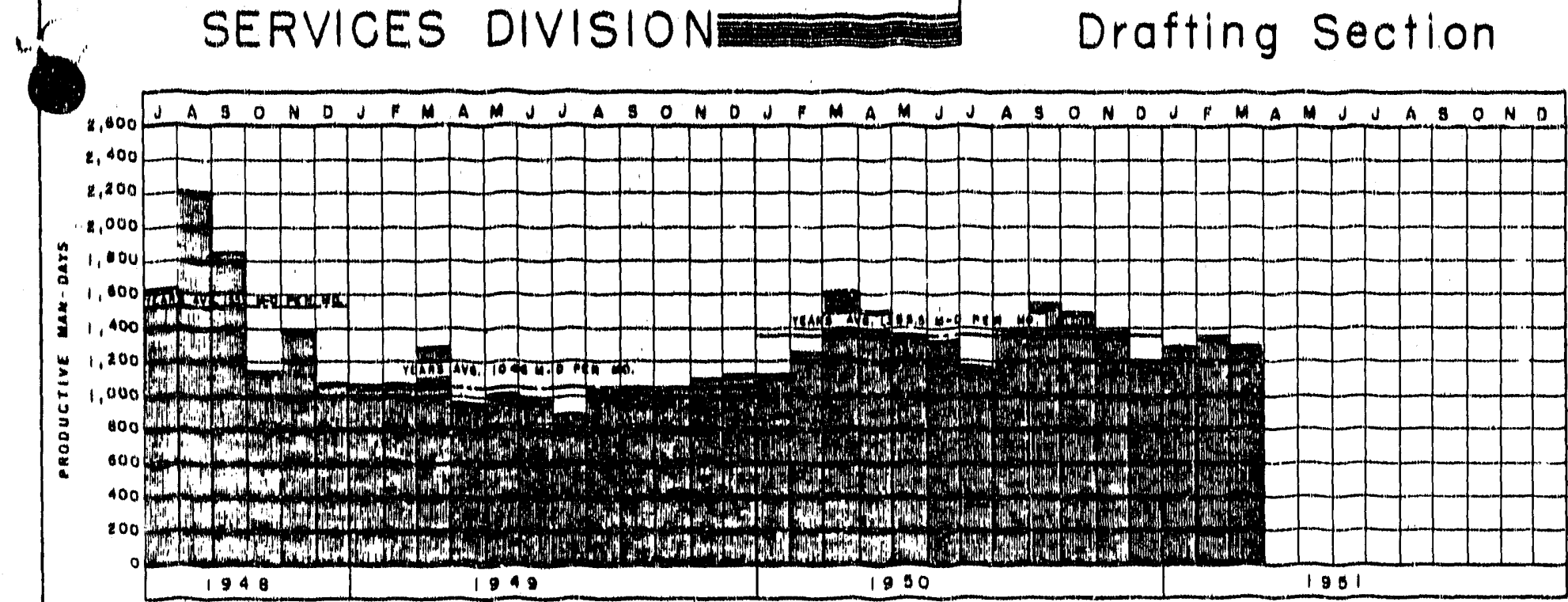

MAN POWER

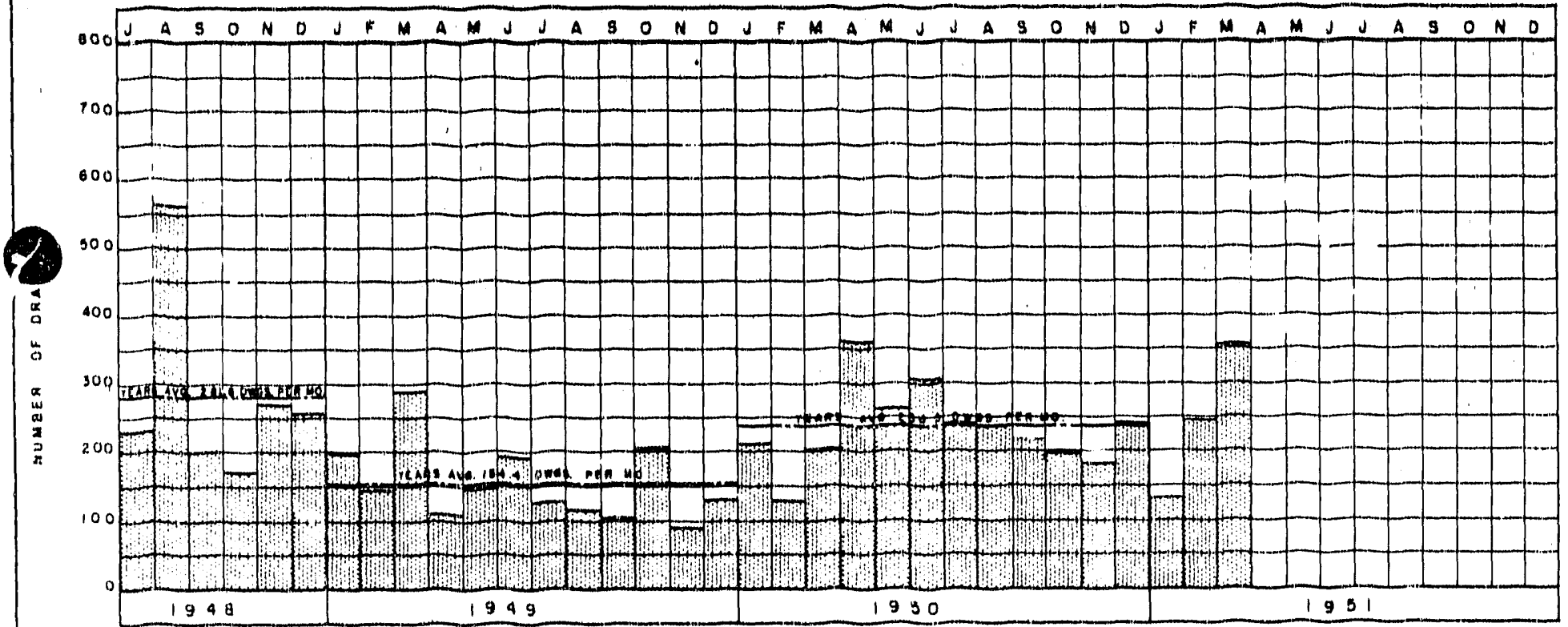

DRAWINGS PRODUCED

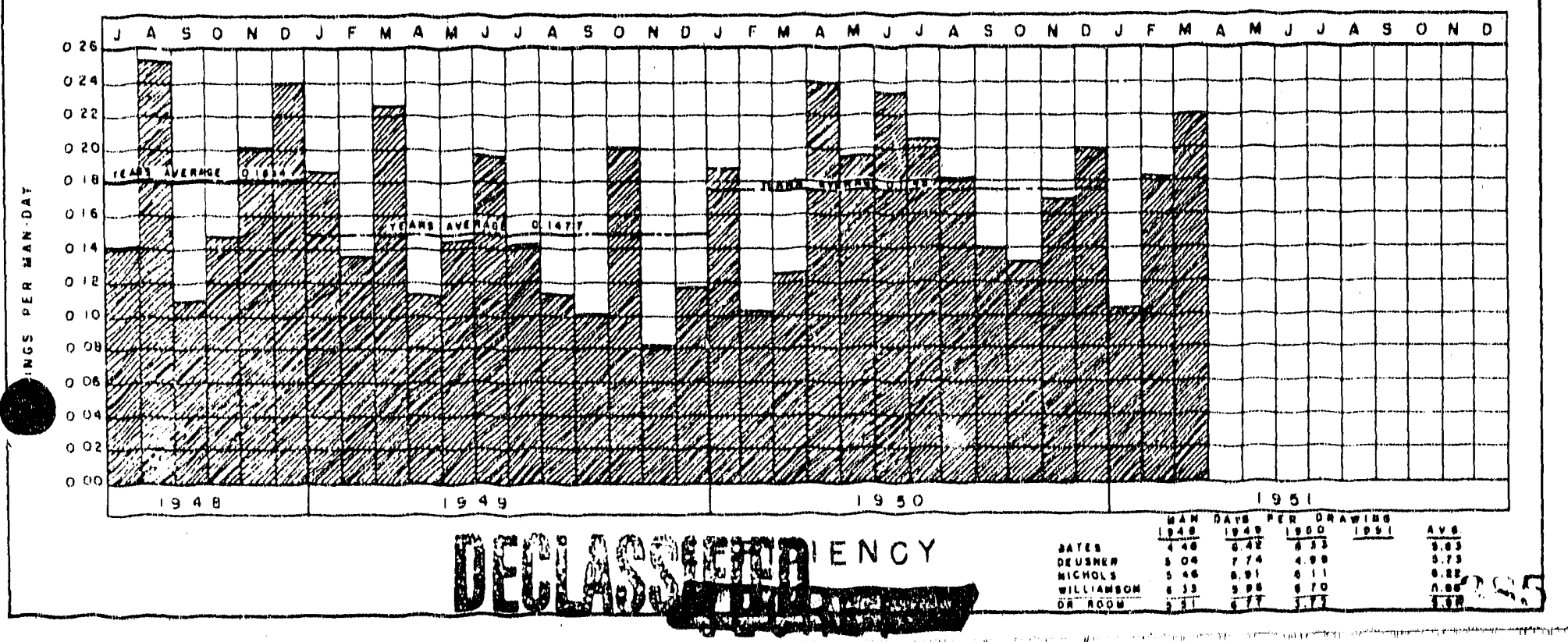




\section{DECLASSTFED}

HTI-20672..LeP

ARTNOTFAI ENGINEERS

\section{STrintery}

The activitiag of ti:o Prinolpal Finglnoers conolated of revilowing and cononting on dranlices, duslgn doounents, speolflontions, preparation

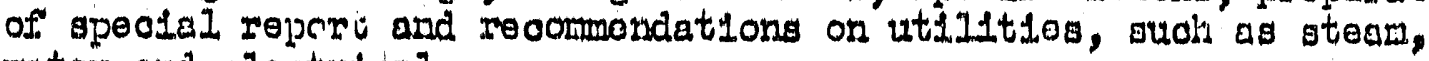
wator and olootrical.

Inrostleation ef the effeots of new profoot olootriogl loads on utilitty systons.

Consulting seivices on tochnioal natters.

Carriod on Rooruttment program of Tochntoo]. Englineors.

II. STATISTICAI SND CENTHAI

Speatal Roporti

Eloctrical and Mochand cal Mnglineers of tho 1951 Graduating 0lass of tho Univorsity of Calffornia at Borkely woro Intorv10wod. Lisoomendations for onploymont of comtaln non mere rado.

Melding and corrosion to gts of stratoglo notals conductad in San Franolsoo In latter part of liarch.

Tho qualities of llotor Control Centerg st sevoral nanufacturers, to detormine polloy in witing future spocifloctions.

Standards dormittoe rork was clone on setting up noro conplote standards for plant oloctrioal roooticlos.

Consult ine and Ldvisory Sorvioos

$\mathrm{C}=361$, UO 3 Plant (NotaI Swootenine and Convorgion Faolilitios)

Cont Imed rork on cast1ne problon at Elsco Foundry, Portland.

C-362, Masto Motal Recovory (TLP)

Fiold wolding problens of trensport I1no.

Q-394, Plat Plan and Ut1Ifties

Worlts, offlelonoy and oconony of turbino drivon omargoncy oloctrits Eonorator vorsus diosol gonorator. Draft of dosign specifications.

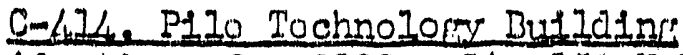

Ldapting of a 2300 volt, $150 \mathrm{H} . \mathrm{P}$. motox for uso on a 480 volt systom by roconnoction of rindirica.

Car 431. Non P110. 100 C Plant

Blast reslstanco factor in closign of structuros. Ellootrionl poror syoten for now purpine urits. 105 vontilation gystor dosien spoolfications. Nocomendations on cortain stainloss applications. 
Ceneral Itens

Standards camitteo "Design Gulde for Stalnless Steels".

Revisions to H. T. Specifications for Welder Qualification Tests and the

Piping Code.

Liscellanoous problens - Substitute naterials effect on NPA Regulations, etc., AIr fliter offlolencles, application possibilities of "Ball Valve Conpany" rotary valve equipment.

Rerierr and Conrents

187-D. Roclox Production Plant

Vossel fabrication and specifications.

C-385, Radionctallurger Buflding

Prelininary plans and spociflcations.

C-39ke Plot Plan and Dtilities

Desien criteria.

C-431. New Recetor 100-C PJant

Design oriteria for 105 Buflding Electrical systons

Genoral Itors

Civ1l Defonse Progran, proposod eloctrical elrcults for control of alarn horns.

3084 Coal Silo, expjosion of conl.

Lrry invitations to bld on contract work for steas services, based on

1950-5I winter conditions, electrical drewings and specifications covering cortain buildings.

Technical paper witton by employeo, for reloase with rospoct to any classiflod material contained thoroin.

III. BIPSONNEI

Enployeas on payroll

$$
\frac{\text { Beginning }}{3} \frac{\text { Morch }}{3} \quad \frac{\text { Not Change }}{0}
$$




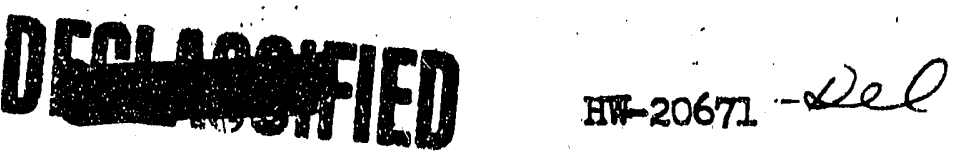

ROMISR AND MEGHANICAL DIVISION

\section{SURMARY}

Mombers of the Design Eroinoerelng group spent 75\% of their time in engineerIng assistance on projects for other divisions.

Not1ce to proceed on a design contract for the now production facility, C-431-A, was effective March 5th, retroactive to Jamuary 25, 1951.

II. STATISTICAI AND GFMPRAI

C-199. Expangtion of 300 Ares Senttary Serrer Disposal Srstem: Ifttle progress has boen made on design erigineering the past month because of high priority assigned to other work.

C-20/-B. Additions and Alterations to Kadlec Hospital \& Medical Arts Bldge: The construction contractor, Walarkey \& Moore, started work early in the month and are malding slow progress due in part to a temporary difficulty in manning the job adequately.

Ce257. Heclth Instrument Control Iciboretory: Tork by the Sound Construct1on \& Englneering Compan progressed sat1afactorly during the month. Foumdations, pler footings, and general concrete work is approximately 15\% complete. Excaration and bock-fliling is tpproximately 75\% complete. Over all, project $1 . s$ approadmately 3\% complete.

C-295 Enlarging 251 Substation: Formal notice to proceed with the construct ion of this project was issued on March 27 to llontgomery Electric Co. of Seattle. The subcontract muber is $\mathrm{G}-359$, which schedules constiuction completion for Norember 26, 1951.

C-353. Richland Water Study: The revised study report was submitted on March $I_{4}$ by the architectmengineer, LIvord, Burdick \& Howson Coples have been transmitted for comment to the Atomic Energy Commission and the Manlcipal Division. Further work will await their rocommendations.

Cu-36/un Aquatic Bjologr Laboratory: Revised plans and speoifications on this project wore submitted by the architect-ong1noer, Barrott \& Logan, on llarch 20. After revlew, these have been transmitted to the Contract Division so that the project may be advertised for lump sum construction bids. Approval ras granted by tho Atomic Enorgy Comnission under the dato of April 2 to Iimlt competition to four constmiction contractors in an attompt to meet the vory short time allowed for construction. This was later modifled to poralt bidding from any interestod parties. It is expected that bids Fill be opened on April 19th.

C-381, Radiochemistry Bulfding: Final plans and speciflcations preparod by Leland S. Rosenor nere rocoived on llarch 7. These have beon carefully chockad, minor corrections havo boen mado, and are bolng prepared for transmittal to the Contract Division. 
C-385. Radiometal7urgy Butlding: Design by Loland $S$, Rosener is approxdmatoly 66\% complete. Design of four items of speclal high-radiation level equipment is $84 \%$ comploto.

C-394a Plot Plan \& Utilities - HDT Ioboratory: Proliminary drawings on all design Fork undor contract to Loland S. Rosener wore recelved on March $3 I$. Dosign work is ostimated to be $84 \%$ complote.

C-1.06. Mechanfical Dore Ionment Butlaing: Directive HW-204, Llodiflcation 2, was issued on dpril 2 authorialng funds for the construction of Phase II of this project. Onder date of March 16, the Cormission also authorizod the negotiation of a Iump sum subcontract with DIx Steel Bullding Company for the dosign and constinution of Phase II.

C-47he P17e Tochnologr Buflding: Plans and spectflcations are about 60\% comploto and were roolowed by G.E. englneors at the Boston office of Chas. T. Inin, Inc., during the month. Design of certain mechanical featuros is somowhat bohind schodule, but is axpected to be approxefmately on schedule by the end of $\Delta$ prif.

C-127. Ifibrary \& F1les. Butlding: Plans and speciflcations being prepared by Chas. T. Mlain, Inc, are now 74\% complete and are on schedule.

C-43I-A 100-C Production Focilftw: Not1ce to proceed on the design of th1s project was.1ssued to Chas. T. Main, Inc., on March 5, retroactive to January 25, 1951, the subcontract mumber boing G-363. During the period from March 12 to April 4, four ropresentatires of the architect-englneer were in Richlend assisting in the proparation of scope material and design criteria. Roquisitions to the value of approxdmately $\$ 2,500,000$ have been turnod over to Purchasing Division, which have thus far resulted in two firm purchase orders totaling $\$ 320,000$. Diroctive Hin-222, Hodification 2, datod llarch 21, 1951, authorized the construction of this project, but did not provide funds for construction. Negotiations leading to a CPFF construction subcontract are in process with Aticinson-Jones Company.

C-433, 384 Stean Plant Addition: Directive HW-229, dated linech 28, 7as issued by the Comission allocating funds for the design and construction of additions to the 384 Stean Plant and 382 Fater Plant. Bid invitations w1II bo 1ssued early in April.

III. PERSOINEL

Erploycos on payroll:

$$
\frac{\text { Boginning }}{57} \frac{\frac{\text { Warch }}{59}}{\frac{\text { Net Clange }}{12}}
$$


PROJECT ENGINERERING DIVISION

\section{SUMMARY}

Work was progressing durtng March on 74 active projects and 18 informal requests representing $\$ 23,400,876$ worth of project work. In addition, this division provldes a considerable volume of assistance and consultIng services to the Operating Divisions in connection with maintenance and minor constmution jobs of $168 \mathrm{~s}$ than project proportions.

Plans for the Civil Defense Program are progressing. Air raid sirens have been recelved and a project proposal submitted to the $A$ and $B$ Comittee for the air raid warning system. Designs are in preparation for air raid shelters and cost of various alternate proposals being studied.

Larger jobs now in progress include the P-10 Program, the Waste Evaporators, and the Hot Semi-Works, with this division responsible $f$ or all phases fram design, through administration of field work or cantract stages, down to and including cost records for each job.

The Industrial Ingineering Study Group is presently concerned mainly with streamlining operational cycles for Manufacturing Divisions, though their assistance is available to all divisions on the plant when need arises.

No Inventions or discoveries reported during March. No major or submajor and but one minor injury was reported up to 3-27-51.

\section{STATISTICAI AND GENERAL}

The following is a brief summary of important project items as listed by areas:

\section{AREAS}

C-172 - Dismantling of Equipment - Demineralizing \& Deaerating Plants

$100 \mathrm{D}$ \& $F$ tanks have been removed, and the special hoisting equipment moved to $100 \mathrm{mB}$, where two tanks have already been lowered.

Arrangements have bieen made by Morrison-Knudsen Campany for repair of damage to $185-F, 189-F$ and $190-F$ Buildings which was caused by the deaerator tank that fell.

C-399- P-10-D Program

Project proposal Part II has been submitted for approval, with design phases now essentially complete, though substitution of altemate materials has become necessary in fabrication work in order to permit completion of extraction and handling facilities in April.

Field work is progressing with CPFF service subcontractor forces. 
C-410 - In Plle Contrelled Atmosphere - Experimental Facilltie日

Plant forces began Installation of equipment March 15, 1951. Shep Fabrication work is nearing completion.

C-411- P-IO-XX J SIug HandIIng Facilitieg

Virtually all, design aspects have been completed utillzing $105-\mathrm{H}$ basin for storage and $105 m \mathrm{~m}$ tranafer area crane for cask handling. Present planning includes a firm order for four casks with material being held avallable in storage for two more if needed. Detalled study of cask heat transfer rates is now in progress.

\section{C-412 - P-10-X Dxtraotion Facilities}

A scope description has been completed covering all phases of the installation at 108-B in detall with the exception of the metallurgioal facility. The latter is covered in general terms only since detalls must remain sanewhat flexible due to the specialired nature of this item. Basically this laboratory consists of Iglove boxes" for handling small "hot" items and a shielded "cave" arrangement to be used for cutting sections from processed furnace charges.

Detailed design is in progress with the product storage building designs scheduled to be completed during April.

Advanced ardering of material is proceeding lapidly.

A letter project is being submitted to the Atamic Energy Commission ren questing approval for construction and also increasing the amount of approved funds eran $\$ 615,000$ to $\$ 800,000$.

M-83I-107-B,D,F,H \& DR Bastns Pemanent Repairs (ER- I249) M-824 - Energency Repair 107 DR \& F Basins

Investigation of various brands of expansion joint compounds (putty, thiokol or latex type) which would be suitable for water temperatures up to $200 \%$ revealed that none would meet all of the $r$ ather rigid requirements. Investigation has now been turned towerd a flat and flexible membrane type of expansion joint.

Same leaks have been repaired in $107-D$ basin, but remaining work has been delayed pending final decision on material to be used.

M-832 - Ball Type Third Safety System

H.I. tests revealed that the balls contained in the fluted step-plug had an insignificant effect on shielding. Design with dump gates at the bottom of the flutes was therefore dropped in favor of a gate above the top of the pile which has the added advantage of permitting an cperational test check without dumping the balls in the hole. Such an arrangement will make the mechanism more accessable for inspection and maintenance.

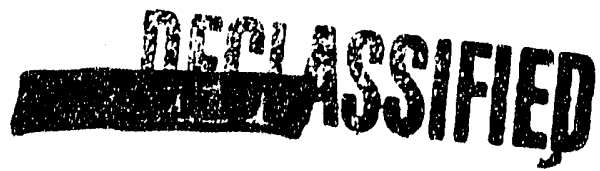




\section{DESUIAOAIIED}

M-832 - Ball Type Third Safety System (Contid.)

Study sketches have been prepared for three alternate types of dumping action, and a comparative analysts has been prepared on these designs.

Improved ball flow and shlelding properties a re indicated for the fluted step-plug on which preliminary design has well advanced.

Tentative designs have been prepared for bottom plugs and auxillary equipment.

\section{AREAS}

\section{C-349-Hot Sem1-Works}

Review of status of General Electric fumished materials indicates that the contractor's schedule will be met. Major excavation is essentially completed and a temporary substation has been provided for the contractoris use.

C-33? and $C-378$ - Dissolver off Gas Filter and S1Iver Nitrate Reaotor

The fourth unit has been installed and authorization has been received for the fabrication of the fifth unit. Material is being ordered for the fifth unit.

C-369 - Evaporation Facilities, 200 West Area

Outside of a few minor changes, the design for 200 West Area is complete.

Field construction is rapldiy progressing, with cutside work completed except for walks and grading. Facilities are scheduled to be ready for use May 1, 1951.

\section{C-423 - Evaporation Facilities, 200 East Area}

The project proposal is belng reviewed by the Atamic Energy Commission.

Designs follow closely the unit now being Installed in 200 West.

ER 2533 - Waste Disposal Facilities for Building $234-5$

The project proposal being routed for approval of the A and B Committee. ER 2547 - Coating Unit for Hood 26, Bullding 235

The project pruposal has been routed for A and B Camittee approval. 
300 AREA

\section{Com 3BO - Increased Vent1lat1on 313-3.14 Bulldirgs}

Eiflciency and particle size tests have been completed on the Hersey bag type filters adjacent to 314 Building, and an analysis and evaluation report is in preparation.

Equipment rearrangement plans for 313 Bullding Chip Recovery Area are pregressing. Lowering the initlal sorting table to floor level has eliminated one manual Iffing operation and improved operator effiolency.

\section{C-077 - Instrument Maintenance \& Development Building}

Construction contract is practically complete, but is being delayed because of certain electrical items and rentilation controls. The extension of time to April I, requested by the cuntractor, may not be sufficient to complete the building.

\section{GENERAL PLANT}

\section{C-390 \& M-770 - Central Stores Warehouse}

There has been no change In the status of this project, which is now awating authorization by the Atomic Energy Commission. A scale model of the rehouse has been completed and is now on display. The local Atamic Energy Commission Office will make all arrangements for the detalied design by an architect-engineer.

\section{C-284-R \& M-8II - Consolidation of Transportation Facilities}

Final action on approval of design funds by the $A$ and $B$ Committee was withheld thirty days pending further investigation and estimates of Individual shop units in lieu of a combined shop. Preliminary design of this new arrangement is complete and a high spot estimate w1ll be available for discussion at the next meeting.

ER A -630 - Solvents Building - 300 Area

The Solvents Storage and Studies Building will now be combtned into a single structure of approximately 2,000 square feet, including 400 square feet for the Stores Division Caption 10 solvents, and 144 square feet for sample preparation room. Preliminary sketch and estimate has been completed and a project proposal will be submitted to the March $A$ and $B$ Comittee meeting. 


\section{D.MAFIFD}

HTw-20671 Del

\section{ELFCTRICAI}

C-404 - Primary Electrfical Power Lines for Hanford Forks Laboratory Area

Design for this profect is essentially complete, and material ordering has been started. It is anticlpated that ane of the feeders will be run underground through the central part of the 300 Area. Construction power has been provided by temporary ine extension.

\section{C-380 - Electricity Motering - Village of Rlchland}

Design work for this project is complete, and subcontract preparation is now underway.

\section{C-419 - Induct1an Heating - Building 3732}

Profect proposal has been approved and specifications for the induction equipment have been forwarded to Purchasing. Design is complete.

C-432 - Air Raid Warning System, Richland - N. Richland

Waming equipment is now on the plant. Design of control system, etc. is in progress. Towers will be installed by Iump sum contract and will include placement of siren and fencing.

ER E-453 - Intercamunication System, Building 234-5

This proposal provides for installation of a 100 line dial exchange for local service within the building, utilizing exchange equipment available on the plant. Since this work was not of informal request proportions it will be accomplished by work order.

ER E-454 - Extension of 300 Area Underground Electrical Power Distribution System

Project proposal is essentially complete. Design is progressing satisfactorily.

ER E-456 - Additional Equipment Richland Telephone Exchange

The project proposal has been rewritten to include a more detailed description of and reason for proposed work. No design work is anticipated.

\section{INDUSTRIAL ENGINEUERING}

\section{P-10 Studies}

A special pickmup tong which could differentiate between $P-10$ and uranium slugs was developed for use in P-10 discharges from the pile, but during March, reduction of production requirements and relaxation of certain technical specifications have made it possible to effect the P-10 dis- 


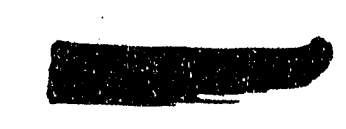

HW-20671-Nel

\section{Pr10 Studies (Cont'd.)}

charge within the noxmal maintenance outage tine. Work has therefore been discontinued on evaluation of the tongs in view of the more relaxed pressure at the pickm operation.

\section{$234 \cdot 5$ Bullding Studies}

Bfforts were concentrated on establishing rate balances and materlal flows for the R. Q. In output of each unit in Part II have been oomputed fram production records. Integration of these results with Part I data is in progress.

Information regarding Hood 8 furnace outage time is being developed fram historical records to determine major causes of maintenance outage as well as extent of down-time due to other causes.

\section{Area Studies}

The slug canning operation preliminary analysis has indicated the feasibility of at least partial mechanization. Efforts will be directed, in Apr11, towards development of a demonstration unit covering the eirst phase of mechanization which includes cap preheating and its final assembly with the can and slug.

Mechanical control of certain aspects of the canned slus welding operation appears practical. The first element of a demonstration unit is to be fabricated and tested in April. This element will cause the electric are to trace a predetermined and reproducible weld pattern on the oap.

The machining studies to increase capacity on the roller turner lathes continued primarily to obtain data on tool life.

\section{Area Group Vehicle Study}

A study of vehicle usage pattern is being made in order to determine the optimum possible usage efficiency pattern. A questionnaire is in preparation in connection with the survey.

\section{PERSONNEL}

Employees on payroll:

\section{MARCH}

$$
\frac{\text { Beginning }}{* 220} \quad \text { End } \quad \frac{\text { Net Change }}{-5}
$$

*Includes 19 Industrial Engineering on loan from Mnufacturing Divisions. * Includes 17 Industrial Engineering on loan from Manufacturing Divisions. 


\section{DENGUFIED}

iWT-20672-Del

REACTOR DIVISION

\section{SUMMARY}

Iffective Marrah 22, Mr. V. D. Nixon is appolnted Manager, Reactor Divisicin; Viso P. E. Lowe, who has accepted other duties with the Manufacturinis Division.

The Reslearah and Devolopement Progran DSC \#I has been transferred to the Technilcal Division. The sactor Division will contimue to do englinouring design only for dovelopecent work. Most of the Tast Prom jects pere discontimied this month so that the Test Ingineers could bo assilgned to $C-431$. (B).

\section{C- -437 (B)}

The Ko.110x Corporation started design March 5 and inftiated two studiog. (1) provido Zono 2 earthquake resistance, (2) probablo consequencos of dosigning for $1000 \mathrm{lb} / \mathrm{sq}$. it. blast resiatance. This lattor study is to include an estinato of cost and schodule delay.

The lottor profect proposal roquesting additional funds was submitted to the comritssion this month.

II. ITATISTICAI AND GENERAI

All of the dosien oriterla oxcopt instrumentation has beon transaltod to the Lrahitoct-Enclneor. Ther this has been roviorod a now schedule is to be submittod by tho drohstect-Englnoer.

Trro Scope matters aro yot to bo rosolvod; thoy aro "corlng" and wator annul. dimonsions.

Waterial roquisitions havine a value of approximatoly $\$ 3,000,000$ hovo boun issueci.

Requiroments for Subcontractor purchased bulk natorial itens are boine survoyod.

Matorial and draftine schodulos aro boing propared.

A prolininary construction schodulo for the fabrication of "B" Blocks has beon dovolopod.

Procoss Tubo Hoat Transfor

Throughout nost of tho nonth tho lloct Transfor Tosts woro discontimuod in favor of highor prlority work for tho $0-431-D$ projoct. The tests wore rosumed liarch 28. Sovoral tests aro boine porforned in conjunotion with the Tochnical Divisions. Sono tosts voro narle on the short longth section. Tho soction usod wiIl bo put into the fIIn bulld up syston and Nili bo tostod cigain poriodicaliy. 1 graphical nethod for calculating bolling curvos has boen dovolopod. 
Matoritals Dorolopomont

The alunimu croop tost has boon complotod with neglible secondary oreop aftor 9800 hours. The zirernilum oroep rato for tho past month mas nil. I satisfactory systom of regulat1ng temporaturos lis boon. rorkod out on tho hieh-tenporature comosion tosts. Rolls are boing fabricatod for tho production of ribbed shoot atrconfum.

\section{Shiolding}

AII of the material has beon requigitioned for the front, roar and sido biologleal shiold. The front, rear and side thormal blocks have beon requisitioned.

\section{Modorator}

Is a result of work dono for the "G" ranctor, the "G" noderator W111 incorporato dosign foatures which w111 maintain graphito temperatures at ralues whych will nininize distortion. Ls a result, the gronth 0111 be antorlaliz less than on "H" reactor with an anticlpated Iongor p1Io I1fo.

Eutiding and Factittios

A signifloant mabor of improvenents have been inconporated in the bullding critoria on a "no dolay" basis. A primary objoctive of our offorts has been to roduce the construction cost of the 105-C facilfty. is an exanplo, a saving of $\$ 920,000$ will be realizod by elininating tho gas wing and incorporating the equiprent in 115-Be The process Ilft station (1608) wiIl also be incorporated in 105-C. AII najor Itoms of bullatig oqufpaent havo been requisitioned.

\section{Continuous Charging}

Tho conplote dischargine nachino and the prototypo charging nachlno are being installod on tho togt stand. In 189-D. Thoso machines will bo tosted usine a full length procoss tube cnd nozzlo to sinulate p1lo oporating conditions. This tost has boon dolayod bocauso of the divorsion of tho tost manpowor to requisition rritinis. Tho Gonoral Enginooring Laboratory has agroed to undortako tho Dovolopoment of a dovico which NIII autonat1cally centor the dischargine nachine on tho dischargo nozzlo. AII of tho facilitios roquirod for continuous charging and dischareine 111 be incorporatod in tho 105-C elevators and butiding.

Gas Syston

LII major oquipment 1toms havo beon requisitioned for $105-\mathrm{C}$.

\section{Eajz Therd Safoty Systor}

Tho ball renoval duct arrangomont whs.ch will bo incorporated in tho foundation of 105-C ras tostod succossfuliny in tho Reactor Divin sion Tost Inboratory, 189-D.

Heating and Vent1lating

17 najor equiprent itons hevo boon roquisitioned.

Iortzontal Roc's

Tho closien and dotailod dravings of the rod soal havo boon complotod and throo (3) assorablios ordurod for tasts. The dosien loyout of tho round tip has boon complotod. 
Vortionl Rodis

Tho desigm layouts of the various components are undorway. Three (3) prolininary drop tosts were nado at the Thite Bluffs Tost Towor. The design and operation of the pneuratic dacelorator appeared to be satisfactory.

P110 Enrtichpont

A study was conplotod of varlous nothods of using enriched naterlals in the now 105-C facility to conpensate for the loss of reactivity due to the enlarged water annulus. The results are sumariarized in report
HDC-2085.

Chargine and D1schargling Elovators

Speclfications and associatod drawings were comploted and roviowod With the Elevator Ninnufacturor. Frocurement negotiations wero conplotod and tho contract was approvod by the General Eloctric Company and the A.I.C., and it is being revieved by the Haughton Elevator Conpang.

III, PERSONNEI

Ire. R. V. Androms joinod tho desien staff. Mr. M. J. Ruthorford was transformod fron the Separations Divisions.

Froployoos on payroll (onoludine rotational onelnoors) $\frac{\text { Bogtrning }}{43} \frac{\frac{\text { March }}{47}}{\frac{\text { Ind }}{46}} \quad \frac{\text { Not Chonge }}{4}$ 
SEPARATIONS DTVISION

\section{SUMARRT}

Installation of equipment for Redox Production Faclifties ras dolayed due to tho incomplete status of cell finishing. Hajor oquipnent deliveries by fabricaticrs did not neet expectations as only 14 ploces of the 30 schedulod moro delivorod in Narch. Construction roachod $68.6 \%$ at months end.

AlI RMA materlal shipmonts for Project C-198, 234-5 Building Program have been rocolved with tho excoption of a for rolatively minor itoms.

Design for phases I and IV of Project C-362, Waste Metal Recovery Facllitios, has been essentially conploted by the Kellox Corporation. Scope for 01 ? phases 18 100\% completo as is dotalled dosign for phases I, III and V. AII detailod desien is $35 \%$ comploto.

II. STATISTICAL SND GEHEHRSI

4. Project C-187-D - Rodox Production Plant

Porrer and Mochanical Division dosign work on Rodox outside facilities and Separations Division design work on the 24l-S Tank Farm has beon conplotod.

Dosicn of oquipnont such as funpors, dunnages, otc. nocessary for the installation of the silvor roactor has boon corploted. The fleld issue of thoso dxavings has boon hold pendine tho dovelopment of firm information regarding dollvery dates on the ongineorod 1toms. It appoars that a decision can bo roachod by wid-April as to whothor the caustic scrubbor units or tho silver reactor units WIII bo installod initially in tho dissolvor colls.

Mafor Equepront Status:

Rocolvod or shippod as of lilarch $23-48(62 \%)$

Schodulod for ilarch 23-3I

Schoduled for April

Schedulod for liny

Major Fquipmont Total 78

Tho construction subcontractor has reported that subytitutions and utilization of corrosion failod natorial where practical have essentialiy overcono tho shortages causod by delayod doliverios and corrosion tost falluros.

Approximatoly $97.5 \%$ of the concroto to be pourod in the 202-S Butldine was placod by Varch 23. Pourine of conoreto in tho silo region of tho bulldine has progrossod to tho silo roof lovel at the north end of tho buildine and in the romainder of the s1lo to the Oporating Gallory flloor lovol.

Coll finlshing oporations aro noaring complotion. Tho stainiess stoel Iiners are essontially comploted. 
The hot plpe tumol rork is noaring complotion. is of March 23, 83\% of tho piping was Installod. It 1 s expocted that $100 \%$ completion 1711 bo attainod by Lpril 9;

Tho schodulod complotion for the ond of March is 79.9\%, whilo actuai is $63.6 \%$ Comparable schodulod and cotual figuros for the and of Fobruary woro $69.6 \%$ and $59.4 \%$ rospoctivoly. Tho slight dotorioration of tho actual progross with rospoct to schodulod progrosis rosults from tho fact that tho canjon and colls have not boon comploted suffictontly to allow the installation of prom cess oquipment which has passod through tho stock-up Bullding. During the coming nonth those installations should be started.

Tho construction subcontractor has boon roquostod to incugurate study of, and polat complotion torards, the complotion of tho 202-S Buflding by soparate "coll units". It is bolloved that the first "coll unit" nay bo turnod over to Operations in lete lay or oarly June.

B. Profoct C-187-E - Rodor Anal It1cal and Plant Assistance Laborctory Construction of tho Iaboratory Is $95 \%$ comploto, Wasto Disposal Syston is $91 \%$ comploto and the orormall project $94 \%$ complote. It now appoars that tho ordor for hoods 111 i not bo conplotod untiI May 2I, with dolivory at tho rato of trjenty por wook starting April 9. With such a schodule somo of tho laboratorlos can be ready for occupancy by ilay l, but conplete occupancy cannot bo glvon until about Juno 1. Balancing of the vontilation syston cannot start unilil all of the hoods aro installod and will tako approxinatoly onc wonth or by Jily 1 .

Loboratory furnituro was rocoivod in danaged condition and with nanufacturing defects. This hes dolayod the installation of this oqutpnont.

C. Proinct C-128-234-5 Fecility Frogross for the month:

$\begin{array}{lccc} & \text { Basie Dosien } & \text { Ovoral1 Dosimn } & \text { Constmiction } \\ \text { Richland } & 92 & 84 & 73 \\ \text { Schonoctady } & - & - & 95.9\end{array}$

Construction rork on C-198 has slowod dom. Contributing factors aro dolays in equipmont dolivorios, insufficiont design information fror schenectady, contract dolnys to tho closoly related Project $6-473$, and gonoral labor unrest. Prospects for Imodiato irprovonont aro good and targat dato completion is still roasonablo.

Lccoptcnco Test Procoduros for Tasks II, III, and XII Texe approved and havo boon issued to the fioli. A roush draft of Oporablitity Test - Task VIII, Hood 24, was propared and transnitted to Schenectady for coments. Test procodures for use in the fleld 03 molI as roports on Schenoctady equipront tosts are scheduled to bo comploted and transintted to Richland by dpril 6, 1951. 


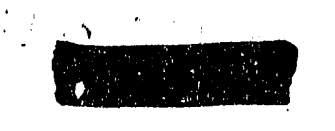

Hiti-20671-Ded

The lacis of equipriont and acceptance tost procedures are dolagline factors alroady offocting tho schoduled corplotion of t'ise projoct. Estinatod construction corplotion is only $73 \%$ conpriod to $84 \%$ schodulod.

D. Pruject C-36I - MotaI Convorelon

Procross for the nonth, exclusivo of "gegregation"

Scope................. 100\%

Dotaliod P"Ians........ 99f\%

Construction.......... 15\%

Madifleation \#5 of Diroctive HI-155 authorizine an additionaI $\$ 150,000$ for "sogregation" has boon rocoivod. Progross statis. tics for subsoquont porlods will bo basod upon the profoct as revised.

Requisitions havo beon issued on all dosign-procured itons. Curront inforration incicates doliveries of the fabricated ressols nay bo throo nonths lator than tho requirod datos. Of fivo fabrication ordors, a.I G. E. suppliod material has beon nhtppod for ono orclor.

E. Project C-36\% - Wasto Motal Rocovery Failities Proeross for the Donth:

Phase:

I II III IV V VI Totel

$\begin{array}{llllllll}\% \text { Scope } & 100 & 100 & 100 & 100 & 100 & 100 & 100\end{array}$

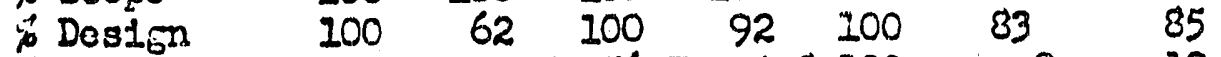

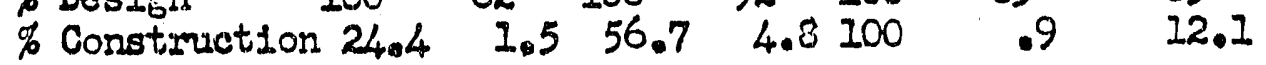

Last nonth tho total percontace of construction ras reported a.s 12. $7 \%$. Lt that tine tho roporting ras on a differont wolghting of the phoses than is currently usod. The fornor besis was on offort or manhours, whorocs that which is now beling used is on a labor and natorials basis. Convorting tho curront total valuo of $12.1 \%$ to tho provious basis for conparison glves the f1euro of $15.7 \%$.

Durlng this nonth the corrosion follurcs, which have beon res ported, have dropprid off to a noglieible quantity, thereforo, if this prosent trond continuas, thoro will be virtually no advorso offect on the vondor fabricatod 1tons other than those which wore involvod in failuros in the nonths of Junuary and Febraxry.

F. Frofoct $C-413$ - Pxpansion of $234=5$ Facilitieg Procross for the ronth: Forcont Cormplote Richlond Brsic Dosim Schenoctady 17 $\frac{\text { Orora } 11 \text { Dosim }}{10} \frac{C_{\text {cetrot }}}{2}$ 28.8 
Delfrory prospocts for coltical procuronont 1tons havo Improved on this projoct and dosicrs work is proeressing as schodulod. Design chances and rovisions havo boon kopt to a minimu so far. It appoars at t'io twonont, howovor, that wo nay bo renutrod to convert all In oquipront-for fabrication of a difforont sizo product prior to ind sturtmup. Tho full offoct of such a chango at this
tiao is ait known but dolays would follow.

Thu construction contract for Project $\mathrm{C}-413$ has not yot boon signod. The continuod dolays in obtaining this documont havo had a dolaying offoct on work in the flold. (Some of the nost ureont itens are bolng rolesased to tho flold for construction on tho Lotter Modificam

G. Profect C-418 - Additional Wasto Storage Facilitios - 241-TY Dro to changes in r xluction forecasts, tho llanufoaturing Division requested on March 27, that Project C-417, Laditional Wasto Storage Facilitios, 200 East Lrea $(241-B Z)$, be cancollod.

Tho oponing of bids for the $200 \mathrm{~g}$ hrea (24I-TY) Tank Farm is schodulod

III. PERSONNEI

Enployoos on payroll

$\frac{\text { Bortnntag }}{110^{*}} \quad \frac{\frac{\text { March }}{\text { End }}}{106^{* *}} \quad \frac{\text { Not Chanro }}{-4}$

* Inclucles four CEL, ono P1Io Technolocy and two Tochnical Graduates on loan to Soparations Division.

* Includos four GEI and five Tochnical Groductes on loan to soparations Division. 
RICHIAND VIILAGE PERSONNEL Comm. Fac111tles (Inc. No. Rlchland)

Govn. Agency, Churches, Clubs, etc.

Organizations

CONSTRUCTION SUB-CONTRACTORS

Atkinson \& Jones

Newberry Neon

Urban, Smyth, Warren Co.

Banley \& Co.

Kellex Corp.

No. Elect. Meg. Co.

J. Gordon Turnbull

Edmond P. Erwin

J. P. Head

Royal Co. Inc.

Fred J. E: rly, Jr.

Steel Const. Co. \& Gilmore Fals. Inc.

V. S. Jenkins

Empire Electric Co.

Morrion \& $\mathrm{Kr}$ udsen Co. Inc.

Assoclated Engrs. Inc.

Johnson Service

Monterey Co. Plumbing co.

Thorgaard Plumbing \& Heating Co.

102

70

Virg11. I. Anderson

Hauserman

X-Ray Products American Plpe \& Const. Judd Co. Inc. Chicago Bridge \& Iron

Valley Roofing Co. A. J. Patton \& Cec1I C. HiII

Cement Gun Const. Co.

Malarkey \& Moore

Wms. Glass Co.

Dix Steel Bldg. Co. Montgomery Electric Co. Comercial Painting \& Dec. Co.

Sound Const. \& Engr. Co.

Star Sheet Metal Works

Monteromery Elevator

J. G, Shotwell

Custodis Const. Co. Martin Fireproofing Co.

Lewis \& Queen

J. C Whitacre Decorating Co.

West Coast Heating \& Plumbing Co. 
CONST. SUB-CONTRACTORS CONT.

Flectric Smith Ino.

Roof Service Inc.

I. H. Horfman

Stler, Shelton \& Shick

Leland S. Rosener

Alvord, Burdick \& Bowbon

Barrett \& Logan

Charlea T. Main

Twin City Const. Co.

Total

General Electric Total

GRAND TOTAL

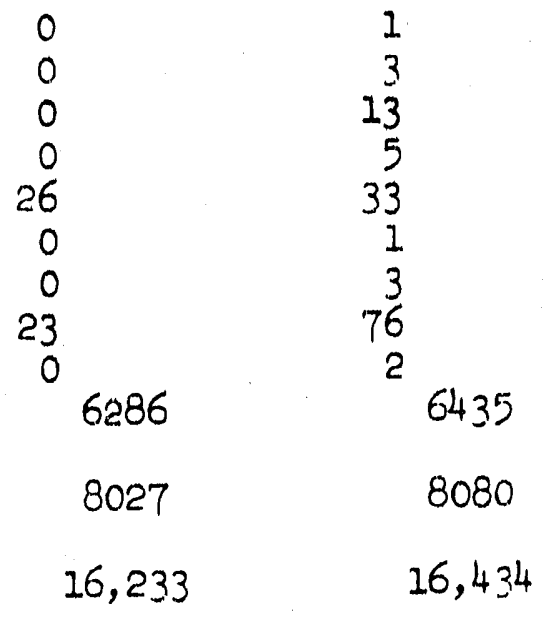



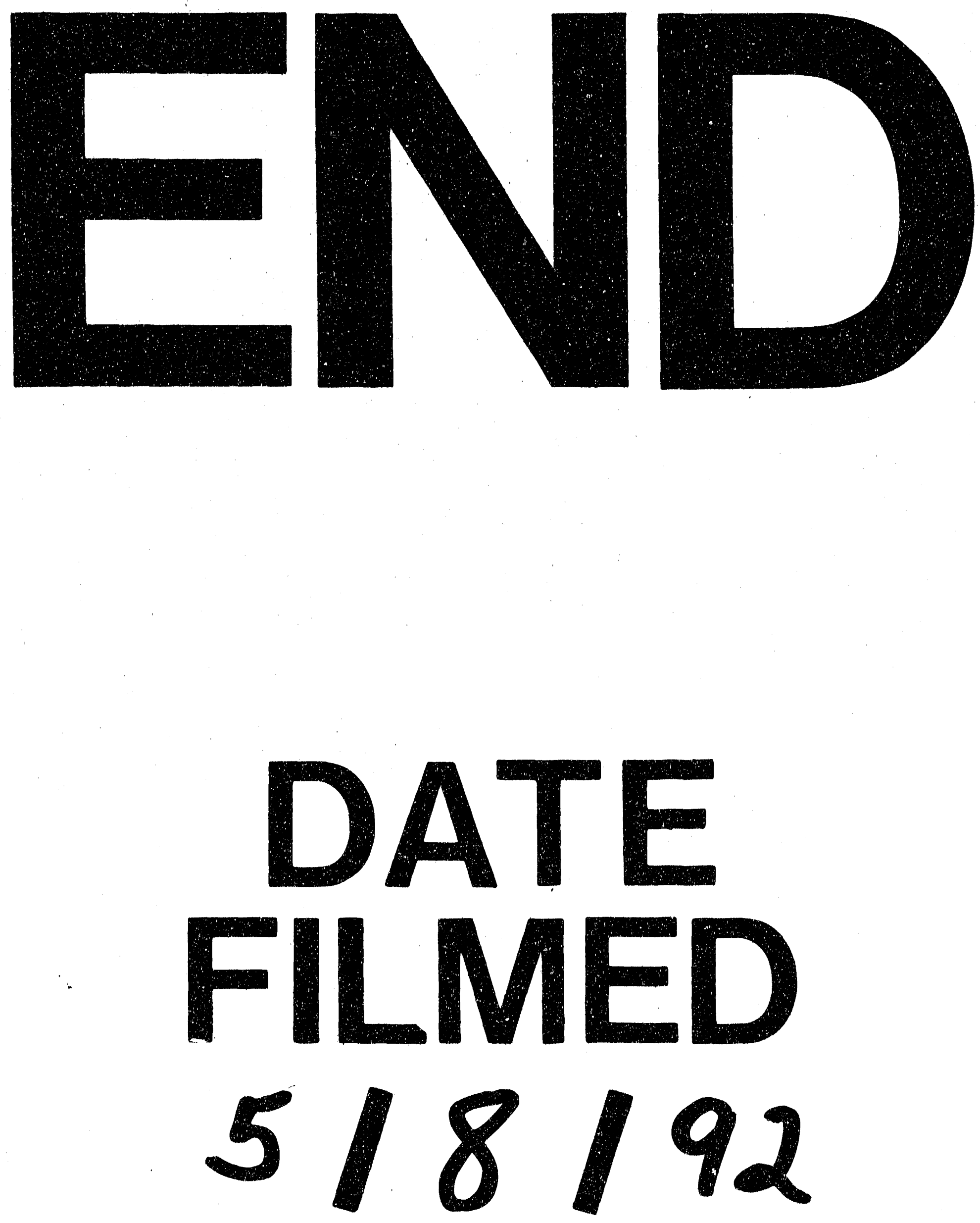

) 
